\title{
ENVIRONMENTAL STATEMENT
}

\section{LIQUID METAL \\ FAST BREEDER REACTOR PROGRAM}

\section{VOLUME IV}

\section{Alternative Technology Options}

MARCH 1974

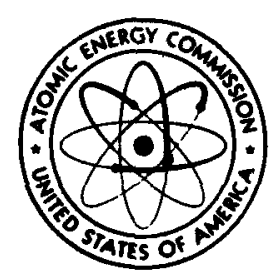

UNITED STATES ATOMIC ENERGY COMMISSION

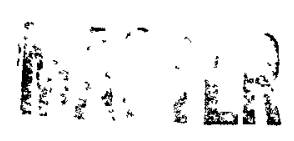




\section{DISCLAIMER}

This report was prepared as an account of work sponsored by an agency of the United States Government. Neither the United States Government nor any agency Thereof, nor any of their employees, makes any warranty, express or implied, or assumes any legal liability or responsibility for the accuracy, completeness, or usefulness of any information, apparatus, product, or process disclosed, or represents that its use would not infringe privately owned rights. Reference herein to any specific commercial product, process, or service by trade name, trademark, manufacturer, or otherwise does not necessarily constitute or imply its endorsement, recommendation, or favoring by the United States Government or any agency thereof. The views and opinions of authors expressed herein do not necessarily state or reflect those of the United States Government or any agency thereof. 


\section{DISCLAIMER}

Portions of this document may be illegible in electronic image products. Images are produced from the best available original document. 
DRAFT

WASH-1535

ENVIRONMENTAL STATEMENT

LIQUID METAL FAST BREEDER REACTOR PROGRAM

VOLUME IV

ALTERNATIVE TECHNOLOGY OPTIONS

Report in Four Volumes

I Summary and Background

(Chapters 1, 2, 3)

II Environmental Impact of The LMFBR (Chapter 4)

III Implication of LMFBR Program Implementation

(Chapters 5, 6, 7, 9, 10, 11)

IV Alternative Technology Options

(Chapter 8)

MARCH 1974

UNITED STATES ATOMIC ENERGY COMMISSION 


\section{ALTERNATIVE TECHNOLOGY OPTIONS}

\section{TABLE OF CONTENTS}

Page

PERSPECTIVE ON ALTERNATIVE TECHNOLOGY OPTIONS $\ldots \ldots \ldots \ldots \ldots \ldots$, P-I

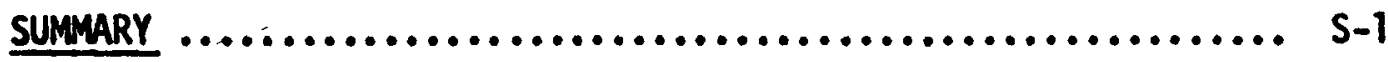

A. ALTERMATIVE ENERGY SOURCES FOR PRODUCTION OF ELECTRICITY

A.1 OTHER FORMS OF NUCLEAR POMER $\ldots \ldots \ldots \ldots \ldots \ldots \ldots \ldots \ldots$ A.1.1-1

A.1.1 LIGHT WATER REACTORS $\ldots \ldots \ldots \ldots \ldots \ldots \ldots \ldots \ldots \ldots$ A.1.1-1

1.1.1 Introduction $. . \ldots \ldots \ldots \ldots \ldots \ldots \ldots \ldots \ldots \ldots \ldots \ldots, A .1 .1-1$

1.1.2 Extent of Energy Resource ..................... A.1.1-4

1.1.3 Technical Description ............................1.1-12

1.1.4 Research and Development Program ................. A.1.1-43

1.1.5 Present and Projected Application ................ A.1.1-46

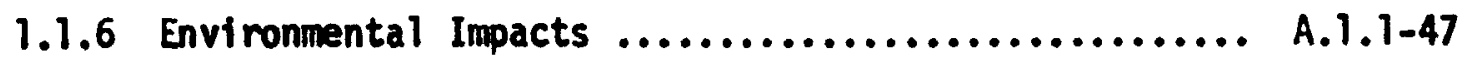

1.1.7 Costs and Benefits ............................. A.1.1-72

1.1.8 Overall Assessment of Role in Energy Supply ........ A.1.1-76

1.1.9 References ............................... A.1.1-81

A.1.2 HIGH TEMPERATURE GAS-COOLED REACTORS $\ldots \ldots \ldots \ldots \ldots \ldots$ A.1.2-1

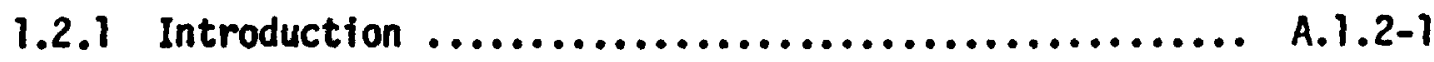

1.2.2 Extent of Energy Resource ........................ A.1.4

1.2.3 Technical Description ............................ A.8

1.2.4 Research and Development Program ....................2-21

1.2.5 Present and Projected Application .................. A.1.2-24

1.2.6 Environmental Impacts $\ldots \ldots \ldots \ldots \ldots \ldots \ldots \ldots \ldots \ldots \ldots$ A.1.2-25 
Table of Contents - continued

Page

1.2.7 Costs and Benefits ........................... A.1.2-31

1.2.8 Overall Assessment of Role in Energy Supply ........ A.1.2-36

1.2.9 References ................................ A.1.2-37

A.1.3 LIGHT WATER BREEDER REACTOR $\ldots \ldots \ldots \ldots \ldots \ldots \ldots \ldots \ldots$ A.1.3-1

1.3.1 Introduction ............................... A.1.3-1

1.3.2 Extent of Energy Resource...$\ldots \ldots \ldots \ldots \ldots \ldots \ldots \ldots$ A.1.3-2

1.3.3 Technical Description ............................... A.2

1.3.4 Research and Development Program ................ A.1.3-9

1.3.5 Present and Projected Application ................. A.1.3-10

1.3.6 Environmental Impacts ....................... A.1.3-12

1.3.7 Costs and Benefits ............................ A.1.3-14

1.3.8 Overall Assessment of Role in Energy Supply ......... A.1.3-16

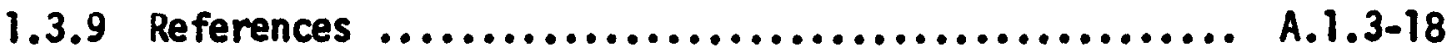

A.1.4 GAS-COOLED FAST BREEDER REACTOR $\ldots \ldots \ldots \ldots \ldots \ldots \ldots$ A.1.4-1

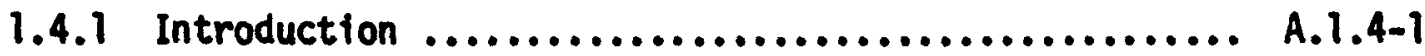

1.4.2 Extent of Energy Resource..$\ldots \ldots \ldots \ldots \ldots \ldots \ldots \ldots$ A.1.4-5

- 1.4.3 Technical Description ......................... A.1.4-6

1.4.4 Research and Development Program ................ A.1.4-13

1.4.5 Present and Projected Application ................ A.1.4-20

1.4.6 Environmental Impacts ....................... A.1.4-22

1.4.7 Costs and Benefits ........................... A.1.4-26

1.4.8 Overall Assessment of Role in Energy Supply ........ A.1.4-31

1.4.9 References ................................... A.1.4-33 
Page

A.1.5 MOLTEN SALT BREEDER REACTOR

A.1.5-1

1.5.1 Introduction

A.1.5-1

1.5.2 Extent of Energy Resource

A.1.5-3

1.5.3 Technical Description

A.1.5-4

1.5.4 Research and Development Program

A.1.5-11

1.5.5 Present and Projected Application

A.1.5-15

1.5.6 Environmental Impacts

A.1.5-15

1.5.7 Costs and Benefits

A.1.5-19

1.5.8 Overall Assessment of Role in Energy Supply

A.1.5-23

1.5.9 References

A.1.5-24

A.1.6 CONTROLLED THERMONUCLEAR REACTOR POWER SYSTEMS

A.1.6-1

1.6.1 Introduction

A.1.6-1

1.6.2 Extent of Energy Resource

A.1.6-11

1.6.3 Technical Description

A.1.6-13

1.6.4 Research and Development Program

A.1.6-15

1.6.5 Present and Projected Application

A.1.6-23

1.6.6 Environmental Impacts

A.1.6-24

1.6.7 Costs and Benefits

A.1.6-39

1.6.8 Overall Assessment of Role in Energy Supply

A.1.6-42

1.6.9 References

A.1.6-43 
Page

A.2 FOSSIL FUELS FOR CENTRAL STATION ELECTRICAL GENERATION. A.2-1

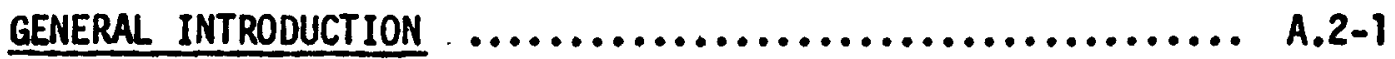

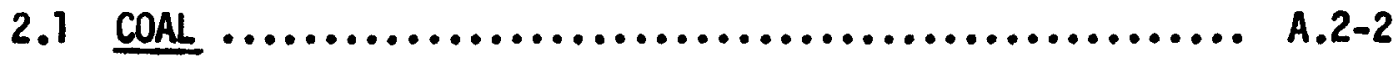

2.1.1 Introduction $\ldots \ldots \ldots \ldots \ldots \ldots \ldots \ldots \ldots \ldots \ldots \ldots \ldots \ldots$ A.2-2

2.1.2 Extent of Energy Resource $\ldots \ldots \ldots \ldots \ldots \ldots \ldots \ldots \ldots \ldots$ A.2-6

2.1.3 Technical Description .......................... A.2-14

2.1.4 Research and Development Program ............... A.2-33

2.1.5 Present and Projected Application ................ A.2-39

2.1.6 Environmental Impacts ....................... A.2-43

2.1.7 Costs and Benefits ......................... A.2-57

2.1.8 Overall Assessment of Role in Energy Supply ........ A.2-66

2.2 NATURAL GAS AND OIL $\ldots \ldots \ldots \ldots \ldots \ldots \ldots \ldots \ldots \ldots$, A.2-68

2.3 OIL SHALES $\ldots \ldots \ldots \ldots \ldots \ldots \ldots \ldots \ldots \ldots \ldots \ldots \ldots \ldots . \ldots . \ldots \ldots$

2.3.1 Introduction $\ldots \ldots \ldots \ldots \ldots \ldots \ldots \ldots \ldots \ldots \ldots \ldots \ldots$, A.2-73

2.3.2 Extent of Energy Resource ................... A.2-80

2.3.3 Technical Description ........................ A.2-81

2.3.4 Research and Development Program ............... A.2-88

2.3.5 Present and Projected Application ............... A.2-89

2.3.6 Environmental Impacts ..................... A.2-90

2.3.7 Costs and Benefits ........................ A.2-92

2.3.8 Overall Assessment of Role in Energy Supply ........ A.2-93

2.4 OTHER FOSSIL FUELS - DOMESTIC TAR SANDS $\ldots \ldots \ldots \ldots \ldots \ldots$ A.2-95

2.5 REFERENCES $\ldots \ldots \ldots \ldots \ldots \ldots \ldots \ldots \ldots \ldots \ldots \ldots \ldots \ldots \ldots$ A.2-99 
Table of Contents - continued

Page

A.3 HYDROELECTRIC POWER SYSTEMS $\ldots \ldots \ldots \ldots \ldots \ldots \ldots \ldots \ldots$ A.3-1

3.1 Introduction $\ldots \ldots \ldots \ldots \ldots \ldots \ldots \ldots \ldots \ldots \ldots \ldots \ldots$ A.3-1

3.2 Extent of Energy Resource $\ldots \ldots \ldots \ldots \ldots \ldots \ldots \ldots \ldots \ldots$ A.3-4

3.3 Technical Description ......................... A.3-5

3.4 Research and Development Program ................. A.3-8

3.5 Present and Projected Application ................. A.3-10

3.6 Environmental Impacts ....................... A.3-12

3.7 Costs and Benefits ................................... A.14

3.8 Overall Assessment of Role in Energy Supply .......... A.3-17

3.9 References $\ldots \ldots \ldots \ldots \ldots \ldots \ldots \ldots \ldots \ldots \ldots \ldots \ldots \ldots \ldots \ldots$ A.3-18

A.4 GEOTHERMAL EMERGY $\ldots \ldots \ldots \ldots \ldots \ldots \ldots \ldots \ldots \ldots \ldots \ldots$ A.4-1

4.1 Introduction $\ldots \ldots \ldots \ldots \ldots \ldots \ldots \ldots \ldots \ldots \ldots \ldots \ldots \ldots, \ldots . \ldots, \ldots \ldots$

4.2 Extent of Energy Resource $\ldots \ldots \ldots \ldots \ldots \ldots \ldots \ldots \ldots \ldots$ A.4-8

4.3 Technical Description ......................... A.4-15

4.4 Research and Development Program ................ A.4-21

4.5 Present and Projected Application ...................4-23

4.6 Environmental Impacts $\ldots \ldots \ldots \ldots \ldots \ldots \ldots \ldots \ldots \ldots \ldots \ldots \ldots . \ldots \ldots$

4.7 Costs and Benefits ............................ A.4-44

4.8 Overall Assessment of Role in Energy Supply .......... A.4-46

4.9 References $\ldots \ldots \ldots \ldots \ldots \ldots \ldots \ldots \ldots \ldots \ldots \ldots \ldots \ldots \ldots \ldots$ A.4-47 
Table of Contents - continued

Page

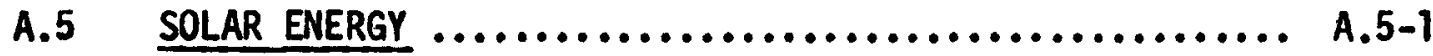

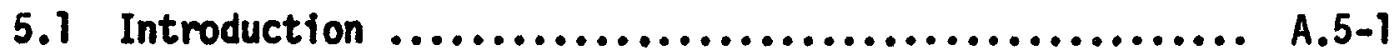

5.2 Extent of Energy Resource $\ldots \ldots \ldots \ldots \ldots \ldots \ldots \ldots \ldots \ldots$ A.5-6

5.3 Technical Description $\ldots \ldots \ldots \ldots \ldots \ldots \ldots \ldots \ldots \ldots \ldots \ldots . \ldots \ldots$

5.4 Research and Development Program ................. A.5-19

5.5 Present and Projected Application ................ A.5-21

5.6 Environmental Impacts $\ldots \ldots \ldots \ldots \ldots \ldots \ldots \ldots \ldots \ldots \ldots \ldots$ A.5-22

5.7 Costs and Benefits ........................... A.5-29

5.8 Overall Assessment of Role in Energy Supply ......... A.5-34

5.9 References $\ldots \ldots \ldots \ldots \ldots \ldots \ldots \ldots \ldots \ldots \ldots \ldots \ldots \ldots \ldots \ldots$ A.5-35

A.6 OTHER NONMUCLEAR ENERGY SYSTEMS $\ldots \ldots \ldots \ldots \ldots \ldots \ldots \ldots$ A.6-1

6.1 WIND POWER $\ldots \ldots \ldots \ldots \ldots \ldots \ldots \ldots \ldots \ldots \ldots \ldots \ldots \ldots$ A.6-1

6.2 OCEAN THERMAL GRADIENTS $\ldots \ldots \ldots \ldots \ldots \ldots \ldots \ldots \ldots \ldots$ A.6-4

6.3 TIDAL ENERGY $\ldots \ldots \ldots \ldots \ldots \ldots \ldots \ldots \ldots \ldots \ldots \ldots \ldots, A, 6,8 \ldots \ldots \ldots$

6.4 HYDROGEN AND OTHER SYNTHETIC FUELS $\ldots \ldots \ldots \ldots \ldots \ldots \ldots$ A.6-10

6.5 References $\ldots \ldots \ldots \ldots \ldots \ldots \ldots \ldots \ldots \ldots \ldots \ldots \ldots \ldots \ldots \ldots$ A.6-16

B. IMPROVED ENERGY CONVERSION AND STORAGE DEVICES

B.1 GENERAL INTRODUCTION $\ldots \ldots \ldots \ldots \ldots \ldots \ldots \ldots \ldots \ldots \ldots$. B.1-1

B.2 STEAM TURBINE SYSTEMS $\ldots \ldots \ldots \ldots \ldots \ldots \ldots \ldots \ldots \ldots \ldots$, B.2-I

2.1 Introduction $\ldots \ldots \ldots \ldots \ldots \ldots \ldots \ldots \ldots \ldots \ldots \ldots \ldots, B, 2-1$

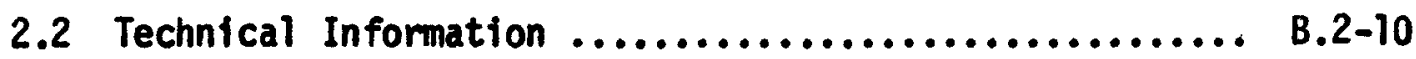


Table of Contents - continued

Page

2.3 Research and Development $\ldots \ldots \ldots \ldots \ldots \ldots \ldots \ldots \ldots \ldots$, B.2-14

2.4 Environmental Impacts ......................... B.2-14

2.5 Costs and Benefits ............................ B.2-14

2.6 Overall Assessment of Role in Energy Supply .......... B.2-15

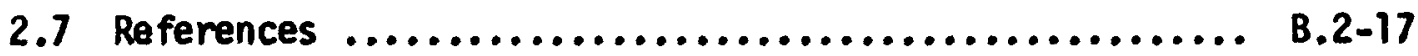

B.3 INTERNAL COMBUSTION ENGINES $\ldots \ldots \ldots \ldots \ldots \ldots \ldots \ldots \ldots . . . . . . .1$

3.1 Introduction $\ldots \ldots \ldots \ldots \ldots \ldots \ldots \ldots \ldots \ldots \ldots \ldots \ldots$, B.3-1

3.2 Technical Information ......................... B.3-4

3.3 Research and Development ....................... B.3-6

3.4 Environmental Impacts $\ldots \ldots \ldots \ldots \ldots \ldots \ldots \ldots \ldots \ldots \ldots$ B.3-6

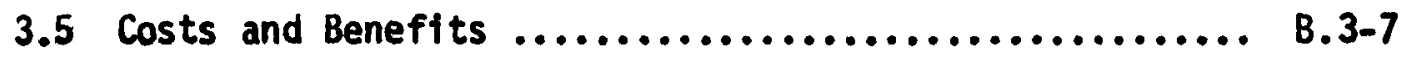

3.6 Overall Assessment of Role in Energy Supply .......... B.3-9

3.7 References $\ldots \ldots \ldots \ldots \ldots \ldots \ldots \ldots \ldots \ldots \ldots \ldots \ldots \ldots \ldots$ B. 3-10

B.4 GAS TURBINES $\ldots \ldots \ldots \ldots \ldots \ldots \ldots \ldots \ldots \ldots \ldots \ldots \ldots, B .4-1$

4.1 Introduction $\ldots \ldots \ldots \ldots \ldots \ldots \ldots \ldots \ldots \ldots \ldots \ldots \ldots, \ldots .4 . \ldots \ldots$

4.2 Technical Information ....................... B.4-4

4.3 Research and Development ..................... B.4-10

4.4 Environmental Impacts $\ldots \ldots \ldots \ldots \ldots \ldots \ldots \ldots \ldots \ldots \ldots . . . \ldots .4-11$

4.5 Costs and Benefits ........................... B.4-13

4.6 Overall Assessment of Role in Energy Supply ......... B.4-14

4.7 References $\ldots \ldots \ldots \ldots \ldots \ldots \ldots \ldots \ldots \ldots \ldots \ldots \ldots \ldots \ldots . \ldots . \ldots . \ldots \ldots$ 
B.5 BINARY CYCLES $\ldots \ldots \ldots \ldots \ldots \ldots \ldots \ldots \ldots \ldots \ldots \ldots \ldots \ldots$, B.5-1

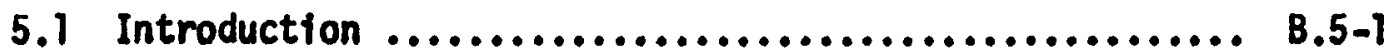

5.2 Technical Information $\ldots \ldots \ldots \ldots \ldots \ldots \ldots \ldots \ldots \ldots \ldots . . \ldots .6$

5.3 Research and Development ...................... B.5-8

5.4 Environmental Impacts $. . \ldots \ldots \ldots \ldots \ldots \ldots \ldots \ldots \ldots . . . \ldots .5-11$

5.5 Costs and Benefits ............................ B.5-12

5.6 Overall Assessment of Role in Energy Supply .......... B.5-12

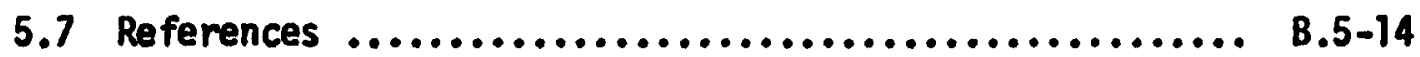

B.6 FUEL CELLS $\ldots \ldots \ldots \ldots \ldots \ldots \ldots \ldots \ldots \ldots \ldots \ldots \ldots \ldots \ldots$, B.6-1

6.1 Introduction $\ldots \ldots \ldots \ldots \ldots \ldots \ldots \ldots \ldots \ldots \ldots \ldots \ldots \ldots, B .6,1$

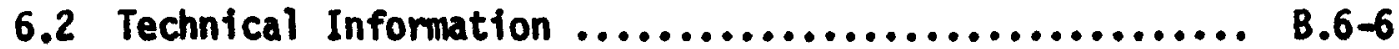

6.3 Research and Development ....................... B.6-12

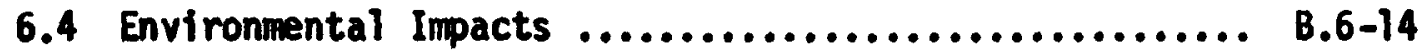

6.5 Costs and Benefits ............................ B.6-15

6.6 Overall Assessment of Role in Energy Supply .......... B.6-17

6.7 References .................................. B.6-19

B.7 BATTERIES $\ldots \ldots \ldots \ldots \ldots \ldots \ldots \ldots \ldots \ldots \ldots \ldots \ldots \ldots \ldots \ldots$, B.7-1

7.1 Introduction $\ldots \ldots \ldots \ldots \ldots \ldots \ldots \ldots \ldots \ldots \ldots \ldots \ldots \ldots . \ldots \ldots \ldots$

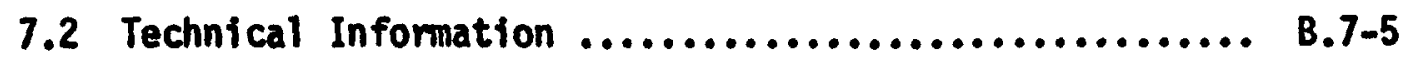

7.3 Research and Development ....................... B.9

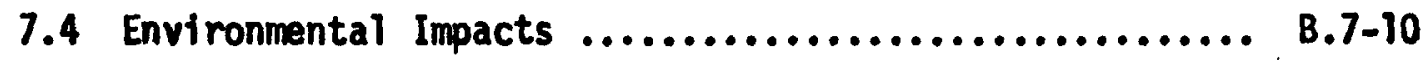

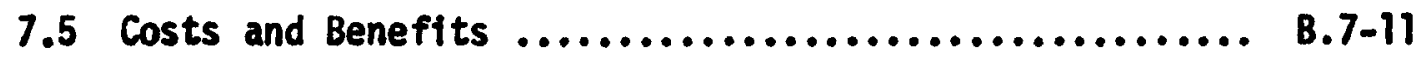


Table of Contents - continued

Page

7.6 Overall Assessment of Role in Energy Supply ......... B.7-12

7.7 References $\ldots . \ldots \ldots \ldots \ldots \ldots \ldots \ldots \ldots \ldots \ldots \ldots \ldots \ldots \ldots . . . \ldots .7-13$

B.8 THERMOELECTRIC CONVERTERS $\ldots \ldots \ldots \ldots \ldots \ldots \ldots \ldots \ldots \ldots, 8.8,1$

8.1 Introduction $\ldots \ldots \ldots \ldots \ldots \ldots \ldots \ldots \ldots \ldots \ldots \ldots \ldots, \ldots, 8,1$

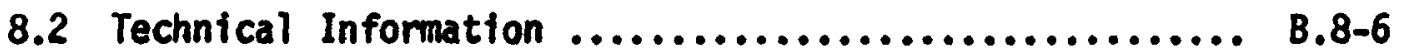

8.3 Research and Development ...................... B.8-9

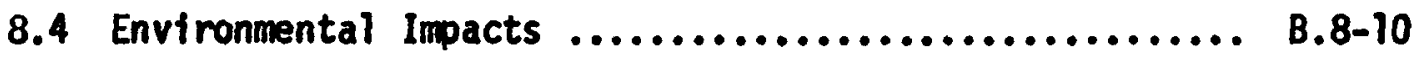

8.5 Costs and Benefits ........................... B.8 -10

8.6 Overall Assessment of Role in Energy Supply .......... B.8-11

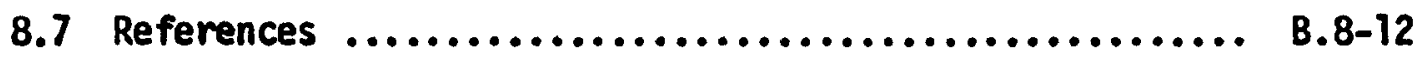

B.9 THERMIONIC CONVERTERS $\ldots \ldots \ldots \ldots \ldots \ldots \ldots \ldots \ldots \ldots \ldots$, B.9-1

9.1 Introduction $\ldots \ldots \ldots \ldots \ldots \ldots \ldots \ldots \ldots \ldots \ldots \ldots \ldots$, B.9.1

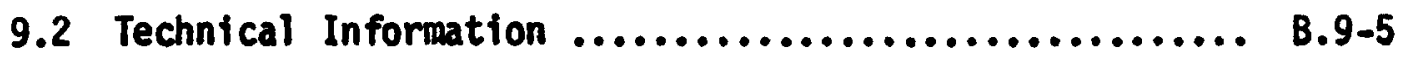

9.3 Research and Development $\ldots \ldots \ldots \ldots \ldots \ldots \ldots \ldots$, B.9-8

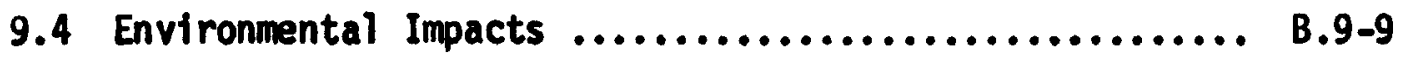

9.5 Costs and Benefits ............................ B.9-10

9.6 Overall Assessment of Role in Energy Supply .......... B.9-1I

9.7 References ................................ B.9-12

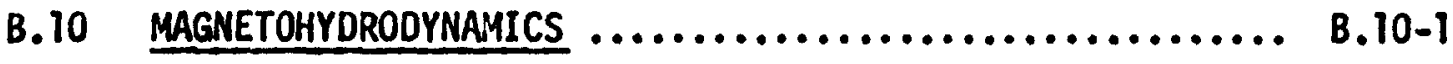

10.1 Introduction $\ldots \ldots \ldots \ldots \ldots \ldots \ldots \ldots \ldots \ldots \ldots \ldots \ldots$, B.10-1

10.2 Technical Information $. . \ldots \ldots \ldots \ldots \ldots \ldots \ldots \ldots \ldots . . . \ldots . \ldots$ 
Table of Contents - continued

Page

10.3 Research and Development B.10-11

10.4 Environmental Impacts B. 10-13

10.5 Costs and Benefits B.10-14

10.6 Overall Assessment of Role in Energy Supply B.10-16

10.7 References

B. 10-18

B.11

SUMMARY

B.11-1

C. CONSERVATION OF ENERGY

C.1 INTRODUCTION .

C.1-1

C.2 EXTRACTION OF ENERGY RESOURCES

C.2-1

2.1 Stimulation of Petroleum and Natural Gas Production ...

2.2 Increased Production from Coal Mines

C.2-8

2.3 Increased Production from Uranium Deposits

2.4 Summation of Potential for Improving Efficiency of Extraction of Energy Resources

C.3 POWER PLANT ENERGY CONVERSION EFFICIENCIES

C. 3-1

3.1 Fossil-Fuel-Fired Steam-Electric Plants

3.2 Nuclear-Fueled Steam-Electric Plants

C. 3-4

3.3 Utilization of Waste Heat from Power Plants

C.3-5

3.3.1 Agriculture

3.3.2 Aquaculture C. 3-13

3.3.3 Urban Use C. 3-16 
C.4 GROSS vS. NET GENERATION OF ELECTRICITY $\ldots \ldots \ldots \ldots \ldots, c .4-1$

4.1 Steam-Driven Auxiliary Equipment ................ C.4-1

4.2 Energy Demands for Pollution Abatement and

Environmental Control $\ldots \ldots \ldots \ldots \ldots \ldots \ldots \ldots \ldots \ldots, c .4-2$

4.2.1 Electric Generating Plants ............... C.4-5

4.2.2 Sewage Disposal Improvement ............... C.4-7

4.2.3 Industrial Water Pollution Control .......... C.4-7

4.2.4 Conversion of Direct Fuel Burning to

Purchased Electricity .................. C.4-8

C.5 TRANSMISSION AND DISTRIBUTION $\ldots \ldots \ldots \ldots \ldots \ldots \ldots \ldots, C .5-1$

5.1 Transmission Systems $\ldots \ldots \ldots \ldots \ldots \ldots \ldots \ldots \ldots \ldots \ldots, C .5-2$

5.1.1 High Voltage AC Systems .................. C.5-5

5.1.2 High Voltage Direct Current (HVDC) Systems ..... C.5-14

5.1.3 Innovative Underground Transmission .......... C.5-15

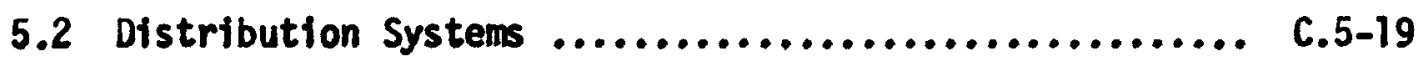

C.6 UTILIZATION OF ENERGY $\ldots \ldots \ldots \ldots \ldots \ldots \ldots \ldots \ldots \ldots, c .6-1$

6.1 Industrial Thermal Processes ..................... C.6-9

6.2 Thermal Performance of Structures ................ C.6-12

6.3 Transportation $. \ldots \ldots \ldots \ldots \ldots \ldots \ldots \ldots \ldots \ldots \ldots \ldots \ldots, 0.6-18$

C.7 CONCLUSIONS $. \ldots \ldots \ldots \ldots \ldots \ldots \ldots \ldots \ldots \ldots \ldots \ldots \ldots \ldots, c .7-1$

C.8 REFERENCES $\ldots \ldots \ldots \ldots \ldots \ldots \ldots \ldots \ldots \ldots \ldots \ldots \ldots \ldots, 0.8-1$ 


\section{LIST OF FIGURES}

Figure

Page

P-1 Reactor Development Time Scales P-5

A.1.1-1 U.S. Uranium Resources at $\$ 10$ to $\$$ ? per Lb $\mathrm{U}_{3} \mathrm{O}_{8}$

A.1.1-5

A.1.1-2 Uranium Resources - Western United States A.1.1-7

A.1.1-3 World Uranium Requirements and Reserves A.1.1-8

A.1.1-4 Drilling, Reserve Additions and Discovery Rates

A.1.1-5 Cutaway of Oxide Fuel for Commercial LWR Power Plant

A.1.1-14

A.1.1-6 Schematic Arrangement of BWR NSSS

A.1.1-16

A.1.1-7 Cutaway View of Internal of Typical BWR Vessel A.1.1-17
A.1.1-8 BWR Fuel Assembly
A.1.1-19

A.1.1-9 Schematic Arrangement of BWR Primary Containment System

A.1.1-22

A.1.1-10 BWR Secondary Containment Buflding Showing

Primary Containment System Enclosed

A.1.1-23

A.1.1-11 Multiple Containment System For Recent Large BWR Plants

A.1.1-25

A.1.1-12 Schematic Arrangement of PWR NSSS

A.1.1-27

A.1.1-13 Cutaway View of Internal of Typical PWR Vessel A.1.1-28

$\begin{array}{lll}\text { A.1.1-14 PWR Fuel Assembly A.1.1-30 } & \end{array}$

A.1.1-15 PWR Containment A.1.1-32

A.1.1-16 BWR Gaseous Waste System A.1.1-36

A.1.1-17 PWR Gaseous Waste System A.1.1-37

A.1.1-18 Heat Rejection From Power Plants A.1.1-48 


\section{LIST OF FIGURES - continued}

Figure

Page

A.1.1-19 Nuclear Fuel Cycle - Light Water Reactor

Uranium Dioxide Fueled - No Plutonium Recycle A.1.1-54

A.1.1-20 Installed Nuclear Capacity, United States A.1,1-77

$\begin{array}{lll}\text { A.1.2-1 HTGR Nuclear Steam System A.1.2-10 } & \text { A. }\end{array}$

A.1.2-2 HTGR Fuel Components A.1.2-12

A.1.2-3 Schematic Flow Diagram - HTGR Power Conversion System

A.1.2-14

A.1.2-4 HTGR Helium Gas Purification A.1.2-29

A.1.2-5 HTGR Radioactive Liquid Waste A.1.2-30

A.1.3-1 LWBR Demonstration Core in Shippingport Vessel A.1.3-4

A.1.3-2 LWBR Demonstration Core Cross Section A.1.3-6

A.1.4-1 Principal Components of the Nuclear Steam Supply System A.1.4-8

A.1.5-1 Reference MSBR System Flow Chart A.1.5-5

A.1.5-2 Flowsheet for Processing A Single-Fluid MSBR A.1.5-10

A.1.5-3 MSBR Off-Gas System Schematic Flow Diagram A.1.5-18

A.1.6-1 Adiabatic Toroidal Compressor (ATC) A.1.6-5

A.1.6-2 ORMAK A.1.6-6

A.1.6-3 Scyllac Experiment A.1.6-8

A.2.1 Schematic of Coal-Fired Electric Energy System A.2-3

A.2-2 Coal Fields of the United States A.2-7

A.2-3 Estimated Original and Remaining Coal Reserves, by Rank, in United States A.2-8

A.2-4 Estimates of United States Coal Supply A.2-12

A.2-5 Simplified Flow Chart of Coal Preparation A.2-21 


\section{LIST OF FIGURES - continued}

Figure

Page

A.2-6 Clean Energy from Coal Program

A.2-7 Production and Distribution of U.S. Bituminous Coal (1970)

A.2-8 Coal-fired Electricity System for a 1000-Mue Power Plant

A.2-9 Schematic Diagram of 011 Shale Surface Processing

A.2-10 Relative State of Knowledge of Various Operations

Required in 0 il Shale Processing

A.2-11 Schematic Representations of Three 0il Shale Retorting Processes

A.3-1 Schematic of A Hydroelectric Generating System

A.3-2 Hydroelectric Capacity

A.4-1 Schematic of a Geothermal Power Plant

A.4-2 Cross-sectional Schematic of a Geothermal Reservolt A.4-3

A.4-3 Map of Geothermal Resource Areas in the Western United States

A.4-4 Schematic of the Magmamax Process

A.4-5 Conceptual Diagram of a Dry-Rock Geothermal

Energy System Developed by Hydraulic Fracturing

A.4-6 Three Projections of Geothermal Electrical

Capacity for Year 2000

A.5-1 Schematic of the Thermal-Conversion Solar Power System

A.5-2 Distribution of Solar Energy Over the United States

A.5-3 Schematic of a Solar Thermal-Conversion Power Sys tem

A.5-4 Schematic of a 10,000-MWe Satellite Solar Power Station 


\section{LIST OF FIGURES - continued}

Figure

$\underline{\text { Page }}$

A.5-5 Schematic of Residential Heating and Cooling with Solar Energy - One Alternative

A.5-6 Comparison of Total Land Disturbed from SurfaceMined Coal and Solar Electric Plants

B.2-1 Operation of a Heat Engine

B.2-2

B.2-2 Basic Components of a Rankine Cycle Heat Engine B.2-4

B.2-3 Rankine Cycle with Reheat B.2-5

B.2-4 Rankine Cycle with Regeneration B.2-6

B.2-5 Estimated Annual Electric Generation by Engine Source

B.3-1 Schematic Drawing of Piston Type Internal Combustion Engine

B.4-1 Regenerative Cycle Gas Turbine

B.4-2

B.4-2 Combined Cycle Gas Turbine

B.4-5

B.4-3 Nuclear Cycle Gas Turbine

B.4-8

B.6-1 Electrochemical 0xidation of Hydrogen in a Fuel Cell

B.6-2 Coal and Uranium Energy Systems

B.6-7

B.8-1 Simple Thermocouple

B.8-2

B.8-2 Efficiency of a Thermoelectric Generator

B. 8-7

B.9-1 Schematic of a Thermionic Energy Converter

B.9-2

B.10-1 Turbine/Generator Electrical System

B.10-2

B.10-2 MHD Generator Electrical System

B.10-3

C.2-1 Relative Land Area Disturbed by Energy Fuel Production

C.2-2 Depletion of $\$ 15$ Reserves as $\$ 8$ Reserves are Mined Out 


\section{LIST OF FIGURES - continued}

Figure

Page

C.5-1 Transmission Capability

C.5-4

C.5-2 Typical Transmission Losses

C.5-6

C.5-3 Transformer Energy Losses

C.5-21

C.6-1 Idealized Projections of Energy Consumption Based on Suggested Conservation Measures

C.6-6

C.6-2 Efficiency of Room Air Conditioners

C.6-17 


\section{LIST OF TABLES}

Table

Page

A.1.1-1

Growth of Commercial LKR Capacity in the USA ...

A.1.1-3

A.1.1-2

Estimated U.S. Uranium Resources

A.1.1-4

A.1.1-3

Curies of Noble Gases Released, Boundary and

Average Individual Doses and Population Doses

A.1.1-52

A.1.1-4

Nuclear Fuel Cycle Industry

A.1.1-56

A.1.1-5

Characteristics of 1000 MWe LWR Maximum Fuel

Cyc le Requirements ............

A.1.1-57

A.1.1-6

Summary of Environmental Considerations for Nuclear

Fuel Cycle - I...............

A.1.1-58

A.1.1-7

Summary of Environmental Considerations for

Nuclear Fuel Cycle - II ..........

A.1.1-61

A.1.1-8 Comparison of Costs and Impacts of Coal and

Light Water Reactor Plants.......... A.1.1-74

A.1.1-9

Projected Uranium Requirements ......... A.1.1-79

A.1.2-1

World Thorium Resources - $\$ 10 / 1 \mathrm{~b}$. $\mathrm{ThO}_{2} \ldots . . . \mathrm{A} \cdot 1.2-5$

A.1.2-2

Estimated U.S. Thorium Resources ....... A.1.2-6

A.1.2-3

Operating Parameters for a Large HTGR ..... A.1.2-9

A.1.2-4

Annual Effects of a 1000 MWe HTGR and its

Supporting Fuel Cycle

A.1.2-32

A.1.4-1

GCFR Demonstration Plant Performance

Characteristics

A.1.4-11

A.1.5-1

Principal Operating Parameters of a 1000 MWe MSBR.

A.1.5-8

A.1.6-1

Long-Lived Activities in the Blanket Structure

of a Fusion Reactor

A.1.6-28

A.1.6-2

Energy Release Potential of Components of a

Reference CTR Producing 1000 MWe

A.1.6-33

A.1.6-3

Yield of Required Metals from Their Ores

A.1.6-35 


\section{LIST OF TABLES - continued}

Table

Page

A.1.6-4 CTR Resource Utilization .......... A.1.6-37

A.2-1 Estimated Available Reserves of Low-Sulfur Coal in the United States .............

A.2-2 Review of Processes for Removal of $\mathrm{SO}_{x}$ from Flue Gases

A.2-3 Technological Status of Some Stack-Gas $\mathrm{SO}_{2}-$

Removal Processes .............

A Summary of Some Proposed Processes for the Production of Low-Btu Gas from Coal

A.2-5 Preliminary Comparison of Some Proposed Low-Btu Gas Processes .................. A.2-31

A.2-6 Technological Status of Liquefaction/ Desulfurization Processes ......... A.2-32

A.2-7 Projections of Domestic Coal Consumption .... A.2-40

A.2-8 Waste Disposal and Environmental Impact Factors for Processes for Removing $S_{x}$ from Stack Gas . A. A.2-51

A.2-9 Projected Electrical Power Plant Costs .... A.2-60

A.2-10 Reclamation Costs in Incremental Costs per Ton of Coal Mined ................ A.2-62

A.2-11 Estimated Development Costs ........ A.2-64

A.2-12 Projected Contributions of 011 and Natural Gas to Total and Electrical Energy Consumption .... A.2-68

A.2-13 0 il Shale Industries of the Past ....... A.2-75

A.2-14 Approximate Annual Tonnages of Solids Processed . A.2-87

A.3-1 Present and Potential Conventional Hydroelectric Capacity of the United States ........ A.3-6

A.4-1 Known Geothermal Resource Areas within the Conterminous United States as of August 1972 . . A.4-10

A.4-2 Comparison of Noise Levels between The Geysers area and other Sources 


\section{LIST OF TABLES - continued}

Table

Page

A.5-1

Summary of Major Technical Problems ...... A.5-20

A.5-2

Summary of Overall Program Funding ...... A.5-20

B.11-1

Energy Conversion Device Summary ....... B.11-2

C.5-1

Overhead Transmission Circuit Capability

In-Service................. c.5-7

C.5-2 Projected Energy Conservation Through Higher

Overhead Transmission Voltages........ C.5-8

C.5-3

Energy Input and System Losses ........ C.5-11

C.5-4

Power Losses in Underground Power Systems

C.5-17

C.5-5

Projected Energy Conservation Using Super-

conducting Cables

C.5-18

C.5-6

Savings in Distribution Transformer Energy Losses.

C.5-23

C.6-1

Energy Consumption in the United States by End

Use

C.6-3

C.6-2

Significant End-Uses of Energy in the U.S. ...

C.6-4

C.6-3

Possible Annual Energy Savings by Sector and End Use .......................

Estimated Shipments, Cooling Capacity, and Amount of Cooling - 1973-1980 ................. C.6-16

C.6-5

Energy and Price Data for Transport

C.6-19

C.6-6

Actual and Hypothetical Energy Consumption

Pattern for Transportation in 1970 


\section{PERSPECTIVE ON ALTERNATIVE TECHNOLOGY OPTIONS}

In meeting an objective, such as the development of a sufficient electrical energy supply, several courses of action are usually avallable. For almost any path that is chosen there are alternative paths which could be taken which might arrive at the same goal, or some equally acceptable goal. Usually, in a well-organized program those alternative actions which are within the control of the program decision makers are examined objectively, and one is selected while the others are assigned lower priorities for various reasons: the technology is too difficult to bring them to fruition within the time frame available; the resource base behind the technology is insufficient to meet the long-term requirements; the alternative, while equally promising, is not better or would be far more expensive, and so on. Sometimes the requirement is so vast and enduring that no one alternative can meet the entire need and several alternatives must be pursued simultaneously. The latter situation corresponds most closely to the problem of meeting the Nation's growing electrical energy requirements.

The energy requirements of the country are so large and pressing that no single method currently available for meeting our needs is completely adequate for the job. The situation is exacerbated by the necessity to protect environmental values while at the same time meeting the challenge to the economy posed by our growing ofl and gas shortages and our increasing dependence on unreliable foreign 
sources. Thus, the energy crisis has stimulated a reexamination of all possible means of producing energy to determine which have the potential of significantly contributing to meeting our energy needs, in the near term as well as in the more distant future, in environmentally acceptable ways.

This chapter will attempt to put all the foreseeable options for generating electrical energy -- those already in existence, those approaching commercial utilization and those which are only conceptual at this time -- in the proper perspective so as to assess their potential for meeting the Nation's electrical energy requirements. No attempt will be made to assess the potential of each energy system for meeting other energy requirements (such as, for example, the transportation or petrochemical industries). However, when such an application is particularly pertinent, attention is drawn to the fact that other uses for the energy source exist.

In the following assessments we will attempt to:

a) Examine the extent of the energy resource to determine whether it is sufficient to support all, or a significant portion, of the Nation's energy requirements.

b) Examine the technology and the amount of research and develooment necessary to bring each system to the point of commercial utilization. Where possible, estimates of the R\&D costs and schedules will be 
provided. In this regard the less developed a system is the less accurate such estimates will be. In many cases insufficient work has been done on the concept to warrant making other than generalized estimates.

c) Evaluate the environmental impact of each alternative system to determine whether the impact is acceptable or what would need to be done to make it acceptable.

d) Evaluate the costs and benefits of each system in terms of dollars where possible. For many of these systems, however, only qualitative evaluations of costs and benefits can be made.

e) Finally, bring each system into perspective by assessing its probable role in the energy supply picture to the year 2000 and beyond.

In a discussion of this sort where many systems are examined which vary in maturity from fully developed, tested and proven systems to conceptual systems which have not as yet been developed, certain milestones must be delineated so that meaningful comparisons can be made. Otherwise, it is inevitable that those systems on which little or no work has been done will look most attractive since the natural enthusiasm of their proponents will highlight the advantages of the system while the difficulties and limitations are minimized or, most likely, have not been discovered. 
These milestones are based on past experience in bringing other concepts from the early stages of establishment of feasibility to commercial utilization. Past experience has demonstrated that three phases of development are usually followed in bringing a technology to maturity:

a) The initial research and development phase in which feasibility is established, and the basic technical aspects of the concept are confirmed through analytical investigations, laboratory scale experiments and conceptual engineering.

b) The second phase in which engineering and manufacturing capabilities are developed. This requires in-depth engineering and proof testing of first-of-a-kind components utilizing complex and costly experimental installations and supporting test facilities to assure adequate understanding of design and performance characteristics.

c) The third phase in which the utflities make large-scale commitments - first through participation in the construction . and operation of one or more demonstration plants to establish whether or not the system is reliable, safe and economical and then through cormitment to full-scale commercial utilization.

Figure $P-1$ illustrates the stages for three nuclear power reactor systems: a mature system - LWR, a nearly mature system - HTGR, and a 


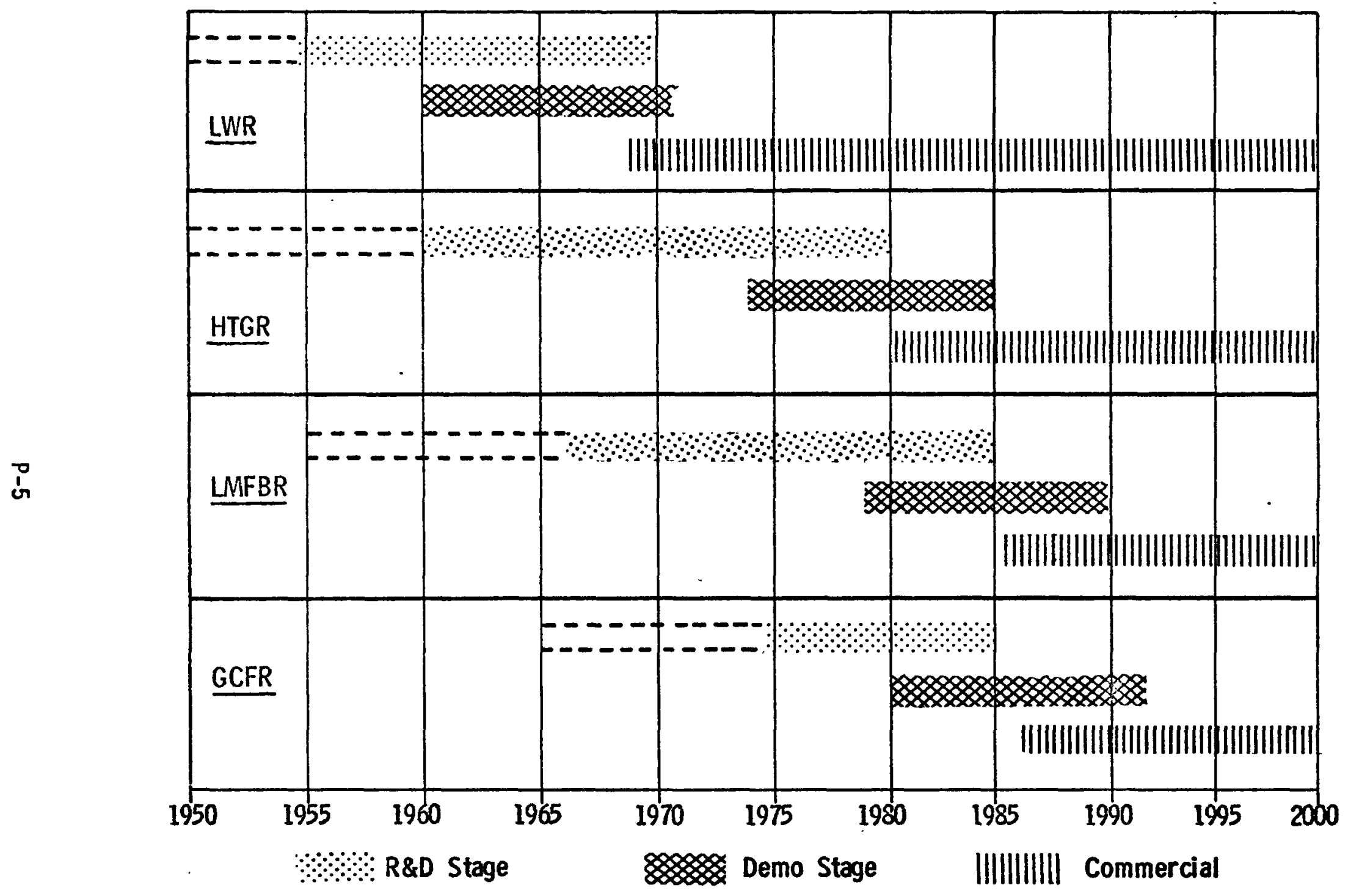

REACTOR DEVELOPMENT TIME SCALES

Figure $P-1$ 
system entering the demonstration reactor phase - LMFBR. The similarity in the time scales for each system is notable. An attempt will be made in Section 8.A to identify the phase each concept is in so as to help assess its potential to help meet the Nation's energy needs.

In addition to expanding our energy resources by developing electrical energy production systems using new fuels such as uranium and deuterium, or exploiting the natural energy available in geothermal formations, the tides and the sun, much can be done in more effectively utilizing the conventional fuels we currently depend upon. Several types of energy conversion and storage devices are avallable or under development which might have the potential for significantly improving or complementing the electrical generation system in most prevalent use today, the stean turbine cycle. Included in this category are the internal combustion engine, gas turbine, binary cycle, magnetohydrodynamic, thermoelectric, thermionic, fuel cell and battery systems. These will be reviewed in Section 8.B under the same guidelines and objectives as those used for alternative energy sources.

Finally, a number of energy conservation measures are available which could be employed to reduce consumption of energy and thereby lead to a closer balance between supply and demand. These range from improving the yield of useful energy extracted from the ground (e.g., improving the percentage of oil recoverable from an oil well) to utilizing waste heat, reducing energy transmission losses and reducing wasteful 
consumption of energy at the consumer level. The extent to which such measures might be successful and therefore become at least a partial substitute to the development of a new energy source such as the LMFBR is considered among the several alternative technology options reviewed in this Chapter. 


\section{SUMMARY}

This chapter examines individually the various options other than the construction of LMFBR's that might be utilized to satisfy the Nation's electric power requirements. The options considered include the further implementation of various types of nuclear power reactors such as the already existing Light Water Reactor and High Temperature Gas-Cooled Reactor, as well as the development of alternative breeder reactors such as the Gas-Cooled Fast Reactor, Light Water Breeder Reactor and Molten Salt Breeder Reactor. The chapter also addresses the development of another potential nuclear energy system, controlled thermonuclear fusion.

The possibilities of increased emphasis on the use of conventional fossil fuels, namely coal, oil and natural gas, and the development of unconventional fossil fuels such as oil shale are discussed. Also considered is the further development of additional non-nuclear energy sources such as hydroelectric power systems, geothermal energy, solar energy, and other potential sources of power.

Each option is examined as to the extent of the energy resource, the research and development program that would be required (if any) to bring the option into commercial use, the environmental implications of its utilization and the costs and benefits associated with its use in order to assess its capability for satisfying projected energy requirements. 
The chapter also discusses the use of improved energy conversion and storage devices such as gas turbines, fuel cells and magnetohydrodynamics, which, while not alternative energy sources per se, can contribute toward alleviating the Nation's energy resource problem by utilizing these resources more efficiently.

Finally, the various elements of a national effort in energy conservation are examined to assess their potential for reducing the need for additional power sources. These elements include improved extraction of energy resources and increased efficiencies of power plant energy conversion, transmission, distribution and utilization of electricity.

In summary, the alternative energy options available to the Nation if the LMFBR is not pursued can be classified as: a) other means of exploiting nuclear energy, b) non-nuclear energy sources, c) more efficient means of converting energy resources to usefur forms, and d) more conservative means of using the available energy. It is most likely that combinations of various options will be necessary to meet the Nation's future energy needs.

In the first category, nuclear energy can be extracted either through the fissioning of heavy metals, notably uranium, plutonium and the thorium derivative, U-233 or by the fusion of light elements, particularly deuterium, and tritium derived from lithium. In the nuclear energy area, fission processes are the most developed 
and a substantial Light Water Reactor (LWR) industry is well established. A comparable High Temperature Gas-Cooled Reactor (HTGR) industry is in the process of becoming established with the placement of multiple orders by utilities for large HTGR power plants. Both of these options depend, however, upon uranium-235 (U-235) as their primary fuel, and the relative scarcity of $U-235$ in relation to its far more plentiful fertile counterpart uranium-238 (U-238) limits the exploitation of uranium resources to about $1-2 \%$ of the total energy available in natural uranium.

Other fission options are less well developed but give promise of utilizing far greater percentages of the energy available in uranium. These are the Light Water Breeder Reactor (LWBR) which has the potential for operating on a self-sustaining uraniumthorium fuel cycle; the Molten Salt Breeder Reactor (MSBR) which also operates on the uranium-thorium fuel cycle and uses liquid fuel with continuous on-line fuel processing to achieve modest breeding with acceptable doubling times; and the Gas-Cooled Fast Reactor (GCFR) which operates on the same fuel cycle, uraniumplutonium, as the LMFBR but has the potential for higher breeding ratios because of its more energetic neutron spectrum. As pointed out none of these has been fully developed nor are there any assurances that any will progress to full commercial utilization. All fission reactor systems have fundamentally the same environmental impacts as the LMFBR and do not offer any significant improvement in that respect. Although thorium-uranium-233 fueled 
reactors do not have to deal with the problems of plutonium, they substitute the high energy radiation problems associated with the handling of U-232.

The remaining nuclear energy option is the Controlled Thermonuclear Reactor (CTR) system which has not yet been demonstrated to be scientifically feasibile. It is estimated that even with a successfur, vigorous research and development effort the CTR option cannot contribute significantly to our energy supply until well after the start of the next century. However, the extensive energy resources this option can exploit coupled with the avoidance of most of the environmental problems associated with fission product production in fission reactors makes it worthwhile to make every effort to develop this system to its full potential.

In the category of energy sources which do not depend on nuclear reactions, the fossil fuels, coal, oil and gas are not only fully established but comprise the great bulk of our energy resources today. However, several problems limit the capability of these fuels to maintain their pre-eminent share of the energy market. First, oil and gas have peaked in production in this country and cannot be expected to sustain their current place in the electrical generation market, much less keep pace with our steadily expanding requirements. Recent developments have shown that oil and gas imports are not practical solutions to this "fuel gap." Second, there is an urgent and mounting need for our oil and gas resources 
in the transportation and petrochemical fields and for residential use. Efforts are under way to develop additional oil and gas supplies from our large oil shale deposits. Successful development of this source would add substantially to oil and gas reserves and ameliorate current supply problems. It would not, however, change the basic, long-range situation.

Although coal reserves are far more plentiful than oil and gas there are environmental problems associated with coal's use, ranging from despoilment of large areas in the mining processes to air and water pollution from its combustion products. Research and development efforts are being intensified to find means to alleviate these problems and these must prove successful if coal is to maintain or increase its share of the energy market.

Conventional hydroelectric power provides a modest percentage (15\%) of our current electrical generating capacity and, because of limitations on the extent of this resource and the geographical restrictions on suitable sites, its share of the energy market is expected to decline to about $7 \%$ in 1990 . Greater utilization of hydroelectric power can be achieved through the use of pumped storage modes of operation, but hydroelectric power would still remain a rather small factor in the Nation's total energy picture.

Geothermal energy has the potential for providing a significant contribution to the Nation's energy resources in those geographical 
areas where it is abundant and feasible to tap. These areas are predominantly in the western third of the contiguous USA and Alaska. Estimates vary widely as to the extent of the available resources, ranging from about a one-half year supply at the projected consumption rate for the entire Nation in the year 2000 to several orders of magnitude higher, depending upon estimates of probable and undiscovered reserves and the technological feasibility of extracting the energy at economical prices. At the present time only a very small amount of this energy source is being tapped, although activities in this area are accelerating somewhat. Further efforts to develop known geothermal resources are in order. It would seem that a strong attempt to narrow the wide range in estimation of the extent of this resource is warranted so that a better assessment can be made of its potential and the importance of pressing ahead vigorously with full scale technological and commercial development.

Solar energy utilization has great appeal since it is the most direct form of energy available. Enormous amounts of solar energy are intercepted by the earth continually at a rate of about 130 watts per square foot $\left(W / f t^{2}\right)$. Various factors such as night, weather, latitude, and atmosphere reduce this to an average of $17 \mathrm{~W} / \mathrm{ft}^{2}$ for the United States, which is still the equivalent of 700 times the energy we produce from conventional fuels. Unfortunately, the poor efficiencies of the available systems for collecting and transforming solar energy into useful forms, the wide 
fluctuations over the period of a day in the energy received (requiring energy storage systems) and the dilute nature of the energy (requiring large collection areas) militate against large scale use of this energy form -- in the next few decades at least. Home heating and possibly some residential electricity production, which would reduce requirements for central station power generation, appear to be the most likely near term applications for solar energy. Research and development looking toward more extensive applications of solar energy is certainly warranted considering the extent of the energy resource available.

There are other energy resources which are solar-related, namely wind power and ocean-thermal gradients. Proponents of these options as well as proponents of tidal energy can marshal impressive statistics as to the total energy available in each of these energy resources. However, each of these suffer to some extent from extractability problems and, geographic, economic, and practical limitations which make these systems more likely to be useful in specific situations rather than as broad-based energy sources of large significance.

Energy conversion and storage devices are means by which existing and prospective energy sources can be more efficiently utilized either by directly increasing the efficiency of energy production (magnetohydrodynamics, binary cycles, gas turbines), by transforming energy into a more convenient form (fuel cells, synthetic 
fuels) or by providing means of energy storage so that it can be used at more convenient times (fuel cells, batteries). Many of these devices are in commercial use today in limited applications and all of them are under investigation for more widespread and large scale use. They deserve attention so that the full potential and the attendant technical and non-technical difficulties and 1 Imitations of each are understood and so that proper choices for development into large-scale commercial utilization can be made.

In addition to new energy sources and conversion methods a wide variety of energy conservation measures could be considered as a means of reducing projected energy growth demands and thereby making the necessity of developing new energy options such as the LMFBR less urgent. The potential of these measures, individually or in combinations, is limited. A number of potential conservation measures, while attractive in principle, appear to offer only minor relief from fuel scarcities and growing energy demands, and some might lead to significant economic or environmental penalties. Included in this category are most possible improvements in methods of resource extraction for coal, ofl, gas and uranium, conventional improvements in power plant conversion efficiencies, and a reduction in the energy devoted to pollution control. The costs and benefits of each of these methods should be carefully balanced before a decision to proceed on a large-scale basis is made. 
Other conservation methods appear to satisfy most energy, economic and environmental criteria and should be implemented where practicable. Foremost among these is the more efficient usage of electricity in commercial, industrial and residential applications. By eliminating waste, switching to more energy-efficient processes, and otherwise making optimum use of the electricity that is consumed, appreciable energy savings are possible. It is plain that energy conservation measures cannot eliminate the need for new energy options, but they can provide some mitigating relief in the transition period during which these options are being developed and brought into use. 
A.

ALTERNATIVE ENERGY SOURCES

FOR

PRODUCTION OF ELECTRICITY 


\section{A.1 OTHER FORMS OF NUCLEAR POWER}

\section{A.1.1 LIGHT WATER REACTORS (LWRS)}

1.1.1 Introduction

\subsubsection{General Description}

Plants known as Light Water Reactor (LWR) plants use light (i.e., ordinary) water both to moderate* the neutron spectrum and to transfer the heat generated in the nuclear fuel to the steam-generating equipment. There are two types ${ }^{1}$ of LWR plants, those using Pressurized Water Reactors (PWR) and those using Boiling Water Reactors (BWR). BWRs, as the name implies, generate steam by bulk bolling of pressurized water in the nuclear core. In PWRs, the pressurized water surrounding the nuclear core is not allowed to go into bulk boiling, but rather is used to generate steam in equipment external to the nuclear core. In either case, pressurized stean is produced as the working fluid used to spin a turbine-generator and produce electricity. Fossil-fueled electric generating plants operate in the same manner.

The heat energy produced during operation of LWRs comes basically from the fissioning of the easily fissioned U-235 atoms in the fuel, with a small contribution (about 5\%) from the fissioning of U-238 atoms (the fission of U-238 occurs only with very

tmoderate - refers to the process of slowing down the fast neutrons generated during nuclear fission to the low energies at which they can readily fission $U-235$. 
energetic neutrons). As the reactor operates, however, another easily-fissioned atom - plutonium-239 (Pu-239) - is produced from U-238 atoms.* For each gram of U-235 consumed in LWR fuel, as much as 0.9 gram of $\mathrm{Pu}-239$ is formed within the fuel. Generally more than half of the plutonium formed undergoes fission in place, thus contributing significantly to the energy produced in the power plant. Plutonium that escapes fission (about 0.25 gram Pu-239 per gram U-235 corisumed) is recovered from the spent LWR fuel when it is removed from the power plant and sent to a reprocessing plant (see subsection 1.1.3.3.1).

\subsubsection{History}

Commercial nuclear electric power was introduced in the U.S. about 17 years ago (1957) through the operation of the $60 \mathrm{~N}(\mathrm{e})$ ** Shippingport nuclear steam-electric prototype plant, a joint venture of the Atomic Energy Commission (AEC) and the Duquesne Light Company in Pennsylvania. The Shippingport reactor is based largely on technology that had been developed for Naval nuclear propulsion units. This was followed in 1960 and 1961, respectively, by the Dresden-1 (200 MWe) BWR and the Yankee Rowe (175 MWe) PWR plants. These plants drew heavily upon Naval reactor base technology but used different nuclear core concepts. The growth of commercial LWR capacity, to date, is indicated in Table A.1.1-1.

\footnotetext{
Fon the average, each fissioning atom in LWR fuel ejects two neutrons, one of which is needed to sustain the fission chain reaction. Those neutrons not entering into fission reactions either leak from the fuel or are captured by surrounding materials. When U-238 captures a neutron not sufficientiy energetic to cause its fission, it transforms spontaneously to neptunium-239 which in turn transforms to plutonium-239 over a relatively short time span.

* Later increased to 90 MWe.
} 
Table A.1.1-1

GROWTH OF COMMERCIAL LWR CAPACITY IN THE USA ${ }^{2}$

\begin{tabular}{lccc}
\hline Year* & No. of Units & MWe, Net & MWe, Cumulative \\
\hline 1957 & 1 & 90. & 90 \\
1960 & 1 & 200. & 290 \\
1961 & 1 & 175. & 465 \\
1962 & 1 & 265. & 730 \\
1963 & 1 & 68.5 & 799 \\
1964 & 1 & 22.5 & 821 \\
1965 & 1 & 70.2 & 891 \\
1966 & 0 & 0 & 891 \\
1967 & 0 & 0 & 891 \\
1968 & 2 & $1,005$. & 1,896 \\
1969 & 2 & $1,265$. & 3,160 \\
1970 & 3 & $1,776$. & 4,936 \\
1971 & 6 & $3,459.3$ & 8,396 \\
1972 & 8 & $5,545.9$ & 13,941 \\
1973 & 10 & $7,769.4$ & 21,710 \\
\hline
\end{tabular}

*Year in which commercial operation was achieved, except 1973 for which all plants achieving initial criticality are included.

\subsubsection{Status}

LWR plants are by far the predominant type of nuclear power plant being purchased and installed by the U.S. utilities at this time. As of December 1973, U.S. utilities had built, ordered or announced plans for 211 commercial nuclear electric plants (203 LWRs and 8 HTGRs) having an aggregate capacity of about 200 thousand electric megawatts. ${ }^{2}$ Thirty-nine LWRs and one high temperature gas-cooled reactor (HTGR) were then in operation. Projecting from present trends in the purchase of fossil and nuclear plants by the utilities, it appears likely that nuclear energy will become the predominant source of electricity in the U.S. within the next 20 years or so. ${ }^{3}$ AEC projections of the growth of the nuclear electric industry are discussed in subsection 1.1.8. 


\subsubsection{Extent of Energy Resources}

\subsubsection{U.S. Uranium Supply}

The currently estimated U.S. uranium reserves at a cut-off cost of $\$ 8$ per pound of $\mathrm{U}_{3} \mathrm{O}_{8}{ }^{*}$ are 273,000 tons. An additional potential resource of 450,000 tons is estimated to occur in known favorable geologic environments. At higher cut-off costs, the resources are larger. Resources up to $\$ 30$ per pound of $\mathrm{U}_{3} \mathrm{O}_{8}$ are primarily in deposits such as those currently being mined, primarily tabular pods in sandstones, sometimes referred to as "conventional" deposits (Table A.1.1-2). There are also large quantities of uranium in certain shales and granites (unconventional ores) but the uranium occurs in "part per million" concentrations (Figure A.1.1-1). The cost of production from these sources would be much higher, and very large tonnages of "ore" would need to be mined and milled to produce significant amounts of uranium (see subsection A.1.1.6). The environmental impact of using "unconventional" ores would also be significantly greater.

Table A.1.1-2

ESTIMATED U.S. URANIUM RESOURCES ${ }^{4,5}$

\begin{tabular}{|c|c|c|c|}
\hline \multirow{2}{*}{$\begin{array}{c}\mathrm{U}_{3} \mathrm{O}_{8} \text { Cost* } \\
\text { up to: } \\
\$ / 1 \mathrm{~b}\end{array}$} & Reserves & Potential & Total \\
\hline & \multicolumn{3}{|c|}{ Cumulative thousands of tons $\mathrm{U}_{3} \mathrm{O}_{8}$} \\
\hline $\begin{array}{r}8.00 \\
10.00 \\
15.00 \\
30.00\end{array}$ & $\begin{array}{l}270 \\
340 \\
520 \\
700\end{array}$ & $\begin{array}{r}450 \\
700 \\
1,000 \\
1,700\end{array}$ & $\begin{array}{r}720 \\
1,040 \\
1,520 \\
2,400\end{array}$ \\
\hline
\end{tabular}

FAEC reserve estimates represent the calculated maximum amount of uranium that could be produced at specified costs. Sales prices are determined by the market. 


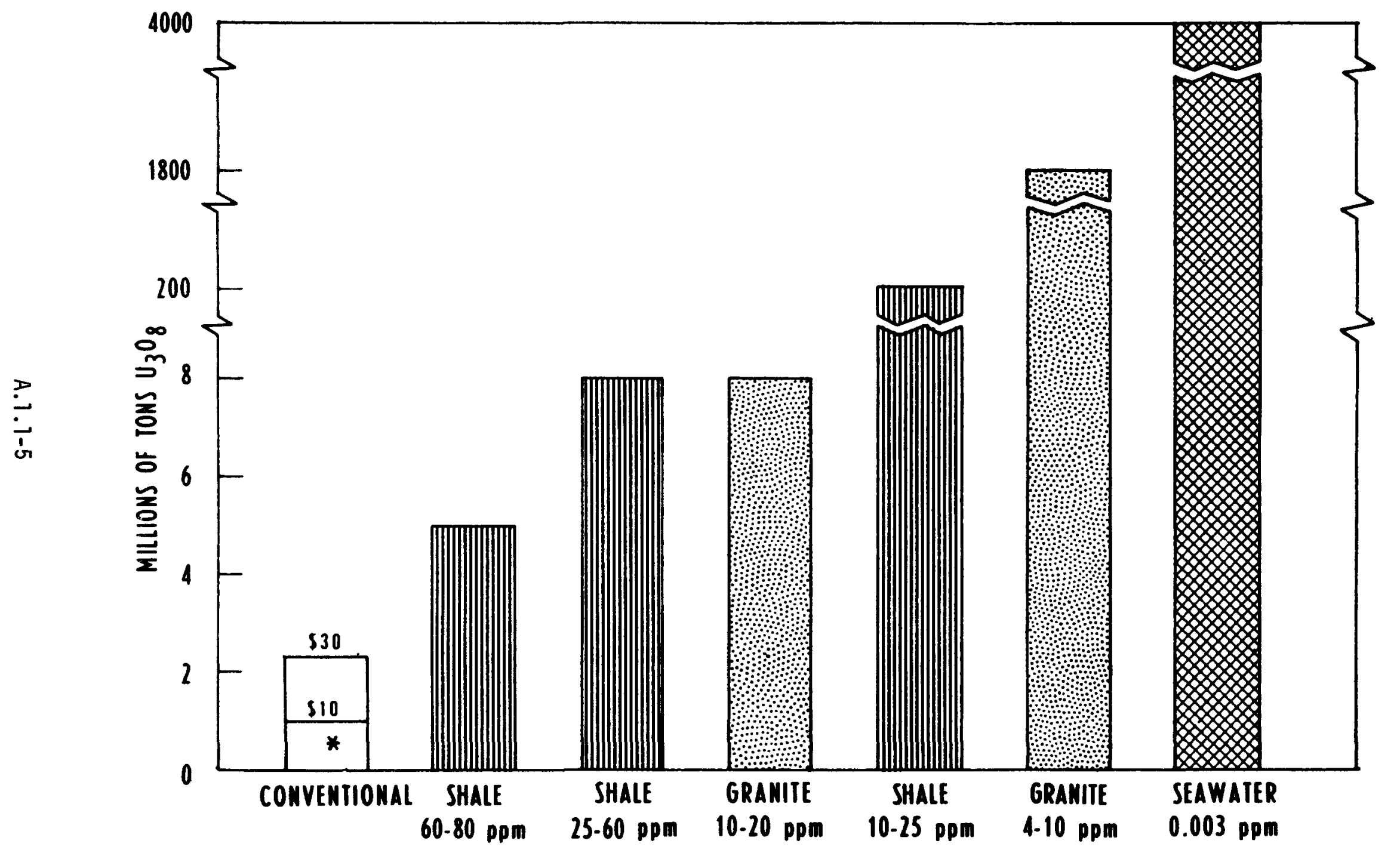

* $700-2100$ ppm

U. S. URANIUM RESOURCES ${ }^{6}$ AT $\$ 10$ TO $\$$ ? PER LB $\bigcup_{3} 0_{8}$

Figure A.1.1-1 
The currently known conventional uranium deposits are located in the western part of the U.S., principally in the States of Arizona, Colorado, New Mexico, Texas, Utah, Washington and Wyoming. Figure A.1.1-2 shows the locations of known reserves and producing areas. Most conventional uranium deposits are small, containing less than 100 tons of $\mathrm{U}_{3} \mathrm{O}_{8}$. A relatively few large deposits have the bulk of the reserves. About $10 \%$ of the known deposits contain $85 \%$ of the $\$ 8 / 7 \mathrm{~b}$ reserves ${ }^{5,6}$. The average uranium content of ore mined in 1972 was about $0.21 \% U_{3} 0_{8}$ (or $2100 \mathrm{ppm}$ ).

\subsubsection{Foreign Uranium Supply}

Foreign reserves ${ }^{5}$ at a cut-off of $\$ 10 / 1 \mathrm{~b} . \mathrm{U}_{3} \mathrm{O}_{8}$ are estimated at about 800,000 tons of $\mathrm{U}_{3} \mathrm{O}_{8}$, and potential additional resources at 500,000 tons at the same cut-off cost. Australia, Canada, South Arica and South West Africa have about $75 \%$ of these reserves. The remainder is primarily in Central Africa and Europe.

Despite an apparently better supply position with respect to low-cost ores than is currently evident in the U.S., there are limitations on the production rates attainable. South African uranium is a byproduct of gold mining. Canadian and South West African resources are contained in a few deposits for which there are physical and economic limitations on production levels.

As depicted in Figure A.1.1-3, the foreign uranium supply-demand ${ }^{6}$ situation is expected to be much like that expected in the U.S. (See 


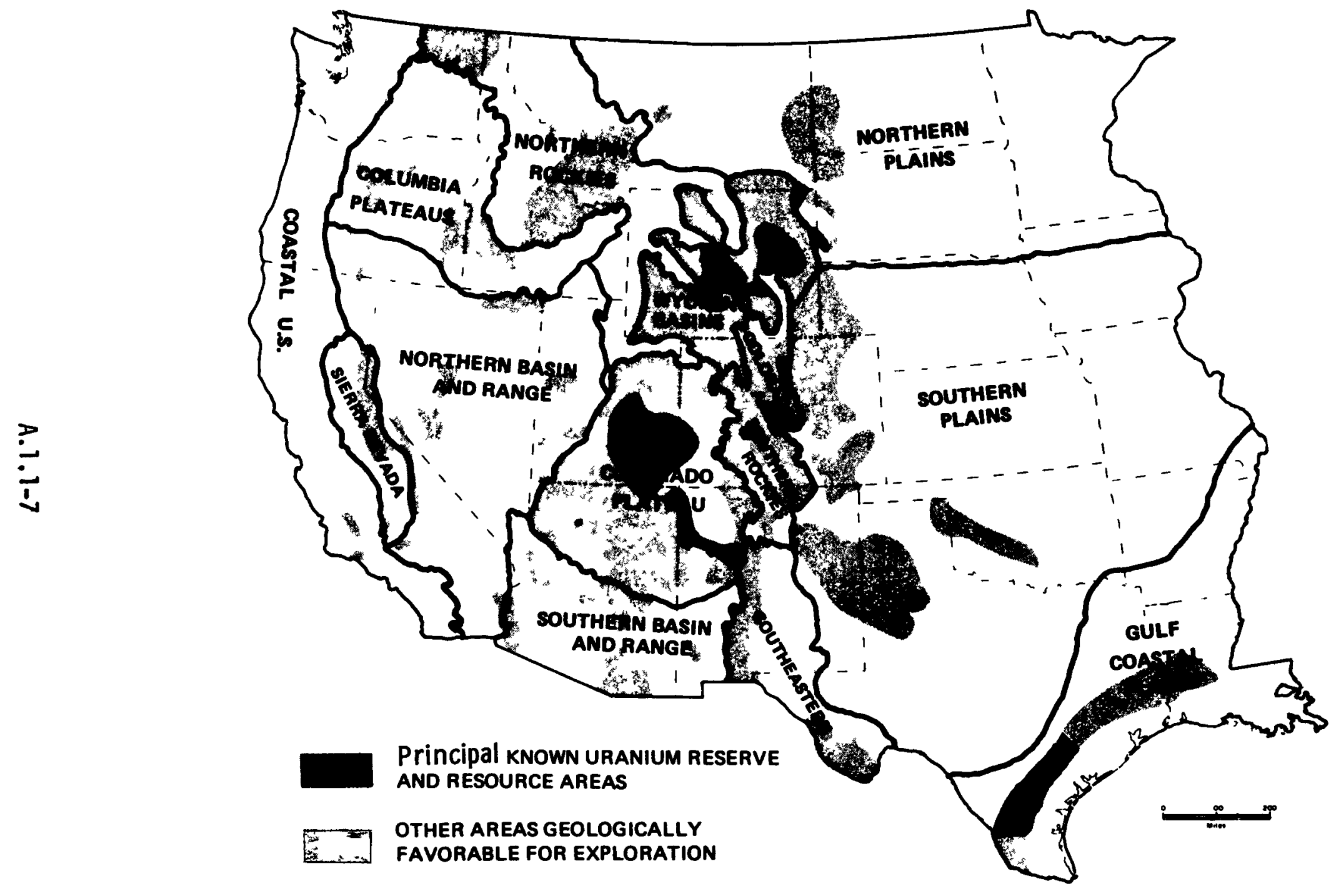

URANIUM RESOURCES IN WESTERN UNITED STATES

Figure A.I.I-2 


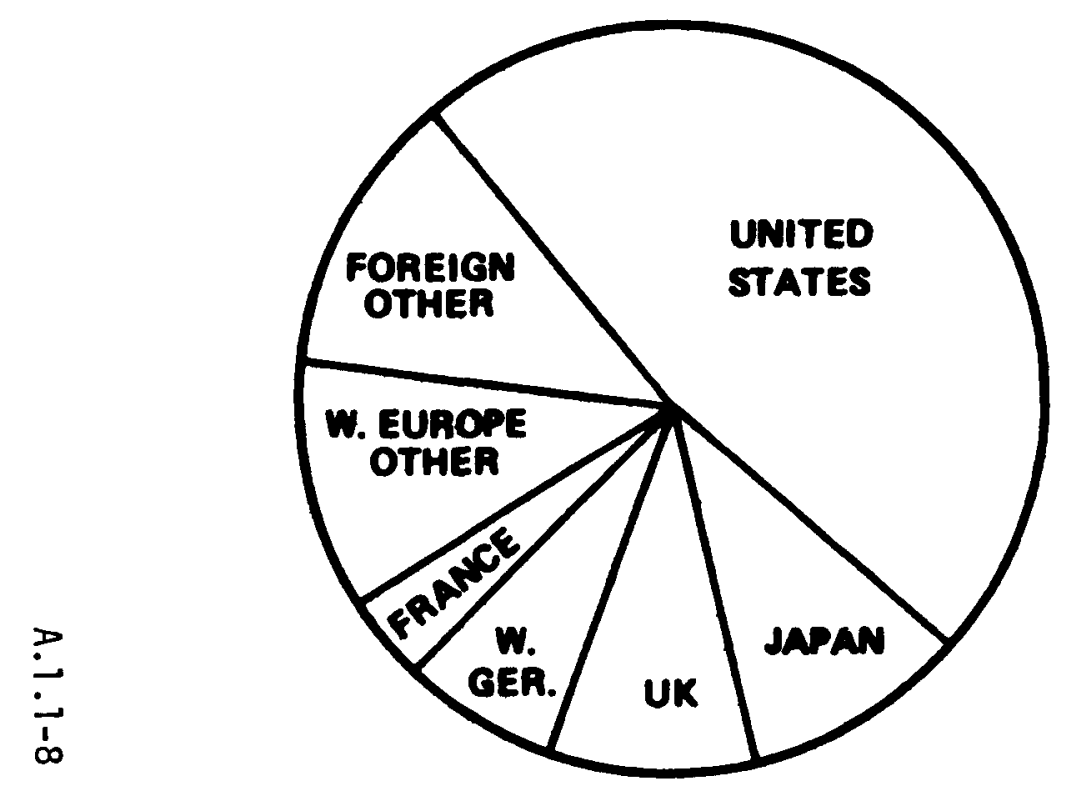

\begin{tabular}{|l|c|c|}
\hline \multicolumn{1}{|c|}{ REQUIREMENTS THRU 1906} & $\begin{array}{c}\text { THOUSAND } \\
\text { TONS } \mathrm{U}_{3} \mathrm{O}_{8}\end{array}$ & $x$ \\
\hline UNITED STATES & 474 & 47 \\
JAPAN & 106 & 10 \\
UNITED KINGDOM & 92 & 9 \\
WEST GERMANY & 65 & 7 \\
FRANCE & 40 & 4 \\
W. EUROPE OTHER & 107 & 11 \\
FOREIGN OTHER & .116 & 12 \\
\hline \multicolumn{1}{|c|}{ TOTAL } & $\underline{1.000}$ & $\frac{100}{}$ \\
\hline
\end{tabular}

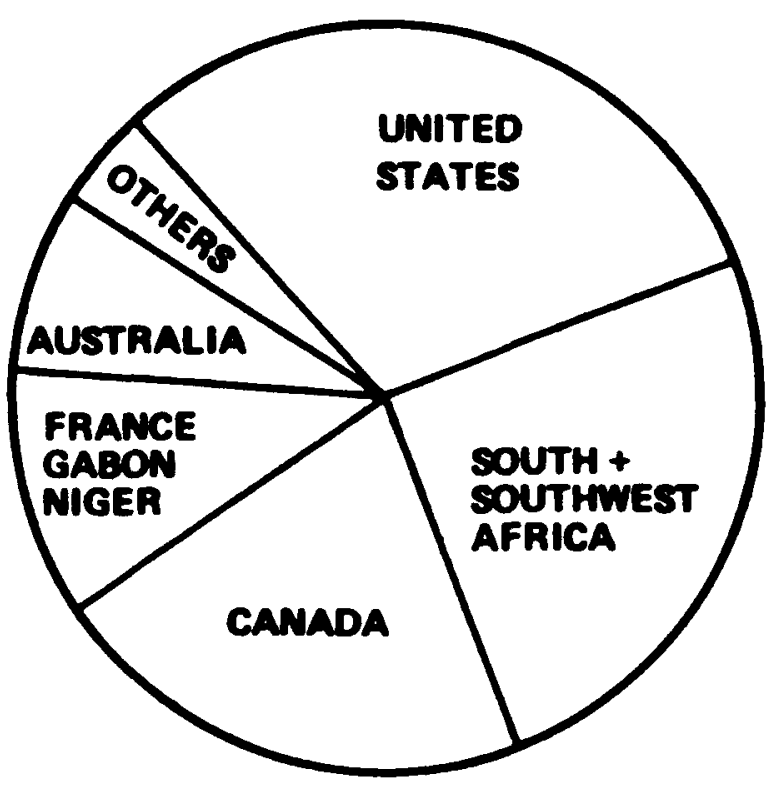

\begin{tabular}{|l|c|c|}
\hline \multicolumn{1}{|c|}{ AESERVES - $\$ 10 /$ LBU $_{3} \mathrm{O}_{8}$} & $\begin{array}{l}\text { THOUSAND } \\
\text { TONS }_{3} \mathrm{O}_{8}\end{array}$ & $\boldsymbol{*}$ \\
\hline UNITED STATES & 330 & 29 \\
SO. + SOUTHWEST AFRICA & 300 & 26 \\
CANADA & 236 & 20 \\
FRANCE, GABON, NIGER & 124 & 11 \\
AUSTRALIA & 92 & 8 \\
OTHERS & 68 & 6 \\
\hline \multicolumn{1}{|c|}{ TOTAL } & 1.150 & 100 \\
\hline
\end{tabular}

WORLD URANIUM REQUIREMENTS AND RESERVES ${ }^{6}$

Figure A.1.1-3 
following subsection and subsection 1.1.8). Thus, it is difficult to foresee to what extent foreign uranium will be available in the long run as a source for U.S. use. It seems unlikely, considering foreign demands, that the U.S. can rely on the availability of large amounts of foreign uranium.

\subsubsection{Estimated Availability and Consumption of Uranium}

Uranium requirements ${ }^{8}$ in the U.S. are currently about 14,000 tons of $\mathrm{U}_{3} \mathrm{O}_{3}$ per year (1974), and are expected to increase rapidly - to about 38,000 tons/yr by 1980 and 118,000 tons/yr by 1990. Current mining/ milling capacity in the U.S. is about 18,000 tons $U_{3}{ }_{8} / y r$., so that the mining/milling industry is facing a period of major growth. Enlargement of U.S. uranium resources will be necessary before this expansion in production will be possible. This will necessitate substantial capital investment in exploration several years in advance of production and construction of new mining and millina facilities. Between 1973 and 1990, the capital investment needed is estimated at $\$ 10$ billion, of which $\$ 6$ billion would be for exploration ${ }^{5}$. The need for substantial exploration stems from the following factors:

1. Ore reserves are far less than forecast requirements for the next few decades. The estimated potential listed in Table A.1.1-2 is yet to be discovered. Additional potential resources also must be identified. The potential resources listed in Table A.1.1-2 have been 
estimated by the AEC by comparing the characteristics of known deposits and their geologic environment to other similar geologic areas. While there is a reasonable expectation that the estimated quantities of ores exist in these areas and will be found, it will take time and effort to discover and delineate the deposits. Exploration effort in the U.S. the last few years has not expanded reserves significantly. (See Figure A.1.1-4). Increased efforts will be needed in the future to maintain a satisfactory resource base.

2. As a practical matter, ore reserves at any time should be equal to at least the following 8 years' requirements. Eight years is the approximate lead time between initiation of exploration and initial production of $\mathrm{U}_{3} \mathrm{O}_{8}$. A reserve base is necessary for justification of investment in mines and mills, for amortization of capital and for contracting for sale of products. About one million tons of $\mathrm{U}_{3} \mathrm{O}_{8}$ must be produced to satisfy requirements between the beginning of 1974 and the end of 1990. An eight-year reserve at that time would be about 1.1 million tons.

Today, there is about a 10-year forward reserve ${ }^{6}$ of $\mathrm{U}_{3} \mathrm{O}_{8}$ in the $\$ 8 / 1$ b. category in the U.S. The practically-achievable production from ore reserves and estimated potential $\$ 8 / 1 \mathrm{~b}$. resources would evidently fall behind demand in the early 1980's. To keep up with 


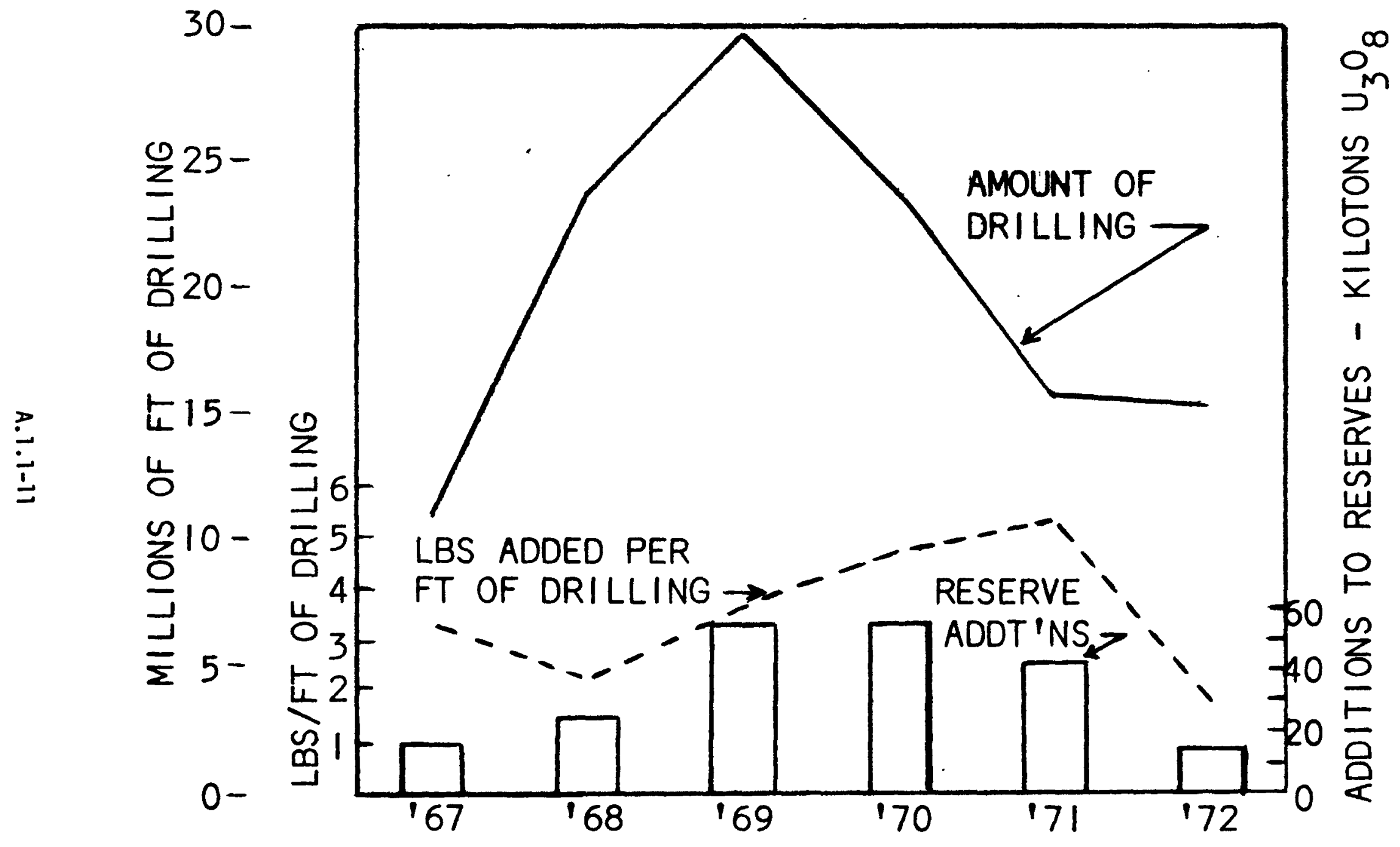

ORILLING ${ }^{6}$, RESERVE ADDITIONS AND DISCOVERY RATES*

*At up to $\$ 8 / 1 \mathrm{~b} \quad \mathrm{U}_{3} \mathrm{O}_{8}$

Figure A.1.1-4 
requirements beyond that time, will require discovery of additional resources or production from progressively higher cost and lower grade conventional ores, and/or use of non-conventional ores.

Exploration is not complete in known uranium areas and, as suggested in Figure A.1.1-2, there are areas in the U.S. which appear geologically worth uranium exploration. It is reasonable to expect that exploration in these areas will reveal some additional supplies of conventional ores, but there is no current basis for estimating what quantities may exist. The AEC has initiated a geolonical assessment program $^{6}$ of the entire country to evaluate more reliably the longrange prospects for U.S. uranium supply.

\subsubsection{Technical Description of LWR Systems}

The various nuclear fuel steps required for the operation of LWRs, from the mining of the uranium ore to the ultimate disposal of wastes, are known as the nuclear fuel cycle. ${ }^{9,10}$ These steps consist of: (1) mining the ore; (2) treatment of the ore to obtain a uranium concentrate; (3) conversion of the concentrate to a chemical form suitable for enrichment; (4) enrichment in gaseous diffusion plants; (5) conversion of the enriched product to a chemical form suitable for fuel; (6) fabrication of fuel; (7) use of fuel in power plant; (8) annual removal of a portion of spent fuel from power plant and storage for about 5 months; (9) shipment of spent fuel to a reprocessing plant; (10) reprocessing of spent fuel and recycle of recovered uranium to enrichment plant or to 
storage, recycle of recovered plutonium to fuel fabrication or to storage; (11) treatment of radioactive wastes for disposal; and (12) packaging and shipment of low-level radioactive wastes for burial and solidification, packaging and shipment of high-level wastes to a Federal repository.

Descriptions of these various steps are necessarily brief and conceptual in this document, but detailed technical descriptions are available in cited references.

\subsubsection{LWR Fuel}

Fuel for commercial LWRs is derived from naturally-occurring uranium which is made up of the isotopes: U-238 (99.284\%), U-235 (0.711\%) and U-234 $(0.005 \%)$. For use in LWR fuel, natural uranium must be enriched in its U-235 content such that U-235 constitutes about 3\% of the enriched product. An isotope enrichment process known as the gaseous diffusion process is used for this purpose. The fuel used in LWRs, therefore contains a mixture of about $3 \% \mathrm{U}-235$ atoms and $97 \% \mathrm{U}-238$ atoms, both in the form of uranium dioxide $\left(\mathrm{UO}_{2}\right)^{*}$ pellets encased (clad) in either stainless steel or zirconium alloy (zircaloy) tubing (See Fig. A.1.1-5). The fuel pellets are riaht

cylinders usually about one-half inch long with the diameter varying from about $3 / 8$ inch to over $1 / 2$ inch, depending on reactor core

*Prior to LMFBR operation, an appreciable fraction of the fuel in some replacement fuel cores will contain plutonium ( $\mathrm{PuO}_{2}$ in place of the U-235 oxide) in a mixed oxide, $\mathrm{UO}_{2} / \mathrm{PuO}_{2}$, pellet. 


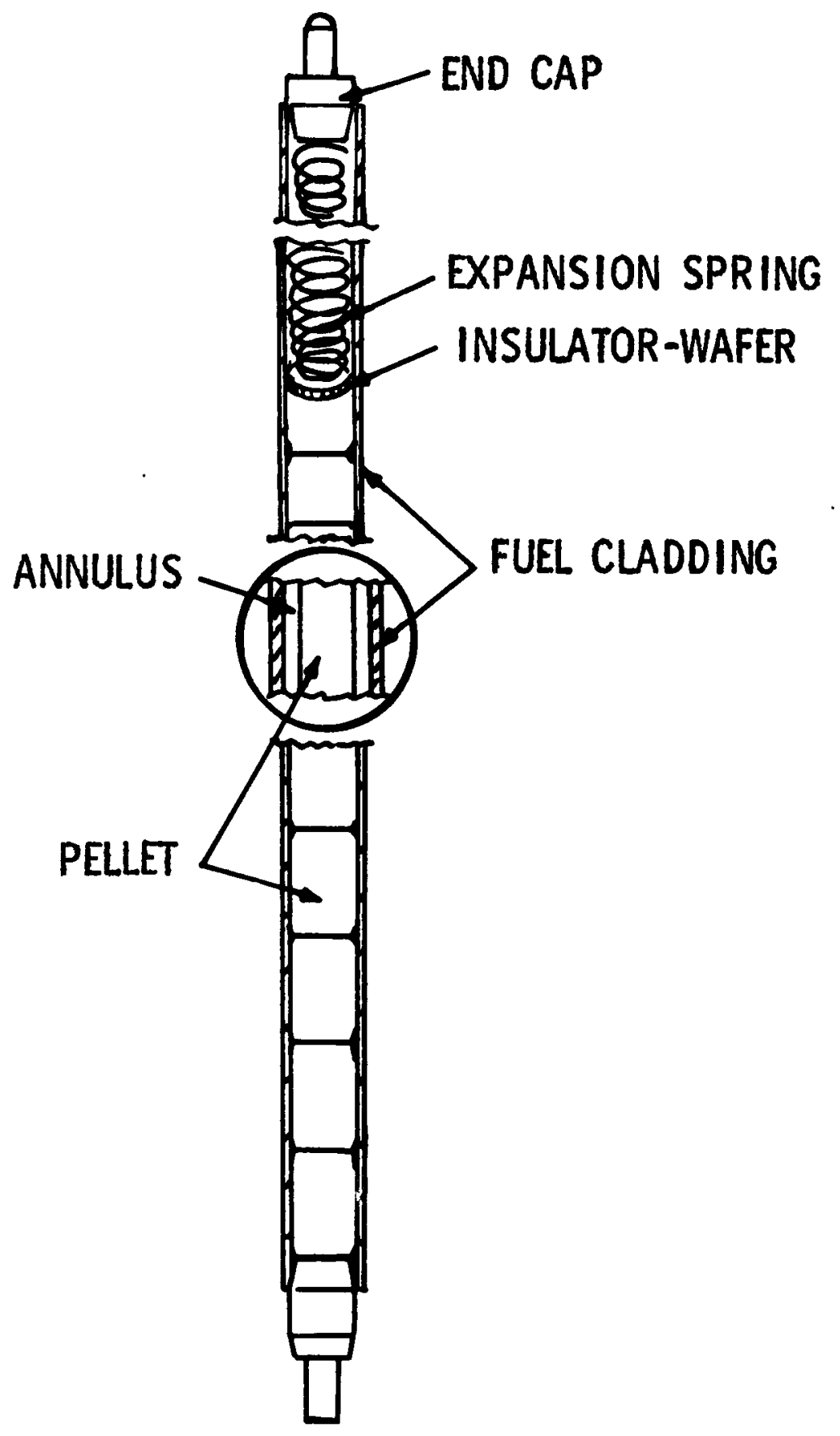

CUTAWAY OF OXIDE FUEL FOR

COMMERCIAL LWR POWER PLANT

Figure A.1.1-5 
design', ground to close dimensional tolerances. The voids in the fuel rod, especially the annulus (0.003" to 0.005 " diametral gap) between the pellet and the cladding, are filled with helium under varying degrees of pressure, commensurate with the anticipated range of external pressure forces during reactor operation.

Completed rods are inspected and assembled into fuel bundles. When inserted in the pressure vessel of an LWR along with associated control rods and structures, the fuel assemblies (bundles) collectively are called the nuclear core of the reactor.

Large PWR and BWR plants typically employ partial refueling annually; in BWRs, about $1 / 4$ of the fuel assemblies are removed and replaced with fresh fuel each year, while in PWRs about $1 / 3$ of the assemblies are replaced annually. Spent fuel assemblies are stored under water at the power plant for a period of 5-6 months prior to shipment to a fuel reprocessing plant.

\subsubsection{Nuclear Steam Supply Systems (NSSS)}

\subsection{BWR Description?}

The nuclear steam supply system of a BWR consists primarily of the reactor vessel and equipment inside the vessel. (See Figures A.1.1-6 and -7 ). The nuclear fuel assemblies are arranged inside a core shroud in the reactor vessel. Water boils in the core and a mixture of steam and water flows out the top of the core and through steam separators at the top of the core shroud. Steam from the 


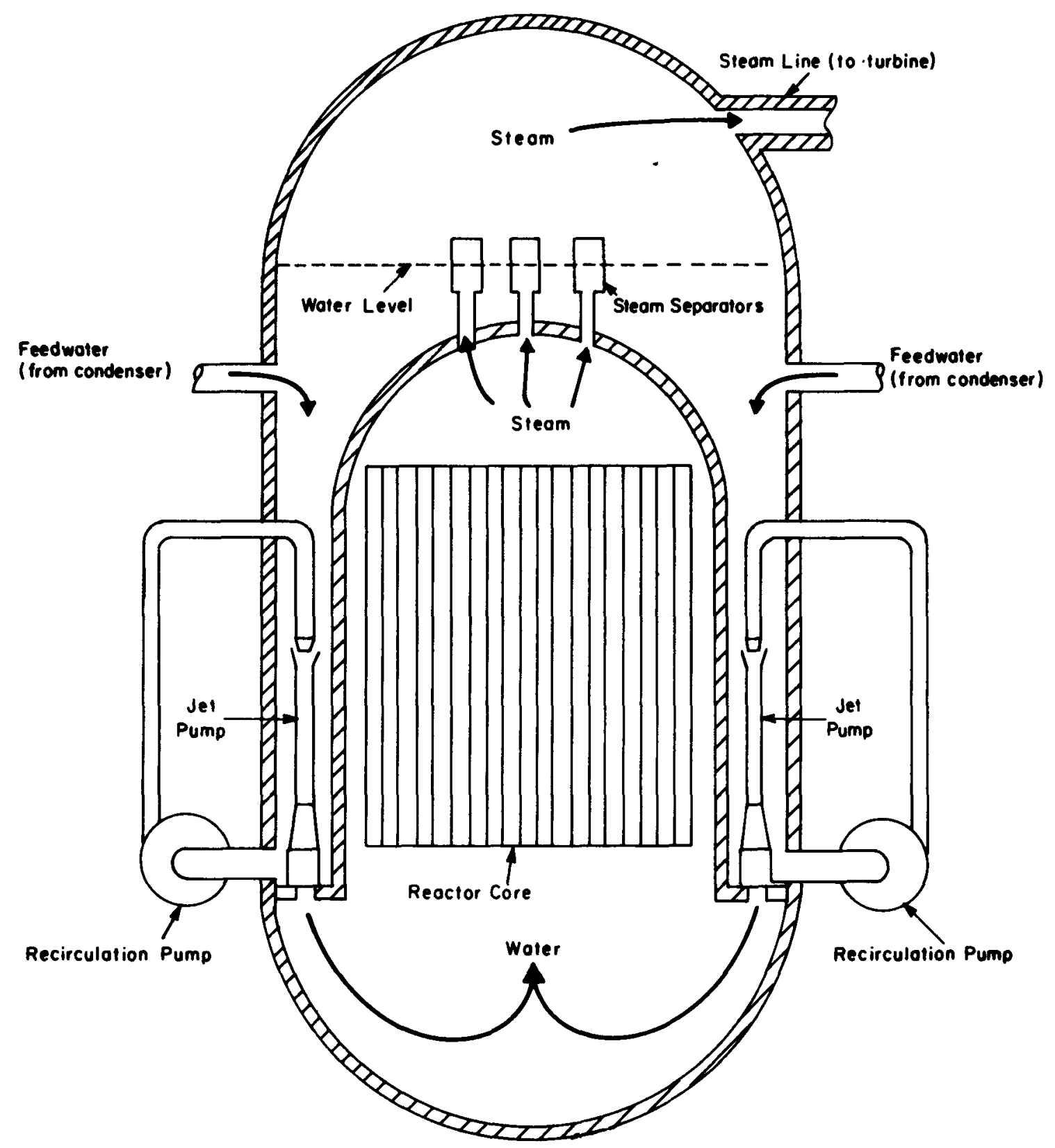

SCHEMATIC ARRANGEMENT OF BWR NSSS

Figure A.1.1-6 


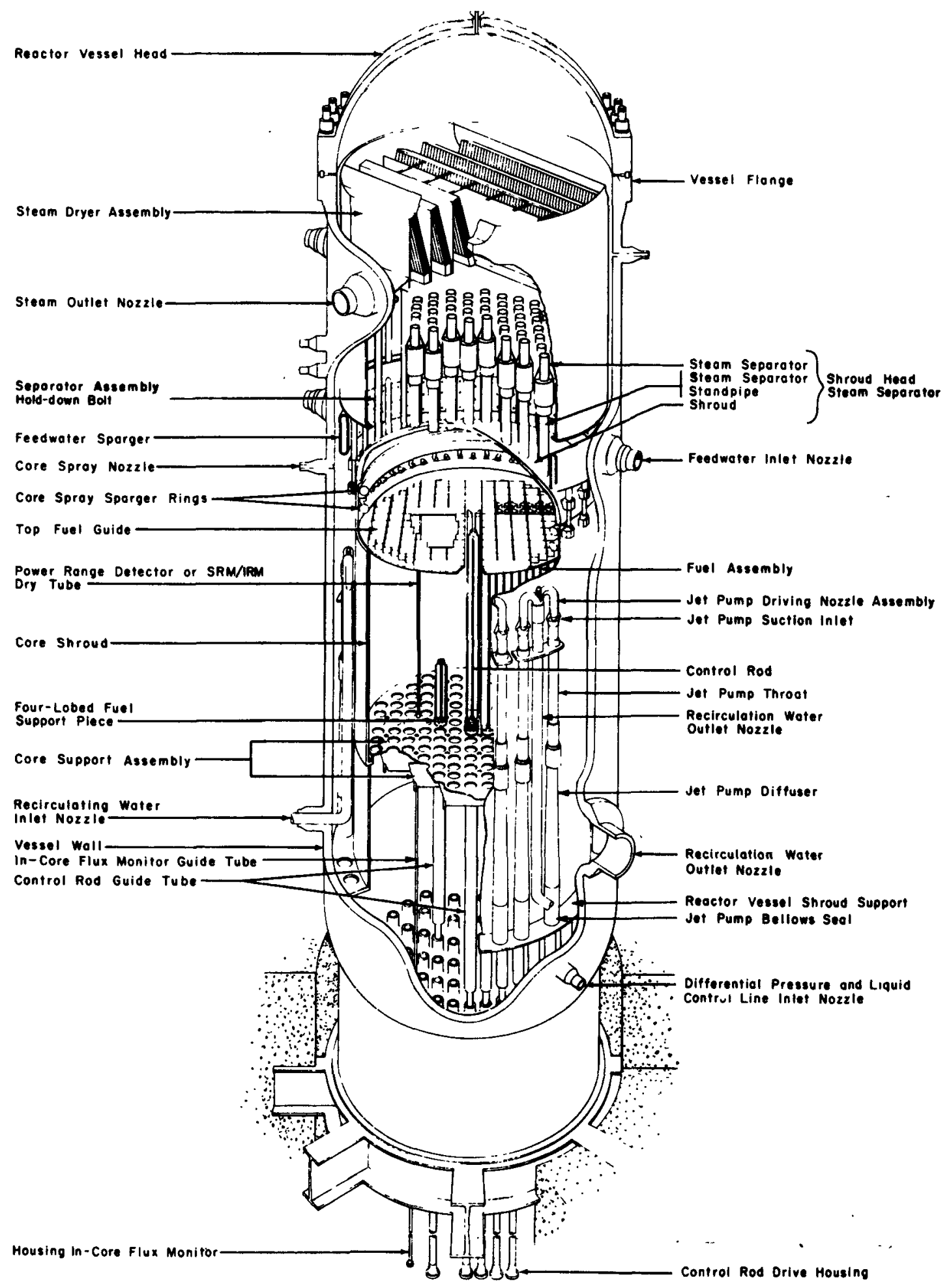

CUTAWAY VIEW OF INTERINALS OF TYPICAL BWR VESSEL

Figure A.1.1-7 
separators passes through dryers to remove all but traces of entrained water and then leaves the reactor vessel through pipes to the turbine generator. Water from the steam separators and water returned from the turbine condenser mix, flow downward through the annulus between the core shroud and the reactor vessel and return to the bottom of the core. Because the energy supplied to the reactor coolant (water) from the hot fuel is transported directly (as steam) to the turbine, the BWR system is termed a "direct cycle" system. The pressure in a typical BWR is maintained at about 1000 pounds per square inch (psi); at this pressure water boils and forms steam at about $545^{\circ} \mathrm{F}$.

Details of the reactor vessel and internals for a typical BWR are shown in Fig. A.1.1-7. Steam flows from the reactor vessel to the turbine-generator in multiple main steam lines. The head of the vessel and the steam separators and dryers are removable for refueling the core. Neutron-absorbing control and safety elements in the reactor core are connected to rods that pass through fittings in the bottom head of the vessel and are operated by hydraulic drives mounted below the vessel. Because the reactor heat output is sensitive to the rate-of-flow of coolant through the core, partial control of the power is effected by varying the driving flow to the pumps that can recirculate some of the water through the core.

Sixty-four fuel rods ( 49 rods in older models, as shown in Fig. A.1.1-8) are installed in a metal channel of square cross section to form a fuel assembly. The channel is open at the top and bottom to 


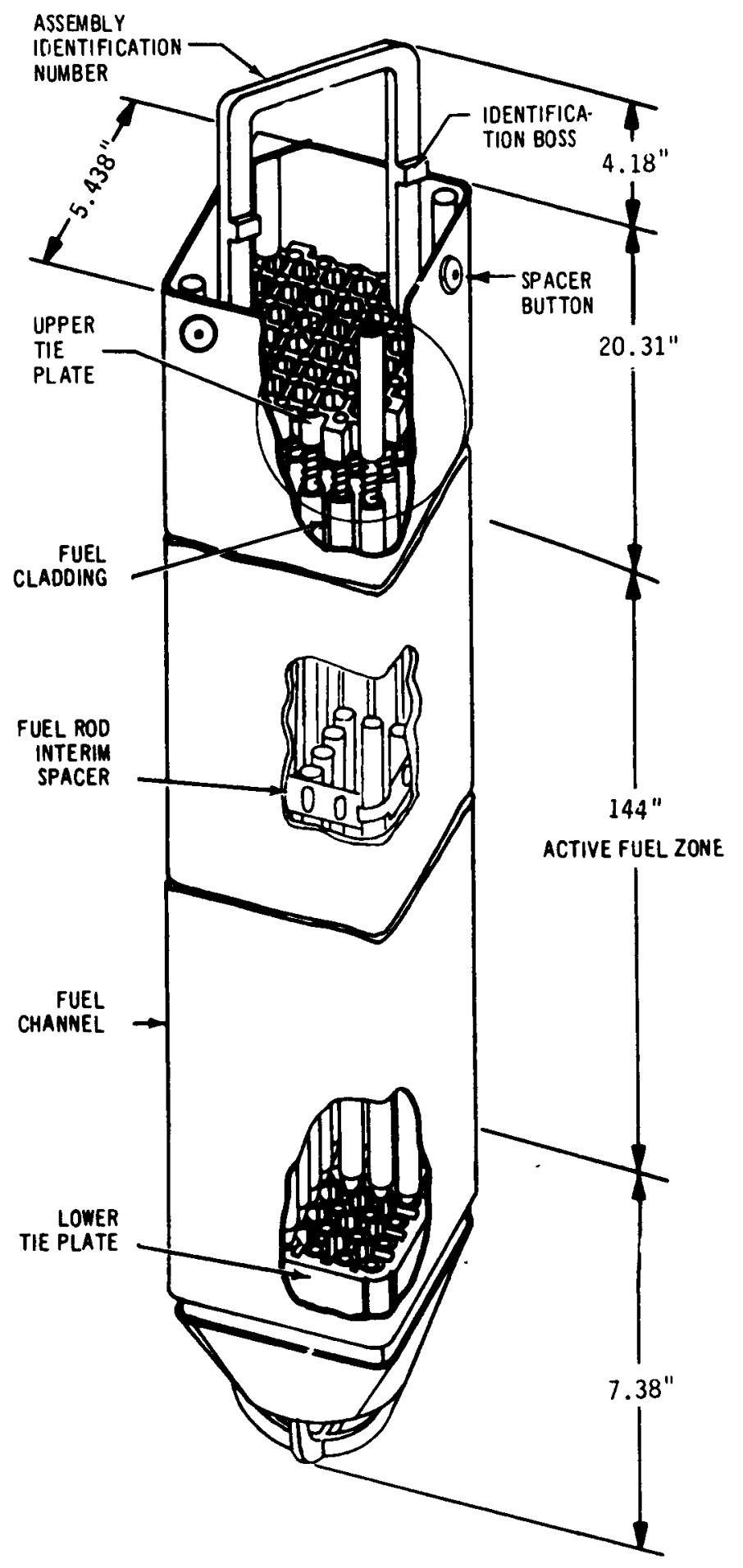

BWR FUEL ASSEMBLY

Figure A.1.1-8

A.1.1-19 
permit coolant to flow upward through the assembly; however, the closed sides prevent lateral flow of coolant between adjacent assemblies in the reactor core. The core of a large BWR of current design may contain as many as 764 fuel assemblies (at 64 rods per assembiy this is almost 49,000 fuel rods per reactor) with a total weight of uranium dioxide of more than $372,000 \mathrm{lb}$.

The amount of heat that can be extracted from a BWR core of a given size depends, among other things, on the rate of recirculation of water through the core. In current BWRs, jet pumps are provided in the annulus outside the core shroud to greatly increase the circulation rate over the natural circulation induced by the boiling in the core. The arrangement of the nuclear steam supply system is shown schematically in Fig. A.1.1-6. BWRs have multiple provisions for cooling the core fuel in the event of an unplanned depressurization or loss-of-coolant from the reactor. The provisions may differ from plant to plant, but all plants have several independent systems ${ }^{1}$ to achieve flooding and/or spraying of the reactor core with coolant upon receiving a signal of efther high drywell pressure or low reactor vessel water level. Typical emergency core cooling systems involve either a high-pressure core spray system (early BWRs) or both core sprays and a high-pressure coolant-injection system (latest BWRs) to assure adequate cooling of the core in the event of a leak that results in depressurization of the reactor system. 
Containment systems of BWRs generally provide both "primary" and "secondary" containment. For current applications, the former is a steel pressure vessel surrounded by reinforced concrete and designed to withstand peak transient pressures which might occur in the most severe of the postulated, though unlikely, loss-of-coolant accidents. This primary containment employs a "drywel1", enclosing the entire reactor vessel and its recirculation pumps and piping. It is connected through large ducts to a lower-level pressure-suppression chamber which stores a large pool of water as shown schematically in Figure A.1.1-9. Under accident conditions, valves in the main steam lines from the reactor to the turbine-generators would automatically close, and any steam escaping from the reactor system would be released entirely within the drywell. The resulting increase in drywe 11 pressure would force the air-steam mixture in the drywell down into and through the water in the pressure-suppression chamber, where the steam would be completely condensed. Steam released through the pressure-relief valves of the automatic depressurization system also would be condensed in the pressure-suppression pool, and this pool serves as a potential source of water for the emergency core cooling system. Systems ${ }^{1}$ for the control of combustible gases from metal-water reactions and radiolytic decomposition of the water are also provided to assure that flammable concentrations are not reached in the containment.

The secondary containment system is the reactor building which houses the reactor and its primary containment system; a typical on-line 
N

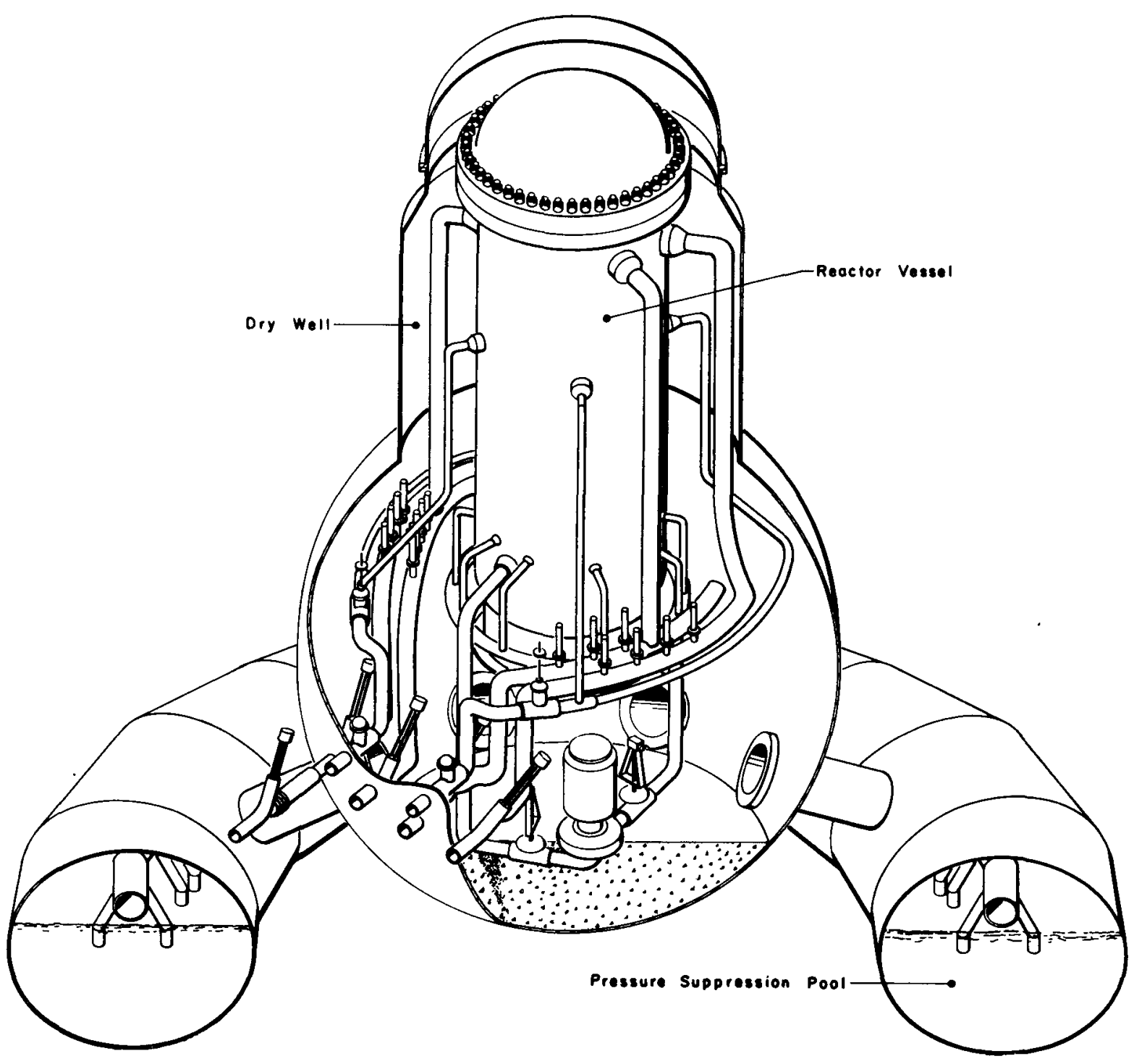

SCHEMATIC ARRAITGEMENT OF BWR PRIMARY CONTAINMENT SYSTEM

Figure A.1.1-9 


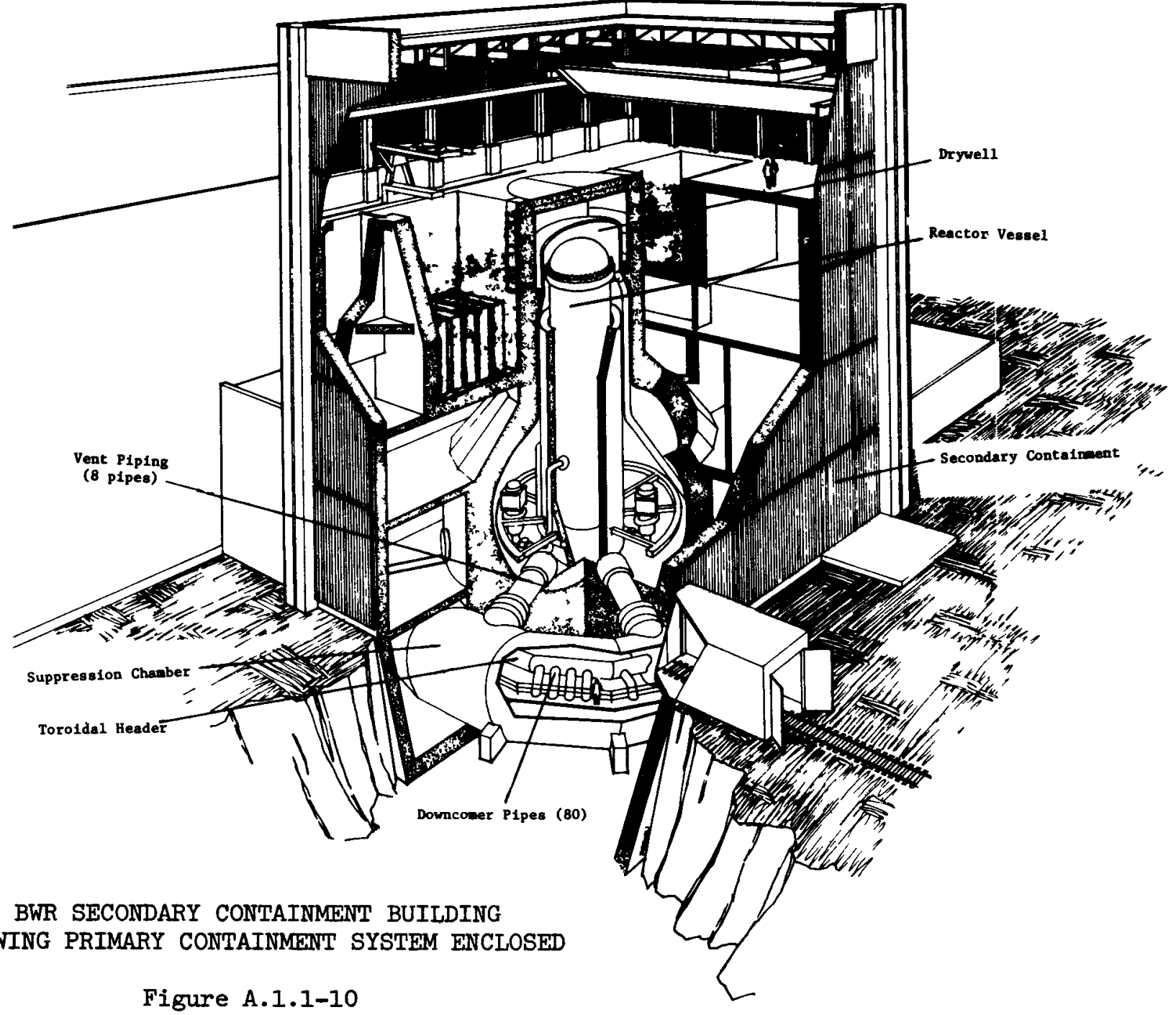


system appears in Figure A.1.1-10 and a schematic for the most advanced plants is shown in Figure A.1.1-11. The buildings, substructures and exterior walls up to a level above the top of the drywell are of poured-in-place reinforced concrete. The secondary containment of operating BWR plants is designed for low leakage, and has sealed joints and interlocked double-door entries. Under postulated accident conditions, the normal building ventilation system automatically would shut down and the buildina would be exhaust-ventilated (so as to maintain a slight negative pressure therein) by two parallel standby systems which discharge through the plant stack or roof exhaust system, to minimize ground-level exfiltration possibilities. The effluent gas passes through treatment systems which include high-efficiency particulate air (HEPA) filters and solid adsorbents for trapping radioactive halogens, particularly iodine, that might have leaked from the primary containment.

The most advanced BWR plants use a separate free-standing leaktight containment shell inside of a sealed building (see Figure A.1.1-11) which provides a further barrier to the escape of gaseous effluents, as well as a shielding to further reduce the escape of radiation emanating from the reactor proper.

\subsection{PWR Description'}

Unlike the direct in-vessel boiling of BWRs, all PWRs employ dual coolant systems for transferring energy from the reactor fuel to the turbine and are called "indirect cycle" systems. The highpressure circuit comprising the reactor vessel, piping, the necessary 


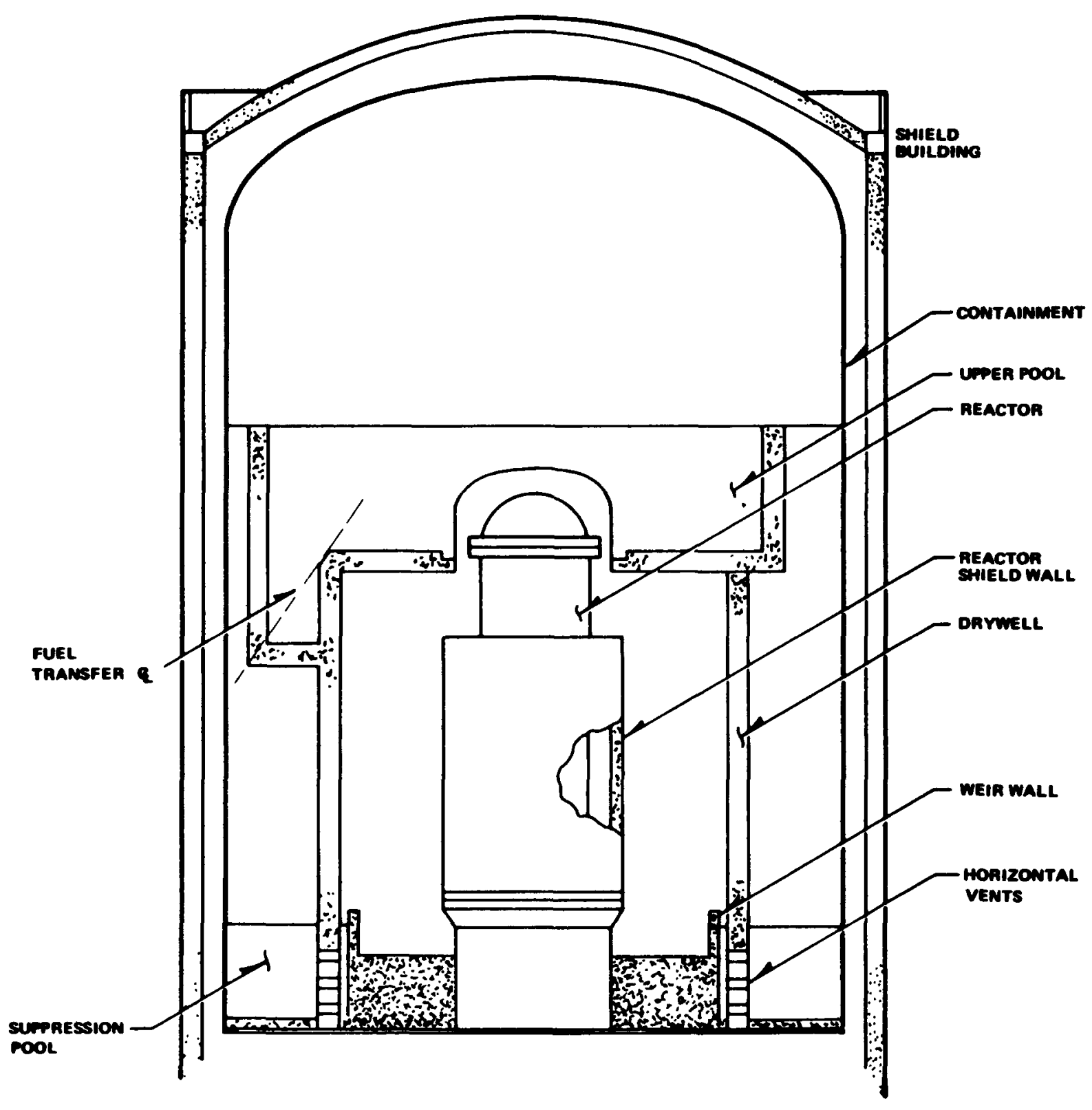

MULTIPLE CONTAINMENT SYSTEM

FOR RECENT IARGE BWR PLANTS

Figure A.1.1-11 
pumps and the inner tube-side of the steam generators is termed the "primary system"; the lower pressure circuit is called the "secondary system." (A schematic arrangement of a 1000 MHe PWR system, with four steam generators and one or two pumps for each steam generator, is shown in Figure A.1.1-12.)

The pressure maintained in a typical large PUR system, about 2250 pounds per square inch (psi), permits water to be heated to about $650^{\circ} \mathrm{F}$ without boiling. The high-pressure water, heated to an average temperature of around $600^{\circ} \mathrm{F}$, is piped out of the reactor vessel into two or more "steam generators." Heat from the highpressure reactor coolant water is transferred through heat exchanger tubes into a secondary stream of water, at considerably lower pressure and temperature than the former, and causes the water of the secondary stream to boil and produce steam for the turbine.

A cutaway view of a typical PWR reactor vessel and its internals is shown in Figure A,1,1-13. The vessels have removable top heads (for refueling) provided with fittings to accormodate the mechanisms for driving neutron-absorbing rods into and out of the core, to control the nuclear chain reaction. Additional control of the chain reaction is provided through the use of variable-concentration neutronabsorbing chemicals, such as boric acid, dissolved in the primary system coolant. 


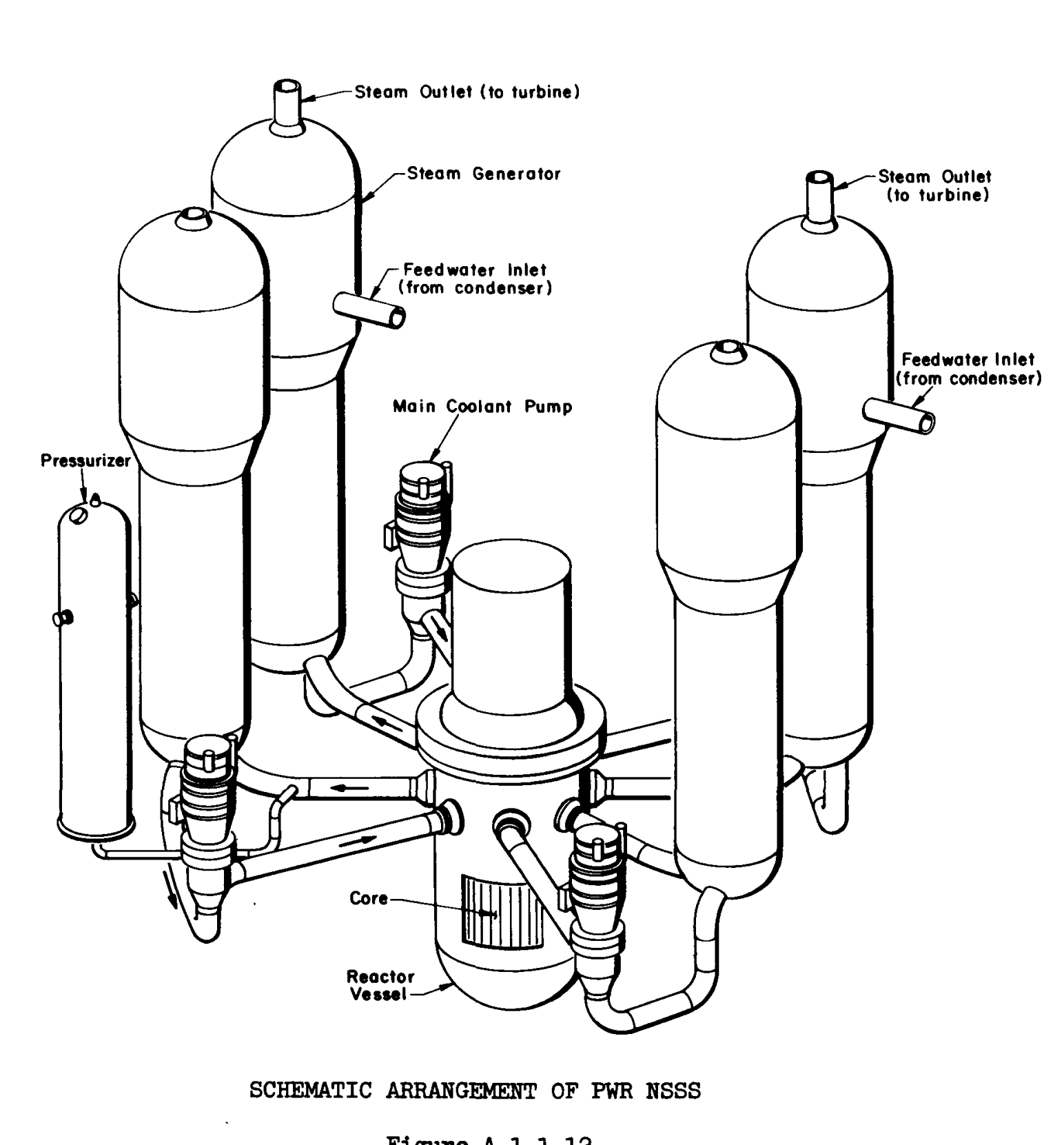




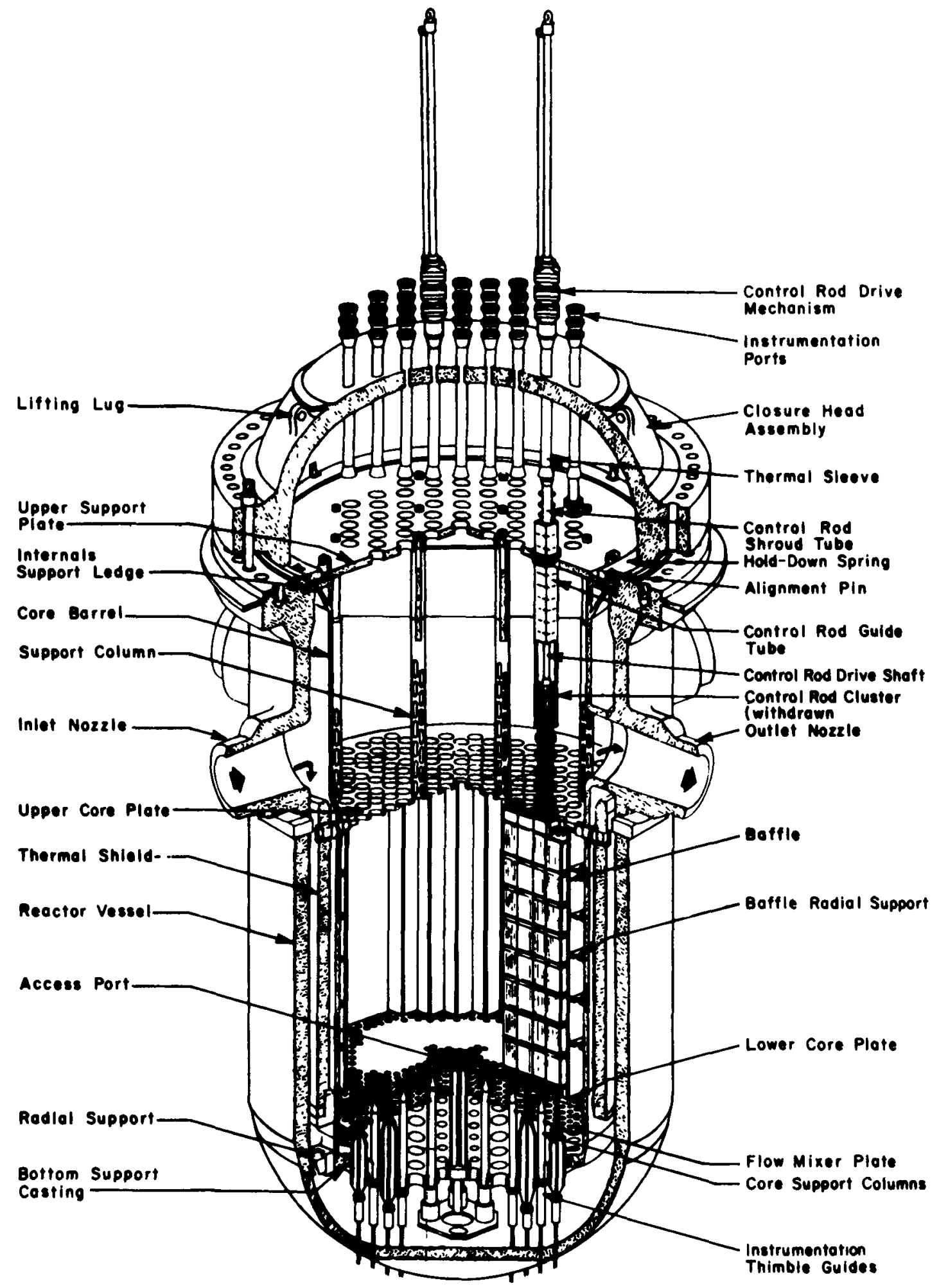

CUTAWAY VIEW OF INTERNALS OF TYPICAL PWR VESSEL

Figure A.1.1-13 
The core of a large PWR contains nearly 40,000 fuel rods, totaling about 100 tons of slightly-enriched uranium dioxide. For current PWRs, 176 to 264 fuel rods are assembled into a bundle of square cross-section which normally is about $8-1 / 2$ inches on a side. PWR fuel assemblies are not surrounded by a channel, but are relatively open arrays which permit some radial mixing of coolant (see figure A.1.1-14).

The PWR plant circulates the primary coolant through large conventional heat exchangers. The high-performance primary-coolant pumps are designed to operate at $650^{\circ} \mathrm{F}$ at pressures up to 2500 pounds per square inch and are manufactured to stringent specifications.

PWR steam supply systems are equipped with pressurizers' (see Figure $A .1 .1-12$ ) to maintain required primary coolant pressure during steady-state operation, to limit pressure changes caused by coolant thermal expansion and contraction as plant loads change, and to prevent coolant pressure from exceeding the design pressure of the entire primary system. Like the reactor vesse1, the steam generators, the pumps and all other parts of the primary system, the pressurizer is also located in the containment.

The major function of the emergency core cooling system of a PWR is to supply sufficient water to cool the core in the event of a break that permits water to leak from the primary system. The break most probably would be very small but accommodation of the effects of 


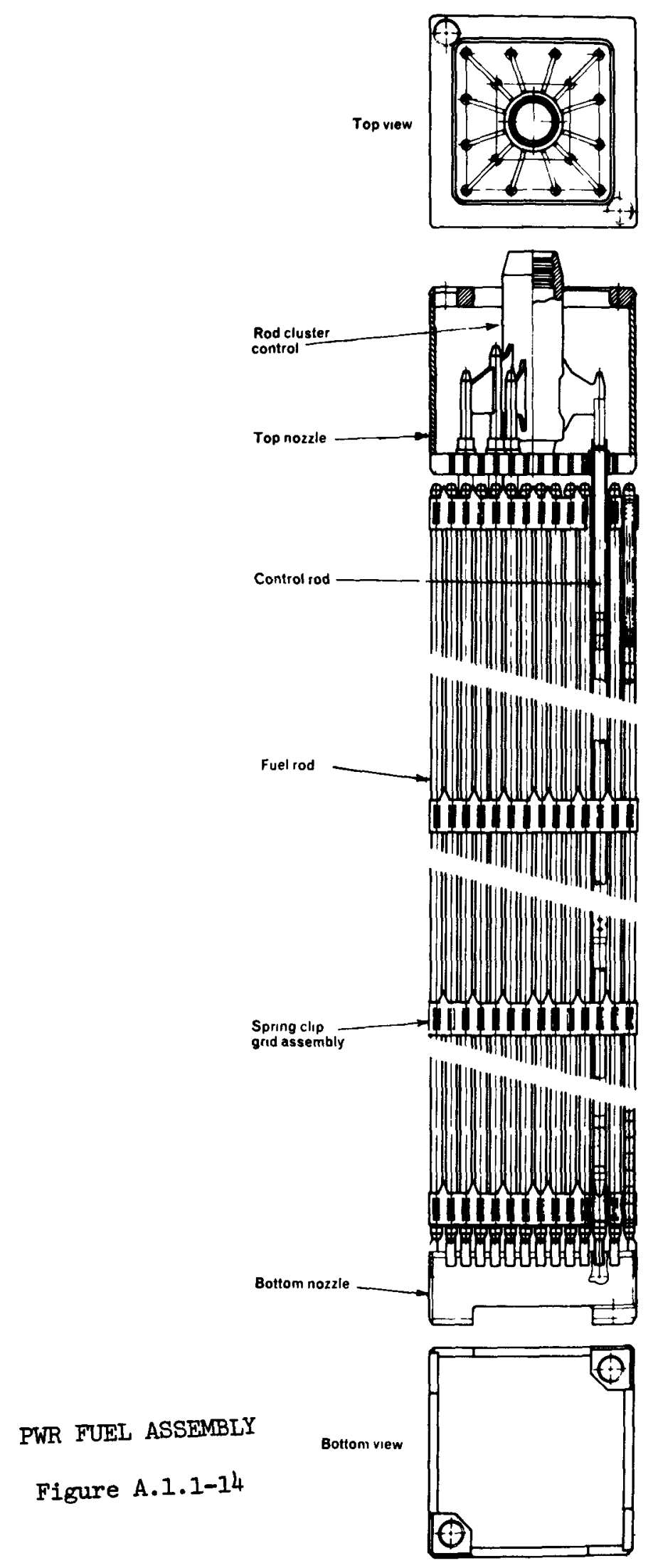

A. $1.1-30$ 
rupture of the largest coolant pipe in the system is a design requirement. PWR emergency core cooling systems ${ }^{11}$ consist of several independent subsystems, each characterized by redundancy of equipment and flow path. This redundancy assures reliability of operation and continued core cooling even in the event of failure of any single component to carry out its design functions. Although the arrangements and designs of PWR emergency core cooling systems vary from plant to plant, depending on the vendor of the steam supply system, all modern PWR plants employ both accumulator injection systems and pump injection systems, with redundancy of equipment to assure operation.

More detailed discussions of design considerations for specific safety systems, practices for assuring safety and analyses of hypothetical accident sequences are presented in References $I$ and 12 .

Most present-day PWR containments are constructed of reinforced concrete with a steel liner (see Figure A.1.1-15). All are sized and designed to withstand the maximum temperature and pressure that would be expected from the steam produced if all the water in the primary system were expelled into the containment. Refinements in containment technology are still being made and containment systems vary widely from plant to plant. For example, in some PWR plants, the containment space is kept at slightly below atmospheric pressure so that leakage through the containment walls would, at most times, be inward from the surroundings. Other systems have double barriers against escape of material from the containment space. 


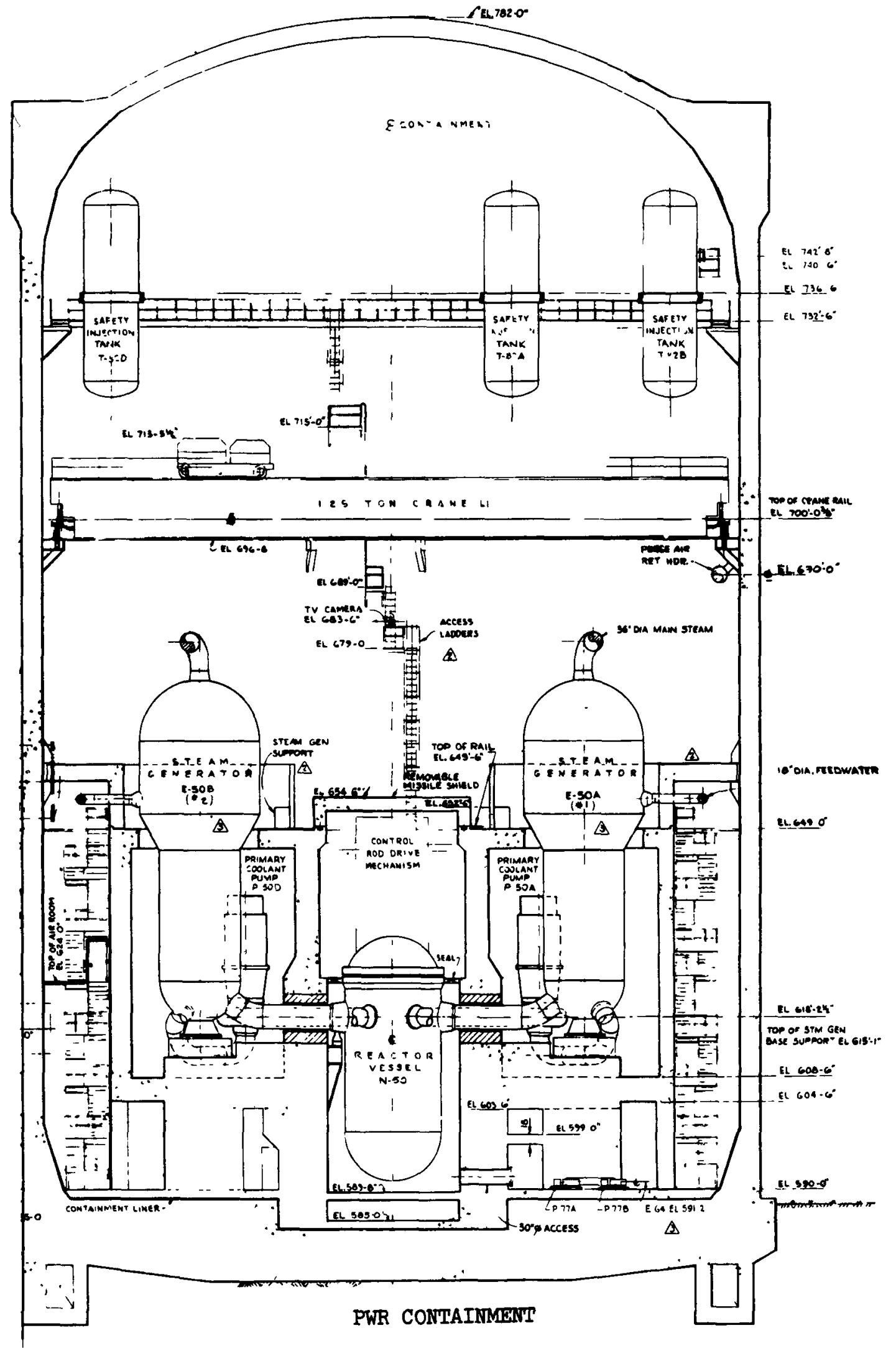

Figure A.1.1-15

A. 1.1-32 
Two kinds of additional measures are taken in PWR plants to minimize the potential for escape to the environment of any accidental release of radioactive materiais. In some plants, cold-water sprays are provided to condense the steam resulting from a major escape of primary system coolant into the containment; in other plants, storedice is used for this purpose. By condensing the steam, and thus lowering the containment pressure, the driving force for outward leakage is reduced. Another safety measure provides blowers to recirculate containment atmosphere through filters and absorption beds, to remove airborne radioactive materials. When sprays are used in the containment, chemicals are usually added to the spray solution to increase the retention of airborne radioactive materials that dissolve in and become entrained by the spray. Systems for the control of hydrogen from both metal-water reactions and radiolytic decomposition of the water are also provided to assure that flammable concentrations are not reached in the containment?

\subsection{Effluent Treatment Systems 10}

Nuclear power plants require equipment for the control of radioactive material, wherever it may be encountered in the plant (outside of the fuel rods). Small quantities of radioactive and nonradioactive gases as well as soluble and insoluble solids are formed in the primary coolant system by neutron activation and corrosion; additional quantities may enter the primary system from leaks in the fuel cladding. Some of these radioactive materials may enter the liquid wastes from the primary coolant system through small leaks 
that may develop in the equipment used to purify the coolant. Gases that must be withdrawn from the coolant loop are diverted to off-gas systems. Additional leakage from fuels with failed cladding can occur during refueling operations or during storage of the spent fuel under water in canals.

The atmospheres in the reactor containment and fuel storage areas, and in other areas where the leakage of radioactive gases may be expected, generally are monitored and the gases passed through charcoal adsorbers and filters to remove radioactive materials, if necessary, prior to the controlled release of the gases, although this was not always done in the earlier commercial plants. Other gaseous effluents, such as the large volumes of reactor and turbine building air, generally are monitored and discharged directly to the atmosphere at roof level. All plant liquid wastes, including that from laundry and showers, are monitored and treated as necessary, before release to the environment.

Conventional waste treatment systems at recently-built BWR and PWR ${ }^{12}$ plants are designed to concentrate and contain radioactive materials by means of filtration and holdup for gases and by demineralization, filtration, and evaporation for liquids.

The amount of radioactive gaseous materials released to the environment can be significantly reduced by storing the gases for a sufficiently long period of time to allow the short-lived radionuclides 
to decay to very low levels. This is accomplished at BWR plants (see Figure A.1.1-16) by retaining the gases for a minimum of 30 $\min$ in large holdup pipes or by adsorbing the radioactive gases on large charcoal beds for periods of approximately $16 \mathrm{hr}$ for radioactive krypton and 9 days for radioactive xenon. At PWR plants (see Figure $A .1 .1-17$ ), the gases from the primary coolant are retained in storage tanks for 30 to 60 days before release.

The waste treatment methods described above do not remove tritium from water; in fact, there is no economical method for separating waste tritium from water, today. In both PWRs and BWRs, any of the primary coolant water which leaves the primary system is collected, purified by demineralization or evaporation, and most of the water is recycled back to the primary coolant system. Since tritium is not separated from the water by such treatment, it remains in the primary coolant inventory. Some waste waters leak from, or are withdrawn from this system; consequently, small amounts of tritium may be discharged from the reactors in these waste waters. Some recent reactor system (plant design and operating procedures) concepts have proposed to recycle all liquids and provide for containment of all primary-system gases (with selective retention of radioactive gases until the radiological hazard has decayed to acceptable levels).

\subsubsection{Out-of-Reactor Fuel Cycle Operations}

The out-of-reactor fuel cycle operations ${ }^{9}$ include: both undergroundand pit-mining of uranium ores; uranium milling to concentrate uranium 


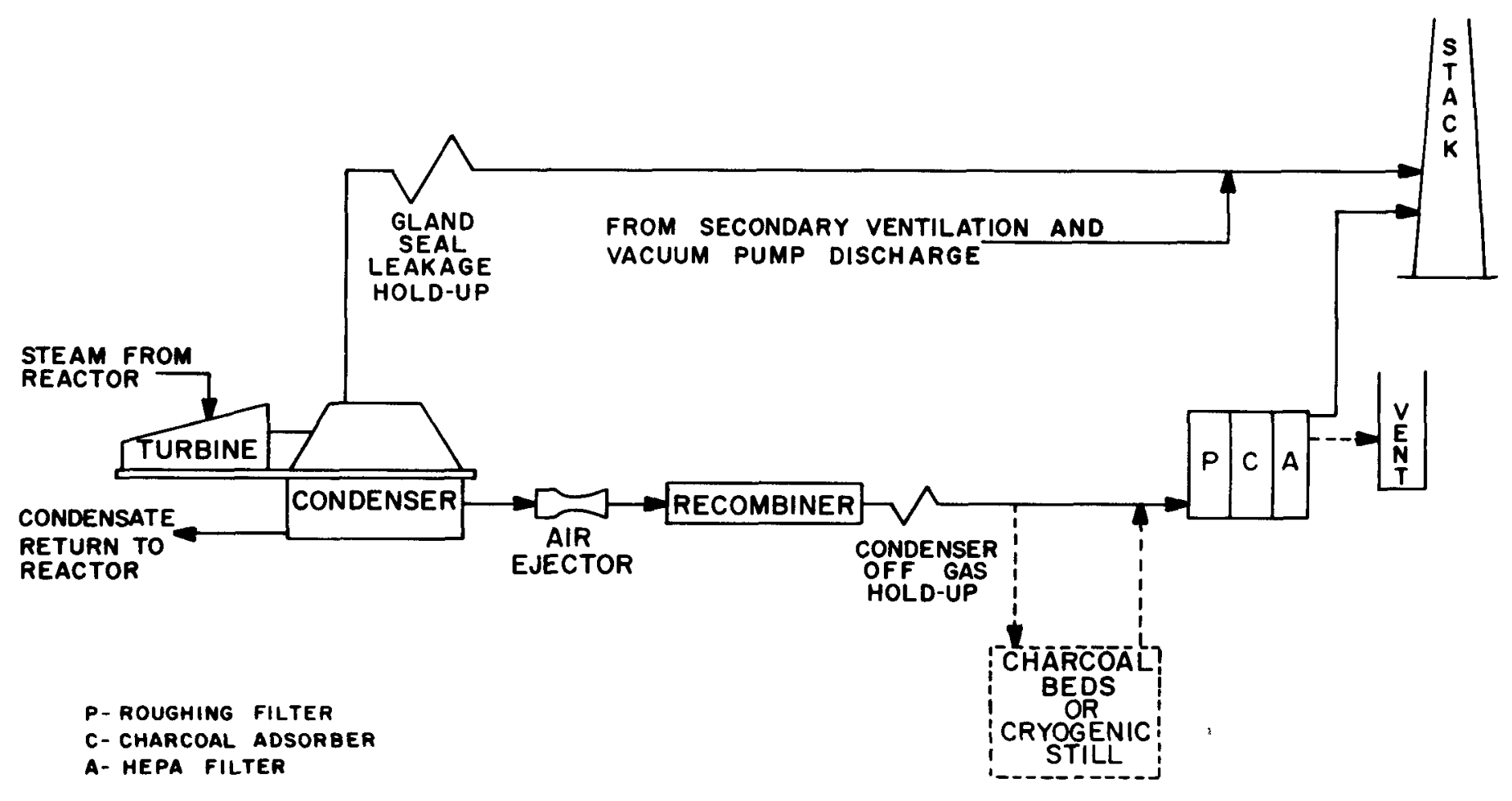

BWR GASEOUS WASTE SYSTEM

Figure A.1.1-16 


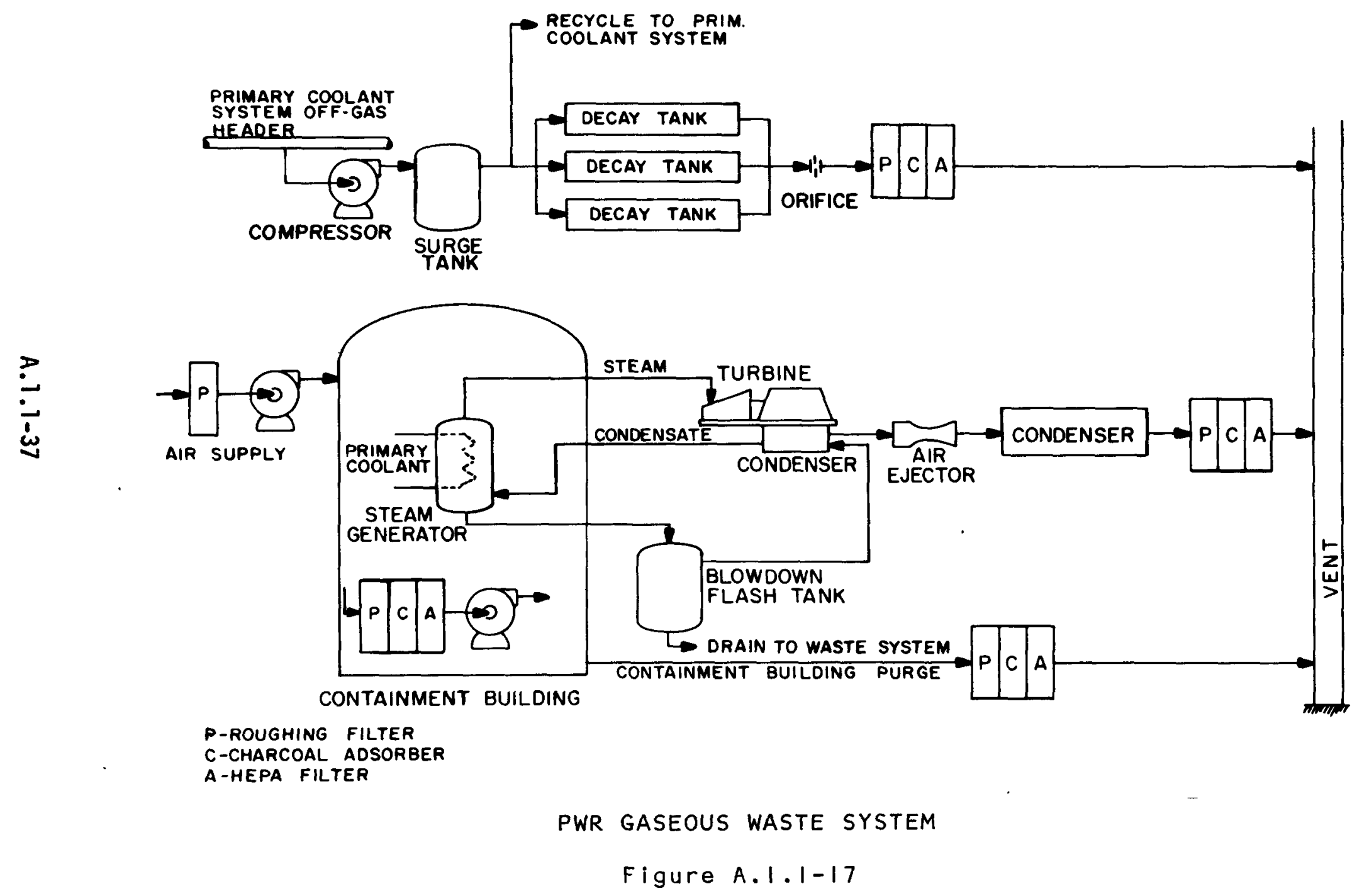


values from the ores and to produce a semi-refined uranium oxide product called "yellowcake" (assayed as equivalent $\mathrm{U}_{3} \mathrm{O}_{8}$ ); conversion of yellowcake to a pure volatile compound $\left(U F_{6}\right)$ which is amenable to isotopic enrichment via gaseous diffusion techniques; the enrichment of uranium hexafluoride in the fissile isotope, $U-235$, to produce an enriched product and a depleted stream known as diffusion plant "tails"; conversion to oxide; fabrication of fuel shapes, encapsulation and assembly into fuel elements; and ultimately the reprocessing of irradiated fuel for recovery and decontamination of uranium and plutonium values; and radioactive waste management.

Brief descriptions of the uranium-mining, milling and enrichment operations follow, since they are unique to the enriched-uranium fuel cycle of LWRs. For descriptions of the other fuel cycle operations, omitted here, the reader is referred to Chapter 4 of this report, where similar operations in the LMFBR fuel cycle are discussed.

\subsection{Uranium Mining-Milling Operations ${ }^{9}$}

Uranium mines usually are located in remote areas where average population densities are 5-10 people per square mile $e^{9}$. The high plateau regions of the Rocky Mountain States contain most of the uranium mines and more than $90 \%$ of the known conventional ore reserves.

Two methods - open-pit and underground mining - produce the bulk of the uranium in the USA. Open-pit mining has a cost advantage over underground methods for deposits occurring less than 400 feet below the surface. 
Underground operations are essential for deep deposits and are characterized in appearance by service buildings, a head-frame with ore handling facility, a mine waste pile and, in some cases, a flow of water pumped to surface drainage from underground sumps in the mine complex. The ground area occupied by the surface facilities may be only a few acres but the reach of the underground workings often range to a mile or more. The volume of the mine waste pile is related to the volume of gross ore processed. The volume of ventilating air, usually downcast through the production shafts and distributed through ore-haulage ways for discharge through vent holes/shafts at the extremities of the workings, is large enough to dilute the radon gas (emanating from uranium ore) to safe levels.

Open-pit mining has a highly-visible effect on the local environment. A model mine, equivalent to about 5.3 annual requirements for a 1000 MWe LWR operating on enriched uranium fuel, would produce about 1600 MT of ore per day for 300 days per year for ten years. At an average $\mathrm{U}_{3} \mathrm{O}_{8}$ content of $0.2 \%$ this is equivalent to about 960 MT of $\mathrm{U}_{3} \mathrm{O}_{8}$ per year. The ratio of overburden volume to ore volume is estimated to be about 30 to 1 (although ratios of 50 to 1 may occur at times). This overburden, stored for later reclamation of the mined area, averages about 9.5 million cubic yards per year. An open-pit mine is characterized by a large open excavation, large piles of earth and rock overburden placed nearby, a network of operating roads and yards, possibly a flow of mine water pumped 
to surface drainage, a number of service buildings and an assortment of heavy earth-moving equipment. Surface heap leaching facilities also are often present.

The uranfum milling operation usually is located adjacent to an operating mine. The mill employs mechanical crushing/screening to control reaction rate in the uranium leach step, uses either an acid leach or a sodium carbonate leach to extract the uranium values from the pulverized ore, concentrates the uranium by ion exchange or solvent extraction processing, recovers the uranium by chemical precipitation, and dries and packages the product for shipment as "yellowcake" (sodium or ammonium diuranate). Although the acid leach process involves greater water consumption and aqueous waste discharge, it is able to handle more of the ores than the sodium carbonate leach process.

A model uranium milling operation ${ }^{9}$ is assumed to be adjacent to an open-pit mine, of equivalent capacity, and uses the acid-leach process. The model mill temporarily occupies about 300 acres of land, of which about 250 acres are devoted to a tailings retention system. This latter includes a pond, about 2.5 acres attributable to each 1000 MWe LWR served, for the permanent disposal of mill tallings and process waste solutions. The mill will be comprised of an ore storage/blending area, a crushing and sampling building, an ore grinding building, a solvent extraction building, a product concentrating/drying/packaging building, an off-gas scrubber system and stack, the tailings pond treatment system, and service buildings. 


\subsection{Uranium Hexafluoride Production}

The "yellowcake" concentrate of uranium must be converted to pure volatile uranium hexafluoride for isotopic enrichment by the gaseous diffusion process. Either the hydrofluor process (continuous successive reduction, hydrofluorination and fluorination followed by fractional distillation to produce a pure product) or wet chemical purification followed by reduction/hydrofluorination/fluorination is used in current plants. Although both processes produce the same product, their waste effluents are quite different (i.e., hydrofluor process generates gaseous and solid effluents, the wet process produces mostly liquid effluents). Since both processes are in current use, the model conversion plant is assumed to share equally the 5000 MTU throughput (annual fuel requirements for about 27.5 of the 1000 MWe (WRs) by both flowsheets. The plant site occupies about 70 acres and is comprised of a wet process building, a gas reactions building, an off-gas treatment system and stack, a product packaging and storage facility, a liquid effluent treatment system and holding pond, and service buildings. Toxic chemical wastes ultimately are recovered from the liquid effluent treatment complex and the off-gas treatment system and are disposed of by burial.

\subsection{Isotopic Enrichment of Uranium}

The present facilities for isotopic enrichment of uranium are government-owned and use the gaseous diffusion process for raising the $U-235$ content (from $0.71 \mathrm{w} / 0$ for natural $U$ to about $2-4 \mathrm{w} / 0$, the initial enrichment for LWR fuel) of a pure uranium hexafluoride 
product stream, while depleting the bulk of the natural-U to a "tails" enrichment of $0.3 \mathrm{w} / \mathrm{O}$, at present. These plants are very large in size, investment and electrical power consumption. The AEC plants are characterized by very large continuous-floor-area buildings on reasonably flat land and require access to abundant and inexpensive electric power and process cooling water. The total AEC complex presently has an estimated capacity of $10.5 \times 10^{6}$ kilograms of separative work units per year while requiring the output from about 3250 MWe of electrical power; the annual requirements of the model 1000 MWe LWR fuel cycle are about $116,000 \mathrm{kilograms}$ of separative work units. It is anticipated that an extensive program ${ }^{9}$ of process improvement and up-rating of the AEC plants will raise the total capacity by 1980 to $27.7 \times 10^{6}$ kilograms of separative work units per year and the required electric power consumption to 7380 MWe per year.

\subsubsection{Energy Transmission ${ }^{14,15}$}

All nuclear, fossil-fueled and hydroelectric power stations, will require transmission lines for the distribution of the electrical energy they produce. Transmission line locations and designs are major aesthetic concerns. Fortunately, the design ${ }^{15}$ of transmission lines has improved considerably in recent years so that it is now possible to deal effectively with most objections of an aesthetic nature. The environmental impact of transmission lines will be minimized through advanced planning, careful design, and through 
review and approval of proposed transmission facilities by appropriate Federal, State, regional and local authorities.

\subsubsection{Research and Development Program}

Components and systems technology for producing nuclear power in LWRs has advanced to the status of commercial applicability and any further R\&D deemed necessary to optimize systems and economics lies within the purview of those industries which will benefit therefrom. While the accumulated information in nuclear technology, as in any other body of knowledge, is not without gaps and uncertainties in the accuracy of data, there are many options available in design, engineering and operation of nuclear plants to compensate for uncertainties and to reduce associated risks to acceptable, low values. Redundancy in components and instruments, conservative engineering practices to provide substantial margins, redundant safety devices and systems, fission product barriers, and a wide range of choices in operating parameters are being used to produce safe and reliable plant designs. Similar flexibility in engineering and operational practices is available to resolve additional questions that may arise during design, construction, testing and over the operating life of a nuclear facility.

Although further optimization of LWR systems has been left to the responsible industries, the $A E C$ continues to undertake and support $R \& D^{16,17}$ on safety issues relevant to implementing the agency's 
licensing responsibilities. The capabilities, reliabilities and lifetimes of some safety-related components and systems are being investigated at National Laboratories, contractors' sites and university laboratories in a number of on-going programs ${ }^{10,16}$. These involve:

1) systematic engineering development and upgrading of standards, codes, criteria and quality assurance practices;

2) development of non-destructive inspection techniques for detecting materials flaws and construction or maintenance errors;

3) the study of thick-section steel behavior under or following irradiation and other stresses;

4) experimental verification of the degree of conservatism resulting from use of various "best available" assumptions in engineering design calculations;

5) research and development work in the area of emergency coolant behavior following a loss-of-coolant accident (LOCA), including studies of the kinetics and mechanisms involved in both loss-of-coolant and introduction-ofemergency-coolant; and 
6) assessment, development and verification of analytical models which describe the course of events in the reactor systems as the result of postulated LOCAs, and ensure the applicability of experimental results to the analyses of full-size reactor plants.

Other AEC-sponsored safety-related tasks include: the study of synergistic effects of steam pressurization on containment leakage, to better predict the performance of containment systems during a postulated LOCA; seismic studies to improve the model for calculating transmission of seismic motions through soils and into reactor structures and systems; thermal effects studies to evaluate the environmental impacts of power plant waste-heat discharges at selected sites; and the development of both near-term and long-term solutions to the problem of perpetual isolation of toxic radioactive wastes from man's biosphere. These studies are described in Chapter 4 of this report, in the context of support for the LMFBR Program, but their results are equally applicable to the design and understanding of future LWR systems.

The recent report on The Nation's Energy Future ${ }^{24}$ recommends a five-year program of research and development on nuclear safety, waste storage management and to reduce the environmental impact of nuclear converter reactors. This program is expected to cost $\$ 719,200,000$ over the FY 1975-79 time period. Additional funding 
of $\$ 294,200,000$ over the same time period is recommended to develop improved uranium enrichment processes including gaseous diffusion, gas centrifuge and isotope separation using lasers.

\subsubsection{Present and Projected Application}

\subsubsection{Current Use}

As discussed in Section 1.1.3, 203 LWRs having an aggregate capacity approaching 200,000 electrical megawatts have been built, ordered or announced as of the end of $1973 .^{2}$ As of the end of 1973, LWR generating capacity in service was about 22,000 MWe, or slightly more than $5 \%$ of the country's on-line generation potential. The total power generated by LWRs in 1973 was approximately 83,000 million Kwh, or $4.4 \%$ of the total electric energy produced.

\subsubsection{Projected Use}

The probable role of the LWR in the electrical energy supply picture up to the Year 2000 and beyond is discussed in some detail in Section 1.1.8.

The application of LWRs would appear to be confined to central station electric power generation. During the remainder of this century it, along with the HTGR most probably will be the major sources of nuclear energy power production, while the LMFBR and potentially other alternative energy systems are being developed and brought into significant commercial utilization. It is anticipated that during this period and for a considerable time thereafter LURs would provide 
a major portion of the Nation's electrical energy while consuming uranium and producing plutonium. In addition, the enrichment process required for LWR fuel would produce large stores of depleted natural uranium.

In the interim period while the LMFBR is undergoing development and initial introduction into the electric utility economy, substantial portions of the plutonium produced in LWRs will be recycled in the LWRs to provide additional energy. Thereafter the LWR plutonium production will be used to fuel new LMFBRs (and/or GCFRs) as they come on line and the depleted uranium "tails" will be used to provide core and blanket material for these breeders. Thus, LWR operation will provide fuel material for breeder reactors sufficient to last many decades into the next century reducing requirements for uranium mining in that time period drastically.

\subsubsection{Environmental Impacts ${ }^{18}$}

\subsubsection{Environmental Impacts of LWR Power Plants}

1.1.6.1.1 Impacts on Land, Water and Air Multi-reactor sites involve controlled land areas of roughly 1000 acres; however, a typical 1000 MWe LWR will require the commitment of less than 200 acres of this site to industrial-type use and the remainder of the site provides a controlled buffer zone. This buffer zone can be dedicated to recreational, agricultural or animal husbandry uses during the normal operating lifetime of the power plant. 


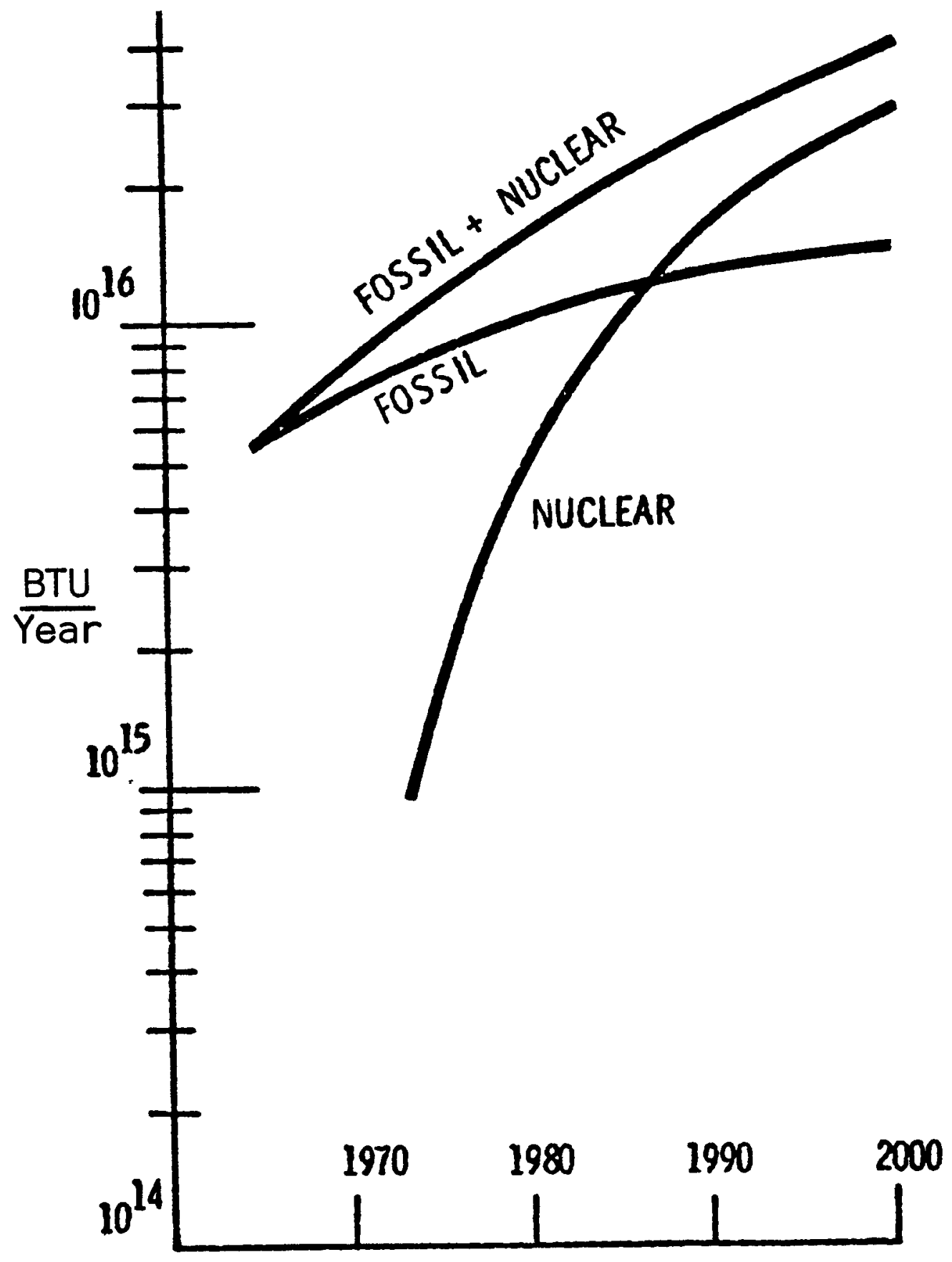

HEAT REJECTION FROM POWER PLANTS 15

Figure A.1.1-18 
1.1.6.1.1.1 ${\text { Therma }{ }^{19}}^{19}$

Since a current LWR will reject $1 / 4$ to $1 / 3$ more waste heat into its condenser coolant than does a current fossil-fueled plant (or a future LMFBR plant) of comparable capacity, the required heat-sink capacity of the site must be proportionately larger for an LWR facility than for fossil-fueled or LMFBR applications. About 50\% of the estimated waste-heat to be rejected by all electric power plants in 1985 (see Fig. A.1.1-18) is expected to be from LWR plants. Pre-operational ecological studies are made of each site and its biota to serve as a basis for defining design-life thermal effects on the site biota and hydrology, and to ensure that no significantly adverse effects result.

Increasingly restrictive water temperature standards will increase the use of methods of heat dissipation other than direct discharge. The alternative methods offer relief from thermal effects in the receiving water body, but involve other environmental effects and economic penalties; these alternative methods include applications of man-made bodies of cooling-water and cooling towers. While artificial lakes or cooling ponds can have very decided advantages, such as for recreation, they can only be used where the needed land is available. On the other hand, cooling towers may pose aesthetic problems. In certain portions of the United States, only dry cooling towers can be used because there is no suitable supply of make-up water for a wet cooling tower system. Coupling of a proposed power plant with dry cooling towers would effectively 
eliminate the "availability of natural waters" as a major constraint in siting the plant. A wet cooling tower requires the availability of adequate make-up water and adds large amounts of water to the atmosphere in the immediate vicinity of a power plant; under certain atmospheric conditions this could result in fog, ice formation on roads and power lines, reduction in visibility, and even the formation of snow. Heat rejection systems using a combination of wet and dry cooling towers may be used to minimize costs under some circumstances.

For more detailed treatment of the thermal impact of waste heat rejection, see Chapter 4 of this report, where the topic is discussed in the context of heat rejection by LMFBR facilities.

\subsection{Chemical}

Chemical releases by LWR facilities, or any nuclear power plants, are negligible and generally enter the environment via a blowdown stream from a closed-cycle cooling system. Further discussion of this potential for environmental pollution is presented in Chapter 4 of this report, in the context of LMFBR operations.

\subsection{Radiological}

See pertinent discussion in Chapter 4. 


\subsection{Impacts on Flora and Fauna}

\subsection{Shelter/Food}

Necessary clearing of wooded areas for plant sites and access roads will result in the relocation of some bird and animal life; however, the fields and trees of the controlled buffer zone may be able to accormodate most of these displacements.

Dredging activities required during establishment of water intake and outfall channels will temporarily interrupt marine feed supplies and may destroy some established beds of mollusks. If pre-operational studies indicate that such incursions would cause excessive destruction of native marine life, some of it may be relocated. ${ }^{20}$ Biological and botanical sampling of the biota will be examined throughout the construction and operational phases of each power plant's life, to ensure that any inadvertent damage to the biota is detected and remedied.

\subsection{Thermal}

See pertinent discussion in Chapter 4.

\subsection{Chemical}

See pertinent discussion in Chapter 4.

\subsection{Radiological}

Nuclear power plant effluents have not added significantly to the natural radioactivity inventory. Table A.1.1-3 indicates ${ }^{21,22}$ that LWR power facilities thus far have contributed a dose of very much 
CURIES OF NOBLE GASES RELEASED, BOUNDARY AND AVERAGE INDIVIDUAL DOSES AND

POPULATION DOSES (MAN-REM) FOR 1971

\begin{tabular}{|c|c|c|c|c|c|}
\hline \multirow[b]{2}{*}{ TYPE } & \multirow[b]{2}{*}{ FACILITY } & \multirow[b]{2}{*}{ CURIES RELEASED } & \multirow[b]{2}{*}{$\begin{array}{l}\text { BOUNDARY DOSE } \\
\text { (mrem) }\end{array}$} & \multicolumn{2}{|c|}{ WITHIN 50 MILES } \\
\hline & & & & $\begin{array}{l}\text { Average } \\
\text { Individual } \\
\text { Dose } \\
\text { (mrem) }\end{array}$ & $\begin{array}{l}\begin{array}{l}\text { Population } \\
\text { Dose } \\
\text { (man-rem) }\end{array} \\
\text { (1) }\end{array}$ \\
\hline PWR & Indian Point & 360 & .035 & .00005 & .77 \\
\hline PWk & Yankee Rowe & 13 & .3 & .0003 & .41 \\
\hline PWR & San Onofre & 7670 & 2.2 & .002 & 6.3 \\
\hline PWR & Conn Yankee & 3250 & 5.6 & .003 & 11 \\
\hline PWR & Ginna & 31800 & 5.0 & .004 & 4.5 \\
\hline PWR & H. B. Robinson & 18 & .05 & .00002 & .015 \\
\hline PWR & Point Beach & 838 & .2 & .0008 & $.15^{(n}$ \\
\hline BWR & Oyster Creek & 516,000 & 31. & .013 & 46. \\
\hline BWR & Nine Mile Point & 253,000 & 4.8 & .009 & 8.2 \\
\hline BWR & Dresden $(1,2,3)$ & $1,330,000$ & 32. & .057 & 420 \\
\hline BWR & Humboldt Bay & 514,000 & 160. & .54 & 61. \\
\hline BWR & Big Rock Point & 284,000 & 4.6 & .026 & 3.1 \\
\hline BWR & Millstone & 276,000 & 5.5 & .0056 & 15. \\
\hline BWR & Montice11o & 76,000 & 4.4 & .0036 & 4,4 \\
\hline
\end{tabular}

(1) The man-rem dose for a group of people is the product of the average dose to those people and the number of people.

(2) Man-rem dose is for the population within 40 miles for this facility. 
less than one millifem per year per person in this country, on the average. The AEC has estimated that future individual-dose exposures will continue to be less than one millirem per year ${ }^{14}$, probably less than 0.2 millirem per year ${ }^{18}$, on the average, by the year 2000 when there may be about 1,000 nuclear power plants in operation.

\subsubsection{Environmental Impacts of Other Fuel Cycle Operations ${ }^{9}, 10$}

Environmental considerations influence the design, licensing and operation of LWR-supported industries which provide the out-of-reactor fuel cycle operations depicted in Figure A.1.1-19. These operations, outlined in Section 1.1.3.3, include: (1) both underground- and pit-mining of uranium ores; (2) milling cand refining ores to produce uranium concentrates called 'yellowcake'; (3) conversion and refining of the 'yellowcake' concentrates into high-purity uranium hexafluoride; (4) isotopic enrichment in fissile content of the uranium hexafluoride, via gaseous diffusion processing, to produce feed material for LWRfuels; (5) conversion of the enriched hexafluoride to oxide, fabrication of the oxide into fuel shapes, encapsulating these fue 1 shapes, and assembling the fuel capsules (rods) into fuel elements; (6) reprocessing of irradiated fuel materials to recover and decontaminate uranium (and other fissile values) from the associated radioactive fission products (previously discussed in part 1.1.3.3.1 of this chapter); (7) storage and management of high-level and lowlevel radioactive wastes at Federal and commercial waste repositories; and $(8)$ the various inter-site transportation operations associated with these operations. General characteristics of the associated 


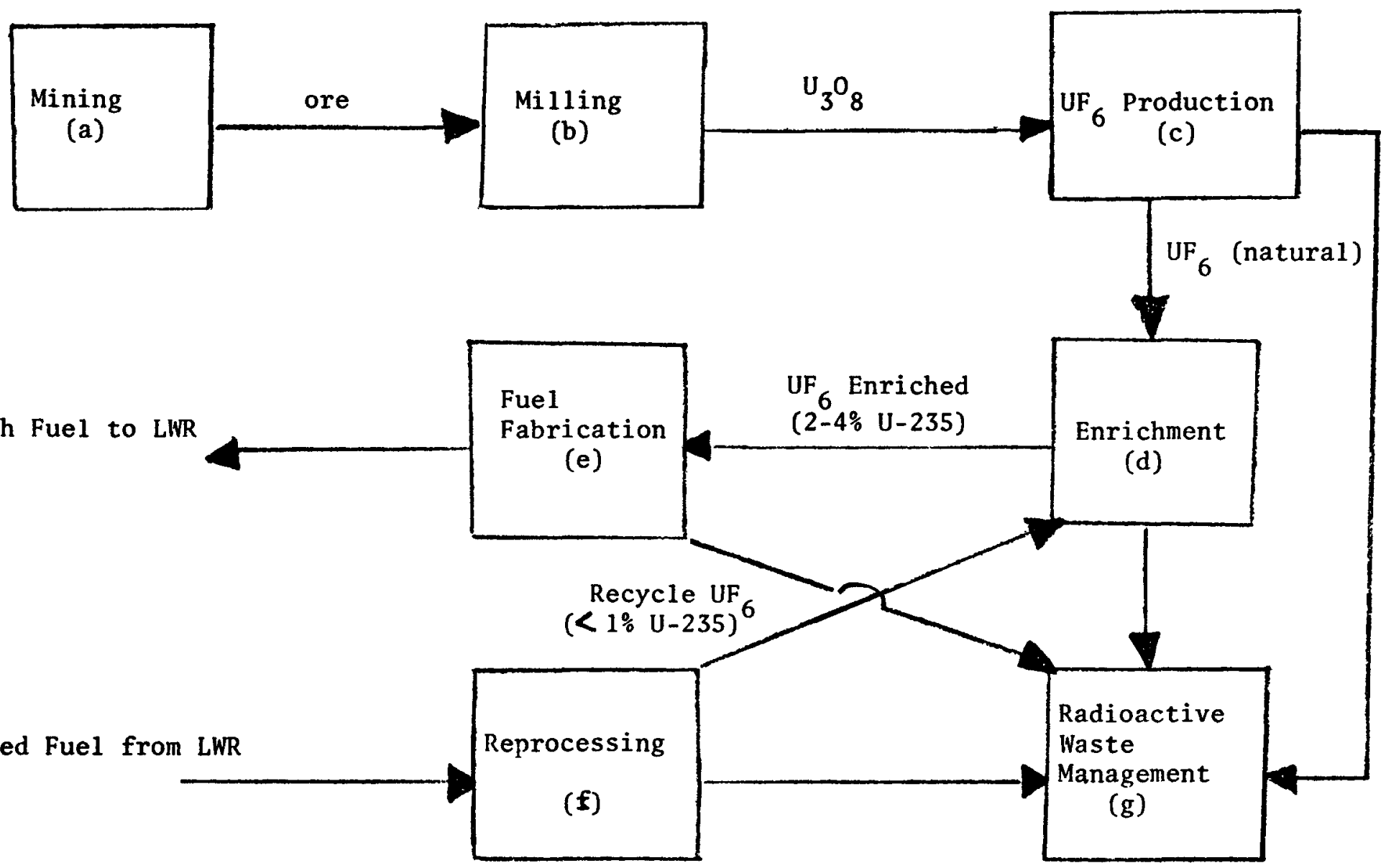

NUCLEAR FUEL CYCLE - LIGHT WATER REACTORS URANIUM DIOXIDE FUELED - NO PLUTONIUM RECYCLE

Figure $A .1 .1-19$ 
nuclear materials industries, for the LWR-fuels market in 1972, are presented in Table A.1.1-4. Typical materials requirements for a 1000 MWe LWR-fuel cycle are listed in Table A.1.1-5.

\subsection{2.1 Impacts on Land, Water and Air}

Typical industrial plants to provide these LWR-fuels cycle services, the operations thereof, and the environmental considerations resulting from such operations are described in Reference 9. Summaries of these environmental considerations are presented in Tables A.1.1-6, on a "per LWR basis" for each fuel cycle operation, and in Table A.1.1-7, on a "per LWR-year basis" for the collective fuel cycle.

Only the first four steps in the LWR-fuel cycle are missing from the LMFBR-fuel cycle, hence the environmental impacts of only these steps will be discussed here. General comments on subsequent steps of the fuel cycle are presented in Chapter 4 of this report and summaries of detailed environmental considerations for the total out-of-reactor fuel cycle follow, as Tables A.1.1-6 and A.1.1-7.

\subsection{Uranium Mining - Milling ${ }^{9}$}

Recent information from the U.S. Bureau of Mines indicates that essentially equivalent tonnages of coal and crude uranium ore are produced per acre of material mined; however, the nominal specific energy content of the crude uranium ore is 35 to 40 times greater than that for coal. On an equivalent power generation bas is ${ }^{9}$, it 
Table A.1.1-4

NUCLEAR FUEL CYCLE INDUSTRY

1972

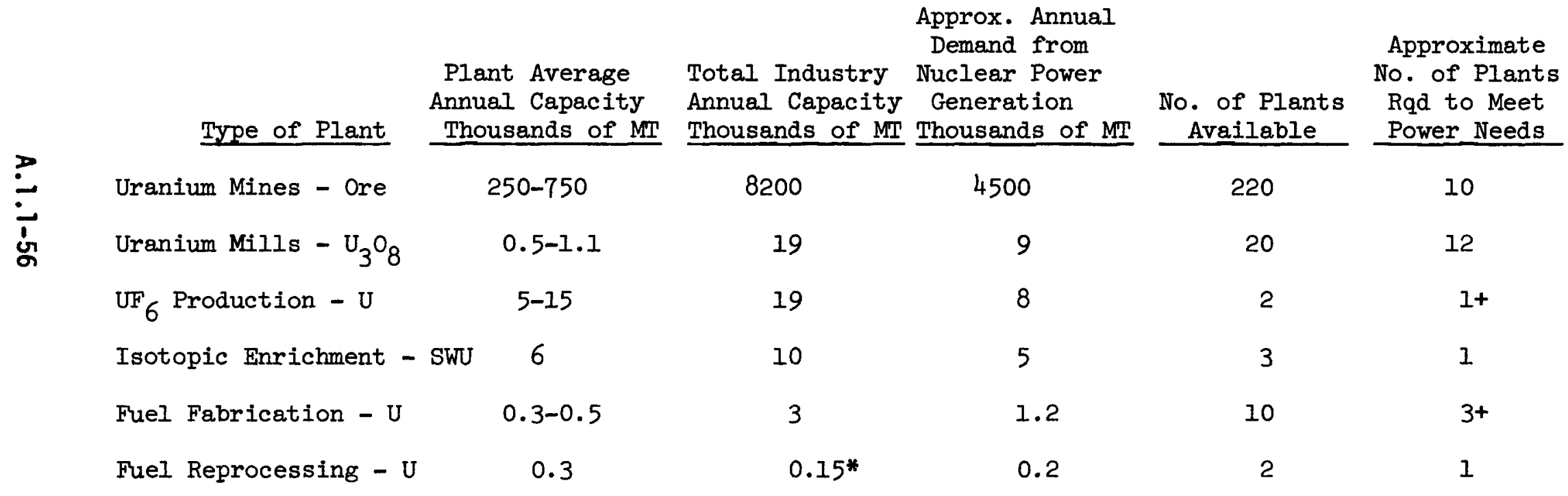

*One plant in operation for about 6 months 
Table A.1.1-5

CHARACTERISTICS OF 1000 MWe LWR MAXIMUM FUEL CYCLE REQUIREMENTS

Core Reload Fuel Requirement

Irradiation leve 1

(MWD $/$ MTU) $\times 10^{-3}$

33

33

Fresh fuel assay

(wt\% U-235)

2.6

3.2

3.2

Spent fuel assay

(wt\% U-235)

0.76

0.84

0.84

Ore supply*

(iT) $\times 10^{-3}$

332

82.5

91

Yellowcake

$\mathrm{U}_{3} \mathrm{O}_{8}$ supply (MT)

665

165

182

Natural UF 6 (MT)

840

250

270

Separative work* (MT SWU)

110

116

Enriched $U_{6}$ (MT)

200

47

52

Enriched $\mathrm{UO}_{2}$ (MT)

152

36

40

Fuel loading (MTU)

134

32

35

Bases

Reactor plant load factor - $80 \%$

Enrichment tails assay*- $0.25 \%$

No plutonium recycle

Reloads include recovered uranium

Losses of $1 \%$ each in fuel fabrication and reprocessing

MT $=$ metric ton $=2,205 \mathrm{lbs}$.

MTU = metric ton uranium

MT SWU = separative work

units in metric tons

*Current diffusion plant operations result in tails assay of $0.3 \mathrm{w} / \mathrm{o}$ and would require input of about $12 \%$ less separative work on about $12 \%$ more natural feed material. 
Table A.1.1-6

SUMMARY OF ENVIRONMENTAL CONSIDERATIONS FOR NUCLEAR FUEL CYCLE - I

(Normalized to 1000 MWe LWR's Annual Fuel Requirement)

\begin{tabular}{|c|c|c|c|c|c|c|c|c|c|}
\hline & $\mathbf{A}$ & B & c & D & E & F & $G$ & $\mathrm{H}$ & \\
\hline Natural Resource Use & Mining & Milling & $\mathrm{UF}_{6}$ Prod. & Enrichment & Fuel Fab. & Reprocessing & $\begin{array}{c}\text { Was te } \\
\text { Management }\end{array}$ & Transportation & Tota1 \\
\hline \multicolumn{10}{|l|}{ Land (Acres) } \\
\hline Temporarily Committed & 55 & 0.5 & 2.5 & 0.8 & 0.2 & 3.9 & -- & - & 63 \\
\hline Undlsturbed Area & 38 & 0.2 & 2.3 & 0.6 & 0.16 & 3.7 & -- & - & 45 \\
\hline Disturbed Area & 17 & 0.3 & 0.2 & 0.2 & 0.04 & 0.2 & -- & -- & 18 \\
\hline Permanently Commited & 2 & 2.4 & 0.02 & 0 & 0 & 0.03 & 0.2 & - & 4.6 \\
\hline Overburden moved (MT $\times 10^{-6}$ ) & 2.7 & -- & - & - & -- & - & -- & - & 2.7 \\
\hline \multicolumn{10}{|l|}{ Water (ga1lons $\times 10^{-6}$ ) } \\
\hline Discharged to air & -- & 65 & 3.7 & 90 & -- & 4.0 & - & - & 163 \\
\hline Discharged to water bodies & -- & - & 41 & 11000 & 5.2 & 6.0 & -- & -- & 11052 \\
\hline Discharged to ground & 123 & - & -- & -- & -- & -- & -- & - & 123 \\
\hline Total Water & 123 & 65 & 44.7 & 11090 & 5.2 & 10.0 & -- & - & 11338 \\
\hline \multicolumn{10}{|l|}{ Foss11 Fue1 } \\
\hline $\begin{array}{l}\left.\text { Electrical energy (MW-hr } \times 10^{-3}\right) \\
\text { Equivalent Coal }\left(\mathrm{MT} \times 10^{-3}\right)\end{array}$ & $\begin{array}{l}0.25 \\
0.09\end{array}$ & $\begin{array}{l}2.7 \\
0.97\end{array}$ & $\begin{array}{l}2.1 \\
0.76\end{array}$ & $\begin{array}{l}310 \\
113\end{array}$ & $\begin{array}{l}1.7 \\
0.62\end{array}$ & $\begin{array}{l}0.45 \\
0.16\end{array}$ & $\overline{-}$ & $\overline{-}$ & $\begin{array}{l}317 \\
116\end{array}$ \\
\hline Natural Gas $\left(8 \mathrm{cf} \times 10^{-6}\right)$ & -- & 68.5 & 31 & -- & 3.6 & -- & -- & -- & 103 \\
\hline
\end{tabular}


Table A.1.1-6 (Cont'd)

SUMMARY OF ENVIRONMENTAL CONSIDERATIONS FOR NUCLEAR FUEL CYCLE

(Normalized to 1000 MWe LWR's Annual Fuel Requirement)

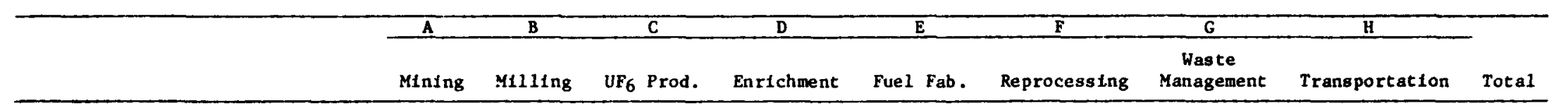

\section{Effluents}

Chemical (MT)

$$
\begin{aligned}
& \text { Gases (1) } \\
& \mathrm{SO}_{\mathrm{X}} \\
& \mathrm{NO}_{\mathrm{X}} \\
& \text { Hydrocarbons } \\
& \mathrm{Co} \\
& \text { Particulates } \\
& \text { Other Gases }
\end{aligned}
$$

Liquids

$\mathrm{SO}_{4}{ }^{-}$

Fluoride

$\mathrm{Ca}^{+}$
$\mathrm{Cl}^{-}$
$\mathrm{Na}^{+}$

$\mathrm{Na}_{3}^{+}$

Tailings Solutions $\left(\begin{array}{ll}x & 10^{3}\end{array}\right)$

F

Solids

$\begin{array}{lcl}3.5 & 37 & 29 \\ 0.9 & 15.9(2) & 10(3) \\ 0.009 & 1.3(2) & 0.6(2) \\ 0.02 & 0.3 & 0.2 \\ 0.9 & 9.7 & 7.6 \\ & & \\ -- & -- & 0.11 \\ & & \\ -- & -- & -- \\ - & -- & -- \\ -- & -- & -- \\ -- & -- & - \\ -- & -- & -- \\ - & -- & -- \\ -- & 240 & -- \\ - & -- & --\end{array}$

$\begin{array}{rc}4300 & 23 \\ 1130 & 6 \\ 11 & 0.06 \\ 28 & 0.15 \\ 1130 & 6 \\ & \\ 0.5 & 0.005 \\ & \\ 5.4 & -- \\ 2.7 & 23 \\ -- & 0.4 \\ 5.4 & -- \\ 8.2 & -- \\ 8.2 & -- \\ -- & 10 \\ -- & -- \\ 0.4 & -- \\ 0.2 & 26\end{array}$

6.2
$7.1(4)$
0.02
0.04
1.6
0.05
0.4
0.2
--
--
0.02
5.3
--
--
-
--

$--$

$--$

$-$

$\begin{array}{lc}- & 4400 \\ - & 1170 \\ - & 13.0 \\ - & 28.7 \\ - & 1156\end{array}$

(1) Estimated Effluents Based Upon Combustion of Equivalent Coal for Power Generation

(2) Combined Effluent from Combustion of Coal and Natural ras

(3) $25 \%$ from natural gas use

(4) $77 \%$ from process 
Table A.1.1-6 (Cont'd)

SUMMARY OF EIVIRONMENTAL CONSIDERATIONS FOR NUCLEAR FUEL CYCLE

(Normalized to 1000 MWe LWR's Annual Fuel Requirement)

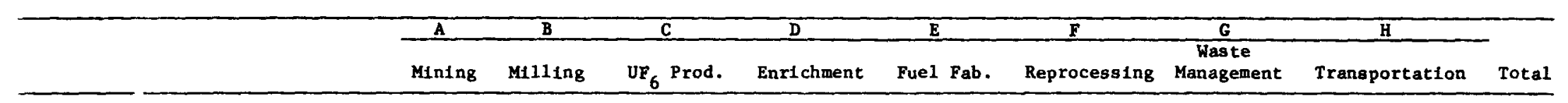

\section{Effluents (cont'd)}

\section{Radiological (Curies)}

\begin{tabular}{|c|c|c|c|c|c|c|c|c|c|}
\hline Gases (including entrainment) & & & & & & & & & \\
\hline $\begin{array}{l}\mathrm{Rn}_{-}-222 \\
\mathrm{Ra}-226\end{array}$ & - & $\begin{array}{l}74.5 \\
0.02\end{array}$ & $\overline{--}$ & -- & $\overline{--}$ & $\overline{-}$ & $\overline{--}$ & $\overline{-}$ & $\begin{array}{l}83 \\
0.02\end{array}$ \\
\hline Th-230 & -- & 0.02 & -- & - & -- & - & -- & $\overline{-}$ & $\begin{array}{l}0.02 \\
0.02\end{array}$ \\
\hline Uranius & -- & 0.03 & 0.014 & 0.002 & 0.0002 & $=$ & - & - & 0.046 \\
\hline $\operatorname{Tr1t1ur}\left(x-\frac{10}{3}\right)$ & $\overline{--}$ & $\overline{-}$ & $\overline{-}$ & - & -- & 15.7 & -- & $=$ & $\begin{array}{l}15.7 \\
350\end{array}$ \\
\hline $\mathrm{I}-129 \mathrm{C}-\mathrm{d}$ & - & $\overline{-}$ & $\overline{-}$ & - & $=$ & $\begin{array}{l}350 \\
0.002\end{array}$ & $\overline{-}$ & $\overline{-}$ & $\begin{array}{rl}350 & 0.002\end{array}$ \\
\hline$I-131$ & - & -- & -- & - & -- & 0.02 & - & - & 0.02 \\
\hline Fission Products & -- & - & - & - & - & 1.0 & - & - & 1.0 \\
\hline Transurantcs & -- & - & - & - & - & 0.004 & -- & - & 0.004 \\
\hline \multicolumn{10}{|l|}{ Liquids } \\
\hline $\mathrm{Ra}-226$ & -- & - & 0.027 & - & - & - & - & - & 0.027 \\
\hline Th -230 & - & - & 0.27 & - & - & - & - & - & 0.27 \\
\hline Th-234 $\quad-3$ & - & - & -- & -- & 0.01 & $\because$ & - & - & 0.01 \\
\hline Tritium $\left(x 10^{-3}\right)$ & -- & -- & -- & - & -- & 2.5 & - & - & 2.5 \\
\hline Other Urantum daughters & - & -- & -- & - & 0.01 & -- & - & - & 0.01 \\
\hline Ru-106 & - & -- & - & - & -- & 4 & - & - & 4 \\
\hline $\begin{array}{l}\text { Sollds (buried) } \\
\text { Other than high level }\end{array}$ & - & 1200 & 0.3 & - & 0.06 & -- & - & - & 1200 \\
\hline Thermal (Btu $\times 10^{-9}$ ) & - & 69 & 30 & 3200 & 9 & 61 & - & 0.03 & 3370 \\
\hline
\end{tabular}


Table A.1.1-7

SUMMARY OF ENVIRONMENTAL CONSIDERATIONS FOR NUCLEAR FUEL CYCLE - II (Normalized to $1000 \mathrm{MWe} \mathrm{LWR}^{\prime} \mathrm{s}$ Annual Fuel Requirement)

Total Maximum Effect per Annual Fuel Requirement of Mode1 1000 MWe LWR

\title{
Natural Resource Use
}

\section{Land (acres)}

Temporarily committed

Undis turbed area

Disturbed area

Permanently committed

Qverburden moved (MT $\times 10^{-6}$ )

Water (gallons $\times 10^{-6}$ )

Discharged to air

Discharged to water bodies

Discharged to ground

Tota

\author{
63 \\ 45 \\ 18 \\ 2.7 Equivalent to 90 Mive coal-fired power plant \\ Equivalent to $90 \mathrm{MWe}$ coal-fired power plant
}

Fossi1 Fue 1

Electrical energy $\left(M W-h r, x^{10^{-3}}\right)$
Equivalent coal $\left(M T-10^{-3}\right)$
Natural gas $\left(\operatorname{scf} \times 10^{-6}\right)$

$\sim 28$ of model 1000 MWe LWR with cooling tower

44\% of model 1000 MWe LWR with once-through cooling

103

<5\% of model 1000 MWe LWR output

Equivalent to the consumption of a 45 MWe coal-fired power plant $<0.2 \%$ of model 1000 MWe LWR energy output 
Table A.1.1-7 (Cont'd)

SUMMARY OF ENVIRONMENTAL CONSIDERATIONS FOR NUCLEAR FUEL CYCLE

(Normalized to 1000 MWe LWR's Annual Fuel Requirement)

Tota1 Maximum Effect per Annual Fue1 Requirement of Model 1000 MWe LWR

Effluents - Chemical (MT)

${ }^{1}$ Gases (including entrainment)

$2 \mathrm{SO}_{\mathrm{NO}}^{\mathrm{x}}$

Hyâx rocarbons

Hydrocarbons

Particulates

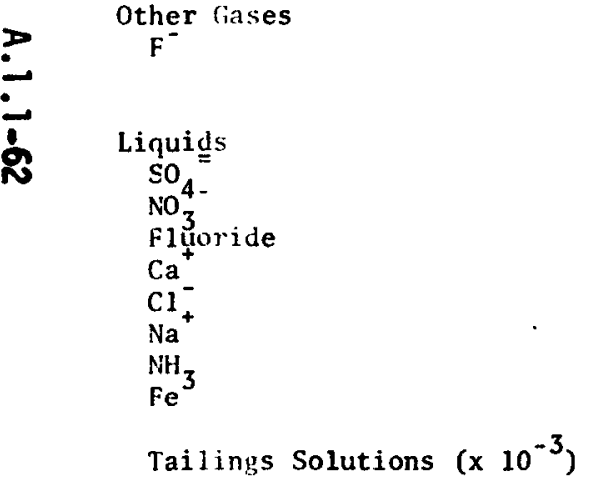

Solids

$$
\begin{array}{r}
4400 \\
1170 \\
11.3 \\
28.7 \\
1156
\end{array}
$$

Equivalent to emissions from 45 MWe coal-fired plant for a year.

$0.7\{$ Principally from UF production and enrichment - $\quad$ Conc. within $\left\{\begin{array}{l}\text { Principally from } \\ \text { range of state standards-below level that has effects on human health. }\end{array}\right.$

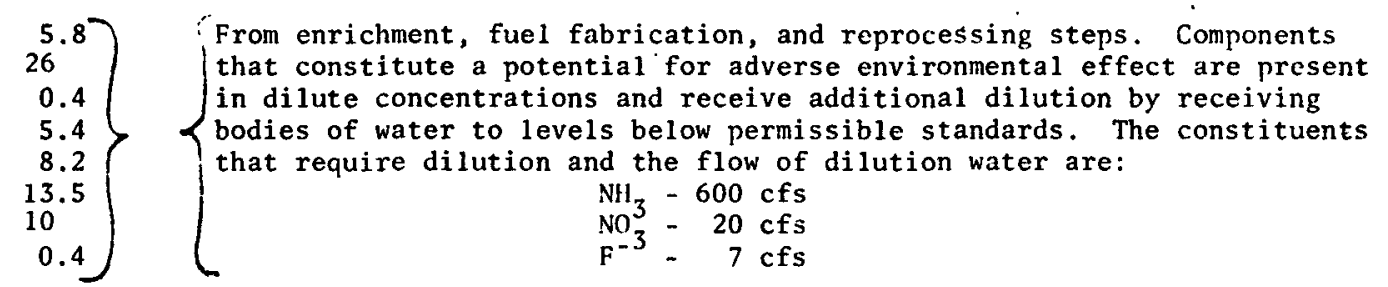

240 From mills only - no significant effluents to environment.

91,000 Principally from mills - no significant effluents to environment.

\footnotetext{
Estimated effluents based upon combustion of equivalent coal for power generation.
}

$2.2 \%$ from natural gas use and process. 
Table A.1.1-7 (Cont'd)

SUMMARY OF ENVIRONMENTAL CONSIDERATIONS FOR NUCLEAR FUEL CYCLE

(Normalized to $1000 \mathrm{MWe} \mathrm{LWR}^{\prime}$ 's Annual Fuel Requirement)

Total

Maximum Effect per Annual Fuel Requirement of Model 1000 Mie LWR

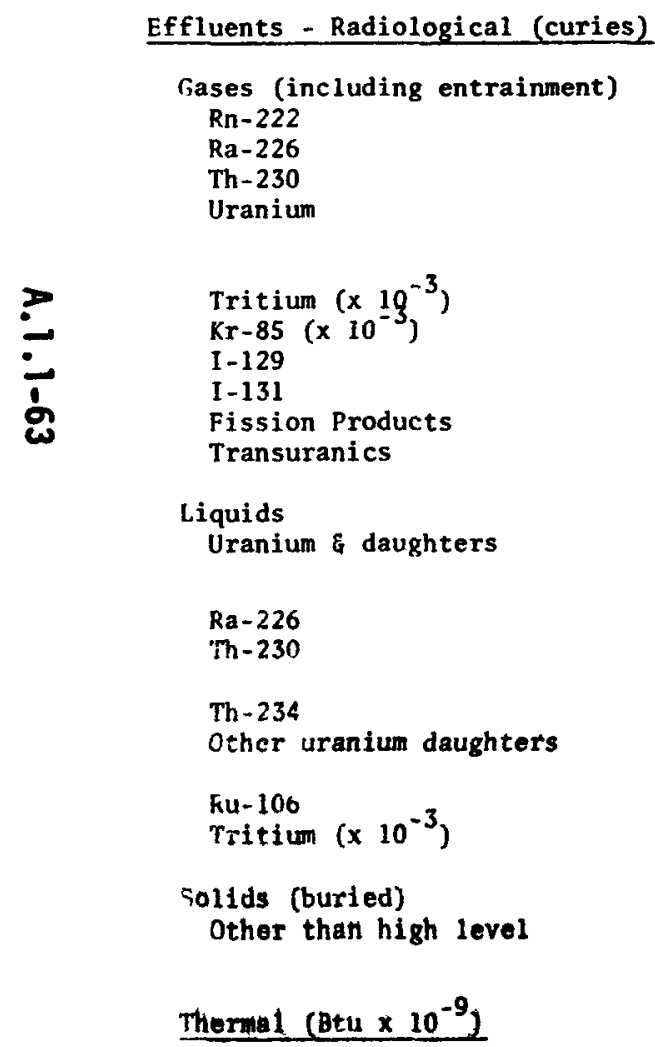

Effluents - Radiological (curies)

Thanium

Tritium $\left(x 10^{-3}\right)$

$1-129$

ion Products

iquids

\& daughters

Th-230

$T h-23$

Ther uranium daughters

Ku- 100

Thermal (Btu $\times 10^{-9}$

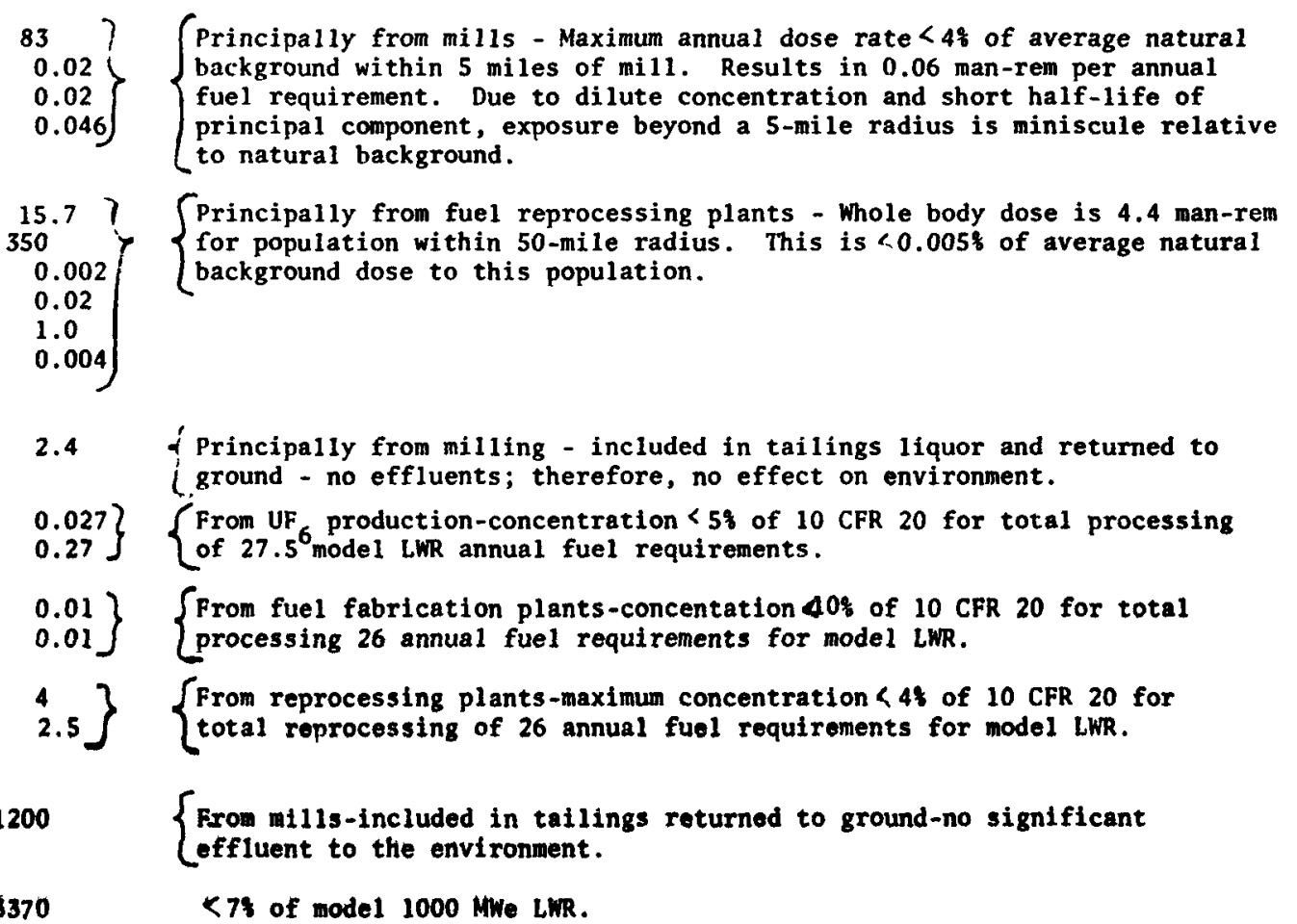


would appear that about 35 times more land is disturbed from mining coal. The land permanently comitted (see Table A.1.1-6) by uranium ore mining amounts to about 2 acres for the annual fuel requirements of the model (1000 MWe) LWR.

The land used for uranium milling that is attributable to annual fuel requirements for the model LWR is about 2.9 acres, of which about 2.4 acres are devoted to a pond for the permanent disposal of mill tailings. In effect, nearly the entire mass of ore processed ends up in the tailings pond and the area eventually is restored to resemble the surrounding terrain.

Approximately 123 million gallons of water (see Table A.1.1-6) are pumped from the model uranfum mine for the annual fuel requirements of the model LWR, but the bulk of this water recycles through natural seepage and evaporation and eventually returns to the groundwater from which it was pumped.

Approximately 65 million gallons of water, attributable to the annual fuel requirements of the model LWR, are discharged from the mill to the tailings pond from which they evaporate. Any mill waters that return to the environment by failure of a dike in the tailings pond or other misadventure are not expected to have an appreciable effect on the environment since any materials contained in these waters would be deposited through sedimentation ${ }^{9}$ over a 
relatively short distance. Recovery would be straight-forward, with either burial-in-place or return to the pond of all waste materials and contaminated soils.

Although air-borne radionuclides and particulate matter result from uranium mining operations (see Table A.1.1-6) underground mines are adequately force-ventilated to dilute radon concentrations effectively to background levels at the site boundaries. Any mine ventilation malfunction immediately would be remedied and any resulting transient exhaust conditions of excessive radon concentration would be too small to be detected beyond the site boundaries.

Air-borne radionuclides and particulate matter are generated during uranium milling operations; however, off-gas treatment and particulate settling reduce the off-site concentrations of air-borne contaminants to levels well below EPA standards and limits defined in 10CFR20.

\subsection{Uranium Hexafluoride (UHF) Production ${ }^{9}$}

Temporary commitment of about 2.5 acres of land are attributable to production of UHF for the annual fuel requirements of the model LWR. Only about 0.02 acres of land, used for burial of toxic wastes generated by production of said amount of UHF, is permanently committed. 
Of the approximately 45 million gallons of water used by the model UHF-production process and attributable to the annual fuel requirements of the model LWR (see Table A.1.1-6), more than $90 \%$ is used primarily as process coolant and then returned directly to the water body from which it came. The remainder, or process waters, leave the plant as raffinates and plant wastes and are held indefinitely in sealed holding-ponds which allow the water to return to the biosphere via evaporation and the solid residues ultimately are recovered and buried. Analyses of ground water samples obtained in the vicinity of an established UHF-production plant showed that even fluoride and nitrate concentrations are well within recommended limits for drinking water sources ${ }^{9}$.

Process off-gas streams are generated which contain volatilized solids, combustion products, gaseous reactants and small amounts of radioactivities (see Table A.1.1-6). Several off-gas treatments are employed to reduce air-borne concentrations of contaminants to levels below limits established by 1OCFR20 and EPA.

\subsection{6.2.1.3 Isotopic Enrichment of Uranium 9,23}

Less than one acre of land is temporarily committed to the enrichment of the annual fuel supply for a model LWR and the bulk of this area serves only as a controlled-access area.

The model gaseous diffusion plant requires the evaporation (and make-up) of about 90 million gallons of cooling water for enrichment 
of the annual fuel supply of the model LWR. (In addition, off-site generation of the electricity consumed by this enrichment process employs--assuming once-through cooling and return to natural water bodies--approximately 11 billion gallons of water per annual fuel requirement of the model LWR.) The primary potential for contamination of man's hydrosphere by this fuel cycle step lies in "blowdown" from operation of the closed-cycle evaporative cooling towers; current plants have adequate quantities of river water to permit dilution of these periodic discharges to levels below established limits for natural water bodies.

By far the primary source of environmental impact ${ }^{9}$ associated with the enrichment of uranium is related to the gaseous effluents from the coal-fired plants which generate the required electric power. Waste gas emissions, including particulates, of approximately 6600 MT are attributable to the production of an annual fuel supply for the model LWR. This impact will be reduced in the future as breeder reactor power plants begin to generate this power. Associated with this generation of electricity is the rejection to the environment of roughly twice as much energy as waste-heat. Some of the off-site power plants would reject their waste-heat to air while others would reject it into available water bodies.

\subsection{6.2.2 Impacts on Flora and Fauna $9,10,13,18$}

Effluents from the out-of-reactor fuel cycle operations are monitored and processed as needed, and subjected to controlledreleases to ensure that the concentrations of any toxic materials 
therein are kept below licensed levels, i.e., "as-low-as-practicable" release limits. With due consideration of natural ecosystems pathways for potential redistribution or concentration of elements, conscientious efforts will be made to ensure that any adverse effects on public health and safety are kept to a negligible level.

\subsection{2.2.1 Uranium Mining - Milling}

The mining and milling of uranium resources usually are accomplished on contiguous acreages which are relatively remote and in regions of low population density. During these operations, roughly 5 acres of forage land per annual fuel requirement for the model LWR are temporarily (at least for a decade) removed from use by wild-life; however, it is expected that current site reclamation requirements would assure the return of most of this acreage to something approaching its former natural status within a few years after the discontinuance of plant operations.

\section{1 6.2.2.2 Uranium Hexafluoride (UHF) Production}

UHF production plants are relatively large throughput operations and are located in regions of low population density. Less than $10 \%$ of the plant site need be disturbed from its natural state during production operations, the bulk of the site serving as a controlled-access perimeter to reduce the off-site impact of any plant malfunction. These plants are designed for and operated with virtually complete recovery of uranium values, total utilization of fluorine, and high utilization of other reactants; consequently, there should be no more than minor 
detrimental effect to the natural flora as a result of plant effluents. Fauna permitted to graze without restriction on all of the undisturbed controlled-access acreage conceivably could be exposed to some accidental releases of hazardous or toxic gases (e.g., $F_{2}$ or HF) which could be harmful even though the exposure was brief. However, no accidents having a detrimental environmental effect have occurred to date.

\subsection{6.2.2.3 Isotopic Enrichment of Uranium ${ }^{9}$}

Substantial amounts of process heat are rejected into the atmosphere at the gaseous diffusion plant and, although occasional misting and fogging results on the site near the cooling towers, experience indicates that the thermal impact on the local flora and fauna is insignificant.

Although small quantities of air-borne fluorides and oxides of nitrogen and sulfur are released at the diffusion plant site, experience indicates that the off-site concentration of each of these contaminants is too low to have a deleterious on the local biota.

\subsubsection{Irreversible and Irretrievable Commitments of Resources} As indicated in Tables A.1.1-5, -6 and -7 , better than $82,000 \mathrm{MT}^{*}$ of uranium-bearing ore, located under the surface of 2.0-4.4 acres of mining-milling land, are committed each year in support of a typical FAssumes a uranium content of $0.20 \%$ or $2000 \mathrm{ppm}$. 
1000 MWe LWR. 8,9 Whenever it becomes necessary to mine lower-grade conventional ores, the quantities of ore removed will become proportionately greater.

Although the LWR currently consumes less than $2 \%$ of the potentiallyavailable nuclear energy in the contained uranium (roughly $30 \mathrm{MTU}$ of design enrichment throughput per year per 1000 MWe LWR), the unburned uranium values are chemically recovered after LWR-irradiation and, presently, are retained either for recycle in the LWR (after some enhancement of its fissile content) or for use as both fertile and fissile material in the LMFBR fuel cycle. The generation of all anticipated nuclear power by LWRs only, through the end of the century, would necessitate exploiting progressively lower grades of uranium ores to produce the 150,000 tons of natural uranium oxide, $\mathrm{U}_{3} \mathrm{O}_{8}$, required each year by the year 2000. Figure A.1.1-1 identifies estimated quantties of uranium in some of the various known sources of uranium in the U.S. and in the ocean. Aside from those labeled "conventional", it is apparent that the bulk of the uranium occurs in "part per million" quantities in shales, granites and seawater. The economic and environmental consequences of having to tap these low-grade sources for the quantities, and at the rates, required to sustain a large burner/converter industry have not been evaluated in any detail. Some idea of these consequences may be gained, however, from the following discussion. 
The Chattanooga shales lie in three layers under some 150 feet of cheety limestone of which only the upper two are considered (second and third bars in Figure A.1.1-1). The upper layer, about 7 feet thick, contains about 70 parts per million (ppm) of uranium and was previously estimated to cost about $\$ 50$ per pound $\mathrm{U}_{3} \mathrm{O}_{8}$ to recover. The middle layer, about 8 feet thick and separated from the upper by 2 feet of silt, contains 25-60 ppm of uranium and was estimated to cost about $\$ 100$ per pound $\mathrm{U}_{3} \mathrm{O}_{8}$ to recover. Both layers mined together (at an average of $50 \mathrm{ppm} U$ ) were expected to cost about $\$ 75$ per pound $\mathrm{U}_{3} \mathrm{O}_{8}$ for mining and milling. These estimates were based on underground mining due to depth of the deposit. Some new, though preliminary, estimates* which include escalation and a more thorough treatment of waste handling indicates that the previous estimates of $\$ 50$ and $\$ 100$ are now more like $\$ 100$ and $\$ 200$, respectively. Even though waste handling and land restoration was examined more completely, certain aspects, such as the logistics of handling and temporarily storing very large volumes of wastes while mining is underway, have not been fully evaluated.

Mining and milling to produce 150,000 short tons of $\mathrm{U}_{3} \mathrm{O}_{8}$ per year would require the mining of about 12 million tons of shale per day throughout the year*t. Milling of this ore would require hundreds of plants (the largest western plant at present has a capacity of

₹Private communication-ORNL; report in preparation. **Assumes $70 \%$ recovery of $U$ in the leaching process, since the uranium concentration is very low and is distributed through a myriad of fine veins throughout the shale. 
6,000 tons per day), requiring a total investment of 50 to 85

billion dollars; the labor force is estimated at about 100,000 men in the mines and 200,000 men in the mills. The operations would be expected to use about 5 times the current U.S. consumption of sulfuric acid for all purposes, and in excess of one billion gallons of water per day. Because of the quantity of water involved, some method of recycle would have to be found. Costs of pumping this water, because of uncertainties in its distribution and disposition, were not included in the estimate.

LWR-fuels are clad in zirconium-base alloys which become radioactive as the result of neutron absorption; roughly one-quarter metric ton of zirconium is committed for every ton of fuel charged to a current Pressurized Water Reactor, or about 7.5 MT of zirconium are consumed/committed per year per 1000 iWe LWR.

\subsubsection{Cost and Benefits}

The nuclear power industry that exists in the United States today is limited largely to light water reactor designs, although the high temperature gas reactor (HTGR) will begin to share this market in the relatively near future. The LWR is offered as an alternative power source to fossil-fueled steam electric plants and has received an increasingly larger share of the market each year. In 1973 approximately 43,000 megawatts of nuclear capacity and about 30,000 megawatts of central station fossil capacity were ordered. The increasing quantity of nuclear orders in the past years is evidence 
of a strong trend to nuclear power.

While nuclear power plants have higher capital costs than coalfueled power plants (oil and gas are no longer seriously considered as fuel options for central station power plants), the differential in fuel costs favors nuclear to the extent that in most areas of the country total power costs are lower for nuclear power plants. It appears that the demand for coal will be greatly increased in the near future. At the urging of the President, electric generating facilities are being switched from oil to coal. It is estimated that this change could result in an increase in coal use of nearly 70 million tons per year by the end of next year. There are other industrial uses of ofl that will switch to coal and coal will also be used as a resource for synthetic liquid or gaseous fuel. It is expected, therefore, that the relative position of nuclear power costs to fossil power costs will further improve due to increases in power plant coal prices resulting from this increased demand.

Table A.1.1-8 provides a comparison of costs and environmental impacts of electric energy production from coal fueled power plants and light water reactor power plants. Gross direct environmental impacts of extracting, processing and transporting fuel -- so visible in the coal fuel cycle -- are essentially absent in the nuclear fuel cycle because of the high energy content (on a mass 
Table A.1.1-8

COMPARISON OF COSTS AND IMPACTS OF COAL AND LIGHT WATER REACTOR PLANTS 25

Basis: 1000 Me Power Plant, 75\% CF

POWER PLANT AND ENERGY SYSTEM EFFICIENCIES

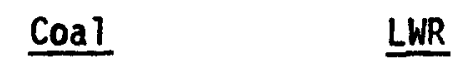

Electrical Energy (billion klhe/year)

Power Plant Heat Rate (BTU/kWhe)

Power Plant Thermal Efficiencies (kwe/kw,$\%$ )
Energy System Efficiency (kwhe consumer/

kwh input, $_{t}$ )

9.700 .57

38

$10,850^{6.57}$

35

32

CONSUMPTION OF NON-RENEWABLE FUEL RESOURCES

Power Plant Fuel Consumption (annual)

Fraction of Reserves Consumed (annual)

2.3M tons

0.000006

2 130 tons $U$

CONVENTIONAL COSTS (mills/kWhe)**

Plant
O\&M
Fuel
Total

\begin{tabular}{l}
6.8 \\
0.53 \\
4.4 \\
\hline 1.7
\end{tabular}

8.5

0.73

$\frac{2.1}{11.3}$

SELECTED ABATEMENT COSTS (mills/kWhe)**

2.5

0.6

OCCUPATIONAL HEALTH AND SAFETY

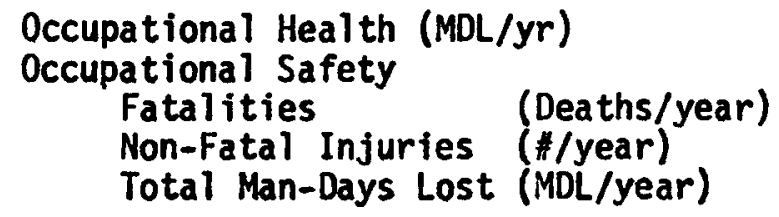

600
1.1
46.8
9,250

PUBLIC HEALTH AND SAFETY

Public Health

Routine Pollutant Release (MDL/year) 
Table A.1.1-8 (continued)

Basis: 1000 MWe Power Plant, 75\% CF

Public Safety

Transportation Injuries

Fatalities
Non-Fatal Injuries ( $($ / /year)
Total Man-Days Lost (MDL/year)

Coal

LWR

Land

Land Use, Inventory (acres)

Air

Land Use, Consumption (acres/year)

$\mathrm{SO}_{2}$ release, $\mathrm{w} / 0$ abatement (tons/year)

120,000

24,000

$\mathrm{NO}_{2}$ release, $w$ abatement $\mathrm{w} / 0$ abatement (tons/year)

27,000

0.009

3,500

0.08

60

Particulate releases, $w / 0$ abatement (tons/year)

Particulate releases, $w$ abatement

Trace Metals releases (tons/year)

Radioactivity releases ( $\mathrm{Ci} /$ year)

Thermal Discharge, power plant stack (billion $\mathrm{kwh}_{\mathrm{t}}$ /year)

Water

Cooling Water Use (billion gal./year)

270,000

2,000

$0.5 \mathrm{Hg}$

0.02

1.64

12

Process Water Use (billion gal./year)

Radioactivity releases (Ci/year)

Other Impacts (billion gal./year)

Thermal Discharge, power plant

(billion $\mathrm{kwh}_{t} /$ year)

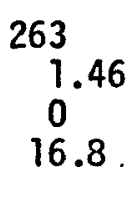

9
3,600

720

810

8,000

60

$250-500 T$

0

424

0.095
$500-1000$

$\mathrm{S}$

14

UEUnevaluated; $S \equiv$ Small; $M \equiv$ Million; $B \equiv B$ Bllion; $T \equiv$ Thousand

* The number of digits shown is not generally indicative of precision. In many cases, several digits are retained merely for calculational purposes.

**1980 dollars 
or volume basis) of nuclear fuels. Similarly, nuclear power plants do not discharge large visible quantities of airborne pollutants.

The current generation of nuclear power plants -- the light water reactors -- discharge about one-third more heat to the environment than do modern fossil plants. Though relatively small in mass and volume, material flows and residuals in the nuclear fuel cycle are not without very substantial potential hazard (see Section 1.1.6 for discussion of environmental impacts). For this reason, nuclear systems are designed, fabricated, and operated with numerous safeguards, high performance radwaste systems, redundancies, and with increasingly vigilant quality assurance programs and standards.

\subsubsection{Overall Assessment of Role in Energy Supply}

\subsubsection{Probable Role up to Year 2000}

The introduction and use of fission energy for the large scale generation of electricity in this country will necessarily be a two phase process. Phase I is the current era of "burner/converter" reactors - now principally LWRs, but with growth expected in the use of HTGRs. Phase II will be the era of breeder reactors, beginning with the Liquid Metal Fast Breeder Reactor (LMFBR), which should be an option available to the utilities by the mid 1980's.

The AEC's most recent projection 8 of nuclear power growth in the U.S. is summarized in Figure A.1.1-20. The "most likely" case projects an 


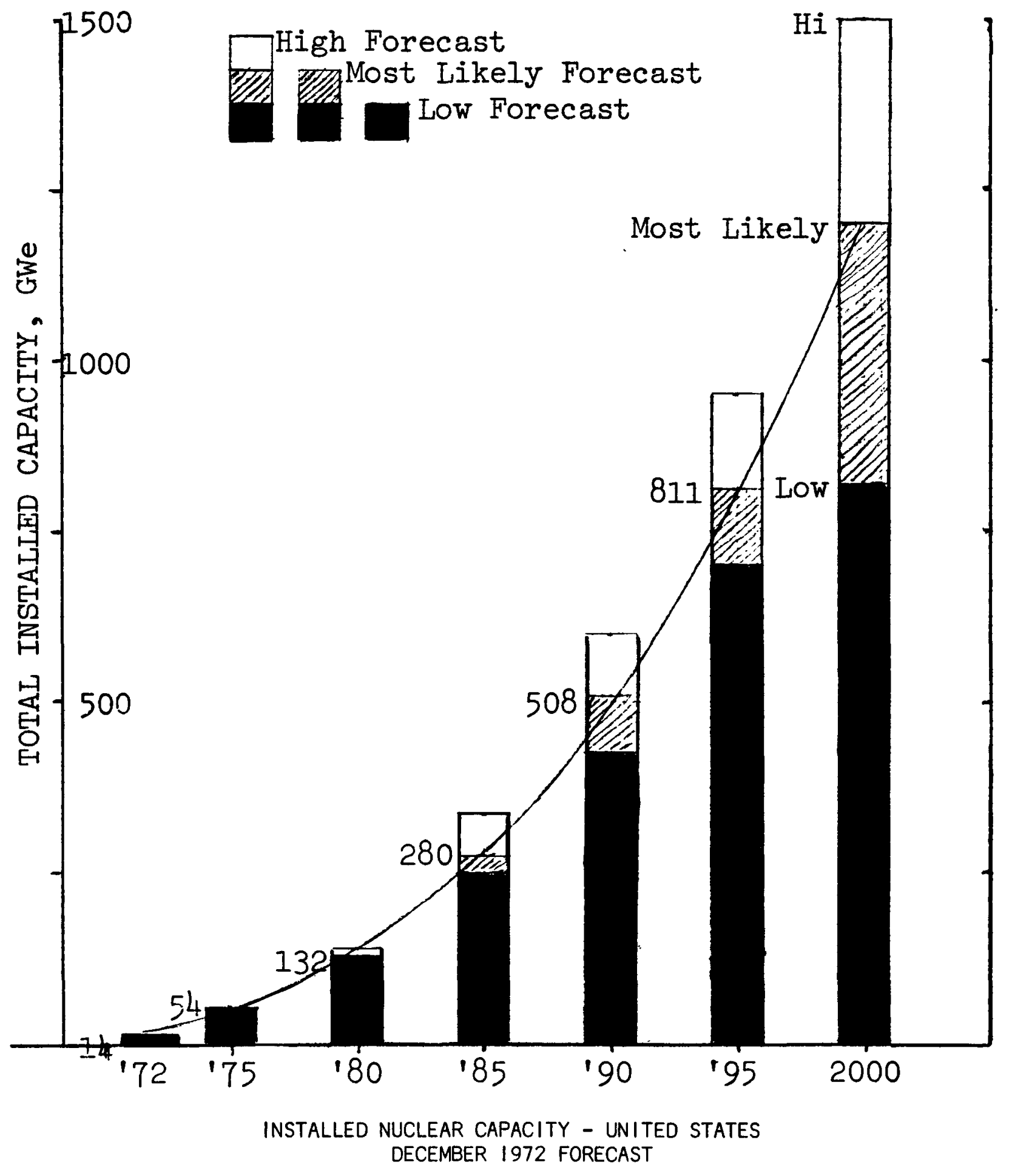

Figure A.1.1-20 
installed nuclear-electric capacity of about 1200 GWe (or 1200 million kWe) by the end of year 2000. This capacity is expected to consist of LWRs (60\%), HTGRs (8\%) and LMFBRs (32\%) if large-scale introduction of LMFBRs begins in 1986, as is assumed. The installed nuclear electric capacity in the year 2000 is expected to account for about $60 \%$ of the total installed electric generation capacity in the U.S.

One assumption inherent in these estimates is that sufficient uranium will be available in a price range that will permit the projected burner/converter plants to be economically competitive, over their service lives, with alternative ways of generating electricity. As previously noted (subsection 1.1.6), there will be large environmental and economic incentives for making the transition from the burner/ converter era to the breeder era without having to use the very low-grade sources of uranium. Thus, it is reasonable to suppose that the conventional uranium ore supply outlook at any given time will be a critical factor in a utility's choice of a burner/converter plant for needed additional capacity.

Table A.1.1-9 shows the cumulative amounts of uranium required to support increasing amounts of installed burner/converter capacity. It is keyed to the WASH-1139 (72) "most likely" projections and assumes that the nominal service life of a nuclear plant is 30 years. The second entry for the year 2000 assumes that breeder introduction is delayed to 2001 and that burner/converter capacity 
is built in lieu of breeders up to that time. $U_{3} 0_{8}$ requirements are sensitive to the timing and rate of breeder introduction.

\section{Table A.1.1-9}

PROJECTED URANIUM REQUIREMENTS*

Year

Installed Burner/Converter

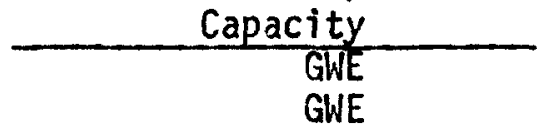

1985

1990

2000 (1986 breeder)

2000 (no breeder)
279

483

800

1200
Plant Lifetime $\mathrm{U}_{3} \mathrm{O}_{8}-$

Requirement to Support

Installed Capacity

millions of tons

*Bases: $0.3 \%$ enrichment plant tails; average lifetime plant factor $71 \%$; nominal service life 30 years.

Recalling that currently-known and estimated potential conventional uranium resources, up to the $\$ 30 /$ pound of $U_{3} 0_{8}$ level, are estimated at about 2.4 million tons of $U_{3} O_{8}$, one can see from Table A.1.1-8 that the ability to continue growth of burner/converter capacity beyond about 1990 would depend upon the location of large additional quantities of conventional ores. Moreover, such additional quantities would have to be identified within the next decade or so to have a timely influence on utility decisions. Decisions to purchase nuclear plants to be in operation by the early-1990s will have to be made in the early - to mid-1980s. 
In summary, LWRs will dominate the nuclear electric scene through the year 2000. The rate of growth of LWR and HTGR capacity beyond 1990 is currently uncertain, and depends upon finding additional sources of conventional ores, either domestic or foreign. To achieve the projected 800 GWe of installed burner/converter capacity by the year 2000 would require a considerable expansion of presently-known and estimated potential resources.*

\subsubsection{Probable Role Beyond Year 2000}

While speculative, it seems prudent to assume that conventional uranium resources probably will not support continued growth of burner/converter capacity beyond the turn of the century. With this assumption, there would be a steady decrease in installed burner/converter capacity beyond year 2000 , al though some new burner/converter plants would probably be built. Within the first decade of the next century, all of the plants built prior to 1980 will be reaching the end of their nominal 30-year service lives, and by 2030 the residual burner/converter capacity on-line would have become a very small fraction of total electric capacity.

FTo actually produce the 4.4 million tons of $U_{3} O_{8}$, as indicated in Table A.1.1-10, at the required rates would require locating much more $\mathrm{U}_{3} \mathrm{O}_{8}$ in the ground. 


\subsubsection{References}

1. USAEC, Division of Reactor Development and Technology, "Current Status of Future Technical and Economic Potential of Light Water Reactors," WASH-1082; Superintendent of Documents, U.S. Government Printing Office, Washington, D.C. 20402 (3/68).

2. Division of Reactor Development and Technology, "Status of Central Station Nuclear Power Reactors - Significant Milestones," WASH-1208 (12-73); U.S. Atomic Energy Commission, Washington, D.C. $20545(12 / 73)$.

3. Joint Committee on Atomic Energy, U.S. Congress, "Civilian Nuclear Power Program Hearings, February 22 \& 23, 1972"; Supt. of Documents, U.S. Government Printing Office, Washington, D.C., 20402 (1972). (Hearings have been held before the JCAE on the Civilian Nuclear Power Program since 1953).

4. U.S. Atomic Energy Commission, "Potential Nuclear Power Growth Patterns," WASH-1098; Superintendent of Documents, U.S. Government Printing Office, Washington, D.C. 20402 (1970).

5. USAEC, Division of Production and Materials Management, "Nuclear Fuel Supply," WASH-1242; Superintendent of Documents, U.S. Government Printing Office, Washington, D.C. 20402 (May 1973).

6. USAEC, Division of Production and Materials Management, "Nuclear Fuel Resources and Requirements," WASH-1243; Supt. of Documents, U.S. Government Printing Office, Washington, D.C. 20402 (4/73).

7. National Petroleum Council, "U.S. Energy Outlook - Nuclear Energy Availability-1973;" National Petroleum Council, $1625 \mathrm{~K}$ Street, NW, Washington, D.C. 20006 (1973).

8. Office of Planning and Analysis, "Nuclear Power 1973-2000," WASH-1139-72; U.S. Atomic Energy Conmission, Washington, D.C. 20545 (December 1972).

9. Directorate of Licensing, "Environmental Survey of the Nuclear Fuel Cycle," WASH-1237; U.S. Atomic Energy Commission, Washington, D.C. 20545 (November 1972).

10. Atomic Energy Conmission, "The Safety of Nuclear Power Reactors (Light Water Cooled) and Related Facilities," WASH-1250; U.S. AEC Technical Information Center, P. 0. Box 62, Oak Ridge, Tenn. 37830 (July 1973).

11. Cadek, F. F., et al, "PWR FLECHT (Full-Length Emergency Cooling Heat Transfer) - Final Report," WCAP-7665, Westinghouse Electric Corp. (4/71). 60612 (1972). 
12. Conmonwealth Edison Company, "Final Safety Analys is Report Zion Station"; U.S. AEC Docket No. 50-295 (1970).

13. Denton, H. R., "Statement on the Sources of Radioactive Material in Effiuents from Light-Water-Cooled Nuclear Power Reactors and State of Technology of Waste Treatment Equipment to Minimize Releases," in AEC Staff Statement "10 CFR Part 50, Licensing of Production and Utilization Facilities, Light-Water-Cooled Nuclear Power Reactors, Numerical Guides for Design Objectives and Limiting Conditions for Operations to Meet the Criterion 'As Low As Practical for Radioactive Material in Light-WaterCooled Nuclear Power Reactor Effluents'." USAEC Docket RM-50-2, Washington, D.C. 20545 (1972).

14. Hearings before the Joint Comittee on Atomic Energy, Congress of the United States, October 28-31 and November 4-7, 1969, "Environmental Effects of Producing Electric Power - Part i"; Supt. of Documents, U.S. Government Printing Office, Washington, D.C. 20402 (1969).

15. Federal Power Commission, "The 1970 National Power Survey Part 1," Supt. of Documents, U.S. Government Printing Office, Washington, D.C. $20402(11 / 71)$.

16. Water Reactor Safety Program Office, Idaho Nuclear Corp., "Water Reactor Safety Program PIan," WASH-1146; U.S. Atomic Energy Cormission, Washington, D.C. $20545(2 / 70)$.

17. Whitman, G. D. et al, "Program Plan for USAEC-RDT Seismic Research," ORNL-TM-3804; Oak Ridge National Laboratory, Oak Ridge, Tennessee, $37830(6 / 72)$.

18. U.S. Atomic Energy Commission, "The Potential Radiological Implications of Nuclear Facilities in a Large Region in the U.S. in the Year 2000,"WASH-1209; Supt. of Documents, U.S. Government Printing Office, Washington, D.C. 20402 (1/73).

19. USAEC, Division of Reactor Development and Technology, "Thermal Effects and U.S. Nuclear Power Stations," WASH-1169; Supt. of Documents, U.S. Government Printing Office, Washington, D.C. $20402(8 / 71)$.

20. Directorate of Licensing, "Final Environmental Statement Related to Operations of Calvert Cliffs Nuclear Power Plant, Units 1 and 2 - Baltimore Gas and Electric Company;" U.S. AEC Docket Nos. $50-317,-318(4 / 73)$.

21. USAEC, Directorate of Regulatory Operations, "Report on Releases of Radioactivity from Power Reactors, In Effuents, During 1971," WASH-1198; Supt. of Documents, U.S. Government Printing Office, Washington, D.C. 20402 (1971). 
22. Logsdon, J. E. and Chissler, R. I., "Radioactive Waste Discharges to the Environment from Nuclear Power Facilities," BRH/DER 70-2; HEW-Public Health Service, Rockville, Maryland 20852 (1970).

23. Atomic Energy Commission, "AEC Gaseous Diffusion Plant Operations," ORO-658; U.S. AEC Technical Information Center, Post Office Box 62, Oak Ridge, Tennessee 37830 (2/68).

24. "The Nation's Energy Future - A Report to Richard M. Nixon, President of the United States," WASH-1281, submitted by Dr. Dixy Lee Ray, Chaiman, United States Atomic Energy Commission, 1 December 1973.

25. Atomic Energy Commission, "Comparative Risk-Cost-Benefit Study of Al ternate Sources of Energy," WASH-1224, in publication. 
A.1.2 HIGH TEMPERATURE GAS COOLED REACTORS

1.2.1 Introduction

\subsubsection{General Description}

The High Temperature Gas Cooled Reactor (HTGR) is an advanced converter reactor operating on the thorium-uranium ${ }^{233}\left(T h-{ }^{233} \mathrm{U}\right)$ fuel cycle. Helium is used as the reactor coolant and graphite is the moderator and core structural material. The fuel is a mixture of thorium and uranium particles coated with thin layers of pyrolytic graphite. These particles are then bonded into fuel rods and inserted into large blocks of graphite. The use of helium as a coolant has the fundamental advantages that the coolant always remains in the same phase and is chemically inert. However, because of its relatively poor heat conduction properties, moderately high pressures must be used. The graphite is used both as a moderator and a core structural material; it has excellent thermal conductivity, high strength even at high temperatures, and extremely high melting and vaporization temperatures. A potential disadvantage of graphite is its tendency to react with steam (which might enter the reactor core if there should be a leak in a steam generator). The resulting steam-graphite reaction might lead to structural damage to the graphite core and the generation of combustible gases. Engineered safety features to prevent or mitigate such occurrences therefore must be incorporated into the design.

The HTGR system operates with coolant temperatures high enough to permit use of optimum plant steam conditions. Thus, overall thermal 
efficiencies of about $40 \%$ are achievable as compared to approximately 33\% for present generation LWRs. In addition, an advanced HTGR concept using gas turbines and a bottoming cycle (vapor turbines to extract electrical power from the reject heat) has the potential for achieving thermal efficiencies of up to $50 \%$.

\subsubsection{History}

The use of gas coolant for large nuclear reactors dates back to the middle 1940's when the United Kingdom used air as a coolant in the Windscale plutonium production reactors. Because of the initial success of this concept, the UK continued to use gas (carbon dioxide) as the coolant for their nuclear reactors which are fueled with natural uranium. However, this concept is not completely satisfactory and it appears that no more of this type of reactor will be built.

Gas cooled reactors using natural uranium fuel have not been adopted for conmercial power generation in the United States, primarily because the capital costs of these reactors are greater than enriched uranium-fueled designs and the private capital funding structure in this country made the power cost of these systems too high. However, in 1957, General Atomic Company* (a subsidiary of Gulf 0 il Corporation and Shell Nuclear (td.) initiated conceptual designs of a helium cooled, graphite moderated power plant using enriched uranium fuel. 1 The results of these studies indicated that the concept had sufficient merit to proceed to a demonstration phase. In 1958, Philadelphia 
Electric Company and other members of the High Temperature Reactor Development Associates (HTRDA), a consortium of utility companies, formally proposed to the AEC the construction of a 40 MWe prototype HTGR under the Power Reactor Demonstration Program. In 1960, an application for a construction permit was submitted by Philadelphia Electric for a prototype plant at Peach Bottom, Pennsylvania. This reactor was placed in commercial operation in May 1967 and has operated satisfactorily since then. The operating experience with this Peach Bottom reactor ${ }^{2}$ has established the potential of the HTGR as a large-scale power source.

\subsubsection{Status}

Continued research and development directed toward adopting the basic features of the Peach Bottom reactor to larger, commercial sized systems resulted in an agreement in 1965 between the Public Service Company of Colorado, the AEC and General Atomic for the construction of a 330 WWe HTGR, the Ft. St. Vrain Reactor (FSVR), to be constructed near Plattville, Colorado. Construction began in 1968 and commercial operation of the plant is expected in 1974. This plant provides a link between the small, 40 Mwe Peach Bottom Reactor and the larger units (770 and 1160 MWe) which are being offered for sale by General Atomic Company. The FSVR is the first U.S. reactor to use a prestressed concrete reactor vessel (PCRV). The use of this type of vessel produces a more compact plant design, and simplifies operation and maintenance. 
Several large HTGR's have been ordered by utilities. In August 1971. Philadelphia Electric announced the purchase of two 1160 MWe plants. Since that time, 4 smaller ( 770 MWe) HTGR's have been sold to Delmarva Power and Light and to Southern California Edison. The Delmarva application for a construction permit for one of its two plants was docketed on August 16, 1973.

Current AEC projections indicate that by 1990 about $15 \%$ of the nonbreeder nuclear power plants will be HTGR's. ${ }^{3}$ It is expected that the successful startup and operation of the FSVR will provide the final proof of the concept and thus add assurance of the commercial viability of the HTGR system.

\subsubsection{Extent of Energy Resource}

An 1160 MWé HTGR requires about 1,600 kilograms of $93 \%$ enriched ${ }^{235} \mathrm{U}$ and 37,500 kilograms of thorium for its initial core. Assuming enrichment tails of $0.25 \%{ }^{235} \mathrm{U}, 380$ tons of natural $\mathrm{U}_{3} \mathrm{O}_{8}$ are required for the initial core loading. For subsequent reloads (assuming recycle of the $233 \mathrm{U}$ produced from the ${ }^{232} \mathrm{Th}$ ), approximately 8,000 kilograms of thorium and 390 kilograms of $93 \%$ enriched $235_{U}$ will be needed annually. The natural $U_{3} 0_{8}$ requirement is about 130 tons/annum.

A discussion of the availability of uranium is presented in the review of Light Water Reactors (Section A.1.1.2).

The availability of thorium throughout the world is presented in Table A.1.2-1. In addition, the estimated U.S. thorium resources by 
Table A.1.2-1

WORLD THORIUM RESOURCES $-\$ 10 / 1 \mathrm{~b} . \mathrm{ThO}_{2}$
(TOns $\mathrm{ThO}_{2}$ )

Indi a I/

Reasonably Possible Assured Additional Total

United States 2 ]

300,000

250,000

550,000

Canada

65,000

335,000

400,000

$100,000^{3 /}$

155,000

255,000

Africa!

50,000

50,000

100,000

Australia!

\& S.E. Asia

10,000

$-$

10,000

Brazil]

10,000

20,000

30,000

TOTAL

535,000

810,000

$1,345,000$

UNITED STATES

Lemhi Pass, Idaho

\& Montana

47,000

335,000

382,000

Placers:

Southeastern

U.S. $\quad 6,600$

Idaho \& Mont. 11,400

-- 6,600

-- 11,400

Placers Total

18,000

$\frac{--}{335,000}$

18,000

TOTAL U.S.

(Rounded)

65,000

400,000

II ENEA 1965. Africa includes Central Africa, South Africa and Madagascar.

2/ USAEC Division of Production and Materials Management, 1973.

3/ Canada, Mineral Bulletin 117, 1971. Mostly by-product of uranium mining. Reasonably assured given as over 100,000; possible additional not given. 
cost is presented in Table A.1.2-2. It can be seen from these tables that thorium availability will not be a deterrent to the full utilization of the HTGR concept. For example, the amount of thorium available in Canada as a by-product of uranium mining operations will be sufficient to fuel all of the HTGR's which will be built in the U.S. during this century.

Table A.1.2-2

ESTIMATED U.S. THORIUM RESOURCES ${ }^{4}$

CUTOFF COST

DOLLARS PER LB. $\mathrm{ThO}_{2}$

10

30 !I

501
THOUSANDS OF SHORT TONS OF $\mathrm{ThO}_{2}$

REASONABLY ESTIMATED

ADDITIONAL

335

400

200

400

600

3,200

7,400

10,600

IIncludes lower cost resources.

Insofar as the extent of helium resources available to serve as coolant for gas-cooled reactors is concerned, the U.S. Government has been storing helium processed from natural gas since 1961. 5 This policy was terminated in early 1973 by which time an assured supply of about 45 billion cubic feet of helium was available. 
A U.S. Bureau of Mines report ${ }^{6}$ states that the amount of helfum in the "proved" U.S. natural gas resources was estimated to be 253 billion cubic feet in 1960 and about $80 \%$ of this would be economically recoverable with current technology. However, the helium-rich natural gas resources now known will probably be depleted by 1990, and helium will have to be recovered from leaner natural gas at an increased cost. The Bureau of Mines report provides estimates of the possible avallability of helium in the natural gas forecast to be produced annually in the U.S. The helium potentially available in the annual U.S. natural gas production would decline from about 20 billion cubic feet in 1975 to about 12 billion cubic feet in 2010 as the natural gas resources are depleted. These quantities could be available from the natural gas resources containing more than $0.09 \%$ helium at an estimated cost of $\$ 80$ or less per thousand cubic feet, which is about 2 to 3 times the current price.

The price of helfum has very little effect on the power generating cost for helium-cooled reactors. At the current cost of about $\$ 35 / 1000$ cubic feet, helium represents $0.002 \mathrm{mills} / \mathrm{kwhr}$ of the generating cost. At $\$ 1000 / 1000$ cubic feet (a cost estimated for recovery from air), this cost would increase to $0.06 \mathrm{mills} / \mathrm{kwhr}^{7}$ Thus it is very probable that as the price of helium rises there will be more economic incentive to recover it from natural gas, and that there will be sufficient helium in the U.S. natural gas resources to recover the amounts needed if a large national commitment to the HTGR (or Gas-Cooled Fast Reactor) were to occur later in this century. 
To put this supply in perspective, one 1000 Me HTGR will require an initial inventory of about $2 \times 10^{6}$ standard cubic feet (scf). At an average helium leakage rate of $0.1 \% /$ day from the coolant system, the plant will need about another $20 \times 10^{6}$ scf of gas to maintain its coolant supply over a thirty-year lifetime. It can therefore be seen that the total helium gas reserve in storage today, if used solely for that purpose, could supply about 2000 gas-cooled reactors (HTGRs and GCFRs) of 1000 MWe-size. There are, of course, other requirements for the stored helium, so that alternative supplies from leaner natural gas, foreign sources, and perhaps by extraction from air at substantially higher (but presumably acceptable) costs will be necessary to support an expanded gas-cooled reactor economy.

\subsubsection{Technical Description of the Energy System}

\subsubsection{Power Generation Plant}

The operating parameters of an 1160 Mhe steam cycle power plant now being marketed are given in Table A.1.2-3. $8,9,10$ The most striking feature of the HTGR is the Prestressed Concrete Reactor Vessel (see Figure A.1.2-1). The PCRV contains the reactor core and entire primary coolant system, including steam generators and helium circulators. The PCRV also serves as the primary coolant system pressure boundary and provides the necessary biological shielding. The vessel consists of a central cylindrical cavity containing the core, surrounded by six cavities containing the steam generators and main helium circulators, and by three smaller cavities containing the auxiliary gas circulators and heat exchangers. 
Table A.1.2-3

OPERATING PARAMETERS FOR A LARGE HTGR

General

Thermal Power, MW(th)

3000

Electric Power, NW(e)

1160

Plant Lifetime, years

40

Conversion Ratio

0.66

Reactor

Fue 1, startup recycle

$T h / U_{235}^{235}$ (93\% enriched)

$\mathrm{Th} / \mathrm{U}^{235}$ (93\% enriched) / $U^{233}$ (recycle)

Fuel form

Coated particles in cylindrical bonded rods

Moderator

Graphite

Avg. Power density, kw/liter

8.4

Outlet temperature, ${ }^{\circ} \mathrm{F}$

1366

Temperature rise across core, ${ }^{\circ} \mathrm{F}$

Fuel Temperature, Avg./Max., ${ }^{\circ} \mathrm{F}$

$1634 / 2467$

Reactor Vessel, height, ft

20.8

Reactor Vessel, diameter, ft

27.8

Coolant Inlet pressure, psi

710

Vessel Material

Prestressed Concrete

Other Components

Number of circulators

Circulator Speed, rpm

7050

Number of Steam Generators

Steam Conditions

Pressure, psi

Temperature, ${ }^{\circ} \mathrm{F}$ 


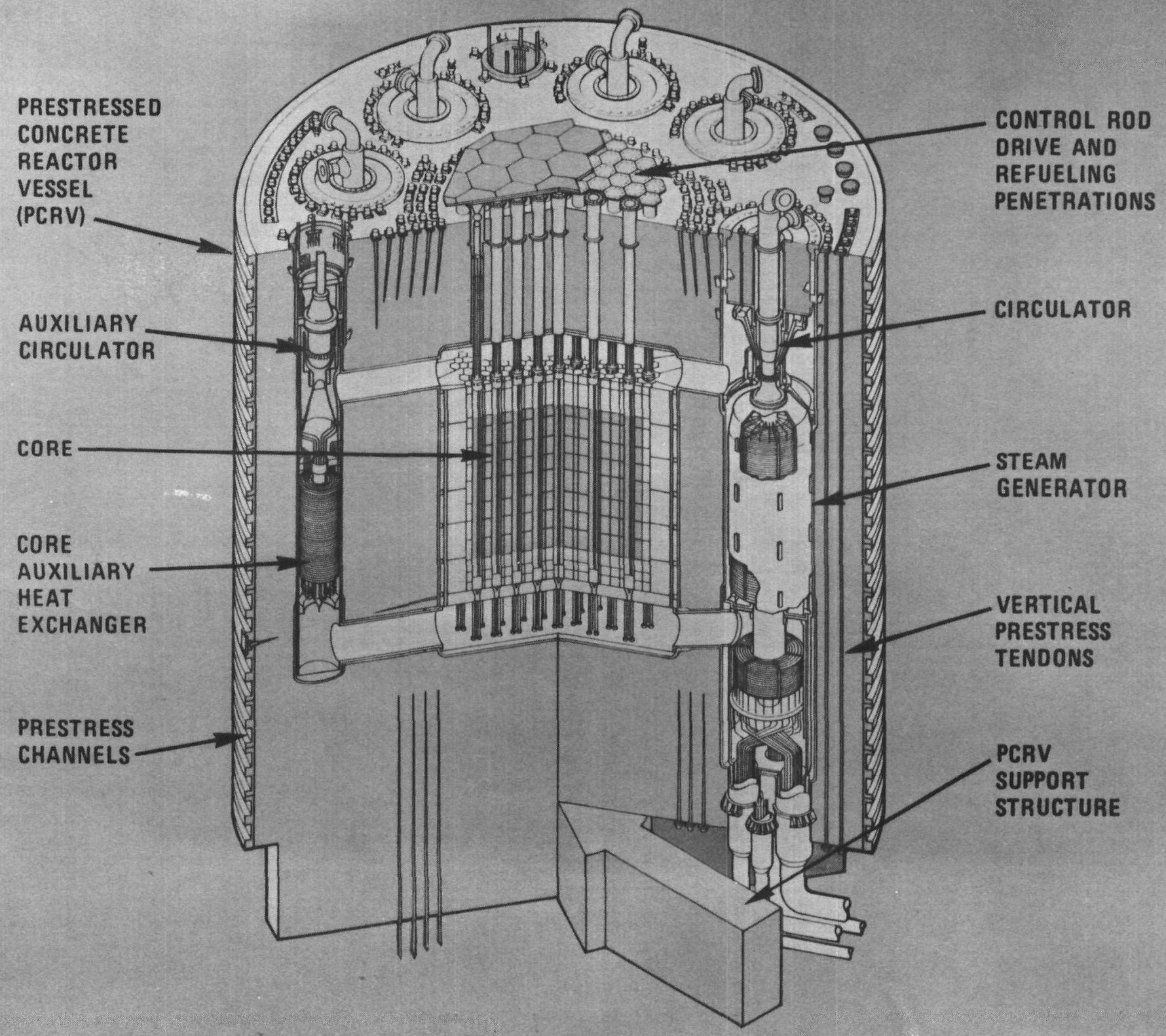


The cavities and all penetrations are lined with welded carbon steel, which act as a leak tight barrier. The top head above the central cavity of the PCRV contains a number of penetrations which house control rod drives, the reserve shutdown system and the core orificing mechanism. When this equipment is removed the fuel is handled through these penetrations. This head also contains wells that house helium purification equipment, source range instrumentation and neutron detectors.

The HTGR uses a ${ }^{233} \mathrm{U} / \mathrm{Th}$ fuel cycle, graphite for moderation and core structure, and helium coolant. The reactor core consists of vertical columns of hexagonal graphite blocks supported by a graphite core support structure. The core is divided into regions, each consisting of a central control rod element column and six surrounding fuel columns. The initial fueling consists of thorium and $93 \%$ enriched ${ }^{235} U$ particles. These particles are coated with pyrolytic carbon and bonded into rods that are loaded into the hexagonal graphite fuel blocks (see Figure A.1.2-2). The particle coatings provide the primary barrier for gaseous fission product retention. The particles containing ${ }^{235} U$ are also coated with silicon carbide which acts as a barrier for the retention of metallic fission products. Later in the fuel cycle, ${ }^{233} \mathrm{U}$ bred from the Th will be used to reduce the requirement for enriched ${ }^{235} \mathrm{U}$ makeup ". The HTGR fuel components are shown in Figure A.1.2-2. 


\section{HTGR FUEL COMPONENTS}

TRISO (U-235)

$\frac{\sqrt{n}}{\frac{1}{2}}$

BISO (Th-232 AND U-233)

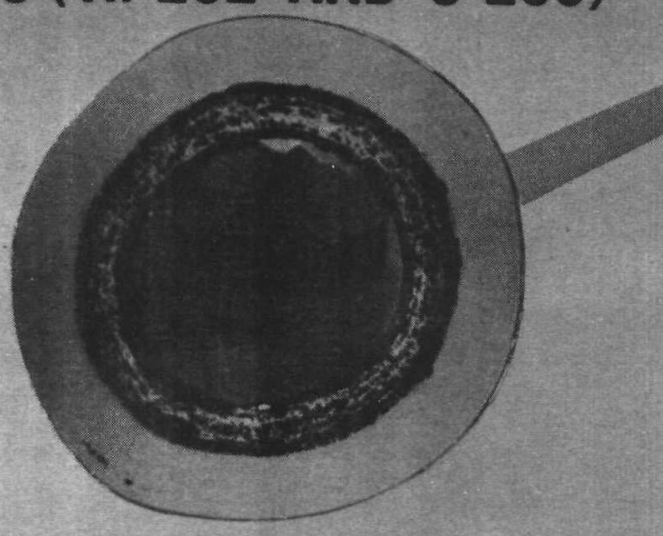

FUEL PARTICLES SCALE: $100 \times$
FUEL ROD $1 X$

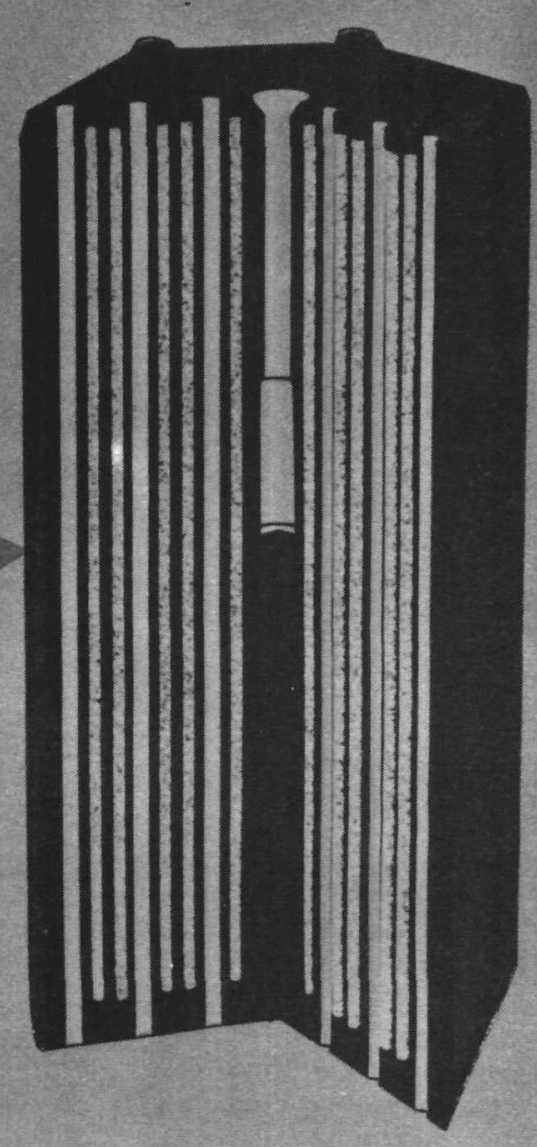

FUEL ELEMENT $1 / 7 x$ 
Reactivity control is accomplished by means of 73 pairs of control rods and drives. The drives are located in refueling penetrations in the PCRV. The drives are powered by electric winches which raise and lower the control rods by steel cables. Gravitational force acts to insert the control rods into the core following a reactor trip.

Each of the six primary circuits in an 1160 Me plant is equipped with a helium circulator. Each circulator consists of a single stage axial flow helium compressor and a single stage steam turbine drive. Motive power is provided by cold reheat steam from the main turbine. The circulators are water lubricated and have a helfum buffer seal that is designed to prevent helium leakage from the primary coolant or water in-leakage to the coolant.

Each steam generator consists of a single helical tube bundle arranged in an annulus of a center duct. Helium leaves the core at $1400^{\circ} \mathrm{F}$ and enters the steam generator. The resultant steam generator outlet conditions are $955^{\circ} \mathrm{F}$ and $2400 \mathrm{psig}$. The outlet from the reheat section is $1002^{\circ} \mathrm{F}$ and 550 psig. This results in a net plant efficiency of $39 \%$. The power conversion system for the HTGR is diagrammed in Figure A.1.2-3.

\subsubsection{Fuel Cycle}

The HTGR operates on the thorium-uranium fuel cycle with the fuel encased in small coated spherical particles. ${ }^{12,13}$ A plutonium 


\section{SCHEMATIC FLOW DIAGRAM}

HTGR POWER CONVERSION SYSTEM

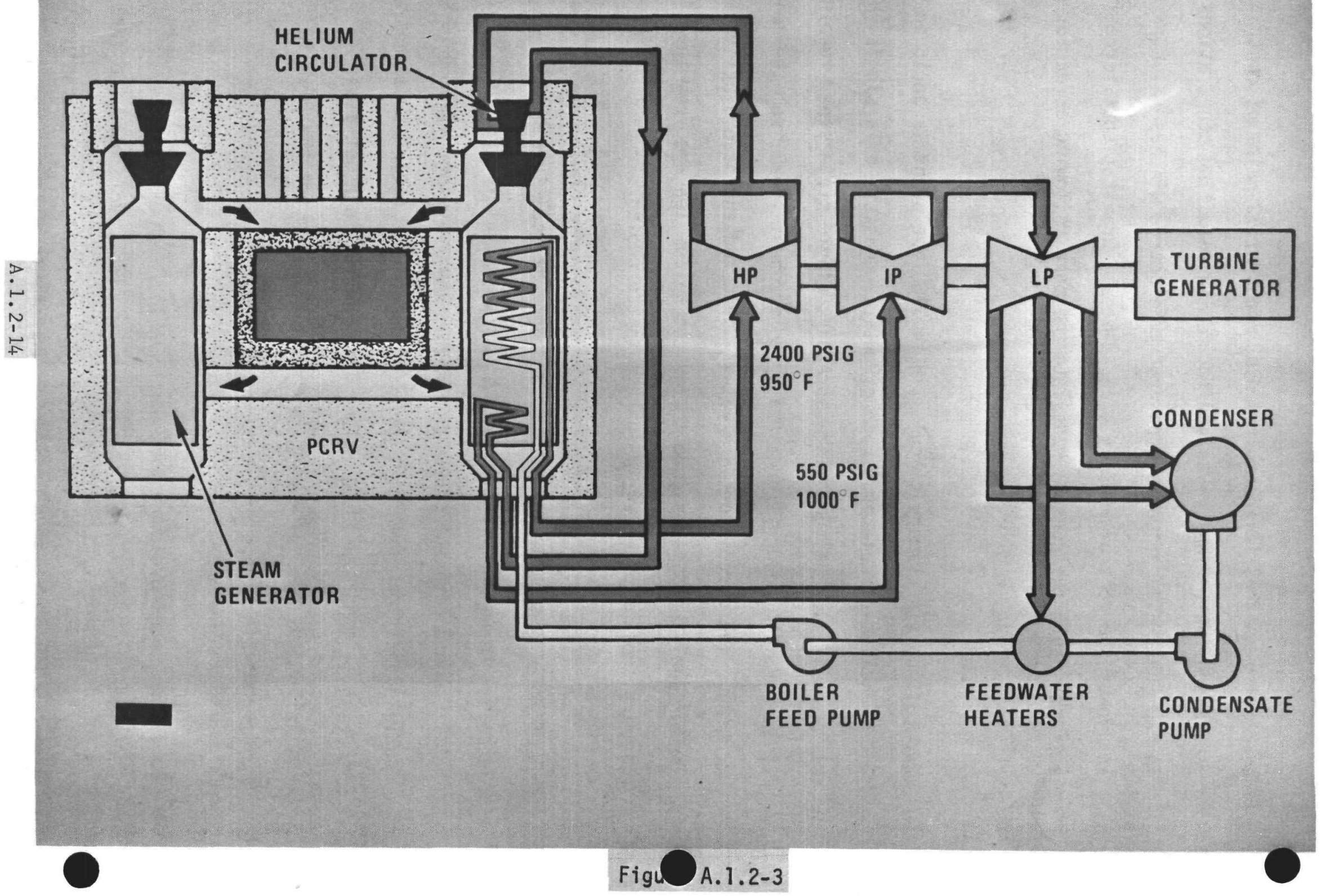


fuel cycle could also be used in the HTGR although the economics favor the thorium-uranium cycle.

The HTGR fuel cycle is slightly more complicated than the LWR cycle because it has both uranium and thorium input; it is of approximately the same complexity as the LMFBR fuel cycle, which uses plutonium and natural or depleted uranium. The uranium requirement of over 113 tons of $\mathrm{U}_{3} \mathrm{O}_{8}$ per year for a 1000 MWe HTGR is considerably below the annual needs of an LWR, but is, of course, above that for an LMFBR. The annual thorium requirement is almost 8 tons of $\mathrm{ThO}_{2}$, the oxide being the usual form of thorium in the ore. Thorium is present in some uranium ores in Canada. This by-product thorium has been accumulating in tailings piles in Canada for some time with the result that the reserves in these tailings dumps are thought to contain about 1000,000 tons of $\mathrm{ThO}_{2}$. Considering the relatively small amount of thorium required for HTGR operation, the by-product thorium in these Canadian tailings piles is more than enough to last the U.S. HTGR industry beyond 1990 even if the HTGR achieves full commercial acceptance. Furthermore, the typical annual HTGR thorium requirement is only about $10 \%$ of the annual HTGR uranium requirement. Economically exploitable reserves of $\mathrm{ThO}_{2}$ in the U.S. have been estimated at 400,000 tons.

The $U_{3} O_{8}$ is separated from the ore by processes which were described in Section A.1.1. Thorium oxide is milled in a similar manner; the ${ }^{220}{ }_{R n}$ which is released from the ore enters the mill ventilation 
system. A good fraction of the ${ }^{220}$ Rn would be expected to decay before discharge through the stack; the effluent would be filtered to remove particulate matter on which decay products tend to collect.

The thorium oxide is then sent directly to the preparation and fabrication plant, while the $\mathrm{U}_{3} \mathrm{O}_{8}$ goes to the conversion plant where it is converted to gaseous $U_{6}$ as in the LWR fuel cycle. The gaseous $U_{6}$ is sent to the gaseous diffusion plant, from which the product stream in the case of the HTGR is UF $_{6}$ with its uranium consisting of approximately 93 weight percent $235 \mathrm{U}$. The tails stream contains depleted uranium having a ${ }^{235} U$ concentration the same as the tails from enrichment for LWRs. These tallings are stored for possible future use.

Enriching uranium to 93 weight percent $235 U$ for HTGR fuel takes more separative work effort than enriching uranium to only two to four percent $235 U$ as is done for LWRs. However, the uranium requirements of the HTGR are so much lower than those of the LWR that the annual separative work at the enrichment plant turns out to be slightly lower for a 1000 MWe HTGR than for an LWR of the same size.

At the fabrication plant the three input streams of fuel materials are the enriched $U F_{6}$ from the gaseous diffusion plant, the thorium oxide from the mill, and the recycled uranium from the reprocessing 
plant. The recycled uranium is mainly ${ }^{233} \mathrm{U}$ which was converted from thorium during exposure in the reactor core. The use of the recycled uranium cuts down on the natural uranium which must be mined and enriched to fuel the HTGR. The most important factor in the handling of recycled $233 U$ is the presence of a small amount of $232 \mathrm{U}$ (72 year half-life) in the recycled uranium. The rapid buildup of the decay products of ${ }^{232} U$ following purification makes remote, well-shielded fabrication of this uranium a virtual necessity.

The fabricated HTGR fuel will have two types of small spherical particles containing oxides or carbides of uranium and thorium and will be coated with pyrolytic carbon. The fertile particles in the recycle mode contain the thorium and recycled uranium. The fissile particle contains the enriched uranium $\left({ }^{235} U\right)$. Fissile particles will have an extra inner layer of silicon carbide to enhance the retention of fission products and allow separation of the particles during reprocessing.

It is evident that fuel fabrication processes for the HTGR will be sufficiently different from the LWR processes that special or separate facilities will be required. Very small quantities of some radionuclides will unavoidably be released to the environment within standards, although the economic incentive to recover the fuel and the necessity for remote procedures tend to minimize possible releases. 
The fabricated fuel is then sent to the reactor. Following about four years of residence time in the reactor, the spent fuel will be removed and stored at the reactor for 5 months. This cooling period allows a significant amount of the fission products to decay at the reactor site before shipment and also allows most of the ${ }^{223} \mathrm{~Pa}$ (27 day half life) to decay to the desired ${ }^{233} U$. The spent fuel is shipped in heavily shielded casks via railroad or truck to a reprocessing facility to recover the remaining $233 \mathrm{U}$ and ${ }^{235} \mathrm{U}$. The spent fuel is reprocessed and the recovered uranium is sent to the fuel refabrication plant. The fission products which are recovered are treated as high level radioactive waste and will be sent to a federal repository for safe storage.

The fissile and fertile particles will be separated at an early stage of reprocessing. Laboratory studies indicate that this could be accomplished mainly by making use of the impenetrability of the silicon carbide coating which the fissile particle has and the fertile particle does not. The graphite, which is shipped to the reprocessing plant along with the fuel imbedded in it, is burned, and the burner off-gas is filtered and scrubbed before discharge to the atmosphere through the plant stack. The off-gas contains carbon-14 (formed from neutron absorption by ${ }^{13} \mathrm{C}$ and by neutron reaction with nitrogen-14). The total activity of ${ }^{14} \mathrm{C}$ released is expected to be on the order of 20 curies per year from the fuel of a 1000 MWe HTGR. Although it is recognized that the dose resulting from 
this release at the site boundary will be a function of the distance to the boundary at the specific site chosen for the reprocessing plant, of the height of release, of local atmospheric conditions, etc., it is currently estimated that the dose from this release will be well within that permitted by AEC regulations.

Other off-gases will be filtered and treated by various systems before release. Discharges to the environment from an HTGR reprocessing plant are estimated to be similar to those that expected during the reprocessing of LWR and LMFBR fuels (See Chapter 4, Section 4.3).

The uranium and thorium recovered from the fertile particles are decontaminated and separated by several solvent extraction steps. The resulting purified uranium is concentrated and shipped to the fabrication plant. The recovered thorium will probably not be used immediately due to the relatively high concentration of thorium-228, whose daughter products emit high energy gamma radiation. Instead, if abundant low-cost natural thorium is available, it will be stored for possible future use. Some thorium may be recycled after roughly a 12-year storage period, but this depends on the price of fresh thorium and storage costs. The uranium in the fissile particles may be recovered and sold if the economics are favorable.

\subsubsection{Safety Aspects}

The HTGR has a number of features which are inherent in its design 
that give this reactor concept somewhat different safety characteristics from either the LHR or the LMFBR. These are:

a. The large mass of graphite in the core with its attendant high heat capacity insures that any temperature change resulting from a reactivity insertion or loss of cooling will be slow;

b. The use of helium gas coolant with its low neutron cross section and low density results in the reactivity of the core being insensitive to changes in coolant density;

c. The use of the PCRV eliminates the need for external coolant piping, thus avoiding the concerns of primary pipe rupture that are encountered in sodium or water-cooled reactors. However, the integrity of vessel closures and flow limitation devices must be assured.

d. The use of coated fuel particles reduces the amount of fission products that would be released from any one fuel fallure, as compared to those which would be released from failure of the metal cladding on a fuel pin in an LWR or LMFBR. However, coated particle fuel does lead to the routine presence of some fission products in the coolant stream, due to diffusion through the coatings. The fission product activity level in the coolant must be maintained within specified limits by the helium purification system. 
In addition to these desirable characteristics, the use of graphite introduces the problem of the reaction of carbon with any steam that may leak into the system as a result of failure of any of the steam generator tubes. If large amounts of steam enter the primary system the reaction could result in loss of some of the structural graphite and release of any metallic fission products which were deposited on the graphite. Other features of the HTGR such as the PCRV and gas coolant result in different potential accident initiation or mitigation mechanisms from other reactor concepts such as the LMFBR or LWR. Although safety R\&D for HTGR's is still going on, as it is for other reactor types, the basic safety of the concept appears well in hand. Large HTGRs are now in the licensing process; based on expertence with Peach Bottom \#1 and the FSVR, it is expected that licensing will proceed as one might predict at this early stage of development, with no major unresolved safety issues expected to surface.

\subsubsection{Research and Development Program}

The successful operation of the Peach Bottom \#1 reactor since 1967 has satisfactorily demonstrated the use of the HTGR concept for power production. This accomplishment along with the construction and preoperational testing of the FSVR has shown that further extensive research and development activities are probably not required for the successful construction and operation of the FSVR type and size plant. However, a safety R\&D program remains necessary to provide an independent assessment of the safety of large HTGRs. With respect to HTGR fuel recycle, processes must be developed to 
reprocess the spent fuel and to fabricate the recovered ${ }^{233} U$ into coated particles for reinsertion into the reactor. The required R\&D program over the next five years fulfilling the above objectives has been estimated in the recent report to the President entitled "The Nation's Energy Future" 14 to cost about $\$ 164$ million.

The key problem in the reprocessing of the fuel is development of a process which will permit separation of the fissile $\left({ }^{235} U\right)$ particles from the kernels containing thorium and ${ }^{233} U$. As mentioned in Section 1.2.3.2, the fuel kernels can be separated from the graphite by burning the graphite and the two type particles may be separated based on the fact that the SiC coated fissile particle will not disintegrate on burning while the $\mathrm{Th}^{235} \mathrm{U}$ particle will. The reprocessing steps beyond the head-end process (dissolution and solvent extract) have been demonstrated in large scale facilities.

The requirement to fabricate the recovered ${ }^{233} U$ in shielded facilities, because of the presence of ${ }^{232} U$ and its daughters and the accompanying high energy gamma radiation, will necessitate the development of processes and equipment to perform these operations. The key to this fabrication development is construction of equipment that can be remotely operated and maintained. Progress has been made in the development of such equipment but an integrated refabrication line has not been built.

It is planned to perform large scale demonstrations of the reprocessing and fabrication technologies in the AEC's Idaho 
Chemical Processing Plant and in the Thorium Uranium Fuel Cycle Development Facility at ORNL, respectively.

While the research and development programs related to the fuel cycle are essential to the commercialization of the HTGR, other R\&D activities are being carried out to develop a better understanding of the reactor system, to improve the performance of the system, and to provide increased knowledge about its safety characteristics. Thus, programs are in progress to improve understanding of: the behavior of the fuel; the mechanism of the steamgraphite reaction; plate-out of fission products in the primary system; the mechanisms for release of fission products; and the high temperature properties of the PCRV and component materials. In addition, R\&D is continuing on the development of fuels which will have improved fission product retention and higher temperature capability. Efforts are also on-going to develop a direct cycle HTGR which would use a gas rather than a steam turbine. ${ }^{15}$ Development of this latter concept when combined with dry air heat rejection would reduce the thermal pollution and consumption of water. The gas turbine HTGR with a bottoming cycle (use of a low temperature vapor turbine to use the reject heat to generate electricity) has potential for achieving a thermal efficiency of $50 \%$, which would further reduce environmental effects and conserve ore resources. The reject heat from the gas turbine HTGR could also be economically used for water desalination by distillation because the heat is rejected at the comparatively high temperature of $400^{\circ} \mathrm{F}$. 


\subsubsection{Present and Projected Application}

The present use of the HTGR is for the generation of electric power. As noted earlier, one 40 Whe plant (Peach Bottom) is in operation, a 330 MWe plant (Ft. St. Vrain) is expected to go into full power operation in the sumer of 1974, and six larger plants (four 770 MWe and two $1160 \mathrm{MWe}$ ) have been ordered, the first, of which is expected to be operational in 1980 . The long range projection ${ }^{6}$ indicates that HTGR capacity will be 23,000 MWe by 1985, 54,000 MWe by 1990, and 100,000 MWe by the year 2000 .

Because of the potential for high temperature operation of the reactor, consideration is being given in the U.S., Europe and Japan for using the HTGR not only for power generation but as a process heat source. Thus, if the technology could be developed which would permit reactor outlet temperatures in excess of $1650^{\circ} \mathrm{F}$, the reactor could be used for coal gasification; an $1800^{\circ} \mathrm{F}$ helium temperature would permit use of the reactor for steelmaking if such temperatures could be accommodated in the entire system. Other process applications such as hydrogen production, heavy oil recovery and tar sands mining have also been proposed. If successful, they could lead to reduced consumption of some fossil fuels and to more efficient utilization of others.

As noted in Section A.1.2.4, research and development is underway toward use of HTGRs in conjunction with direct cycle gas turbines and dry cooling towers, to possibly lower plant cost, but more 
importantly to reduce the need for large amounts of evaporative (makeup) cooling water as currently used by power plants operating on the steam cycle, such as LWR's, LMFBR's, and fossil-fired plants. This capability may be possible due to the higher temperature reject heat from the gas turbine cycle as opposed to the steam cycle, and the compatability of the gas turbine with dry cooling towers. It has been proposed by the developer of this system that the gas turbine HTGR could be in operation, with a thermal efficiency of about $36 \%$, within the next decade. Its acceptance at that time by the utility industry is open to speculation but would obviously be subject, among other things, to the developmental status of the other alternative energy sources discussed in this Chapter. The $36 \%$ efficiency would be a reduction of $10 \%$ from the $40 \%$ efficiency avallable from modern steam cycle plants, and this would have to be taken into consideration.

\subsubsection{Environmental Impacts}

The environmental impacts from an HTGR are generally the same as for an LMFBR of comparable size. An exception to this is the amount of uranium ore that must be mined to fuel each reactor. The HTGR, as is the case for any other converter reactor, will require more uranium ore than an LMFBR, because the HTGR system is non-breeding. Whereas the uranium requirements for an LMFBR will be met by using the "tails" from the diffusion processes, a 1000 MWe HTGR will require approximately 113 tons of natural $U_{3} 0_{8}$ 
and 8 tons of $\mathrm{ThO}_{2}$ per year. If a symbiotic power generation system were to be developed (see Section A.1.4.5) wherein a fast breeder such as the GCFR (or LMFBR) produces ${ }^{233} U$ for use in the HTGR, uranium makeup needs would be eliminated.

The use of direct cycle helium turbines with the HTGR has the potential to reduce the requirements for cooling water because dry cooling towers can be used in place of a cooling pond, wet towers or once-through systems. An advanced direct cycle system would utilize an organic "bottoming" cycle. If this system can be developed, thermal efficiencies aapproaching $50 \%$ can be rrealized. The reduced need for cooling water in a direct cycle HTGR may potentially be of considerable environmental (and resource) significance. Some studies have shown that adequate supplies of cooling water for evaporative use by power plants will be a problem by the year 1990 to 2000 . The potential capability of the HTGR to alleviate this problem is significant. In addition, the potential siting flexibility in not being dependent on large supplies of cooling water would be an important advantage.

From the standpoint of radiological impact the HTGR offers a situation similar to all other reactor systems. The use of thorium introduces a problem similar to that encountered during uranium mining. Natural thorium has only a single isotope, ${ }^{232} \mathrm{Th}$, which decays with a half life of 14 billion years. Included in the decay 
chain is radon-220, which is gaseous and diffuses into mine atmospheres al though its short half life of 55 seconds indicates that this radon isotope has less chance for escape to the atmosphere than the radon-222 ( 3.8 day half- 1 ife) in the $238 \mathrm{U}$ series. The daughters of ${ }^{220} \mathrm{Rn}$ are also relatively short-lived and include some alpha particle emitters, which give the principal dose to the lungs. Thus, thorium mining would be expected to have an associated increased respiratory cancer risk, as has already been discussed for uranium. (See Section A.1.1.6.2).*

Tritium is produced in the HTGR by ternary fission and is mostly retained in the fuel particles and the graphite matrix. Tritium is also produced by neutron activation reactions with helium $\left({ }^{3} \mathrm{He}\right)$ and lithium. The activation of ${ }^{3}$ He is the main source of tritium in the coolant. The tritium is removed from the coolant by the hydrogen getter unit in the helium purification system through which a fraction of the helium passes rather than going through the reactor. The titanium sponges in these getter units are replaced monthly and are shipped off-site as solid waste. The tritium release to the environment from a large HTGR is expected to be less than 5 curies per year.

The krypton and xenon isotopes will also be removed from the conlant in the helium purification system by using a low temperature absorber

\#It is to be noted, however, that additional uranium mining will be required for LWRs but not for LMFBRs. The latter's use of already mined uranium tails eliminates the need for further uranium mining. 
delay bed. Rather than releasing the gas produced after regeneration of the low temperature delay (mostly long-lived $\mathrm{Kr}-85$ as the other radionuclides have decayed), it can be bottled for off-site disposal or it can be returned to the primary coolant system where it will be taken out again by the low temperature absorber. The lifetime inventory of krypton can be retained this way with the result that less than 10 curies of ${ }^{85} \mathrm{Kr}$ are expected to be released to the environment annually at a large HTGR. Figure A.1.2-4 is a diagram of the helium purification system. Liquid wastes will be accumulated at the HTGR from decontamination operations or as a result of equipment failure such as a steam generator tube leak. Under normal conditions the liquid radwaste is expected to be about 10 curies/year. Treatment systems utilizing devices such as those which are used in LWRs will keep liquid releases as low as practicable. The radioactive liquid waste system is shown in Figure $A .1 .2-5^{16}$.

Compared to the LWR, the HTGR produces a somewhat lower volume of solid wastes to be shipped to the federal repository or commercial burtal grounds. This is mainly due to the higher thermal efficiency of the reactor, the elimination of cladding hulls, and the relatively high amount of thermal energy extracted per unit mass of fuel material in the HTGR. The burial ground area needed to store the solid wastes from an HTGR has been estimated to be about $70 \%$ of the area needed for a similarly sized PWR. 


\section{HTGR HELIUM GAS PURIFICATION}

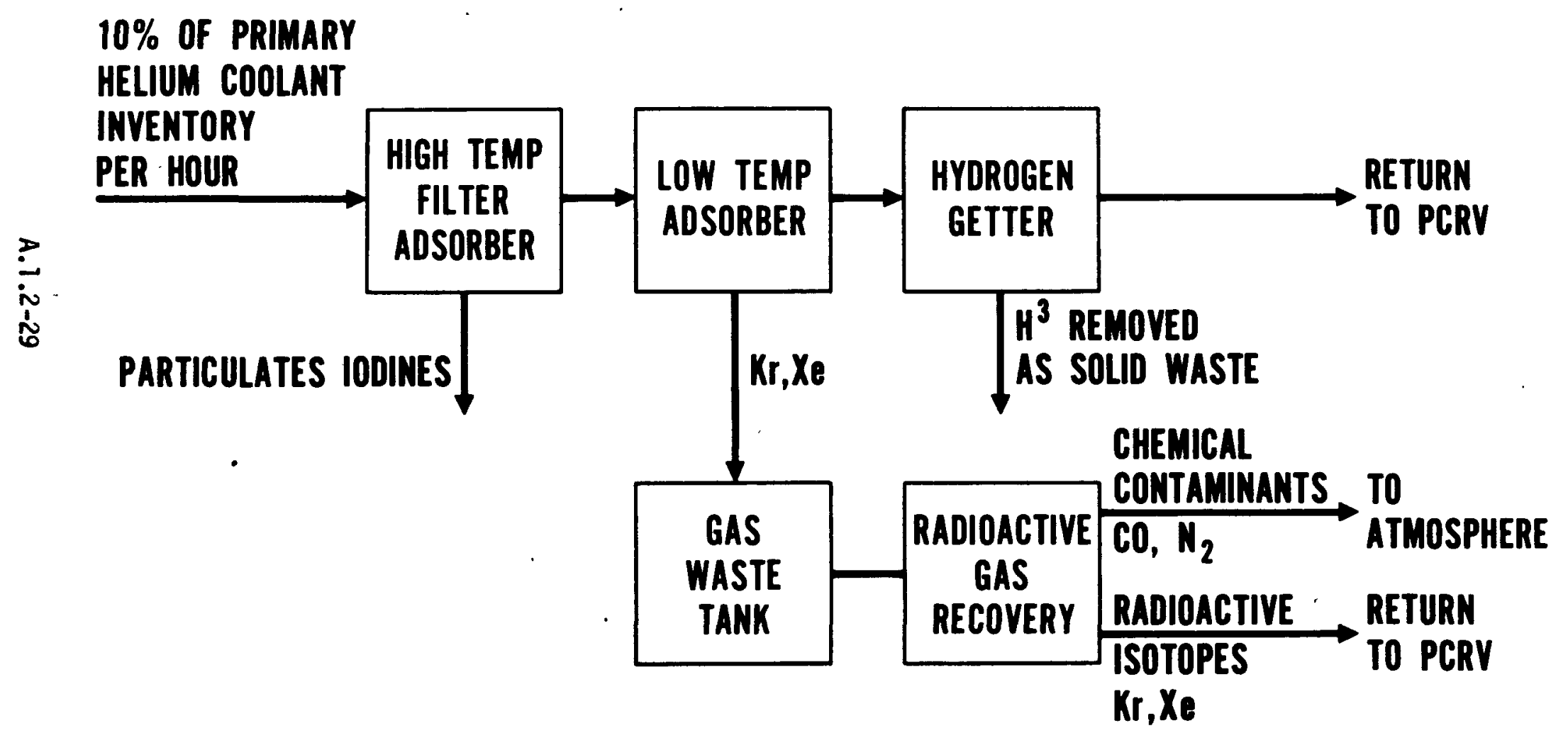




\section{HTGR RADIOACTIVE LIQUID WASTE}

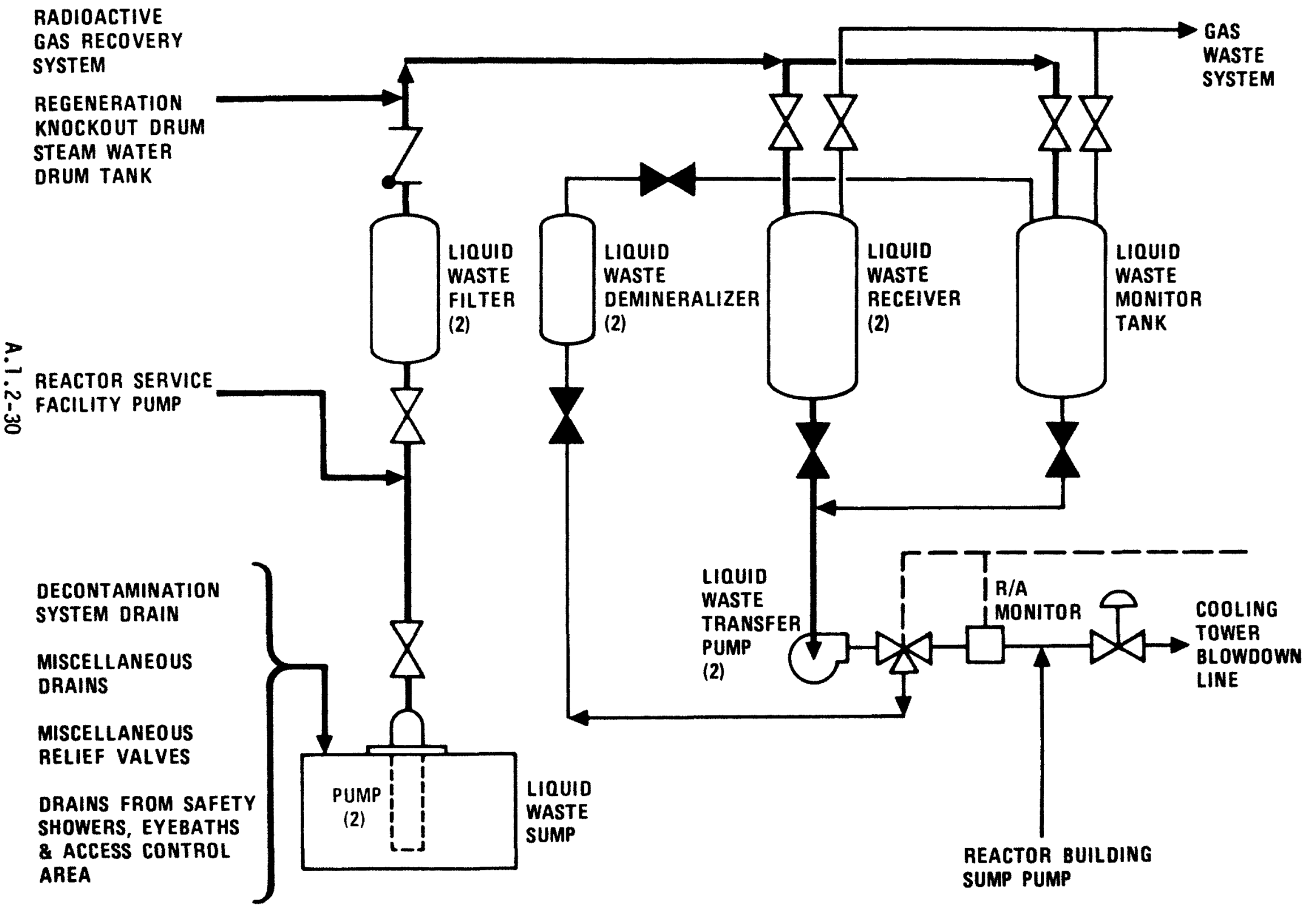


Most of the transportation steps in the HTGR fuel cycle are similar to those in the LWR and LMFBR fuel cycles. One attractive feature of the HTGR cycle is that, under current plans, the reprocessing plant and the fuel fabrication plant would be located at the same site, thereby avoiding the need for off-site transportation. However, the transportation of the recycled uranium from the fabrication plant to the reactor in the HTGR fuel cycle presents special considerations because of the relatively rapid butldup of decay products of ${ }^{232} \mathrm{U}$. Also, the shipment of highly enriched uranium as required by HTGR's from the gaseous diffusion plant and fabrication plant presents some special problems, especially with respect to safeguards. The extra difficulties encountered in these shipments are balanced somewhat by the fact that the HTGR has significantly less material to be shipped in most steps in the fuel cycle compared to LWR's.

Table A.1.2-4 summarizes annual data ${ }^{17}$ for a 1000 MWe HTGR operating at $75 \%$ plant factor, that is, power plant and fuel cycle data corresponding to the production annually of 6.57 billion kilowatt hours of electrical energy. A more complete discussion of the environmental impacts of the complete HTGR fuel cycle, including shipping considerations, is provided in reference 18.

\subsubsection{Costs and Benefits}

\subsubsection{Costs}

The capital costs for an HTGR will be less than those for a comparably sized LMFBR due to several differences in their engineering 
Table A.1.2-4

AMUUAL EFFECTS OF A 1000 ine HiGR AHD ITS SUPPORTIHG FUEL CYCLE

Basis: 6.57 billion kilowatt hours (one year operation $75 \% \mathrm{CF}$ )

$\frac{\text { Conventional costs }}{\text { (1985 dothars }}\left(10^{6} \$\right)$

Fuel

Plant Cap1tal

08M

Rounded Total

$\frac{\text { Abatement Costs }}{\text { (1980 dollars) }}\left(10^{6} s\right)$

Cooling Towers

Occupational Accidents

Deaths

Non-Fatal Infuries

Man-days Lost

(20)

(21)

Mining and ilililing Imoacts

Strip Mininn of Uranium

\& Mill Tailinns (Acres)

Taflinas Produced o Mill

(103 ${ }^{3}$ (T) Public Accidents in Transportation of

radfoactivity)

Deaths

Mon-Fatal Injurtes

Man-Days Lost

Occupattonal health

Miners' radiation exposure

(miner-IHL)

Other occupational

exposure (ran-rad)

Solld Radinative Waste Disposal

Volume $\left(10^{2} \mathrm{ft}^{3}\right)$

Burlal Area (acres)

Effects at the Power Plant

Thermal Discharce $\left(10^{10} \mathrm{kwh}(t)\right)$

Net destruction of uranium (i:T)

Net destruction of thorium (iT)

Routine Radioactive Releases to the Atmosphere (CT)

H-3

Kr -85

I-129

[-131

$\mathrm{Xe}-131 \mathrm{~m}$

xe-133

Cs-137

Rn-222 \& 220

U-232

$\mathrm{U}-233$

Total U

Others

Mining $\begin{array}{ll}\text { Millina } & \text { Rabrication } \\ & \text { Reactor } \\ \text { Power Plant } & \begin{array}{l}\text { Reprocessinn } \\ \text { Transportation }\end{array}\end{array}$ Totals

$1.1 \quad 7.5$

$3.5^{\circ}$
4.8

2.4

1.5

15
57

$\frac{4.8}{77}$

2.4

$0.05 \quad 0.003$

1.8

0.75

383

47

2.7

1.2

- 43

$=$

58

$\begin{array}{ll}- & 15\end{array}$

$\begin{array}{ll}- & 31 \\ - & 0.06\end{array}$

$\div \quad=$

$=$
0.01

$110^{1.3}$

110

0.002
0.06

14

0.07

354

3.9

43

- 43

0.009
60

0.009

-

0.08

60

58

300

12

327

22

0.04

10

0.26

63

1.1

0.3

$=$

1.1

0.3

$\begin{array}{cc}16000 & 16000 \\ 570000 & 570000 \\ 0.0003 & 0.0003 \\ 3 . & 3 . \\ \vdots & \vdots \\ 0.002 & 0.002 \\ \vdots 0 & 23 \\ -0 & 0.4 \\ 0 & 0.2 \\ 2 . & 0.7 \\ & 2 .\end{array}$


Routine Radioactive Releases

to Waterways (Ci)

H-3
$I-129$
$I-131$
Cs-137
U-232
U-233
TotaI U
Others

others

Population Exposure from

Routine Releases of Radionuclides

Global Model: All-time commitment,

Iona-lived nuclides

World (whole body man-rad)

$\mathrm{Kr}-85$

$\mathrm{H}-3$

Total World

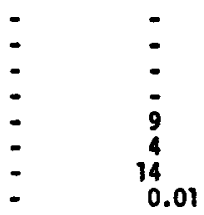

350

0.0002

0.0002

0.02

0.004

$-$

:

0.004

9

4
14
6

U.S. (whole body man-rad)

$\mathrm{Kr}-85$
$\mathrm{H}-3$

Total U.S.

256

$\frac{21}{277}$

$12.0 \quad 12.0$

$2.3 \quad \frac{2.3}{14.3}$

Local Model: Airborne short-lived noble cases \& tritium.

Total man-rem within 50 miles

High Population Assumption

Hedium Population Assumpticn

Low Population Assumption

a. Workina capital charaes.

b. Includes all transoortation stops.

c. Milling, conversion, enrichment, and preparation and fabrication. 
design. Although the use of a PCRV and associated equipment in an HTGR would be more costly than that of the steel pressure vessel in an LMFBR, the need for an intermediate heat exchanger loop in the LMFBR more than offsets the additional costs of the PCRV. The relative costs of other structures, buildings and equipment for an HTGR or LMFBR are not so different as to affect the overall cost differential caused by the two major engineering differences. In the Appendix to Chapter 11 of this statement, the relative capital costs in $\$ /$ KWe of several reactor types are compared; in 1985 these costs would be $\$ 419$ and $\$ 520$ for a 1300 MWe HTGR and LMFBR respectively. Future engineering changes, such as the possible elimination of the need for the intermediate cooling loop in LMFBR's, could obviously change this cost differential significantly.

The operating and maintenance costs for an HTGR would also tend to be lower than those for an LMFBR, as shown in the Appendix to Chapter 11. The respective annual costs for 1300 MWe plants introduced before 1990 are estimated at $\$ 12.7$ million for an HTGR vs $\$ 14.5$ million for an LMFBR, both operating at $80 \%$ plant factor.

With regard to fuel cycle costs, the HTGR is obviously less advantageous than the LMFBR as the HTGR does not breed new fuel. However, in comparision to other "burner" reactors such as the LWR, the HTGR shows up quite favorably. This results from the HTGR's operation on the thorium cycle and its relatively higher conversion ratio. $U_{3} 0_{8}$ ore requirements for a 1000 MWe HTGR are

$$
\text { A.1.2-34 }
$$


half those of a similarly sized LWR. The impact of this is that while a $100 \%$ increase in $\mathrm{U}_{3} \mathrm{O}_{8}$ costs results in an increase of about $0.5 \mathrm{mill} / \mathrm{s} / \mathrm{kwhr}$ for the LWR, it results in only a $0.3 \mathrm{mills} /$ kwhr increase for the HTGR. Thus, in the year 2000, the savings to the public if ore costs were to double, and assuming the HTGR represents a conservative $7 \%$ of the electric generating capacity in the U.S., would be $\$ 112 \times 10^{6}$ when compared to the LWR.

Developmental costs for the HTGR will be considerably less than those for the LMFBR. The major questions of technical feasibility appear to have been resolved and further development will likely be directed to improvements in fuel performance, added safety assurance, demonstration of economical fuel reprocessing, etc., rather than to the major developmental and prooftesting type of activities still ahead for the LMFBR.

The main benefit that may accrue from HTGR's as compared to LWR's is the HTGR's significantly lower thermal discharge. Because of the small quantities of both liquid and gaseous radioactive wastes requiring processing at the reactor site, the HTGR is expected to make control of effluent release relatively simple.

In addition, HTGR operation on the uranium-thorium fuel cycle will help conserve uranium and thorium resources by utilizing thorium reserves with high efficiency. Finally, as noted in Section A.1.2.5, the HTGR's potential for use with a direct cycle gas turbine and 
dry cooling towers could significantly reduce the need for large amounts of makeup cooling water as currently needed by power plants operating on the steam cycle. As growing power needs draw more and more heavily on the nation's cooling water resources, this potential feature of the HTGR could become of greater significance.

\subsubsection{Overall Assessment of Role in Energy Supply}

\subsubsection{Probable Role Up To Year 2000.}

Based on current plans, R\&D status and projections, etc., it is expected that the HTGR will provide approximately 7 to 8 percent of the electrical generating capacity and about $12 \%$ of the nuclear capacity by the year $2000 .^{3}$ These percentages are subject to change depending upon the success of the first large HTGR's, the date of introduction of the LMFBR, and the relative role of other energy sources.

\subsubsection{Possible Role Beyond Year 2000}

In later years, the HTGR is expected to decrease in use because it, like the LWR, is dependent upon enriched ${ }^{235} U$ for fuel and as the costs of ore and separate work increases the use of any system requiring enriched ${ }^{235} U$ will decrease in favor of a breeder system. Of course, if a symbiotic power generation system were to be developed, this consideration would not apply and the use of HTGR's as thorium fuel burners might continue indefinitely. 


\subsubsection{References}

1. Joint Committee on Atomic Energy, FY 1960 Authorization Hearings before Subcomittee on Legislation, 86th Congress, p. $70 \mathrm{ff}$, February 1959.

2. Philadelphia Electric Company, "Semiannual Operations Report No. 68, January 1, 1973 thru June 30, 1973," report submitted to the USAEC pursuant to Provisional Operating License \#DPR-12.

3. U.S. Atomic Energy Commission, "Nuclear Power 1973-2000," USAEC Report WASH-1139(72), December 1, 1972.

4. Estimates prepared by the U.S. Atomic Energy Commission, Division of Production and Materials Management, May, 1973.

5. Department of the Interior News Release, "Secretary Morton Terminates Helium Purchase Contracts," February 2, 1973.

6. U.S. Bureau of Mines Bulletin 650, "Helium," by Harold W. Lipper, a chapter from Mineral Facts and Problems, 1970.

7. Gas-Cooled Reactor Technology, H. B. Stewart, C. L. Rickard, and $G$. B. Melese in Advances in Nuclear Science and Technology, Vol. 4, Academic Press, New York (1968).

8. U.S. Atomic Energy Commission, "The Use of Thorium in Nuclear Power Reactors," USAEC Report WASH-1097, 1969.

9. U.S. Atomic Energy Commission, "An Evaluation of High Temperature Gas-Cooled Reactors," USAEC Report WASH-1085, December 1969.

10. Landis, J. W., et al, "Gas-Cooled Reactor Development in the United States," A-CONF/49/p-833, U.S. Papers for the Fourth United Nations Conference on the Peaceful Uses of Atomic Energy, Volume 1, September 6-16, 1971, Geneva, Switzerland, National Technical Information Service, Springfield, Virginia 22151.

11. Cobby, L. J., et al, "HTGR Fuel and Fuel Cycle-Summary Description,"GA-10233, Gulf General Atomic Company, San Diego, California 92112 , May 25, 1971.

12. Stewart, H. B., et al, "Utflization of the Thorium Cycle in the HTGR," A/CONF/49/p-837, U.S. Papers for the Fourth United Nations Conference on the Peaceful Uses of Atomic Energy, Volume 1, September 6-16, 1971, Geneva, Switzerland, National Technical Information Service, Springfield, Virainia 22151. 
13. Lotts, A. L., and Wymer, R. G., "Economic and Technology of HTGR Fuel Recycle," ORNL-TM-2377, paper presented at IAEA Symposium on "Advanced and High Temperature Gas-Cooled Reactors," Julich, Germany, October 21-25, 1968, Oak Ridge National Laboratory, Oak Ridge, Tennessee, October 1968.

14. WASH-1281, The Nation's Energy Future, A Report To The President By The Chairman, U.S. Atomic Energy Commission, December, 1973.

15. Gulf General Atomics, Nuclear Gas Turbine Power Plant, Preliminary Development Plan (Draft), Gulf-GA-A12709, Gulf General Atomics, San Diego, California 92112, August 15, 1973.

16. Gitterman, M., and Goodjohn, A. J., "Radioactive Waste Management System for High-Temperature Gas-Cooled Reactors," Proceedings of the American Power Conference, 1972, 31 p. 155 (1972).

17. U.S. Atomic Energy Comission, "Comparative Risk-Cost-Benefit Study of Al ternate Sources of Electrical Energy," USAEC Report WASH-1224, to be published.

18. U.S. Atomic Energy Commission, "Environmental Survey of the High Temperature Gas-Cooled Reactor (HTGR) Fuel Cycle", to be published. 


\section{A.1.3. LIGHT WATER BREEDER REACTOR}

\subsubsection{Introduction}

\subsubsection{General Description}

The Light Water Breeder Reactor (LWBR) utilizes the uranium-233 thorium fuel cycle in a light water cooled and moderated thermal (slow) neutron spectrum to obtain breeding of nuclear fuel. It is one of several concepts potentially capable of improving the utilization of nuclear fuel resources over that currently available in LWR's. 'The LWBR possesses the added feature of using proven LWR technology and is compatible with conventional pressurized water reactor plant desians without major plant modifications.'

To demonstrate the technology of this system, a breeding demonstration core (net $50 \mathrm{MWe}$ ) for the pressurized water reactor plant at Shippingport, $\mathrm{Pa}$. has been designed and is being fabricated. This demonstration core is designed to simulate a large core environment in its central portion and to breed in the entire core.

\subsubsection{History}

The LWBR program was initiated in 1965, building on technology developed in the Shippingport project which was started in 1953. Initial funding for the breeding demonstration core was provided in the AEC budget for fiscal year 1969. 2 


\subsubsection{Status}

The breeding demonstration core and associated hardware needed to install it in the Shippingport reactor vessel are being manufactured. Installation of the breeding demonstration core in the Shippingport reactor plant is expected in $1975 .^{3,4}$

\subsubsection{Extent of Energy Resource}

\subsubsection{Geographic Distribution}

The primary energy resource for the LWBR system is thorium. A limited amount of natural uranium ( 21300 tons) is required to provide the fissile fuel needed to establish an equilibrium breeding cycle in a 1000 MWe plant. The geographical distribution of both fuels is world wide with major reserves in both the United States and Canada. Information on the distribution of thorium and uranium resources is provided in Sections A.1.2 and A.1.1 respectively.

\subsubsection{Estimated Availability}

The amount of energy potentially obtainable from the reasonably assured reserves of thorium ore is well in excess of that obtainable from fossil fuel resources. 5 The estimated U.S. thorium reserves according to price range are discussed in Section A.1.2, wherein it is shown that thorium is in sufficient supply.

\subsubsection{Technical Description of Energy System}

\subsubsection{Power Generation Plant}

The plant cycle is the same as for other pressurized water reactors, as discussed in Section A.1.1.3. It begins with a nuclear heat 
source which transfers heat to the primary coolant (pressurized water at approximately 2000 psi) which is then circulated to heat exchangers. Within these heat exchangers, heat is transferred from the primary plant to the secondary plant where saturated steam is formed which, in turn, drives the plant turbine generator. Upon exiting from the heat exchangers the primary fluid is returned to the reactor vessel. The primary plant fluid is pressurized ordinary light water of high purity and is operated in its own closed system at subcooled conditions.

The major primary plant components typically include: the nuclear reactor core, pressure vessel (see Figure A.1.3-1), and reactor coolant system consisting of three or four reactor coolant loops each connected in parallel to the reactor. Each coolant loop contains a heat exchanger as well as a pump which circulates the primary coolant in that loop. An electrically heated pressurizer is connected to one of the loops to maintain pressure in the primary plant system during plant operation.

The steam produced in the secondary side of the heat exchanger is carried by steam lines to the turbine generator unit to generate electrical power for distribution by the utility power transmission system. The turbine exhaust is discharged to a condenser where the unused energy is dissipated. The resulting liquid is then returned to the heat exchanger. 


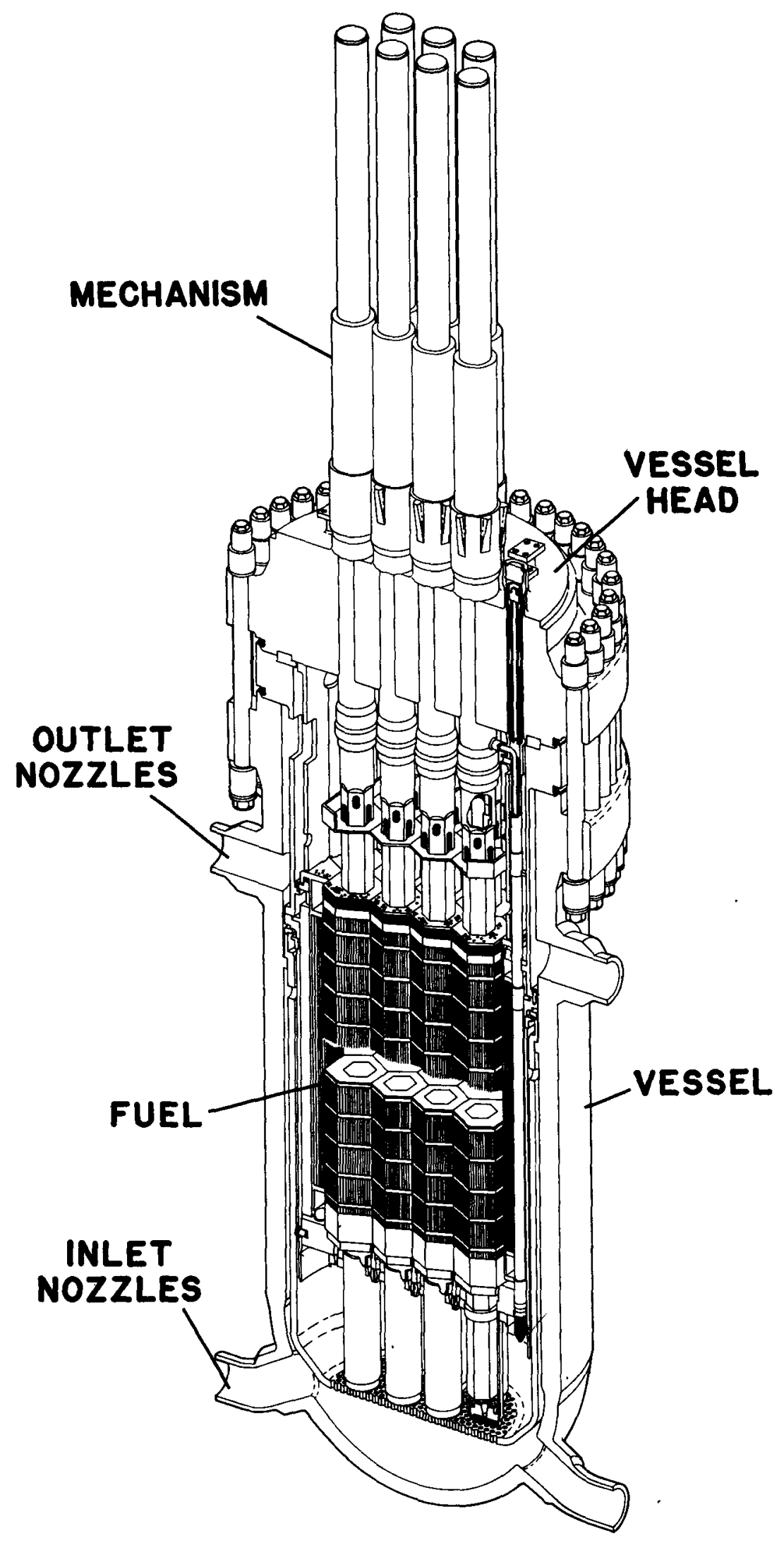

LWBR DEMONSTRATION CORE IN SHIPPINGPORT VESSEL

Figure $A: 1.3-1$

A.1.3-4 
A typical fuel module in the demonstration core contains a central, axially-movable, hexagonal seed and a stationary, annular, hexagonal blanket (see Figure A,1.3-2). The demonstration core will be a breeder core rather than a pre-breeder core (see 1.3.3.2 below). The seed is made up of full length Zircaloy-4 clad fuel rods about 0.3 inch in diameter. The seed fuel consists of solid thorium oxide $\left(\mathrm{ThO}_{2}\right)$ pellets containing zero to about 6 weight percent $(\mathrm{w} / 0)$ uranium-233 oxide $\left(\mathrm{U}^{233} \mathrm{O}_{2}\right)$. The blanket fuel rods are about 0.6 inch in diameter and the $\mathrm{ThO}_{2}$ pellets contain zero to about $3 \mathrm{w} / \mathrm{O} \mathrm{U}^{233} \mathrm{O}_{2}$. The fuel height in both the seed and blanket rods is $8-1 / 2$ feet, including about 9-inch long natural thoria $\left(\mathrm{ThO}_{2}\right)$ reflector blanket regions at the top and bottom of each rod. The seed and blanket rods also contain gas plenums designed to accommodate fission gas release.

The nuclear design is such that the more highly loaded seed has a neutron multiplication factor greater than one and the lower loaded blanket has a neutron multiplication factor less than one. Reactivity is controlled by varying the leakage of neutrons from the small seed regions into the subcritical blanket regions. This is achieved by axially positioning the seed section of the module so as to change module geometry rather than by using conventional parasitic neutron-absorbing materials. With this method of control, which is one of the major features of the seed-blanket concept, excess neutrons will be absorbed in fertile thorium material, and good neutron economy 
’

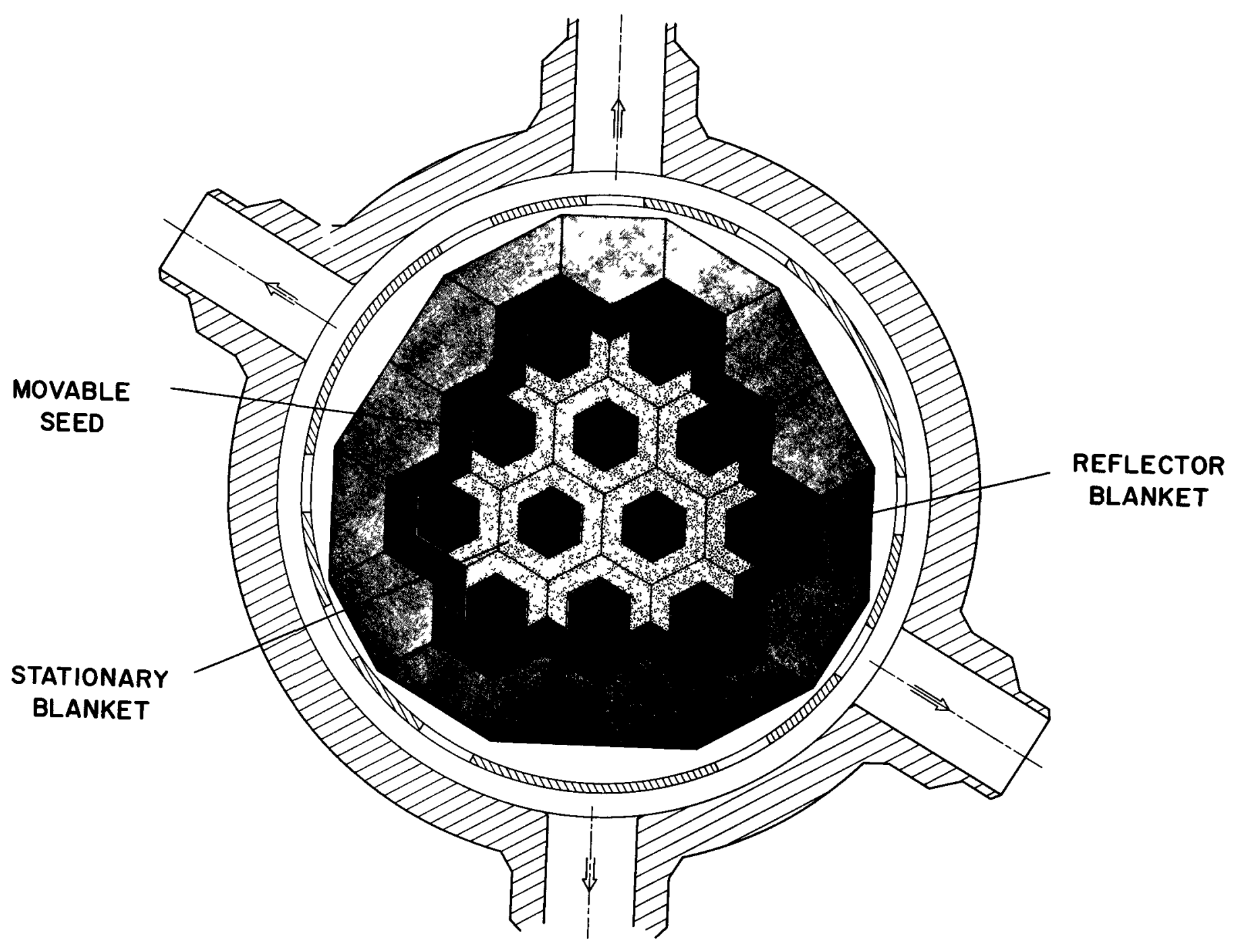

LWBR DEMONSTRATION CORE CROSS SECTION

Figure A.1.3-2 
can be achieved. The reactivity worth of the movable seed is increased by using partial lengths of natural thoria in some of the seed and blanket rods.

The design of the LWBR system module evolved from the technology developed in PWR (Shippingport) Core 1 and Core 2. The control mechanisms used in LWBR for reactor control are of the same demonstrated basic design previously used for positioning the PWR control elements. The seed fuel assemblies are slowly raised to increase reactivity and bring the reactor to full power. Reactor shutdown is accomplished by lowering the movable seed assemblies.

The demonstration core will normally be fueled and defueled by removing complete modules after the vessel closure is removed. It is also possible to remove the seed of an individual module through a hole in the vessel closure following removal of the associated control drive mechanism.

Surrounding the twelve fuel modules of the demonstration core is a natural thoria region about 8 inches thick, which serves as a reflector blanket. The reflector blanket will limit neutron leakage from the core to less than about 0.8 percent of all neutrons. Larger light water breeder cores (1000 MWe) can be designed with leakage of 0.1 percent or less, thereby achieving even better breeding performance than in the LWBR demonstration. Use of this peripheral reflector 
blanket in the small LWBR demonstration core assures an unambiguous quantitative demonstration of breeding within the entire core.'

\subsubsection{Fuel Cycle}

Initially fissile fuel is required to operate a pre-breeder core to build up the necessary inventory of uranium-233 by irradiation of thorium. Either enriched uranium-235 or plutonium could be used. After about ten years of pre-breeder core operation sufficient uranium-233 would be available to fuel a breeder core. Once a core can be operated on the breeding cycle there would be no further need for enriched uranium or plutonium and the only makeup material required for the fuel cycle would be thorium. When a plant operating on this breeding cycle reaches the end of its useful life (30-40 years), replacement of its electrical generation capacity could be by a plant started up directly as a breeder using the fissile inventory from the old plant, without requiring further mining or enrichment of uranium. ${ }^{7}$ The LWBR core being placed in Shippingport is designed to demonstrate the breeding potential of this concept.

The equilibrium fuel cycle of an LWBR system is similar to that of the PWR system. The mining and preparation involves natural thoria in the LWBR system instead of uranium as in a conventional pressurized water reactor. The thoria is sent directly to the fuel element fabrication point where it is added to reprocessed uranium and thoria as makeup for the fissioned fuel and reprocessing losses of the previous cycle. 
The refabricated fuel elements are then installed for another cycle of reactor power operation. At the end of core life the fuel modules are removed and, following a radioactive cooling period, are shipped to a fuel reprocessing plant.

In the fuel reprocessing plant, the thorium, uranium, and fission products are chemically separated. The reprocessed uranium is sent back to the fuel element fabrication plant to be refabricated into fuel elements while the fission products and radioactive wastes are placed in appropriate long term storage (see Section A.1.2.3). The reprocessed thoria, which will contain some radioactive Th-228, could be sent back for refabrication or stored for later use depending upon the resource availability and economic situation prevailing at the time.

\subsubsection{Energy Transmission}

The electrical power distribution system associated with an LWBR nuclear central station would be similar to that for any other electricity generating station.

\subsubsection{Research and Development Program}

Research and development for the Light Water Breeder Reactor has been underway since 1965, building on the technology developed by the Shippingport reactor program which started in 1953. Most of the necessary research and development has been completed to the point where fabrication of the breeding demonstration core is currently

$$
\text { A.1.3-9 }
$$


underway toward a 1975 installation in the Shippingport reactor plant. ${ }^{3,4}$ Research and development at reduced levels is planned to continue as necessary to support the breeding demonstration and to confirm that breeding actually occurred. This R\&D effort is included as part of the program described in The Nation's Energy Future. ${ }^{6}$

Should the LWBR proceed beyond the current breeding demonstration phase into full scale commercial use, additional research and development may be required. One area which might warrant further $R \& D$ effort would be the extension of the technology now being demonstrated in the manufacture of the breeding demonstration core to a large-scale commercial process for the refabrication of reprocessed uranium-233 into fuel elements, since the refabrication is complicated by the fact that the recycled fuel is radioactive. It should be noted, however, that if nuclear power is to be a major energy source in the future, all fission reactor cycles will, of necessity, use recycled fuel.

\subsubsection{Present and Projected Application}

\subsubsection{Current Use}

Although LWBRs are not yet in use, the technology has advanced to the point that, as noted above, a demonstration core is being manufactured and will be used to demonstrate the breeding capability of a thoriumuranium-233 fueled LWBR type core in an existing pressurized light water reactor plant. Successful completion of this program will demonstrate technology which could permit the conversion of existing 
and future pressurized water reactor plants to self-sustaining breeders. This could turn out to be a very practical approach to obtaining the high fuel utilization needed to make nuclear power fulfill its promise of providing mankind an essentially unlimited energy source. This approach would avoid many of the technical problems associated with other high fuel utilization systems while making use of highly developed light water technology. The performance of this small plant demonstration can be extrapolated to predict the performance of large light water breeder reactors. $1,3,4$

\subsubsection{Projected Use}

Following successful operation of the demonstration plant (50 MWe) the next step in exploiting the potential of the light water breeder system would be design and construction of large light water breeders (1000 MWe) that would achieve a high degree of fuel utilization on a long term basis. As previously stated, pre-breeder cores would be needed for about the first ten years of operation. Once the breeding cycle cores are operating, only thorium would be needed as makeup to the fuel cycle and about fifty percent of the thorium added would eveniually be utilized to generate power. This high degree of fuel utilization would represent a very significant increase over present types of light water power reactors which utilize only 1 to 2 percent (including plutonium recycle benefits) of the energy potential of the mined uranium. 


\subsubsection{Environmental Impacts}

\subsubsection{Energy Conversion Plant}

The environmental impact resulting from the operation of an LWBR core is essentially the same as for a light water reactor of comparable capacity. Aside from the LWBR uranium-thorium fuel cycle, all other aspects will be the same as would result from operation of a pressurized water reactor of comparable capacity (see Section A.1.1).

The fuel elements in the LWBR consist of pelletized nuclear fuel materials encapsulated in high integrity zircaloy rods. The design of these elements utilizes the fuel element design experience gained from years of operation of PWR plants. The abtlity of the LWBR fuel system to withstand the effects of irradiation has been confirmed from PWR operations and extensive irradiation testing. Hence, any release of fission product activity that might occur is expected to be about the same for an LWBR as that experienced in PWRs (see Section A.1.1).

A typical LWBR plant is expected to provide three independent containment barriers between the fissile fuel and the plant environment. These are (1) the cladding which encapsulates the pelletized fuel materials, (2) the walls of the reactor coolant system, and (3) the containing structure surrounding the reactor plant. These barriers are all designed, fabricated and inspected to ensure high integrity. A more complete discussion of reactor safety is provided in Section 4.2.3.2 of Chapter 4. 
It is concluded from the foregoing that the installation and operation of a large scale LWBR plant will have no significant effect on the quality of the environment beyond that of a pressurized water reactor nuclear central station of comparable capacity. The economic and social impacts would similarly be no different than those resulting from the installation and operation of an ordinary pressurized water reactor plant.

\subsubsection{Off-Site Support Activities and Facilities}

The LWBR system utilizes an integrated fuel cycle that involves reprocessing and refabricating of fuel material as is typical of all other nuclear fuel systems. Cormercial facilities capable of fuel reprocessing and refabrication to accommodate uranium-233-thorium reactor systems would have to be provided as noted in Section A.1.3.4 and will have to operate with minimal effect on the environment. The design of these plants will be regulated by very stringent criteria such as those associated with existing commercial reprocessing plants and with plutonium recycle facilities.

\subsubsection{Irreversible and Irretrievable Commitments of Resources}

The LWBR breeding fuel cycle is based on converting fertile thorium to fissile uranium-233 at a rate faster than uranium-233 is consumed to generate power. Thus, the only irretrievable commitment of resources is the gradual consumption of thorium. The decrease in the supply of thorium by conversion to and use as a nuclear fuel is relatively minor compared to the availability of thorium resources as shown in

$$
\text { A.1.3-13 }
$$


Section A.1.2. During about 10 years of operation of the pre-breeder cores, about 1300 tons of natural uranium would be consumed for each 1000 MWe of generating capacity. ${ }^{7}$

The installation and operation of a large scale LWBR plant will result in no irreversible and irretrievable commitments of local environmental resources. The land occupied by the buildings and the use of source water to reject plant heat are the only impacts on the local environment and are reversible. Irretrievable and irreversible commitments of resources include the following:

(1) Quantities of construction materials which cannot be economically retrieved.

(2) Spent nuclear fuel which is converted into radioactive waste material, or other materials which become radioactive.

\subsubsection{Costs and Benefits}

\subsubsection{Energy Production Costs}

The energy production costs for the LWBR system are estimated to be slightly higher than for present types of Light Water Reactor plants of comparable size due to the added costs of processing radioactive recycled fuel. However, if nuclear power is to be a major energy source in the future all reactor cycles will of necessity use recycle fuel. Consequently, in the long range, costs of power from LWBRs will 
be comparable to the cost of power from other fission reactor sources.

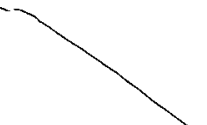

The energy production costs of a nuclear power system are normally broken into three parts: capital costs, operating and maintenance costs, and fuel cycle costs. It is reasonable that the first two components, which contribute approximately two-thirds of the total, would be the same for an LWBR system and a PWR system of the same capacity since they would both fit into the same plant. The fuel cycle costs which contribute the remaining approximately one-third are slightly higher in the LWBR system due to the use of recycled radioactive fuel in the core. The difference is not expected to be a barrier to use of LWBR type nuclear central stations when other energy resources become limited. The environmental cost of LWBR operation would be the same as for a pressurized water reactor of comparable capacity (as discussed in Section A.1.1) except the LWBR would require mining of small amounts of thorium and much less uranium, as previously discussed.

\subsubsection{Development Costs}

Most of the development work associated with the LWBR system has been completed as discussed above. The major forseeable area of future developmental costs would be the area of refabricating techniques for reprocessed thorium and ${ }^{233} U$ which would benefit not only the LWBR system but all systems that rely either wholly or in part on the Uranium-233-thorium fuel cycle. 


\subsubsection{Benefits}

The major benefit of the LWBR system is the use of existing pressurized water reactor technology with high fuel utilization, i.e.; the potential that approximately 50 percent of the mined thorium could be used to generate electricity compared to only one to two percent of the mined uranium in present types of light water reactors (PWR or BWR including plutonium recycle). Although enriched uranium or plutonium is required to establish a self-sustaining LWBR breeding cycle, none would be required after the ten year pre-breeder period for as long as the cycle is continued. This system would be subject to higher uranium ore prices only to the extent enriched uranium is necessary to fuel pre-breeders. This system also has the potential that it can be backfit into existing PWR plants, thus converting them to breeders with higher fuel utilization. $1,3,4$

\subsubsection{Overall Assessment of Role in Energy Supply 1.3.8.1 Probable Role up to Year 2000} The probable role of the LWBR system in the world's energy production up to the year 2000 is either as replacement cores for conventional PWR cores in large electric generating plants, or as new electric plants. It is envisioned that if the LWBR concept proves successful, many LWBR systems may have gone through the pre-breeding portion of their cycles and be operating as self-sustaining breeder systems by the end of the century, contributing significantly to better fuel utilization for the industry. The magnitude of the energy fraction produced 
by this system will be dependent upon the acceptance of the LWBR system by the electric power industry following the demonstration of the concept at Shippingport.

\subsubsection{Possible Role Beyond Year 2000}

An expanded role is possible for the LWBR system beyond the year 2000. This role is dependent upon the growth of electrical energy demands and the success of development and economics of other energy sources. 


\section{REFERENCES}

1. Naval Nuclear Propulsion Program - 1969, Hearings Before the Joint Committee on Atomic Energy, Ninety-First Congress, First Session on Naval Nuclear Propulsion Program, Arpil 23, 1969.

2. Naval Nuclear Propulsion Program - 1967-1968, Hearings Before the Joint Committee on Atomic Energy, Ninetieth Congress, First and Second Sessions on Naval Nuclear Propulsion Program, March 16, 1967 and February 8, 1968.

3. Public Works for Water and Power Development and Atomic Energy Commission Appropriation Bill, 1974, Hearings Before a Subcommittee of the Committee on Appropriations, House of Representatives, Ninety-third Congress, First Session, Part 4, Atomic Energy Commission, April 4, 1973.

4. Senate Hearings Before the Conmittee on Appropriations, Public Works for Water and Power Development and Atomic Energy Commission Appropriations, Fiscal Year 1974, 93rd Congress, First Session, Part 4, Atomic Energy Commission, April 5, 1973.

5. Civilian Nuclear Power - A Report to the President - 1962, U.S. Atomic Energy Commission, November 1962.

6. WASH-1281, The Nation's Energy Future, A Report to the President of The United States by the Chaiman, U.S. Atomic Energy Commission, December 1973.

7. AEC Authorizing Legislation, Fiscal Year 1971, Hearings Before the Joint Committee on Atomic Energy, Ninety-first Congress, Second Session on Light Water Breeder Reactors (LWBR) and other subjects, March 19, 1970, Part 4. 


\section{A.1.4 GAS COOLED FAST BREEDER REACTOR}

\subsubsection{Introduction}

\subsubsection{General Description}

Al though most of the development work on fast breeder reactors has been devoted to the use of liquid metal cooling, interest has been expressed for a number of years in alternative breeder concepts using other coolants. One concept in which interest has been retained is the Gas-Cooled Fast Reactor (GCFR).?

The Gas-Cooled Fast Reactor, as the name implies, uses helium at high pressure to cool the reactor core. The core does not contain a moderator, so that a fast neutron spectrum is maintained and breeding is achieved. The plant arrangement is of the "integrated" type, with all major components of the primary system contained within a prestressed concrete reactor vessel (PCRV). The PCRV contains the reactor core, the entire helium flow system, the independent steam generating loops, and the auxillary cooling loops. The use of helium as the coolant gas leads to several potentially favorable attributes of the GCFR. Helium is both optically and neutronically transparent, does not become radioactive, does not change phase and is chemically inert. The GCFR has a potentially high breeding ratio resulting largely from the good neutronic properties of the coolant.

\subsubsection{History}

GCFR development was initiated in November 1963 by the AEC under a contract with Gulf General Atomic (GGA)* to investigate the concept *Gulf General Atomic formerly was the General Atomic Division of General Dynamics Corporation. It has recently been reorganized as the General Atomic Company. 
which had evolved from earlier privately-supported GCFR studies. The AEC-sponsored work outlined a development program that started with the objective of a gas-cooled fast reactor experiment of 50 MWt which was to lead to a demonstration power plant as a step towards a full-scale plant. An outcome of the next year of AEC-sponsored R\&D (1964) was a conceptual design for a reactor experiment which would serve as a test bed for fuel development, and would provide experience in designing and constructing a special prestressed concrete reactor vessel (PCRV).

In the period 1965-68, the AEC and GGA continued studies of the GCFR. A conceptual design for a 1000 MWe GCFR power plant was evolved which featured a horizontal PCRV instead of the original vertical arrangement and also differed in other important respects from the original concept. This effort incorporated ideas of the utility companies, particularly as to the layout and design of the nuclear steam supply components from the viewpoint of operation, maintenance and safety. Also, a new design for a reactor experiment was developed to reflect engineering aspects of the new large-plant design. The 1000 MWe GCFR reference conceptual design prepared by GGA for study by the AEC Fast Breeder Reactor Alternate Coolant Task Force $2,3,4$ was an extension of the above conceptual design. During 1967, to satisfy the needs of the Alternate Coolant Task Force as well as to meet AEC contractual requirements, a Preliminary Development Plan for the GCFR was also prepared. ${ }^{5}$ 
The AEC evaluated the GCFR concept in 1969 and issued "An Evaluation of Gas-Cooled Fast Reactors," WASH-1089, April 1969, along with a companion report, "An Evaluation of Alternate Coolant Fast Breeder Reactors," WASH-1090, April 1969. The results of this study indicated that "GCFR's are feasible to build and operate, and that the concept has the potential of providing low power costs and high breeding gains. A sizable body of research and development work is required to guarantee safe and reliable operation at the design performance levels, but the basic feasibility of the concept does not depend upon an improbable degree of success in the development programs. In the components and plant areas, this concept depends to a considerable degree on the successfur development of the HTGR and its introduction into utility systems."

Evolution of the GCFR concept has continued with the goal of developing a GCFR design which could take maximum advantage of the development work being performed in other reactor development programs, specifically the High Temperature Gas-Cooled Reactor (HTGR) program which is developing plant components similar to those needed in the GCFR, and the Liquid Metal Fast Breeder Reactor (LMFBR) program which uses the identical mixed uranium-plutonium oxide reference fuel cycle as the GCFR. These efforts by Gulf General Atomic have been supported in part both by the Atomic Energy Commission and a group of interested electric utility companies.

Under the utility program, a conceptual reference design for a 300 Me demonstration plant was completed in 1970. Modifications to this design 
were made in 1971 and 1972 to simplify the design to bring it more in line with applicable HTGR design modifications since 1970, and to meet specific design or safety requirements that have been clarified through reviews by Regulatory Staff and the ACRS. In 1972, a preliminary plant cost estimate and a detailed development plant with associated schedules were completed. 6

\subsubsection{Status}

Research and development are continuing on various elements of GCFR technology, with emphasis on fuels and materials development, physics, safety, program planning and surveillance of LMFBR technology applicable to GCFR's. Fuel development is being carried out in a GGA-Argonne National Laboratory-0ak Ridge National Laboratory cooperative program supported by the AEC. In the fuel rod irradiation program, both thermal and fast irradiations are being conducted.

A Preliminary Safety Report for a 300 Me Demonstration Plant has been submitted to the AEC's Regulatory Staff and several hearings were held with the Advisory Committee on Reactor Safeguards (ACRS) and the ACRS subcommittee on the GCFR. The program plan has been refined, and schedule and cost estimates completed.

The utility industry continues to show interest in the GCFR concept. A Utility Review Conmittee reviewed the GCFR Demonstration Plant program plan $^{7}$ in 1972 and concluded that the GCFR continues to be a viable, economic alternative to other fast reactor types and its development should proceed on an orderly basis. It also noted that a more detailed 
engineering design should be made to allow firmer estimates of costs and schedules, and to meet licensing requirements. Based on this recommendation, a balance-of-plant design and cost estimate are currently being carried out by Bechtel Corporation.

In addition to U.S. work on this concept, several foreign groups are actively supporting research efforts. Core heat transfer and fluid flow studies are being performed at the Swiss Federal Institute for Reactor Research (EIR) under a cooperative program with GGA. The Nuclear Energy Agency is supporting a significant effort on GCFR research, and eight companies from Western Europe have associated in the Gas Breeder Reactor Association to conduct related research.

\subsubsection{Extent of Energy Resource.}

The GCFR will use the identical fuel cycle as the LMFBR.* Consequently, the geographical distribution and estimated availability of its fuel resource (uranium) is the same as that for Light Water Reactors, as presented in Section A.1.1. As noted therein the status of uranium reserves for LWR operation is a cause of some concern and will require further exploration and discovery to support the industry in the next century. Breeder reactors, on the other hand, utilize $60 \%$ or more of the energy available in natural uranium (as opposed to $1-2 \%$ in converter reactors) and, in addition, the breeder fuel cycle cost is much less sensitive to ore cost than is the converter reactor, so that the

*see Section 1.4.5.2 for discussion on using a thorium blanket in the GCFR. 
much more plentiful reserves of higher cost ore can be economically utilized. Moreover, as in the case of the LMFBR, present and projected tails* stockpiles accumulated from the uranium enrichment process will be sufficient to provide the uranium requirements of the breeders projected to be in operation well into the next century without any additional uranium mining required. All of these considerations point to the fact that a fast breeder economy can operate for many centuries on avallable uranium resources.

In addition to the fuel requirements, the supply of helium is a consideration in the growth of a GCFR economy, al though it does not appear this will be a limiting factor. This subject is discussed in Section A.1.4.2 on the High Temperature Gas-Cooled Reactor (HTGR).

\subsubsection{Technical Description}

The most complete GCFR plant design prepared is that for a proposed 300 MWe Demonstration Plant. ${ }^{8}$ Conceptual designs have also been prepared for 1000 MWe commercial plants. A description of the Demonstration Plant with emphasis on its nuclear steam supply system follows. The remainder of the plant is typical of modern high temperature steam-turbine practice.

*tails - the natural uranium depleted in the U-235 isotope which remains after the gaseous diffusion process has produced the enriched uranium required for LWRs and HTGRs. 
The 300 MWe GCFR demonstration plant includes a reactor building, a fuel service building, and a turbine building. The reactor building, which contains the prestressed concrete reactor vessel (PCRV), functions also as a secondary containment structure and includes the fuel-handling area and some reactor plant process and service systems.

The entire primary system (see figure A.1.4-1) is contained within the PCRV, which eliminates the possibility of rapid depressurization by major duct fallure and thus loss-of-coolant problems are restricted mainly to those associated with failure of penetration closures. To limit the maximum rate of depressurization into the secondary containment, structuraliy-independent flow restrictors are designed into each large PCRV penetration closure.

The primary coolant system contains three main loops, each with independent steam generators and circulators, and three auxiliary loops for long-term shutdown cooling. Each main loop and auxiliary loop is housed in a separate cavity in the multicavity PCRV. The helfum coolant, at a pressure of about 1250 psia, flows downward through the core where it is heated to a temperature of $1010^{\circ} \mathrm{F}$. The flow is also downward across the helically coiling tube banks of the once-through steam generators to accommodate the use of upflow boiling in the generators. Top-mounted circulators discharge the coolant to the reactor inlet plenum at a temperature of $595^{\circ} \mathrm{F}$. 


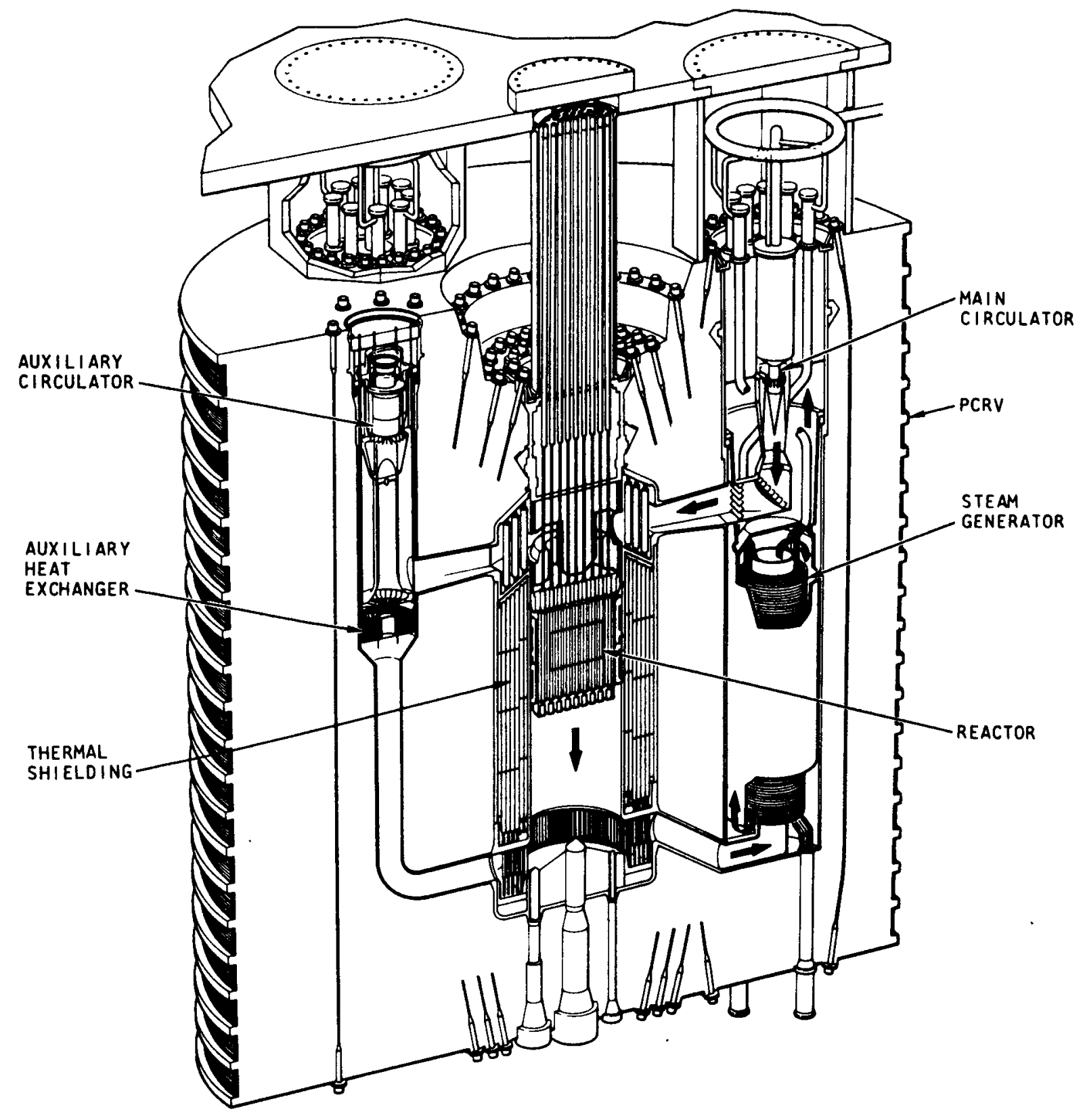

PRINCIPAL COMPONENTS OF THE NUCLEAR STEAM SUPPLY SYSTEM

Figure A.1.4-1 
The main coolant circulator is a single-stage axial compressor driven by a series steam turbine in the high-pressure steam line. This arrangement provides the circulator power $(22,300 \mathrm{hp}$ each), avoids the need for extemal power sources, and makes each main loop as self-contained and independent of the others as possible. Thus, following shutdown, fission product decay heat initially provides power for its own removal. Circulation through backup auxiliary cooling loops is provided by centrifugal circulators, each driven by a 500-hp electric motor.

The reactor core contains 118 hexagonal fuel elements and 93 blanket elements. The elements are supported from a top-mounted grid plate and are clamped to the plate at their cold ends. Each standard fuel element contains 271 fuel pins. The fuel pin consists of annular $(\mathrm{Pu}-U) \mathrm{O}_{2}$ pellets within a type 316 stainless-steel cladding about $20 \mathrm{mi}$ is thick. The surface of the fuel pin cladding is roughened to increase (double) the heat-transfer coefficient and thus reduce core size and fissile inventory. Upper and lower axial blankets are contained in the ends of the fuel pins and consist of depleted $\mathrm{UO}_{2}$ pellets.

The fuel pin design conditions include a maximum mid-cladding temperature of $700^{\circ} \mathrm{C}\left(1292^{\circ} \mathrm{F}\right)$, including hot-spot factors. The maximum design burnup was chosen to be $100,000 \mathrm{MWd} / \mathrm{Te}$, and the maximum linear rating at full power is a conservative $12.5 \mathrm{~kW} / \mathrm{ft}$. These design parameters were selected after evaluation of existing irradiation data and are similar to values typical of LMFBR demonstration plant designs. A listing of 
some of the pertinent design characteristics of the GCFR demonstration plant is given in Table A.1.4-1.

An important feature of the GCFR core design is the fuel element pressure equalization system (see Figure A.1.4-2) which differs significantly from current practice in metal-clad oxide fuel reactor systems. The fuel pins are vented to equalize the internal gas pressure to that of the reactor coolant outside the pin. Assuming the venting feature performs its function throughout the fuel pin life, there will be no stress in the cladding due to internal gas pressure during normal operation. If internal gas pressure proves to be the determining factor in the pin failure mechanism, this feature could provide a basis for reducing cladding thickness, which would lead to an improved breeding ratio. Radiation monitors on the vent lines leading to the helium purification system provide means for detecting and locating any leaks in the fuel pin. The fuel elements contain charcoal-filled fission-product traps to delay the passage of the volatile and gaseous fission products long enough to minimize subsequent heat release. The flow of vent system gas from the element traps is swept by a purge gas flow through the grid plate connector into the lines to the helium purification systems. The main reactor coolant loop can be maintained at very low activity levels, even with leaking fuel rods.

Reactivity control is provided by 27 rods in the control fuel elements, which have central channels to accommodate the absorber rods. The control-rod drives are located above the reactor. Normal operation of 
Table A.1.4-1

GCFR DEMONSTRATION PLANT PERFORMANCE CHARACTERISTICS

Net electric power, $\mathrm{MW}$.......................... 311 Proportions:

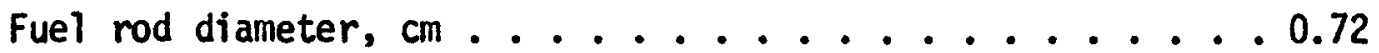

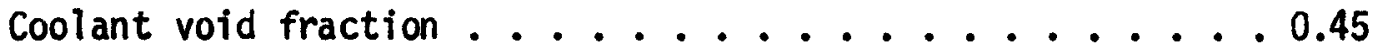

Core diameter, $\mathrm{cm}$.................... 200

Core length, $\mathrm{cm}$.................. 100

Reactor vessel diameter, $\mathrm{ft}$............ 84

Reactor vessel height, ft ............. 71 Operating conditions:

Maximum cladding hot spot, ${ }^{\circ} \mathrm{C} . \ldots . . . . . . . . .700$

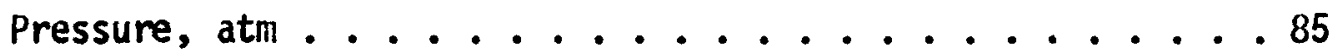

Pumping power, (\% thermal output), $\%$......... 5

Gas in, ${ }^{\circ} \mathrm{F} \ldots \ldots . \ldots . \ldots 595$

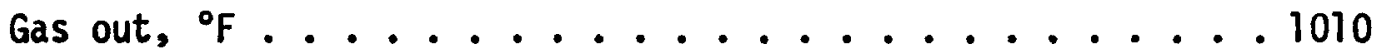

Performance:

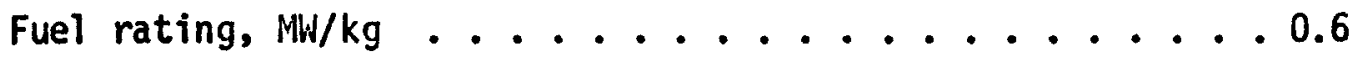

Linear rating, $\max , \mathrm{kW} / \mathrm{ft} \ldots \ldots . . \ldots 12.5$

Overall efficiency, ...................... 37

Conversion ratio ..........................

Doubling time, yr......................

*These figures are for the 300 Mhe Demonstration Plant. For the proposed 1000 Mkie plant, the breeding ratio has been calculated to be in the range of $1.40-1.50$, and the corresponding doubling time is $8-10$ years. 


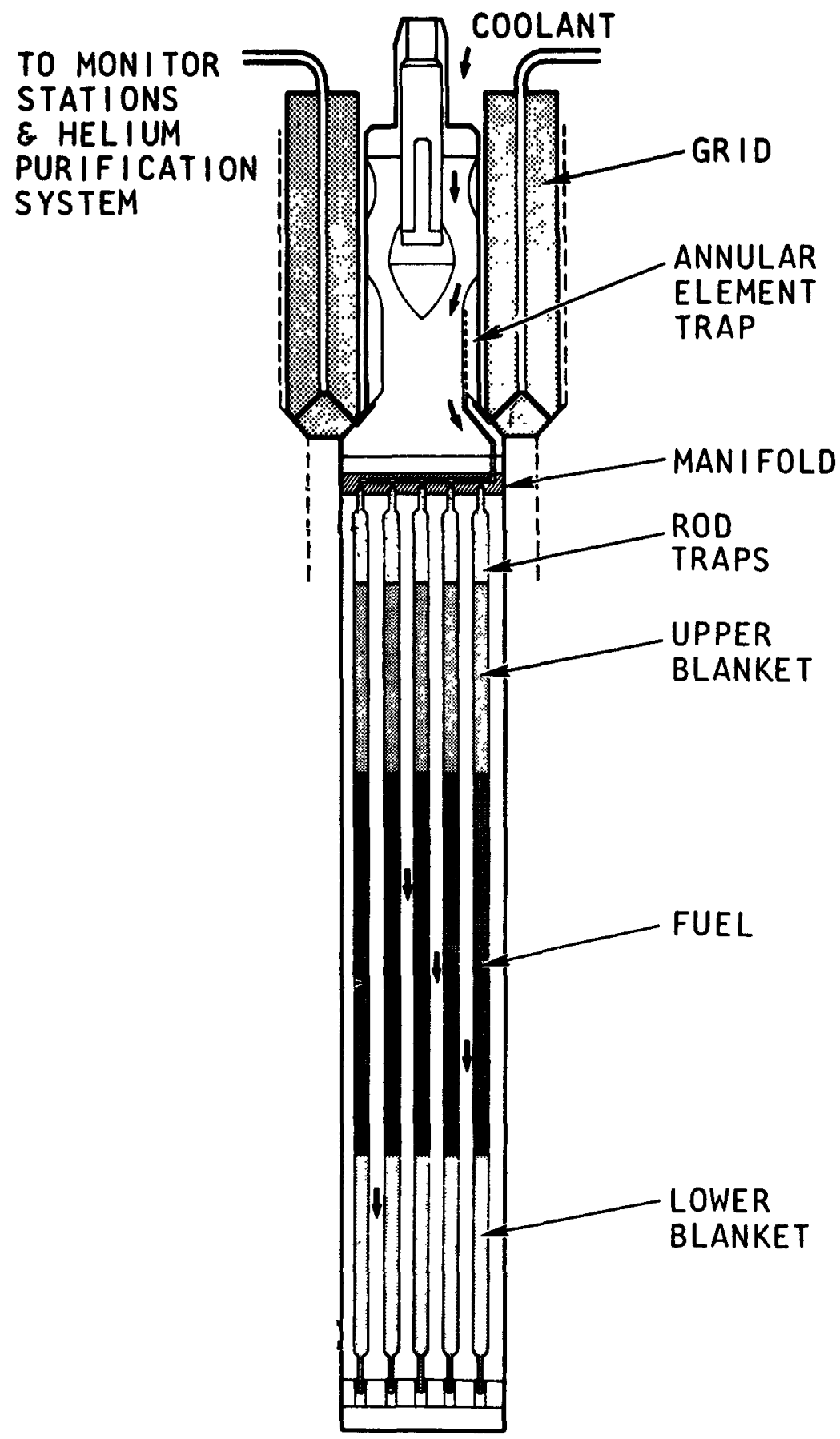

SCHEMATIC OF FUEL ELEMENT PRESSURE EQUALIZATION SYSTEM

Figure A.1.4-2 
the reactor is provided by 21 control rods. Six shutdown rods form a backup system capable of independently shutting down the reactor from any anticipated operating condition.

The PCRV liner and ducts are protected from neutron irradiation by thermal shielding. Around the core, this shielding is in the form of a replaceable inner layer of steel blocks surrounded by an annular region consisting of steel cylinders containing graphite. Cooling of the radial shielding is by a small bypass from the inlet helium.

The concrete plugs above the steam generators incorporate large central holes for circulator installation and smaller surrounding holes for steam pipes. Steam-generator tube plugging can be done externally; the main penetration closure is removed only for complete removal of a steam generator.

To limit the consequences of a possible penetration closure failure, separate secondary containment is provided, similar to that proposed for the large commercial HTGRs. It performs two functions: it insures a minimum coolant pressure ( 2 atmospheres) for core cooling following an accidental primary system depressurization and it confines fission products that potentially could be released from the fuel.

\subsubsection{Research and Deve lopment Program}

The research and development effort required to bring the GCFR to the status of a safe, reliable, economical power reactor plant is considerable. 
The technical areas that require further work are summarized below. A comprehensive research and development program is described in reference 6. The need for GCFR R\&D is also discussed in reference 9, wherein a $\$ 140$ million program is proposed over the next five years to provide the required technology on fuel and reactor core development, physics, critical assembly tests, and safety analyses.

\subsubsection{Component Development Needs}

While the development of the GCFR depends to a significant degree on the successful operation, maintainability, and reliability of Fort St. Vrain (FSV) and future large HTGRs, there are major problem areas unique to the GCFR design that require development effort and proof testing, over and above HTGR needs.

1. Containment of the entire primary coolant system within the PCRV is fundamental to the GCFR concept. Additional model testing is needed to validate the design at the higher GCFR pressure (1250 psi vs 700 psi for HTGR), although some of the PCRV development needed for GCFR will be accomplished as part of the HTGR development program.

2. There are a number of first-of-a-kind components that represent a significant engineering extrapolation from other first-of-a-kind components, some of which have yet to be designed and built and others which have yet to be prooftested under actual operating conditions or operated in a reactor plant. These components, in particular gas circulators and steam generators and their associated maintenance equipment, need to be developed, fabricated and tested along with related development and proof-test facilities.

$$
\text { A.1.4-14 }
$$


3. Reactor mechanisms, such as control drives, have to be operated in hot helium with the attendant problems of lubrication, prevention of self-welding, vibration, metallurgical creep and radiation damage in a fast neutron flux environment. In this regard, experience with similar HTGR components will be applicable.

4. Providing spent fuel cooling during removal from the core and transport to a water storage pool presents a difficult requirement. Such a requirement is influenced by the proposed vented fuel concept. Provisions for sealing the fuel assembly to prevent ingress of water will have to be provided prior to transport to storage.

5. Other components requiring first-of-a-kind engineering development and proof testing includes the GCFR refueling system and special reactor instrumentation.

6. The GCFR core, because of the use of gas cooling with its heat transfer limitations, has a large core void fraction which leads to neutron streaming and leakage problems and might introduce problems relating to the internal shielding of components. The wider coolant channels do have the advantage that problems caused by irradiation induced metal swelling and bowing are reduced. 


\subsubsection{Fuel and Core Development Needs}

In order to maximize the benefits to be gained from other ongoing activities, the GCFR effort in this category should utilize to the extent possible the spin-off technology from the large scale efforts being carried out under the top priority LMFBR program. However, there are major areas unique to the GCFR concept that require development.

a. Fuel venting introduces a number of questions that require substantial development effort to resolve, including the rate of release of fission products from the fuel pellets, their diffusion rate through the length of the rod to the charcoal traps, the effects of breathing at the juncture of the fuel assembly vent and the grid plate that occurs with changes in plant load, fission product plateout throughout the vent system, charcoal behavior under fast flux irradiation, the maintenance of alignment of seals under bowing and vibration stresses, and lastly the operation of the venting system as a whole under pressure transients with and without cladding leaks. Test information on this concept is being developed but much more remains to be done before the reliability of vented fuel can be established. This includes a variety of integral in-pile proof tests of prototypical fuel subassemblies and assemblies and safety tests relating to the vented concept, under a range of operating, transient and shutdown conditions.

b. The fuel pins proposed for the GCFR are different from those planned for LMFBR designs in that they have roughened outer 
surfaces, and are designed for venting of fission gases from the fuel pins and assembly. Surface roughening may affect the strength of the cladding and irradiation testing is required to evaluate such effects.

c. While fast reactor physics methods and fundamental data developed for the LMFBR program will benefit the GCFR program, additional effort is required to meet GCFR needs. Further work is needed on reactivity effects due to the presence of steam which might be introduced into the core as a consequence of a steam generator tube failure.

d. There are heat transfer questions to be resolved as to the effects of rod spacers, fuel-element box walls, and possible rod bowing. Knowledge of the heat transfer over the whole range of flow up to full power conditions would be required for transient and safety analysis purposes. Experimental heat transfer work with respect to these questions is being carried out. in Switzerland in cooperation with GGA.

e. Flow induced vibration of the fuel rods and of the fuel element assembly is a potential problem to be overcome including the effects of seismically induced loads.

f. There are questions respecting the behavior of the interfaces at the spacer/fuel rod and the fuel element/grid in the hot hel fum environment.

$$
\text { A.1 . 4-17 }
$$


g. Difficult problems, common to any fast reactor, are those related to obtaining the desired fuel burnup of $100,000 \mathrm{Mwd} / \mathrm{T}$ and coping with irradiation-induced swelling and creep for all metal parts in the core. Much reliable data are needed in these areas.

\subsubsection{Safety Needs}

In addition to many of the problems that have been raised on other reactors, there are a number of critical safety questions which have been identified for GCFRs. Discussions of GCFR safety and licensing have been underway with the USAEC Regulatory staff and the Advisory Committee on Reactor Safeguards (ACRS) since 1971 aimed at resolution of these questions. Principal areas of concern are:

a. More detailed assurances including test data are needed to assure that adequate reliability of core cooling in potential emergency and faulted conditions could be provided. Startup requirements and adequacy of reliability of the auxiliary cooling loops need to be further analyzed and demonstrated.

b. Depressurization of the primary coolant system has been considered as the design basis for engineered safeguards in the GCFR. The maximum allowable depressurization rate depends on some type of flow limiting devices in the large penetrations. This subject is being reviewed by the AEC Regulatory staff to assess whether the system design can acconmodate the proposed depressurization 
accident. Assurance is needed that the design provides adequate margin for a more rapid depressurization than that associated with the design flow limiting devices and for combinations of other failures occurring simultaneously and/or separately in the main and auxiliary cooling systems, on three or two loop operation.

c. Although analysis indicates that the reactivity change of the core is small and negative for all conceivable steam concentrations resulting from steam generator tube failures, additional analyses and critical assembly experiments would have to be carried out to confirm this.

d. The use of a core support system in which the fuel elements are tightly clamped at one end into a thick grid plate with no additional radial restraint, along with the potential deleterious effects of such materials phenomena as radiation damage and stainless steel creep, has led to detailed questioning by the Regulatory staff and the ACRS on the integrity of the system and the reactivity effects under transients and earthquakes. These problems need to be resolved.

e. The adequacy of the proposed protection provided by control system actions backed up by two independent shutdown rod systems against anticipated transients needs to be proven. Preliminary evaluations have been made of the consequences of failure of protective action in anticipated transients but these have to be analyzed further to establish their acceptability. 
f. A design basis accident (DBA) has not yet been estabilished which is acceptable to the USAEC Regulatory Staff.

\subsubsection{Present and Projected Application}

\subsubsection{Current Use}

The GCFR is in the early stages of development and consequently is not in current use. However, important aspects of GCFR technology are embodied in HTGR systems which are presently in the process of entering the commercial utility market. Also, the GCFR uses the same mixed uranium-plutonium-oxide fuel cycle as the LMFBR. This fuel

cycle is undergoing extensive testing in the U.S. and abroad and is in the process of being demonstrated in prototype reactors in Europe.

\subsubsection{Projected Use}

The GCFR as an alternative fast breeder option to the LMFBR will have similar utilization incentives. It will exploit the same virtually limitless energy resource, uranium, have the same environmental advantages vis-a-vis thermal reactors, and the same environmental problems with respect to fission product containment and control. Since it is in an earlier stage of development, notwithstanding the benefits expected to accrue to it from the HTGR and LMFBR programs, the GCFR is expected to lag behind the LMFBR in date of cormercial introduction. The extent of this delay will depend upon the amount of funding applied to its development. At present the GCFR R\&D effort is proceeding at a modest rate $(\$ 1,000,000$ per year).

This rate of effort will have to be heavily increased if the GCFR is to be introduced within a decade of the time that the LMFBR is 
expected to become commercial. Funds for this effort will have to be provided in addition to those funds already committed for development of the LMFBR or the date of introduction of the LMFBR will be seriously compromised. An attempt to accomplish development of both breeder systems using the funds barely sufficient for one runs the risk of failure to develop either system.

In the event that the decision is made to pursue a vigorous parallel breeder program with sufficient funding and effort starting in FY 74 or FY 75, it is believed that commercial introduction of the GCFR might be achieved by the middle of the last decade of this century. It would thereafter compete directly with the LMFBR and other available sources of energy production on a straight economic basis taking into consideration the comparative environmental impacts of each option, as well as the relative industrial resources available to meet the demand.

One rather novel application ${ }^{10}$ of the GCFR has been proposed by its proponents. This is the use of a thorium blanket in a GCFR to produce U-233 for use as makeup fuel in HTGR's. This would make the HTGR independent of the uranium enrichment process for its fuel and reduce the separative work* required to sustain the nuclear power economy. Presumably the GCFR would produce just

"Separative work" is a measure of the work required to enrich natural uranium in the gaseous diffusion plant to the U-235 enrichment needed in the reactor. 
enough plutonium to provide its own fuel supply and also produce enough U-233 to maintain several HTGRs. This symbiotic mode of operation would provide a means for exploiting thorium resources using uranium-plutonium as the driver fuel. This, of course, might also be done using the LMFBR with a thorium blanket al though not as effectively, since the LMFBR has a lower breeding ratio. Whether this node of operation will be preferable to direct exploitation of the uranium-plutonium fuel cycle will depend upon system analysis studies performed at the time all the pertinent data becomes available.

\subsubsection{Environmental Impacts}

\subsubsection{Energy Conversion Plant}

In all important respects the Gas Cooled Fast Reactor will have approximately the same environmental impacts as those associated with the LMFBR. In particular, the GCFR has the identical fuel cycle as the LMFBR and a similar steam supply system. Accordingly, the environmental impacts determined in previous chapters of this study for the LMFBR are generally applicable to the GCFR.

The major difference between the two systems lies with the coolant. The GCFR uses helium instead of sodium to cool the reactor and transmit heat to the steam generators. The use of helium as a cool ant leads to several advantages which have environmental significance. The minimum interaction between the coolant and the neutrons leads to significantly lower radioactivity in the coolant system. The chemical inertness of 
the gas permits elimination of the intermediate cooling loop required by LMFBRs and could simplify operation and maintenance. In addition, the environmental consequences of any leakage of coolant are correspondingly reduced. Also, since helium does not become radioactive, it does not present a waste disposal problem such as encountered with sodium. Nor is helium flammable, thereby avoiding the potential safety hazard of sodium fires which exists in an LMFBR.

On the other hand, helium is not a good heat transfer medium and therefore high coolant pressure and rapid flow is required to extract the heat from the reactor core. Any interruptions to the circulator flow or any depressurization incidents potentially threaten overheating of the reactor core and must be carefully guarded against. To assure coolant flow, the reliability of the forced circulation systen must be very high and greater reliance must be placed in the GCFR on the auxiliary cooling system, in contrast, for example, to the HTGR which has a high heat capacity graphite-moderated core. The possible occurrence and extent of depressurization accidents are minimized by several safety features inherent in or specifically added to the PCRV for this purpose. It should be noted, however, that in the unlikely event that one of these accidents should occur, a gas coolant does not offer any significant natural convection cooling, which is one of the attractive features of sodium.

Another substantive difference between the GCFR and the LMFBR which may have environmental significance is the GCFR's planned use of vented fuel 
assemblies. Vented fuel, although advantageous for the several technical reasons described in Section 1.4 .3 of this chapter, eliminates the noble gas fission product containment feature regarded as an important advantage of non-vented fuel, with its attendant implications on other plant characteristics such as maintenance and fuel handling. This feature effectively transfers the bulk of the noble gas fission product handling problem from the reprocessing plant to the reactor site. One result of the use of vented fuel is that shipment of irradiated fuel elements could be made at lower internal pressures and lower fission product inventory, although at the expense of making provisions for sealing the vented fuel assemblies.

Another area of comparison of environmental characteristics between the GCFR and the LMFBR is that of thermal effects. Although both reactor systems are limited in thermal efficiency by the maximum allowable temperature of their stainless steel fuel cladding and the similar requirements of their steam cycles, the LMFBR does have a slightly higher thermal efficiency of about 40-41 percent, as compared to 38-39 percent projected for the GCFR. Thus, the GCFR will require slightly more cooling water than the LMFBR, which, depending on the method of heat dissipation selected, might result in a somewhat larger cooling tower, a higher $\Delta T$ in once-through cooling water, a larger cooling pond, etc. 
0ther aspects of environmental concern of the GCFR appear to be equivalent to those for the LMFBR--land usage, need for and type of electrical transmission lines, size of operating crew, extremely low permissible level of gaseous radioactivity release, and the low probability of occurrence of accidents.

\subsubsection{Off-Site Support Activities and Facilities}

Since the associated off-site support activities and facilities of the GCFR, insofar as the environment is concerned, are essentially similar to the LMFBR (with the exceptions noted above), its environmental impacts on flora and fauna, its aesthetic, recreational and cultural impacts and its economic and social impacts should be essentially the same as those encountered with the LMFBR as discussed in previous chapters. Thus, any decisions eventually reached as to further development or commercial introduction of the GCFR will likely be based more on technical and economic reasons rather than on environmental characteristics.

\subsubsection{Irreversible and Irretrievable Commitment of Resources}

Since GCFR operates on the same fuel cycle as the LMFBR with essentially the same characteristics, the cormitment of fuel resources for the GCFR is almost identical to the LMFBR. In fact, in either system little if any additional fuel resources are required beyond those already committed to the LWR program. The plutonium required to fuel the GCFR core would be provided from that produced as a by-product of LWR operation and the uranium needed for the mixed-oxide fuel and the blanket would be provided from the huge supply of diffusion 
plant "tails" which will be sufficient to meet projected demand for many decades.

Since the GCFR is a breeder it would produce more plutonium than it would consume and therefore be a net producer of an energy resource. of course, there would be a corresponding decrease in the supply of natural uranium, but on the breeder cycle there would be sufficient uranium to maintain the electric power generating economy for many centuries.

A discussion of helium gas resources is provided in Section 1.4.2. It can be seen that the makeup requirements of $20 \times 10^{6}$ scf over the 30 year life of one 1000 MWe gas-cooled reactor, when multiplied by the number of gas-cooled reactors estimated to be in service in the year 2020, represent a significant fraction of currently available helium reserves. Action must therefore be taken to substantially increase these reserves (such as through alternate helium production methods) and to decrease the gas leakage rate if helium-cooled reactors are to form a significant part of the Nation's future nuclear power generating capacity.

\subsubsection{Costs and Benefits}

The costs and benefits of the GCFR should parallel very closely those expected from development of the LMFBR, which are discussed in detail in Chapter 11. This is so because of the similiarity in purpose, function, 
fuel cycle and operation. The major difference other than plant design between the two systems is one of timing, with the LMFBR expected to become conmercially available about a decade before the GCFR.

The consequences of this difference in timing can be illustrated if one makes the assumption that the LMFBR does not materialize as a commercial power generation system and the burden of providing the electrical generating capacity during the 10 year delay until the GCFR would become comercially available is relegated to fossil-fired, LWR and HTGR power plants. In that case there would be an increased need not only for fossil fuels but for enriched uranium to fuel the converter (non-breeder) reactors. The extent of this increased enriched uranium requirement can be expressed in terms of separative work demand, which is a measure of the requirement for diffusion plant capacity. The increased demand for enriched uranium would translate into an increase in separative work demand of about 65 kilotonnes per year. " This increase in demand is approximately four times the total installed diffusion plant capacity in the United States today.

In order to provide this additional enriched uranium, about $1,200,000$ tonnes of additional $\mathrm{U}_{3} \mathrm{O}_{8}$ would have to be mined through the Year 2020. 11 If one assumes an average ore grade of 0.2 per cent this would translate to 600 million tonnes of additional ore which would have to be mined. The environmental costs relative to uranium mining are discussed in Section A.1.1. 
As discussed in Section 1.4.6, in nearly all other respects the environmental impacts of the LMFBR and the GCFR are similar. Their thermal efficiencies are almost the same so that waste heat effects should be similar. Chemical effluents from the plants relative to the operation and maintenance of their steam condensing systems would also be approximately the same.

The environmental impacts associated with irradiated fuel processing and transportation of the fuel should be similar since the same fuel is used in both reactor systems. However, the use of vented fuel in the GCFR would decrease both the inventory of stored fission products and the internal pressure in the fuel pins as they are transported to the reprocessing plant, since the volatile gases would be partially removed during operation in the reactor. As mentioned earlier, this transfers that portion of the radioactive waste problem from spent fuel transportation and the reprocessing facility to the reactor site where the removed fission product gases must be stored and eventually transported to a radioactive waste depesitory site.

Releases of radioactive gases from either reactor system to the environment during operation will be negligible. The environmental impacts associated with construction of the generating plants and the transmission line systems should be identical.

The GCFR, of course, will not have the environmental problem of dealing with the contaminated sodium remaining after decommissioning 
of an LMFBR, although this problem might be resolved by decontaminating the sodium to the degree desired and reusing it.

The reason for proceeding with the costly development of either the LMFBR or the GCFR is to provide the nation with a new form of electric energy production which is environmentally acceptable and which enlarges our energy resource base significantly. In these respects both LMFBR and GCFR have similar advantages. Both extend our economically useful uranium resources from decades to many centuries with minimal environmental impacts, although the necessity for long-term storage of radioactive wastes may impose a continuing requirement on future generations.

The GCFR is expected to have a superior breeding ratio as compared to the LMFBR. This advantage would result in shorter doubling times for the GCFR if the specific power and fuel inventory of the two systems were similar. Some penalty in specific power in a GCFR relative to an LMFBR is expected due to the poorer heat removal capability of helium. The improved GCFR breeding ratio must more than compensate for this loss for there to be an improvement in doubling time. Doubling time is a measure of the time it takes for a breeder reactor to produce enough additional fuel to fuel another reactor of the same type. It is thus an indicator of the ability of the breeder reactor to keep up with the increasing demand for more electrical generating capacity. The potentially better doubling time for the GCFR could give it an advantage over the LMFBR as a 
"fuel factory," if the concept of symbiosis with HTGRs is pursued, since a GCFR would be able to service more HTGRs than an LMFBR would. Depending upon the relative doubling times of each concept with respect to the doubling time for electrical generating capacity demand, there might or might not be an advantage for the GCFR. That is, if the doubling time for the GCFR were shorter than the doubling time for electrical generating capacity and the doubling time of the LMFBR were longer, then the GCFR could meet the required demand while the LMFBR could not. On the other hand if the doubling times of both systems were shorter than the doubling time for electrical generating capacity, then there would be no advantage for either system from that standpoint.

One final possible benefit of the GCFR as opposed to the LMFBR might be mentioned. Since the GCFR does not use sodium as the coolant it does not require an intermediate heat exchanger system and other equipment associated with the special handling of sodium. This makes the GCFR somewhat simpler in design and therefore might make its capital cost somewhat less expensive. On the other hand the higher pressure at which the GCFR operates, the large blowers and circulators required and the massive PCRV add to GCFR costs. It is difficult to make judgments on relative capital costs at this time since the GCFR is only in the early development stages, but the presumption might be made that the GCFR may have somewhat lower capital costs. 
In summary, a cost-benefit analys is of the GCFR yields conclusions essentially similar to those for the LMFBR with the following exceptions. Due to its later introduction into the electric power economy, the GCFR would require the mining of a significantly larger quantity of uranium ore to maintain the converter reactors. In addition, the GCFR does not have to contend with the operational consequences of using sodium as the coolant. In its place it must deal with the poorer qualities of helium as a coolant with the precautions necessary to avoid loss of coolant.

\subsubsection{Overall Assessment of Role in Energy Supply}

\subsubsection{Probable Role up to Year 2000}

The GCFR is not expected to be ready for commercial introduction into the electric utility system before the mid-1990's. Consequently, its role up to the year 2000 will be minimal, even if the decision is made to proceed with a full scale R\&D program which successfully achieves its goals. The successful introduction of the GCFR in the last decade of this century would have an impact on future planning and trends which would begin to become apparent in the 1990's in the form of changed ratios of orders and commitments for the mix of power plants to be build in the years beyond 2000 .

\subsubsection{Possible Role Beyond Year 2000}

The role of the GCFR beyond the year 2000 is clouded, as is the case for all other systems, by the uncertainties of determining the extent of success achieved by other competing power technologies. When, and 
to what extent will controlled thermonuclear fusion systems be available? What role will solar power play? Will the LMFBR be viable? What will the competing costs of each system be? An almost infinite variety of scenarios might be composed.

Restricting the possibilities to one example, if only breeder reactors prove to be economically feasible energy production systems, sufficient energy resources will be available for many centuries after the year 2000. Without a breeder reactor, LMFBR, GCFR or both, converter reactor fuel prices will follow an inexorably rising curve similar to that now being experienced by fossil-fueled power plants as low-cost, easily extracted uranium ores are used up. Thus, inevitably our energy requirements will be severely restricted by the increasingly scarce and more expensive fuels required to meet their requirements. Since breeder reactor power generation costs are very insensitive to fuel costs and the breeder increases utilization of the energy inherent in uranium by almost two orders of magnitude, the combined effect of increased utilization and ability to use very expensive ores without undue penalty in economic costs provides an almost inexhaustible energy resource base. 


\subsubsection{References}

1. USAEC, The 1967 Supplement To The 1962 Report To The President, February, 1967.

2. Staff Report, A 1000 MWe Gas Cooled Fast Reactor Study for the Alternate Coolant Task Force, USAEC Report GA-7804, General Atomic, July 21, 1967.

3. General Atomic, Addendum to 1000 MWe Gas Cooled Fast Reactor Study for the Alternate Coolant Task Force, USAEC Report GA-7804 (Add.), September 28, 1967.

4. General Atomic, Addendum 2 to 1000 MWe Gas Cooled Fast Reactor Study for the Alternate Coolant Task Force, USAEC Report GA-7804 (Add. 2), November 12, 1967.

5. General Atomic, Preliminary Development Plan for the Gas Cooled Fast Reactor (GCFR), GA-8257, October 1967.

6. Gulf-GA-A10788 - Gas-Cooled Fast Breeder Reactor Demonstration Plant Development Program Plan, September 1972.

7. Status and Safety Aspects of the 300-MW(e) GCFR Demonstration Plant, S. S. Miliott and J. L. Larrimore, (p.2), paper presented at American Power Conference, Chicago, Ill inois, May 8-10, 1973.

8. GA-10678 (Rev.) - Gas-Cooled Fast Breeder Reactor Studies J. B. Dee, P. Fortescue, and S. A. Larrimore, July 1973.

9. WASH-1281, The Nation's Energy Future, A Report to the President of The United States by The Chairman, U.S. Atomic Energy Commission, December 1973.

10. "A Reactor Strategy: FBR's \& HTGR's," Dr. P. Fortescue, Nuclear News, Apri 11972.

11. USAEC Report, WASH-1184, Updated (1970) Cost-Benefit Analys is of the U.S. Breeder Reactor Program, January 1972. 


\section{A.1.5 MOLTEN SALT BREEDER REACTOR \\ 1.5.1. Introduction}

The Molten Salt Breeder Reactor (MSBR) concept is based on use of a circulating fluid fuel reactor coupled with on-line continuous fuel processing. As presently envisioned, it would operate as a thermal spectrum reactor system utilizing a thorium-uranium fuel cycle. Thus, the concept would offer the potential for broadened utilization of the nation's natural resources through operation of a breeder system employing another fertile material (thorium instead of uranium).

\subsubsection{History}

The development of molten salt reactors began in the late 1940's as part of the U.S. Aircraft Nuclear Propulsion (ANP) Program. Subsequently, the Aircraft Reactor Experiment (ARE) was built at Oak Ridge and in 1954, it was operated successfully for nine days at power levels up to $2.5 \mathrm{MW}(\mathrm{th})$ and fuel outlet temperatures up to $1580^{\circ} \mathrm{F}$. The ARE fuel was a mixture of Uranium Tetraflouride $\left(U F_{4}\right)$, Sodium Flouride (NaF), and Zirconium Tetraflouride $\left(\mathrm{ZrF}_{4}\right)$. The moderator was Beryllium Oxide and the piping and vessel were constructed of Inconel.

In 1956, Oak Ridge National Laboratory (ORNL) began to study molten salt reactors for use as central station converters and breeders. These studies concluded that graphite moderated, thermal spectrum reactors operating on a thorium-uranium cycle were most attractive for economic power production. Based on the technology at that time, 
it was thought that a two-fluid reactor, in which the fertile and fissile salts were kept separate, was required in order to have a breeder system. The single fluid reactor, while not a breeder, appeared simpler in design and also seemed to have the potential for low power costs.

Over the next few years, ORNL continued to study both the two fluid and single fluid concepts, and in 1960 the design of the single fluid 8 MW(th) Molten Salt Reactor Experiment (MSRE) was begun. The MSRE was completed in 1965 and operated successfully during the period 1965 to 1969.

Concurrent with the construction of the MSRE, ORNL performed research and development on means for processing molten salt fuels. In 1967 new discoveries were made which suggested that a single fluid reactor could be combined with continuous on-line fuel processing to become a breeder system. Because of the mechanical design problems of the two fluid concept and the laboratory-scale development of processes which would permit on-line reprocessing, it was determined that a shift in emphasis to the single fluid breeder concept should be made; this single fluid system ${ }^{1}$ is the system which will be discussed in this report.

\subsubsection{Status}

At present, the MSBR concept is essentially in the initial research and development phase, with emphasis on the development of basic 
MSBR technology. Government funding of R\&D activities has recently been reestablished, and Industrial support remains at a moderate level.

The basic feasibility of operating a fluid fueled reactor for prolonged periods has been demonstrated by operation of the MSRE for about 13,000 equivalent full power hours. However, there are many areas of molten salt reactor technology which must be expanded and developed in order to proceed from this small experiment to a safe, reliable and economic 1000 MWe MSBR with a 30-year life. Because of the present state of the technology, much of the following discussion concerning the description of the power plant and supporting facilities and the potential environmental impact of the MSBR must be considered very preliminary. These impacts may change due to improvements in design of the reactor system and as a result of the experience which may be gained from operating additional molten salt reactor systems.

\subsubsection{Extent of Energy Resource}

Because the MSBR is a breeder reactor operating on the thorium cycle, the primary energy source needed is thorium. A discussion of the availability of this resource is presented in Section A.1.2. A moderate amount of natural uranium would also be required to provide the fissile fuel needed to establish an equilibrium breeding cycle in an MSBR (unless startup can be accomplished using plutonium or $233 \mathrm{U}$ bred in another reactor plant). The availability of uranium has been discussed in Section A.1.1. The availability of lithium and beryllium salts needed for MSBR operation will not be a limiting factor. 


\subsubsection{Technical Description of Energy System}

\subsubsection{Power Generation Plant}

The development of the MSBR has not progressed to the stage where an exact description of a reactor and auxiliary systems can be provided. However, the following surmary of a conceptual design study for a single-fluid, 1000 MWe MSBR prepared in 1971 provides some conceptual background.

The reference $M_{S B R}{ }^{2}$ (See Fig. A.1.5-1) would operate on the ${ }^{233} \mathrm{Th}-U$ cycle, with both fissile and fertile materials incorporated in a single molten-salt mixture of the fluorides of lithium, beryllium, thorium, and uranium. This salt has a melting point of $930^{\circ} \mathrm{F}$, has adequate flow and heat transfer properties, and has a very low vapor pressure in the operating temperature range. It is also nonwetting and virtually noncorrosive in the pure form to graphite and the Hastelloy $\mathrm{N}$ container material.

The $22 \mathrm{ft}$-diameter by $20 \mathrm{ft}$-high reactor vessel contains graphite for neutron moderation and reflection, with the moderating region divided into zones of different fuel-to-graphite ratios. As the salt flows upward through the passages in and between the bare graphite bars, fission energy heats it from about $1050^{\circ} \mathrm{F}$ to $1300^{\circ} \mathrm{F}$. Graphite control rods at the center of the core are moved to displace salt and thus regulate the nuclear power and average temperature, but these rods do not need to be fast scramming for safety purposes. Long-term reactivity control is by adjustment of the fuel concentration.

$$
\text { A.1.5-4 }
$$




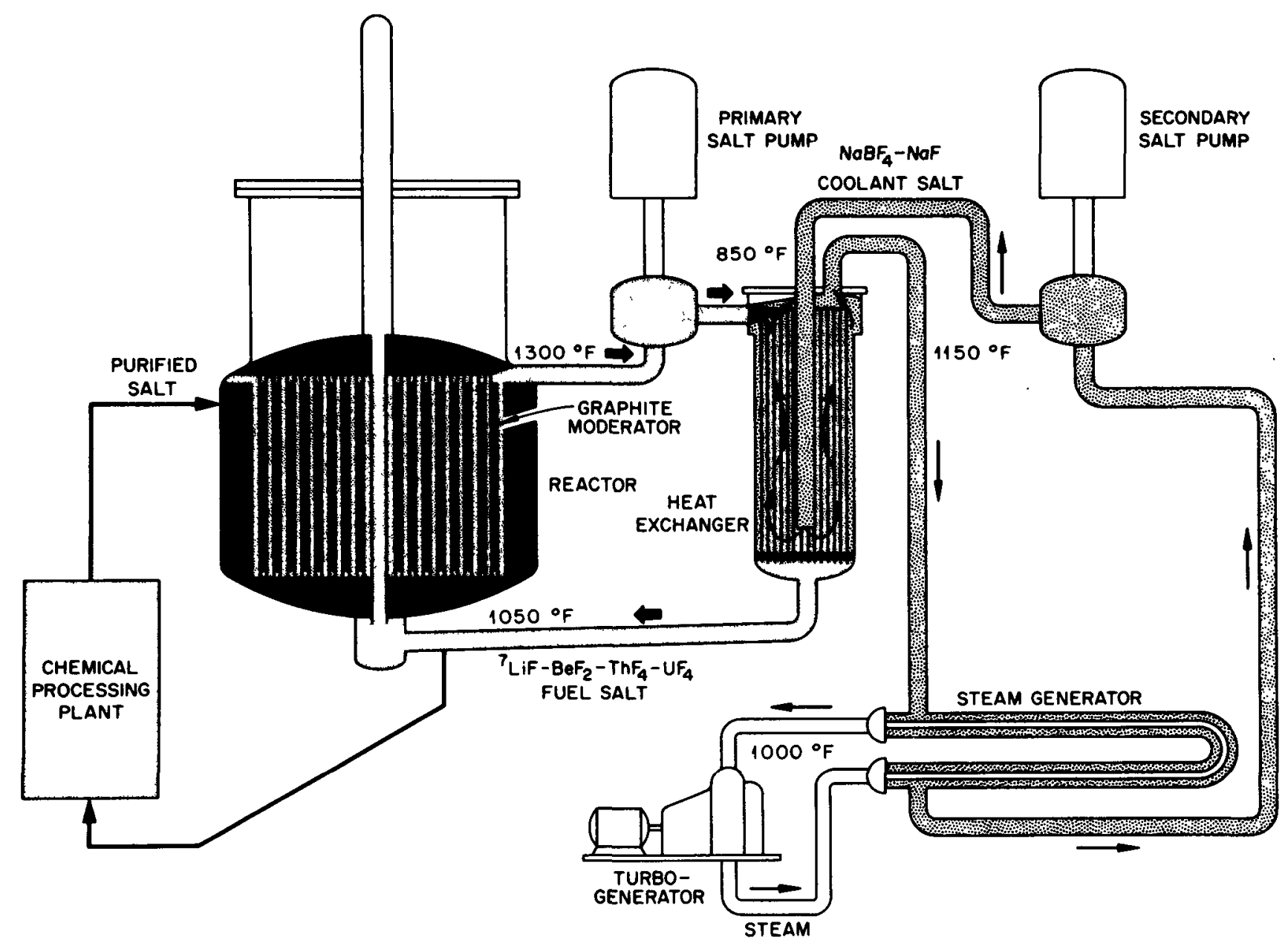

REFERENCE MSBR SYSTEM FLOW CHART

Figure $A .1 .5-1$ 
The core neutron power density results in a moderator life of about four years. The specific inventory of the plant including the processing system is about $1.5 \mathrm{~kg}$ of fissile material per Mike, which together with the projected breeding ratio of 1.06 , gives an annual fissile yield of about $3.3 \%$ and a compound doubling time of 22 years. The heat-power system has a net thermal efficiency of over $44 \%$, which makes a reactor plant of about 2250 MWt ample for a net electrical output of 1000 MWe.

A simplified flow diagram of the MSBR is shown in Figure A.1.5-1: The primary salt is circulated outside the reactor vessel through four loops. (For simplicity, only one loop is shown in the figure.) Each circuit contains a $16,000-\mathrm{gpm}$ single-stage centrifugal pump and a shell-and-tube heat exchanger. Tritium, xenon, and krypton are sparged from the circulating primary salt by helium introduced in a side stream by a bubble generator and subsequently removed by a gas separator. A l-gpm side stream of the primary salt is continuously processed to remove ${ }^{233} \mathrm{~Pa}$, to recover the bred ${ }^{233} \mathrm{U}$, and to adjust the fissile content. A drain tank provides safe storage of the salt during maintenance operations.

Heat is transferred from the primary salt to a secondary fluid, sodium fluoroborate, having a composition of $\mathrm{NaBF}_{4}-\mathrm{NaF}(92-8 \mathrm{~mole} \%)$ and a melting point of $725^{\circ} \mathrm{F}$. Each of the four secondary circuits has a 20,000-gpm centrifugal pump with variable-speed drive. The secondary salt streams are divided between the steam generators and the reheaters 
to obtain $1000^{\circ} \mathrm{F}$ steam temperatures from each. Steam is supplied to a single 3500 -psia, $1000^{\circ} \mathrm{F} / 1000^{\circ} \mathrm{F} 1035$-Mve turbine-generator unit exhausting at $11 / 2 \mathrm{in}$. $\mathrm{Hg}$ abs. Regenerative heating and live steam mixing are used to heat the feedwater entering the steam generator to $700^{\circ} \mathrm{F}$ to provide assurance that the coolant salt remains liquid.

The principal operating parameters for a 1000 MWe MSBR power station are shown in Table A.1.5-1.

\subsubsection{Fuel Cycle}

In order to achieve nuclear breeding in the single fluid MSBR, it is necessary to have an on-line fuel processing system. This would accomplish the following:

a. Isolate protactinium-233 from the reactor environment so it can decay into the fissile fuel isotope uranium U-233 before being transmuted into other isotopes by neutron irradiation.

b. Remove undesirable neutron poisons from the fuel salt and thus improve the neutron economy and breeding performance of the system.

c. Control the fuel chemistry and remove excess uranium-233 which is to be exported from the breeder system.

A fuel processing scheme has been proposed to accomplish breeding in the MSBR, and the flowsheet processes involve: 
Table A.1.5-1

PRINCIPAL OPERATING PARAMETERS OF A 1000 MMe MSBR

General

Thermal Power, MW(th)

2250

Electric Power, MW(e)

1000

Plant Lifetime, Years

30

Fuel Processing Scheme

On-line, continuous processing

Breeding Ratio

1.06

Reactor

Fuel Salt

Moderator

Reactor Vessel Material

$7_{\text {LiF-BeF }}-\mathrm{ThF}_{4}-\mathrm{UF}_{4}$ Unclad, sealed graphite

Power Density, KW/liter Modified Hastelloy-N

Exit Temperature, ${ }^{\circ} \mathrm{F}$ 22

Temperature Rise Across Core, ${ }^{\circ} \mathrm{F}$ 1300

Reactor Vessel Height, Ft. 250

Reactor Vessel Diameter, Ft. 20

Vessel Design Pressure, psia 22

Peak Thermal Neutron Flux, 75

Neutrons $/ \mathrm{cm}^{2}-\mathrm{sec}$

$8.3 \times 10^{14}$

Other Components and Sys tems Data

Number of Primary Circuits

4

Fuel Salt Pump Flow, gpm 16,000

Fuel Salt Pump Head, Ft. 150

Intermediate Heat Exchanger Capacity, MW(th)556

Secondary Coolant Salt

Number of Secondary Circuits $\mathrm{NaF}-\mathrm{NaBF}_{4}$

Secondary Salt Pump Flow, gpm 4

Secondary Salt Pump Head, Ft. 20,000

Number of Steam Generators 300

Steam Generator Capacity, MW(th) 16 121 A.1.5-8 
a. Fluorination of the fuel salt to remove uranium as $U_{6}$.

b. Reductive extraction of protactinium by contacting the salt with a mixture of lithium and bismuth.

c. Metal transfer processing to preferentially remove the rare earth fission product poisons which would otherwise hinder breeding performance.

The fuel processing system shown in Figure A.1.5-2 is in an early stage of development at present and this type of system has not been demonstrated on an operating reactor.

In developing this conceptual design, it was assumed that the problems which have surfaced in the course of the development program would be resolved. The principal development questions, as discussed in Section 1.5 .4 below, relate to tritium confinement, fuel-salt processing, structural materials behavior in the presence of fission products and nuclear irradiation, and development of components for a 1000 MWe power plant. Reports as to the status of MSBR technology and a more complete discussion of the required research and development needed to produce a viable system are presented in references 2 and 3. 


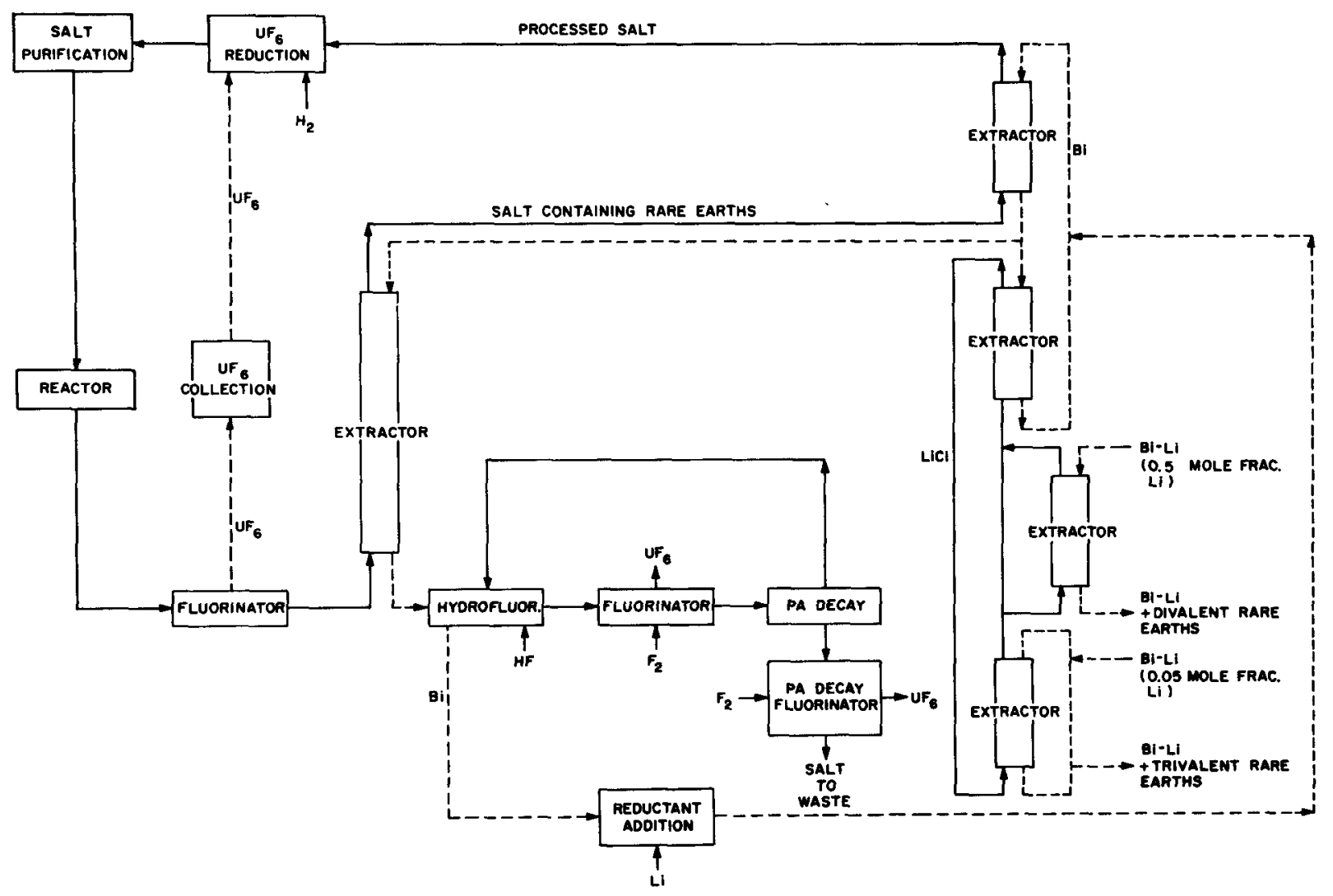

FLOWSHEET FOR PROCESSING A SINGLE-FLUID MSBR BY FLUORINATION-REDUCTIVE EXTRACTION AND THE METAL-TRANSFER PROCESS.

Figure A.1.5-2 


\subsubsection{Research and Development Program}

Consistent with the policy established for all power reactor development programs, the MSBR would require the successful accomplishment of three basic research and development phases:

- An initial research and development phase in which the basic technical aspects of the MSBR concept are confirmed, involving exploratory development, laboratory experiment, and conceptual engineering.

- A second phase in which the engineering and manufacturing capabilities are developed. This includes the conduct of in-depth engineering and prooftesting of first-of-a-kind components, equipment and systems. These would then be incorporated into an experimental test reactor and supporting test facilities to assure adequate understanding of design and performance characteristics, as well as to gain overall experience associated with major operational, economic and environmental parameters. As these research and development efforts progress, the technological uncertainties would need to be resolved and decision points reached that would permit development to proceed with necessary confidence. When the technology is sufficiently developed and confidence in the system was attained, the next stage would be the construction of large demonstration plants. 
- A third phase in which the utilities make large scale commitments to electric generating plants by developing the capability to manage the design, construction, test and operation of these power plants in a safe, relaible, economic, and environmentally acceptable manner.

As in any reactor development program, achievement of economic moltensalt breeder reactors will require that the basic technology be well established in research and development programs and be demonstrated and expanded by the construction and operation of several increasingly larger reactors and their integral processing plants. The technology program is in progress now, and the construction of a 150- to 200-MNt Molten-Salt Breeder Experiment (MSBE) has been suggested as the next reactor in the sequence to an MSBR. The MSBE might have the power density and all the features and systems of a full-scale breeder reactor. Other steps are possible, including the construction of a larger but lower performance converter reactor that would evolve into a breeder. However, the more direct route of the high performance breeder experiment appears preferable.

In this R\&D program several advances must be made before the next reactor can be built and operated successfully. The most important problem is the surface cracking of Hastelloy $\mathrm{N}$. Some other developments, such as the testing of some of the components or the latter stages of the processing plant development, could

$$
\text { A.1.5-12 }
$$


actually be completed while a reactor is being designed and butlt. The major developments that should be pursued during the next several years are the following:

1. A modiffed Hastelloy $N$, or an alternative material that is less subject to attack by tellurium, must be selected and its compatibility with fuel salt demonstrated with out-of-pile forced convection loops and in-pile capsule experiments; means for giving it adequate resistance to radiation damage must be found, if needed, and commercial production of the alloy may have to be demonstrated; the mechanical properties data needed for code qualification must be acquired if they do not already exist.

2. A method of intercepting and isolating tritium to prevent its passage into the steam system should be demonstrated at realistic conditions and on a large enough scale to show that it is feasible for a reactor.

3. The various steps in the processing system must first be demonstrated in separate experiments; these steps must then be combined in an integrated demonstration of the complete process, including the materials of construction; and finally, after the MSBE plant is conceptually designed, a mock-up containing components that are as close as possible in design to those which will be used in the actual process must be built and its operation and maintenance procedures demonstrated. 
4. The various components and systems to go on the reactor must be studied, developed, and demonstrated under conditions and at sizes that allow confident extrapolation to the next reactor if required. These include the xenon stripping system for the fuel salt, off-gas and cleanup systems for the coolant salt (facilities in which these could be done are already under construction), steam generator modules and startup systems, pumps, and other components and systems. The construction of an engineering mock-up of the major components and systems of the reactor would be desirable, but whether or not that is done would depend on how far the development program had proceeded in testing various components and systems individually.

5. Graphite elements that are suitable for the MSRE should be purchased in sizes and quantities that assure that a commercial production capability does exist, and the radiation behavior of samples of the commercially-produced material should be confirmed. Methods for sealing graphite to limit xenon diffusion should continue to be explored.

6. On-line chemical analysis devices and the various instruments that will be needed for the reactor and processing plant should be purchased or developed and should be demonstrated on loops, processing experiments, and mock-ups. 
Other research and development will be required in a number of areas, including the development of MSBR design bases to provide a focal point for the MSBR technology program. This approach represents a desirable program for advancing and testing molten-salt breeder technology in the absence of a commitment to build a reactor, and most become necessary if a reactor is to be built.

\subsubsection{Present and Projected Application}

\subsubsection{Current Use}

As noted above, iASBR's are not yet in use, but the technology has been examined to the point that a breeder reactor experiment has been proposed, and other $R \& D$ is being conducted.

\subsubsection{Projected Use}

If the technology proves technically, economically and environmentally successful, MSBR's might be expected to produce a moderate part of our electricity requirements some time after the year 2000 . There might also be other applications, e.g., process heat, for which an advanced MSBR might be applicable. The extent of the electricity market that might be captured by MSBR's is difficult to predict, and would be dependent on the success of other reactor concepts as well as the solution of the technical problems currently envisioned for molten salt reactors.

\subsubsection{Environmental Impacts}

\subsubsection{Energy Conversion Plant}

The environmental impacts resulting from construction and normal 
operation of an MSBR plant would likely be similar to those for an LMFBR plant of comparable size. The MSBR would utilize a ${ }^{233} U$-Thorium fuel cycle, possibly with a requirement for enriched ${ }^{235} U$ for startup, and thus would involve different mining, and possibly enrichment, requirements.

A major uncertainty with regard to the MSBR's environmental characteristics is the handling of tritium. ${ }^{1,2,3}$ Tritium is produced in an ASBR through the interaction of thermal neutrons with the lithium according to the following reactions:

$$
6_{L i}(n, \alpha){ }^{3} H \text { and }{ }^{7} L i(n, \alpha){ }^{3} H \text {. }
$$

Tritium is a special problem because of its high rate of production in the fuel salt and because it readily diffuses through metals at MSBR temperatures. Approximately $2400 \mathrm{Ci} /$ day are produced by each 1000 MWe plant. In the current reference design, it has been estimated that approximately $800 \mathrm{Ci} /$ day would be released in the $560,000 \mathrm{gal} / \mathrm{min}$. stream of cooling water unless specific tritium control measures are implemented. The effluent concentration $\left(0.26 \times 10^{-3} \mu \mathrm{Ci} / \mathrm{ml}\right)$ is a factor of 52 greater than the AEC's numerical guidelines for effluent from LWRs. Because of this "tritium problem," a method for the retention and control of tritium must be developed and proven before the MSBR concept can be considerable viable. Several modifications in design and operation 
offer ways for reducing tritium escape. The objective of limiting tritium release to within present guidelines for light-water-cooled reactors appears attainable, but the best measures are yet to be chosen and demonstrated. 4

The noble gases are continuously stripped from the fuel salt by a purge of helium. The system being considered (Figure A.1.5-3) would allow for the decay of the short-lived fission gases and total retention of all long-lived gaseous fission products. Therefore, it is not expected that the MSBR will release any noble gases.

\subsubsection{Off-Site Activities}

All high level waste streams from the reprocessing plant will be combined in order to recover the residual uranium prior to disposal. The reference processing scheme would result in the discarding of about $0.3 \mathrm{ft}^{3}$ per day of fuel salt containing the rare earth fission products and possibly significant quantities of thorium, although it may prove desirable to recover and recycle the thorium in the interest of achieving higher resource utlization. It is expected that this waste will be in a form which is acceptable for storage in a federal waste repository. Most of the fission products remain in the fuel salt and these become a concern when the plant is finally decommissioned. At present, no demonstrable method exists for the ultimate disposal of this material.

With regard to other high-level and low-level solid liquid and gaseous wastes, the current state-of-the-art is such that an estimate of their 


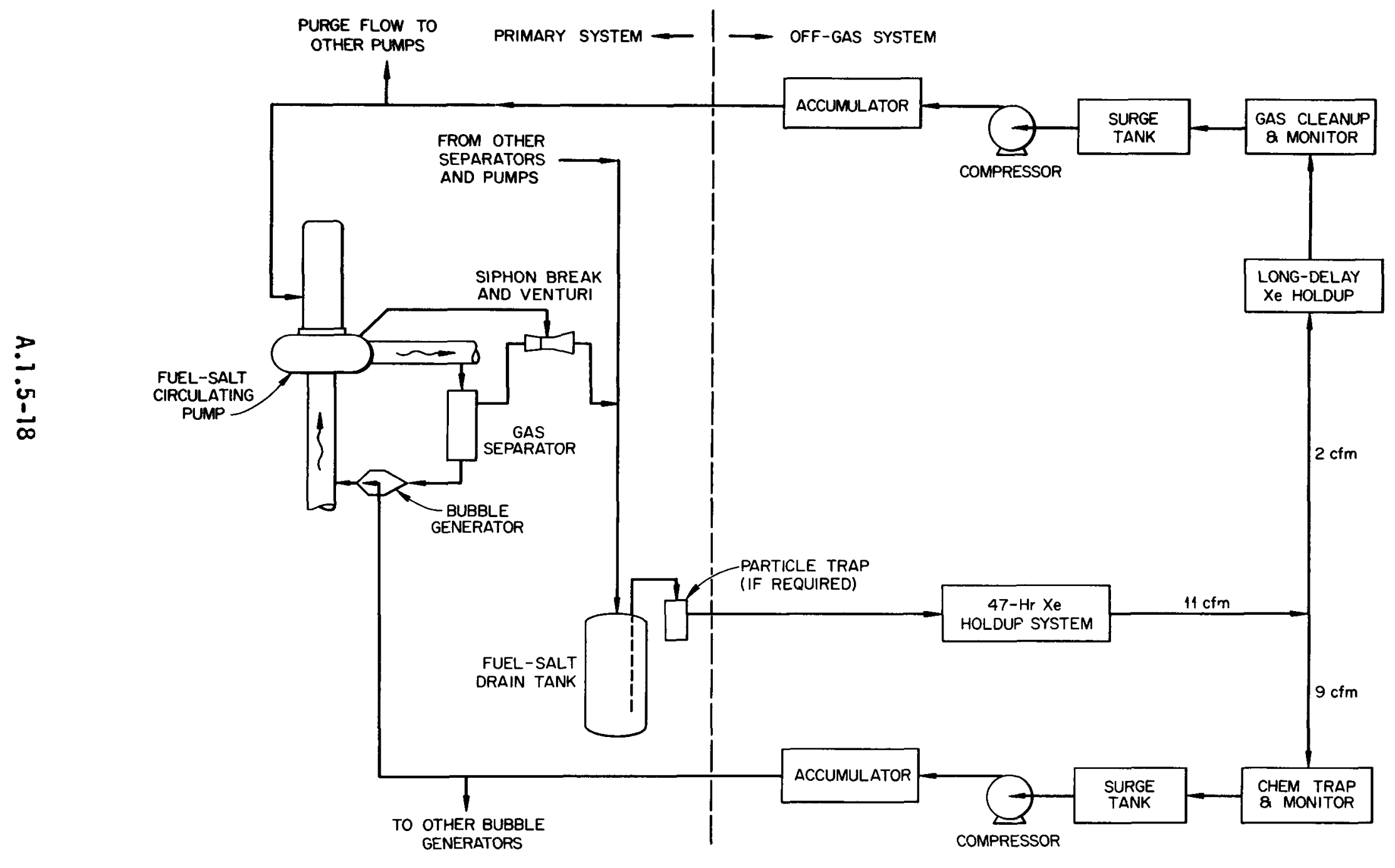

MSBR OFF-GAS SYSTEM SCHEMATIC FLOW DIAGRAM

Figure A.1.5-3 
quantity cannot be made, although it is expected that their overall impacts should be comparable to those of other reactor systems.

\subsubsection{Costs and Benefits \\ 1.5.7.1 Costs}

Based upon the AEC's experience with other complex reactor development programs, it is estimated that a total government investment up to about 2 billion dollars in undiscounted direct $\cos t^{5}$ could be required to bring the molten salt breeder or any parallel breeder to fruition as a viable, commercial power reactor. A magnitude of funding up to this level would be needed to establish the necessary technology and engineering bases; obtain the required industrial capability; and advance through a series of test facilities, reactor experiments, and demonstration plants to a commercial MSBR safe and suitable to serve as a major energy option for central station power generation in the utility environment.

With regard to capital and operating costs, the problem of assessment is more difficult because it not only involves uncertainties in MSBR costs but also uncertainties about what the cost of the competing system will be. The major cost item in the fuel cycle is the capital cost of the processing plant, and this is probably the most certain of the estimates. Based on (1) a reasonably conservative es timate, including, for example, an allowance of $\$ 200$ a pound for the cost of fabricating the molybdenum used to contain bismuth (see Figure A.1.5-2), and (2) additional conservatism in the processing costs based on using the processing plant for only 1000 MWe of 
reactor capacity (whereas the unit costs of processing plants come down very rapidly if the throughput is increased), it is concluded the capital costs for MSBRs will be about the same as for LWRs.

It should be noted that estimation of capital costs of plants to be built far in the future with some yet undeveloped technology is full of uncertainties. Because of the way LWR cost data were used, these uncertainties appear to have more to do with the design of the plant than with the ability to make cost comparisons for a given design. Nevertheless, there is limited room for error in the comparison with an LWR because the cost of "reactor equipment" (including the reactor itself, the salt pumps, the heat exchangers and steam generators, the salt storage tanks, and the off-gas system and other equipment) is only one-third of the total cost of the power plant.

Because the fissile inventory is fairly low and the credit for sale of bred fuel is modest, the fuel cycle economics of MSBR's are not very sensitive to these factors nor to the cost of enriched uranium. Increasing uranium ore cost from $\$ 8$ to $\$ 16$ a pound without reoptimization of the reactor would only increase the fuel cycle costs by about 0.1 mi 11/kwh.

One other factor that can affect the power cost is plant availability. Since molten-salt reactors do not have to be shut down for refueling, and the frequency of graphite replacement is low and can be scheduled to coincide with major turbine maintenance, MSBR's start off with an 
availability advantage over LWR's. The MSBR plant must, however, be made reliable and must be specially designed so that the initial advantage is not offset by the increased difficulty of maintenance.

Based on earlier design studies, the cost of power from an MSBR has been estimated to be about $0.5 \mathrm{mill} / \mathrm{kwh}$ less than that of a light-water reactor at present uranium ore prices. If uranium ore costs increase by $\$ 8 / 1 b$ by the time breeders are introduced, the cost advantage of an MSBR would increase by $0.3 \mathrm{mill} / \mathrm{kwh}$. Thus there is a fair margin for error in our comparison with present day LWR's. However, LWR costs are certain to change some in two or so decades, and HTGR's rather than LWR's could be the converter with which to compete at the time. Thus strong conclusions about the MSBR meeting our cost criterion are not appropriate, but the chances seem reasonably good with low uranium prices, and of course, increase as the cost of uranium ore goes up.

\subsubsection{Benefits}

Potential benefits from MSBR's include:

1. Use of a fluid fuel and on-site processing would eliminate the problems of solid fuel fabrication and the handling, and shipping and reprocessing of spent fuel elements which are associated with all other reactor types under active consideration. 
2. MSBR operation on the thorium-uranium fuel cycle would help conserve uranium and thorium resources by utilizing thorium reserves with high efficiency.

3. The MSBR is projected to have attractive fuel cycle costs. The major uncertainty in the fuel cycle cost is associated with the continuous fuel processing plant which has not been developed.

4. The safety issues associated with the MSBR are generally different from those of solid fuel reactors. Thus, there might be safety advantages for the MSBR when considering major accidents. An accurate assessment of MSBR safety is not possible today because of the early state of development.

5. Like other advanced reactor systems such as the LMFBR and HTGR, the MSBR would employ modern steam technology for power generation with high thermal efficiencies. This would reduce the amount of waste heat to be discharged to the environment.

It is too early in the development of the concept to evaluate the benefits or penalties that will be associated with the reactor. For example, development of methods for the control of tritium would prevent the release of this material to the environment and therefore it would not be necessary to consider tritium. However, should the 
development efforts fail, then it is probable that the release of some $800 \mathrm{ci} /$ day would prohibit use of this reactor.

\subsubsection{Overall Assessment of Role in Energy Supply}

It is too early in the development program to assess the penetration the MSBR would make if it were to become a viable reactor concept. Even if the AEC and the nuclear industry were to significantly increase the funding for the MSBR development program, it is estimated that the earliest that the system could be marketed would be 1990, and thus MSBR would not be expected to supply a significant amount of electrical energy until past the Year 2000. 


\section{References}

1. Robertson, R. C., Comp., "Conceptual Design Study of a SingleFluid Molten Salt Breeder Reactor," ORNL-454l, Oak Ridge National Laboratory, Oak Ridge, Tenn. 37830, June 1971.

2. Rosenthal, M. W., et.al., "The Development Status of Molten Salt Breeder Reactors," ORNL -4812 , Oak Ridge National Laboratory, Oak Ridge, Tenn. 37830, August 1972.

3. U.S. Atomic Energy Commission, "An Evaluation of the Molten Salt Breeder Reactor," USAEC Report 1222, September 1972.

4. AEC Authorizing Legislation for Fiscal Year 1974, Hearings Before the Joint Committee on Atomic Energy, Congress of the United States, Part 3, March 14, 1973.

5. U.S. AEC Report WASH-1184, "Updated (1970) Cost-Benefit Analysis of the U.S. Breeder Reactor Program," January, 1972. 


\section{A.1.6 CONTROLLED THERMONUCLEAR REACTOR POWER SYSTEMS}

\subsubsection{Introduction}

Nuclear fusion is the process of joining together two light nuclei with the accompanying release of energy. This reaction can occur only when the reacting ions collide with sufficient energy to overcome the repelling forces between them; one method of accomplishing this is by raising the temperature of the reacting nuclei to a sufficiently high level. Fusion reactions brought about by this means are called thermonuclear reactions.

The Atomic Energy Commission supports two programs aimed primarily at utilizing the nuclear fusion process for commercial electrical power production. One program involves the use of magnetic fields to confine a plasma* of fusion fuels, while the other emphasizes the use of high energy, short pulse lasers focused on suitable thermonuclear pellets to compress, heat and ignite the fuel to release the fusion energy. These programs are managed by the AEC's Division of Controlled Thermonuclear Research and the Division of Military Application respectively.

The goal of the AEC's Controlled Thermonuclear Research (CTR) program and of the AEC's laser-fusion program is the development of fusion as a major source of abundant, economical and environmentally attractive energy, particularly for the generation of electricity. The primary fuels for fusion reactions are the hydrogen isotopes

FA fully fonized gas, i.e., one in which all the electrons have been stripped from the nuclei. 
deuterium and tritium. These reactions can only take place at very high temperatures (about 100 million degrees), and at such temperatures the fuels are present as a state of matter called plasma. The central problem at present in the fusion research program is to confine a reacting fusion plasma at conditions of density, temperature and confinement time sufficient so that more energy will be released from fusion reactions than is necessary to initiate them. Achievement of these conditions would be a major accomplishment in phase I of the Controlled Thermonuclear Reactor Program. (See Section, Perspective on Alternative Energy Options, for a discussion of the phases involved in any R\&D program.)

\subsubsection{Magnetic Confinement Program}

One of the major approaches to meeting the requirements for achieving useful power from controlled thermonuclear reactors is that of magnetic confinement. The magnetic confinement program began in 1951 as a classified program called Project Sherwood. It was declassified in 1958 and a program summary was published that year. ${ }^{1}$ By the early 1960's plasmas had been created at the temperatures and densities required for fusion and a number of scientific problems relating to containing the plasma for sufficiently long times were identified and a systematic study of them begun.

The difficulties that arose during these studies became the central problem of fusion research -- the isolation of a reacting fusion

$$
\text { A.1.6-2 }
$$


plasma from its surroundings. The principal approach to this problem, then as now, was to confine a fusion plasma through the use of specially shaped magnetic fields, which were to control the motions of its individual ions and electrons. However, it was soon discovered that spontaneously arising turbulence and unstable plasma oscillations significantly weakened the confining effect of the magnetic fields. As a result of several years of intensive theoretical and experimental research, the plasma instability problem was brought under reasonable control by the late 1960's. In fact, the understanding of instabilities and means for their control was sufficient to permit experiments which exhibited confinement conditions close to the "classical" upper limit -- the theoretical maximum possible in a completely quiescent plasma at a particular density and temperature. This achievement was obtained in several different experiments, and it provided a basis for renewed optimism with respect to ultimate success.

Three concepts of magnetic confinement are under study in the United States. These are called low beta*, high beta and open systems. Low beta toroidal systems, principally the tokamak, are under investigation primarily at the Oak Ridge National Laboratory and the Plasma Physics Laboratory of Princeton University. These contain a plasma in a toroidal configuration, at comparatively low particle density. High beta systems, principally the theta pinch, are being

*Beta is defined as the ratio of the outward pressure exerted by the plasma to the inward pressure which the magnetic confining field is capable of exerting. 
developed at the Los Alamos Scientific Laboratory. These devices operate at conditions where the pressure generated by the plasma is almost as strong as the confining pulsed magnetic field. The latest experiment is being assembled in a toroidal configuration. Finally, experiments known as open systems, or magnetic mirrors, are being conducted at the Lawrence Livermore Laboratory. These systems contain a plasma in magnetic bottles designed to reflect the charged particles repeatediy from regions of strong magnetic field.

The 1972-73 time period has seen significant advances in the magnetic confinement program. Important experimental results were achieved in the ORMAK, the ATC and the Scyllac experiments. These are all experiments designed to isolate the plasma from its surroundings through use of specially shaped magnetic fields--the principal approach to the development of first generation fusion power plants.

The ATC (the Adiabatic Toroidal Compressor at the Princeton Plasma Physics Laboratory) Figure A.1.6-1, and the ORMAK (the large-bore toroidal tokamak at Oak Ridge National Laboratory), Figure A.1.6-2, successfully demonstrated two plasma heating techniques -- plasma compression and neutral beam injection respectively. Each has the potential to boost plasma temperature past the ohmic heating barrier* to

Fohmic heating is similar to the process that heats an electric toaster; the plasma electrons are resistively heated. The ohmic heating barrier is not specifically a limit on the current that can flow in the plasma, but rather the point at which plasma losses (particularly bremsstrahlung) equal the effect of ohmic heating; plasma losses increase with plasma temperature while the effectiveness of ohmic heating decreases.

$$
\text { A. 1.6-4 }
$$


3
$\vdots$
$\vdots$
$\vdots$

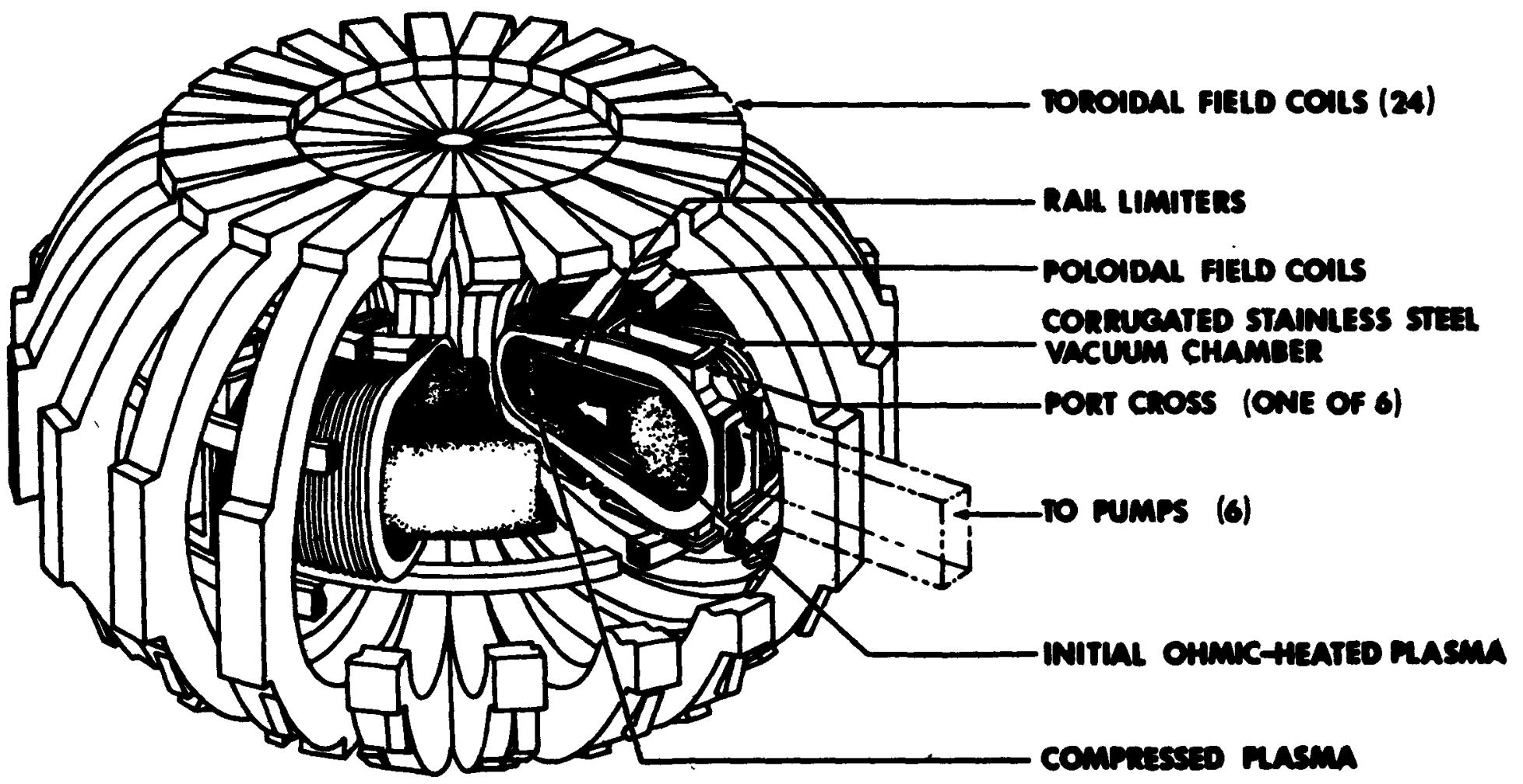

ADIABATIC TOROIDAL COMPRESSOR (ATC)

Figure A.1.6-1 


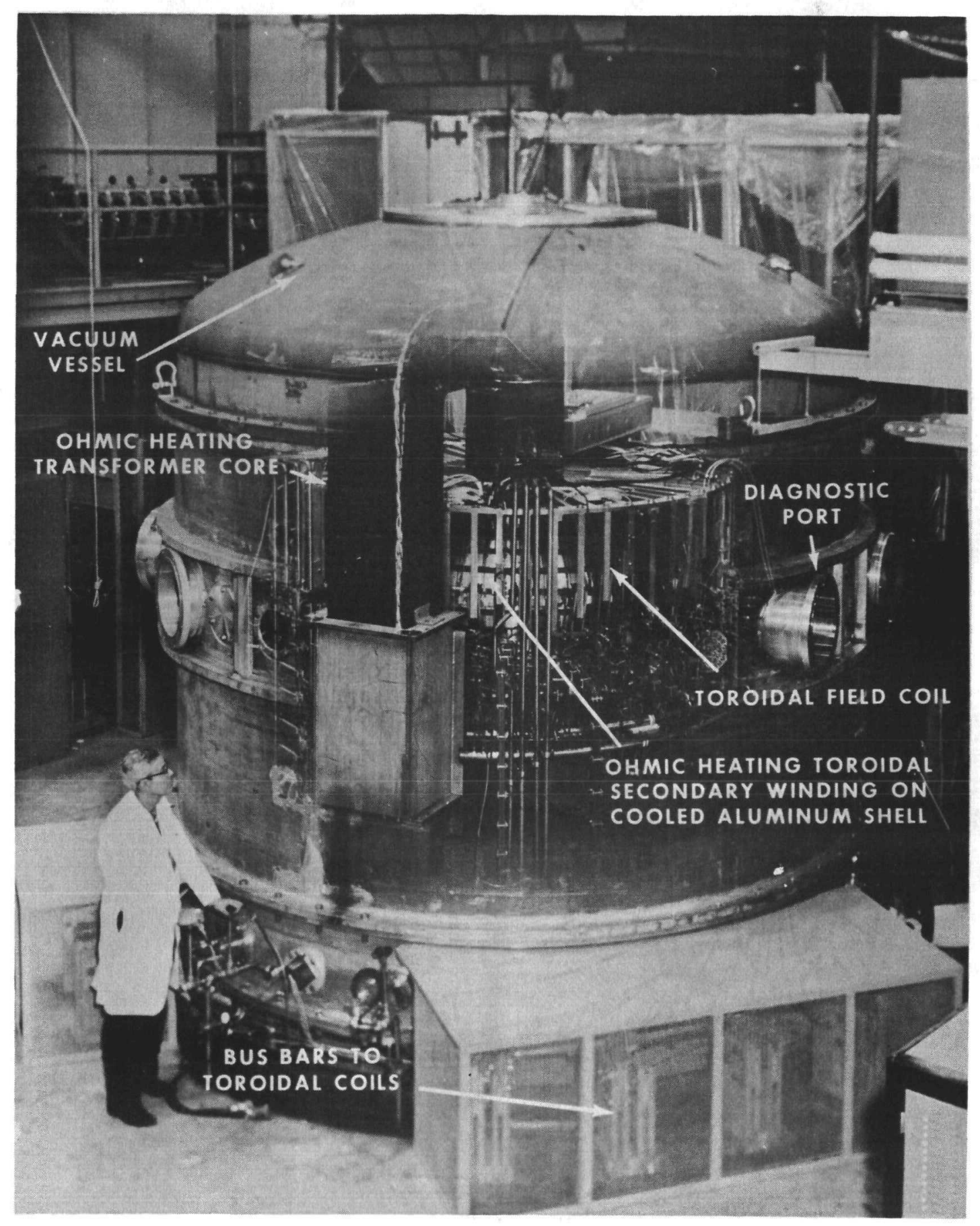

ORMAK

Figure A.1.6-2

A. 1.6-6 
thermonuclear levels. Further, ORMAK confirmed that increases in size would result in better plasma parameters, and the ATC plasma was compressed to a density beyond that required for a Tokamak reactor.

In the Scyllac experiment (Figure A.1.6-3) at Los Alamos Scientific Laboratory, stable confinement, terminated only by end effects, was observed in both the 5 meter and 8 meter sectors of the torus. Based on these results, the full torus, completed in February 1974, could possibly attain 50 to 100 microsecond ( $\mu \mathrm{sec}$ ) containment. Achievement of a containment time in this range would signify a confirmation of the correctness of our understanding of the basic physical laws governing high beta plasmas in toroidal geometry. The affirmation of our theories would be a major accomplishment in the High Density Systems program and would provide us with a critical scaling law required in the design of a thermonuclear reactor based upon this concept.

The parameter characterizing attainment of thermonuclear reactor conditions is the product of the plasma density, $n$, and the containment time, $\tau$, for the reaction considered. Future $D-T$ fusion reactors confining $10 \mathrm{keV}\left(100,000,000^{\circ} \mathrm{C}\right)$ temperature plasmas are expected to require an $n \tau$ product of the order of $10^{14} \mathrm{~cm}^{-3} \mathrm{sec}$. Since the plasma density in the Scyllac device will be $2 \times 10^{16} \mathrm{~cm}^{-3}$, a demonstration of 50-100 $\mu \mathrm{sec}$ confinement time would yield an $n \tau$ 
value of $1-2 \times 10^{12} \mathrm{~cm}^{-3} \mathrm{sec}$, a level of considerable physical significance.

Based on the above experiments and other advances in theory, experiment and hardware development, it is expected that the U.S. program should have deuterium-tritium burning experiments operating about 1980 producing the first significant release of controlled fusion energy for peaceful purposes. Following that, the principal second phase milestone of operation of experimental power reactors producing useable amounts of power could be achieved in the latter part of the 1980's and the operation of a demonstration fuston power plant of 500 Mwe or more could come in the mid-1990's.

\subsubsection{Laser-Fusion Program}

The laser-fusion program constitutes an alternative to the magnetic confinement fusion effort for producing commercial electric power. It involves the use of high energy, short pulse laser beams focused on suitable thermonuclear pellets to heat and compress the fuel causing the release of fusion energy. This is done repetitively with the energy converted to electrical power through a thermal cycle, or other system.

The program was initiated by the AEC in 1962 as physics investigations to provide understanding of the military potential of lasers for the generation of plasmas. The effort was conducted at a modest level for several years, with greater emphasis on laser-fusion

$$
\text { A.1.6-9 }
$$


for energy cormencing in 1969. This was due to increasing optimism for achieving laser-induced thermonuclear reactions resulting from (a) developments in laser technology that demonstrated the feasibility of high energy, subnanosecond laser pulses and (b) analyses based on thermonuclear principles that indicated that the laser requirements for achieving fusion were orders of magnitude less than those initially anticipated. Also, the potential of this new technology for civilian power application was more clearly perceived and was deemed sufficient to merit an energetic program even though portions of the program must be considered as having substantial uncertainty.

Since the late 1960's the program has been broadened in scope and effort, and significant progress has been made in many of the basic technology areas involved, including laser developments, fast diagnostic instrumentation, theory and understanding of laser-plasma interactions. These developments provide a firm technology base for further advances.

The current AEC program is being conducted at the Lawrence Livermore Laboratory (LLL), Los Alamos Scientific Laboratory (LASL), and Sandia Laboratories-Albuquerque (SLA), with contract support by selected contractors, primarily the Naval Research Laboratory (NRL). Contract research is currently undertaken with organizations whose existing facilities and capabilities can be used for highly programatic research. 
The program is strongly oriented, in the near term, toward evaluating the overall scientific feasibility of laser-fusion. High energy, spherical irradiation experiments are planned within the next few years to normalize the computer codes that are used for target design. These early, high energy target irradiation experiments will define the probability of achieving laser-fusion feasibility.

Assuming success in these irradiation experiments and achievement of laser-fusion scientific feasibility, and the advances in theory and hardware developments anticipated in this field, it is anticipated that net energy gain (fusion energy from pellet greater than total energy input to system) can be achieved by 1980--this would be for nonrepetitive pulse operation in contrast to repetitive reactor-type operation. It is planned that this achievement would be followed by an experimental reactor in the mid-1980's and an experimental power reactor possibly by 1990. Subject to successful achievement of the experimental power reactor within this time frame, a Demonstration Power Reactor might be feasible in the mid-1990's.

\subsubsection{Extent of Energy Resource}

Because of its high energy gain and its relatively low plasma temperature, the deuterium-tritium reaction is considered the most attractive for first generation fusion power reactors. Deuterium is present in sea water and may be extracted at low fuel cost by means of proven processes. It is virtually an unlimited fuel resource. Tritium, on the other hand, does not occur naturally and must be bred by means of neutron absorption in lithium. Hence, the 
supply of lithium determines the capacity to utilize tritium in fusion reactors. Lithium is currently produced from pegmatitic rocks and by solar evaporation of subsurface brines. Known lithium reserves are large and the potential for expanding lithium resources is excellent. Higher cost lithium could also be recovered in substantial amounts from several sources. An assessment of adequacy of lithium supplies ${ }^{2}$ indicated that "Even the most conservative estimates of exploitable lithium supplies lead to the conclusion that or fusion reactors, breeding their tritium from natural lithium, could meet an electricity demand much larger than today's for centuries."

Further down the road, when the technology has been developed to permit the commercial use of $D-D$ reactions, requirements for 11 thium will be alleviated and the CTR industry could eventually be based upon the virtually inexhaustible deuterium resource.

A discussion of the requirements and availability of material resources needed for fusion reactor construction is given in Section 5.6 .3 below. It is shown there in some detail that a fully developed world fusion power economy would cause some resource use conflicts which would have to be resolved. It should be recognized, however, that design improvements and technology developments might provide possibilities for alternative materials utilization. 


\subsubsection{Technical Description.}

In 1972, scoping studies were made of the four major fusion concepts - the tokamak, the theta pinch, the magnetic mirror, and the laser-fusion systems. ${ }^{3}$ The first three involve magnetic confinement of the hot plasma to isolate it from the reactor chamber walls, thereby avoiding quenching of the plasma below the thermonuclear reaction temperature. Laser-fusion reactions, on the other hand, are envisioned to occur so rapidly that inertial forces provide adequate confinement during the thermonuclear fusion process.

Fusion power systems presently envisioned ${ }^{3,4}$ would utilize the DT fuel cycle, $D+T+{ }^{4} \mathrm{He}+n$, in which $80 \%$ of the fusion energy is carried by the neutrons. These systems will require a blanket region to convert the neutron kinetic energy to thermal energy, and to breed tritium fuel by neutron absorption in lithium, present either as the liquid metal or an inorganic salt. The blanket will also serve as the inner portion of the biological shield. A thermal power conversion system would be required for generation of electricity. Advanced fusion systems could have a large fraction of the total fusion energy carried by charged particles which might make direct power conversion an attractive alternative.

Materials of construction will dictate permissible operating temperatures in fusion power systems. For example, the torus of a tokamak reactor might be fabricated of an alloy of a refractory 
metal, such as vanadium, if it were possible to assure a virtually oxygen-free coolant in contact with the vanadium structure. This should permit operation at elevated temperatures, with overall plant efficiencies of $40-50 \%$. A vanadium alloy of this type has not been developed as yet and would require extensive research to assure that it would meet requirements necessary for purposes such as fabricability into large segments and compatability with possible coolants. Vanadium materials known today require an essentially oxygen-free environment to prevent corrosion and consequent deterioration of mechanical properties. If this characteristic persists in the new alloys to be developed, designs using vanadium would have to assure that the coolant in contact with the vanadium structure would be virtually oxygen-free.

Should it prove necessary to use stainless steel, operating temperatures would be reduced from those for a vanadium alloy to prevent excessive corrosion by metallic lithium in the blanket. It would then be possible to raise steam at perhaps $900^{\circ} \mathrm{F}$ to drive a conventional steam power plant and obtain an overall thermal efficiency of 30 to $36 \%$.

Studies conducted to date have served primarily to define general operating conditions and provide a basis for more detailed assessments. Such assessments are presently underway for a theta pinch concept, a mirror concept, three variations on the tokamak confinement systems, and a number of power plants based on the

$$
\text { A. 1.6-14 }
$$


laser-fusion process. These studies will provide a basis for determining further research and development requirements and will also permit a more detailed analysis of environmental impact of fusion power plants.

Transportation and storage of fusion reactor fuels would pose no problems, as neither the deuterium nor the lithium are radioactive and they can be shipped according to acceptable safe practice. The two fusion reaction products are stable ${ }^{4} \mathrm{He}$ and a neutron. Most of the neutrons are absorbed in the lithium blanket and the balance in the structural members (resulting in activation of these members) while the helium is an inert product that may be separated from unburned tritium-deuterium fuel and used as makeup for the helium refrigerant for the superconducting magnet system.

Present understanding indicates that fusion power plants could be built with the same electric output as other types - about 1000 MWe or larger.

\subsubsection{Research and Development Program}

Both the magnetic confinement and laser-fusion programs have significant efforts underway which are in the early stages of the first phase of a research and development program (see Section, Perspective on Alternative Energy Options) leading to the determination of scientific feasibility. Many possible additional efforts in this 
phase have been identified. These efforts and efforts of subsequent phases will be undertaken in parallel or in sequence, as the logic of the program dictates, as prerequisites to the initiation of major engineering activities in the later phases of the R\&D program.

In view of the fact that scientific feasibility has yet to be established in either the magnetic confinement or laser-fusion approach to CTR power, the research and development program described herein and particularly the schedules for progressive development in the research and development programs have a large degree of uncertainty attached to them. The early stages of the research and development program deal with experiments designed to achieve scientific breakthroughs. These experiments can be scheduled, but there is no assurance that the results will be satisfactory or that they will be achieved on the anticipated schedules. At least three tasks can be identified which will have to be achieved before R\&D leading to achievement of engineering feasibility can be successfully accomplished: the good plasma confinement already achieved in small experiments must be achieved in reactor-sized experiments; plasma heaters developed for small experiments must be scaled to larger size units with reasonable efficiency; and development of either the means for continuously removing the helium "ash" produced or getting a sufficiently high burn-up of the fuel each cycle to much more than take care of the energy required to heat and ignite the plasma. 
Research and development requirements for the different fusion power concepts have been assessed in a report originally prepared as part of the study done for the Federal Council on Science and Technology's Energy R\&D Goals Study in $1972^{5}$. These requirements are summarized below.

\subsubsection{Magnetic Confinement Program}

For all of the systems in the magnetic confinement program, the theoretical and experimental efforts are directed toward a common goal - the understanding of conditions necessary for creating, heating, and sustaining a deuterium-tritium plasma so that it may be used as an energy source for the generation of electric power.

The major share of funding at present is allocated to relatively large and sophisticated experiments devoted to the study of plasma properties, particularly those techniques that may be employed to heat plasmas to thermonuclear temperatures. Many aspects of plasma physics, however, need not be studied in complex experiments, and there is a significant research program devoted to the development of plasma science by means of simpler experiments intended to build the necessary base of understanding. In addition to the experimental programs, development and technology programs are underway which concentrate on providing the engineering support, both design data and hardware, necessary for planned future experiments. 
Plasma experiments presently in progress employ hydrogen, deuterium or helium, since use of tritium would require special facilities to handle and control a radioactive gas safely. However, more complex facilities are now contemplated for construction as part of the next generation of plasma experiments, so that the technology of burning deuterium-tritium gas mixtures may be fully explored. Initially, these experiments would be operated with hydrogen plasmas, to clarify appropriate questions of physics. They would then be fueled with DT, and the physics and engineering problems relating to burning fusion plasmas would be studied.

In addition to DT burning experiments, other experiments operating solely with hydrogen plasmas will be undertaken for the purpose of addressing separable physics and engineering problems. Such experiments will provide critical data without the necessity of providing tritium handling capability and incorporating shielding for the neutrons generated in the DT reactions.

It is anticipated that magnetic confinement experiments to be conducted in the future will be as follows:

\section{Phase I}

Deuterium-Tritium Physics Test Reactors, 1-10 MW(t), two or three to be completed about 1980;

$$
\text { A.1.6-18 }
$$


Phase II

Experimental Power Reactor $\# 1,20-50$ :WW(e), to be completed in 1983-84;

Experimental Power Reactor \#2, $100 \mathrm{MW}(\mathrm{e})$, to be completed in 1986-87; and

\section{Phase III}

Demonstration Power Reactor, $500 \mathrm{MW}(\mathrm{e})$, to be completed about the mid-1990's.

Development and technology efforts will be expanded to provide the necessary hardware for the new large experiments and to begin those long lead time efforts related to fusion power experimental power reactors and demonstration plants. The engineering requirements of power producing systems may differ markedly from experiments designed solely to acquire data on operating characteristics, so it is critical that work be conducted in recognition of potential differences. The most important development problems which must be faced in the near term magnetic confinement fusion program include superconducting magnets, magnetic energy storage systems, and neutral beam sources.

The research program will also be expanded to develop further understanding of plasma behavior. It is reasonable to expect that there will be a continuing need for study of the basic principles of plasma physics, to provide a greatly needed predictive capability. 
For example, a greatly increased effort is to be undertaken on computer simulation of plasmas, including three-dimensional computer simulation. This will permit modeling of proposed experiments to assure proper machine design, and in the longer term, will provide the capability to more easily optimize fusion reactor power plants.

Input to such computer codes will be largely dependent on progress in understanding of plasma behavior, in much the same way that fission reactor analysis is predicated on precise neutron cross section data.

\subsubsection{Laser-Fusion Program}

The laser-fusion program encompasses both theoretical and experimental effort. The status of unclassified research was recently reviewed $^{6,7}$. Program efforts to date have been predominantly directed toward laser research and laser system hardware development, with increasing emphasis in recent years on lasers with high energy outputs in subnanosecond* pulses. This work has been supported and guided by theoretical and calculational efforts on laser-plasma generation, laser energy absorption mechanisms, pellet configurations, and laser irradiation experiments using various target configurations and materials.

The first priority of the laser-fusion program is to obtain experimental data on the interaction of high energy laser beams with \# 1 nanosecond $=10^{-9}$ seconds. 
target materials and thermonuclear pellets. Such data are critically needed to assess the validity of theoretical predictions of target performance. The small amount of tritium required for pellet experiments presents no difficult safety or handling problems and the current program includes irradiation of targets containing tritium. The present output of glass lasers is sufficient to begin serious experimental studies but is too low in energy to achieve meaningful pellet compressions. Therefore, another high priority of the current program is to develop higher output lasers.

The best hope for substantial energy gains in the near-term lies in the further development of Neodymium-glass lasers. A 10,000 joule glass laser system is presently under development. In the long-term, gas lasers appear much more promising for providing energies of 100,000 joules and higher at reasonable costs. A 10,000 joule $\mathrm{CO}_{2}$ laser is under development in order to evaluate the desians and components for a proposed 100,000 joule $\mathrm{CO}_{2}$ system expected to be started in 1975. Larger follow-on systems are in the planning stage. A modest facility is planned for evaluating the potential of electron-beam technology for achieving fusion.

Future experiments in the laser-fusion program are anticipated as follows:

\section{Phase I}

Single cavity experimental reactor at $50 \mathrm{MW}$ (thermal) in early to mid-1980's. 


\section{Phase II}

Experimental Power Reactor (100 MWe) to be completed by 1990.

\section{Phase III}

Demonstration Power Reactor (single or multiple 100 MWe modules to be completed about the mid-1990's.

As discussed above, these experiments will be supported by the development of lasers having increasingly higher energies and efficiencies, the design and fabrication of the required fuel pellets, and developments and tests of reactor components such as optical hardware, tritium processing, laser gas flow systems, cavity and blast containment vessels, direct conversion systems, etc.

As in the magnetic confinement program, more detailed attention will be given to assessment of the characteristics of laser-fusion power reactors. This will permit identification of engineering developments necessary to reduce the laser fusion process to practice initially in experimental and demonstration reactors. Theoretical studies will also continue to assure that the physics of laserpellet interaction processes is well understood and that the techniques employed make maximum use of the incident laser energy. 


\subsubsection{Present and Projected Application}

Since the Controlled Thermonuclear Reactor Program is in the early stages of its development effort, present and projected applications must be measured in terms of mi lestones along the way toward development of the technology. The major milestones anticipated to be achievable which are associated with the magnetic confinement fusion research program are as follows:

\section{Phase I}

(1) Achievement of reactor-level plasma conditions in a hydrogen plasma in the mid to late 1970's.

(2) Achievement of DT burning at the multi-megawatt level in about 1980 in Physics Test Reactors.

Phase II

(1) Electrical power production in $1983-84$ in a first generation Experimental Power Reactor (EPR-1) at many tens of electrical megawatts.

(2) Electrical power production in 1986-87 in a second generation Experimental Power Reactor (EPR-2) at 100 electrical megawatts.

\section{Phase III}

(1) Electrical power ( 500 Whe or more) in a Demonstration Reactor in the early to mid-1990's. 
(2) Commercial introduction of fusion power plants on a significant scale beginning in the early 21 st century.

Milestones for the laser-fusion effort are as follows:

Phase I

(1) Achievement of significant thermonuclear burn in the mid-1970's.

(2) Achievement of scientific breakeven* in the late 1970's.

(3) Achievement of net energy gain by about 1980.

\section{Phase II}

(4) Operation of single cavity experimental reactor at $50 \mathrm{NW}$ (thermal) in mid-1980's.

(5) Electrical power generation (100 Me) in an experimental power reactor by 1990 .

(6) Electric power (single or multiple modules) in a Demonstration Reactor in the mid-1990's.

\subsubsection{Environmental Impacts}

Since the fusion research program encompasses three approaches to magnetic confinement and one to laser-fusion, and is only in the early phases of research and development, it would be

FFusion energy from the pellet equals the laser light energy incident on the pellet. Efficiency of laser would then determine how close to energy breakeven the system has approached. 
premature to attempt a definitive assessment of environmental impact. However, a preliminary analysis was done for a so-called Reference $C T R^{3}$, and others are to be undertaken based on more detailed power plant scoping studies scheduled for completion by the end of 1973. A summary of the anticipated environmental impact of fusion reactors based on the studies conducted to date is provided below.

\subsubsection{Energy Conversion Plant}

\subsection{Radioactive Effluents}

Any radioactivity releases that occur during routine operation of a fusion power plant will be due to tritium leakage. It appears that this can be maintained at very low values. Tritium leakage which does occur will come about by:

(a) diffusion through the blanket region walls into the magnet shield region, directly and from that region to the atmosphere of the building,

(b) leakage from joints and/or components of the tritium handling system, and

(c) diffusion through heat exchanger walls into the working fluid of the thermodynamic cycle and subsequent leakage to the atmosphere.

Direct diffusion from the blanket region to the atmosphere is expected to be trivial because representative reactors, for example 
a tokamak, can be designed to surround the thermally hot section which contains the tritium with a cold wall. By evacuating the intervening space and drawing and recycling any tritium in this space, the tritium loss would be inconsequential because the remaining diffusion path would be through a cold wall. The design and attainment of highly leak tight blanket coolant systems will impose a severe engineering requirement on fusion systems. The actual severity of the requirement will depend on the allowable leak rate which in turn may be highly dependent on the details of the system design and allowable dose rates.

For the systems utilizing a steam cycle, any tritium which diffused from the blanket system would interact with water in the steam cycle to form HTO. Recovery of the tritium once in this form would require use of an exorbitantly expensive isotope separation process. Conventionally, liquid losses from steam cycles occur due to intentional operational discharges to maintain control of coolant chemistry and leakage. The problems associated with maintenance and operation of steam cycles in fusion plants are expected to be identical with those encountered in present conventional steam generating systems. The potential presence of HTO in the steam cycle is a factor which will require the evaluation of the applicability of current steam cycle design, maintenance and operational practice to fusion plants. An attractive alternate to the steam cycle is the closed cycle gas turbine power system such 
as will be used with high temperature gas-cooled fission reactor power plants.

It may prove possible to operate certain fusion power plants solely as bumers. The necessary fuel could be obtained from breeder fusion reactor systems located in more remote sites and shipped to the burner stations as needed. This would result in a minimum tritium inventory in burner stations and might permit urban siting of such fusion power plants.

\subsection{Long-Lived Radioactive Wastes}

Fusion reactors will produce nonvolatile, long-lived radioactive wastes in modest quantities. The primary source of such waste will be activated structural materials of the blanket, which will have a finite useful lifetime within the reactor owing to radiation damage. Table A.1.6-1 (from Ref. 8) shows the principal long-lived activities of a blanket structure composed of vanadium or niobium. This table gives the annual rate at which activity is generated normalized to one megawatt of reactor thermal power, the accumulated activity resulting from 1000 years of continuous generation*, and the biological hazard potential associated with this amount of accumulated activity. Note that in Table A.1.6-1 the maximum permissible concentration in water is used, which seems more appropriate than the value in air in the context of underground disposal.

*In 1000 years the accumulated hazard potential will approach its steady-state value. 
Table A.1.6-1

\section{LONG-LIVED ACTIVITIES IN THE BLANKET STRUCTURE}

OF A FUSION REACTOR

\begin{tabular}{|c|c|c|c|c|c|}
\hline Nuclide & $\begin{array}{l}\text { Mean } \\
\text { Life (Yrs.) }\end{array}$ & $\begin{array}{c}\text { Activity } \\
\text { Generation Rate } \\
\text { (curies/MW }(t)-y r)\end{array}$ & $\begin{array}{l}\text { Accumulated }{ }^{c} \\
\text { Activity at } 1000 \text { yrs. } \\
(\text { curies } / \mathrm{NW}(t))\end{array}$ & $\begin{array}{c}\text { Maximum Pemissible } \\
\text { Concentration in } 3 \text { Water } \\
\left(\mu \text { curies } / \mathrm{cm}^{3}\right)\end{array}$ & $\begin{array}{l}\text { Bioloqical Hazard } \\
\text { Potential Activity } \\
\text { at } 1000 \text { yrs } \div \mathrm{MPC} \\
(\mathrm{km} \text { of water/iNN }(\mathrm{t}))\end{array}$ \\
\hline \multicolumn{6}{|c|}{ If Fabricated with Vanadium } \\
\hline Long-Live & d Activities & Due to Activation of & $\begin{array}{l}\text { Wiobium Inpurity in Van } \\
\text { If Fabricated with }\end{array}$ & $\begin{array}{l}\text { dium } \\
\text { Niobium }\end{array}$ & $0.00014-0.0014$ \\
\hline $93_{i N b}^{i m}$ & 19.6 & 8,800 & 173,000 & $4 \times 10^{-4}$ & 0.4 \\
\hline $94_{\text {iib }}$ & $2.9 \times 10^{4}$ & 2.9 & 2,900 & $3 \times 10^{-6^{e}}$ & 1.0 \\
\hline
\end{tabular}

\footnotetext{
$a_{D}$. Steiner and A. P. Fraas, "Preliminary Observations on the Radiological Implications of Fusion Power," Nuclear Safety, Vol. 13, No. 5, Sept-0ct 1972, p. 353, Ref. 8.

${ }^{b}$ Average generation rate based on twenty years of reactor service.

$c_{B}$ ased on 1000 years of continuous generation.

Assuming niobium is present at an atomic concentration of 100 to $1000 \mathrm{ppm}$.

e "Default" value listed in USAEC Rules and Regulations, 10 CFR, Part 20, Appendix 8.
} 
The use of vanadium as the blanket structural material would dramatically reduce the problems associated with radioactive waste disposal. Vanadium exhibits no known long-lived activity as a result of activation; therefore, the long-lived activities result only from the activation of impurities and alloying additions within the vanadium. Niobium is typical of such an impurity and might be present in vanadium at an atomic concentration somewhere between 100 to $1000 \mathrm{ppm}$ (parts per million). Assuming this concentration range, the biological hazard potential associated with the activated vanadium structure would be three to four orders of magnitude lower than that associated with the niobium structure (see Table A.1.6-1). The same arguments would also be valid for several promising vanadium alloys, i.e., those containing titanium and chromium. However, use of vanadium must be accomplished in a manner to maintain the oxygen content of the coolant low enough (on the order of $100 \mathrm{ppm}$ ) to prevent corrosion of vanadium structures. This susceptibility of vanadium to significant corrosion in the presence of low oxygen concentrations has limited its present use and minimized previous materials development programs on vanadium to a far smaller scale than those accomplished on niobium.

Structural material selections for fusion power plants are by no means fixed. Studies are under way to assess the suitability of blanket and structural materials that would minimize activation ${ }^{9}$. Materials such as graphite and aluminum are being assessed to 
establish whether they could meet all the engineering requirements imposed by the reactor operation.

\subsection{Waste Heat Rejection}

The DT fuel cycle requires the use of a thermal power conversion system, although a potential exists for direct power conversion in both advanced mirror-fusion and laser-fusion systems. The efficiencies of thermal systems are determined in large part by the maximum temperature of the heat transfer fluid, which is determined by the maximum temperature of the core structure. A fusion reactor utilizing a refractory metal alloy might be capable of operation at $1000^{\circ} \mathrm{C}$. Tests with $\mathrm{Nb}-1 \% \mathrm{Zr}$ indicate that it might be suitable for this service, and could be used with a potassium topping cycle superimposed on a conventional steam system. The combined cycle should give a plant efficiency between $50 \%$ and $60 \%$ depending on the auxiliary power requirements, particularly for fuel injection. Use of a closed cycle gas turbine power system might result in efficiencies in the $40 \%$ to $50 \%$ range.

The use of cooling water versus wet or dry cooling towers has not been considered in detail for fusion reactors because the choice of heat rejection mode is such a sensitive function of plant site considerations. Obviously the high operating temperatures of a refractory metal fusion reactor would allow increased flexibility in optimization of a system using cooling towers over power cycles operating at lower temperatures. With a high peak cycle temperature, 
heat can be rejected from fusion power plants at $100-200^{\circ} \mathrm{C}$ without seriously reducing plant thermal efficiency. This heat minht then be used in urban siting applications for building heating and cooling and/or industrial processes, before being ultimately rejected at lower temperatures.

\subsection{Land Despoilment}

There are two aspects of land despoilment related to the fusion power plant. The first is the direct land use by the power plant itself, which includes buildings, switchyards, transformer yards, transmission lines, cooling equipment, etc. To a significant extent fusion reactors would be similar to fission reactors in this reaard, and fusion fuel storage space requirements will be nealigible.

The second aspect of land despoilment is associated with the projected flexibility of fusion reactor siting. If, the low radiological hazard potential of fusion reactors makes urban siting acceptable, then the larae land areas usually required for power transmission from rural to urban areas would be significantly reduced.

\subsection{Accident Hazards}

Any reasonable appraisal of accident hazards requires a detailed examination of a specific design because many potential problems are in large measure dependent upon specifics of the system. As discussed in WASH-1239 (reference 3), only one conceptual fusion 
reactor design has been examined in any depth in an attempt to maximize safety and minimize accident potential. That Reference CTR (RCTR) served as a basis for the analysis. (See page 9ff of WASH-1239 for a description of the RCTR and page $28 f f$ for a discussion of the potential accident hazards involved in the RCTR.)

A listing of the principal hazards recognized as requiring attention in the research and development program is given below. WASH-1239 discusses each of these in some detail with the general conclusion that the hazards are small and amenable to control by proper design.

a. Stored energy in the system in nuclear and chemical forms - the largest source is the lithium in the blanket (see Table A.1.6-2).* The upper limit on the nuclear energy release via nuclear reaction of the fuel in the plasma region (about $1 \mathrm{gram}$ ) would at worst provide a minor temperature perturbation.

b. Plasma instabilities leading to a localized plasma dump onto an adjacent wall and consequent wall burnout with lithium leakage into the plasma. This would quench the fusion reaction in a fraction of a second.

c. Magnet failure leading to damage to the magnet system.

Fote that the selection of lithium as a coolant in some conceptual fusion reactor designs is very preliminary and could give way to more conventional fiuids such as water or helium. 
d. Loss of coolant accident with consequent minor afterheat problems.

e. Lithium leakage and the consequences of such leakage.

f. Leaks in the potassium condenser-steam generator of the RCTR.

g. Leakage of the tritium inventory in the fusion reactor including the lithium coolant.

Table A.1.6-2

ENERGY RELEASE POTENTIAL OF COMPONENTS OF A REFERENCE CTR PRODUCING 1000 MWe

\begin{tabular}{lcc} 
Plasma, complete fusion & $\begin{array}{l}\text { Energy in } \\
\text { Megajoules }\end{array}$ & $\begin{array}{c}\text { Equivalent Gallons } \\
\text { of Fuel 0il }\end{array}$ \\
\cline { 2 - 3 } & $6.9 \times 10^{4}$ & -430 \\
Magnet & $2.4 \times 10^{5}$ & $\sim 1500$ \\
Lithium + water + air & $6.4 \times 10^{7}$ & $\sim 4 \times 10^{5}$ \\
Potassium + water + air & $6.4 \times 10^{5}$ & $\sim 4000$ \\
Primary vacuum vessel & 640 & $\sim 4$ \\
Secondary vacuum vessel & $1.6 \times 10^{4}$ & $\sim 100$
\end{tabular}

\section{1,6.6.2 Offsite Activities}

\subsection{Procurement of Materials}

The major activities off-site from the power plant which contribute to environmental impact are associated with the procurement of the fuel and construction materials. 
DT fusion power plants would consume deuterium and lithium as fuels. Deuterium is obtained from water which is universally available. Its extraction results in no despoilment, but it does result in the production of useful quantities of conmercial grade hydrogen and oxygen and modest quantities of purified water.

Lithium is obtainable from surface and underground brines (the least expensive extraction process) and from the oceans (a more expensive process but still relatively insignificant in cost). The land despoilment associated with the extraction of lithium and the metals incorporated in the structure of a tokamak reactor ${ }^{3}$ are shown in Table A.1.6-3, which shows that the ore residues resulting from extraction of lead and copper are of greatest concern.

\subsection{Transportation}

To start up a fusion power plant an initial fuel charge of deuterium and tritium will be needed. Thereafter a continuous supply of deuterium and lithium will be required at the rate of about a kilogram per day. Tritium shipment will be necessary only to supply the initial charges to start new power plants, since recycling within each plant is assumed as the principle operating mode. It is estimated that only about $10 \mathrm{~kg}$ quantities of tritium would be shipped from each operating plant every few years on the average, depending upon the rate of growth of the fusion power industry. Thus, the transportation of nuclear fuels for CTRs is seen to be a relatively minor problem as compared to other nuclear or fossilfueled power plants. 


$$
\text { Table A.1.6-3 }
$$

YIELD OF REQUIRED METALS FROM THEIR ORES

\begin{tabular}{|c|c|c|c|}
\hline & $\begin{array}{l}\text { Reguirement for } \\
107 \text { MWe - metric } \\
\text { megatons } \\
\end{array}$ & $\begin{array}{l}\text { Approximate } \\
\text { average yield of } \\
\text { metal from crude } \\
\text { ore - percent } \\
\end{array}$ & $\begin{array}{l}\text { Ore Requirement } \\
\text { for } 10^{7} \text { MWe - } \\
\text { metric megatons } \\
\end{array}$ \\
\hline $\mathrm{Nb}$ & 7 & 2 & 350 \\
\hline Be & .6 & 2 & 30 \\
\hline $\mathrm{Cr}$ & 11 & 5 & 220 \\
\hline Ni & 5 & -1 & 500 \\
\hline Li & 5 & -5 & 100 \\
\hline $\mathrm{Cu}$ & 40 & .9 & 4,400 \\
\hline $\mathrm{Pb}$ & 107 & 1.5 & 7,100 \\
\hline Al & 10 & 10 & 100 \\
\hline V & 4 & 5 & 80 \\
\hline Mo & 6 & 2 & 300 \\
\hline Sn & .8 & 10 & 8 \\
\hline $\mathrm{Fe}$ & 170 & 45 & 380 \\
\hline $\mathrm{Zr}$ & .07 & $\sim 5$ & $=$ \\
\hline & & & tal 13,600 \\
\hline
\end{tabular}


The blanket structure of a fusion plant will become radioactive during operation. This structure has a lifetime of the order of 10-20 years and when it is replaced, the used activated unit will have to be shipped from the power plant to a site wherein it would be stored. The structure itself will be nonvolatile and consequently its hazard potential should be relatively low. It will not require a large amount of shielding during shipment nor would it present a difficult cooling problem.

\subsubsection{Irreversible and Irretrievable Commitment of Resources}

A prel iminary survey has been made of U.S. and world resources of the various materials needed for fusion reactor construction. ${ }^{3}$ The results are shown in Table A.1.6-4 where, in order to emphasize maximum resource requirement the largest quantity of a given material required by any of the several reactor designs is presented. For instance, a pulsed theta-pinch reactor would use more copper and less superconducting material than would a tokamak reactor. The larger needs for both materials are included in the Table. Clearly no one reactor design would use all of the materials 1 isted and this approach thereby overestimates the quantities of material needed.

In the extreme of a fully developed world fusion power economy, ten terawatts $\left(10^{7} \mathrm{MWe}\right)$ of electric power might be generated by fuston reactors. Therefore the third column of the Table shows the mass of 
Table A.1.6-4

CTR RESOURCE UTILIZATIOH

\begin{tabular}{|c|c|c|c|c|c|c|c|c|c|c|}
\hline \multirow[t]{2}{*}{ Material } & \multirow[t]{2}{*}{$\begin{array}{l}\text { Approx. Mass In } \\
\text { Metric Tons Per } \\
1000 \text { Mwe Reactor }\end{array}$} & \multirow[t]{2}{*}{$\begin{array}{c}\text { For } \\
\text { Reactor }\end{array}$} & \multirow[t]{2}{*}{$\begin{array}{l}\text { Mass In } \\
\text { Metric Mega- } \\
\text { tons For } \\
10^{7} \text { Me }\end{array}$} & \multicolumn{2}{|c|}{$\begin{array}{l}\text { Total Esti- } \\
\text { mated Produc- } \\
\text { tion in Year } \\
2000 \text { In } \\
\text { Metric } \\
\text { Megatons }\end{array}$} & \multicolumn{2}{|c|}{$\begin{array}{l}\text { Known Re sources } \\
\text { Present Prices } \\
\text { Metric Megatons }\end{array}$} & \multicolumn{2}{|c|}{$\begin{array}{l}\text { Re sources At } \\
\text { Increased } \\
\text { Prices } \\
\text { In Metric } \\
\text { Megatons }\end{array}$} & \multirow[b]{2}{*}{ Commente } \\
\hline & & & & U.S. & WORLD & u.s. & WORLD & U.S. & HORLD & \\
\hline Nb & $\begin{array}{l}\sim 400 \text { atructural } \\
\sim 130+180 \text { in } \\
\quad \text { NoTl and } \mathrm{Nb}_{3} \mathrm{Sn}\end{array}$ & $4,1,2$ & 7 & .009 & .020 & .07 & 6 & .14 & Ma & $\begin{array}{l}\text { Present mining operations are relatively nonpolluting; greatiy } \\
\text { increased demand wight necessitate strip mining to obtain low } \\
\text { grade deposits }\end{array}$ \\
\hline Li & $\sim 900$ & 1 & 9 & .01 & .016 & 5 & $6-8$ & 9 & 250,000 & $\begin{array}{l}100 \text { metric megatons probable land resources; extraction from } \\
\text { sea water possible, } 1.5 \mathrm{lbs} \text {. of } \mathrm{L} 1 / 100,000 \mathrm{ga} 1 \text {. of sea water }\end{array}$ \\
\hline $\mathrm{Be}$ & $\sim 60$ & 2 & .6 & .002 & .003 & .026 & .38 & .072 & 1 & $\begin{array}{l}\text { Little information on world Be resources avallable, Be presents } \\
\text { health hazards in wining and handling }\end{array}$ \\
\hline cr & $\sim 1100$ in ss & 5 & 11 & 1 & 4.3 & 0 & 700 & 1.6 & M & Resources almost entirely outside of U.S. \\
\hline N1 & $\sim 500$ in ss & 5 & 5 & .5 & 1.3 & .2 & 68 & 5.0 & MA & $\begin{array}{l}\text { World estimates are based on fragmentary Information and are } \\
\text { possibly low }\end{array}$ \\
\hline TI & $\begin{array}{l}-400 \text { structural, } \\
\sim 80 \mathrm{in} \mathrm{NbTi}\end{array}$ & 1,1 & 5 & 2.3 & 6.9 & .15 & 6.4 & .4 & 30 & $\begin{array}{l}\text { Significant quantities of mud ind slimes result from dredging } \\
\text { Ti minerals from sand deposits }\end{array}$ \\
\hline He & $\sim 350$ & 3 & 4 & .012 & .015 & $1.2 \star$ & $1.2 *$ & 5* & $29,000^{+}$ & $\begin{array}{l}\text { *In the ground } \\
+ \text { Extracted from atmosphere at up to } 30 \text { times current prices }\end{array}$ \\
\hline $\mathrm{cu}$ & $\begin{array}{l}\sim 2900 \text { coll } \\
\sim 1100 \text { in } \mathrm{NbT} 1\end{array}$ & 3,1 & 40 & 6.12 & 35 & 77 & 280 & 180 & 1,100 & $\begin{array}{l}\text { Considerable secondary recovery possible; ignificant land-use } \\
\text { conflict will result from an expanded copper industry }\end{array}$ \\
\hline Graphite & $\sim 2200$ & 1 & 22 & .1 & 1.4 & .5 & $>100$ & Mn & M & Very rough estimates of world reserves avallable \\
\hline $\mathbf{P b}$ & $\sim 10,700$ & 1 & 107 & 3 & 7.3 & 32 & 86 & 45 & 95 & Considerable secondary recovery posaible \\
\hline A1 & $\begin{array}{l}\sim 570 \text { structural, } \\
\sim 390 \text { in } \mathrm{Mb}_{3} \mathrm{Sn}\end{array}$ & 3,2 & 10 & 33 & 75 & 12 & 2200 & 275 & M & $\begin{array}{l}\text { Large land areas and great awounts of energy needed to mine } \\
\text { and process A1 }\end{array}$ \\
\hline $\mathbf{v}$ & $\sim 400$ & 4 & 4 & .03 & .06 & .1 & 9 & 3 & M & \\
\hline Ho & $\begin{array}{l}\sim 400 \text { atructural, } \\
\sim 200 \text { in SS }\end{array}$ & 4,5 & 6 & .08 & .24 & 2.9 & 5 & MA & $>10$ & $\begin{array}{l}\text { Substantial resources of sub-anrginal-grade ore throughout } \\
\text { the U.S. And world }\end{array}$ \\
\hline $\mathbf{k}$ & $\sim 20$ & 1 & .2 & 11 & 56 & 120 & $>10,000$ & 770 & $\begin{array}{l}\text { virtually } \\
\text { unlimited }\end{array}$ & \\
\hline ìn & $\sim 80 \mathrm{in} \mathrm{Nb}_{3} \mathrm{Sn}$ & 2 & .8 & .12 & .41 & .006 & 4 & .042 & 7 & Some secondary recovery possible \\
\hline g & $\sim 500$ in fl1be & 2 & 5 & 2.2 & 7.5 & 4.9 & 35 & m & MA & $\begin{array}{l}\text { Increased price would stimulate expanded exploration for } \\
\text { fluorspar }\end{array}$ \\
\hline $\mathrm{Pe}$ & $\sim 12,600$ stee 1 & 1,5 & 170 & 180 & 800 & 2000 & 90,000 & 20,000 & $>300,000$ & Potential reserves are vast \\
\hline
\end{tabular}

$t_{\text {Reactor code }}$

1) ORNL Tokawak, 2) PPPL Toksank, 3) LASL Theta-Pinch, 4)LLL DT M1rror, 5) LLL D3 ${ }^{3}$ le Mirror 
materials in metric megatons needed to construct and operate ten thousand 1,000 MWe fusion reactors. Plant replacement at about 5\% per year would be required at a later time but is not considered here.

Also presented in the Table are estimates of the total production of the various materials projected to be required in the year 2000, along with quantities of known reserves at present prices and estimates of resources available at increased prices.

A great many evaluations of U.S. and world raw materials resources have been made but these are usually a matter of expert opinion. Consequently, values such as "known resources at current costs" vary widely from one source to another. Often the estimated quantities of a raw material available at increased costs are based on industrial projections. However, when adequate reserves of a given ore are available to supply the demand for 20-30 years, exploration for additional reserves is usually curtailed with the result that total projected reserves can be underestimated to a significant degree. Most of the values quoted are from the 1970 edition of "Mineral Facts and Problems." In addition to estimating materials needs, some comments concerning environmental problems associated with a particular raw material are included in Table A.1.6-4. 3 
It is apparent that the production of $10^{7}$ MWe of fusion power would give rise to some resource use conflicts which will have to be resolved. For example, the requirements for niobium could just be met by known reserves. However, additional reserves may be found or other superconducting materials developed. In addition to niobium, other possible resource conflicts exist in the projected usage of nickel, chromium beryllium, titanium, helium, lead, vanadium, and molybdenum, and some of these problems will also be common to other power generating concepts.

\subsubsection{Costs and Benefits}

\subsubsection{Costs}

For the period Fiscal Year 1951 through Fiscal Year 1973, USAEC funding of magnetic confinement fusion research totals $\$ 490.7$ million. Non-Government funds have been expended on fusion research for many years, but reliable estimates of cumulative funding are unavailable. Current industrial support is estimated to be in the range of $\$ 2-3$ million per year.

Government funding of laser fusion research totals about $\$ 76$ million for the period Fiscal Year 1963 through 1973. Non-Government research on laser fusion is funded by industry at a current rate of expenditure of about $\$ 4$ million per year.

Although estimates of the total funding requirements are based on incomplete data, it is reasonable to assume that funding of the 
order of $\$ 8-10$ billion will be required to carry the fusion research program through the demonstration power plant operation. This would encompass both fabrication of experiments and all associated research and development.

Very preliminary studies ${ }^{3}$ show that demonstration power reactor costs might be about $\$ 500 /$ kwe for the nuclear "island." Ul timate magnet costs (20\%-25\% of current costs) would reduce mirror and tokamak reactor costs substantialiy. The superconducting coil in the theta-pinch reactor serves as an energy storage element separated from the plasma vessel, and it operates at low fields. It represents a small fraction of the system total cost and is little affected by the ultimate magnet cost patterns. Maturing of the fusion reactor industry should bring reductions associated with production quantity manufacturing and the removal of design uncertainties, further reducing costs. Projected fusion commercial reactor capital costs then correspond roughly to the level projected for other types of plant in the year 2000. Because of the uncertainties, it is believed that present cost estimates serve only to suggest that fusion power capital costs could be competitive with other energy sources. To conclude any capital cost advantage or disadvantage at this stage of development would clearly be premature.

Fusion fuel cycle costs are determined by the costs of deuterium and lithium (from which tritium will be bred). Based upon current 
prices, it has been calculated that dueterium plus lithium will represent about $7 \times 10^{-3}$ mills per kilowatt-hour ${ }^{3}$. Fuel transportation costs will be negligible because of the small quantities of materials involved and because handling techniques for gases and liquid metals are already well developed and inexpensive.

\subsubsection{Benefits}

The benefits associated with employment of fusion power systems are as follows:

(1) An effectively infinite supply of fuel;

(2) No possibility of nuclear runaway;

(3) A complete absence of chemical combustion products;

(4) Relatively low radioactivity and attendant hazards;

(5) Minor shutdown reactor cooling problem; and

(6) No use of weapons grade nuclear materials, thus no possibility of diversion for clandestine purposes.

Because of these very attractive features, fusion reactors may be acceptable for urban siting, particularly for systems designed to operate with small radioactive inventories (deuterium-tritium burners that do not breed tritium in-situ, or deuterium-deuterium burners). 
It is worth noting that an attractive feature of laser-fusion reactors is the modular aspect of a power plant. A single module is conceived as a $100 \mathrm{Mw}$ power source. Therefore, a power plant can be envisioned as operating in the $100 \mathrm{Mw}$ to few thousand Mw range. Consequently, small power plants could be built to supply each urban area, if environmental considerations permit, with significant savings in power transmission costs, which might offset or more than offset the loss of the usual economic gains obtained from scaling power plants to larger sizes.

\subsubsection{Overall Assessment of Role in the Energy Supply}

It is anticipated that a successful, vigorously supported fusion program will lead to construction of a Demonstration Power Reactor which will begin operation in the mid-1990's. Considering time requirements for accruing operating experience, and reflecting such experience in the design of improved commercial power plants, fusion power plants could be expected to contribute significant quantities of electric power to the Nation early in the 21st century. 


\subsubsection{References}

(1) Amasa S. Bishop, "Project Sherwood - The U.S. Program in Controlled Fusion," Addison-Wesley Publishing Co., Inc., Reading, Mass. (1958).

(2) John P. Holdren, "Adequacy of Lithium Supplies as a Fusion Energy Source," Appendix 37 to "Control led Thermonuclear Research," Hearings before the Joint Comittee on Atomic Energy, Congress of the United States, November $10 \& 11,1971$.

(3) "Fusion Power: An Assessment of Ultimate Potential," WASH-1239, USAEC, Washington, D.C., February 1973.

(4) Princeton University, "A Short Course in Fusion Power," October 30 - November 3, 1972.

(5) "Fusion Power: Research and Development Requirements," WASH-1267, USAEC, Washington, D.C., July 1973.

(6) Keith Boyer, "Review of Laser-Induced Fusion," Presentation at the 1972 Annual Meeting of the Plasma Physics Division of the American Physical Society, Monterey, California, November 13-16, 1972.

(7) F. C. Gilbert, "Laser-Induced Fusion," presentation at AEC Scientific and Technical Symposium, AEC Headquarters, Germantown, Maryl and, January 12, 1973.

(8) D. Steiner and A. P. Fraas, "Prel iminary Observations on the Radiological Implications of Fusion Power, " Nuclear Safety, Vo1. 13, No. 5, September-October 1972, p. 353.

(9) W. C. Gough, "CTR Engineering Systems Study Review Meeting", WASH-1278, USAEC, Washington, D.C., September 1973. 


\section{A.2 FOSSIL FUELS FOR CENTRAL-STATION ELECTRIC POWER GENERATION GENERAL INTRODUCTION}

011, gas, and coal provide about $93 \%$ of our current total energy needs, distributed ${ }^{1}$ as follows:

Domestic production Imported Total

$0 i l$ (million barrels/day)

Gas (billion $\mathrm{ft}^{3} /$ day)

Coal (thousand tons/day)
9.5

57

1425
6.5

3

0
16

60

1425
Percent contribution to total energy

\section{2}

33

18

Together, oil and gas supply a fourth of the energy required by the electric utilities, over half the industrial energy requirements, and nearly all of the transportation and nonelectric commercial and residential requirements. Of the coal used domestically, electric utilities consume two-thirds and industry utilizes most of the rest. The remaining $7 \%$ of our total energy supply comes from hydroelectric and nuclear electric power plants and from wood and is devoted exclusively to electricity production. Our oil shale resources have not been developed as yet and consequently are not being used for energy production.

This section explores the usage of these fossil fuels, their environmental impacts, and their use in the production of electricity projected to the Year 2000 and beyond. 


\subsection{COAL}

\subsubsection{Introduction}

\subsubsection{General description}

Coal, which represents well over $80 \%$ of the nation's fossil-fuel reserve in terms of energy value, is burned in large quantities to produce electricity. The essential elements of a coal-fired electric energy system are depicted in Fig. A.2-1. The first step in the coalenergy system is extraction, and involves either surface mining, which removes the overburden to expose the coal seam, or underground (deep) mining, which extracts the coal from beneath the overburden. After extraction, most of the coal mined in recent years for power plant use has been processed ${ }^{2}$ by either wet or dry (pneumatic) cleaning to partially remove impurities before the coal is transported by railroad, truck, barge, conveyor belt, or slurry pipeline to a power plant. At the power plant, the heat released by combustion of the coal in a boiler produces high-pressure steam to drive a turbine, which is linked to a generator that converts the rotary mechanical energy into electricity. The electricity is transmitted and distributed, usually by overhead power lines, to load centers such as homes, offices, and manufacturing facilities, where it is used for lighting, heating, air conditioning, powering machinery, and other purposes.

\subsubsection{Historical aspects}

From 1900 through 1972, U.S. coal consumption has totaled about $35 \times 10^{9}$ tons. $^{3}$ Since 1905, total annual domestic use has dropped 


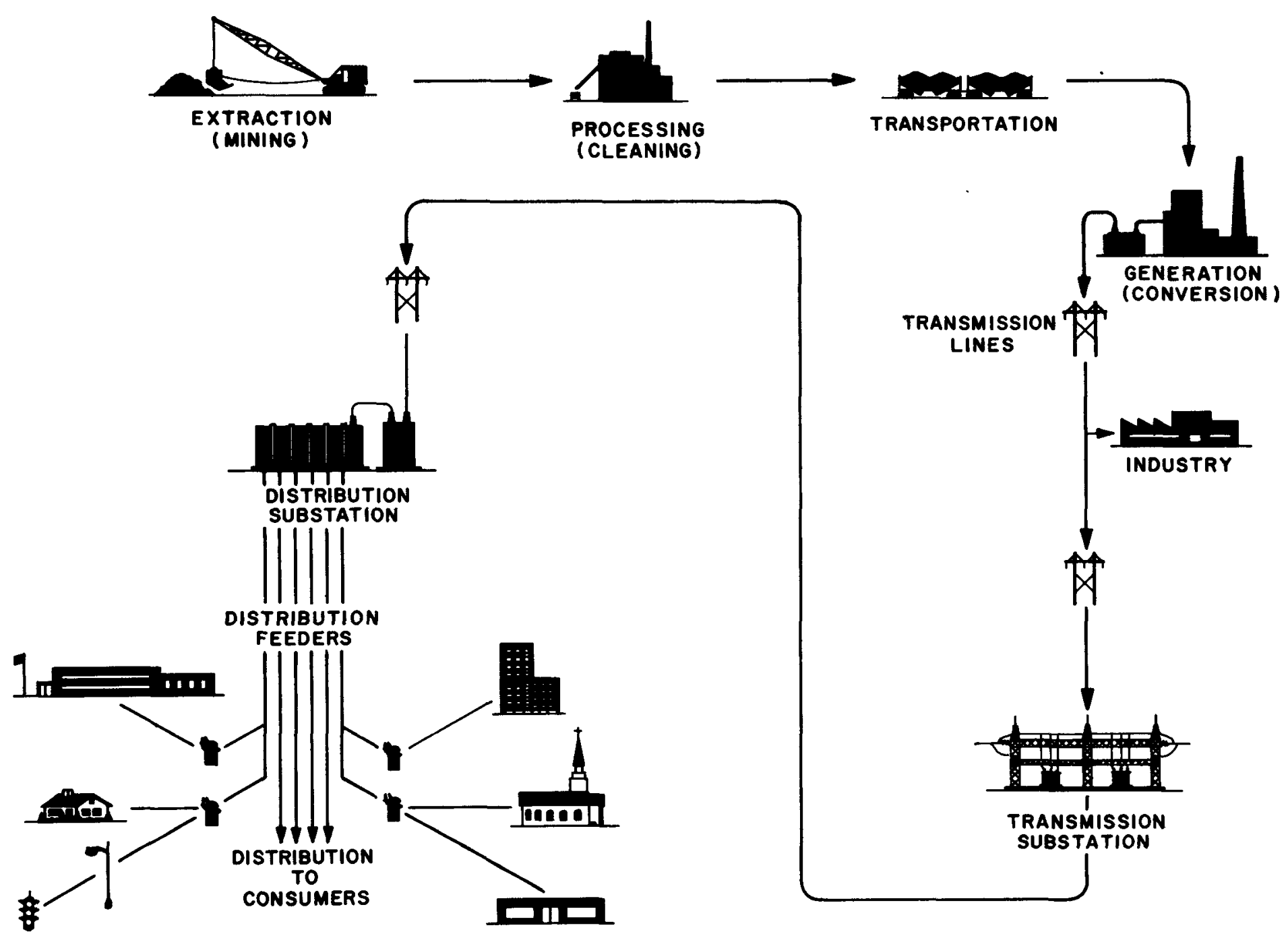

SCHEMATIC OF COAL-FIRED ELECTRIC ENERGY SYSTEM

Figure A.2-1 
below 10 quads*, or about $385,000,000$ tons, only during the depression years 1932 and 1933. The peak annual U.S. consumption occurred during the World War years 1918 and 1943, at 17 quads (about $654,000,000$ tons). The 1970 total consumption of 13.6 quads (about $523,000,000$ tons) was equaled during seven years in the period 1912-1948.**

\subsubsection{Status}

Although the fraction of the nation's total energy demand met by coal has declined from $78 \%$ in 1920 to about $18 \%$ at present, ${ }^{1,5}$ the energy output of coal-fired electrical power plants decreased only from 50-53\% of the total electrical energy production for the period $1955-1966^{6}$ to $44 \%$ in $1972 .^{7}$ Conversely, of all the coal consumed domestically, the portion used by electrical utilities has increased from $57 \%$ in $1970^{4}$ to about $65 \%$ currently. ${ }^{1,8}$ It should be noted that the current energy crisis is fostering a conversion of oil-fired electric power plants to coal. Some of these plants had only recently been converted to oil in order to meet environmental standards. These conversions could eventually significantly increase the percentage of the total electrical energy produced by coal as they are implemented.

The portion of U.S. coal surface-mined by all methods has increased from $3 \%$ in 1929 to $35 \%$ in $1969^{9}$ to about $50 \%$ in $1971^{3}$ and appears still to be growing. Essentially all additions of lignite and bituminous

\footnotetext{
ऋ quad is $10^{15}$ Btu or $0.001 \mathrm{Q}$, which is $10^{18}$ Btu. ** In the preceding examples of consumption variation, 3,4 the thermal energy and tonnage values were interconverted by means of the relation 426 quads $=10^{9}$ tons of coal, which corresponds to a total heating value of $13,000 \mathrm{Btu} / \mathrm{lb}$.
} 
coal mined since 1970 have been obtained by stripping. This major change in mining pattern over the past few years is attributable principally to the higher productivity and lower costs achievable by stripping coal as compared with extracting it from deep mines. This is a substantial cause of the number of United States coal miners dropping to about a fifth of its historic peak. ${ }^{3}$ There is some uncertainty as to the amount of available coal that can be extracted by strip mining techniques. Recent statenients reported in the news media indicate that only 3 to $12 \%$ of the currently recoverable coal is economically strippable, however, this has been disputed by others who use different economic criteria to arrive at a substantially larger figure.

Few new coal mines were opened during the 1960's because of competitive pressure from cheaper natural gas, increased oil importation, the possibility of a significant market penetration by nuclear energy, and environmental legislation that restricts $\mathrm{SO}_{\mathrm{x}}$ emissions and influences strip mining.

Currently, coal-fired steam plants represent a large fraction of the total national electric capacity (about $164,000 \mathrm{MW}$ in 1971). ${ }^{12}$ This type of plant has been operated for decades, its reliability is proven, its conversion efficiency is high, and the technology and maintenance are well-understood. The President's Energy Message to Congress of April 18, 1973, urged expanded use of the nation's coal resources, stating that "each decision against coal increases petroleum or gas 
consumption, compromising our national self-sufficiency and raising the cost of meeting our energy needs."

\subsubsection{Extent of Energy Resource}

\subsubsection{Geographical Distribution}

Coal deposits are widely distributed throughout the nation, and major reserves exist relatively near many large centers of industry and population. In contrast, ${ }^{13}$ about two-thirds of the known petroleum and natural-gas reserves lie in the West South Central Region, primarily in Texas, Oklahoma, and Louisiana, which contain only about $8 \%$ of the U.S. population. Other major potential fuelresource bases are also remote from most of the major population centers: for example, oil shales are concentrated in the Green River formation in Colorado, Utah, and Wyoming, and the Athabasca tar sands are in Alberta, Canada.

Figure $A, 2-2$ is a map ${ }^{6}$ that shows the major coal-producing areas. Known coal resources underlie about 459,000 sq miles in 37 states. $^{9}$ Figure A.2-3 depicts the 1965 estimate of the original and remaining U.S. coal reserves, ${ }^{6}$ by coal rank (type) and by State. The tonnages indicated include only coal in seams at least 14 in. thick and less than $3000 \mathrm{ft}$ deep in explored areas. About $75 \%$ of the additional low-rank peat reserve of about $14 \times 10^{9}$ tons occurs in Minnesota, Wisconsin, and Michigan. ${ }^{14}$ of the total bituminous reserve indicated in Fig. A.2-3, about two-thirds is located east of the Mississippi. of the high-rank coals (bituminous and anthracite) that contain 1.0\% 
ALASKA $=265.1$

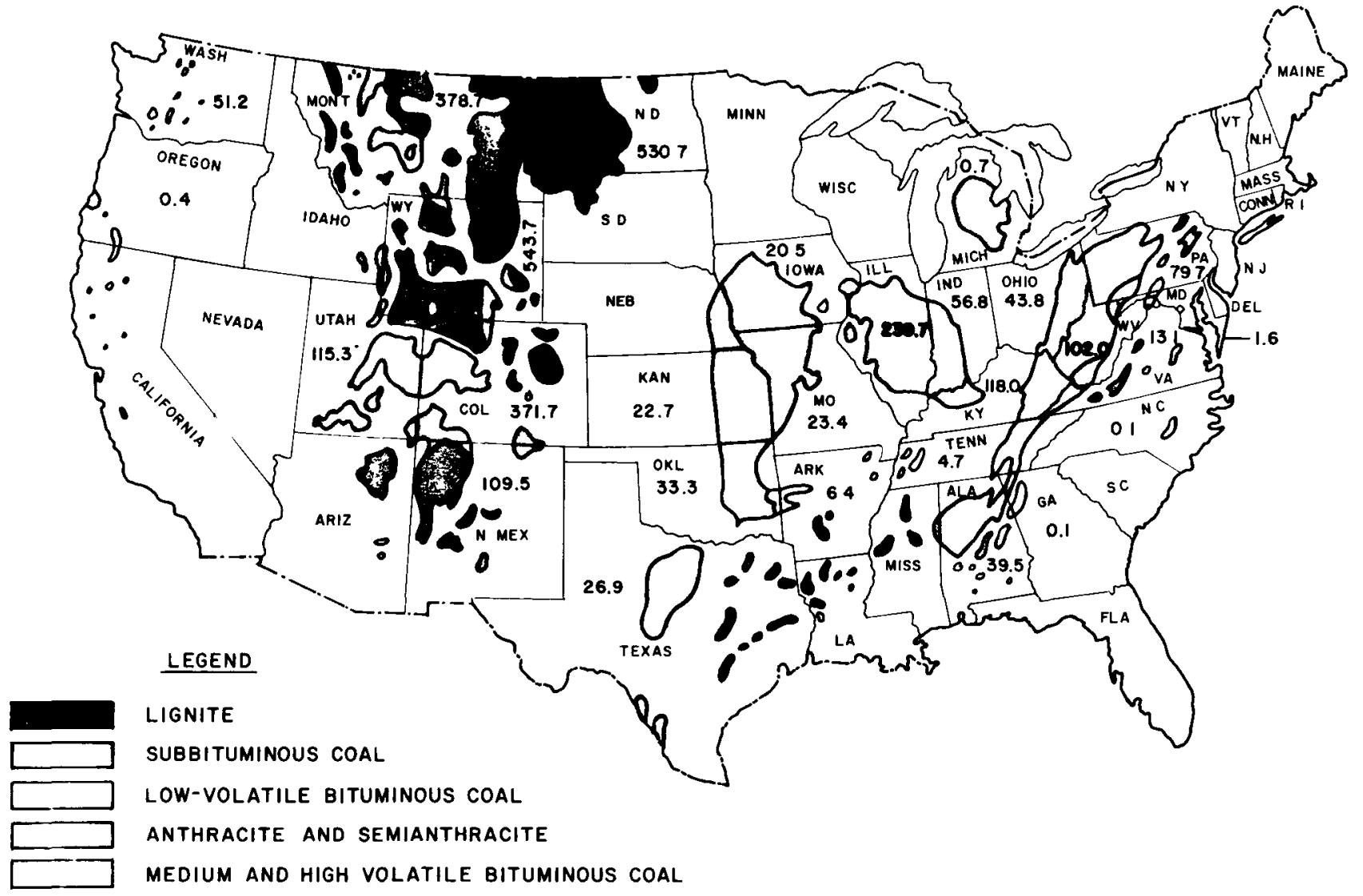

NUMBERS INDICATE ESTIMATED RESERVES FOR STATES, TONS $\times 10^{9}$ TOTAL U S. RESERVE $=3.2 \times 10^{12}$ TONS

COAL FIELDS OF THE UNITED STATES

Figure A.2-2 


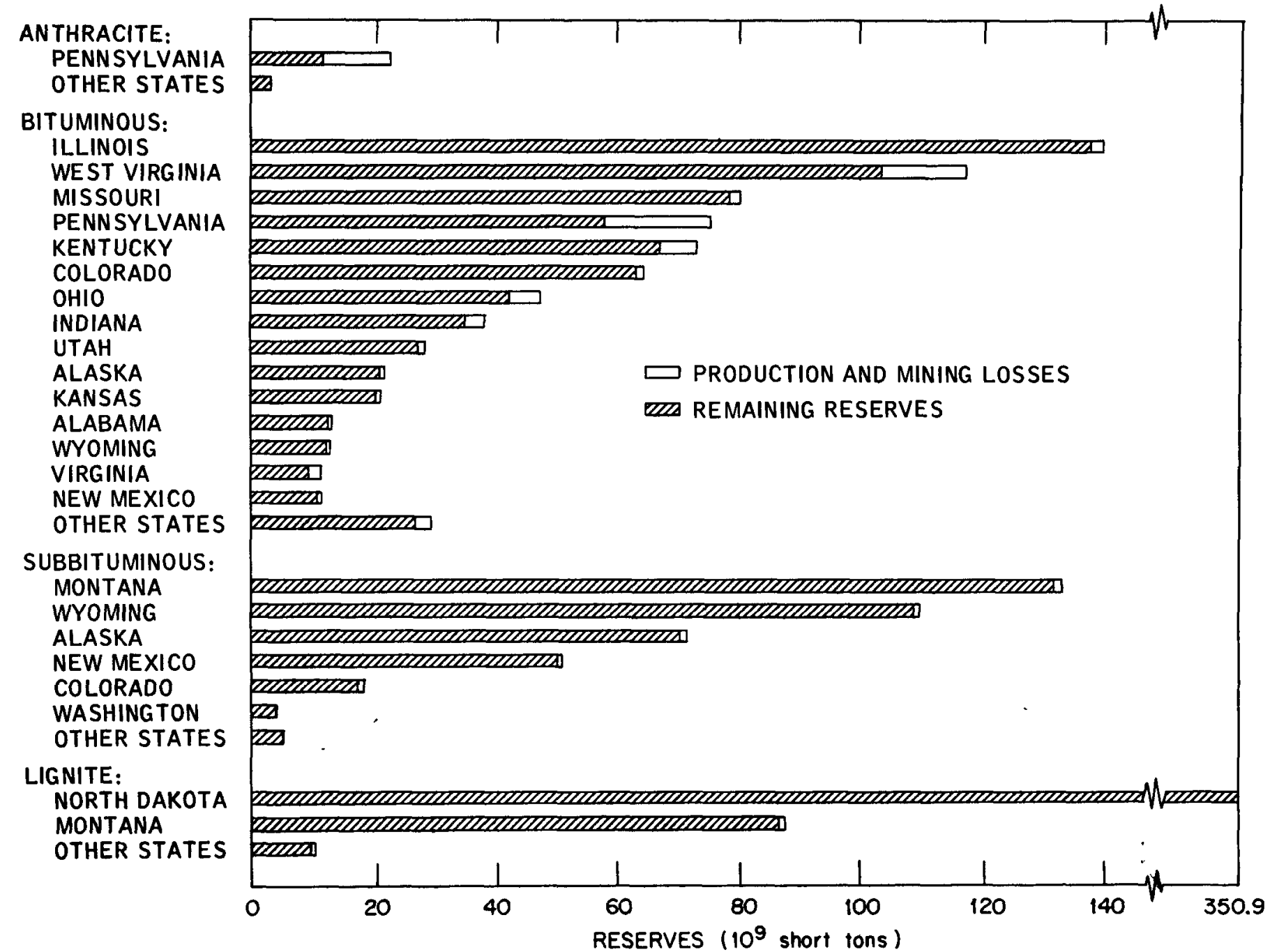

ESTIMATED ORIGINAL AND REMAINING COAL RESERVES, BY RANK, IN UNITED STATES, JANUARY 1, 1965

Figure A.2-3 
sulfur or less, the States east of the Mississippi River contain about $40 \%$ of the nation's supply. ${ }^{6}$ Illinois contains the largest reserves of bituminous coal of any state and, east of the Mississippi, the largest total reserves. ${ }^{13}$ About $98 \%$ of the nation's lignite reserves (usually low in sulfur) are located in North Dakota and Montana. Estimates of coal reserves in the State of Montana alone range from $222 \times 10^{9}$ tons (in seams 14 in. or more thick at depths less than $3000 \mathrm{ft}$ ) 6 to $700 \times 10^{9}$ tons (total reserve). ${ }^{15}$

Very large beds of low-sulfur lignite and subbituminous and bituminous coals suitable for power generation, liquefaction, and gasification occur in the Rocky Mountain States. ${ }^{9}$ The billions of tons of lowsulfur fossil solids in the Upper Missouri Basin in thick (to about $100 \mathrm{ft}$ ) seams that underlie modest earth overburdens in flat or rolling terrain and that promise yields to $10^{5}$ tons/acre offer the potential ${ }^{3}$ for transforming Montana, Wyoming, and the Dakotas into an immense new natural-energy center that may displace the premiumfossil-fuel States of Texas, Louisiana, and Oklahoma.

\subsubsection{Estimated Availability}

\subsection{Using Present Technology}

The Department of the Interior estimates ${ }^{9}$ that the U.S. total remaining coal resources are $3.20 \times 10^{12}$ tons (to a depth of 6000 $\mathrm{ft}$ ), with $1.60 \times 10^{12}$ tons at depths less than $1000 \mathrm{ft}$; the former estimate represents 17 to $20 \%$ of the global coal resource. 16,17 The Department of Health, Education, and Welfare has estimated ${ }^{6}$ a 
total resource of $1.58 \times 10^{12}$ tons for coal seams at least $14 \mathrm{in}$. thick at depths less than $3000 \mathrm{ft}$ in explored areas.

Because of various technical and economic constraints, a large part of the estimated total resource base probably will not be recovered. Total estimated reserves technically recoverable, without regard to economics, range from $790 \times 10^{9}$ tons $^{6}$ to $850 \times 10^{9}$ tons, $^{13}$ or about one-fourth of the estimated total resource. Estimates of amounts commercially recoverable from established formations with present mining technology under current economic conditions have varied from $150 \times 10^{9}$ tons $^{17,18}$ to $390 \times 10^{9}$ tons. ${ }^{9,19}$ These quantities represent available reserves adequate for periods of 268 and 696 years, respectively, at the 1972 total coal-consumption rate. Considering only the low-sulfur bituminous, subbituminous, and lignite in the Rocky Mountain States, the recoverable resources to a depth of $1000 \mathrm{ft}$ have been estimated to be $94 \times 10^{9}$ tons, of which $26 \times 10^{9}$ tons are so well identified and characterized that they are considered to be proven reserves. ${ }^{9,20}$ It seems reasonable to regard the recoverable reserve, using technology available through about 1975, as about $400 \times 10^{9}$ tons, or about one-eighth of the estimated total base.

For coal with a sulfur content of 1.0 wt $\%$ or less, a probably conservative estimate of the amount presently available can be made by taking one-eighth of the estimated remaining low-sulfur reserves in seams at least $14 \mathrm{in.} \mathrm{thick} \mathrm{at} \mathrm{depths} \mathrm{less} \mathrm{than} 3000 \mathrm{ft}$ in explored areas, as published in ref. 6 . This procedure gives an 
estimated available low-sulfur national reserve of about $128 \times 10^{9}$ tons (about 1/25 of the estimated total base), distributed by coal rank as shown in Table A.2-1. The Chase Manhattan Bank has published a corresponding estimate of $124 \times 10^{9}$ tons. 21

Table A.2-1

ESTIMATED AVAILABLE RESERVES

OF LOW-SULFUR COAL IN THE UNITED STATES

\begin{tabular}{lcc}
\hline \multicolumn{1}{c}{ Rank } & Amount $^{\mathrm{a}}$ (millions of tons) & Percent of tota $^{\mathrm{b}}$ \\
\hline Bituminous & 26,878 & 29.5 \\
Subbituminous & 48,400 & 99.6 \\
Lignite & 50,752 & 90.7 \\
Anthracite & 1,844 & 97.1 \\
All & 127,874 & 64.8 \\
\hline
\end{tabular}

aith $1.0 \%$ maximum sulfur and based on avallability of $12.5 \%$ of estimated reserve. Derived from Table 4-1 of "Control Techniques for Sulfur Oxide Air Pollutants," NAPCA Publication No. AP-52, U.S. Department of Health, Education, and Welfare, January 1969. bercent by rank with sulfur content of $1 \%$ or less.

The preceding observations on estimates of resource availability based on various premises are summarized in Fig. A.2-4, where the shaded bar areas indicate lower and upper bounds of the cited projections. 
BILLIONS OF TONS

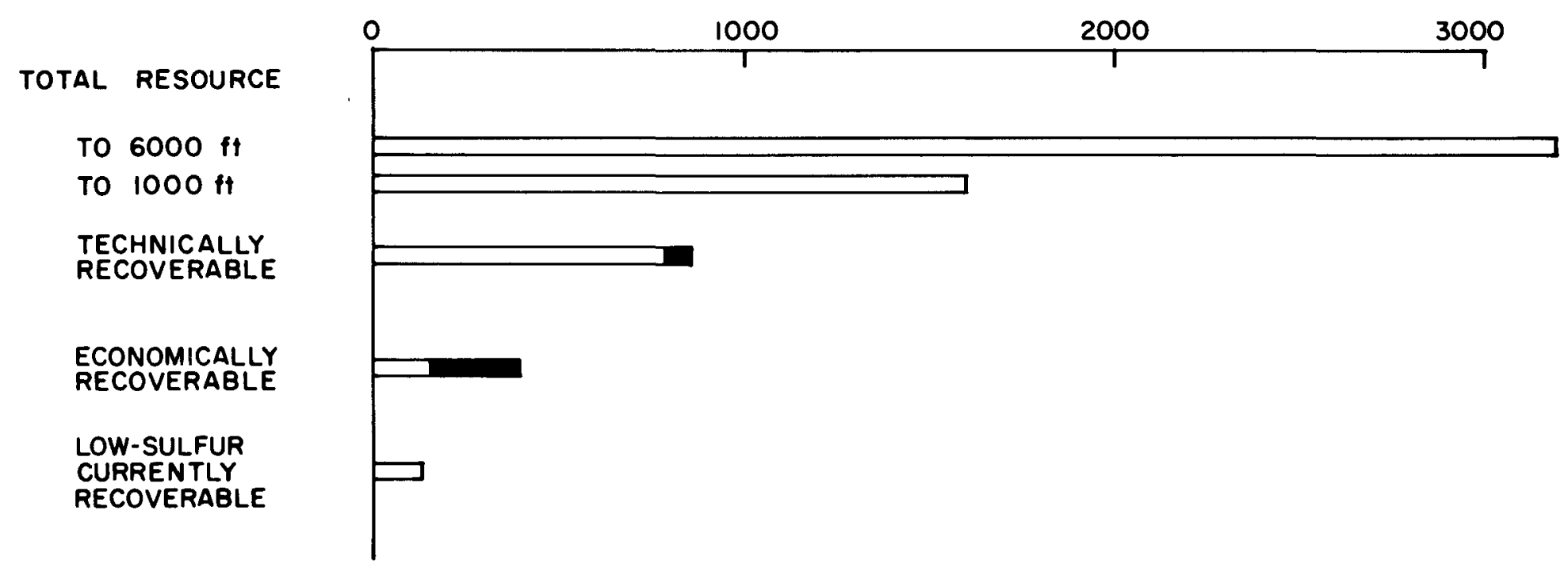

ESTIMATES OF UNITED STATES COAL SUPPLY

Figure A.2-4 


\subsection{Using Advanced Technology}

Very large tonnages of coal are available by use of current mining technology (probably enough for four centuries at an average use rate of $10^{9}$ tons/year). Expressed differently, only about $0.15 \%$ of this base would be required for the projected 1985 coal-fired electrical generation (ref. 8 , Table 18). Based on the current state of the art, a $400 \times 10^{9}$ ton recoverable resource, used entirely in electrical power plants, would be sufficient to generate almost 900 billion MWhr of electricity. For this reason, technological development over the next several decades is likely to be oriented more to increasing production rates than to availability. Since coal use has been deemphasized in recent years in favor of other fuel sources, the potential for technology advancement is probably large. Institutional actions that should increase the efficiency of coal-energy systems include: increasing vocational training for miners, increasing the number of mining-school graduate engineers, and implementing a more active technology transfer program to convert research and development results from other areas to common practice in an industry that has been characterized as technologically conservative.

Controlled underground (in-situ) combustion and transfer of the heat to water tubes or extraction of the low-Btu gas generated could make available the energy in some coal deposits not economically minable or in previously mined areas where about half the original coal 
remains. Conceivably, such combined actions could lead to an available coal resource of $400 \times 10^{9}$ to $500 \times 10^{9}$ tons by the year 2000, after allowance is made for probable extraction depletion beyond 1973. This estimated availability is based not only on the factors cited but also on the assumption that conversion systems will be successfully developed which will allow ultimate use of coal that contains more than $1 \%$ sulfur. Annual production rates, which are likely to attain very high levels toward the end of this time

period, 3,13 could be made more feasible by improved systems analyses of mining cycles to minimize element mismatch, thereby maximizing average material flow rates, and by intensified study and implementation of other mining methods, including hydraulic (high-pressure water jet) extraction. 22

\subsubsection{Technical Description}

\subsubsection{Power Generation Plant}

Processed coal for boiler firing is taken from pulverizers, which usually produce particles of about $75-\mu$ diameter (about 200 mesh), by a stream of air supplied to the pulverizer at a temperature of 300 to $700^{\circ} \mathrm{F}$, depending on the moisture content of the coal. The flow of fine coal and primary air is mixed and directed by fuel burners to ensure rapid ignition and to maximize combustion. In the commonly employed radiant-type boilers, virtually all the steam is generated in the tubes that form the furnace-enclosure walls, by the heat radiated from the flame and from the hot combustion gases. To improve thermal efficiency, the high-pressure steam is superheated 
in tubular elements exposed to the combustion products and also is often reheated, in one or more stages, at lower pressures following expansion through the high-pressure turbine. After it is dried and purified, the steam is expanded through a 3600-rpm steam turbine, which is the driving element of a condensing turbine-generator set.

Turbine-inlet steam pressure and temperature in large plants are commonly in the ranges 1800 to $2400 \mathrm{psig}$ and 1000 to $1100^{\circ} \mathrm{F}$, respectively. A few units have been constructed in which the steam is at pressures to $5000 \mathrm{psig}$ and temperatures to $1200^{\circ} \mathrm{F}$, but many of the recent units operate at the 3500-psig level with initial temperature at about $1050^{\circ} \mathrm{F}$, conditions that yield thermal efficiencies of 40 to $42 \%$. The exhaust steam flows to a large water-cooled surface condenser, which produces a low back pressure (usually 1.0 to $3.5 \mathrm{in.} \mathrm{Hg}$ abs) at the turbine exhaust in order to improve the heat rate, to deaerate the condensate, and to conserve the condensate for reuse as boiler feed. The water from the condenser is then reheated and pumped again through the boiler. Comprehensive descriptions of steam-cycle variations, boiler-water circulation modes, and components such as steam separators, economizers, air preheaters, condensers and air ejectors, feedwater heaters and pumps, and cooling towers are readily accessible. ${ }^{23,24}$ 


\subsection{Current variations}

To meet relatively brief peak power demands and emergency services requirements, pumped-storage installations as well as gas-turbinedriven generators and diesel engine-generator units are employed. The pumped-storage concept involves pumping water into a higherelevation reservoir during periods of low power demand for later release through the reversible pump turbines when the power demand exceeds the base load. The 1973 installed capacity of pumped storage installations is 4500 MWe. Gas turbine and diesel peaking units operate at heat rates of 12,000 to $15,000 \mathrm{Btu} / \mathrm{kWhr}^{25}$ and at the end of 1972, these units represented installed capacities of $4800 \mathrm{MW}$ (internal-combustion plants) and 28,000 MW (gas-turbine plants). 7

Cyclone furnaces are sometimes used to retain most of the ash from low-ash-fusion-temperature coals in the slag, thereby minimizing ash flow past the heat-absorbing surfaces and reducing stack flyash emissions. In this variation the coal, crushed to a size of about 4 mesh, is admitted tangentially with the primary air. The coarser fuel particles are transported centrifugally to the outer furnace wall, from which, after final combustion, the molten ash drains through an opening in the boiler furnace floor into a slagcollection tank. Tangential admission of both primary and secondary air at high velocity (to about $300 \mathrm{ft} / \mathrm{sec}$ ) produces high turbulence levels and volumetric heat-release rates (to about $5 \times 10^{5} \mathrm{Btu} / \mathrm{hr} / \mathrm{ft}^{3}$ ). 


\subsection{Future Variations}

The technical feasibility of fluidized-bed combustion has been demonstrated. 26,27 The basic concept of a fluidized-bed boiler involves passing air upward through a grid plate supporting a bed, several feet thick, of granular, noncombustible material such as coal ash or lime. This air fluidizes the granular particles and, with the relatively small amount of air used to inject the coal, serves as the combustion air. Crushed or finely ground coal is fed near the base of the fluidized bed, above the grid plate. The fuel burns rapidly in the suspended bed, and the bed temperature is controlled by water-tube walls or internal heat-transfer surfaces. Flue gases leaving the bed pass over a convection heat-transfer surface above the bed, and the elutriated ash is mechanically or electrostatically collected. Operated at atmospheric pressure, fluidized units would replace conventional boilers. Pressurized systems - coal-fired gas turbines fed by external fluidized combustors operated at pressures up to perhaps $25 \mathrm{~atm}$ - could achieve thermal efficiencies of about $45 \%$. Such systems also could use lowgrade coals and offer the potential of effective removal of the oxides of sulfur $\left(\mathrm{SO}_{x}\right)$ during combustion by burning the coal in the presence of a sulfur-acceptor such as limestone or dolomite. In addition, the relatively low operating temperature of about $1600^{\circ} \mathrm{F}$ would reduce fixation of atmospheric nitrogen and significantly diminish $\mathrm{NO}_{x}$ emissions. 
Assessment of various alternative thermodynamic cycles, including potassium-vapor topping and ammonia (or fluorocarbon) bottoming cycles, is continuing ${ }^{4,28}$, but such systems are only one route to increased thermal efficiencies. Magnetohydrodynamic (MHD) power generation 4,28 is another process, several variations of which continue to receive attention. of greater near-term interest is the combined gas-turbine-steam cycle, ${ }^{4,29}$ which entails combusting fossil fuel to drive a gas turbine and recovering the heat in the hot (about 1000 to $1200^{\circ} \mathrm{F}$ ) exhaust gas with a waste-heat boiler to generate steam to drive a bottoming steam turbine. All of these systems are discussed in detail in Section B of this Chapter.

The results of studies to develop low-temperature superconducting electric generators have been promising, ${ }^{4}$ and as generator unit capacity continues to increase (1500-MVA units are currently available), the decreased rotor sizes and other advantages of such alternators would be significant. This development, once reduced to practice, could be used in any generation plant that uses turbine-generators.

\subsubsection{Fuel Cycle}

\subsection{Mining and Preparation}

In underground mining, deep coal beds (which are grid- and contourmapped in advanced operations) are made accessible by slope, drift, or vertical shafts, depending on the orientation of the seam relative to the terrain. The stages of cutting (sometimes by continuous 
machines), loading, and conveying (by narrow-gage rail car or by conveyor belt) in deep coal mining have become highly mechanized. Provisions are made for tunnel ventilation, atmosphere monitoring, dust control, water drainage, and safety equipment adequate to satisfy the regulations established by the 1969 Coal Mine Health and Safety Act.

Near-surface coal ( 0 to about $200 \mathrm{ft}$ deep) has been extracted. increasingly by surface mining because of the favorable economics. Area strip mining is conducted when the terrain is flat or gently rolling; contour stripping is done along hillsides. The overburden is removed with large power shovels and scrapers. The coal is then scooped up with smaller power shovels and loaded into large trucks. A small amount of coal is auger-mined $(3.3 \% \text { in } 1970)^{30,31}$ with 2- to 7-ft-diam horizontal augers to penetrate vertical outcroppings to depths of about $200 \mathrm{ft}$. Recovery efficiencies (fraction of coal in the worked bed which is recovered) range from about $40 \%$ for auger mining to about $57 \%$ for deep mining to $80 \%$ for strip mining, ${ }^{2}$ al though recoveries as high as $90 \%$ have been attained with area stripping.

During the coal-preparation or cleaning step, gross impurities such as rock, shale, slate, and clay are first removed, and often the refuse is deposited in large piles near the mine or coal-cleaning plant. The introduction of mechanized mining has given impetus to coal cleaning and preparation since such mining does not differentiate 
well between coal and impurities. Usually, further separation of impurities from steam coal is by a liquid-washing process based on differences in density (the coal being lighter than an equal volume of impurities). This cleaning often significantly reduces the sulfur content by removing particles of pyrite $\left(\mathrm{FeS}_{2}\right)$. One study, ${ }^{32}$ based on 1968 data from 113 mines, showed that when the raw coal was crushed to 3/8-in. diam and floated in a heavy medium (an organic liquid of 1.60 specific gravity), the coal from about $20 \%$ of the mines could be cleaned to $1 \%$ sulfur or less. A later and more extensive study, 33 using 322 coal samples obtained primarily from mines east of the Mississippi River producing coal for utilities, also showed that less than $30 \%$ of the samples could be cleaned to a total sulfur content of $1 \%$ or less. By removing $40 \%$ of the heavy impurities (60\% yield) by specific gravity (float-sink) separation of coal first crushed to $3 / 8-i n$. diam, only 20 to $25 \%$ of the coals tested could produce a product containing $1 \%$ or less total sulfur. The overall operation can be fairly complicated; ${ }^{34}$ a simplified schematic ${ }^{6}$ is shown as Fig. A.2-5.

\subsection{Iransportation and Storage}

of the coal loaded at the mine mouth, about $70 \%$ is carried by rail, ${ }^{31}$ although some is transferred later to other carriers. In the electrical utility sector, $52 \%$ arrives by rail, $34 \%$ by barge, and the remainder by other means (truck, conveyor belt, and slurry pipeline). 31 The average transport distance from mine to power plant is 300 miles, by either rail or waterway. ${ }^{2,31}$ Unit trains, which consist of 


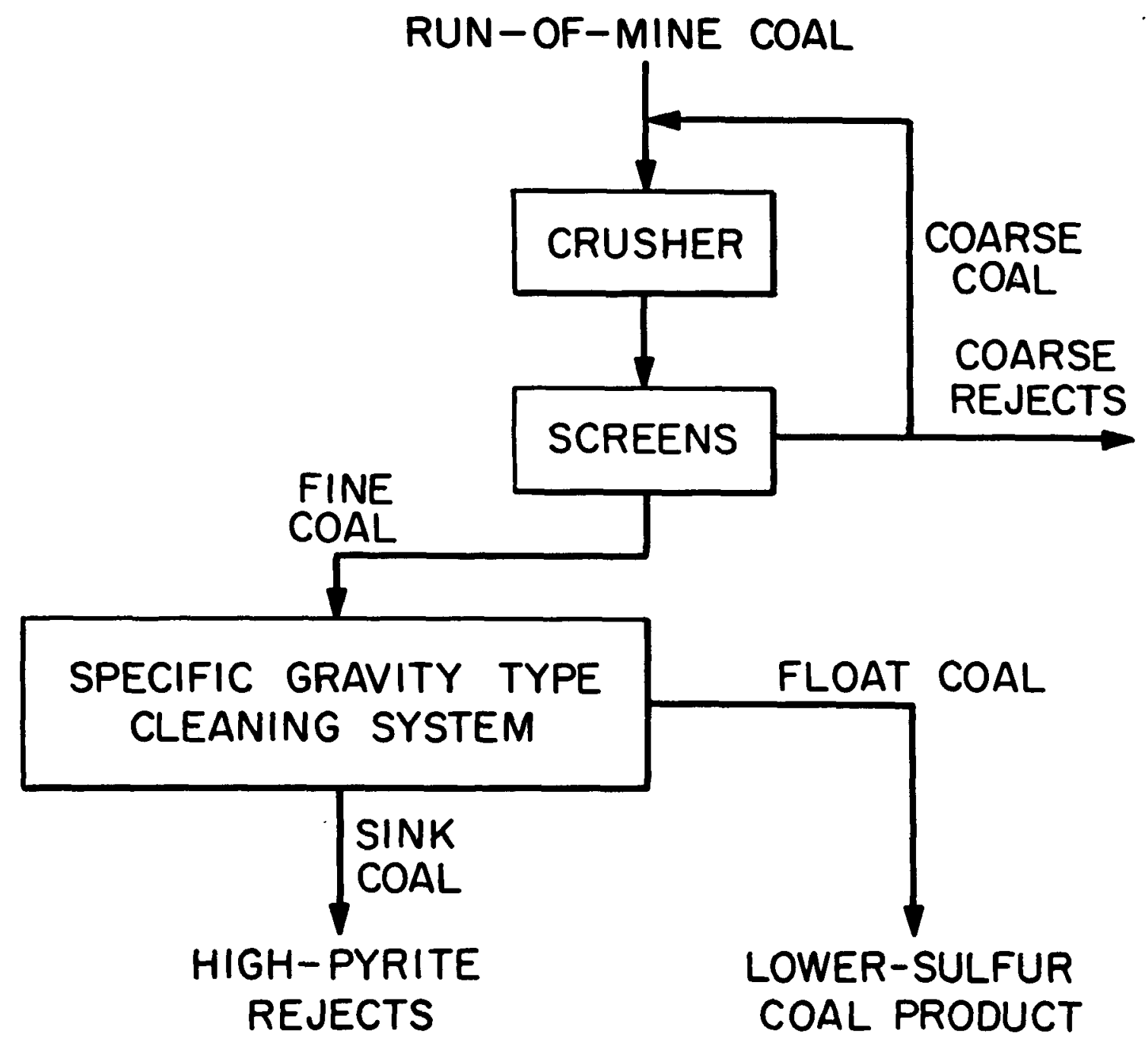

SIMPLIFIED FLOW CHART OF COAL PREPARATION

Figure A.2-5 
conventional equipment operating continuously between a coal mine and a power plant in the service of one customer, are often used since rail car utilization is greatly increased, and since transit time (as compared with a general train carrying mixed goods) is reduced.

The only operating conmercial coal-slurry pipeline in the U.S. delivers coal a distance of 273 miles from the Black Mesa mine in Arizona to the 1580-MWe Mohave power plant in Nevada. Operating since mid-1970, the pipeline delivers about 660 tons of coal (0.3 to $0.8 \%$ sulfur content) per hour through an 18-in.-diam pipe. The slurry, which is 50 wt \% coal ( 214 mesh particle size) flowing at about $6 \mathrm{fps}$, is fed to centrifuges at the power plant to be dewatered to about 15 wt $\%$ water. ${ }^{35}$ An earlier pipeline, ${ }^{4}$ operated in Ohio from 1958 to 1963, used a combination of vacuum filtration and thermal drying to dewater the received slurry. After separation of the coal from the water, the spent water could be returned by a second pipeline for reuse or used at the power plant for ash handling, cooling-tower makeup, or evaporation from disposal ponds. ${ }^{9}$

Tests that used slurry ( 30 wt \% water) directly to fire a cyclone boiler 4,36 showed a reduction in boiler efficiency of only $4 \%$. The suggestion that oil rather than water be used for slurrying to increase the energy throughput of coal slurry pipelines ${ }^{4}$ may soon be implemented in Canada. 37 It was recently reported ${ }^{38}$ that North Dakota lignite with a moisture content of $38.5 \mathrm{wt} \%$ has been burned 
successfully for 3 years in a 235-MW cyclone furnace. The crushed lignite was predried with hot air, and the coal and drying air fed to the boiler furnace.

A 90-day coal supply at the power plant is generally considered desirable. Spontaneous heating of this coal pile, which may lead to ignition, is caused by oxidation of the coal, and the likelihood is greatest with coals of lower ranks and finer sizes. Overheating (beyond about $120^{\circ} \mathrm{F}$ ) is usually prevented by compacting the pile in layers with a roller to minimize access of air.

\subsection{Waste Processing and Disposal}

In current practice, waste processing at the mine is minimal; rejected solids are deposited in large refuse banks. In contour stripping, spoil material is generally dumped down slope. However, in area stripping, the overburden can be partially replaced by working long parallel trenches and by using the material excavated from the second cut to fill the first. Neither reclamation of surface-mined areas to a condition that approximates the original nor controlled backfilling of deep mines has been practiced to a significant degree. Settling ponds are commoniy used in coal processing to reduce the discharge of black-water solids; these discharges would be about 250 times as large without such ponding. ${ }^{2}$ Coal dust from dry processing and from thermal drying of some wet-processed coal is collected by cyclone separators, which pay for themselves in reclaimed coal. ${ }^{2}$ At the power plant, electrostatic precipitators with collection efficiencies 
to about $99 \%$ collect fly ash, which is disposed of in settling ponds. Changes in stack-gas composition resulting from use of low-sulfur fuel, from desulfurization by limestone addition, or from changes in ash characteristics generally alter the precipitator performance and usually require larger units. ${ }^{39}$ Some of the flue-gas sulfur-dioxideremoval processes under development control particulate emissions with high efficiency by wet scrubbing, but others require a high level of particulate removal as a preliminary treatment.

of the large number of stack-gas sulfur-dioxide-removal systems that have been proposed and are under development, none is yet in routine full-scale operation on large boilers burning high-sulfur coal. The basic problem of post-combustion desulfurization is that of continuously removing a large fraction of a small concentration of sulfur dioxide from a very large flow of stack gas. For example, a modern power plant of 1000-MWe capacity, burning coal with a sulfur content of 2.5-3.0 wt \%, will emit about $2 \times 10^{6} \mathrm{cfm}$ of flue gas with a sulfur dioxide concentration between 0.2 and 0.3 vol $\% .40$

The main processes under consideration are listed in Table A.2-2. ${ }^{41}$ of these, the limestone-injection-wet-scrubbing variation is probably commanding the most attention. The mid-1973 technological status of the processes is sumarized in Table A.2-3. 41 Through May 1973, the percent availability of stack-gas $\mathrm{SO}_{x}$ abatement systems ranged from nil to $33 \%$ (for one scrubber in a dual-scrubber installation), and the longest continuous on-stream time for any U.S. coal-fired plant 
Table A.2-2

REVIEW OF PROCESSES FOR REMOVAL OF $\mathrm{SO}_{x}$ FROM FLUE GASES

\begin{tabular}{|c|c|c|}
\hline Type of process & Sulfur disposal method & Demonstration plant status \\
\hline MgO slurry scrubbing & Sale of $98 \% \mathrm{H}_{2} \mathrm{SO}_{4}$ & $\begin{array}{l}\text { 150-MW oil-fired in operation; } \\
100-\mathrm{MW} \text { coal-fired under construction }\end{array}$ \\
\hline Na solution scrubbing & $\begin{array}{l}\text { Sale of sulfur }{ }^{a} \text { ( } 5 \% \text { of sulfur } \\
\text { to } \mathrm{Na}_{2} \mathrm{SO}_{4} \text { waste) }\end{array}$ & $\begin{array}{l}\text { 75-MW oil-fired in operation; } \\
115-\mathrm{MW} \text { coal-fired under construction }\end{array}$ \\
\hline Catalytic oxidation & Sale of $80 \% \mathrm{H}_{2} \mathrm{SO}_{4}$ & 100-MW coal-fired in startup \\
\hline $\begin{array}{l}\text { Limestone into boiler } \\
\text { with wet scrubbing }\end{array}$ & $\mathrm{CaSO}_{3}-\mathrm{CaSO}_{4}$ waste sludge & $\begin{array}{l}\text { Several demonstration plants shut } \\
\text { down due to operating problems; } \\
\text { others canceled }\end{array}$ \\
\hline $\begin{array}{l}\text { Wet scrubbing with } \\
\text { lime slurry feed }\end{array}$ & Same as above & $\begin{array}{l}150-\mathrm{MW} \text { operating with coal of } 2 \% \text { sulfur } \\
\text { content; others under construction }\end{array}$ \\
\hline $\begin{array}{l}\text { Wet scrubbing with } \\
\text { limestone slurry feed }\end{array}$ & Same as above with excess $\mathrm{CaCO}_{3}$ & $\begin{array}{l}\text { 175-MW coal-fired in startup stage; } \\
\text { many others under construction }\end{array}$ \\
\hline $\begin{array}{l}\text { Dry limestone into } \\
\text { boiler only }\end{array}$ & $\mathrm{CaSO}_{3}-\mathrm{CaSO}_{4}$ with ash & $\begin{array}{l}\text { Inadequate sulfur removal (10 to } 40 \%) \text {; } \\
\text { no further operation planned }\end{array}$ \\
\hline
\end{tabular}

Basis for selection: These are processes for which a demonstration plant with a capacity of at least $100 \mathrm{MWe}$, using high-sulfur coal, has been completed, is under construction; or is anticipated.

${ }^{a}$ Concentrated $\mathrm{SO}_{2}$ can also be converted to other products. 
Table A.2-3

TECHNOLOGICAL STATUS OF SOME STACK-GAS

$\mathrm{SO}_{2}$-REMOVAL PROCESSES

\begin{tabular}{|c|c|c|c|c|c|}
\hline \multirow[b]{2}{*}{ Process } & \multirow[b]{2}{*}{$\begin{array}{l}\text { Major U.S. engineering } \\
\text { activities }\end{array}$} & \multicolumn{2}{|c|}{ Status of demonstration plants } & \multirow[b]{2}{*}{$\begin{array}{l}\text { Status of process } \\
\text { chemistry }\end{array}$} & \multirow[b]{2}{*}{$\begin{array}{l}\text { Major technological } \\
\text { problem areas }\end{array}$} \\
\hline & & $\begin{array}{l}\text { U.S. plents } \\
\text { operating on } \\
\text { coal of }>2 \% \mathrm{~S}\end{array}$ & $\begin{array}{l}\text { Other plants, U.S. and } \\
\text { foreign, openting on } \\
\text { oil or low-S coul }\end{array}$ & & \\
\hline MgO wet scrubbing & Chemico & $100-M W$ unit near startup & $\begin{array}{l}\text { Two 150-MW units in } \\
\text { operation; U.S. on oil, } \\
\text { Japan with throwaway cycle }\end{array}$ & No major uncertainties & Ash removal requirements \\
\hline $\begin{array}{l}\text { Na solution } \\
\text { scrubbing }\end{array}$ & Wellman-Lord & 125-MW unit under construction & $\begin{array}{l}\text { 250-MW unit near startup } \\
\text { for coal of } 1 \% \mathrm{~S} \text {. Smaller } \\
\text { units of soveral types } \\
\text { operating without difficulty }\end{array}$ & $\begin{array}{l}\text { Additives required to } \\
\text { minimize oxidation to } \\
\mathrm{Na}_{2} \mathrm{SO}_{4}\end{array}$ & $\begin{array}{l}\text { Sulfate forhation requires } \\
\text { waste bleed and caustic } \\
\text { makeup }\end{array}$ \\
\hline Catalytic oxidation & Monsanto & $\begin{array}{l}100-M W \text { unit completed in } \\
1972 \text { but not yet in } \\
\text { operation }\end{array}$ & $\begin{array}{l}\text { Small units for process } \\
\text { development only }\end{array}$ & Apparently no problems & $\begin{array}{l}\text { Ash removal requirements; } \\
\text { high operating temperature; } \\
\text { catalyst attrition; low } \\
\mathrm{H}_{2} \mathrm{SO}_{4} \text { quality }\end{array}$ \\
\hline $\begin{array}{l}\text { Limestone into } \\
\text { boiler with } \\
\text { wet scrubbing }\end{array}$ & Combustion Engineering & $\begin{array}{l}\text { Shut down as a result of } \\
\text { continuing operating } \\
\text { difficulties }\end{array}$ & $\begin{array}{l}\text { No additional plants; } \\
\text { scheduled units have } \\
\text { been canceled }\end{array}$ & $\begin{array}{l}\text { Complex CaSO, scaling } \\
\text { diffeult to control }\end{array}$ & $\begin{array}{l}\text { Severe boiler operating } \\
\text { problems; poor limestone } \\
\text { utilization; rovere } \\
\text { scaling, demister plugeing }\end{array}$ \\
\hline $\begin{array}{l}\text { Wet scrubbing with } \\
\text { lime slurry } \\
\text { feed }\end{array}$ & $\begin{array}{l}\text { Combustion Engincesing, } \\
\text { CHEMICO }\end{array}$ & Several near startup & $\begin{array}{l}\text { Successful operation of } \\
150-M W \text { unit in Japan on } \\
\text { coal of } 2 \% \mathrm{~S} \text {; other plants } \\
\text { operatins }\end{array}$ & $\begin{array}{l}\text { Complex } \mathrm{CaSO}_{4} \text { scaling } \\
\text { difficult to control }\end{array}$ & $\begin{array}{l}\text { Severe scaling, demister } \\
\text { pluesing }\end{array}$ \\
\hline $\begin{array}{l}\text { Wet scrubbing } \\
\text { with limestone } \\
\text { slurry feod }\end{array}$ & $\begin{array}{l}\text { Babcock \&ilcox, } \\
\text { Combustion Enginoering, } \\
\text { TVA }\end{array}$ & $\begin{array}{l}\text { 175-MW unit completed in } \\
1972 \text {; has not yet met } \\
\text { acceptance tests; many } \\
\text { others of }>100 \mathrm{MW} \\
\text { under construction }\end{array}$ & $\begin{array}{l}\text { Smallecale development } \\
\text { units only }\end{array}$ & $\begin{array}{l}\text { Complex, not completely } \\
\text { understood; blinding of } \\
\text { limestone surface } \\
\text { problem }\end{array}$ & $\begin{array}{l}\text { Demister plugeing; poor } \\
\text { dependability; low lime- } \\
\text { stone utilization; waste } \\
\text { sludse disposal }\end{array}$ \\
\hline
\end{tabular}


was about three weeks. ${ }^{42}$ It is anticipated by some that present difficulties will be overcome by continued development and that successful regenerative units will be installed on perhaps threefourths of the coal electrical capacity by $1980 .{ }^{43}$ In the fuel cycle, solid wastes generated by air-pollution controls - for example, fly ash and limestone sludge - would be disposed of in settling ponds and waste banks.

\subsection{Fuel-to-Fuel Conversion}

This subject, which includes conversion of coal into low-Btu gas for boiler firing and into either fuel oil or syncrude (synthetic crude oil convertible to motor fuels), is treated in some breadth by Hottel and Howard. ${ }^{4}$ The importance of these processes is emphasized by their ability also to produce liquid fuels for the transportation sector gasoline for cars, diesel fuel for trucks and locomotives, and jet fuel for airplanes - for which electric power from any source, fossil or nuclear, is not presently substitutable. A schematic that depicts some of the systems under development ${ }^{44}$ is shown in Fig. A.2-6.

Low-Btu gas (120 to 200 Btu/scf, typically) is considerably cheaper per million Btu than SNG (synthetic or substitute natural gas of high-Btu pipeline-quality); and sulfur compounds, principally hydrogen sulfide, can be removed more easily and economically before combustion than after. Processes generally involve use of a gasifier in which hot coal or coke is contacted with air and steam at temperatures from 1500 to $2500^{\circ} \mathrm{F}$ and at pressures from 1 to $450 \mathrm{psig}$. After 


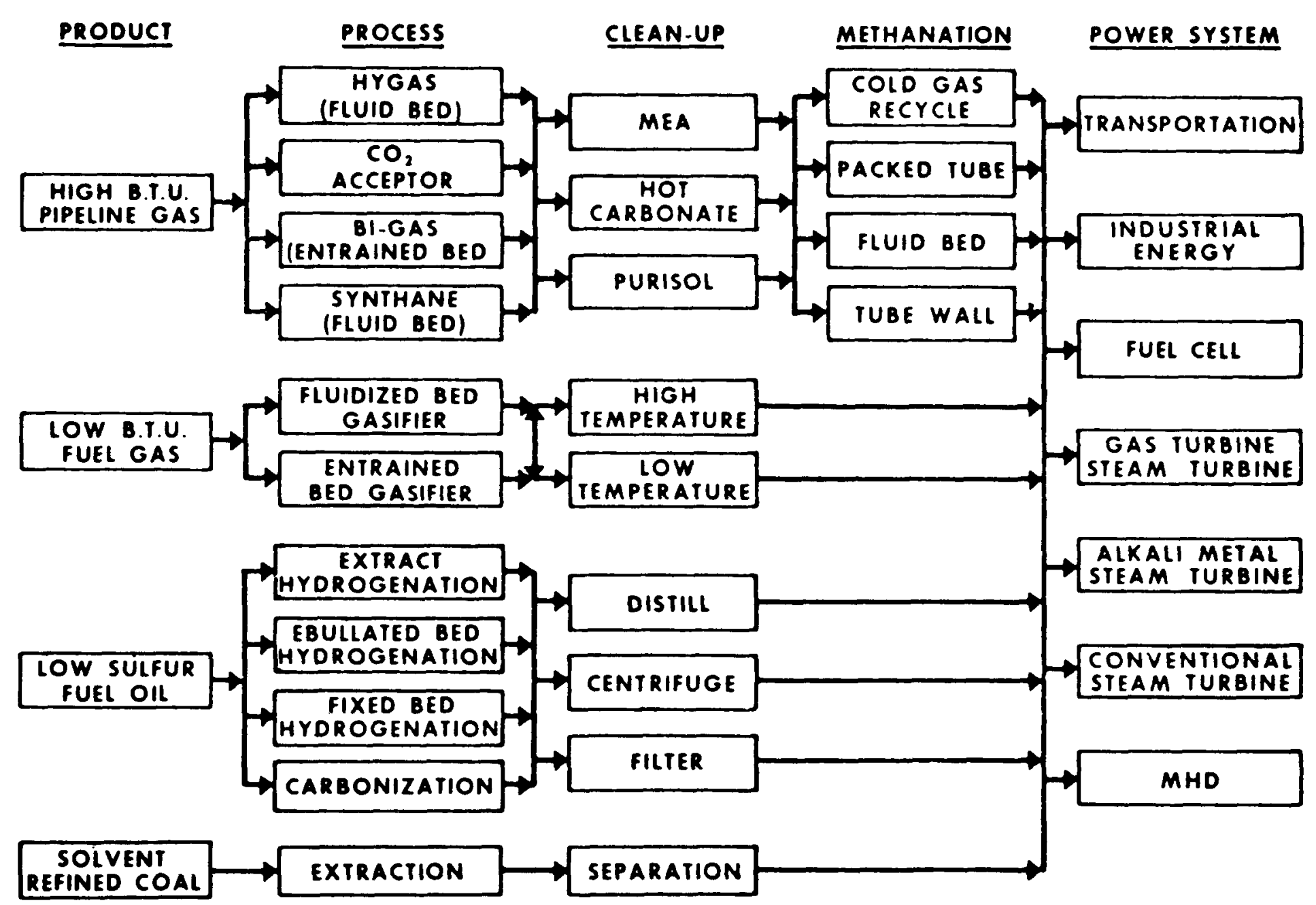

CLEAN ENERGY FROM COAL PROGRAM

Figure A.2-6 
impurities have been removed from the reaction products, the principal constituents of the gas are carbon monoxide, hydrogen, nitrogen, carbon dioxide, water vapor, and methane. The principal processes for producing low-Btu gas from coal are summarized and are compared ${ }^{41}$ in Tables A.2-4 and A.2-5. Processes currently being used to produce fuel gas commercially include the Lurgi, Koppers-Totzek, and Wellman-Galusha; the Lurgi is the furthest advanced with respect to coal gasification on an industrial scale. Liquid processes for desulfurizing raw low-Btu gas ${ }^{41}$ include seven in which absorption is accompanied by chemical reaction and five in which absorption takes place by physical solvent action alone; these processes operate at 0 to $260^{\circ} \mathrm{F}$ and 1 to $1000 \mathrm{psig}$ and produce hydrogen sulfide or sulfur products.

Coal liquefaction-desulfurization may proceed by several routes. Table A.2-6 summarizes the current technological status of the major processes. ${ }^{41}$ The Solvent Refined Coal (SRC) product has a sulfur content below $1 \%$ and an ash content of about $0.1 \%$, solidifies at 300 to $400^{\circ} \mathrm{F}$, and has a heating value of about $16,000 \mathrm{Btu} / \mathrm{lb}$. The Meyers process removes about $95 \%$ of the pyritic sulfur by simple chemical leaching, but the organic sulfur content is essentially unchanged. ${ }^{41}$ The H-COal process is inherently flexible in that the proportions of fuel oil and synthetic crude can be varied over a wide range. For example, if the throughput in a given plant is increased, the contact time in the reactor is reduced, the degree 
Table A.2-4

\section{A SUMMARY OF SOME PROPOSED PROCESSES FOR THE PRODUCTION OF LOW-BTU GAS FROM COAL}

\begin{tabular}{|c|c|c|c|c|}
\hline Process $^{a}$ & Gasifier type & $\begin{array}{l}\text { Gasifier } \\
\text { pressure } \\
\text { (psig) }\end{array}$ & $\begin{array}{l}\text { Oxidizing } \\
\text { medium }\end{array}$ & Comments \\
\hline Lurgi & $\begin{array}{l}\text { Downward-moving stirred } \\
\text { bed, nonslagging }\end{array}$ & $300-450$ & Air & $\begin{array}{l}\text { Process is in commercial operation } \\
\text { on sized noncaking coal. Plans } \\
\text { are under way to test operation on } \\
\text { caking bituminous coal }\end{array}$ \\
\hline Koppers-Totzek & $\begin{array}{l}\text { Cocurrent solid-ges } \\
\text { combustion, slagging }\end{array}$ & $1-5$ & $\begin{array}{l}\text { Oxygen or } \\
\text { oxygen- } \\
\text { enriched } \\
\text { air }\end{array}$ & $\begin{array}{l}\text { Process is in commercial operation } \\
\text { using oxygen. Tests are planned } \\
\text { using enriched air. Can handle } \\
\text { any type of coal }\end{array}$ \\
\hline Wellman-Galusha & $\begin{array}{l}\text { Downward-moving stirred } \\
\text { bed, nonslagging }\end{array}$ & $1-300$ & Air & $\begin{array}{l}\text { Process is in commercial operation } \\
\text { using coke or noncaking coals, } \\
\text { mostly in the steel and ceramics } \\
\text { industries. Bureau of Mines has } \\
\text { a pilot plant operating on caking } \\
\text { coal at pressures up to } 125 \text { psig, } \\
\text { capacity about } 20 \text { tons/day. Tests } \\
\text { are planned at } 300 \text { paig to increase } \\
\text { throughput }\end{array}$ \\
\hline Union Carbide & $\begin{array}{l}\text { Ash-agglomerating } \\
\text { fluidized bed, } \\
\text { separate fluidized } \\
\text { regenerator }\end{array}$ & 100 & Air & $\begin{array}{l}\text { Process is in the pre-pilot-plant } \\
\text { stage. Plans are proceeding for } \\
\text { design and construction of a } \\
25-\text { ton/day pilot plant }\end{array}$ \\
\hline $\begin{array}{l}\text { ATGAS } \\
\text { (Applied Technology } \\
\text { Corp.) }\end{array}$ & $\begin{array}{l}\text { Coal is dissolved in } \\
\text { molten iron with } \\
\text { limestone-air } \\
\text { injection }\end{array}$ & 1 & Air & $\begin{array}{l}\text { Bench-acale unit operating ( } 2.5 \mathrm{ft} \\
\text { diam). Development work is in } \\
\text { progress. Can handle any type } \\
\text { of coal }\end{array}$ \\
\hline General Electric & $\begin{array}{l}\text { Slow-moving bed with } \\
\text { inert bulk diluents }\end{array}$ & 300 & Air & $\begin{array}{l}\text { Few details available. Process } \\
\text { is in bench-scale stage. Uses } \\
\text { extrusion feeder instead of lock } \\
\text { hoppers; membrane scrubber for } \mathrm{H}_{2} \mathrm{~S} \\
\text { removal. Plans are under way for } \\
\text { 6-ton/day pilot plant }\end{array}$ \\
\hline Bi-gas & Twostage entrained bed & 300 & Air & $\begin{array}{l}\text { Pilot plant with } 120 \text {-ton/day capacity } \\
\text { is under construction. Process } \\
\text { can handle any type of coal }\end{array}$ \\
\hline
\end{tabular}

${ }^{a}$ Processes such as Hygas, Synthane, and $\mathrm{CO}_{2}$ Acceptor are not included in this table since they are intended primarily for high-Btu gas production. 
Table A.2-5

\section{PRELIMINARY COMPARISON OF SOME PROPOSED LOW-BTU GAS PROCESSES}

\begin{tabular}{|c|c|c|}
\hline Process & Claimed or potential advantages & Potential disadvantages or problems \\
\hline Lurgi & $\begin{array}{l}\text { 1. Process is in large-scale commercial } \\
\text { operation on noncaking coal }\end{array}$ & $\begin{array}{l}\text { 1. Possible problem with caking coals } \\
\text { 2. Low degree of automation } \\
\text { 3. High operating and maintenance } \\
\text { requirements }\end{array}$ \\
\hline Koppers-Totzek & $\begin{array}{l}\text { 1. Process is in commercial operation } \\
\text { using } \mathrm{O}_{2}\end{array}$ & $\begin{array}{l}\text { 1. May have difficulty operating with } \\
\text { air instead of oxygen. Oxygen adds } \\
\text { appreciably to cost } \\
\text { 2. Not readily adaptable to high- } \\
\text { pressure operation }\end{array}$ \\
\hline Wellman-Galusha & $\begin{array}{l}\text { 1. Many gasifiers are in commercial } \\
\text { operation on coke and noncaking } \\
\text { coals, principally in steel and } \\
\text { ceramics industries }\end{array}$ & $\begin{array}{l}\text { 1. Process is lower pressure than } \\
\text { Lurgi, hence probably lower } \\
\text { throughput per gasifier } \\
\text { 2. Low degree of automation } \\
\text { 3. High operating and maintenance } \\
\text { requirements } \\
\text { 4. Possible difficulty with swelling } \\
\text { caking coals }\end{array}$ \\
\hline $\begin{array}{l}\text { Union Carbide } \\
\text { ash-agglomerating } \\
\text { fluidized bed }\end{array}$ & $\begin{array}{l}\text { 1. Can handle any type of coal } \\
\text { 2. Fluidized-bed technique gives high } \\
\text { throughput per unit volume } \\
\text { 3. Separate regenerator permits use } \\
\text { of air without nitrogen dilution of } \\
\text { product }\end{array}$ & $\begin{array}{l}\text { 1. Process is still in the development } \\
\text { stage } \\
\text { 2. Possible difficulty in establishing } \\
\text { proper conditions for fluidization of } \\
\text { ash particles }\end{array}$ \\
\hline ATGAS & $\begin{array}{l}\text { 1. Can handle any type of coal } \\
\text { 2. Gas purification greatly simplified } \\
\text { 3. Low cost claimed }\end{array}$ & $\begin{array}{l}\text { 1. Process is still in the development } \\
\text { stage } \\
\text { 2. Possible engineering and materials } \\
\text { problems }\end{array}$ \\
\hline General Electric & $\begin{array}{l}\text { 1. Can handle swelling caking coals } \\
\text { 2. Eliminates lock-hopper feeders } \\
\text { 3. Simplified } \mathrm{H}_{2} \mathrm{~S} \text { removal } \\
\text { 4. Eliminates stirring devices }\end{array}$ & $\begin{array}{l}\text { 1. Process is still in the development } \\
\text { stage } \\
\text { 2. Use of inert bulk diluents may pose } \\
\text { problems }\end{array}$ \\
\hline Bi-gas & $\begin{array}{l}\text { 1. Can handle any type of coal } \\
\text { 2. Entrained-bed gasifier is simple } \\
\text { and reliable } \\
\text { 3. High throughput per unit volume }\end{array}$ & $\begin{array}{l}\text { 1. Process is still in the development } \\
\text { stage } \\
\text { 2. Molten ash may cause deposits in } \\
\text { gasifier }\end{array}$ \\
\hline
\end{tabular}


Table A.2-6

TECHNOLOGICAL STATUS OF LIQUEFACTION/DESULFURIZATION PROCESSES

\begin{tabular}{|c|c|c|c|c|c|c|}
\hline \multirow[b]{2}{*}{ Process } & \multirow{2}{*}{$\begin{array}{l}\text { Process developer } \\
\text { and sponsor }\end{array}$} & \multicolumn{3}{|c|}{ Pilot plant } & \multirow{2}{*}{$\begin{array}{l}\text { Major technological } \\
\text { problem areas }\end{array}$} & \multirow{2}{*}{$\begin{array}{l}\text { Process improvement } \\
\text { research and development }\end{array}$} \\
\hline & & Location & $\begin{array}{c}\text { Capacity } \\
\text { (tons coal/day) }\end{array}$ & Status and cost & & \\
\hline \multirow[t]{2}{*}{ Solvent Refined Cosl } & $\begin{array}{l}\text { Pittsburg and Midway Coal } \\
\text { Mining Co.; Office of } \\
\text { Coal Research (OCR) }\end{array}$ & $\begin{array}{l}\text { Tacoma, } \\
\text { Wash. }\end{array}$ & 50 & $\begin{array}{l}\text { Under construction; } \\
\text { startup Mar. 1974; } \\
\$ 17 \text { million }\end{array}$ & $\begin{array}{l}\text { 1. Solid separation of } \\
\text { unreacted coal } \\
\text { 2. Production of } \mathrm{H}_{2} \text { for } \\
\text { process } \\
\text { 3. Extent of sulfur removal }\end{array}$ & $\begin{array}{l}\text { 1. Solids separation techniques } \\
\text { 2. Increased sulfur removal } \\
\text { 3. Use of } \mathrm{CO}+\mathrm{H}_{2} \text { instead of } \mathrm{H}_{2} \\
\text { for hydrogenation } \\
\text { 4. Gasification of unreacted solids } \\
\text { for } \mathrm{H}_{2} \text { production }\end{array}$ \\
\hline & $\begin{array}{l}\text { Southern Services Co.; } \\
\text { Electrical Power Research } \\
\text { Institute }\end{array}$ & $\begin{array}{l}\text { Wilsonville, } \\
\text { Ala. }\end{array}$ & 6 & $\begin{array}{l}\text { Under construction; } \\
\text { startup Jan. 1974; } \\
\$ 6 \text { million }\end{array}$ & Same as above & Same as above \\
\hline Meyers process & TRW, Inc.; EPA & $\begin{array}{l}\text { Rodondo Beach, } \\
\text { Calif. }\end{array}$ & $\begin{array}{l}\text { Bench scale } \\
\text { (12-ton/day } \\
\text { pilot plant to } \\
\text { be built) }\end{array}$ & & $\begin{array}{l}\text { 1. Removal of elemental } \\
\text { sulfur from the coal after } \\
\text { the leach step }\end{array}$ & $\begin{array}{l}\text { 1. Studies of organic sulfur removal } \\
\text { by solvent extraction }\end{array}$ \\
\hline H-Coel process & $\begin{array}{l}\text { Hydrocarbon Research, } \\
\text { Inc.; } O C R \text { and group } \\
\text { of oil companies }\end{array}$ & $\begin{array}{l}\text { Trenton, } \\
\text { N.J. }\end{array}$ & $\begin{array}{l}\text { 3-8 } \\
\text { (250-ton/day } \\
\text { pilot plant } \\
\text { proposed) }\end{array}$ & $\begin{array}{l}\text { Process development } \\
\text { unit in operation }\end{array}$ & $\begin{array}{l}\text { 1. Solid separation of } \\
\text { unreacted coal } \\
\text { 2. Production of } \mathrm{H}_{2} \text { for } \\
\text { proces } \\
\text { 3. Catalyst regeneration }\end{array}$ & $\begin{array}{l}\text { 1. Solids separation techniques } \\
\text { 2. Evaluation of cataly sts } \\
\text { 3. Scale-up to commercial-sized } \\
\text { equipment }\end{array}$ \\
\hline Consol process & $\begin{array}{l}\text { Consolidated Coal Co.; } \\
\text { OCR }\end{array}$ & $\begin{array}{l}\text { Cressp, } \\
\text { w.va. }\end{array}$ & 24 & $\begin{array}{l}\text { Operated 1967-1970; } \\
\text { currently shut down; } \\
\text { may be used for coal } \\
\text { liquefaction demon- } \\
\text { strations }\end{array}$ & $\begin{array}{l}\text { 1. Solid separation of } \\
\text { unreacted coal } \\
\text { 2. Equipment mechanical } \\
\text { problems } \\
\text { 3. Production of } \mathbf{H}_{2} \text { for } \\
\text { process }\end{array}$ & $\begin{array}{l}\text { 1. Solids separation techniques } \\
\text { 2. Mechanical modification of } \\
\text { pilot plant to permit continuous } \\
\text { operation }\end{array}$ \\
\hline COED proces: & $\begin{array}{l}\text { FMC Corp.; OCR } \\
\text { Coges Devel. Corp. (FMC } \\
\text { Corp., Panhandle Eastern } \\
\text { Pipeline Co., and Tenn. } \\
\text { Gas Pipeline Co.) }\end{array}$ & $\begin{array}{l}\text { Princeton, } \\
\text { N.J. }\end{array}$ & 36 & $\begin{array}{l}\text { In operation } 1970 \text { to } \\
\text { date; } \$ 4.5 \text { million }\end{array}$ & $\begin{array}{l}\text { 1. Separation of solids from } \\
\text { oil produced during oil } \\
\text { pyrolysis } \\
\text { 2. Gasification of the residual } \\
\text { chas produced during coal } \\
\text { pyrolysis }\end{array}$ & $\begin{array}{l}\text { 1. Development of an oil absorption } \\
\text { system to eliminate oil } \\
\text { filtration } \\
\text { 2. Product evaluation studies } \\
\text { 3. Development of char gasification } \\
\text { techniques }\end{array}$ \\
\hline $\begin{array}{l}\text { Bureau of Mines } \\
\text { Hydrodexulfurization } \\
\text { process }\end{array}$ & U.S. Bureau of Mines & $\begin{array}{l}\text { Bruceton, } \\
\text { Pr. }\end{array}$ & $\begin{array}{l}0.5 \\
\text { (6-ton/day } \\
\text { pilot plant } \\
\text { proposed) }\end{array}$ & $\begin{array}{l}\text { Began operation } \\
\text { Aug. } 1973\end{array}$ & $\begin{array}{l}\text { 1. Solids separation of } \\
\text { unrescted con } \\
\text { 2. Production of } \mathrm{H}_{2} \text { for the } \\
\text { process } \\
\text { 3. Scale-up of reactor to } \\
\text { commercial sizes }\end{array}$ & $\begin{array}{l}\text { 1. Filter and centrifuge developmen } \\
\text { for solids separation } \\
\text { 2. Substitution of } \mathrm{H}_{2}+\mathrm{CO} \text { for } \mathrm{H}_{2} \\
\text { used during hydrogenation } \\
\text { 3. Determination of catalyst } \\
\text { consumption }\end{array}$ \\
\hline
\end{tabular}


of hydrogenation of the coal is less severe, and the ratio of fuel oil to lower-boiling naphtha produced is increased.

Flowsheets for the cited processes for producing gas, oil, and clean solid fuel from coal may be found in references 4 and 41 , and simplified color schematics in Lessing's article. ${ }^{45}$

\subsubsection{Energy transmission}

The energy-transmission system element is common to both fossilfueled and nuclear electrical systems. Current practice involves overhead-1ine ac transmission at 230 to $765 \mathrm{kV}$ followed by local distribution by means of either overhead lines or, in large metropolitan areas, buried cables. Average electrical transmission efficiency in 1969, expressed as power sold divided by power produced, was $91.2 \%{ }^{2}$ Future additions of caloric oils and gases produced from coal would introduce the alternative of transporting energy by pipeline as synthetic fuel.

\subsubsection{Research and Development Program}

This section considers the large-scale research and development (R\&D) program which seems called for in order for fossil fuels to complement other energy sources in meeting the total electrical (and other) energy demands of the nation. Coordination and exchange of technology among participants - governmental agencies, utilities, vendors, and consortia - to avoid costly duplication of effort will be important because of the multiple demands on limited R\&D funds for energy. As 
indicated by Lapp, ${ }^{3}$ energy R\&D recommendations contained in the initial fiscal 1974 budget corresponded to $19 \%$ of the total designated for fossil fuels. Including the later supplemental funding for energy R\&D during fiscal. 1974, this fraction increases to about $25 \%$. Lapp, addressing coal conversion specifically, asserts ${ }^{3}$ that "the R\&D effort demands a sense of urgency and concomitant technological daring that is lacking today."

In the mining area, a need exists for extensively automating the already highly mechanized deep coal mines. If the need for miners to be underground were thus minimized, the high death and injury rates associated with U.S. deep mining could be reduced to the significantly lower levels experienced by other industrial coal-mining nations. The same end could be achieved by development of combustion of underground coal in situ for extraction of heat or of low-Btu gas. Hydraulic mining with high-pressure water jets, in those areas where water supply is abundant, offers the potential of increased extraction rates, removal of the coal from the mine in a slurry (by using the cutting water and in arid areas, recycling it), and the elimination of explosions caused by the ignition of methane or suspensions of coal dust by sparks from metal-rock impacts.

In addition, the mechanisms of delayed subsidence of deep mines should be determined, and control steps, including blind pressurized backfilling, should be developed and put into practice. If environmental-protection activity results in prohibition or (more likely) 
legislative restriction of strip mining, the demand for deep-mine extraction would increase severalfold, in which case the suggested R\&D would take on added importance. The current primary need in surface mining appears to be application of existing technology (for example, regarding land reclamation and siltation control) rather than a large R\&D program. Steps such as limiting stripping to areas with slopes under $20^{\circ}$ fall within the legislative domain. Section 2.1.2.2 gives other general suggestions.

Research and development in fuel transportation should include the development of pipe with higher strength-to-weight ratios for gas transmission; ${ }^{4}$ general slurry preparation, fluid dynamics, and slurry utilization studies aimed at increasing the general usability of coal-slurry pipelines; and the development of commercial integral trains, highly automated and consisting of oversize gondolas, semipermanently swivel-coupled, and designed for rapid loading and unloading.

Processing R\&D would entail continuing efforts to curtail emissions of undesirable effluents, to improve stack-gas plume rise and dispersion predictive capability, to increase the utilization of limestone in current stack-gas desulfurization processes, and to broaden studies of by-product uses, with and without beneficiation.

In power generation, the need for more intensive R\&D oriented toward increasing thermal-conversion efficiencies seems generally accepted. 
This work would encompass the large-scale development of improved thermodynamic cycles, including gas turbines integrated with clean gas from coal, and the R\&D necessary to build advanced fluidizedbed boilers and cryogenic alternators in sizes adequate to permit realistic evaluation.

In the area of fuel conversion, a greatly increased level of process R\&D leading to large plants producing clean coal, low-Btu gas, and synthetic fuel oil is clearly needed. To prevent prematurely forced process decisions, extensive testing of the multiple attractive fuelconversion combinations should be conducted, and the results evaluated, at the process-demonstration-unit stage. This R\&D could lead to significant future reductions in power plant requirements for fly-ash removal and post-combustion $\mathrm{SO}_{\mathrm{X}}$ controls of perhaps uncertain reliability. A common-basis technical and economic evaluation of competitive processes should be made and frequently updated by an objective, competent group, perhaps dedicated to this sole function.

A salient point made by the National Science Foundation (NSF) Energy Task Force ${ }^{46}$ is that satisfactory determination of energy-area R\&D strategies is too complex and too important to be conducted under ad hoc conditions and that a long-term continuing multidisciplinary effort, effectively located within the government, is required. A program of this nature aimed at substituting the use of coal for oil and gas has been proposed as part of a national energy R\&D program described in The Nation's Energy Future ${ }^{47}$. The coal R\&D recommendatione included four essential elements as follows: 
1. Development and demonstration of more productive, safe coal mining technology to the point where it can be used in greatly expanded future operations. This element will include: the development and demonstration of surface coal mining systems featuring integrated extraction and reclamation processes that meet environmental, social, and economic constraints; the development of underground coal mining systems that increase average productivity to 30 tons/man shift with as complete extraction as possible in a manner that ensures safety and environmental protection; and the development of systems for mining ofl shale in an environmentally safe and productive manner.

2. Development of coal-fired boilers for electric power generation which have improved thermal conversion efficiency, reduced costs, and acceptable environmental impact. This will include the completion of pilot-scale tests of four methods of clean combustion of coal, and the construction and operation of one pressurized fluidized-bed boiler system.

3. Development of technology for converting coal to clean liquid and gaseous fuels. This program element will cover the investigation of several processes for converting coal to pipeline quality gas and the construction and operation of a demonstration coal gasification plant; the construction and operation of three to five pilot plants and two combined-cycle 
demonstration plants to test four processes for converting coal to gas of a low BTU content; the investigation of several processes for converting coal to liquid boiler and distillate fuels, the selection of three or more of these for further testing in pilot plants, and the design of one demonstration plant; and the construction of two commercial-scale plants incorporating state-of-the-art processes and techniques for producing oil and gas from coal and the measuring monitoring, and evaluation of the operation of these plants.

4. Providing the necessary supporting research and development to achieve the other coal objectives and to develop the technology necessary for reducing, to acceptable levels, the environmental impact of commercial scale coal processing, transportation, conversion, and combustion operations. The objectives of this program element would be to obtain data through laboratory research on materials and component development for various coal conversion processes, to provide exploratory data for development of new processes, to develop an economical method of removing sulfur dioxide from flue gas, to reduce impurity and pollutant discharges resulting from the combustion of coal, to improve the technology for impurity removal from coal by physical and chemical treatment, to ensure the environmental acceptability of commercial scale processes of converting coal to gas and to liquids, to develop economical methods of disposing of wastes resulting from the use of coal, and to investigate the feasibility of converting coal to gas in situ. 
A brief surmary of the costs of conducting a coal research and development program of this scope and magnitude is included in Section A.2.1.7.2.

\subsubsection{Present and Projected Application}

Recent and current application of coal in the electrical energy sector was outlined in Sect. 2.1.1.2. It has been projected that coal's share of the total energy demand will remain ${ }^{2}$ at the 1972 level of about $18 \%$ or will decrease slightly ${ }^{18}$ until 1985, but that the total amount consumed will increase ${ }^{2,18}$ by about $75 \%$ to $1.0 \times 10^{9}$ tons/year in 1985. These projections, and others, are sumarized in Table A.2-7.

Risser gives estimates ${ }^{13}$ of coal production rates for Synthetic Natural Gas (SNG) and gasoline for the period 1980 to 2000 which are comparable with Linden's. ${ }^{51}$ However, these synthetic-fuel projections may be low since production of $6,260,000 \mathrm{bbl}$ of syncrude per day, or $25 \%$ of the estimated total United States petroleum demand in 1985,8 would require about $800,000,000$ tons of coal per year.

Lapp estimates ${ }^{3}$ that his projection for the year 2000 would increase to about $3.4 \times 10^{9}$ tons/year if coal were totally substituted for the nuclear electrical generation anticipated for that year. Taking the maximum total consumption rates obtainable from Table A.2-7 for the years 1985 and 2000 , and increasing them by 8.9 and $7.6 \%$, 
Table A.2-7

\section{PROJECTIONS OF DOMESTICA COAL CONSUMPTION (TONS/YEAR)b}

\begin{tabular}{llrc}
\hline Year & Electrical generation $^{c}$ & Other & Total $^{d}$ \\
\hline 1980 & $460 \times 10^{6}(48)$ & $12 \times 10^{6}(51)^{e}$ & $665 \times 10^{6}(48)$ \\
& $500 \times 10^{6}(33,49)$ & $205 \times 10^{6}(48)^{f}$ & \\
1985 & $600 \times 10^{6}(49)$ & $85 \times 10^{6}(51)^{e}$ & $0.89 \times 10^{9}(48)$ \\
& $613 \times 10^{6}(48)$ & $280 \times 10^{6}(48)^{f}$ & $0.96 \times 10^{9}(52)$ \\
& $645 \times 10^{6}(50)^{g}$ & & $1.0 \times 10^{9}(2,18,50)^{g}$ \\
1990 & $700 \times 10^{6}(49)$ & $306 \times 10^{6}(51)^{e}$ & $1.5 \times 10^{9}(53)$ \\
2000 & $750 \times 10^{6}(30)$ & $555 \times 10^{6}(48)^{f}$ & $1.3 \times 10^{9}(3,48)$ \\
& $755 \times 10^{6}(48)$ & $872 \times 10^{6}(51)^{e}$ & \\
2020 & $1.0 \times 10^{9}(33)$ & & \\
\hline
\end{tabular}

about 10\% of the net production was exported during 1970-1972.

$b_{\text {References in parentheses. }}$

$c_{\text {By }} 2000$, coal's share of electrical generation is expected to decrease to about half its current contribution, i.e., to $22 \%$ (ref. 12), which will correspond to an electrical generation about 13\% larger than the 1972 total generation (ref. 54).

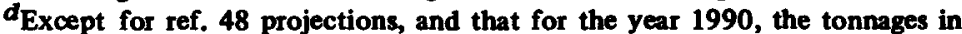
this column are not the sum of those in the two preceding columns.

EFor production of SNG and synthetic crude oil only.

$f_{\text {Industrial consumption, household and commercial use, and synthetic gas }}$ production.

gAlso reported in Business Week, p. 65, Nov. 17, 1973.

hum of "electrical" and "other"; underestimates actual total. 
respectively, to account for export demand, ${ }^{48}$ the total rates come to $1.6 \times 10^{9}$ tons (1985) and $2.0 \times 10^{9}$ tons (2000). Currently, about $66 \%$ of the gross raw coal production is cleaned, of which about $23 \%$ is lost $(12 \% \text { coal and } 11 \% \text { rock, etc. })^{2}$ If this cleaning loss of about 15\% of gross production remains unchanged, the maximum total mining rates in 1985 and 2000 would be about $1.8 \times 10^{9}$ and $2.3 \times 10^{9}$ tons, respectively.

All recent projections, made by use of various probable energy-mix patterns, point to significantly increased coal consumption rates over the next 40 to 50 years for combined electricity generation and motor-fuel production. To meet increased energy demands and to satisfy current and future requirements of the Federal Clean Air Act of 1970 and the Water Quality Act of 1972, much of the new fossil-fuel technology under development must be on line to a significant degree within a decade.

Recently estimated commercial introduction dates that seem attainable if the developments are funded at increased levels commensurate with the apparent need and without delay include:

1. $\mathrm{SO}_{2}$ stack-gas cleanup: ${ }^{43}$ scrubbers installed on about 10,000 MWe coal capacity by late 1975, a transition to regenerative (vs throwaway) processes in the late 1970's, to units installed on about $75 \%$ of the coal electrical capacity in 1980. 
2. Improved stack-gas dispersion modeling: ${ }^{55}$ by about 1977 .

3. Advanced steam-generator furnaces, ${ }^{56}$ including fluidized beds: 27 by late 1970's to early 1980's.

4. Alkali-metal topping ${ }^{57}$ and ammonia bottoming ${ }^{58}$ cycles: by early 1980's.

5. Low-Btu gas from coal: from late $1970^{\prime}$ 's to early $1980^{\prime} s, 50,59$ 1980 earliest, ${ }^{45}$ by $1985 .^{1}$

6. Combined (gas and steam) turbine cycles: ${ }^{50}$ early 1980 's, including the case of advanced gas turbines driven by gas from coal or oil. 29

7. Clean fuels from coal (desulfurized coal, syncrude, fuel oil, and low-Btu gas): early 1980's, 45,51,60 significant supply by early 1990's.'

Though some of these introduction dates are almost certainly more realistic than others, it appears reasonable to anticipate the large-scale use, if needed, of most of these capabilities by 1985 .

If the "Decade Program" proposed by Wilson" were implemented, $50 \%$ of our total energy need would be met by coal by 1985, the coal coming predominantly from western surface mines operated under strict 
restoration regulations. This program, which would reduce reliance on all energy imports to $10 \%$ of the national need by 1985 , includes a tentative plan to meet $75 \%$ of the energy demand with coal by the year 2000. Wilson strongly urges the mobilization of a massive crash program of parallel pilot and demonstration plants for the promising coal-utilization processes, including production of synthetic oil and low-Btu utility gas, the direct firing of coal with pre- or postcombustion treatment, and, especially, the creation of an immense SNG capacity. Even if the national energy growth rate were reduced to $3 \%$ per year by 1975, the actions proposed would require a coal consumption of about $2 \times 10^{9}$ tons/year by 1985 .

\subsubsection{Environmental Impacts}

The principal environmental impacts considered are those caused by coal-fired power plants and those related to off-site support activities, which include mining, cleaning (processing), transportation, and anticipated fuel-to-fuel conversion.

Figure A.2-7, adapted with minor modifications from ref. 31 , and based on National Coal Association (NCA) data, 62,63 depicts the approximate production and disposition of U.S. bituminous coal in 1970. Some of the tonnages were necessarily inferred or estimated, since the NCA production figures are net $-i . e .$, the net yield after cleaning.

The relationship between the power plant and the off-site activities for a typical current coal-fired electricity system is shown in 


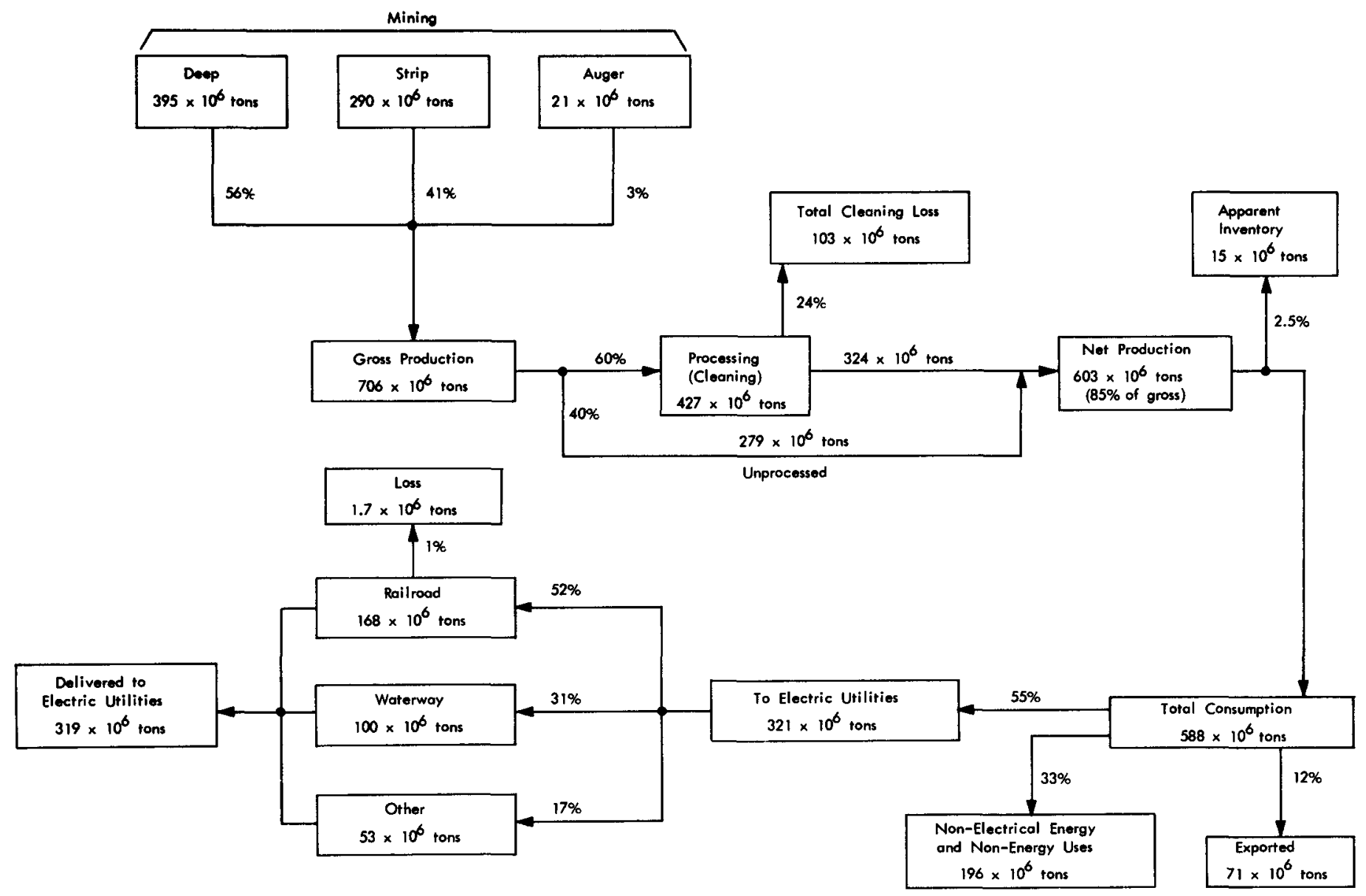

PRODUCTION AND DISTRIBUTION OF U.S.

BITUMINOUS COAL (1970)

Figure A.2-7 
Fig. A.2-8, adapted from ref. 2; average mass flows, losses, energy inputs, and stage efficiencies are shown. When the "reference" system or power plant is cited in this section, the referent is the system depicted by Fig. A.2-8.

\subsubsection{Energy Conversion Plant}

Typical coal-fired power plants emit significant quantities of particulates (fly ash) and noxious gases such as sulfur oxides, nitrogen oxides, carbon monoxide, and hydrocarbons. For each ton of coal burned, about $200 \mathrm{lb}$ of ash is produced; and for a national-average sulfur content of $2.5 \mathrm{wt} \%$, about 80 ib of sulfur dioxide gas. 31 With minimal or currently prevalent environmental controls, the reference plant of Fig. A.2-8 - i.e., a 1000-MWe coal-fired plant with a load factor of 0.75 , a heat rate of $9000 \mathrm{Btu} / \mathrm{kWhr}$ ( $38 \%$ conversion efficiency), and burning puiverized coal with 10 wt \% ash and 2.58 wt \% sulfur - produces ${ }^{2}$ about 352,000 tons of air emissions per year, about 93\% of which is $\mathrm{SO}_{x}$ and particulates.

In an average pulverized-coal-fed furnace, about $80 \%$ of the ash in the coal appears as fly ash (about $160 \mathrm{lb} /$ ton of coal), the remaining $20 \%$ constituting slag waste. For a cyclone-boiler plant, these ash percentages are approximately reversed - i.e., 70 to $80 \%$ of the ash goes to slag. Preliminary estimates have been made ${ }^{2}$ indicating that a pulverized-coal reference plant produces roughly 800 tons of water pollutants per year, almost entirely inorganic (about $77 \%$ suspended solids and boron compounds). 


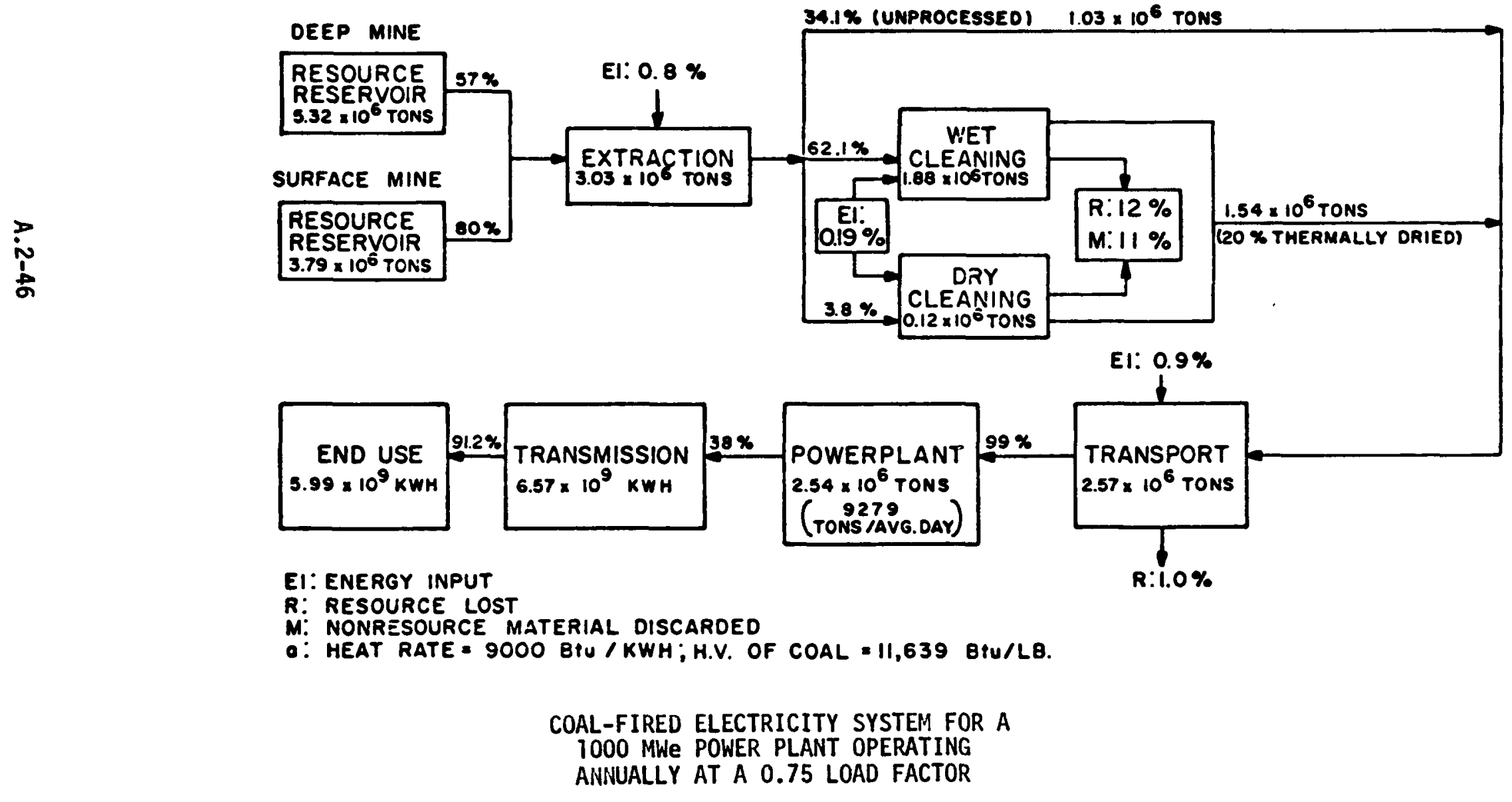

Figure A.2-8 
Emitted hydrocarbons may contain small quantities of carcinogens such as benzo[a]pyrene (BAP), ${ }^{31,64}$ but the total hydrocarbons comprise only about 0.1 wt $\%$ of the total air emissions; ${ }^{2}$ other sources, especially autos and petroleum refineries, emit enormously greater amounts of hydrocarbon vapors. No quantitative data regarding this potential hazard from coal-fired plants appear to exist. Because coal contains traces of uranium, thorium, and radium, there has been a continuing debate regarding radionuclide emissions from coal plants; it appears, however, that a 1000-MWe plant discharges a total activity of only about 2.2 curies annually. ${ }^{2}$ of this total, a plant equipped with electrostatic precipitators emits about 0.03 curies/year to the atmosphere (as radium-226 and radium-228), 31 and over $98 \%$ is associated with the collected fly ash sent to settling ponds. Under certain climatic conditions, sulfuric acid mist may form in the atmosphere, causing damage to a wide range of objects, including stone buildings. 65

Heat rejected by the condenser cooling water to rivers and lakes is considerable; in 1964, for example, of all industrial cooling water used in the United States, $81 \%$ was for electric power plants. ${ }^{2}$ The heat rejected per unit of electrical eneray produced is about the same as that from the HTGR and the proposed LMFBR, but is 40 to $50 \%$ less than that from current LWR's because of the fossil-fueled plant's higher thermal efficiency. 
The total land commitment for the reference 1000-MWe coal power plant with minimal environmental controls is about 700 acres, $^{2}$ or about 130\% larger than for a current LWR with the same power rating. Solid wastes generated by air-pollution controls (fly ash and limestone sludge) require significant additional land use for disposal. An annual incremental land use of 15 acres for this purpose has been estimated ${ }^{2}$ for a controlled reference plant, based on 99\% fly ash removal $(201,000$ tons of dry ash per year averaging $33 \mathrm{ft}^{3} /$ ton $)$ and $85 \% \mathrm{SO}_{\mathrm{x}}$ removal $(742,000$ tons of 1 imestone sludge per year averaging $22 \mathrm{ft}^{3} /$ ton). Some of the environmental impact factors associated with six $\mathrm{SO}_{x}$ stack-gas removal processes ${ }^{41}$ are given in Table A.2-8. In addition, if natural-draft wet cooling towers are used, they would occupy about 10 acres per 1000 MWe capacity.

At the power plant stage, about 113 workers are involved per 1000 Me capacity. ${ }^{2}$ Since major accidents such as boiler explosions and transient high-concentration toxic-gas releases are now quite rare in coal-fired power plants, the occupational death and injury rates are estimated to be minimal. ${ }^{2}$

Aesthetic intrusions and noise emissions of modern plants with environmental controls are generally low level. Although difficulties are being encountered with some aspects of various programs for reducing the environmental impacts of coal-fired power plants, 
it is anticipated that the impact factors can be moderated to a significant degree by the application of available and emerging technologies.

\subsubsection{0ff-site Support Activities and Facilities}

\subsection{Mining}

Current mining practices, which are improvable in many regards, cause extensive environmental impacts, the nature of which depends on whether the mining is conducted underaround or on the surface.

\subsection{Deep Mining}

In deep mining, workers are exposed to the hazards of fire and explosions (from methane and coal dust), slate falls, bronchitis, dyspnea, and "black lung" (coal workers' pneumoconiosis, or CWP). In recent United States experience, ${ }^{2}$ the incidence rates of simple and of complicated (acute) CWP are approximately 3.47 and 1.60 cases per thousand man-years, respectively. Other studies indicate significantly lower rates in British experience: ${ }^{31}$ about 2 total cases per thousand man-years, and only about 0.2 acute case per thousand man-years, each following a minimal exposure time of 15 years. Occupational hazards in the United States in 1970 led to 0.65 death and 28.07 nonfatal injuries per million tons of coal mined, and to an average of 55 workdays lost per injury. ${ }^{2}$

Subsidence caused by deep mining can damage surface structures, disrupt groundwater hydrology, and, if sudden, precipitate localized 
earth tremors. Subsidence affects about 0.2 acre per thousand tons of coal produced, and about $30 \%$ of the total area undermined for coal has already subsided to some extent. ${ }^{2}$ The area potentially altered by subsidence varies inversely with the seam thickness for a given tonnage extracted; based on 1800 tons of coal per acre-ft and $50 \%$ recovery, the coal extracted increases from 9000 to 90,000 tons/acre as the seam thickness increases from 10 to $100 \mathrm{ft}$. A large United States deep coal mine produces about 2,000,000 tons/ year. Manpower requirements may be estimated from recent average productivities of about 14 tons of coal per man-day ${ }^{13,30}$ for roomand-pillar-type mining. Increased use of the newer short-wall and long-wall deep-mining techniques and shifting to the much thicker Western coal beds should lead to significant increases in productivity. The long-wall mining system can also attain 90 to $95 \%$ coal recovery and allows controlled subsidence of the surface to the point of natural stabilization.

The land disturbed by storage of underground mining wastes has been based, in one estimate, ${ }^{2}$ on a use rate of 84,400 tons of waste per acre of waste bank, which corresponds to an average refuse density of 1.5 tons $/ \mathrm{yd}^{3}$ and a bank height of $35 \mathrm{ft}$.

Based on 1969 Appalachian-area data, the annual water-pollutant runoff from a deep mine supplying the reference power plant of Fig. A.2-8 would be ${ }^{2}$ approximately 2129 tons of sulfuric acid, 532 tons of dissolved iron salts, and negligible silt, probably continuing 
Table A.2-8

\section{WASTE DISPOSAL AND ENVIRONMENTAL IMPACT FACTORS \\ FOR PROCESSES FOR REMOVING $S \mathrm{SO}_{x}$ FROM STACK GAS}

Basis: Coal of $4 \% \mathrm{~S} ; \mathrm{H}_{2} \mathrm{SO}_{4}$ of $>90 \%$ concentration, $\mathrm{S}$, and $\mathrm{SO}_{2}$ are not waste products

\begin{tabular}{|c|c|c|c|c|}
\hline Process & $\begin{array}{l}\text { Additional dry } \\
\text { solid waste }\end{array}$ & $\begin{array}{c}\text { Additional } \\
\text { solution waste }\end{array}$ & $\begin{array}{l}\text { Additional } \\
\text { slurry waste }\end{array}$ & $\begin{array}{c}\text { Effect on } \\
\text { particulate emissions }\end{array}$ \\
\hline MgO wet scrubbing & None & None & $\begin{array}{l}\text { None except } \\
\text { ash scrubber }\end{array}$ & $\begin{array}{l}\text { Excellent particulate } \\
\text { removal necessary as a } \\
\text { preliminary step }\end{array}$ \\
\hline $\begin{array}{l}\text { Na solution } \\
\text { scrubbing }\end{array}$ & None & $\begin{array}{l}\mathrm{Na}_{2} \mathrm{SO}_{4} \text { purge; } 0.02 \text { ton per } \\
\text { ton of coal as } 15 \% \text { solution }\end{array}$ & $\begin{array}{l}\text { None except } \\
\text { ash scrubber }\end{array}$ & $\begin{array}{l}\text { Particulate removal } \\
\text { necessary as preliminary } \\
\text { process step }\end{array}$ \\
\hline $\begin{array}{l}\text { Catalytic } \\
\text { oxidation }\end{array}$ & $\begin{array}{l}\text { Small'amount } \\
\text { of catalyst } \\
\text { fines }\end{array}$ & $\begin{array}{l}\text { Low-quality } \mathrm{H}_{2} \mathrm{SO}_{4} ; 0.10 \\
\text { ton per ton of coal; might be } \\
\text { considered a waste product }\end{array}$ & None & $\begin{array}{l}\text { Excellent particulate } \\
\text { removal necessary with } \\
\text { minimum heat losses as a } \\
\text { preliminary process step }\end{array}$ \\
\hline $\begin{array}{l}\text { Limestone into } \\
\text { boiler with } \\
\text { wet scrubbing }\end{array}$ & $\begin{array}{l}\mathrm{CaSO}_{3} \text { and unreacted } \\
\text { lime with ash, } 0.1 \text { ton } \\
\text { per ton of coal }\end{array}$ & None & $\begin{array}{l}\text { About } 0.15 \text { ton } \\
\text { Ca compounds } \\
\text { and ash per ton of } \\
\text { coal; } 40 \% \mathrm{H}_{2} \mathrm{O}\end{array}$ & $\begin{array}{l}\text { Electrostatic precipitators } \\
\text { operate poorly, but wet } \\
\text { scrubbing completes par- } \\
\text { ticulate removal }\end{array}$ \\
\hline $\begin{array}{l}\text { Wet scrubbing } \\
\text { with lime } \\
\text { slurry feed }\end{array}$ & None & None & $\begin{array}{l}\text { About } 0.15 \text { ton } \\
\text { Ca compounds per } \\
\text { ton of coal; } 30 \% \\
\mathrm{H}_{2} \mathrm{O}\end{array}$ & $\begin{array}{l}\text { Wet scrubbing completes } \\
\text { particulate removal }\end{array}$ \\
\hline $\begin{array}{l}\text { Wet scrubbing } \\
\text { with limestone } \\
\text { slurry feed }\end{array}$ & None & None & $\begin{array}{l}\text { About } 0.2 \text { ton } \\
\text { Ca compounds per } \\
\text { ton of coal; } 60 \% \\
\mathrm{H}_{2} \mathrm{O}\end{array}$ & $\begin{array}{l}\text { Wet scrubbing completes } \\
\text { particulate removal }\end{array}$ \\
\hline
\end{tabular}


over a 15-year period. The acid drainage from deep mines contaminates receiving water bodies, al though less seriously when the sulfur content of the coal is low, as in Western areas.

\subsection{Surface Mining}

In surface mining, the U.S. (1970) death and nonfatal injury rates were 0.12 per million tons and 5.40 per million tons, respectively, ${ }^{2}$ with an average of 36 workdays lost per injury. The incidence of CWP among surface miners is clearly lower than that among deep miners working in confined spaces, but the rate apparently has not yet been quantitatively determined. Surface mining, al though safer than deep mining as currently practiced, disrupts large land areas, causing adverse effects on vegetation, crops, wildlife, habitat, and water supply and quality, as well as conflicting with timber, grazing, and other resource uses.

The land area disrupted by stripping varies inversely with the amount of coal recovered per acre. Contour stripping on hilly terrain in the eastern United States has yielded only about 1700 tons of coal per acre, ${ }^{3}$ since the coal seams involved are often only 1 to $2 \mathrm{ft}$ thick. The national average surface-mining recovery is about 3300 tons/acre. ${ }^{2,31}$ Production of coal by area stripping of thicker beds can lead to greatly reduced surface-area disruption. Based on 1800 tons of coal per acre-foot and $80 \%$ recovery, the coal extracted increases from 14,400 to 144,000 tons/acre as the bed thickness increases from 10 to $100 \mathrm{ft}$. Of all United States 1 and 
area disturbed by surface mining to $1965,41 \%$ was attributable to $\operatorname{coal}^{66}$ (adding sand and gravel production accounts for $67 \%$ of the total).

According to the Council on Environmental Quality, ${ }^{2}$ about $90 \%$ of the overburden from surface mining is redeposited on the site. The major solid waste produced by surface mining is silt, as shown by the following estimate ${ }^{2}$ of annual water pollutants for a surface mine supplying the reference power plant of Fig. A.2-8: approximately 166 tons of sulfuric acid, 42 tons of dissolved iron salts, and 35,612 tons of silt. Siltation of receiving water bodies, resulting from waste overburden runoff, was estimated at 3.0 tons/ acre per year for 15 years.

Under some geological conditions, waste piles and high walls (vertical earth banks left by mining) can slide or slump, causing property damage and posing a safety hazard to people and animals. High dust concentrations can occur in the vicinity of pits, spoil piles, and haulage roads; consequent wind erosion could contribute to dust storms. Noise and vibration levels generated by surface-mining activities such as drilling and blasting can be obtrusive. The demand on local water supplies may be excessive, especially in some Western areas with limited rainfall. 67

A large United States surface coal mine produces about $5,000,000$ tons/year. Labor requirements can be estimated from recent average 
productivities of about 32 tons of coal per man-day for all strip mining ${ }^{13}$ and about 36 to 40 tons per man-day ${ }^{30,31}$ for area stripping.

For both deep and surface mining, the air emissions from burning coal seams and waste banks and from power mining equipment seem at present to be undetermined.

\subsection{2.2 Processing Plant}

A large coal processing plant may clean a million tons of raw coal per year, ${ }^{2}$ occupy about 40 acres, and produce about 1.5 tons of waste water per ton of coal processed. ${ }^{31}$ During cleaning of the raw mine product, about $24 \%$ of the feed is discarded, of which about half is coal. ${ }^{2,31}$ Coal-dust emissions arise almost entirely from thermal drying of wet-processed coal; from data in ref. 2 (pp. 43 and 45), it may be calculated that the 1968 emission rate was about 15 tons of dust per thousand tons of cleaned and thermally dried coal. By adding wet scrubbers and air recirculation to the cyclone separators in common use, it is estimated ${ }^{2}$ that dust emissions can be reduced to about 0.2 ton per thousand tons of input coal.

Reject-solid waste forms refuse heaps, and the siltation rate from processing waste banks has been taken ${ }^{2}$ to be 42 tons/acre per year for 15 years, a rate about 14 times that from present surface-mine waste banks. Black-water discharges, consisting of water-suspended fines from the washing operation, can be impounded by slurry dikes, but careful geological studies and dike design are necessary for 
safe, high-level retention. Death and injury rates for processing operations are much lower than for either surface or deep mining, ${ }^{2}$ averaging 0.0147 death and 1.58 nonfatal infuries per million tons, with 39 workdays lost per injury.

For the reference system of Fig. A.2-8, if half the coal is deep mined and half surface mined, the combined mining and processing fatalities total 1.2 per year.

\subsection{Transportation}

Surface transportation of coal by rail or truck requires land for right-of-way (about $50 \mathrm{ft}$ width for rail) ${ }^{2}$ and restricts free travel of people, animals, and other vehicles across the committed areas. Dust is caused by heavily loaded trucks on unpaved roads and by blowaway of coal from rail cars (about $1 \%$ unless wetted or covered). ${ }^{2}$ Truch transport contributes to grade-crossing accidents, many fatal. Two hundred ton-miles of cargo movement requires about 1 gal of diesel fuel rated at $136,000 \mathrm{Btu} / \mathrm{gal}$. For an average shipping distance of 300 miles, $2,31,68$ the diesel fuel energy expended, by train or water, is less than $1 \%$ of the energy content of the coal, 31 and the transportation-associated air pollution is negliglble compared with that from other sources.

Processes for conversion of coal to clean solid fuel, oil, or gas would involve land commitment and water usage and the control of ash and slag from plants generating process steam and/or power. 
Potential environmental contaminants include solids (char, ash, spent catalyst, sulfur, and sludges from waste-water treatment), liquids (phenols, cresols, oils, tars, and ammonia solutions), gases (hydrogen sulfide and sulfur dioxide), and heat (probably released to the atmosphere from cooling towers). Techniques for controlling or disposing of these effluents are available or under development. Flowsheets for fuel-to-fuel conversion processes may be found, in increasing order of detail, in references 45,4 , and 41. Since it has been shown that some coal-derived liquids, especially the higher-boiling fractions, exhibit carcinogenic activity $69,70,71$ (primarily relating to skin cancer), it will be necessary to develop data that can be used in establishing limits for exposure to and inhalation and ingestion of coal-derived products.

\subsubsection{Irreversible and Irretrievable Commitments of Resources}

Since the coal resource base is so large, relative resource depletion will be minor over the short term. Land surface dedicated to extraction, cleaning, conversion, and transportation is not likely to be permanent except in part. Land at the mining and cleaning sites, for example, could be periodically reclaimed on a regular basis, such as at six-or twelve-month intervals, although it is recognized that this has not been done in a number of instances. Surface disruption and subsidence caused by mining activities are potential irreparable consequences that are in some instances amenable to mitigation by surface reclamation of stripped areas, and by backfilling, sealing, 
and chemical treatment of acid drainage from deep mines. Depending on the particular sites selected for various stages of the fossil-fuel energy system, some on-site and off-site ecological balances would be disturbed and potentially altered irreversibly in the framework of a human lifetime. Obvious examples include the complex interactions among soil condition, water quality, vegetation, crops, wildlife, and human habitation. High use rates of water supplied by deep wells in water-deficient areas could have a drawdown effect on shallower wells supplying people or livestock, and the lowered water table might prove irreversible in the same time context. Successful long-term reclamation of reseeded overburden spoil in arid areas has not yet been demonstrated.

\subsubsection{Costs and Benefits}

\subsubsection{Energy Production and Delivery Costs}

\subsection{Direct or Internal Costs}

Direct or internal costs are difficult to estimate accurately because of the nonuniformly increasing costs being experienced in different areas of the electrical energy sector. A recent study by the CEQ ${ }^{2}$ included an estimated 1973 electrical generation cost for the reference coal-fired 1000-MWe power plant of Fig. A.2-8, with minimal environmental controls, of $7.66 \mathrm{mills} / \mathrm{kWhr}$. Estimates were also made ${ }^{2}$ for a controlled system - i.e., one with efficient electrostatic precipitators, wet 1 imestone stack-gas scrubbing, and wet natural-draft cooling towers at the power plant, disposal of solid wastes from air and water pollution controls, control of silt runoff and acid mine drainage, and land reclamation at the mine and processing sites after one year of 
use. The controlled system generation costs totalled 9.79 and 10.07 mills/kWhr for plants using deep- and surface-mined coal, respectively. Most of the cost increase of 2.1 to $2.4 \mathrm{mills} / \mathrm{kWh}$ was incurred by reducing the power plant $\mathrm{SO}_{\mathrm{X}}$ emissions by $85 \%$ with the stack-gas scrubber system.

Some of the component costs (1973 dollars) included $\$ 180 / \mathrm{kW}$ for the basic (uncontrolled) power plant, $\$ 0.35$ per million Btu for fuel, $0.39 \mathrm{mill} / \mathrm{kWhr}$ for operation and maintenance, $\$ 2000 /$ acre for land reclamation, $\$ 10 / \mathrm{kW}$ for the cooling towers, and $\$ 40 / \mathrm{kW}$ for the scrubber system including settling pond $(1.8 \mathrm{mills} / \mathrm{kWhr}$ annualized cost). Following transmission and distribution an average distance, the increase in generation cost of about $30 \%$ would be felt by the average residential consumer as an increase of perhaps $12 \%$.

Some of the costs used in this estimate may be low; in some areas, for example, a land reclamation cost of $\$ 4000$ per acre is doubtless more realistic, operation and maintenance costs may be double the value used, and higher scrubber-system cost forecasts have been made by many others, including about $\$ 60$ to $\$ 66$ per kilowatt, ${ }^{41}$ $\$ 75$ per kilowatt, ${ }^{72}$ and to $\$ 80$ per kilowatt. ${ }^{50}$ Total costs (capital and operating) for retrofit scrubber-system installations have been estimated to be as high as $\$ 0.85$ per million Btu by some utility companies having experience with scrubber systems. ${ }^{73}$ 
Approximate estimates of low-Btu gas-production costs have varied from 60\$ to 85 per million Btu ${ }^{41}$ (Lurgi and Bi-Gas processes) to about $95 \$$ per million Btu. ${ }^{73}$ By contrast, current estimates of SNG production costs are generally in the range of $\$ 1.05$ to $\$ 1.50$ per million Btu, $45,73,74$ or about one-third higher. Syncrudeproduction cost estimates vary from $\$ 1.00$ to $\$ 1.60$ per million Btu ( $\$ 6$ to $\$ 10$ per barrel). 45,75 Hottel has concluded ${ }^{76}$ that while gas from coal appears to have a slight edge today, not one of the processes has had its true cost established, and that almost certainly the nation will need both gas and oil from coal.

The 1968 capital cost for large deep coal mines of about $\$ 10$ per ton of annual capacity ${ }^{13}$ is probably now about $\$ 13$. The 1970 average cost for large surface mines of about $\$ 8$ per ton of annual capacity ${ }^{9}$ has likely increased to about $\$ 9$.

Partial cost estimates which have been developed at 0ak Ridge National Laboratory (ORNL) for use in Section 11.C.I are summarized in Table A.2-9. The costs are for the power plants only, operating at an 80\% load factor, and expressed in mid-1974 dollars. Startup times for coal-fired and nuclear plants are assumed to be 6.0 and 7.5 years, respectively. The coal-fired plants are assumed to be equipped with wet natural-draft cooling towers, electrostatic precipitators, and wet- 1 imestone ${ }^{S}{ }_{x}$ scrubbers and to burn coal containing 3.5 wt \% sulfur and 20 wt \% ash. 
Table A.2-9

PROJECTED ELECTRICAL POWER PLANT COSTS

\begin{tabular}{|c|c|c|c|}
\hline \multirow{2}{*}{$\begin{array}{l}\text { Plant } \\
\text { type }\end{array}$} & \multicolumn{2}{|c|}{ Capital cost $(\$ / \mathbf{k W e})$} & \multirow{2}{*}{$\begin{array}{l}\text { Operating and } \\
\text { maintenance cost } \\
\text { (mills/kWhr) }\end{array}$} \\
\hline & $\begin{array}{l}\text { Twin } 1300-\mathrm{MWe} \\
\text { units (to } 1990 \text { ) }\end{array}$ & $\begin{array}{l}\text { Twin 2000-MWe } \\
\text { units (after 1990) }\end{array}$ & \\
\hline LWR & 420 & 370 & 0.7 \\
\hline Coal & 345 & 315 & 2.2 \\
\hline HTGR & 420 & 370 & 0.7 \\
\hline LMFBR & $a$ & $a$ & 0.8 \\
\hline
\end{tabular}

aPresently anticipated to be approximately $\$ 50$ to $\$ 100 / \mathrm{kWe}$ more than the LWR costs. 


\subsection{Indirect or External Costs}

Indirect or external costs are those not borne by the purchaser. The environmental effects of effluents which are controllable by modifications in mining and processing practices and by equipment added to the power plant would be transferred to direct costs recoverable from utility revenue. Adoption of full-cost pricing at all stages of the energy system - 1.e., internalizing the environmental costs of energy production and use - would significantly reduce but not eliminate those external costs.

The incremental cost per ton of coal associated with land reclamation is given in Table A.2-10 for various yields (tons per acre) and reclamation expenditures per acre. The operations involved in rehabilitating strip-mined land to a pleasing, natural contour include backfilling, compacting, soil conditioning, regrading, reseeding, and revegetating. Current basic cost estimates range from $\$ 2000$ per acre 2,61 to $\$ 6000$ per acre, ${ }^{30}$ the latter figure corresponding to an anticipated incremental coal cost of $20 \notin$ to 30 per $\operatorname{ton}^{8,30}$ (for coal yields of 20,000 to 30,000 tons/acre). For Western coal, the surcharge for extensive reclamation might be only $3 \$$ to $4 \$$ per ton. ${ }^{67}$ A speculative projection has been made ${ }^{30}$ that average reclamation costs may fall to a level as low as $1 \$$ to $2 \$$ per ton by the year 2020 .

For deep mines, rehabilitation operations include backfilling (perhaps by pressurized slurry) to minimize subsidence, selective 
Table A.2-10

RECLAMATION COSTS IN INCREMENTAL COSTS PER TON OF COAL MINED

\begin{tabular}{cccrrrr}
\hline \multirow{2}{*}{$\begin{array}{c}\text { Tons of coal } \\
\text { recovered per acre }\end{array}$} & \multicolumn{5}{c}{$\begin{array}{c}\text { Incremental cost (cents) for } \\
\text { land reclamation cost (per acre) of }-\end{array}$} \\
\cline { 2 - 7 } & $\$ 1000$ & $\$ 2000$ & $\$ 3000$ & $\$ 4000$ & $\$ 5000$ & $\$ 6000$ \\
\hline 3,000 & 33 & 67 & 100 & 133 & 167 & 200 \\
10,000 & 10 & 20 & 30 & 40 & 50 & 60 \\
20,000 & 5 & 10 & 15 & 20 & 25 & 30 \\
30,000 & 3.3 & 6.7 & 10 & 13 & 17 & 20 \\
50,000 & 2 & 4 & 6 & 8 & 10 & 12 \\
100,000 & 1 & 2 & 3 & 4 & 5 & 6 \\
\hline
\end{tabular}


sealing to reduce access of water to acid-producing strata and of air to residual coal, and lime treatment of acid drainage. On an initial demonstration basis, a cost of $\$ 11,000$ per acre has been estimated, 30 which is equivalent to an incremental cost of $37 \$$ per ton for a coal yield of 30,000 tons/acre. Cost forecasts for complete treatment of acid drainage and black-water emissions have ranged from $5 \$$ per ton 30 to $19 \$$ per ton. 2

Indirect costs include a portion of those related to occupational health. Incidence rates for fatalities, nonfatal injuries, work time lost, and CWP ("black lung")-related disability are known reasonably well, but no estimates seem to have been made of the effect of significant system changes on these rates and associated costs.

\subsubsection{Development Costs}

It is assumed that these costs (borne by all financial sources) would fund development through the design, construction, operation, and evaluation of a prototype unit or demonstration plant smaller than commercial scale. The total development cost, obtained primarily from recent FPC and ORNL estimates, is approximately $\$ 1.7$ billion (1973 dollars), of which about half would be required for development of desulfurized coal (SRC and Meyers process) and of low-Btu gas and fuel oil from coal. The distribution by program is shown in Table A.2-11. High-Btu gas (SNG) is not included since it is not an electric-utility fuel and is approaching full development. 51 When an estimate spanned a range, the higher cost was used. If the 
Table A.2-11

ESTIMATED DEVELOPMENT COSTS

\begin{tabular}{lc}
\hline \multicolumn{1}{c}{ Program } & $\begin{array}{c}\text { Cost } \\
\text { (millions of dollars) }\end{array}$ \\
\hline Synthetic fuel oil from coal & 500 \\
Low-Btu gas from coal & 300 \\
Desulfurized coal & 100 \\
SO $_{\mathbf{x}}$ stack-gas cleanup & 75 \\
NO $_{\mathbf{x}}$ abatement & 15 \\
Advanced steam-generatot furnaces, & 85 \\
including fluidized-bed combustion & \\
Advanced (high-temperature) gas turbines & 250 \\
Alkali-metal topping cycle & 200 \\
Steam-ammonia cycle, including NH & 110 \\
turbine & 80 \\
Dry cooling-tower development & 0.3 \\
Improved stack-gas dispersion modeling & 1715.3 \\
$\quad$ Total &
\end{tabular}


period of intensive development continues through 1985 and inflation rates remain at recent levels, this sum will easily exceed $\$ 2$ billion. Extensive development in the areas of mining, land reclamation, fuel transportation, and energy transmission would require additional expenditures. The funding required to attain, at an accelerated pace, large-scale production of gas and synthetic oil from coal on an initial commercial basis is believed to be $\$ 2$ billion to $\$ 3$ billion. 45

The more recently proposed R\&D program described in reference 47 and discussed briefly in Section A.2.1.4 of this Chapter would entail funding of $\$ 2.175$ billion over the next five years. This would include $\$ 325$ millition on coal mining technology, $\$ 200$ milliton on direct combustion, $\$ 1,200$ million on the production of synthetic fuels (oil and gas) from coal, and $\$ 380$ million on general coal technology. Whichever R\&D program or element thereof is selected for support, it is clear that the potential funding that will be needed for coal development is substantial. The related benefits that may be expected to accrue are discussed below.

\subsubsection{Benefits}

The major benefits derived from modernizing the coal electrical-energy system would include, on a cumulative basis over the next two decades, a means of narrowing the projected energy deficit, moderating the environmental impacts of current units, and minimizing reliance on imported premium fossil fuels (oil and natural gas) and the associated 
balance of payments problem. The number of people employed in research and development, mining, transportation, construction, and plant operation would be large but would likely decrease as the system matures and becomes increasingly capital-intensive. By-product markets might develop but probably would not be of major economic significance. If other electrical energy programs, including the LMFBR, lag scheduled introduction dates or if they are, for any reason, followed at a more deliberate pace, an efficient, clean coalbased energy system would provide a realizable alternative in the interim. Additionally, such a system could produce large quantities of synthetic motor fuels - a capability shared only by oil shale among the other options under current consideration. If circumstances combine in such a manner that we are dealing simultaneously with a short fall in nuclear generating capacity, a decline in domestic petroleum and natural gas reserves, and a decreased access to foreign fuel, availability of domestic fuel would override normal economic considerations, and the use of synthetic fuels produced from coal could become a necessity.

\subsubsection{Overall Assessment of Role in Energy Supply}

To the year 2000 , it is probable that coal will continue to play a vital role both in electrical power production and in meeting total energy needs, and that the total mining rate will approach two billion tons/year by that date, approximately half of which will be used in electrical utility power plants. Very large coal mines, with capacities of perhaps 40 million tons/year, will probably be developed. 
Coal usage will increase if low-sulfur deposits in the Western states are developed and if current efforts to produce clean oil and low-Btu gas from coal and to desulfurize stack gases are commercially successful. Selective relaxation of evolving environmental standards, if they occur, will contribute further to increased usage.

Beyond the year 2000, it seems likely that mined tonnages will be so large that even higher consumption rates will be deterred not only by major contributions of other electrical energy systems and stricter environmental standards but also by limitations on the enormous amount of solids handling, from mining to waste disposal. 


\subsection{NATURAL GAS AND OIL}

As shown by the tabulation in the General Introduction, oil and natural gas supply jointly about $75 \%$ of the total energy consumed in the United States. During 1972, oil and gas supplied $15.6 \%$ and $21.5 \%$, respectively, of the total electrical energy generated. ${ }^{7}$ Projections of petroleum contributions to the total energy consumption ${ }^{77}$ and to the electrical-energy sector ${ }^{12}$ are shown in Table A.2-12. These projections, developed in 1972, are subject to a substantial margin of error, especially under present oil-import conditions. For example, a number of electric power plants which had only recently switched from coal to oil to meet environmental pollution standards, have been directed to switch back to coal because of the current shortages in oil supply.

Table A.2-12

PROJECTED CONTRIBUTIONS OF OIL AND NATURAL GAS TO TOTAL AND ELECTRICAL ENERGY CONSUMPTION

Contribution to energy use (\%)

$\begin{array}{lll}1975 & 1980 \quad 1985 & 2000\end{array}$

Total use

0 il ${ }^{a}$

Natural gas

Electrical use

$0 i 7^{2}$

Natural gas
43.8

31.4

43.9

28.1

43.5

24.3

37.2

17.7

ancluding natural-gas liquids. 
The proportion of world natural-hydrocarbon production represented by U.S. output is declining, and at the same time, our consumption has been increasing. 78 our recent import rate of crude $0 i 1$ and petroleum products was 6 to 7 million bbl/day. Even in 1970, our rate of consumption of natural gas exceeded the discovery rate; $;^{73,79}$ since the gas demand has grown faster than can be satisfied by domestic production, we have been importing substantial amounts of gas from Canada and Mexico, and these imports will be increased by the arrival of LNG (liquefied natural gas) from North Africa in the near future. The leveling off of domestic gas production during 1971 to 1973 led to an unsatisfied demand for energy that could be met only by oil in fact, only by imported oil. 79

The ratio of proven reserves to annual production for domestic natural gas has fallen ${ }^{78}$ from 37 in 1945 to about 12 in 1970; for domestic crude oil, this reserve ratio has declined ${ }^{75}$ during the same period from about 15 to about 10.

Estimates of the excess of U.S. oil and gas needs beyond domestic production in 1985 vary, but the consensus appears to be that the deficiencies, after allowing for Alaskan North Slope contributions, and for expected discoveries, will be quite large: ${ }^{74}$ around $16 x$ $10^{6}$ barrels of oil per day and up to $36 \times 10^{9} \mathrm{ft}^{3}$ of natural gas per day.* If this entire 1985 oil deficit were to be imported in 250,000-ton tankers, an armada of 350 such ships would be needed, Fthis does not consider oil that may become available from oil shale, which is considered separately in Section 2.3. 
and one would dock every two hours around the clock. ${ }^{74}$ If only one-third of the estimated 1985 gas deficiency of 36 billion $\mathrm{ft}^{3}$ per day were imported as LNG in 100,000 ton cryogenic tankers, a fleet of 120 would be required, one docking every ten hours. ${ }^{74}$

If the nation were to continue to rely as heavily in the future as in the past on natural fluid fuels, a growing import rate would be inescapable. Though the proven oil reserve of the world is large, amounting to 500 to 600 billion barrels, $16,79,80$ it is by no means uniformly distributed, since at least $60 \%^{79}$ and probably $70 \%$ of the secure reserve is in the nations of the Middle East and North Africa, concentrated in the Persian Gulf countries. Of total proved non-Communist world reserves, $82 \%$ lies in the Middle East and Africa. ${ }^{81}$ Further, it seems likely that the world's probable oil reserves - i.e., those yet to be discovered which will supply the needs of the coming decades, lie predominantly in the Middle East. 79 The same pattern holds for natural gas; of the world's proven reserve, less than $20 \%$ is in the United States. 16

To increase the resource base, the technology of the oil and gas industries is focused on exploration for new producing fields and on increasing fractional resource recovery by secondary and tertiary techniques. These methods include hydrofracturing tight gas sands and gas-bearing rock to increase the flow rate, and application of pressure to oil-bearing strata (or burning part of the oil in situ) to force out additional oil. 
Costs of oil and natural gas will almost certainly increase significantly in the future. Imported crude oil was selling in December, 1973 for $\$ 8$ to $\$ 9$ per barrel on the East and Gulf Coasts, a price double that of half a year earlier, and almost five times the price paid in $1963^{17}$, and is continuing to escalate. Regulation of wellhead gas prices by the Federal Power Commission may soon end, and the FPC has proposed that the field price of new-contract gas sold in interstate commerce be essentially deregulated. 31 such actions could lead to a doubling of the consumer price of natural gas from its present level of about $50 \%$ per thousand cubic feet. Natural gas imported in the future from new fields in the Alaskan and Canadian Arctic will probably cost at least $\$ 1.10$ per thousand cubic feet, transportation representing about three-fourths of the total cost. 31 In other words, natural-gas energy prices may be expected to double within one to two years.

To summarize, neither short-term nor long-term prospects for natural gas and oil in the U.S. energy economy are especially hopeful. It does not appear that continued extensive use of oil and gas as fuels for electric power plants is warranted. The current situation with regard to these fuels serves to highlight the need to develop alternative energy sources and to shift partially to other resource bases in order to preserve these fuels for transportation and residential uses, to reduce future balance-of-payments deficits, to minimize the perils of dependence on unreliable foreign imports of crude oil, petroleum products, and LNG, and to retain a sizable part of these dwindling 
domestic hydrocarbon supplies for petrochemical-industry feedstocks. This need is now well established and increasingly accepted as a current reality. 


\subsection{OIL SHALES}

\subsubsection{Introduction}

\subsubsection{General Description}

0il shale is a finely textured, sometimes laminated, sedimentary rock generally containing about one-third mineral matter. ${ }^{82}$ In the rich Colorado deposits, the shale is highly consolidated and impervious. Mixed with the marlstone host rock is a solid, insoluble, organic material called kerogen. The kerogen is a mixture of complex compounds, and a typical macromolecule is a polymer with a highly naphthenic structure 82 and a molecular weight exceeding 3000 . When oil shale is retorted (heated), the kerogen decomposes and yields a crude oil which can be upgraded and refined to give various products. The potential oil shale resource in the U.S. is large, and its possible development must, therefore, be considered an alternative energy option independent of oil available from conventional sources.

If a domestic shale-oil industry is developed, a portion of the fuel products (residual fuel oil and gas) from the refinery could be used to fuel a central station producing electric power. The essential elements of oil-shale surface processing are depicted in Fig. A.2-9. The remainder of a shale-oil-fired electric-energy system - i.e., the electrical transmission and distribution stages - would be similar to other systems as shown in Fig. A.2-9. The component efficiencies and environmental impacts of both controlled and uncontrolled electricenergy systems using oil (onshore and offshore domestic and imported) and natural gas are outlined in ref. 2 (pp. 46-54). 


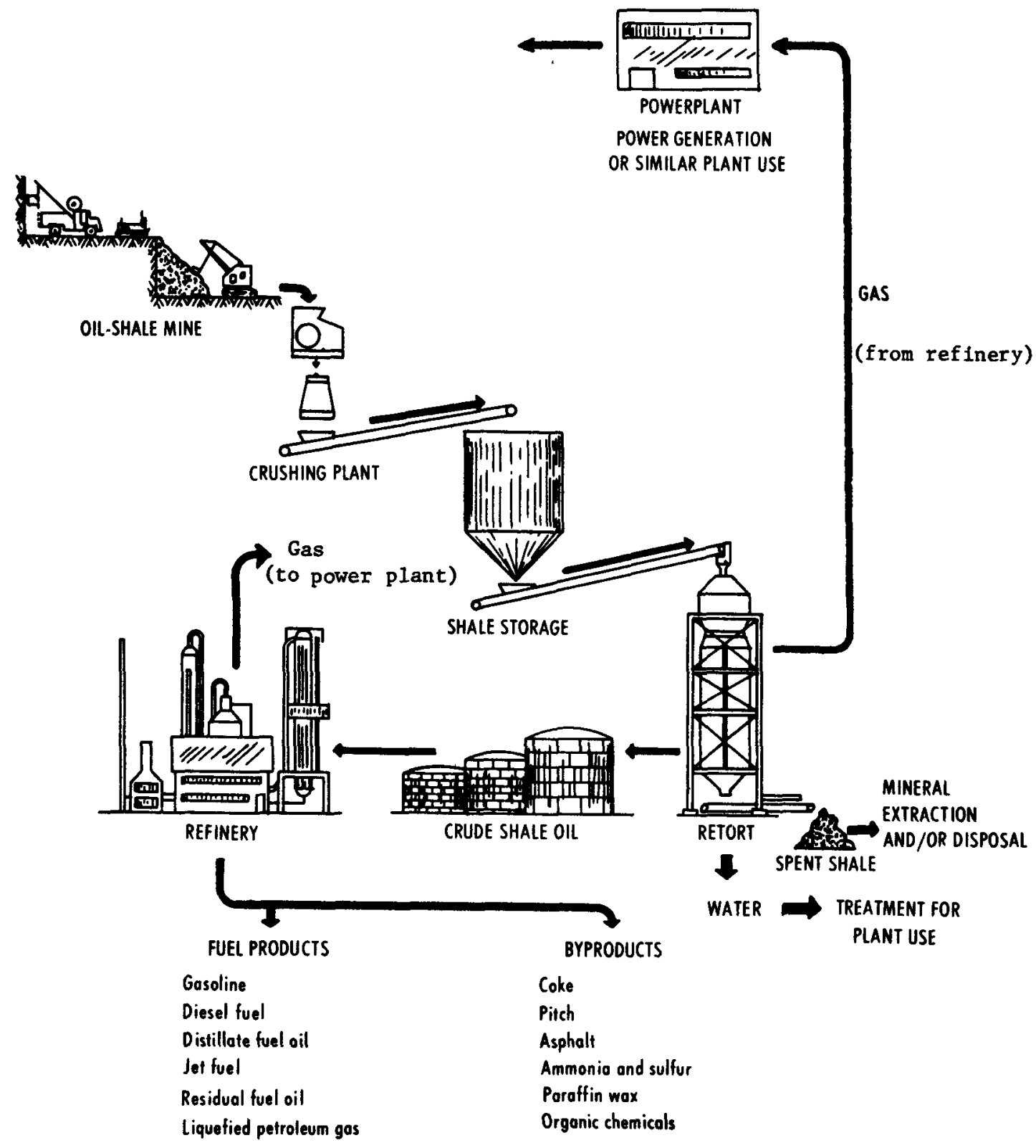

SCHEMATIC DIAGRAM OF OIL SHALE SURFACE PROCESSING

Figure A.2-9 


\subsubsection{Historical Aspects and Status}

of the eight oil shale industries which have been developed over the past one hundred years, only those in the Soviet Union and in mainland China are in existence today. Brazil currently has an experimental ofl shale plant operating at a 2500 tons/day rate. The maximum shale throughputs attained in industries of the past are listed in Table A.2-13, developed from Prien's historical review. ${ }^{83}$ Depletion of the deposit forced closure of the South African operation; in the other nations, the industries were discontinued for economic reasons when relatively inexpensive imported petroleum became widely available.

Table A.2-13

OIL SHALE INDUSTRIES OF THE PAST

\begin{tabular}{lcc}
\hline \multicolumn{1}{c}{ Nation } & Period of operation & $\begin{array}{c}\text { Peak shale throughput } \\
\text { (tons/year) }\end{array}$ \\
\hline South Africa & $1935-1962$ & $\sim 250,000$ \\
Australia & $1940-1952$ & 350,000 (1947) \\
France & Until 1957 & 500,000 (1950) \\
Spain & Until 1966 & $1,000,000$ (late 1950's) \\
Sweden & $1940-1966$ & $2,000,000$ \\
Scotland & $1862-1962$ & $3,300,000$ (1913) \\
\hline
\end{tabular}

Since the Soviet oil shale industry represents one of the greatest current users of this energy resource, an examination of its history and status is of interest. Of the 1971 Soviet production of about 
24 million tons of oil shale, $77 \%$ was mined in the Estonian S.S.R., where significant production of the rich kukersite shales began in the 1920's. The Soviet industry is estimated to have mined shale at an average annual rate of 13 million tons/year during the period 1945-1970. The primary production in the past has been from 15 underground mines, but large new open-pit mines with capacities to 9 million tons/year have been opened or approved, and open-pit mining will probably account, in a few years, for nearly half the total Soviet shale production, which is scheduled to increase to $30-35$ million tons/year by $1975 .^{83}$

About $60 \%$ of the shale mined has been burned directly for power generation in pulverized-shale boilers with capacities to 1625 MWe (the Baltic Thermal Power Station at Narva). Because of the high kerogen content (double to triple that of U.S. shales), the heating value of the solid fuel shale has been, since 1965, about 5800 Btu/lb. 83 However, about 40 wt $\%$ of the shale fed appears as stack-gas fly ash; and since the dust collectors have not operated efficiently, an "almost insurmountable air pollution problem has been created in the Estonian oil shale area." 83 To minimize this problem, the cleaner route of burning ash-free liquid and gaseous hydrocarbons from retorted shale is being considered.

The remaining $40 \%$ of Soviet oil shale mined is retorted to produce crude naphtha, petrochemical feedstocks, specialty products, and heating gas. The fuel gas, with an average heating value of 
$450 \mathrm{Btu} / \mathrm{ft}^{3}$, is produced in Estonia at a rate of 35 to 37 billion $\mathrm{ft}^{3} /$ year. 82,83 Two complexes, each processing 16 million tons of raw shale per year, were proposed in 1970 to generate electrical power and to produce chemicals. The current status of the proposals is unknown.

The nation processing the most oil shale is the People's Republic of China, in which production has been continuous since the 1920's. In 1970, 40 to 50 millition tons of shale were processed, primarily in Manchuria, where crude shale oil production has increased from 3600 barrels/day during World War II ${ }^{82}$ to perhaps 60,000 barrels/day in 1971. 83 Little more is known about the Chinese shale industry, but indications are that it is still expanding.

In the United States, no major shale-oil operation has yet been conducted, and views have been expressed 82,84 that Federal Government policies have discouraged adequate development and/or that it has been deliberately retarded by major petroleum company interests. 84 Most oil-shale lands are Federally owned and have been closed to leasing since 1930,82 although one lease was available in the 1960s; two bids were submitted, but both were rejected. The numerous and extraordinarily entangled technical, economic, political, legal, and institutional factors which have contributed to domestic shale lands remaining virtually untouched over the past 50 years have been addressed by Welles. ${ }^{84}$ 
Prien $^{83}$ rejects this obstructionist rationale and cites ample supplies of inexpensive petroleum products, the lack of a national energy policy, and uncertainties regarding shale-oil costs and environmental restraints as factors explaining the absence of a U.S. ofl shale industry. Prien concluded (in 1971), however, that "recent improvements in technology have reduced U.S. shale oil costs to the point where they are already more than competitive with new domestic petroleum. "83 A Final Environmental Statement on the prototype 011 Shale Leasing Program for private development of up to six parcels of public oil shale lands has been released, 85 and the leasing of these Government lands has begun. Bidding on the first tract lease was completed in January 1974; the highest bid of $\$ 210,000,000$ was submitted by Gulf 011 and Standard 011 of Indiana. The second tract release received a high bid of $\$ 117,700,000$ from The 0il Shale Corporation (TOSCO), Atlantic Richfield, Ashland 011, and Shale 0 il Company groups. The leasing program's goal, following development of a prototype industry with a capacity of about 250,000 barrels/day, is a mature industry producing $1,000,000$ barrels of shale oil per day by 1985.

\subsubsection{Qualitative Overview of Relative Merits}

Attractive features of oil shale include minimal exploration costs as compared with crude-oil production and a slightly higher hydrogen-tocarbon ratio than Canadian tar sands. ${ }^{4,75}$ Compared with oil from coal, oil-shale processes are simpler ${ }^{4}$ and at a more advanced stage of development, 51 and there is less apparent need to develop technically 
sophisticated methods for syncrude production. Because oil-shale beds are much thicker than coal seams, oil-shale mining would affect less acreage than mined coal with an equivalent energy content. 86 Raw oil from shale is relatively low in sulfur, 86 typically 0.7 to 0.8 wt $\%, 87$ and extensive desulfurization would not be required. Advocates have claimed ${ }^{84}$ that shale oil could be produced at a much lower cost than oil from coal. Other estimates ${ }^{4}$ do not support this claim, though some 51 indicate a significant advantage for syncrude from relatively rich oil shale. If in-situ (underground) retorting of oil shale is successfully developed, the difficult spent-shale disposal problem would be largely avoided; production costs would likely be less; and, compared with surface retorting, the oils produced will contain smaller quantities of heavy fractions, so they should be more amenable to further processing. 88

On the other hand, rich oil shale is not nearly as widely distributed across the nation as coal. Total process water requirements seem rather uncertain, the forecasts varying from 1.42 barrels to 4.50 barrels of water per barrel of shale oil. ${ }^{89}$ Though the sulfur content of crude shale oil is low, the nitrogen content is relatively high, averaging about 2 wt $\% .87$ Techniques for economically mining oil shale at high rates are less developed than those for coal; open-pit mining of deep, thick beds, for example, has not yet been demonstrated. ${ }^{4}$ In situ processing of oil shale $e^{4,82}$ will require the use of naturally occurring or artificially created permeability underground so that circulating gases can retort the shale in place. 
The spent shale from surface retorting amounts to 80 to $90 \mathrm{wt} \%$ of that processed; $4,83,90,91$ and since the volume of spent shale if uncompacted is about $50 \%$ greater than that of the in-place shale, and about $15 \%$ greater even after compaction, ${ }^{86,87}$ a massive solids-disposal problem results. In addition, the oil yield from U.S. shale, in terms of barrels per ton of solid processed, is only about one-third of that obtainable from coal.

\subsubsection{Extent of energy resource}

Though oil shale occurs in 30 states, $^{84}$ the richest deposits are concentrated in the Green River formation in Colorado, Utah, and Hyoming. On a basis of estimated total oil in place, the $1.8 \times 10^{12}$ barrels in this formation ${ }^{92}$ represent $82 \%$ of the $2.2 \times 10^{12}$ barrels $^{82}$ in the U.S. The Green River formation (Eocene in geologic age) underlies about 25,000 sq miles of semiarid, sparsely populated land, at an elevation of 5000 to $8000 \mathrm{ft}$. Of this area, about two-thirds is thought to be commercially developable in the foreseeable future. ${ }^{92}$ The richest regions in the formation are in the Piceance Creek (Colorado), Uinta (Utah), and Green River (Wyoming), basins.

In $\mathrm{places,} \mathrm{the} \mathrm{formation} \mathrm{is} \mathrm{up} \mathrm{to} 1800$ to $3500 \mathrm{ft}$ thick, under an overburden of 1000 to $3000 \mathrm{ft}^{84}$ Though yields vary from insignificant volumes to about 100 gallons (2-1/2 barrels) of oil per ton of shale, ${ }^{84}$ the usual range in the more commercially interesting regions is 15 to 35 gallons of raw oil per ton of shale, ${ }^{96}$ and a ton of shale yielding 30 gallons of raw oil is considered relatively 
rich. ${ }^{4}$ In the central portion of the Piceance basin, a 2000-ft bed which underlies about 1000 to $2000 \mathrm{ft}$ of barren overburden should produce an average of 25 gallons ( 0.6 barrel) of oil per ton of shale. 82

Approximately one-third of the Green River formation oil, or about 600 billion barrels, is in beds at least $10 \mathrm{ft}$ thick and assaying 0.6 barrels or more per ton of shale, ${ }^{92}$ an amount about two-thirds larger than the 1972 proved Middle East oil reserves of $355 \times 10^{9}$ barrels. ${ }^{80}$ If $5 \%$ of the Green River formation proves suitable for near term development, the equivalent shale oil reserve of $90 \times 10^{9}$ bbl would exceed twice the current proved U.S. liquid petroleum reserve of about $39 \times 10^{9}$ bbl. ${ }^{86}$ This vast quantity of oil, if significantly recoverable, could substantially ameliorate the national energy situation with regard to supply and economics.

Since present technology has not yet been utilized on a commercial scale, estimates of future availability using advanced technology would be extremely nebulous.

\subsubsection{Technical Description}

\subsubsection{Power Generation Plant}

Residual fuel oil and gas from a shale-oil refinery would be burned in standard radiant-type boilers to generate steam to drive a condensing turbine-generator set. The power plant characteristics 
would be essentially identical to those of current oil-and gas-fired units $^{93}$ as discussed in Section A.2.2. Standard provisions would probably be made for meeting peak power and emergency services requirements - i.e., pumped-storage installations, diesel enginegenerator units, and gas-turbine-driven generators. The combined gas-turbine-steam cycle described in Section A.2.1.3.1 would be a probable future variation.

\subsubsection{Fuel Cycle}

The relative state of the art for the various operations involved in ofl-shale processing is shown in Fig. A.2-10. This figure, as well as the others in Section A.2.3, was taken from ref. 87 .

\subsection{Mining, Transportation, Preparation, Retorting, and Refining}

Mining costs are expected to constitute a major fraction (perhaps $50 \%)^{83}$ of the total cost of shale-oil production. For thin, shallow seams, room-and-pillar deep mining has been demonstrated. ${ }^{4,87}$ Shale from thick, deep beds would probably be extracted by open-pit mining, or with the "cut and fill" technique, in which continuous cutters remove the shale in horizontal layers, and a portion (possibly twothirds) of the spent shale is recycled for floor material on which to operate as higher shale levels are reached. 


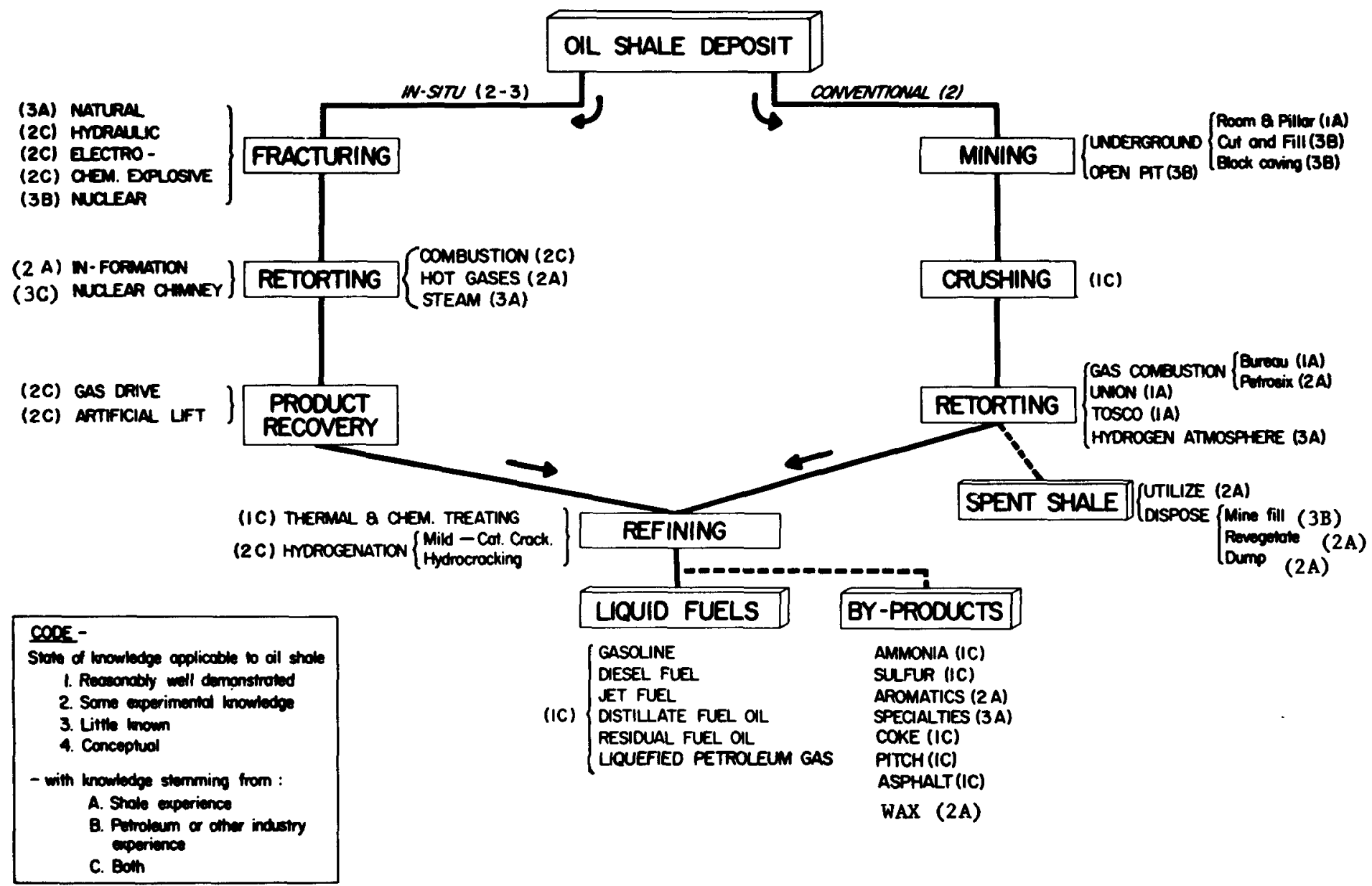

RELATIVE STATE OF KNOWLEDGE OF VARIOUS OPERATIONS REQUIRED IN OIL SHALE PROCESSING

Figure A.2-10 
Only recently has an appreciable effort been devoted to the in situ approach. There are a number of ways in which access to the shale can be achieved, heat supplied for retorting the shale, and the products recovered. However, so far only one -- a combined mining and collapse technique to prepare the shale for retorting followed by combustion with air to supply the required heat -- has been successfully demonstrated in an operation of sufficient size to indicate the possibility of near term commercial application.

In an underground mine system, the shale, following transportation to ground leve1, probably by conveyor belt, would be crushed and fed to a retort. Of the many surface retorting processes which have been proposed, only three have been developed in the United States to a significant extent and operated at a scale (maximum rates of 360 to 1200 tons of shale per day) ${ }^{83}$ that permits realistic evaluation. In addition, another system, the Petrosix process, has been operated at a 2500 ton/day rate in Brazil. The three U.S. systems (Bureau of Mines' Gas Combustion, Union 0il, and TOSCO II) are characterized by retorting-zone temperatures of about $900( \pm 50)^{\circ} \mathrm{F}, 4,84$ and local temperatures as high as about $2200^{\circ} \mathrm{F}$. These three retorting processes are shown schematically in Fig. A.2-11. 87 Extraction efficiencies, defined as percent of Fischer assay of the feed, have varied from 90 to $105 \% .4$ Interior Department estimates are usually based on an upgraded oil yield of $90( \pm 5)$ vol $\%$, based on in-place crude shale-oil potential. ${ }^{87}$ 


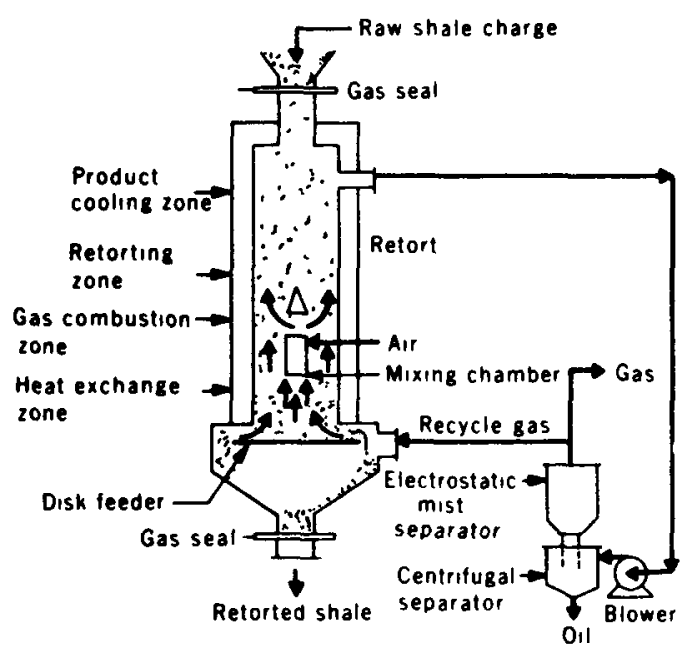

GAS COMBUSTION RETORT

Recycle gas is mixed with air and burned within the retort Gases flow upward and shale moves downward

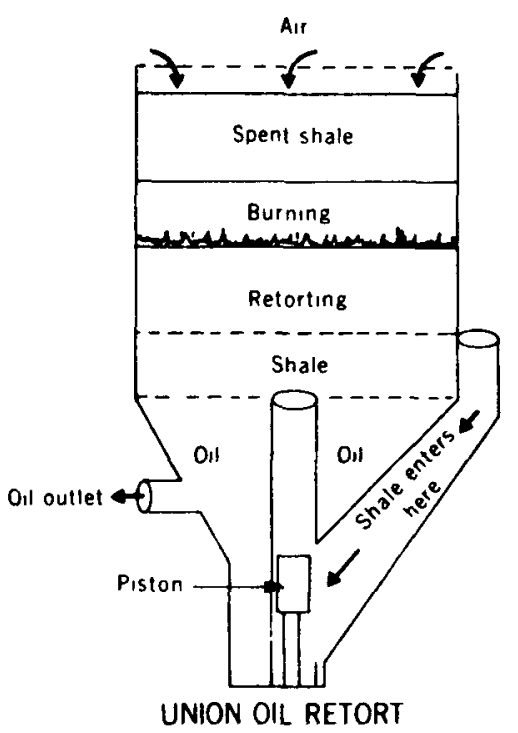

Shale is introduced near bottom of retort and forced upward Air enters at the top and flows downward

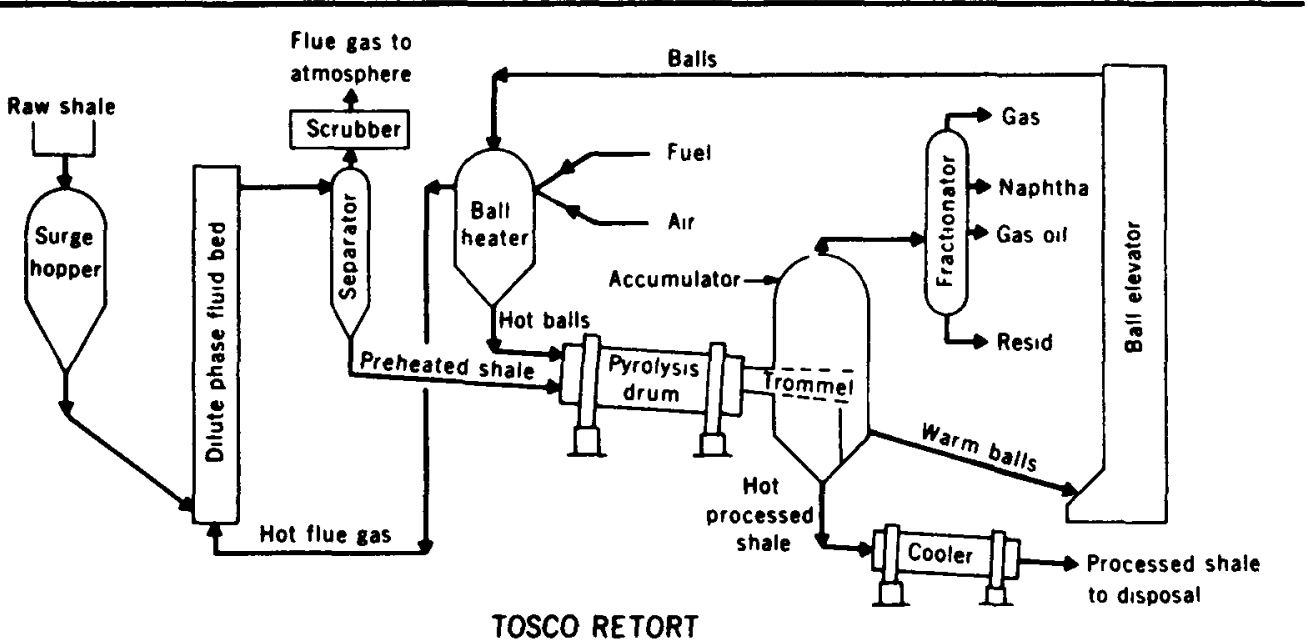

Ceramic balls transfer heat to the shale No combustion takes place in retort

\section{SCHEMATIC REPRESENTATIONS OF THREE OIL SHALE RETORTING PROCESSES}

Figure A.2-11 
The kerogen distills into about 66 wt $\%$ shale oil (usually a vapor initially), 25\% coke-like solid, and $9 \%$ combustible gas containing some hydrogen sulfide. ${ }^{84}$ The retort off-gas, which has a heating value of about $100 \mathrm{Btu} / \mathrm{scf}$, is usually recycled and burned to generate additional heat for retorting. 82 To prevent coking or clinkering and to optimize yields, some degree of temperature control is required in the preheating, combustion, retorting, and cooling zones of the retort chamber.

The raw oil - a dark, viscous liquid - would normally be upgraded, if destined for feedstock use, to reduce the viscosity and the dust, wax, nitrogen, and sulfur contents. ${ }^{4}$ Refining would follow standard petroleum industry practice to yield low-sulfur liquid fuels and by-products such as ammonia, sulfur, coke, pitch, asphalt, and aromatic chemicals. Hydrogenation at 400 to $1500 \mathrm{psi}$, which reduces sulfur to hydrogen sulfide and nitrogen to ammonia, gives a desulfurized product representing about 98 wt $\%$ of the raw shale oil. 82 The processing described increases the heating value of the shale as rock (about $2600 \mathrm{Btu} / 1 \mathrm{~b}$ for Colorado shale) ${ }^{82}$ to about $5.8 \times 10^{6} \mathrm{Btu} /$ barrel (about $18000 \mathrm{Btu} / \mathrm{lb}$ ) for product oil. ${ }^{9}$ The shale can also be hydrogasified, converting the kerogen to a methane-rich, $930+\mathrm{Btu} / \mathrm{ft}^{3}$ gas by reaction with hydrogen at pressures of 1200 to $2000 \mathrm{psi}$ and temperatures of 1000 to $1500^{\circ} \mathrm{F} .^{82,83}$ 


\subsection{Waste Processing and Disposal}

To supply a small 100,000 barrel/day oil plant would require the surface processing and disposal of about $45,000,000^{13}$ to $60,000,000^{17}$ tons of shale per year. For the same oil production, a plant processing tar sands would require about 70,000,000 tons of tar sand per year, ${ }^{13}$ whereas a coal liquefaction plant would require only about 13,000,000 tons of coal input per year. Though some of the spent shale ash might be used to make cement, cellular building block, rock wool, and mortar, as in Estonia, ${ }^{82}$ very large tailling volumes per unit of oil production would have to be disposed of by recycle to the mine, surface layer compaction, or dumping in nearby canyons.

For the reference 1000-MWe power plant of Fig. A.2-8, the approximate annual requirements of oil shale, tar sand, and coal, and the associated solid wastes would be those listed in Table A.2-14. The estimates do not include overburden.

Table A.2-14

APPROXIMATE ANNUAL TONNAGES OF SOLIDS PROCESSED AND OF ASSOCIATED SOLID WASTES FOR A-1000 MWe POWER PLANTa

\begin{tabular}{lcc}
\hline Fuel source & $\begin{array}{c}\text { Solids processed } \\
\text { (tons/year) }\end{array}$ & $\begin{array}{c}\text { Solid waste } \\
\text { (tons/year) }\end{array}$ \\
\hline $0 i 1$ shaleb & $13 \times 10^{6}$ & $11 \times 10^{6}$ \\
Tar sandc & $15 \times 10^{6}$ & $13 \times 10^{6}$ \\
Coal & $3 \times 10^{6}$ & $0.5 \times 10^{6}$ \\
Direct combustion & $4 \times 10^{6}$ & $1.5 \times 10^{6}$ \\
Solvent Refined Coal & $6 \times 10^{6}$ & $0.8 \times 10^{6}$ \\
Fuel oil from H-Coal process & & \\
a The reference power plant of Fig. A.2-8. & \\
byield: 0.8 barrel of oil per ton of shale. \\
cyield: 0.7 barrel of oil per ton of tar sand. \\
dusing light gas oil and heavier fractions as boiler feed (boiling \\
point $>400^{\circ} \mathrm{F}$ ).
\end{tabular}




\subsubsection{Energy Transmission}

The comments made in Section 2.1.3.3 are applicable, except that caloric oils and gases would in this case be derived from oil shale rather than from coal.

\subsubsection{Research and Development Program}

Areas worthy of research and development include new mining and ore-handling techniques; separation and utilization of associated minerals such as trona (sodium carbonate/sodium bicarbonate), dawsonite (sodium aluminum dihydroxy carbonate), and nahcolite (sodium bicarbonate); spent shale disposal and revegetation techniques; and fundamental heat transfer and fluid dynamics studies of gas flow through retorts with fixed and moving beds of crushed shale. To eliminate or minimize the spent-shale solids handling problem, research and development should be focused primary on in-situ retorting and the prefracturing by hydraulic pressurization (or chemical explosives) required to increase the shale porosity to allow adequate fluid flow between hot gas injection wells and nearby producing wells. The recent report on the Nation's Energy Future 47 discusses a five year R\&D program to increase the production of synthetic petroleum from oil shale by developing and demonstrating methods for processing oil shale in situ to recover liquid products. In situ retorting would be tested in the Rocky Mountain basins using a combination of several different fracturing techniques and retorting conditions. The recovery rates for each combination and the control problems encountered would be studied to determine optimum technical design. 


\subsubsection{Present and Projected Application}

The Interior Department's recently issued 3200-page, six-volume Final Environmental Statement for a proposed prototype oil shale leasing program $85,9,87$ describes a six-tract stepwise program for initial development of the Green River formation. It is estimated that about $5 \%$ of the $1.8 \times 10^{12}$ barrels of oil in place is suitable for near-term development. A prototype program aimed at production of 250,000 barrels/day would require about 13,000 acres of land over a 30-year period, with initial oil costs in the range of $\$ 3$ to $\$ 4$ per barrel. An extended development producing 1,000,000 barrels/day would require about 80,000 acres of land, and the projected oil production costs are about $\$ 2.25$ to $\$ 3$ per barrel. The larger production capacity, utilizing both public and private lands, and following introduction of second-generation extraction/retorting systems and possible initiation of commercial-scale in-situ retorting by the early $1980^{\prime} \mathrm{s}$, is thought by the Interior Department to be realizable by 1985. Other estimates place the probable 1985 production of shale oil at $300,000^{51}$ to 500,000 barrels/day. ${ }^{18}$ It is noted that production of 1,000,000 barrels/day would represent only $4 \%$ of the projected national crude-oil requirement for 1985.77

Hater availability will probably set the upper limit to the size of industry the region can sustain, and further increases in production would depend on technological improvements to reduce consumptive water requirements. Long-term upper limits to shale-oil production 
which have been suggested span the range of $3 \times 10^{6}$ barrels/day ${ }^{51}$ to $5 \times 10^{6}$ barrels/day. ${ }^{91}$

\subsubsection{Environmental Impacts}

The environmental impacts caused by both controlled and uncontrolled energy conversion plants using oil and gas are described in references 2 (pp. 46-54), 93 and 94 .

Environmental impacts caused by off-site support activities and facilities (mining, retorting, upgrading, and refining, for example) are described in considerable detail in the Interior Department's Final Environmental Statement. Since the land area involved in the prototype oil shale leasing program is relatively small and distributed among six designated tracts, two in each of three adjacent states, the site-specific features of the impacts could be included in the Statement and are treated in some depth. The effects on the regional environment include those on land, water, air, and flora and fauna. Aesthetic, recreational, cultural, economic, and social impacts are also considered.

Other than the spent-shale waste disposal problem, the major physical impacts are runoff water pollution and water usage. Sodium and calcium salts leached from spent-shale waste piles by melted snow and summer showers could enter surface water and deteriorate its quality. This would presumably be mitigated by leveling, compacting, and replanting 
the refuse piles. Process gases are expected to be amenable to standard gas-treating methods developed for other industries. 88 Critical barriers are not foreseen in these areas, ${ }^{91}$ but adequate definition and solution of such problems will require a continuing effort.

Water-requirement estimates for processing, including mining and crushing, retorting, oil upgrading, processed-shale disposal, power, revegetation, and sanitation, vary from a minimum of 1.4 to a maximum of 4.5 barrels of water per barrel of shale o11..$^{89}$ For a 1 million barrel/day capacity, the most likely water consumption rate has been estimated to be about 3 barrels of water per barrel of shale oil (3.3 as derived from ref. 86 and an average value of 2.9 from ref. 89). For a 1000-MWe power plant, shale-oil-fired, a processing water requirement of 3 barrels per barrel of oil would correspond to about $172 \times 10^{6} \mathrm{ft}^{3}$ of water per year.

The best current estimates of irreversible and irretrievable commitments of resources are in the Interior Department's 1973 Final Environmental Statement (Volumes I and III). These include essentially permanent dedication of land surface to extraction, processing, and waste disposal, surface disruption not fully reclaimable, and regional disturbances of ecological balances. 


\subsubsection{Costs and benefits}

\subsubsection{Shale oil costs}

The costs and benefits of oil from shale in the electrical energy sector seem quite uncertain, since so little experience has been accumulated in the United States in developing this resource on a large scale. Recent estimates of future production costs of shale oil are given in Sect. 2.3.5. A 1968 Soviet estimate of $\$ 2.85$ per barrel has been cited. ${ }^{83}$ In June 1971, The 011 Shale Corporation (TOSCO) announced an estimated cost of $\$ 1.95$ per barrel at the plant gate, 83 including "all environmental protection systems, the recovery of by-products, inflation through 1974, and depreciation...." for a 66,000 -ton/day plant processing shale assaying 0.86 barrel of oil per ton and producing 53,000 barrels/day of premium (upgraded) shale crude, which in turn was estimated to have a market value of $\$ 4.15 /$ barrel (including $\$ 0.20 /$ barrel by-product credits). Prien estimates that environmental protection costs for a new shale industry (one not requiring more expensive retrofit measures) will be about $6 \%$ of the production cost. ${ }^{83}$

In view of current and anticipated petroleum costs, shale oil at the estimated production costs would indeed be "more than competitive." 83

\subsubsection{Development Costs}

To attain a significant production level by the mid- to late 1980 's, a development cost, through 1980 , of approximately $\$ 200$ million has been suggested by some as a minimal requirement. This sum would be 
spent primarily for development of fracturing technology and in-situ retorting, but would include amounts for refining surface processing and assessing more accurately the rich oil shale resource. The five year R\&D program discussed in reference 47 and summarized in Section A.2.3.4 of this Chapter would cost $\$ 128$ million for investigation of in situ combustion.

\subsubsection{Benefits}

The major benefit of developing an oil-shale industry would probably be its ability to supplement available supplies of motor fuels. This complementing of conventional domestic fuel supplies would also reduce dependence on imports, thereby improving the Nation's balance of payments position. The prospect of using shale oil fractions as fuel for significant electrical power generation, except for limited use by some western utilities, seems small.

\subsubsection{Overall Assessment of Role in Energy Supply}

\subsubsection{Probable Role Up to the Year 2000}

To the year 2000, successful development of the technology could result in oil extracted from shale making an appreciable contribution toward alleviating though not eliminating the Nation's shortage of domestic oil. 


\subsubsection{Probable Role After the Year 2000}

Beyond the year 2000 , it seems probable that fuels from oil shale will contribute a declining portion of the total energy requirement as other energy systems grow in importance. 


\subsection{OTHER FOSSIL FUELS - DOMESTIC TAR SANDS}

Tar sands, also known as oil sands and bituminous sands, are rocks whose interstices contain viscous to semisolid to solid hydrocarbon material which in its natural state is not recoverable by primary (i.e., conventional) crude-oil production techniques. The rock types range from consolidated and unconsolidated sandstone to shale, dolomite, limestone, and conglomerate. ${ }^{91}$ The nonfluid bitumen (tar) content may be as high as 25 wt. $\%, 96$ but is usually considerably lower, and a deposit with $14 \%$ or more bitumen is considered rich. ${ }^{4,75}$

Until 1967, only four of the world's major tar sand deposits had been exploited - LaBrea (Trinidad), Selenizza (Albania), Derna (Romania), and Cheildag (U.S.S.R.) - and none on a large commercial scale. 97 The first major venture for producing syntheitc crude from tar sands was begun that year by Great Canadian 0il Sands, Ltd. (GCOS), in the Athabasca area in the northeastern part of the Province of Alberta, Canada. The Athabascan deposit, which contains over 700 billion barrels of bitumen, is the world's largest, 97,98 and the only other really sizable deposits occur in eastern Venezuela in the Orinoco Tar Belt and in the Llanos area of Colombia. ${ }^{99}$ The South American deposits, each estimated to contain in excess of 500 billion barrels of in-place tar, have not been defined or validated to the same degree as those in Alberta. ${ }^{99}$

U. S. tar sands are not comparable to those of Canada in extent. The maximum estimates of in-place resource are in the range of 27 to 29 
billion barrels of bitumen. $96,99,100$ of this total, estimates of the proved and currently recoverable reserve in surface and nearsurface deposits amenable to known mining methods vary from a minimum of $\sim 1$ billion barrels ${ }^{75,76,101}$ to a maximum of $\sim 5$ billion barrels. 102 The higher estimate is based $n$ unverified reserve estimates for seven states available in the literature in 1964.

At least $95 \%$ of the estimated U.S. resource is located in Utah in five major deposits 96,100 ; and the state with the second largest resource base, California, contains only $\sim 7 \%$ of the national total. 96

Descriptions of the extraction and processing techniques presently used in Canada are widely available. ${ }^{98,103}$ In brief, track-mounted bucket-wheel excavators strip the surface sands, to a proposed depth of about $150 \mathrm{ft}$. , and transfer them to a conveyor belt feeding a hot-water extraction plant. About 3.5 tons of sand and overburden must be moved for each barrel of syncrude produced. 99 The separated crude bitumen is upgraded to a synthetic crude suitable for standard refining operations by hydrogen enrichment either by coking and hydrogenation of the coker distillates or by hydrovisbreaking folwed by hydrogenation of the visbreaker distillates. ${ }^{4,99}$ Based on the proven Athabascan-field recoverable reserve, to a depth of $150 \mathrm{ft}$., of 74 billion barrels of crude bitumen, an extraction efficiency of $\sim 51 \%$, and a combined efficiency for bitumen separation and conversion to syncrude of $70 \%$, GCOS anticipates a potential recovery of $\sim 27$ billion barrels of syncrude. ${ }^{103}$ Total Canadian production of syncrude 
from all operations is expected to attain $\sim 800,000 \mathrm{Bbl} /$ day by 1985 and ultimately to reach a level of perhaps 3 million $\mathrm{Bbl} /$ day. ${ }^{103}$

Several factors are likely to delay significant production of syncrude from domestic tar sands, including the large Utah deposits:

a. Reserves of domestic coal and oil shale are much larger, as are their oil yields.

b. The Utah sands are believed to be harder (more consolidated) and therefore more difficult to produce than those of Alberta.

c. Average overburdens are thicker in Utah than in Alberta, which sharply limits large-scale surface mining and would require the successful development of in-situ recovery methods usable on a commercial scale. Estimated bitumen recovery efficiencies by in-situ techniques such as steamemulsion drive or "fire-flooding" are significantly lower than those for surface extraction. 99

d. Most of the Utah deposits underlie federal lands and appropriate leasing arrangements would be necessary. In addition, public-use proposals have already been made for much of the subject surface area in Utah.

e. Water supplies may be insufficient for significant exploitation.

The role of syncrude from domestic tar sands in the future U.S. energy supply seems at best a minor one. Assuming 4 billion barrels as the 
proved in-place reserve and using the recovery factors estimated for the Athabasca field, syncrude production would total 1.43 billion barrels, which over a 15-year period, would correspond to an average output of only $260,000 \mathrm{Bb} 1 /$ day. Summarized projections of others include "not significant, 76 "little incentive to develop the deposits in the near future," 96 significant production improbable before 1985,100 and "unlikely that such deposits will significantly affect the total U.S. energy supply... even to the year $2000, " 99$

Canadian deposits will be the primary and probably the only North American source of tar-sand oil until at least 1985,96,99 and negotfations to provide the U.S. with a share of this resource have been recommended. 104 


\subsection{REFERENCES}

1. M. K. Udall, America's Energy Potential: A Surmary and Explanation, Subcommittee on the Environment for Use of the Committee on Interior and Insular Affairs, U.S. House of Representatives, 93rd Congress, 1st Session, U.S. Government Printing Office, October 1973.

2. Council on Environmental Quality, Energy and the Environment: Electric Power, U.S. Government Printing Office, August 1973, pp. 40-45.

3. R. E. Lapp, "The Chemical Century," Bull. Atomic Scientists, pp. 8-14, September 1973.

4. H. C. Hottel and J. B. Howard, New Energy Technology - Some Facts and Assessments, the M.I.T. Press, Cambridge, Mass., 1971.

5. Council on Environmental Quality, op. cit. (ref. 2), p. 7.

6. U.S. Department of Health, Education, and Welfare, Control Techniques for Sulfur Oxide Air Pollutants, U.S. Government Printing Office, January 1969, Table 4-1.

7. Federal Power Commission News, 6(26): 13 (1973).

8. W. G. Dupree, Jr., and J. A. West, United States Energy Through the Year 2000, U.S. Department of the Interior, U.S. Government Printing Office, December 1972, Table 5.

9. U.S. Department of the Interior, Final Environmental Statement for the Prototype 0il Shale Leasing Program, vol. II of VI, "Energy Alternatives," Chapter 5, Sect. B.5, "Coal," U.S. Government Printing Office, Aug. 30, 1973, pp. V-103 to V-142.

10. Directorate of Regulatory Standards, U.S. Atomic Energy Commission, Nuclear Power, 1973-2000, WASH-1139(72), U.S. Government Printing Office, Dec. 1, 1972, p. 4.

11. Federal Power Commission, The 1970 National Power Survey, U.S. Government Printing Office, December 1971, Part I, p. I-5-7.

12. W. G. Dupree Jr., op. cit. (ref. 8), Tables 8 and 10.

13. H. E. Risser, Gasification and Liquefaction - Their Potential Impact on Various Aspects of the Coal Industry, I11inois State Geological Survey, Circular 430, 1968. 
14. Bureau of Mines, U.S. Department of the Interior, Minerals Yearbook, 1964, vol. 1, "Metals and Minerals," Washington, D.C., 1965.

15. City of Seattle, Power Generation Alternatives, 2nd ed., October 1972, p. 18.

16. H. C. Hottel and J. B. Howard, "Mixture of Data on Energy Resources", New Energy Technology Seminar, American Institute of Chemical Engineers Today Series, Philadelphia, Pa., Nov. 14, 1973.

17. "Enough Energy - If Resources are Allocated Right," Business Week, Sp1. Rept., Apr. 21, 1973, pp. 50-60.

18. International Petroleum Encylcopedia, Petroleum Publishing Company, Tulsa, Ok1a., 1973, pp. 4-9.

19. Senate Committee on Interior and Insular Affairs, 1971, The President's Energy Message, A National Fuels and Energy Policy Study: Hearings, U.S. 92nd Congress, 1st Session.

20. Bureau of Mines, U.S. Department of the Interior, Strippable Reserves of Bituminous Coal and Lignite in the United States, Information Circular 8531,1971, p. 15.

21. The Chase Manhattan Bank, Outlook for Energy in the United States to 1985, New York, June 1972, p. 47.

22. First International Symposium on Jet Cutting Technology, Papers E1, E2, and E4, Coventry, England, Apr. 5-7, 1972.

23. G. A. Gaffert, Steam Power Stations, 4th ed., McGraw-Hill, New York, 1952.

24. The Babcock \& Wilcox Co., Steam: Its Generation and Use, New York, 1972.

25. Federal Power Commission, op. cit, (ref. 11), pp. I-8-5 and I-8-7.

26. U.S. Environmental Protection Agency (Sponsor), Proceedings of Third International Conference on Fluidized-Bed Combustion, Sessions I-IV, College Corner, Ohio, Oct. 29-Nov. 1, 1972.

27. Federal Power Commission National Power Survey, Report on Candidate Energy Conversion R\&D Projects (draft), Sect. 1.A.3, "Fluidized-Bed Combustion," May 1973.

28. Federal Power Commission, op. cit. (ref. 11), pp. I-9-3 to I-9-5. 
29. Federal Power Commission National Power Survey, Report on Energy Conversion Technologies (draft), Sect. 1.0, "Advanced Gas Turbine - Steam Cycles Including Coal and 011 Gasification," May 1973.

30. Federal Council for Science and Technology, Committee on Energy R\&D Goals, Panel Report on Extraction of Energy Fuels, Sect. VI - "Primary Extraction of Coal" (draft), June 1972.

31. Division of Reactor Research and Development, U.S. Atomic Energy Commission, Risk-Cost-Benefit Study of Alternate Sources of Electrical Energy (draft), WASH-1224, August 1973, Sect. 3.2.

32. U.S. Dept. of Health, Education and Welfare, op. cit. (ref. 6), pp. 35 and 37.

33. Bureau of Mines, A. W. Deurbrouck, Sulfur Reduction Potential of the Coals of the United States, Report of Investigations No. 7633, U.S. Government Printing Office, Washington D.C., 1972.

34. J. W. Leonard and D. R. Mitchell, Eds., Coal Preparation, American Institute of Mining, Metallurgical, and Petroleum Engineers, 1968.

35. "Hydraulic Transport of Minerals," Mining Magazine, April 1972.

36. "Coal Slurry Burns Without Drying," Chem. Eng. News, p. 35, Nov. 13, 1961.

37. Weekly Energy Report, p. 4, Oct. 22, 1973.

38. G. Bougie, "North Dakota Lignite Burns Cleanly in Cyclone Furnace," Power Engineering, pp. 62-65, November 1973.

39. S. L. Soo, "A Critical Review on Electrostatic Precipitators," AIChE Sympos. Series 68(126): 185 (1972), pp. 185-193.

40. U.S. Dept. of Health, Education and Welfare, op. cit. (ref. 6), p. 49.

41. Staffs of ORNL, OVEC, and AEPSC, Study of Options for Control of Emissions from an Existing Coal-Fired Electric Power Station, ORNL-TM-4298, September 1973.

42. R. B. Engdahl et al., "SO Control: Low-Sulfur Coal Still the Best Way," Power Engineering, pp. 72-76, November 1973.

43. Federal Power Commission National Power Survey, Sect. I.A.1, Stack Gas Cleaning $\left(\mathrm{SO}_{2}\right)$ (draft), March 1973. 
44. Office of Coal Research, 1973 Annual Report for Calendar Year 1972, "Clean Energy from Coal - A National Priority," Feburary 1973, p. 14.

45. L. Lessing, "Capturing Clean Gas and 0i1 from Coal," Fortune, November 1973, pp. $129 \mathrm{ff}$.

46. National Science Foundation Energy Task Force, An Assessment of New Options in Energy R\&D, (draft summary), June 1973.

47. WASH-1281, The Nation's Energy Future, A Report to the President of the United States by The Chairman, U.S. Atomic Energy Cormission, December 1973.

48. W. G. Dupree Jr., op. cit. (ref. 8), Table 18, p. 33.

49. FNderal Power Commission, op. cit. (ref. 11), p. I-4-2.

50. National Petroleum Council, U.S. Energy Outlook, Fuels for Electricity, 1973.

51. H. R. Linden (Inst. of Gas Technology), as reported in "Synthetic Fuels: What, When?", Chem. Eng., pp. 64-65, April 17, 1972.

52. The Chase Manhattan Bank, op. cit. (ref. 21), p. 46.

53. C. Bagge (National Coal Association), as reported in ref. 17, p. 55 .

54. Derived from ref. 7 and ref. 8 (p. 19).

55. Federal Power Commission National Power Survey, Sect. I.A.5, Summary Report on Stack Gas Dispersion Modeling and Experimental Verification (draft), May 1973.

56. Federal Power Commission National Power Survey, Energy Conversion Task Force, $R$ and D Technical Advisory Conmittee, Sect. II-B, Advanced Steam Generator Furnaces (draft), April 1973.

57. Federal Power Commission National Power Survey, Report on Energy Conversion Technologies, Sect. II.C.1, Alkali Metal Topping Cycle for Central Station Steam Powerplants (draft), April 1973.

58. Federal Power Commission National Power Survey, Report on Energy Conversion Technologies, Sect. II.C.2, Steam-Ammonia Cycle (draft), June 1973.

59. Federal Power Commission National Power Survey, Report on Energy Conversion Technologies, Coal Gasification (draft), June 1973. 
60. Report to Office of Science and Technology Overview Pane1, Clean Fuels from Coal (draft), November 1972.

61. C. L. Wilson, "A Plan for Energy Independence," Foreign Affairs, pp. 657-675, July 1973.

62. National Coal Association, Bituminous Coal Data, Washington, D.C., 1971.

63. National Coal Association, Coal Traffic Annual, Washington, D.C., 1970.

64. C. Starr and M. A. Greenfield, Public Health Risks of Thermal Power Plants, Report UCLA-ENG-7242, May 1972, p. 19.

65. C. S. Cook, "Energy: Planning for the Future," American Scientist, pp. 61-65, January-February 1973.

66. Council on Environmental Quality, op. cit. (ref. 2), p. 11.

67. "NAS: Water Scarity May Limit Use of Western Coal," Science, p. 525, Aug. 10, 1973.

68. National Coal Association, Bituminous Coal Facts, Washington, D.C., 1970.

69. W. E. Poel et al., "Carcinogenic Coal Tar Distillates," Proc. Amer. Assoc. Cancer Res., Vol. 2, No. 40, 1955.

70. W. C. Hueper, "Experimental Carcinogenic Studies on Hydrogenated Coal 0ils, I. Bergius 0ils," Industrial Medicine and Surgery, pp. 51-55, February 1956; II. Fischer-Tropsch 0ils, Ibid., October 1956, pp. 459-462.

71. R. J. Sexton et al., "The Hazards to Health in the Hydrogenation of Coal," Archives of Environmental Health, pp. 181-233, September 1960.

72. A. V. Slack, "Removing $\mathrm{SO}_{2}$ from Stack Gases," Environ. Sci. \& Technol., pp. 110-119, February 1973.

73. C. W. Draffin, Jr., and J. B. Howard, "Coal Gasification and Processing: Low-Btu gas," Position Paper No. 10, Task Force on Technical Aspects of the Federal Power Commission's Technical Advisory Committee on Conservation of Energy, Aug. 10, 1973.

74. H. C. Hottel, "Challenges in Production of Fossil Fuels," Chemical Engr Progress 69(6): 35-39 (1973).

75. H. C. Hottel and J. B. Howard, "New Energy Technology Seminar," A.I.Ch.E. Today Series, Philadelphia, Pa., Nov. 14, 1973. 
76. H. C. Hottel, "Combustion \& Energy for the Future," Plenary Lecture, Fourteenth Symposium (International) on Combustion, Pennsylvania State University, August 1972.

77. W. G. Dupree Jr., op. cit. (ref. 8), Table 6, p. 17.

78. E. N. Tiratsoo, Natural Gas - A Study, 2nd ed., Chapter 16, Scientific Press Ltd., Beaconsfield, England, 1972.

79. J. E. Akins, "The Oil Crisis: This Time the Wolf is Here," Foreign Affairs, pp. 462-490, April 1973.

80. Time, Economy and Business, p. 95, Nov. 19, 1973.

81. R. C. Gunness, "The Energy Crisis: Real or Imaginary?", pp. 13-19 in Declining Domestic Reserves - Effect on Petroleum and Petrochemical Industry, A.I.Ch.E. Symposium Series, Vol. 69, No. $127,1973$.

82. R. E. Gustafson, "Shale $011, "$ pp. $1-20$ in vol. 18 of Encyclopedia of Chemical Technology, 2nd ed., Interscience, New York, 1969.

83. C. H. Prien, "Current Developments in World 011 Shale Technology," 42 pages, Reports from a Symposium on the Science and Technology of Shales, Curitiba, P.R., Brazi1, Dec. 12-17, 1971.

84. C. J. Welles, The Elusive Bonanza, The Story of Oil Shale America's Richest and Most Neglected Natural Resource, E. P. Dutton \& Co., New York, 1970.

85. Weekly Energy Report, pp. 2-3, Sept. 3, 1973.

86. Council on Environmental Quality, op. cit. (ref. 2), pp, 22-23.

87. U.S. Department of the Interior, Final Environmental Statement for the Prototype 0 il Shale Leasing Program, Vol. I (of VI), "Regional Impacts of 011 Shale Development," pp. I-1 to I-5i, U.S. Government Printing Office, Aug. 30, 1973.

88. G. U. Dinneen, "Recent Research of the Bureau of Mines on the Recovery of Shale 0 il from the Green River Formation," 39 pages, Reports from a Symposium on the Science and Technology of Shales, Curitiba, P.R., Brazi1, Dec. 12-17, 1971.

89. U.S. Dept. of Interior, op. cit. (ref. 87), pp. III-34 to III-44.

90. U.S. Dept. of Interior, op. cit. (ref. 87), p. VII-1. 
91. J. W. Watkins, G. A. Mills, and J. E. Phillips, "Outlook for Hydrocarbon Production from Domestic Oil Shale, Coal, and Tar Sands," pp. 32-34 in Declining Domestic Reserves - Effect on Petroleum \& Petrochemical Industry, A.I.Ch.E. Symposium Series, vol. 69, No. 127, 1973.

92. U.S. Dept. of Interior, op. cit. (ref. 9), p. IV-1.

93. Council on Environmental Quality, op. cit. (ref. 2), pp. 46-54.

94. Division of Reactor Research and Development, op. cit. (ref. 31), Sects. 3.3 and 3.4 .

95. Derived from Council on Environmental Quality, op. cit. (ref. 86), pp. 22-23.

96. National Petroleum Council, U.S. Energy Outlook, 011 Shale Avallability, 1973.

97. W. B. Cashion, "Bitumen-Bearing Rocks," pp. 99-103 in "United States Mineral Resources," United States Geological Survey Professional Paper 820, 1973.

98. P. H. Phizackerley and Z. O Scott, "Major Tar Sand Deposits of the World," pp. 551-571 in Seventh World Petroleum Congress, Proceedings, Vol. III, Elsevier Publishing Co., 1967.

99. F. W. Camp, "Tar Sands," pp. 682-732 in Vol. 19 of Encyclopedia of Chemical Technology, 2nd Ed., Interscience, New York, 1969.

100. Tar Sands Task Group Report, Chapter 12, pp. 171-182, in U.S. Energy Outlook, An Initial Appraisal, 1971-1985, Summaries of Task Force Groups, Vol. 2, National Petroleum Council, Nov. 1971.

101. Ref. 9, "Tar Sands," pp. V-157 to V-160.

102. Ref. 99, p. 174 .

103. Ball Associates, Ltd. (Compilter), "Surface and Shallow 011Impregnated Rocks and Shallow Oil Fields in the United States," U.S. Bureau of Mines Monograph 12, 1965.

104. "Industry Gearing Up for Assault on Athabasca Tar Sands," 011 and Gas Journal, pp. 85-86, Feb. 4, 1974.

105:. Weekly Energy Report, p. 8, Feb. 11, 1974. 


\section{A.3 HYDROELECTRIC POWER SYSTEMS}

\subsection{Introduction}

\subsubsection{General Description}

Hydroelectric generating systems are conceptually simple. Water is directed into an hydraulic turbine, where it impinges on the blades or buckets of a waterwheel, as Fig. A.3-1 11lustrates. The energy associated with the flow of the water causes the wheel to rotate and is thus transferred through a rotating output shaft to an electric generator.

In most hydroelectric installations, large dams are built to store water in reservoirs; the dams provide control of the hydraulic head (the difference in elevation between the upstream and downstream water levels) and of the flow rate through the turbines. In this way, the available head can be localized at the dam, and water can be used as required and at a flow rate through the turbines which can be much greater than the normal flow of the river.

An extension of this technique is based on the pumped-storage concept. During periods of low power demand, and where power from other sources is available, the turbine-generator is used as a motor-pump to pump water up into a reservoir for release to the turbines during periods of greater electrical-power demand. By use of low-flow rivers or lakes as the original water supply, pumped-storage plants can be located in areas unsuitable for conventional hydroelectric plants. 


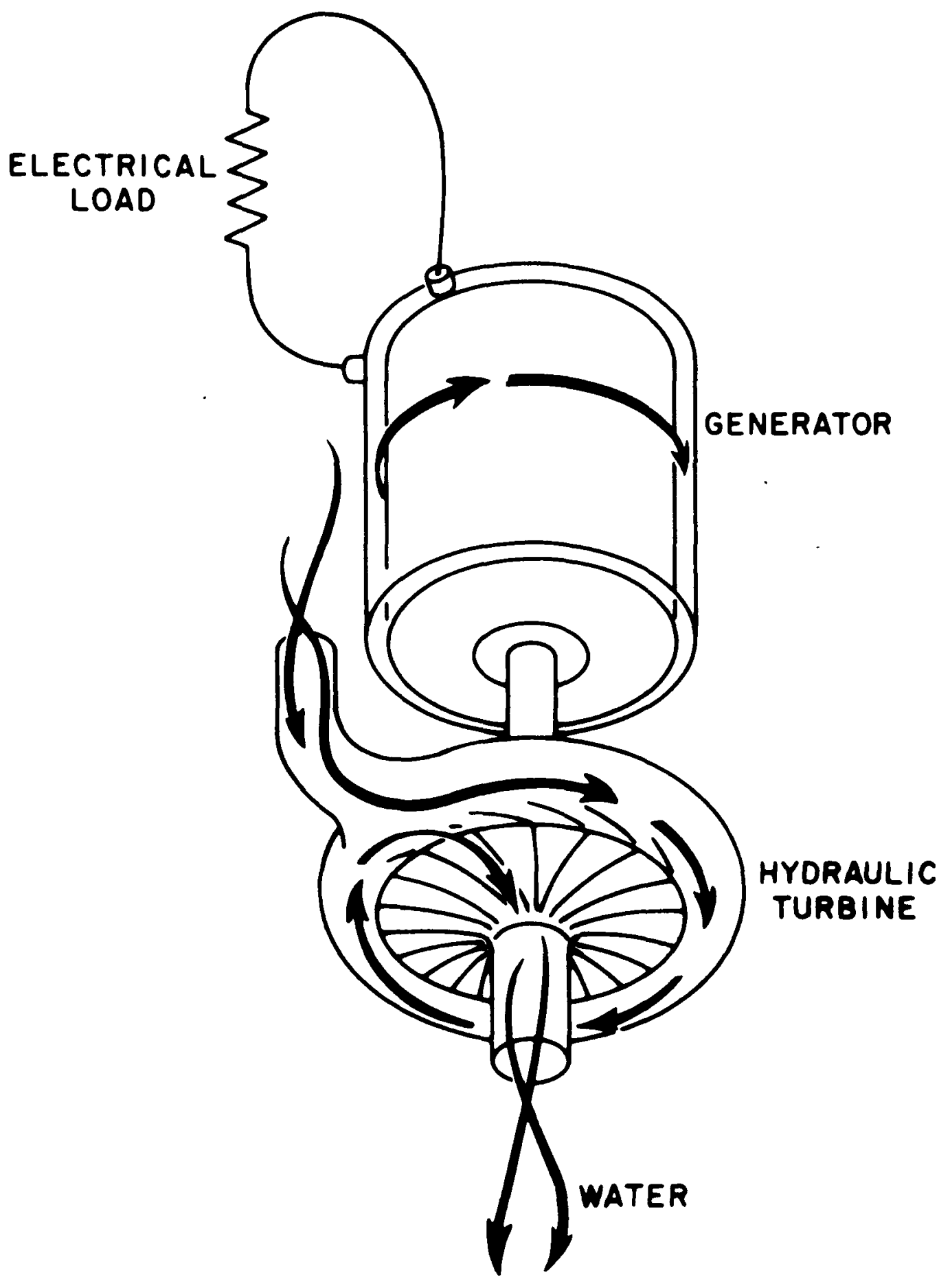

SCHEMATIC OF A HYDROELECTRIC GENERATING SYSTEM

Figure A.3-1

A. 3-2 


\subsubsection{History}

The generation of electrical power from water power in the United States occurred first on the Fox River in Wisconsin in 1882. The rapid expansion of hydroelectric power generation after 1910 is credited as being one of the most striking engineering accomplishments of the first half of the twentieth century.

Most early hydroelectric plants were used to satisfy base-load electrical needs. About 30 years ago, hydroelectric power constituted $30 \%$ of the United States' electrical capacity and supplied $40 \%$ of the electrical energy. ' Although the absolute capacity of hydro plants has continued to expand, hydroelectric's fraction of total electrical capacity is declining, and the trend is to use the hydro plants as peaking units.

\subsubsection{Status}

As of January 1971, the total installed conventional hydroelectric power was 51,900 MWe, which was about 15\% of the total United States' generating capacity. ${ }^{2}$ About $46 \%$ of the conventional hydroelectric capacity is in the Pacific Coast States of Washington, Oregon, and California. 3 The Columbia River Basin alone provides $33 \%$ of the total United States hydro capacity.

Despite the continuing increase in total conventional hydroelectric capacity, the number of active hydroelectric plants is actually decreasing. Many older plants with small capacities are being retired. The new plants tend to be of large capacity. The largest hydroelectric generating station in the United States is the John

$$
\text { A.3-3 }
$$


Day Dam, built by the Corps of Engineers on the Columbia River. The 2272-Mke plant went into operation in 1972 and has 16 hydroelectric generator units, each rated at 142 MWe.

Another significant trend in hydroelectric power is the increasing importance of pumped-storage plants. ${ }^{3}$ The first pumped-storage plant, the Rocky River plant in Connecticut, was placed in operation in 1929. By the end of 1966, a total of only nine plants were operating, with a total capacity of about 1500 MWe. At the end of 1970, total pumped-storage generating capacity amounted to about 3700 MWe. About half of this capacity was in the Northeast. California also had a significant share (22\%).

\subsection{Extent of Energy Resource}

From a strictly theoretical viewpoint, the ultimate hydroelectric potential (conventional) is fixed by the average flow of all streams and the change in the elevation of the flow as water moves to the oceans. On this basis, the hydroelectric potential of the United States (excluding Alaska and Hawaii) has been estimated to be as much as 390,000 MWe. ${ }^{4}$ In the absence of suitable dam sites and because of constraints imposed by social, economic, and environmental considerations, the ultimate capacity can never be achieved.

The Federal Power Commission has estimated ${ }^{2}$ the conventional hydroelectric potential of the conterminous United States to be 147,200 MWe and of the 50 states to be 179,900 MWe. These estimates take 
into consideration probable engineering feasibility but do not consider economic feasibility, environmental constraints, and legislative prohibitions. These latter considerations will substantially reduce the number of developable sites.

The details of the Federal Power Commission's estimate are shown in Table A.3-1. Of the 179,900 MWe potential of the United States, 128,000 MWe remained undeveloped as of December 1970. Of this undeveloped potential, $51 \%$ is located in the Pacific and Mountain States, whereas $25 \%$ is located in Alaska, far from load centers.

In contrast with conventional hydroelectric sites, pumped-storage sites require little or no streamflow. The availability of pumpedstorage sites depends primarily on the existence of topography that permits development of a high head (elevation difference) between two reservoirs in the same area. Although no detailed studies have been made, the Federal Power Commission staff ${ }^{3}$ believes that several hundred potential pumped-storage sites exist.

\subsection{Technical Description}

The power that can be developed by a hydroelectric generating unit is a product of the available hydraulic head and flow rate. The head, or difference in elevation between the water level upstream of the turbines and the level downstream of their discharge, may be provided by the existence of a natural waterfall but is more frequently created by the construction of a dam. In the United 
Table A.3-1

PRESENT AND POTENTIAL CONVENTIONAL

HYDROELECTRIC CAPACITY OF THE UNITED STATES

\begin{tabular}{|c|c|c|c|c|c|}
\hline $\begin{array}{l}\text { Geographic } \\
\text { region }\end{array}$ & $\begin{array}{c}\text { Potential } \\
\text { power } \\
\left(10^{3} \mathrm{MW}\right)\end{array}$ & $\begin{array}{l}\text { Percent } \\
\text { of total }\end{array}$ & $\begin{array}{c}\text { Developed } \\
\text { capacity } \\
\left(10^{3} \mathrm{MW}\right)\end{array}$ & $\begin{array}{c}\text { Percent } \\
\text { developed }\end{array}$ & $\begin{array}{l}\text { Undeveloped } \\
\left(10^{3} \mathrm{MW}\right)\end{array}$ \\
\hline New England & 4.8 & 2.7 & 1.5 & 31.3 & 3.3 \\
\hline Middle Atlantic & 8.7 & 4.8 & 4.2 & 48.3 & 4.5 \\
\hline East North Central & 2.5 & 1.4 & 0.9 & 36.0 & 1.6 \\
\hline West North Central & 7.1 & 3.9 & 2.7 & 38.0 & 4.4 \\
\hline South Atlantic & 14.8 & 8.2 & 5.3 & 35.8 & 9.5 \\
\hline East South Central & 9.0 & 5.0 & 5.2 & 57.8 & 3.8 \\
\hline West South Central & 5.2 & 2.9 & 1.9 & 36.5 & 3.3 \\
\hline Mountain & 32.9 & 18.3 & 6.2 & 18.8 & 26.7 \\
\hline Pacific & 62.2 & 34.6 & 23.9 & 38.4 & 38.3 \\
\hline Subtotal (48 states) & 147.2 & 81.8 & 51.8 & 28.5 & 95.4 \\
\hline $\begin{array}{l}\text { Alaska } \\
\text { Hawaii }\end{array}$ & $\begin{array}{r}32.6 \\
0.1\end{array}$ & $\begin{array}{r}18.1 \\
0.1\end{array}$ & 0.1 & 0.3 & $\begin{array}{r}32.5 \\
0.1 \\
\end{array}$ \\
\hline Total (50 states) & $\overline{179.9}$ & $\overline{100.0}$ & 51.9 & 28.8 & 128.0 \\
\hline
\end{tabular}

Source: U.S. Department of the Interior, Final Environmental Statement for the Geothermal Leasing Program, vol. I, 1973, p. IV-170. 
States, Niagara Falls is the only waterfall site that provides major amounts of power. The dams used to create water-supply reservoirs are constructed of earth and rock fill or of reinforced concrete. Water is carried to the turbines by inlet pipes (penstocks) that are constructed of welded steel or concrete or of both. The turbines provide a rotating-shaft output to drive generators. The generators usually produce three-phase, $60-\mathrm{Hz}$, alternating current that can be fed directly to a power grid.

To maintain a steady output of electrical power as the reservoir empties and the available head decreases, larger flow rates must be provided. Generally, hydroelectric sites that have a hydraulic head of less than $30 \mathrm{ft}$ are not economical to develop, but, even for low-head cases, potential sites for economic development are limited. Providing $30 \mathrm{ft}$ of head on a river that flows through a flat broad terrain might entail flooding of large areas of land or construction of many miles of levees. Usually, low-head units are justified as multipurpose projects where substantial benefits to navigation and to flood control are obtained by the installation of a dam. In some special situations, sites that provide heads as low as $21 \mathrm{ft}$ have been developed.

Low rotational speeds and the pressure limitation fixed by the available hydraulic head combine to make possible rapid startup and shutdown of hydroelectric units as compared with steam turbinegenerators. This ability to start quickly and to rapidly change 
power output makes hydroelectric plants particularly well adapted for meeting peak loads and for frequency-control and spinning-reserve duty.

Hydroelectric generating stations are normally very efficient. The efficiency of modern hydraulic turbines in converting the potential energy of the water to shaft work is about 90 to $95 \%$ at the design load. The overall efficiency of converting the water's potential energy to electrical power is usually above 80\% for conventional hydroelectric plants.

Since conventional hydroelectric plants consume no fuel and are based on the natural water cycle, the resource base is inexhaustable. However, pumped-storage plants are not a primary source of energy since they simply store energy produced by primary sources such as fossil-or nuclear-fueled plants. The effect of pumped-storage installations is to reduce the total required capacity of the primary sources. Nevertheless, primary fuel consumption is increased because pumped-storage units only return about two units of electrical energy for each three units generated by the primary energy plant.

\subsection{Research and Development Program}

The technology for the components of hydroelectric power stations is well established, and the technical feasibility of a particular project is seldom in question. Even so, refinements in existing 
technology would be beneficial. Of even greater importance is the need to understand long-term effects on the environment, in particular on fish and on wildlife, and to develop methods of alleviating adverse effects.

Maximal use of the hydroelectric power potential of the United States will require R\&D in the following areas:

1. Methods to reduce silting of reservoirs.

2. Improved designs to reduce leakage from reservoirs and, in particular, pumped-storage systems.

3. Improvements in the efficiency and cost of transporting energy generated at remote hydroelectric sites.

4. Improvements in pump-turbine designs for pumped-storage applications.

5. Methods for improving the quality of water released from deep reservoirs. 
6. Improved fish-passage systems for anadromous fish (fish that move upstream to spawning grounds).

7. Improved understanding of effects of reservoir-level changes on aquatic life.

\subsection{Projected Application}

According to Federal Power Commission (FPC) estimates, ${ }^{2}$ the conventional hydroelectric power capacity of the conterminous United States will increase from 51,800 MWe in January 1971 to 82,000 MWe in 1990. A major portion (74\%) of this projected increase will be in the western United States. Even though an absolute increase is expected, the proportion of total electric capacity attributable to conventional hydroelectric plants will decline from the present $15 \%$ to about $7 \%$ in 1990.

The largest increase in future hydroelectric capacity is expected to be in pumped storage. The $\mathrm{FPC}^{3}$ estimates that pumped-storage capacity will increase from the 3700 MWe in 1970 to about 70,000 MWe in 1990. Most of this increase will be in the eastern United States.

Figure A.3-2 summarizes the location and amount of existing and projected hydroelectric capacity. 


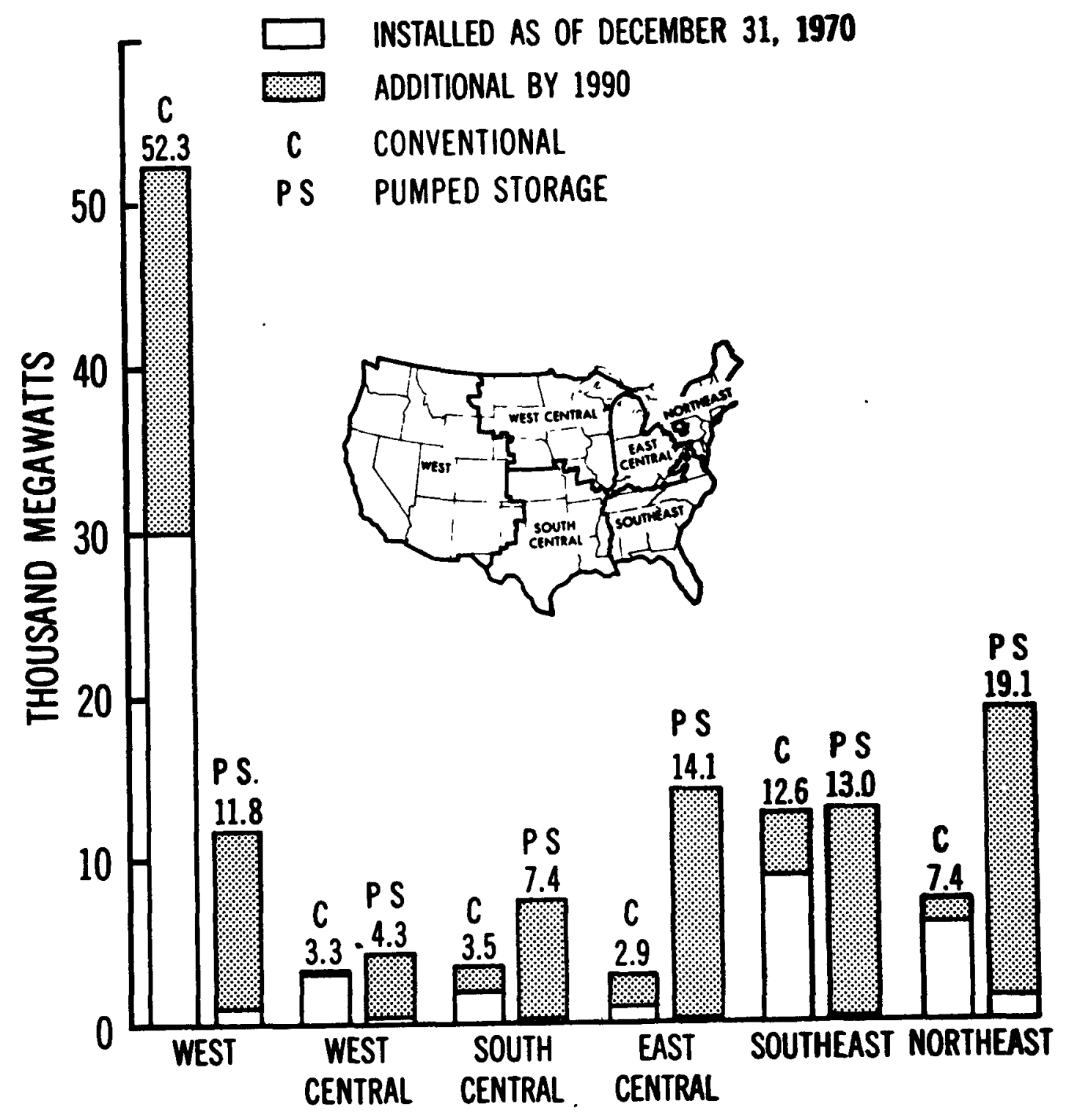

HYDROELECTRIC CAPACITY (EXISTING AND PROJECTED TO 1990; INDUSTRIAL CAPACITY NOT INCLUDED)

Figure A.3-2 


\subsection{Environmental Impacts}

The environmental impact of a hydroelectric power project results from: (1) interposition of barriers to upstream and downstream movement of aquatic life forms, suspended materials, and floating objects; (2) flooding of lands by the impounded waters and an increase in water depth above that of the former stream bed; (3) changes in the downstream flow - flow amounts may be changed from their normal daily, seasonal, and long-term patterns, and water composition may be altered; and (4) alteration of the appearance of the site.

Construction of a hydroelectric plant represents an irretrievable commitment of a large amount of land area beneath a dam and lake. Lost resources include agricultural land, minerals, wildlife habitat, and recreation on a free-flowing river.

Hydroelectric plants may cause impairment of water quality, especially downstream of the project. At deep reservoirs, water released from the bottom may be extremely cold and devoid of oxygen. Even though cold water may benefit cold-water fisheries, such as trout and salmon, warm-water fisheries are adversely affected. Oxygen deficiency would be detrimental to all fish. Another water-quality problem is associated with dissolved nitrogen. At some dams, release of water over spillways causes the water to become supersaturated with nitrogen; high fish mortality results. 
By proper design of a reservoir, water-quality impaiment can be reduced. 3 The Corps of Engineers is testing several methods of reducing nitrogen supersaturation. The cold-water problem has been alleviated at a number of projects by designs that require the water to be taken from the upper levels of the reservoir to the hydraulic turbines. Oxygen concentration of the water has also been increased at some projects through various aeration techniques.

In addition to water-quality effects, hydroelectric plants may have other detrimental effects on certain species of fish. Although fish-passage facilities may be constructed for the protection of anadromous fish during their runs, the cumulative effect of a series of dams might be to substantially reduce such runs. Apparently, this is the case on the Columbia River. ${ }^{3}$ Research is needed to improve fish-passage systems for high dams. Also, wide fluctuations in reservoir levels, which are especially characteristic of pumpedstorage systems, could adversely affect the spawning of some fish. Hydroelectric dams also have the potential for hazardous accidents. Many river systems have geologic faults associated with them. Dam failures, while rare, can have catastrophic consequences in those areas where population centers are grouped along the river banks immediately downstream from the dam. 5

In contrast with water quality, air quality is little affected by the operation of hydroelectric plants. 
Not all environmental effects of water impoundment are considered to be detrimental. Lakes behind dams created for hydroelectric purposes provide recreational opportunities such as swimming, camping, and boating. Although running-water fishing may be reduced, the overall fishing opportunity may be greatly expanded. Flood control, irrigation water supply, and water transportation are also positive aspects of some impoundment projects.

The overall results of environmental changes, as they directly or indirectly affect people, depend strongly on site. Whether the net consequences are beneficial or detrimental often depends on individual viewpoints. Even for those consequences clearly assigned to one category or the other, views will differ as to their importance or significance.

\subsection{Costs and Benefits}

\subsubsection{Internal Costs}

On the average, the investment cost per kilowatt for conventional hydroelectric plants can exhibit wide swings that reflect the variations in type, size, and location of project; cost of land; and relocation of existing roads and structures. Investment costs also are affected, to a lesser extent, by changes in labor, materials, engineering, and other factors in construction costs.

The most up-to-date cost information reported by the Federal Power Commission for conventional hydroelectric plants includes 
two recently constructed units ${ }^{6}$ - one non-Federal, the other Federal. For the non-Federal plant (118-MWe), the investment cost was $\$ 381$ / KWe; for the Federal (405 MWe), \$346/kWe. The latter cost includes a portion of the cost of facilities, such as the dams and the reservoirs, that are used jointly for power and other purposes. The joint-use costs allocated to power, as well as the cost of all facilities provided specifically for power development, are recovered from power revenues.

Operating expenses per kilowatt-hour are substantially less in hydroelectric than in steam-cycle plants, principally because no fuel costs are associated with hydroelectric plants.

The weighted-average unit cost-of-operating expenses for 20 nonFederal utility hydroelectric systems, as reported by the Federal Power Commission for 1970 operations, was $0.56 \mathrm{mill} /$ (net $\mathrm{kWhr}$ ). This cost was made up of $0.35 \mathrm{mill}$ for operations and $0.21 \mathrm{mill}$ for maintenance. For the Tennessee Valley Authority's system of 29 plants, the weighted average unit cost was $0.72 \mathrm{mill} / \mathrm{kWhr}$, of which operation cost was $0.48 \mathrm{mill}$ and maintenance cost was 0.24 mill.

Pumped-storage hydroelectric plants, as opposed to conventional hydroelectric units, are selected on the basis of low first cost and the ability to use low-cost off-peak pumping energy to generate high-value peaking energy. Costs of development depend largely 
on site topography and geological conditions. Reservoirs, dams, waterways, pump-turbines, and motor-generators account for about 70 to $75 \%$ of the total fixed costs.

At the end of 1970, seven pumped-storage installations, combined with conventional hydroelectric developments, and nine recirculating-type-or "pure" pumped-storage projects were in operation, but operating-cost data were not available for these units. Limited information indicates that economically attractive pumped-storage projects will have a cost range of $\$ 75$ to $\$ 125$ per kilowatt (electric).

\subsubsection{External Costs}

A number of external costs are involved in the development of hydroelectric power plants. The presence of large dams has a major impact on site ecology, both upstream and downstream. Interference with normal river flow often alters water quality and temperature. An environmental argument against the further development of hydroelectric potential is made by those who are concerned about the shrinking wilderness area in the United States. The enormous land area required for the reservoir makes a major dam economically possible only in unsettled regions. The question becomes one of whether or not a significant fraction of our remaining wilderness, which is irreplaceable, should be given up for an increase in capacity to generate electrical energy. 


\subsubsection{Benefits}

One major benefit from hydroelectric plants is electricity, but reservoirs are also of value for recreation and for flood control. Hydroelectric generating plants can be started and stopped quickly; thus, they have the capacity to adjust rapidly to power-demand fluctuations. In addition, hydroelectric plants are essentially pollution-free relative to their effects on air quality and have no fuel-cycle wastes.

\subsection{Overall Assessment of Role. in Energy Supply}

Hydroelectric power is an important component of the electricenergy-generating system. Nevertheless, the percentage of total capacity is declining, and this trend will continue. Primary use in the future will be to meet peaking requirements. By 1990, conventional hydroelectic capacity will be no more than $7 \%$ of total need. Thus, the available hydroelectric power will not alter the need to develop alternative energy systems. 


\subsection{References}

1. Federal Power Commission, Hydroelectric Power Evaluation, FPC P-35, March 1968.

2. U.S. Department of the Interior, Final Environmental

Statement for the Geothermal Leasing Program, vol. I, 1973.

3. Federal Power Commission, The 1970 National Power Survey, Part I, December 1971.

4. H. H. Landsberg et al., Resources in America's Future, published for Resources for the Future, Inc., by The Johns Hopkins Press, Baltimore, Md., 1963, p. 416.

5. P. Gast, "Divergent Public Attitudes Toward Nuclear and Hydroelectric Power Safety," ANS Transactions, Vol. 16, No. 2, June 1973.

6. Federal Power Commission, Hydroelectric Plant Construction Cost and Annual Production Expenses--1970 Supplement, April 1972. 


\section{A.4 GEOTHERMAL ENERGY}

\subsection{Introduction}

\subsubsection{General Description}

The temperature of the earth increases with increasing depth, and, except for a very thin crust, the earth is very hot. Consequently, the interior of the earth is a vast energy reservoir that could be tapped for human uses such as space heating, industrial processing, and electricity generation. Figure A.4-1 is a schematic of a typical geothermal power plant. In this example, geothermal steam is used to drive a turbo-generator.

The three classes of geothermal reservoirs ${ }^{1,2,3}$ are: hydrothermalconvection systems, geopressured reservoirs, and dry hot-rock systems. The hydrothermal-convection systems, which form the basis for all current geothermal power generation, are normally associated with regions of youthful volcanism, crustal deformation, and recent mountain building. Hydrothermal reservoirs are concentrated in the western third of the United States. Such reservoirs are created naturally when (1) a significant quantity of hot rock exists at depth, (2) the hot rock is overlain by a permeable formation that is an aquifer by which groundwater can reach the hot rock, and (3) the aquifer is capped by an impermeable layer that prevents the loss of water and energy. As Fig. A.4-2 illustrates, groundwater, which can percolate down to depths of several miles, is heated directly or indirectly by the underlying magmas and circulates by convection within the permeable formation. Hydrothermal systems may be further 


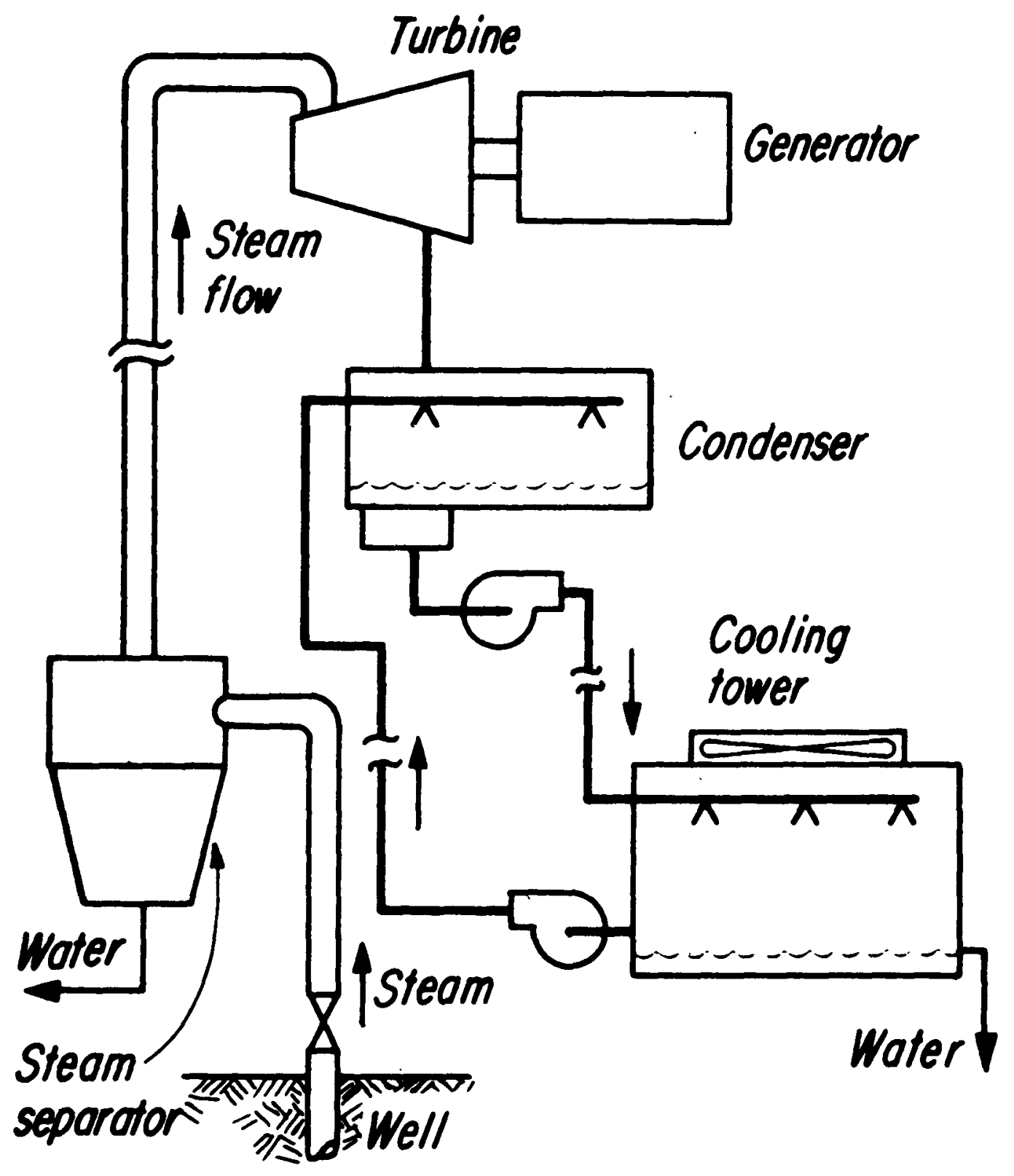

SCHEMATIC OF A GEOTHERMAL POWER PLANT

Figure A.4-1 


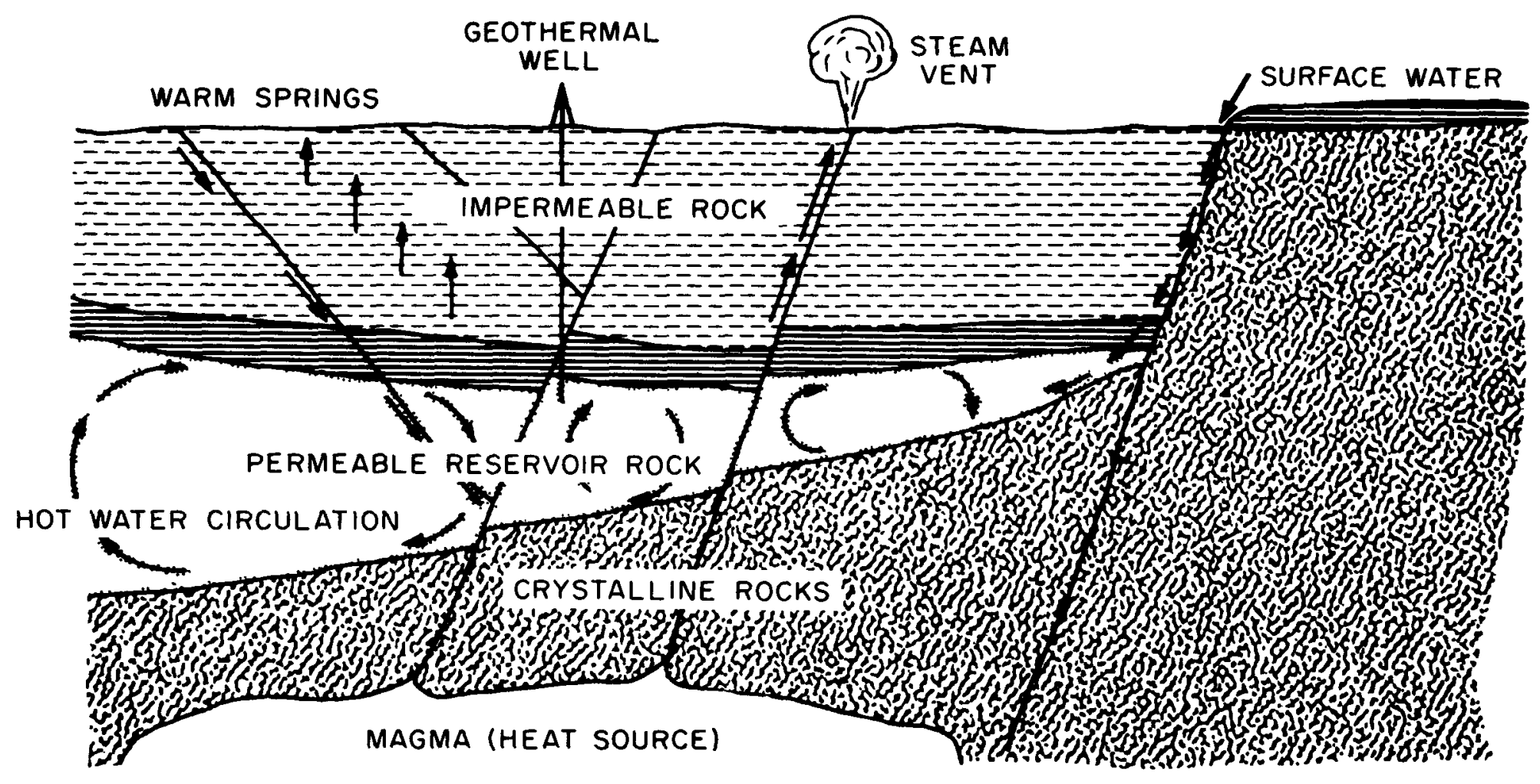

SCHEMATIC OF A GEOTHERMAL RESERVOIR CAPPED

BY IMPERMEABLE ROCKS WITHIN A FAULTED STRUCTURE

Pigure A.4-2 
classified as "vapor-dominated" reservoirs or "liquid-dominated" reservoirs. When the fluid that circulates in at least the upper portion of the aquifer is either dry or superheated steam, the reservoir is said to be vapor-dominated. When temperatures are lower or pressures higher so that the circulating fluid is water or brine, the reservoir is liquid-dominated. Surface manifestations of a geothermal reservoir are geysers, hot springs, and fumaroles. However, geothermal reservoirs exist that do not have surface manifestations; to find such resources is one of the challenges in geothermal exploration. ${ }^{4}$

Geopressured reservoirs form another class of "wet" geothermal deposit. They contain highly porous sands saturated with hightemperature high-pressure brine. They are located in sedimentary basins that have undergone geologic deformation but, unlike hydrothermal systems, are belfeved not to be associated with magmatic intrusions or volcanisms.

Apparentiy, geopressured zones arise from the trapping of normal heat flow by overlying clays that form an insulating layer. During the course of oil exploration, large geopressured zones have been found along the Texas and Louisiana Gulf coasts. Whether geopressured brines can be used to produce electric power is not yet known. 
As implied, the existence of a wet geothermal system requires some relatively specific combinations of geologic structure. Much more conmon are the "dry" geothermal resources. In principle, dry hot rocks of temperatures suitable for usefur purposes can be reached from anywhere on the earth's surface by drilling to sufficient depths. Geothermal temperature gradients in what might be termed "normal" areas range from 4 to $28 \mathrm{~F}^{\circ}$ per thousand feet; ${ }^{5}$ a typical value is about $16 \mathrm{~F}^{\circ}$ per thousand feet. ${ }^{6}$ For power generation, temperatures of 300 to $400^{\circ} \mathrm{F}$ above surface temperatures are desirable. Thus, power generation from geothermal energy in most areas would require wells of $20,000-\mathrm{ft}$ depth or greater. The difficulty of economically extracting energy from such depths suggests that most "normal" areas will be unsuitable for geothermal development in the foreseeable future. ${ }^{5}$ However, many areas have temperature gradients many times normal and are potentially promising for deriving useful energy from hot dry rocks. In the absence of a naturally occurring heat-transfer medium, such as exists in the wet geothermal systems, the exploitation of dry hot-rock reservoirs requires a man-made energy-extraction system. Such a system involves drilling a deep hole to rock of sufficiently high temperature, fracturing the rock by some means to produce a large amount of heat-transfer surface, drilling a second shallower hole into the fractured zone, and circulating water through the fractured rock by injecting the water into the deep well and removing it from the shallow well.' 


\subsubsection{History}

The first production of power from geothermal energy occurred in 1904 at Larderello, Italy. By the 1930's, the plants at this site totaled about 100 WN of capacity, but they were destroyed during World War II. The plants were rebullt and expanded after the war and now have capacity of over 300 MW. Marginally successful attempts at geothermal power production were made in 1922 in Japan and in California, and in 1925 in New Zeal and and Scotland. By 1930, Reykjavik, Iceland, was successfully using geothermal water for space heating. New Zealand achieved successful power production from the Wairakei power project between 1950 and 1960, after which a total of $160 \mathrm{MW}$ of capacity was installed. These successes were followed by development programs in the later 1950's and early 1960 's in Mexico, Japan, Russia, and the United States. Worldwide, about 20 countries are now involved in geothermal exploration and development.

Among the earliest developments of geothermal resources in the United States were the hot-spring spas in Arkansas and Georgia during the 19th century. Yellowstone National Park and several other recreational developments also were among the early users of geothermal energy. The Geysers area in Sonoma County, California, which is the only major source of geothermal power production in the United States, started as a spa in the late 1800's. Power-producing wells were drilled there in the 1920's, primarily to supply power to the spa. In the 1950 's, Magma Power Company began to explore The 
Geysers area, and Pacific Gas and Electric Company constructed an electrical generating plant there in 1960.

The Imperial Valley region of California southwest of the Salton Sea was the second area in which exploration was started. A well drilled there in 1927 indicated that the quality of the steam was inadequate to produce energy. Some commercial production of dry ice occurred from this area until the carbon dioxide gas was flooded out by the Salton Sea. In 1957 during oil-exploration drilling operations, hot brine (22 to $26 \%$ solids at 600 to $\left.680^{\circ} \mathrm{F}\right)$ was hit at a depth of about $5000 \mathrm{ft}$. This discovery resulted in renewed interest in mineral production from this area, but the highly corrosive liquid inhibited the development of power production.

In the late 1960's, the success of a 3.5-Mwe power plant at Cerro Prieto, Mexico, stimulated interest in the potential for large-scale power production and for desalting in the Imperial Valley. Cerro Prieto, although not in the United States, plays a significant role in the history of geothermal development in the Imperial Valley because it is located in a common geoloaic feature, the Salton Trough. The first well was drilled there in 1956 and led to the construction of the 3.5-Me experimental plant.

\subsubsection{Status}

Geothermal energy is currently being used to produce power in several countries and its use is still expanding. A 75-MWe power plant is being erected at Cerro Prieto, and a 50-MWe plant was operating in late 1973 (ref. 7), although not at full power. Experience gained 
at Cerro Prieto likely will be applied later in the Imperial Valley, al though many areas are known to have much more saline brines than found at Cerro Prieto. The hope is that resources of the Imperial Valley can be used to produce desalted water, as well as electric power, and thus to augment the water supply based on the Colorado River. The Bureau of Reclamation is currently conducting tests on geothermal desalting in the Imperial Valley. ${ }^{8,9}$ Also, as noted above, the Geyser area in California is still being used to produce electricity. The installed electrical capacity at The Geysers was about 400 MWe in December, 1973.

Since many of the areas of the United States which may be valuable for geothermal energy are on Federal land, the Geothermal Steam Act of December 24, 1970 (30 U.S.C. 1001-1025) provides for exploiting this resource. Pursuant to the Geothermal Steam Act, the U.S. Department of the Interior has issued proposed leasing and operating regulations along with a final environmental statement for the leasing program. 10 An announcement was made in December, 1973 regarding the decision to proceed with the leasing program. The final lease sale was held in January, 1974.

\subsection{Extent of Energy Resource}

\subsubsection{Geographical Distribution}

The U.S. Geological Survey has the responsibility to classify areas according to their potential geothermal-resource value. Areas are classified as Known Geothermal Resource Areas (KGRA's) when "the prospects for extraction of geothermal steam or associated geothermal resources from an area are good enough to warrant expenditures of 
money for that purpose." 11 Several factors are involved in identifying geothermal areas; two important ones are (1) the existence of geysers, mud volcanoes, fumaroles, or thermal springs that have temperatures at least $40 \mathrm{~F}^{\circ}$ above average amblent temperature; and (2) subsurface geothermal temperature gradients generally in excess of two times normal. 11 About 1.8 million acres of land has been designated as being within KGRA's. ${ }^{12}$ All this land, except two areas in Alaska, is in the western third of the United States, and $56 \%$ of the KGRA's involve Federal land. Table A.4-I identifies the KGRA's in the conterminous United States; Fig. A.4-3 shows their locations.

In addition to the 1.8 million acres classified as being within KGRA's, another 96 million acres in the western United States has been listed as having prospective value for geothermal resources. 12 A few areas outside the western United States could have some geothermal resource potential; these are the geopressured brines along the Texas and Louisiana Gulf coasts and the hot springs of Arkansas, Georgia, and the Appalachian Range.

\subsubsection{Estimated Avallability}

Opinion on the extent of the geothermal resource suitable for electricity generation varies widely. Theoretically, the geothermal resource base of the United States is vast. For example, White ${ }^{5}$ estimates that the stored heat above surface temperatures to a depth of $10 \mathrm{~km}(33,000 \mathrm{ft})$ in the United States is about $6 \times 10^{24}$ cal. If $1 \%$ of that energy could be converted to electricity, the total generated would be about $8 \times 10^{9}$ Me-years, or enough for 
Table A.4-1

KNOWN GEOTHERMAL RESOURCE AREAS WITHIN THE CONTERMINOUS UNITED STATES AS OF AUGUST 1972

\begin{tabular}{|c|c|c|c|}
\hline Name & $\begin{array}{l}\text { Location on } \\
\text { Fig. 8.5.3 }\end{array}$ & Name & $\begin{array}{l}\text { Location } \\
\text { Fig. 8.5.3 }\end{array}$ \\
\hline \multicolumn{2}{|c|}{ California } & \multicolumn{2}{|c|}{ Oregon } \\
\hline The Geysers & 1 & Breitenbush Hot Springs & 1 \\
\hline Salton Sea & 2 & Crump Geyser & 2 \\
\hline Mono-Long Valley & 3 & Vale Hot Springs & 3 \\
\hline Calistoga & 4 & Mount Hood & 4 \\
\hline Lake City & 5 & Lakeview & 5 \\
\hline Wendel-Amedee & 6 & Carey Hot Springs & 6 \\
\hline Cosco Hot Springs & 7 & Klamath Falls & 7 \\
\hline Lassen & 8 & & \\
\hline Glass Mountain & 9 & \multicolumn{2}{|c|}{ Washington } \\
\hline Sespe Hot Springs & 10 & & 1 \\
\hline $\begin{array}{l}\text { Heber } \\
\text { Prawley }\end{array}$ & 11 & \multirow{2}{*}{\multicolumn{2}{|c|}{ Idaho }} \\
\hline $\begin{array}{l}\text { Brawley } \\
\text { Dunes }\end{array}$ & $\begin{array}{l}12 \\
13\end{array}$ & & \\
\hline Glamis & 14 & Yellowstone & 1 \\
\hline East Mesa & 15 & Frazier & 2 \\
\hline \multicolumn{2}{|c|}{ Nevada } & \multicolumn{2}{|c|}{ Montana } \\
\hline Beowawe & 1 & Yellowstone & 1 \\
\hline Fly Ranch & 2 & & \\
\hline Leach Hot Springs & 3 & \multicolumn{2}{|c|}{ New Mexico } \\
\hline Steamboat Springs & 4 & & \\
\hline Brady Hot Springs & 5 & Baca Location No. 1 & 1 \\
\hline Stillwater-Soda Lake & 6 & & \\
\hline Darrough Hot Springs & 7 & \multicolumn{2}{|c|}{ Utah } \\
\hline Gerlach & 8 & Crater Springs & 1 \\
\hline Moana Springs & 9 & Roosevelt & 2 \\
\hline Double Hot Springs & 10 & & \\
\hline Wabuska & 11 & & \\
\hline Monte Neva & 12 & & \\
\hline Elko Hot Springs & 13 & & \\
\hline
\end{tabular}




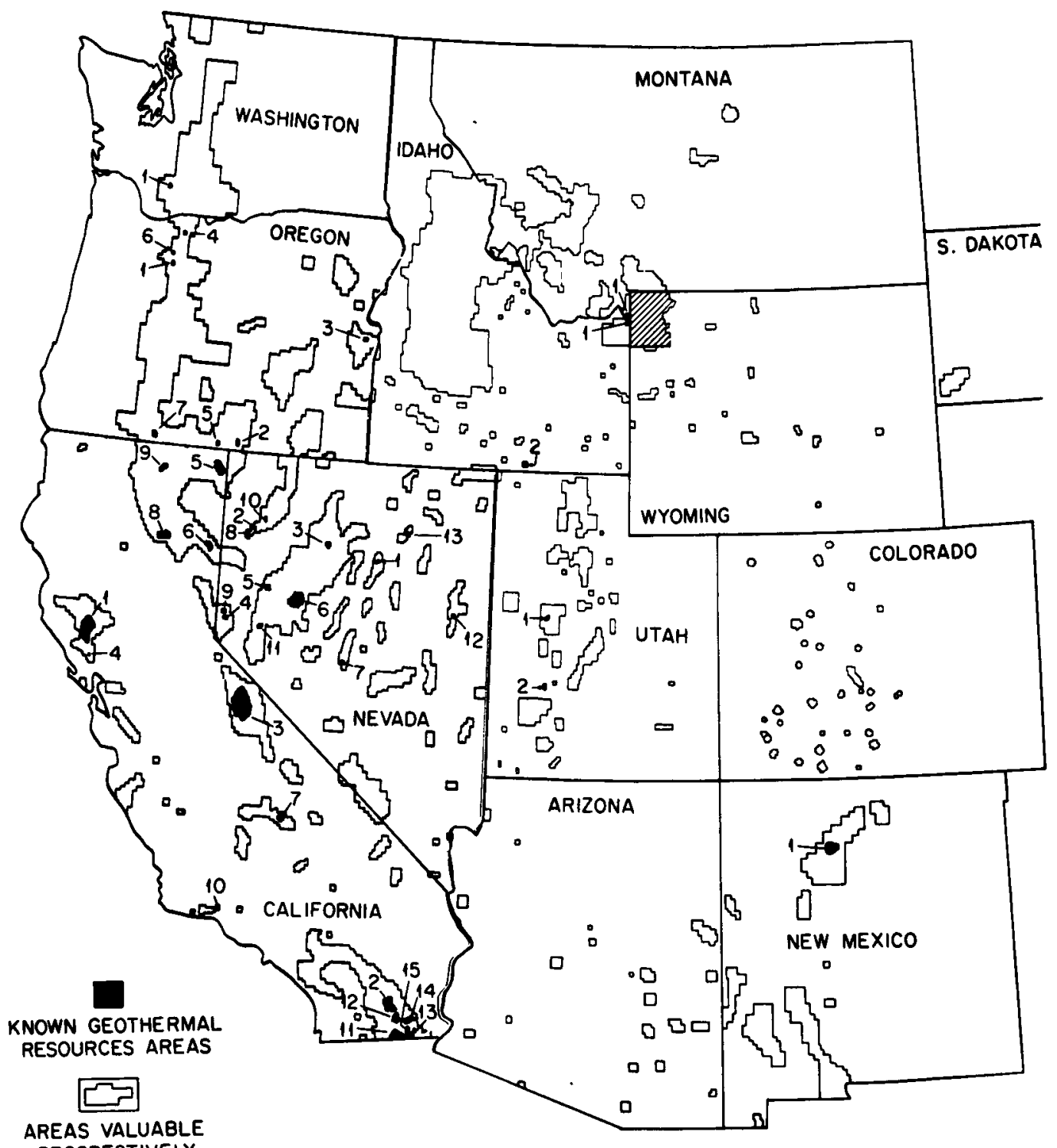

PROSPECTIVELY

MAP OF GOETHERMAL RESOURCE AREAS IN THE WESTERN UNITED STATES

Figure A.4-3 
about 8000 years at the rate of consumption predicted for the year 2000 (annual consumption of 1,000,000 Me-years). ${ }^{13}$ However, this estimated resource base does not constitute a recoverable resource because the estimate considers neither the cost nor technical feasibility of extracting energy from the earth's crust. The extent of the geothermal resource suitable for electricity generation is a matter of widely differing opinions among knowledgeable people.

White's estimates of the proved, possible, and probable geothermalenergy reserves are (1) 60,000 Mwe-years recoverable at present costs and with present technology and (2) 200,000 to 400,000 MWeyears recoverable at a one-third increase in cost and with present technology. 5

These estimates, which encompass the hydrothermal systems of sufficient temperatures to operate energy-conversion plants according to present technology, would indicate a fairly minor resource, equivalent to no more than one-half year of electricity supply at the consumption rate predicted for the year 2000. White notes, however, that with technological breakthroughs, including improvements in extracting and using low-temperature heat and new low-cost methods of drilling holes to great depths, the geothermal resources could be expanded substantially.

Rex and Howe $11^{14}$ appraise the United States geothermal resources as follows: (1) known reserves, about 3,000,000 Me-years; (2) probable reserves, 100,000,000 MWe-years; and (3) undiscovered reserves, $7,400,000,000$ we-years. The known reserves are the hydrothermal 
reservoirs in The Geysers area and in the Imperial Valley region. Probable reserves include all hydrothermal systems in the western third of the conterminous United States and Hawait. In addition to including hydrothermal systems in the western United States (including Alaska and Hawaii), the estimate of undiscovered reserves assumes the development of dry hot-rock resources to a depth of $35,000 \mathrm{ft}$ over $5 \%$ of the area of the western third of the United States. Rex and Howell also indicate that geothermal resources in the eastern and midwestern areas could substantially increase their estimates. In essence, then, their assessment is that known reserves could provide a 3-year supply of electrical energy at the year-2000 consumption rate, but, if probable and undiscovered reserves are included, geothermal energy could satisfy our needs for a millenium. Implicit in this assessment is the assumption that new technology will be available to economically extract and convert the energy from the more difficult geothermal reservoirs, in particular the dry hot-rock systems.

Factual information about the extent of geothermal resources is severely lacking. The interpretation and extrapolation of existing data inevitably lead to disparate estimates. Thus, part of the apparent disagreement on the size of the geothermal resource is related to a lack of knowledge about the nature of geothermal energy, but perhaps a greater part concerns the definition of an eneroy resource. Any potential resource must be subjected to technical, economic, and social tests: Do technically feasible ways exist to 
extract the energy at reasonable costs - costs competitive with known alternatives - in a manner that society will accept? As would be expected, judgments on these questions, in the absence of hard data, vary considerably. However, some points of agreement are that (1) vapor-dominated geothermal systems, which are easiest to tap and which represent about $75 \%$ of present world geothermal electricity capacity, are relatively rare; (2) liquid-dominated reservoirs are much more plentiful than vapor-dominated; (3) dry hot-rock systems are the most common of $\mathrm{all}$; and (4) most of the geothermal "hot spots" are located in the western third of the United States.

In terms of contribution to the nation's future electrical energy needs, a reasonable interpretation of present information - although not necessarily a consensus one - is that ( 1 ) if geothermal energy is limited to present technology and costs $(24-7 \mathrm{mills} / \mathrm{KWh})$, the resource potential is limited to vapor-dominated reservoirs and, al though important locally, is small in terms of national needs; (2) with some improvements in technology and some increases in cost ( $28-12 \mathrm{mills} / \mathrm{KWh})$, the higher-temperature liquid-dominated reservoirs could be tapped and could have considerable regional significance in the West but would have little impact nationally; and (3) geothermal resources of national significance would be available only when the feasibility of tapping lower-temperature liquid-dominated reservoirs and dry hot-rock systems has been demonstrated. 


\subsection{Technical Description}

\subsubsection{Systems Based on Vapor-Dominated Reservoirs}

The technical characteristics ${ }^{15,16}$ of The Geysers power station may reasonably represent geothermal electric plants based on vapordominated reservoirs. Wells that produce vary in depth from 600 to $9000 \mathrm{ft}$ and have diameters that decrease from $20 \mathrm{in}$. at the surface to $8-3 / 4$ in. at the bottom. Several wells (usually, 14) are required to feed one centrally located power station of 110-MWe capacity which consists of two 55-MWe turbine-generators. Power plants tend to be relatively small because the distance steam can be transported from outlying wells is limited. Typically, 5 acres may be associated with each well. The areal extent of the field associated with each power station, determined through exploratory drilling prior to the construction of the power plant, is fixed so that new wells can be drilled as old ones become nonproductive and thus the design power output can be maintained for the life of the plant ( 30 to 50 years).

The reservoir pressure of 450 to 500 psig reduces to about $126 \mathrm{psig}$ at the wellhead. Restrictions to flow in the formation and in the well bore account for the pressure reduction. Steam flows through a centrifugal separator near each wellhead to remove particulate matter. Feeder steam lines, as small as 10 in. in diameter, from each well feed into main trunk lines (36-in.-diam) to the power station. Relief valves are used in the steam lines to prevent overpressurizing the lines should the power plant shut down. 
Steam is delivered to the turbines at $100 \mathrm{psig}$ and $355^{\circ} \mathrm{F}$ and is exhausted at $4 \mathrm{in}$. $\mathrm{Hg}$ abs $\left(125^{\circ} \mathrm{F}\right)$. The turbine is a single-shell, double-flow design with 23-in.-long last-stage blades. A directcontact condenser is used, and heat is rejected by a mechanicaldraft wet cooling tower. About $80 \%$ of the steam that flows to the turbine is evaporated in the cooling tower; the remaining $20 \%$ is reinjected into the less-productive wells.

Noncondensable gases, which consist of carbon dioxide, hydrogen sulfide, methane, ammonia, nitrogen, hydrogen, and ethane, are removed from the condenser by a steam-jet ejector. The noncondensables constitute as much as 2 wt $\%$ of the steam flow.

\subsubsection{Systems Based on Liquid-Dominated Reservoirs}

\subsubsection{High-Temperature Systems}

In broad outline, the characteristics of a power system based on high-temperature geothermal brine would be similar to those for dry steam systems. However, some important differences exist which add technical complexity and increase cost. Experience in the use of geothermal brines for power generation has been obtained in New Zealand and at Cerro Prieto, Mexico.

At Cerro Prieto, well depths average about $5000 \mathrm{ft}$, and reservoir temperatures generally are greater than $550^{\circ} \mathrm{F} .^{17}$ When well-bore pressures are lowered, some of the brine flashes to steam, and a mixture of brine and steam rises to the surface. About $20 \%$ of the 
mixture is steam ${ }^{17}$ (13 to $\left.25 \%\right)$, which is separated from the brine by a cyclone separator. ${ }^{8}$ Brine is discarded, and steam is piped to the turbine at an inlet pressure of about 75 psig. ${ }^{18}$ The remainder of the steam cycle is similar to that described previously for The Geysers plant. However, overall efficiency is somewhat lower but generally is in the range 10 to $15 \% .^{18}$

Several problem areas have been identified which make the geothermalbrine reservoirs more difficult to tap than are the dry-steam reservoirs. The highly mineralized water, which may contain silica, calcium carbonate, chlorides of sodium and of calcium, boron, ammonia, arsenic, and noncondensable gases, is a source of several potential problems. ${ }^{5}$ Cooling of the brine on flashing may cause precipitation and deposition of silica and of calcium carbonate in wells and surface pipes. If similar deposition should occur in the reservoir that immediately surrounded the well, the production rate of the well would be adversely affected. Disposal of the brine in an environmentally acceptable manner is another problem. Disposal through surface drains is used in New Zeal and and at Cerro Prieto, Mexico, but reinjection of the brine is probably the most desirable method. Reinjection has not been tested extensively, and some concern exists that minerals contained in the concentrated effluent may precipitate out and reduce the permeability of the reservoir. In many fields, removal of a large volume of brine will cause ground subsidence; this has been observed at Cerro Prieto. ${ }^{19}$ Reinjection will be required to alleviate this problem. 


\subsubsection{Low-Temperature Systems}

A high percentage of geothermal reservoirs contain low-temperature brine (below $360^{\circ} \mathrm{F}$ ). These resources might be exploited by using binary cycles in which heat is transferred from the brine to a secondary fluid (such as Freon or isobutane) that operates the turbines. The cooled brine would be reinjected. Binary systems require development and demonstration before they can be used for commercial power generation. At least one such process (Magmamax) is under study. ${ }^{20}$ Figure A.4-4 is a flow chart of the Magmamax process.

\subsubsection{Systems Based on Dry Hot Rock}

Systems to exploit the energy contained in dry hot rock have been proposed by the Los Alamos Scientific Laboratory of the Atomic Energy Commission ${ }^{1}$ and by the Battelle-Northwest Laboratories. ${ }^{21}$ Figure A.4-5 illustrates the general concept. These systems would consist of two or more wells, a heat exchanger, a turbine, and cooling towers for heat rejection. Water-injection wells would be drilled to depths of 7000 to $15,000 \mathrm{ft}$ to reach rock having temperatures near $600^{\circ} \mathrm{F}$ if possible. Rock in the vicinity of the well bottom would be fractured hydraulically or with explosives. An additional well would be drilled into the fracture zone several thousand feet above the injection well. Water would be circulated by injection through the deep well, and hot water would flow out of the shallow well into a heat exchanger, where it would vaporize the working fluid (steam, Freon, or isobutane) if a binary cycle is used. Otheenergy conversion systems which are under development may also be suitable for use with hot rock/water circulating systems. 


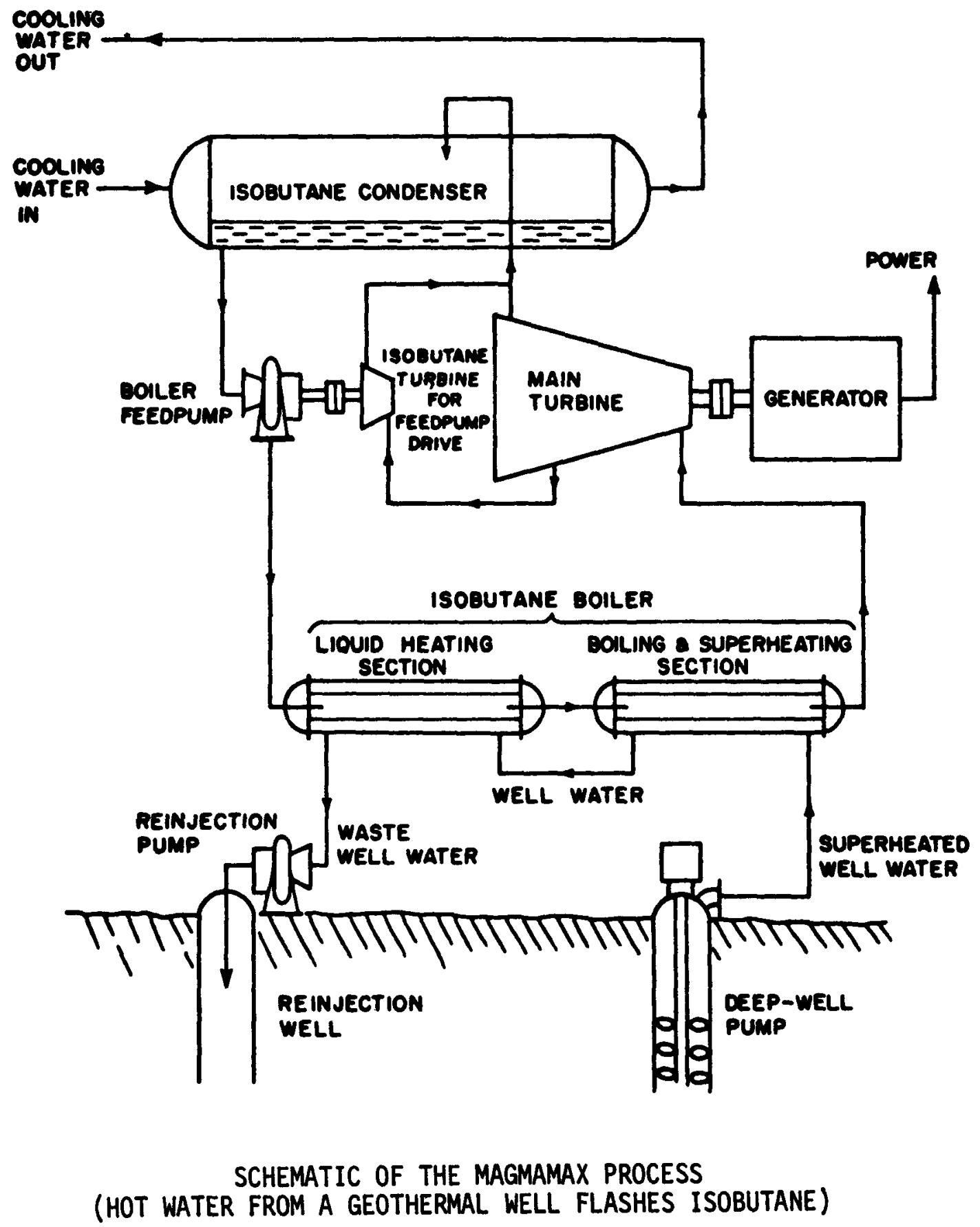

Figure A.4-4 


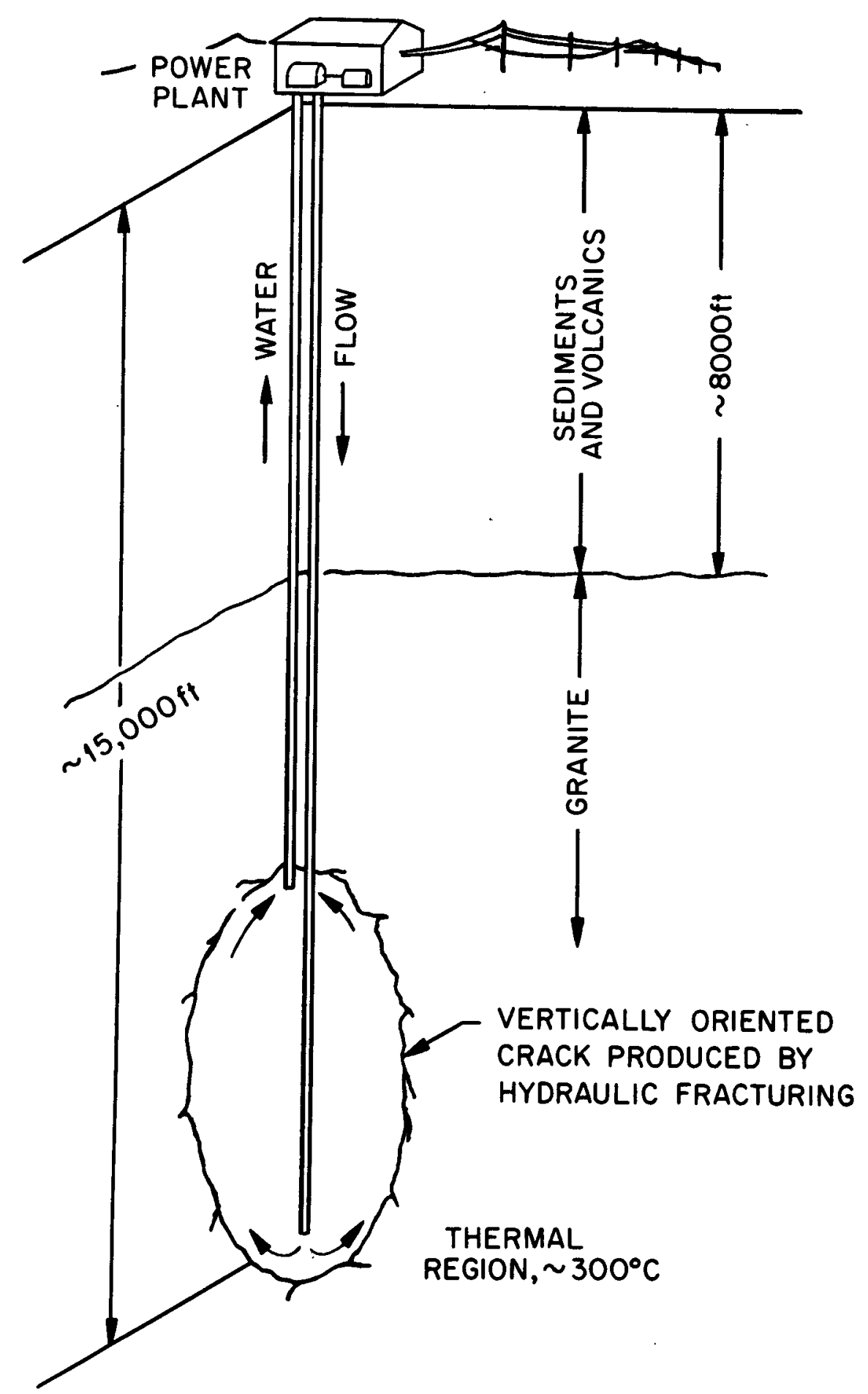

CONCEPTUAL DIAGRAM OF A DRY-ROCK GEOTHERMAL ENERGY SYSTEM DEVELOPED BY HYDRAULIC FRACTURING

Figure A.4-5 


\subsection{Research and Development Program}

The Hickel Panel on Geothermal Energy Resources 22 identified the following areas in which the technology is not well enough developed to allow rapid exploitation of geothermal resources:

1. Resources appraisal. Better estimates are needed of the extent of the geothermal resources in order to manage their development and use.

2. Exploration methods. Better and cheaper methods are needed for geophysical prospecting, for drilling test holes, for logging wells, and for sampling fluids.

3. Reservoir development and production. This technology includes mathematical modeling of reservoirs, investigation of recharge methods, geochemistry of fluids, control of scale, artificial stimulation by fracturing of rocks, and exploitation of hot rocks.

4. Utilization technology and economics. Economical techniques, such as binary-fluid power cycles, are needed for use of moderately hot geothermal waters. Techniques are desired to recover minerals, gases, and/or desalted water, in addition to power.

5. Environmental. Techniques are required for control of pollutants such as hydrogen sulfide and for reducing noise. 
The proponents of geothermal-energy development have proposed a tenyear development program of $\$ 500$ million to $\$ 600$ millition to resolve these technical questions. ${ }^{22}$ In addition, geothermal energy has been examined as part of a comprehensive study on The Nation's Energy Future. ${ }^{23}$ Under this review, a geothermal R\&D program totalling $\$ 185$ million has been proposed over the next five years. The objectives of this program would be:

1. To increase present knowledge of the location, nature and extent of the Nation's geothermal energy resources,

2. To identify and resolve the environmental, legal and institutional barriers to geothermal resource utilization,

3. To advance, through technology development, the operational efficacy and efficiency of relevant components, devices, and techniques as required to achieve practical geothermal resource utilization, and

4. To accelerate, through demonstration plants, the commercial production of electricity from geothermal sources.

Important emphasis would be given under this program to geothermal resource utilization ( $\$ 79$ million out of the $\$ 185$ million total 
geothermal program). Several different types of geothermal resources will be examined, four different demonstration plants will be completed and a fifth plant will be started. The potential results of the complete geothermal R\&D program, if successful, in supplying useful electrical power are discussed in the following section.

\subsection{Present and Projected Application}

The only firm plan to develop geothermal energy in the United States is that of Pacific Gas and Electric at The Geysers. The present (early 1974) capacity of about 400 MNe will be expanded by about 100 Whe each year ${ }^{24}$ until the ultimate capacity of the field (estimated to be about 5000 MWe) is developed. ${ }^{25}$ Beyond this, estimates of future geothermal capacity are speculative. Nevertheless, several estimates have been made, and the range of variation reflects the disagreement, discussed previously, on the extent of geothermal resources.

In a study by the National Petroleum Council, Kilkenny ${ }^{26}$ estimated that generating capacity based on geothermal fluids might amount to 1500 MWe by $1975,10,500$ MWe by 1980 , and 19,000 Me by 1985. Only about one-half of that estimated for 1975 now appears achievable.

The Hickel Panel ${ }^{22}$ made the following projections of installed geothermal power: 


$\begin{array}{ccc}\text { Year } & \begin{array}{c}\text { Capacity with } \\ \text { moderate R\&D } \\ \text { program (MWe) }\end{array} & \begin{array}{c}\text { Capacity with } \\ \text { accelerated R\&D } \\ \text { program (MWe) }\end{array} \\ 1980 & 10,500 & 36,000 \\ 1985 & 19,000 & 132,000 \\ 1990 & 35,000 & 242,000 \\ 2000 & 75,000 & 395,000\end{array}$

The lower estimates, which are identical with those of the U.S. Department of the Interior, ${ }^{12}$ are based on the assumptions that a moderate R\&D program will result in the discovery of more geothermal reservoirs and that the technology will be developed to tap the deeper and lower-temperature hot-brine systems. The higher estimates are based on the assumption that an intensive program will result in the technology needed to tap more difficult reservoirs including dry not rocks.

Rex and Howe $11^{14}$ judge that 400,000 Mule of geothermal capacity "could be discovered and developed in the Western United States in 20 years by the resource industry." Their projection of the potential is based on the assumption that the dry hot-rock systems are technically and economically exploitable.

J. 0. Horton, 27 Assistant Secretary of the Interior for Land and Water Resources, indicated in a statement to the Senate Interior and Insular Affairs Subcomittee on Water and Power Resources that 
"although we estimate that geothermal energy would constitute only 1 to 2 percent of the total United States energy supply forecast for the year 2000 , it could mean up to 10 percent or more of the total energy supplies forecast in the western states by that time."

The results of analyses by the Bureau of Mines ${ }^{12}$ forecast a geothermal electrical capacity of 4000 MWe in 1985 with an increase to 40,000 MWe in 2000 . The $1985-$ to-2000 increase assumes that about 15\% of new power-generation capacity in the western states would be from geothermal sources.

The research and development program proposed in reference 23 is designed to stimulate the cormercial production of at least 20,000 MWe by 1985 from various types of geothermal resources, plus important additional fuel savings through use of geothermal energy for such non-electric purposes as space heating and air conditioning. The corresponding goals for the years 2000 and 2020 are 80,000 MWe and 200,000 MWe respectively. The year 1985 and 2000 electrical capacity projections are seen to be approximately the same as those projected by the Hickel Panel for a moderate R\&D program.

Figure A.4-6 summarizes the range of some of these projections. Speculations on the projected application of geothermal energy by the year 2000 vary from an insignificant $2 \%$ to an important $20 \%$ of the predicted electrical capacity at that time. In reality, the amount of electrical capacity would be quite limited with presently developed and tested technology. Therefore, technological advances on several 


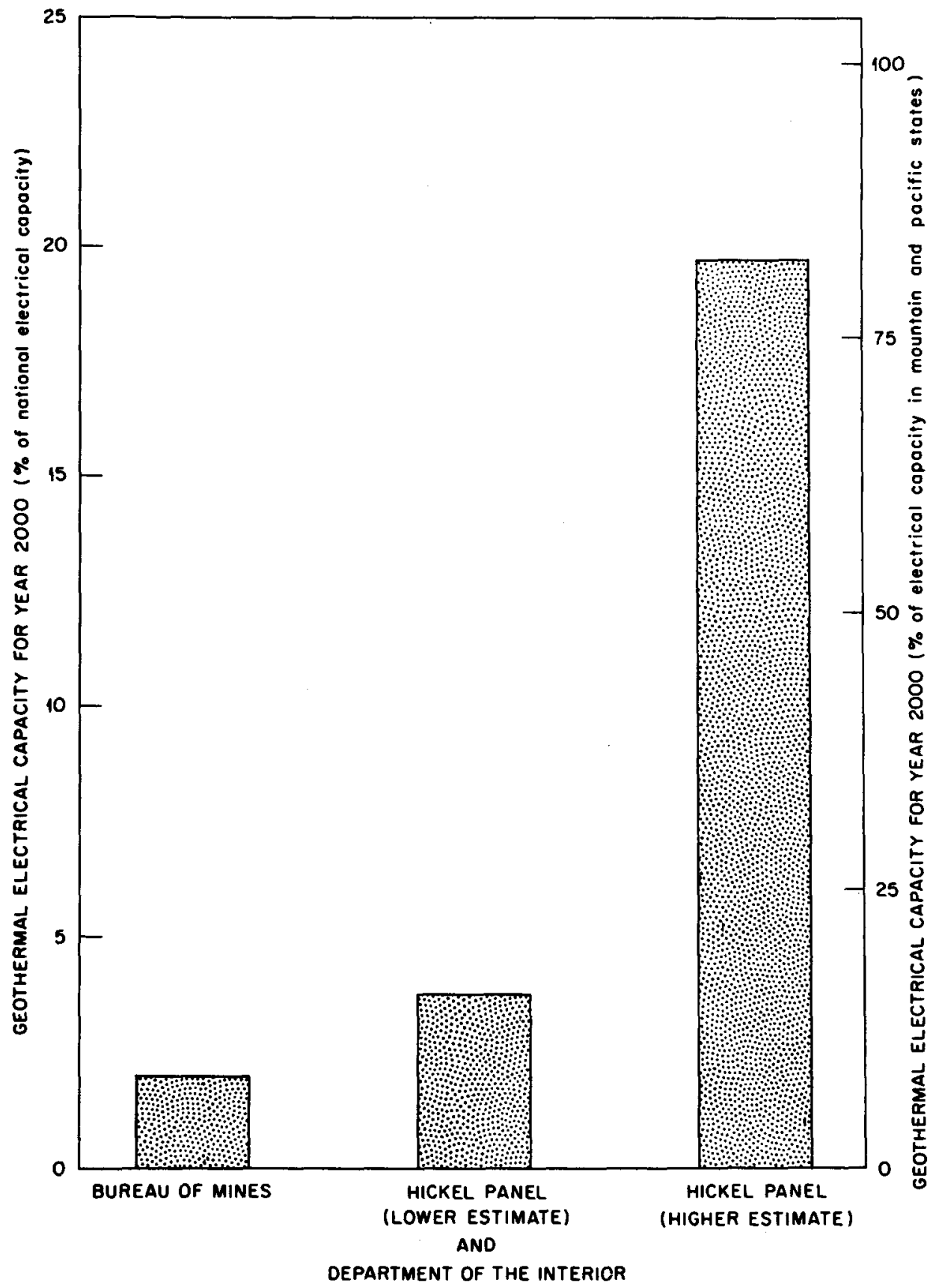

THREE PROJECTIONS OF GEOTHERMAL ELECTRICAL CAPACITY FOR YEAR 2000

Figure A.4-6 
fronts will be required for geothermal energy to have national significance. But technology is only one of several important limitations on the growth of geothermal-energy utilization. Other factors include legal and political constraints, environmental restrictions, and institutional and financial considerations.

Many of the country's geothermal resources probably will not be developed until political and legal frameworks are provided to define ownership and to establish procedures for management and regulation of geothermal resources. ${ }^{28}$ The lack of a sound legal framework may, in some cases, dampen enthusiasm for investment. But a factor of equal importance is that, with present technology in exploration, the magnitude of a given reservoir is difficult to define with confidence. Yet an electric utility must have assurance of sufficient steam reserves to sustain operation over the amortization period ( 30 to 40 years) of the power plant.

Large-scale geothermal development implies the establishment of a geothermal industry that, if the upper ranges of the above projections are accepted, must develop thousands of megawatts of power each year with trained geologists, engineers, exploration rigs, drilling equipment, hardware supplies, etc. For example, $0^{\prime}$ Conner 29 points out that, to meet the optimistic projections of implementation, geothermal drilling in the next decade will be comparable with that of the oil industry. The associated human and capital resources 
cannot be built up quickly without either government investment or the promise of large quick profits, or both.

\subsection{Environmental Impacts}

\subsubsection{General Nature of Environmental Impacts}

Environmental studies ${ }^{10}$ indicate that the major potential impacts of the use of geothermal energy are in the general areas of (1) surface and groundwater quality impairment as a result of fluid disposal, (2) air emissions, particularly hydrogen sulfide, (3) noise from drilling and steam venting during operation, (4) uncontrolled blowouts, (5) aesthetic impact, (6) land subsidence from fluid withdrawal, (7) seismic activity from fluid withdrawal or reinjection, (8) land use, and (9) damage to vegetation and wildlife. The environmental impact of geothermal generation is largely restricted to the generating site and its immediate surroundings a contrast with fossil-fueled or nuclear generation, for which impacts occur at several locations (mines, processing plants, disposal sites).

The different types of geothermal systems present very different environmental impacts. Because of the relatively pure fluid in the vapor-dominated reservoirs, the fluid-disposal problem is relatively small compared with that of the hot-brine systems, 
whose high salinity represents a potentially serious environmental impact. The environmental impact of hot-rock utilization has not yet been thoroughly evaluated and cannot now be fully defined. The environmental impacts of advanced geothermal power systems now in the conceptual stage, such as binary cycles and proposed systems for dry hot-rock use, have not been thoroughly evaluated and will not be discussed. However, indications are that these advanced systems which would extract geothermal energy with closed loops may have much less environmental impact than do current systems, especially with regard to' liquid and gaseous effluents from the geothermal fluid.

\subsubsection{Mechanism for Regulation of the Environmental Impacts}

The proposed leasing and operating regulations issued pursuant to the Geothermal Stean Act of 1970 (ref. 30) provide a framework for the regulation of exploration, development, and use of geothermal resources on Federal lands. The Secretary of the Interior and his official representatives are required to review the environmental impact of each proposed lease and to develop special stipulations when necessary to protect the environment and all other resources.

The Sierra Club, in commenting on the Department of the Interior's draft environmental statement on the geothermal leasing program, 31 stated that the proposed regulations lack specifics and might not be strictly enforced. They suggested that full-scale implementation of the Geothermal Steam Act be deferred pending successful completion 
of a carefully monitored pilot project. The regulations were subsequently revised, are now more specific in certain areas, and have since been published.

The State of California provides for regulation of geothermal activities on non-Federal land comparable with that proposed by the Department of the Interior on Federal land. The State also requires geothermal developers to comply with all valid ordinances of cities and counties which are applicable; county zoning commissions have considerable control over the use of private lands.

Other states have developed or undoubtedly will develop similar regulations when further geothermal development is proposed.

\subsubsection{Surface Effects}

As noted previously, all the environmental impacts of geothermal power plants arise from the production site itself; the area of the site depends on the spacing of the wells. Well spacing is an important factor in the efficient use of a geothermal reservoir. The spacing of the wells should be such as to minimize the total number of wells required during the plant lifetime while exploiting the full energy potential of the field. Generally, wider spacing would require fewer replacement wells but would result in a larger area associated with each power plant. The extent of the area 
involved for a 1000-iwe plant that would operate for, say, 30 years can be inferred from data obtained at The Geysers. ${ }^{15}$ Production data on wells with a density of one well per 5 acres indicate that production declines almost exponentially with a half-life (time required for well production to decrease by one-half) of 5 years. If this interpretation is correct and if short-term (5-year) data can be extrapolated, the implication is that new wells which would number about $14 \%$ of the original number of wells must be added each year. Based on an initial production rate of 7 Mue per well, the initial number of wells for 1000 MNe would be 140 in an area of 700 acres. For 30 years of production, the total number of wells needed would be 740 in an area of 3700 acres. Similar estimates for a density of one well per 45 acres indicate that, initially, 140 wells over an area of 6300 acres would be required. For 30 years of production, the total number of wells would be 280 over 12,600 acres. Surface environmental effects would be related to the construction and maintenance of roads, wells, steam lines, transmission lines, and power plants.

A network of roads would be required to gain access to each well site. Roads would have to be built in accordance with an approved plan to control erosion and to minimize dust. Although these problems are fairly easy to solve in flat lands, they would require much more attention for steep terrain. During drilling of a well, provisions would have to be made for the disposal of drilling muds

$$
\text { A.4-31 }
$$


and fluids, prevention of blowouts, and containment of reservoir fluids. Backfilling of mud pits and fluid ponds, use of blowout preventers, and casing and cementing of wells are required by the proposed Federal regulations. Steam lines as large as $30 \mathrm{in}$. in diameter would lace an area of 1/2- to 1 -mile radius surrounding each power plant. These lines would be regularly inspected to detect leakage, and wellheads would be inspected by the operators and by regulatory inspectors for exterior corrosion damage or structural weakness to avold blowouts or leakage. By comparison with the other portions of a geothermal development, the power plant, including switchgear and cooling towers, would be small; it would occupy only a few acres.

The facilities to transmit geothermal power would be similar to those for other central-station power plants, but the environmental impact might be greater than for other alternatives because of the long distances between geothermal fields and load centers and because of the need to transmit power from many small generating plants to the power grid. This problem would not occur, however, in the case of the two largest proven geothermal resources in the United States, viz, The Geysers and Imperial Valley, California. Both of these sites are very close to large load centers in northern and southern California respectively. 
Evidently, the development of a large geothermal field would severely restrict surface uses of the land over an area of several thousand acres. Where grazing is the predominant alternative use of the land, as at The Geysers, cattle might be allowed on the developed land among the wells and steam lines. Where other uses are prevalent, such as agriculture or recreation, those uses would be disrupted to some extent. If geothermal-energy extraction were properly regulated, it would not permanently damage land for future uses.

\subsubsection{Impact on Water}

The proposed Federal regulations would minimize the impact of drilling and production-testing on water resources. The major potential impacts that would have to be avoided would be siltation of surface water from road construction and from drilling-site excavation; contamination of surface or groundwater from spills or uncontrolled blowouts; contamination of groundwater from improperly executed recharge; accidental interception of artesian aquifers that were not properly cased off; degradation of hot springs, fumaroles, and geysers; and contamination of freshwater aquifers by casing failures.

The Geysers area is a good example of a difficult site for road building and test drilling. The steep terrain and relatively loose 
soil create sediment that must be controlled by reseeding and by other means of protection until ground cover is established. Unfortunately, many other geothermal areas are also located in remote mountainous regions, although some are more accessable.

The flat Imperial Valley has minimal impact from road building and site excavation. Because of the agricultural nature of the valley, of its use of groundwater for irrigation, and of the presence of the Salton Sea, the Imperial Valley is subject to water-resource pollution in the event of accidents. Some brines were discharged into the Salton Sea in 1962; they resulted in a $4.5 \%$ increase in dissolved minerals in just 90 days. Existing regulations prohibit such discharges and prohibit the raising of river temperatures more than $2^{\circ} \mathrm{F}$. The potential for such impacts still exists, especially following blowouts, and must be guarded against very carefully.

Test-production fluids would be channeled to settling or storage ponds for containment. At the end of the test period, the ponds would be filled in and replanted. For longer-term testing, reinjection of geothermal fluids might be a common method of eliminating water pollution, but the reinjection would have to be made by properly planned and regulated methods.

Consumptive use of water for drilling muds represents a minor impact on local water resources, but might prove troublesome in desert areas. 


\subsubsection{Impact on Air}

Venting of steam to the atmosphere can create environmental damage If the steam contains large quantities of undesirable gases such as hydrogen sulfide or ammonia. For example, the steam phase in New Zeal and is reported to contain $\mathrm{CO}_{2}(5400 \mathrm{ppm}), \mathrm{H}_{2} \mathrm{~S}(140 \mathrm{ppm})$, and $\mathrm{NH}_{3}(15 \mathrm{ppm}), 32$ and The Geysers steam contains $\mathrm{CO}_{2}(12,400 \mathrm{ppm})$, $\mathrm{H}_{2} \mathrm{~S}(330 \mathrm{ppm}), \mathrm{NH}_{3}(250 \mathrm{ppm})$, and $\mathrm{H}_{3} \mathrm{BO}_{3}(18 \mathrm{ppm}) ;{ }^{31}$ steam from Larderello is similar. Such gases could produce undesirable effects, and their removal might be required during the test-production stage. Other potential atmospheric effects include fogs in cold climates.

Mercury vapor and traces of radioactive elements have been found in some geothermal fluids. Fluids from each well should be analyzed for these elements. Although removal technology is not available for these materials, methods are available and should be used to prevent overexposure of employees.

\subsubsection{Ecological Impacts}

Most of the impacts on fish and wildlife during field development would occur on or adjacent to well sites, although water-quality impairment might cause much more widespread damage. Habitat would be destroyed at well sites and in the vicinity of roads. Noise would displace wildlife, although the extent of disturbance cannot be accurately predicted. 
The greatest potential impact on fish and wildiffe would result from improper control of the geothermal fluid. The addition of toxic geothermal effluents to surface streams or lakes would probably alter the fisheries habitat and the waterfowl feeding and nesting areas. Similarly, heated effluents could result in damage to the aquatic habitat. Finally, if toxic geothermal effluents should find their way into streams or lakes and be picked up by fish or wildlife, these contaminents may also find their way into the human food chain. Adequate control measures would be required to minimize such occurrences.

\subsubsection{Aesthetic and Recreational Impacts}

Many of the geothermal resources of the westem United States are in remote areas valued for wilderness and other natural aesthetic qualities such as volcanos, hot springs, fumaroles, and geysers. The national parks and some other designated wilderness areas are not subject to geothermal exploration. Decisions on whether to develop other scenic areas might be very difficult.

One of the principal aesthetic impacts of geothermal field development is the noise of the drilling operation and of the testing. Typical noise levels at 1500-ft distance from The Geysers are $55 \mathrm{~dB}$ for air drilling and $65 \mathrm{~dB}$ for a muffled testing well (Table A.4-2). The actual aesthetic impact of noise depends on surrounding terrain, weather, and human psychology, but the overall effect is a significant aesthetic impact. 
Table A.4-2

COMPARISONS OF NOISE LEVELS BETWEEN THE GEYSERS AREA

AND OTHER SOURCES

\begin{tabular}{lcr}
\hline Source & Level, dB (A) & Distance, ft \\
\hline & The Geysers area & \\
& 126 & 25 \\
Drilling operation (air) & 55 & 1500 \\
Drilling operation (air) & 100 & 25 \\
Muffled testing weli & 65 & 1500 \\
Muffled testing weil & 100 & 50 \\
Steam-line vent & 90 & 250 \\
Steam-line vent & & \\
& Comparative levels & \\
& 125 & 200 \\
& 120 & (Average) \\
Jet aircraft takeoff & 100 & 50 \\
Threshold of pain & 75 & (Average) \\
Unmuffled diesel truck & 40 & Average) \\
Street corner in a large city & & \\
Residential area at night & & \\
\hline
\end{tabular}

Source: U.S. Department of the Interior, Fiani Environmental Statement for the Geothermal Leasing Program, vol. II, 1973, p. V-56. 
In the areas of natural scenic beauty, the greatest visual impacts would result from the construction of new roads with attendant hillside scarring, of a network of steam lines, of the power plant with associated cooling towers, and of transmission lines. The presence of steam plumes from steam wells and from cooling towers would also result in aesthetic impact. Drilling rigs would be conspicuous throughout the life of a geothermal reservoir.

Recreation might be influenced to the extent that access to a geothermal field would have to be limited for safety reasons. Also, destruction of vegetation and fisheries and any noise might affect recreation by disturbing wildlife and reducing the aesthetic enjoyment by sportsmen. The use of geothermal areas as spas or tourist attractions might be adversely affected by construction activities nearby.

\subsubsection{Blowouts}

Uncontrolled blowouts represent an important hazard during geothermal development. The adverse effects associated with blowouts are noise, air contamination from gaseous emissions, possible pollution of surface water or groundwater, and waste of the resource. Proper casing design and drilling execution should prevent blowouts.

Nevertheless, a blowout that occurred at The Geysers in 1957 is still active. Its cause has been attributed to minor shifting of the land, which resulted in a casing failure that allows steam to escape from around the well. The casing extended to only 500-ft 
depth; present California and proposed Federal regulations require better casings and make such a blowout unlikely. They also require quickly operable shutoff equipment at the wellhead to restrain any uncontrolled flow that might occur. About $\$ 1$ million has been spent unsuccessfully to control The Geysers blowout.

More recent experiences at The Geysers, in the Imperial Valley, and in New Zealand indicate no serious blowouts in about 200 wells completed since 1960. Two blowouts have occurred at the Cerro Prieto field in Mexico. In 1961, one resulted from a mechanical failure due to vibrations in the wellhead equipment. This was brought under control by directional drilling and by cement injection. The other blowout, which was uncontrolled for four months in 1972, started with water and steam being ejected from a large crater about $300 \mathrm{ft}$ from the well. Several days later, a violent blowout occurred at the crater. This subsided, but emissions continued during the four-month period while corrective measures were tried. Another mishap, at Beowawe, Nevada, occurred in August 1972 when three capped wells appeared to have been dynamited by vandals. Strong ejections of steam and water came from the damaged wells.

\subsubsection{Earthquakes}

In some ofl-production regions, the pressure changes resulting from drilling into a reservoir have been accompanied by increased seismic activity. Such instabilities due to production have occurred in the Wilmington ofl field, California; others due to water injection have occurred at the Baldwin Hills oil field, California, and at the Rangely oil field, Colorado. ${ }^{31}$ Also, the seismic activity associated 
with injection of waste waters at the Rocky Mountain Arsenal in Colorado gave rise to considerable publicity. Similar increases in seismic activity have also been noted in association with the filling of large surface reservoirs and with the attendant changes in hydrostatic head; the affected areas have included Lake Mead on the Colorado River and Lake Kariba in Africa. In general, such earthquakes have not proven disastrous, but the potential for a major quake cannot be ruled out. In any event, earthquakes must be counted as a potential environmental impact associated with geothermal development, and provisions must be made for seismic monitoring before and during major production. On the other hand, the argument is presented that the geothermal areas are naturally active seismic regions, and therefore it would be difficult to say that drilling at depths less than $10,000 \mathrm{ft}$ can trigger earthquakes whose epicenters are several miles deep. The brines are reinjected at pressures much lower than those that caused seismic activity at other places, and the low-pressure fluids may lubricate slippage planes and gradually relieve stresses.

The problem is a major concern for large-scale development, and its solution probably lies in extensive base-line data collection prior to field development and in close monitoring of seismic activity during production. 


\subsubsection{Subsidence}

The many instances of land subsidence from freshwater production and from oil production are well documented. Therefore, concern is expressed that geothermal production will also contribute to land subsidence, which has been noted at Cerro Prieto, Mexico. Although subsidence can be predicted roughly by geological theory, the only safe way for development to proceed appears to be with base-line data and a good monitoring of elevation changes. The U.S. Geological Survey has initiated a program to monitor possible ground movement in The Geysers area and in the Imperial Valley. 27

Reinjection of geothermal or other water into the geothermal area is cited as a possible method of alleviating subsidence. The feasibility of this approach may be related to the local geology and geochemistry. Monitoring of ground movement would still be required to inform the operator and the regulatory agencies of the consequences of production operations.

Land subsidence in some undeveloped areas may not be of significant concern; it would be of great concern in flat agricultural regions such as the Imperial Valley.

\subsubsection{Power-Plant Thermal Effects}

Because of the relatively small temperature driving forces in geothermal power cycles, the overall thermal efficiency is low. For example, at The Geysers the heat rate is about $22,000 \mathrm{Btu} / \mathrm{kWhr}$ 
compared with 8000 to $9000 \mathrm{Btu} / \mathrm{kWhr}$ for a modern fossil-fueled plant or for an efficient nuclear plant such as the HTGR or the proposed LMFBR. In terms of the heat rejected to the atmosphere for a generating capacity of 1000 We, the comparison is: geothermal, $6140 \mathrm{MWt}$; fossil-fueled or advanced nuclear, $1500 \mathrm{WWt}$. Although geothermal plants reject more energy than do large central-station plants by a factor greater than 4 , the increase in environmental impact may not be proportional to the increase in heat rejected because geothermal plants, and consequently heat rejections, would be dispersed over a large area. Nevertheless, the implications of the large amount of heat that would be associated with large-scale geothermal development have not been thoroughly evaluated.

\section{4:6.12 Economic and Social Effects}

Geothermal development requires substantial investment in the drilling of wells and the construction of roads, pipelines, power and by-product plants, and transmission lines. Such investments result in an increased tax base for the area of development. The laborintensive phase is short-term (during field development), and only a moderate number of people would later be required to operate and maintain a large geothermal field. 


\subsubsection{Irreversible and Irretrievable Commitments of Resources}

The principal commitment of resources would be the depletion of thermal energy and water from the local geothermal reservoir. Both are eventually renewable but not within the life of a specific project. No alternative use of the stored energy is foreseen, and the geothermal water might be developed for other uses after it had been used for power production.

Compaction and resulting land subsidence that might occur are potential irreparable consequences. If substantial adjustment were required to accommodate such changes, the cost and impact should be considered in arriving at decisions.

Some onsite or related ecological features such as plant life and aesthetics would be irreversibly altered. The extent of such alterations would depend on the particular site and characteristics involved.

Finally, dedication of the land surface to use for wells, associated surface facilities, power plants, and transmission lines, while not permanent except for minor portions of the area, would represent an irreversible commitment in the context of human lifetimes. Norma 11y, 30 to 50 years is required to amortize the investment in power facilities at a given field. 


\subsection{Costs and Benefits}

\subsubsection{Energy Production and Delivery Costs}

\subsubsection{Direct Costs}

The direct costs, or those costs that are accounted for in the price of geothermal energy, include the following major components: (1) steam supply, (2) power conversion, and (3) power transmission. Little is known about the cost of transmission should geothermal energy become a major electrical-energy source except that the cost would probably be somewhate higher than that for central-station fossil-fueled or nuclear plants. The reason for higher transmission costs is that, on the average, geothermal energy-generation sites would be farther from load centers than fossil-fueled or nuclear plants would be. However, the amount of this cost differential is not likely to be a major element in the overall cost of geothermal power.

Various estimates have been given of the cost to extract and convert geothermal energy. But these estimates, like many published estimates for nuclear and fossil-fuel energy, appear to be somewhat dated and, in particular, fail to take into consideration the rapid increases in all energy costs experienced in the past year or two. Probably, the best current estimate is that by Pacific Gas and Electric Company for their Geysers unit 14, scheduled to go on line in 1976. 24 The estimated production cost in terms of 1973 dollars is $9.11 \mathrm{mills} / \mathrm{kWhr}$ for a $70 \%$ plant factor and $8.55 \mathrm{mills} / \mathrm{kWhr}$ for a $90 \%$ plant factor. These costs would seem to represent a lower limit on geothermal-energy costs since dry-steam reservoirs, such 
as The Geysers, are generally conceded to be the least expensive to tap.

\subsubsection{Indirect Costs}

Certain costs of geothermal energy will not appear in the market price of the products. These may include: (1) ground subsidence, (2) environmental effects of gaseous and liquid effluents, (3) withdrawal of 1 and from other potential uses, and (4) increased seismic activity. Of course, not all of these will be present in every geothermal development, and some, such as environmental effects of effluents, may be controlled by added power-plant equipment and would thus be transferred to direct costs recoverable from power revenue.

\subsubsection{Development Costs}

As noted in Section 4.4, the proponents of geothermal energy have suggested a ten-year R\&D program that would amount to $\$ 500$ million to $\$ 600$ million, and a five-year $\$ 185$ million program has also been suggested as part of a national energy R\&D program.

\subsubsection{Benefits}

The major benefit from geothermal energy in the context of the present study would be electric power, with no dependence on externally acquired fuels. Other benefits might include:

(1) desalted water, (2) commercial minerals and gases, and (3) process

or space heat. The multiple-use aspects would appear to warrant increased attention because of the depletable nature of the resource 
and because of the small fraction of the stored energy that is available for power generation.

\subsection{Overall Assessment of Role in Energy Supply}

A major advantage of geothermal energy is that electric power can be produced without the consumption of fuels. The potentially significant environmental impacts might, by R\&D, be made acceptable. Knowledgeable people have made widely different judgements about the amount of the recoverable resource and the rate at which this resource can be exploited in the future. Present information indicates that geothermal energy might become an important source of energy in some regions of the western United States, especially at The Geysers and in the Imperial Valley, before the end of the century. This potential for regional significance could justify a significant R\&D program. It might also be noted that the development of geothermal power in one part of the United States would release some fuels for consumption elsewhere.

Whether geothermal energy will become of national significance in the foreseeable future is highly speculative. The successful use of energy in dry hot rocks would go far towards making it so, but this approach is now only in the conceptual stage. At any rate, the planning to meet a significant part of future energy needs cannot be based solely on geothermal energy. Therefore, no basis seems yet to exist for altering the course of development of other energy sources, including coal and nuclear energy. 


\subsection{References}

1. M. C. Smith, Geothermal Energy, LA-5289-MS, Los Alamos Scientific Laboratory, Los Alamos, New Mexico, May 1973.

2. R. G. Bowen and E. A. Groh, "Geothermal - Earth's Primordial Energy," Technol. Rev., October/November 1971, pp. 42-48.

3. U.S. Department of the Interior, Final Environmental Statement for the Geothermal Leasing Program, vol. I, 1973, p. II-10.

4. J. Combs and L. J. P. Muffler, "Exploration for Geothermal Resources," pp. 95-128 in Geothermal Energy, P. Kruger and C. Otte, Eds., Stanford University Press, Calif., 1973.

5. D. E. White, "Characteristics of Geothermal Resources," ibid., pp. 69-94.

6. M. Smith et al., "Induction and Growth of Fractures in Hot Rock," ibid., pp. 251-268.

7. Geothermal Report, Richard Arlen Smith, Publisher-Editor, vol. II, No. 21, Nov. 1, 1973.

8. Bureau of Reclamation, U.S. Department of the Interior, Geothermal Resource Investigations - Imperial Valley, California - Developmental Concepts, January 1972.

9. Water Desalination Report, Richard Arlen Smith, PublisherEditor, vol. IX, No. 44, Nov. 8, 1973.

10. U.S. Department of the Interior, Final Environmental Statement for the Geothermal Leasing Program, 1973 (a report in four volumes).

11. L. H. Godwin et al., Classification of Public Lands Valuable for Geothermal Steam and Associated Geothermal Resources, U.S. Geological Survey Circular 647, 1971.

12. U. S. Department of the Interior, Op. Cit., Vol. I.

13. Directorate of Regulatory Standards, USAEC, Nuclear Power 1973-2000, WASH-1139(72), Dec. 1, 1972.

14. R. W. Rex and D. J. Howe11, "Assessment of U.S. Geothermal Resources," Pp. 59-67 in Geothermal Energy, P. Kruger and C. Otte, Eds., Stanford University Press, Calif., 1973. 
15. C. F. Budd, Jr., "Steam Production at The Geysers Geothermal Field," ibid., pp. 129-144.

16. J. P. Finney, "Design and Operation of The Geysers Power Plant," ibid., pp. 145-161.

17. J. B. Koenig, "Worldwide Status of Geothermal Resources Development," ibid., pp. 15-58.

18. G. Weismantel, "Geothermal Power Still Iffy," Chem. Eng. (New York) 80(6): 40-41 (1973).

19. J. Henahan, "Full Steam Ahead for Geothermal Energy," New Sci. 57(827): 16-17. (1973).

20. J. H. Anderson, "Vapor-Turbine Cycle for Geothermal Power Generation," pp. 163-175 in Geothermal Energy, P. Kruger and C. Otte, Eds., Stanford University Press, Calif., 1973.

21. J. B. Burnham and D. H. Stewart, "Recovery of Geothermal Energy from Hot-Dry Rock with Nuclear Explosives," pp. 223-230 in Geothermal Energy, P. Kruger and C. Otte, Eds., Stanford University Press, Calif., 1973.

22. Hearings before the Committee on Interior and Insular Affairs, U.S. Senate, Ninety-Second Congress, Second Session, on the role of "Geothermal Energy Resources and Research," Serial No. 92-31, June 15 and 22, 1972, p. 185.

23. WASH-1281, The Nation's Energy Future, A Report To The President of The United States by the Chairman, U.S. Atomic Energy Commission, December, 1973.

24. Geothemal Report, Richard Arlen Smith, Publisher-Editor, vol. II, No. 16, Aug. 15, 1973.

25. U.S. Department of the Interior, op. cit., vol. II, p. V-10.

26. Hearings before the Committee on Interior and Insular Affairs, op. cit., p. 236.

27. Statement of J. 0. Horton, Assistant Secretary, Land and Water Resources, before the Senate Interior and Insular Affairs Subcormittee on Water and Power Resources, June 13, 1973.

28. D. R. Allen, "Legal and Policy Aspects of Geothermal Resource Development," Amer. Water Resour. Assoc. Bull. 8(2): 250-256 (1972). 
29. J. J. O'Connor, "What Can We Expect from Geothermal?" Power $117(2): 9$ (1973).

30. Fed. Regist. 38(140), Pt. II, 19748-19779 (1973).

31. U.S. Department of the Interior, Draft Environmental Impact Statement for the Geothermal Leasing Program in Compl iance with Sec. 102(2)(C) of the National Environmental Policy Act of 1969, September 1971.

32. I. Spiewak et al., Prel iminary Investigation - Desalting of Geothermal Brines in the Imperial Valley of California, ORNLTM-3021, Oak Ridge National Laboratory, Oak Ridge, Tenn., Mar. 4, 1970. 


\section{A.5 SOLAR ENERGY \\ 5.1 Introduction}

\subsubsection{General Description}

In response to the impending shortage of some fossil fuels, various proposals have been made to use solar energy as a substitute for other energy sources. The proposed applications include the production of electricity, thermal energy, and fuels.

Energy from the sun falls on the earth's atmosphere at a rate of about 130 watts per square foot $\left(w / \mathrm{ft}^{2}\right) .^{1}$ Nights, weather, seasons, attenuation by the atmosphere, and variations in latitude reduce this rate to an average of $17 \mathrm{~W} / \mathrm{ft}^{2}$ for the surface of the United States. $^{2}$ Even so, the energy received from the sun exceeds the energy we produce from conventional fuels by a factor of nearly 700.

The methods that have been proposed to produce electricity from solar energy are: (1) thermal conversion, (2) photovoltaic conversion (solar cells), and (3) burning of photosynthetic materials. In the thermal-conversion process, shown schematically in Fig. A.5-1, solar energy is collected in a heat-transfer fluid that is used in a thermodynamic cycle to generate electricity as in other steamelectric plants. In the photovoltaic process, solar energy is converted directly to electricity in solar cells. Electricity production based on photosynthetic materials would be accomplished 


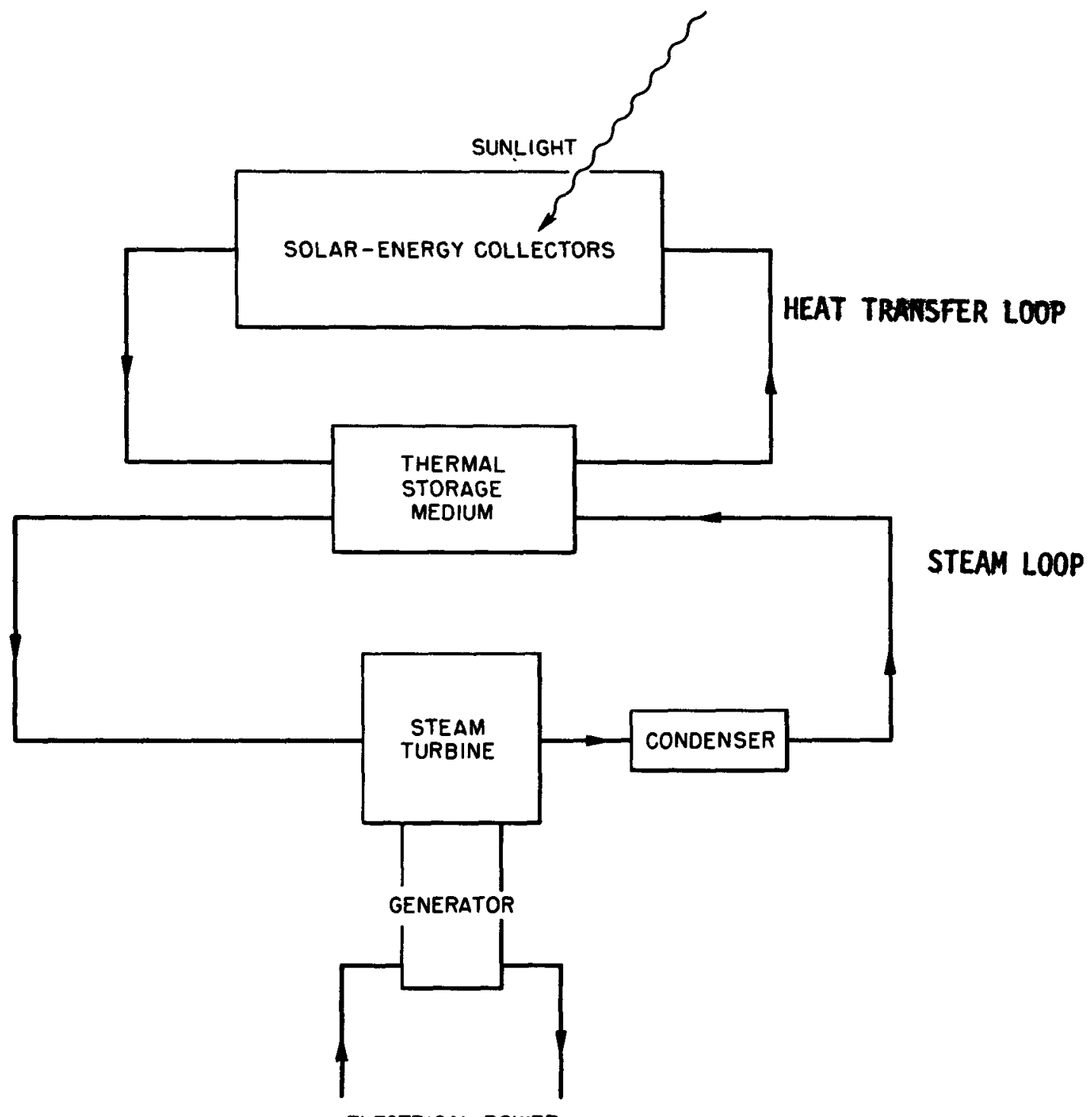

ELECTRICAL POWER

SCHEMATIC OF A THERMAL-CONVERSION SOLAR POWER SYSTEM

Figure A.5-1 
primarily by combustion of vegetable carbohydrates in a conventional steam-electric plant. All of these methods may be applicable to central-station power generation, and the thermal conversion and photovoltaic processes have also been proposed for small units suitable for residential or commercial buildings. Solar cells, in particular, may be suitable for this application.

Thermal energy derived from solar radiation can also be used for space conditioning, i.e., heating and cooling of buildings and residential-water heating.

The production of high-energy fuels from solar energy involves two basic steps. The first step is the managed conversion of solar energy into plant tissue (e.g., trees, grasses, water plants, and algae) by photosynthesis. Because plant tissue has a low energy content per unit volume, conversion to a high-energy gaseous, liquid, or solid fuel is desirable. Conversion methods include fermentation, pyrolysis, and chemical reduction.

\subsubsection{History}

The collection and use of solar energy for thermal applications has been practiced for centuries. Early uses were primarily scientific in nature. "Burning lenses" were, and still are, used in chemical and metallurgical researches involving high temperatures. 
Although electrical generation from solar energy by thermal conversion has not been attempted, the technical feasibility of doing so is not questioned. Thermal conversion to mechanical energy was demonstrated in the latter part of the 19th century. A workable solar-powered water pump was displayed by Mouchot at the Paris World Fair in $1878 .^{3}$ Frank Shuman, an American engineer, built a 100-hp solar-powered steam engine in Egypt in $1912 .^{3}$ But all attempts at a practicable system have been less than satisfactory, primarily because collectors have not been developed that will collect solar energy efficiently and, at the same time, provide high temperatures necessary for good efficiency of a heat engine.

\subsubsection{Status}

Most contemporary uses of solar energy are to provide thermal energy for buildings. Solar water heaters are manufactured and used in several countries including the United States; they were once common in Florida, but their use has diminished because of the availability of natural gas. Space heating by use of solar energy has been demonstrated in about 20 experimental buildings. ${ }^{4}$ Some experimental work on solar-powered air conditioning by use of absorption refrigeration has been conducted, but large-scale demonstration has not been achieved. Solar energy systems for residential and commercial buildings that combine water heating, space heating, and air conditioning are considered to have the most promise since solar collectors and energy storage units - the major cost centers - are common to all three functions. Little work has been done, however, on combined systems. 
The recent resurgence of interest in thermal conversion is due primarily to the efforts of Drs. Aden and Margorie Meinel of the University of Arizona. They propose a solar collection system that would use selective surfaces and optical intensification; the hope is that the system would provide temperatures comparable with those achieved in modern fossil-fueled steam-electric plants.

Electric generation by use of solar cells is a well-established technology for a number of specialized applications. Arrays of silicon cells are used in spacecraft to supply electrical needs. Terrestrial uses include power for navigation lights on offshore platforms, microwave repeater stations, air-navigation beacons, highway emergency call systems, and railroad signaling devices. ${ }^{4,5}$ Solar-cell power units vary in size from a few watts to over $20 \mathrm{~kW}$ for Skylab. The annual United States production of silicon solar cells is 50 to $70 \mathrm{~kW}$, most of which are for space applications. ${ }^{4}$ Large photovoltaic systems for terrestrial applications are still in the research stage.

The production of high-energy fuels from solar energy has been demonstrated to be technically feasible but has not been applied commercially. ${ }^{4}$ The managed production of raw photosynthetic materials for fuels would be analogous to tree farming for lumber and paper, the cultivation of grasses for hay, and algae culture for removing nutrients in sewage ponds. Conversion of the raw material 
to high-energy gaseous liquid and solid fuels via biological and chemical processes has been demonstrated on a pilot scale. ${ }^{14}$

\subsection{Extent of Energy Resource}

\subsubsection{Geographical Distribution}

The resource base, i.e., the rate at which solar energy falls in the United States, is reasonably well established and amounts to about $1.43 \times 10^{9}$ MW-years (thermal) per year for the conterminous United States. If converted at $10 \%$ efficiency, solar energy could provide electricity at a rate greater than a thousand times the rate of consumption expected for the year 2000 . The resource base is not uniformly distributed over the United States and ranges from an average of about $12 \mathrm{~W} / \mathrm{ft}^{2}$ for portions of Michigan and Wisconsin to about $24 \mathrm{~W} / \mathrm{ft}^{2}$ for southern Arizona and New Mexico. Figure A.5-2 shows the distribution of solar energy over the United States for an average day. 6

\subsubsection{Estimated Avallability}

The resource base does not, of course, constitute a recoverable resource unless and until the cost of recovery is competitive with the costs of alternative energy sources. At the present, the recoverable resource is very small since the economic feasibility of solar energy has been demonstrated for only a few specialized applications. 


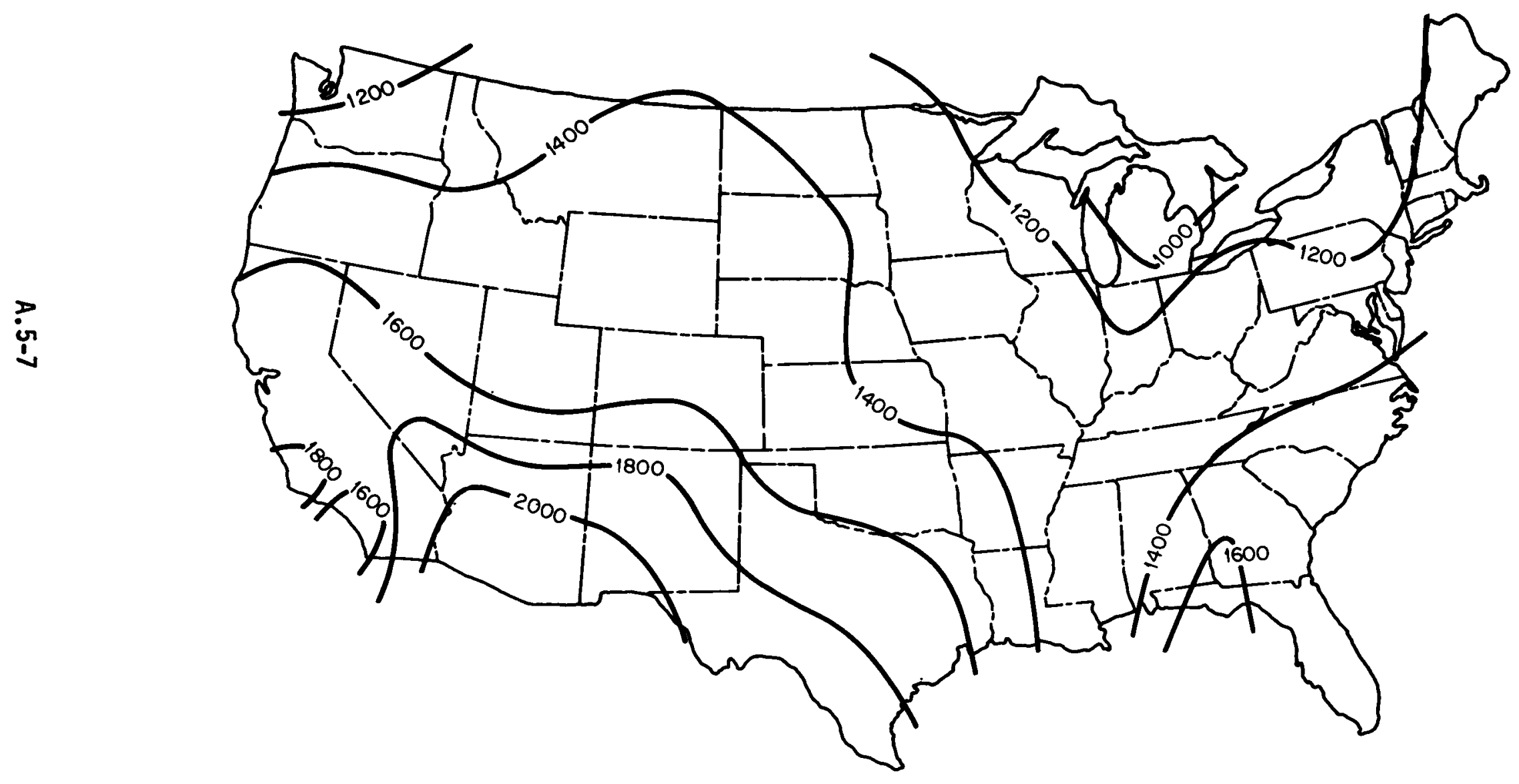

DISTRIBUTION OF SOLAR ENERGY OVER THE UNITED STATES *

Figure A.5-2

*Figures give solar heat in $\mathrm{Btu} / \mathrm{ft}^{2}$ per average day. 
For central-station electric power based on solar energy, the availability of large tracts of land with high solar inputs is essential. Most proposals for central-station plants are based on the assumption that the plants will be located in the desert southwest. More than 100,000 sq miles in the western United States are desert. ${ }^{7}$ Some estimates ${ }^{7,8}$ indicate that as little as $10 \%$ of this land would be needed to provide the electrical capacity required in the year $2000(2,000,000$ MWe $)$.

\subsection{Technical Description}

\subsubsection{Thermal Conversion}

Several variations of thermal-conversion systems are possible, but the one proposed by the Drs. Meine ${ }^{8}$ has attracted most attention, and the elements of their system are reasonably representative of others. The basic components of a thermal-conversion solar electric plant are: (1) an energy-collection system, (2) an energy-storage system, and (3) an energy-conversion system. Figure A.5-3 illustrates the system.

The Meinel concept for a collector system stems from recent developments in producing selective films that have high absorptivity for short-wavelength solar radiation and low emissivity for the long-wavelength infrared radiation. ${ }^{9,10}$ Infrared radiation accounts for much of the energy loss of a heated surface. The use of selective films in conjunction with some optical concentration of the 


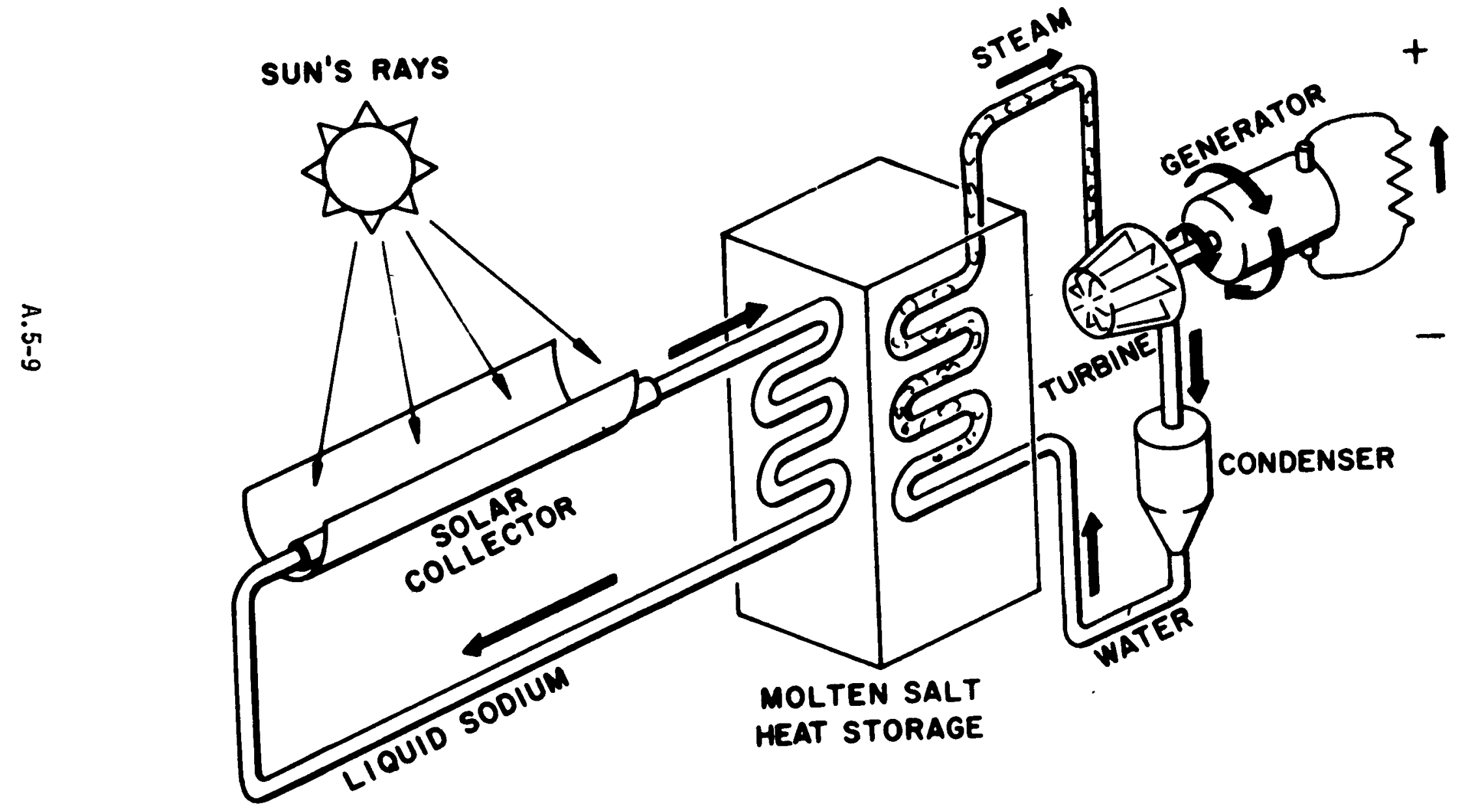

SCHEMATIC OF A SOLAR THERMAL-CONVERSION POWER SYSTEM

Figure A.5-3 
incident radiation by suitable lenses or mirrors may make possible the attainment of temperatures of the order of $1000^{\circ} \mathrm{F}$ in the collecting fluid. The collector pipes, containing a heat transfer fluid such as sodium, are oriented in an east-west direction, as a reasonable alternative to tracking the sun (with the attendant cost of the tracking mechanism). Each pipe is coated with a selective film and is located within an evacuated glass envelope. Either this enclosed pipe is located at the focus of a parabolic mirror, or, in an alternate arrangement, a Fresnel lens focuses the sun's rays on the collector tube.

Heat is transported from the collector field by circulation of molten sodium inside the collector tubes. From the sodium, the energy is transferred to a thermal storage tank, where it is stored as the heat of fusion of a eutectic salt. Energy storage is required if the plant is to be capable of operating continuously. The heat-storage unit serves as the source of energy to generate steam, which drives a conventional turbine-generator. Heat could be rejected from the cycle by any means suitable for fossil-fueled plants, but since most studies of solar thermal-conversion plants assume a desert location, dry cooling towers would seem to be required.

Proponents of thermal conversion of solar energy believe that efficiencies of 20 to $30 \%$ (percent of incident radiation converted to electricity) can be achieved. ${ }^{4}$ others estimate the range to be 10 to $20 \%$. 
In the southwestern United States, about 6400 acres (10 sq miles) would be needed for a 1000-MWe plant capable of operating, on the average, at $70 \%$ of capacity. 4

\subsubsection{Photovoltaic Conversion}

Photovoltaic conversion systems are based on the principal that in some solid-state materials (e.g., silicon) the absorption of photons (light) generates free electrical charges. These charges are collected on contacts applied to the surfaces of the semiconductor. The solar-cell materials most frequently mentioned are silicon, cadmium sulfide, and gallium arsenide. 11,12 The maximal theoretical conversion efficiency is about $25 \%$ for a single semiconductor device operating at room temperature. ${ }^{4}$ Efficiencies of 13 to $14 \%$ for silicon cells and 4 to $6 \%$ for cadmium sulfide cells are achieved in terrestrial applications. 4

Individual cells are connected in series-parallel arrays to obtain the desired de voltage and current. Several solar panels, the number depending on the application, would be assembled to form an electric power source. Essentially three types of electric plants that would use solar cells have been proposed. They are: (1) terrestrial central power stations, (2) earth-satellite central power stations, and (3) power units for buildings.

Terrestrial central power stations would consist of a large number of solar panels dispersed over a large area. The collector field 
would need to be prepared so as to protect the panels from damage during storms, to minimize dust formation on the cells, and to provide access for maintenance. If the plant were to be a continuous source of power, energy storage in a mechanical or chemical form would be necessary. The energy could be stored by use of batteries, pumped water storage, rotating masses, or electrolytic hydrogen. 13 of these, batteries might be the most promising, although batteries for central-station energy storage are presently in the developmental stage. If the solar-energy plant were to be connected to an ac grid, dc-to-ac converters would be required. At an efficiency of $10 \%$ for the combined collection-storage-converter system, a 1000-Mke power station located in the southwestern United States would require about 9500 acres (15 sq miles) of cell surface, which would cover a total area of about 19,000 acres ( $30 \mathrm{sq}$ miles). The needed plant area is larger than the cell area because space is required between panels to eliminate shading and to provide access for maintenance.

Satellite central power stations, illustrated in Fig. A.5-4, represent the most imaginative of all solar-energy source proposals. ${ }^{14}$ Satellites that contained fields of solar. cells could be placed in synchronous orbit around the earth's equator. The 10,000-MWe station shown in Fig. A.5-4 would require a 5- by 5-mile field of solar cells. Electricity generated in the solar-cell fields would be fed to microwave generators arranged in the form of an antenna. That antenna would beam the microwave energy to a receiving antenna 


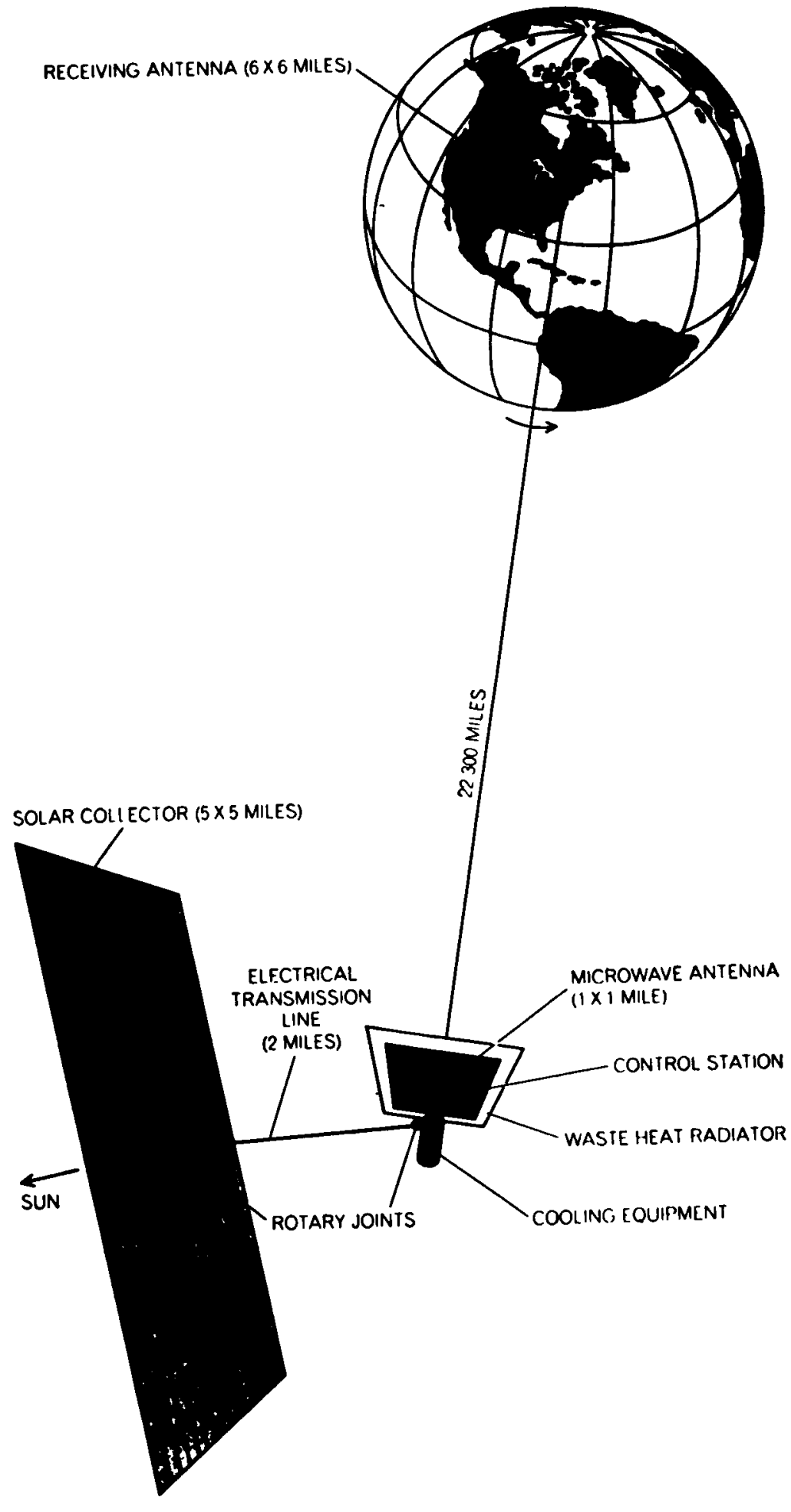

SCHEMATIC OF A 10,000-MWe SATELLITE SOLAR POWER STATION Figure A.5-4 
on earth which would convert the microwave energy back to electricity. The advantages of producing electricity this way are that a satellite receives solar energy unattenuated by the earth's atmosphere for the entire 24 hours a day, except for short times at the equinoxes, and that microwaves can be transmitted to earth, even through cloud covers, with little loss. ${ }^{15}$ since satellite power plants would require technical achievements far beyond those needed for terrestrial solar-energy plants, including many flights by second generation space shuttles, the development of space "tugs" to move the massive amounts of material required for the many square miles of solar panels, and orders of magnitude reductions in the cost of solar cells, satellite power plants are not likely to play a role in supplying energy in the foreseeable future.

The use of solar cells on buildings locates the generator at the place of the load, and the system matches the nature of distribution of solar energy to the pattern of distribution of the energy being consumed. Photovoltaic arrays would be mounted on buildings or incorporated within their structures; thus, no additional land would be required. Since most buildings require both thermal and electrical energy, the combination of solar-cell arrays with flat-plate thermal collectors has been proposed. ${ }^{4}$ The estimate is made that the combined system would use as much as $60 \%$ of the available solar energy. As in all terrestrial solar-energy systems, energy storage would be needed. To provide local storage capacity for more than an average day's requirement is, in general, considered to be uneconomical. ${ }^{4}$ Storage 
could be provided by batteries, flywheels, or a combination of electrolysis cells and fuel cells. In addition to collectors and energy storage, solar electric plants for buildings would also require an electrical power conditioning system to convert dc to 60-cycle ac of the appropriate voltage.

A consideration not discussed by solar-energy proponents is that, since proposed solar electric systems for buildings require an external source of electricity during a series of cloudy days, the required external capacity (generating plant, transmission system, and distribution system) would not be reduced significantly. Thus, solar electric systems for buildings would save fuel but would not materially affect the local utility's investment in power facilities.

\subsubsection{Combustion of Photosynthetic Materials}

A power plant that burned wood, grasses, water plants, or algae would be similar to a conventional fossil-fueled steam-electric power plant. Since photosynthetic materials contain much less energy per unit volume than do fossil fuels, the transportation of such materials long distances would probably be uneconomical, and, therefore, power plants would need to be located close to the growing site.

In ordinary agriculture, solar-energy conversion to dry plant material is achieved at conversion efficiencies of about $0.1 \%$. With intensive agriculture, conversion efficiencies might be improved to 
3 to 5\%. If a power plant could convert this energy to electricity at 33 to $40 \%$ efficiency, the overall solar-energy to electrical-energy conversion efficiency would be 1 to $2 \%$, which would be more attractive than current solar design efficiencies in terms of cost per unit of electricity produced. Enormous amounts of land suitable for agriculture or tree farming would be required. For example, a 1000-MWe power plant has been estimated to require a "forest plantation" of 250,000 to 320,000 acres ( 400 to 500 sq miles). Dual purpose use of this land (e.g., grazing or agriculture along with production of photosynthetic material) may be attempted if site conditions warrant.

In addition to the power plant and fuel "farm", facilities and equipment would be required to harvest, transport, and ship the wood.

\subsubsection{Thermal Collection}

Hot water for household use as well as for space heating and cooling could be supplied by solar energy. Figure A.5-5 shows one such home energy system. The estimate is made ${ }^{4}$ that in a temperate, sunny, location in the central United States, a $1500-\mathrm{ft}^{2}$ house could be provided with about $75 \%$ of its heating and cooling needs by a 600 to $800-\mathrm{ft}^{2}$ collector and 2000 gallons of hot-water-storage capacity. The additional 25\% of heating and cooling energy needed under adverse weather conditions would be supplied by some auxiliary source.

In addition to a flat-plate collector, a system such as that in Figure A.5-5 would include an insulated storage tank; an auxiliary heat-supply 


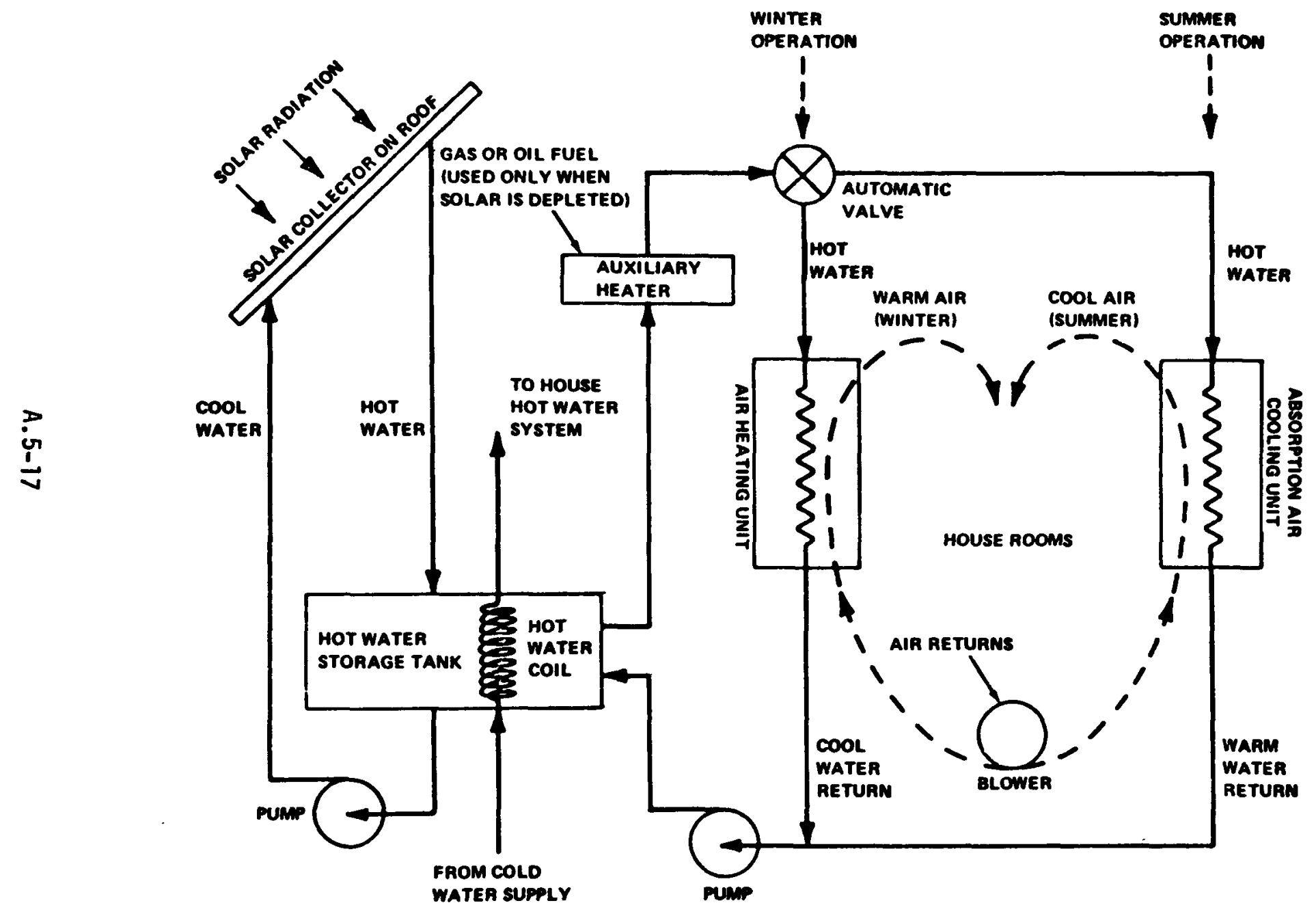

SCHEMATIC OF RESIDENTIAL HEATING AND COOLING WITH SOLAR ENERGY ONE ALTERNATIVE

Figure A.5-5 
system; an absorption air conditioner; and various pumps, controls, and ducts to circulate air from the conditioned space to either the heating or cooling unit. No additional land would be required for most bufldings since the surface of the structure would be of sufficient area for the collectors.

\subsubsection{Production of High-Energy Fuels}

As noted previously, one drawback to the use of raw photosynthetic material for fuel is that it must be used near its source because of its low energy content per unit volume. Conversion to high-energy transportable fuels in the form of gases, liquids, or solids could be achieved by various processes. However, such processes convert the raw fuel at less than 100\% efficiency; therefore, the land area required to yield a given amount of energy would be more than that required if the raw fuel were burned directly. However, dual use of the land as noted earlier could serve to lessen the impact of allocation of large amounts of land.

Anaerobic fermentation of organic materials produces a gas mixture that contains 50 to $70 \%$ methane, 30 to $50 \%$ carbon dioxide, and trace amounts of hydrogen sulfide and nitrogen. This crude product, with an energy content of 500 to $700 \mathrm{Btu} / \mathrm{ft}^{3}$, could be burned in a power plant or be refined to remove carbon dioxide and other impurities. The pure methane, with a heating value of about $1000 \mathrm{Btu} / \mathrm{ft}^{3}$, could be introduced into existing pipelines as a replacement for natural gas. 
Pyrolysis is a process of destructive distillation carried out in a closed vessel in an atmosphere devoid of oxygen and at high temperature $\left(900\right.$ to $\left.1700^{\circ} \mathrm{F}\right)$. Organic materials treated by pyrolysis yield gases, oil-like liquids, and solids similar to charcoal. Typically, the gases are mixtures of hydrogen, methane, carbon dioxide, carbon monoxide, and lower hydrocarbons. Conversion efficiencies have been rather low in the past, ${ }^{5}$ and the process is probably of greatest interest for reducing solid wastes.

\subsection{Research and Development Program}

The NSF-NASA Solar Energy Panel ${ }^{4}$ recommended an R\&D program that would cover all aspects of solar-energy applications. The Federal government would take a lead role in the program. Table A.5-l lists major technical problems to be resolved, and Table A.5-2 gives the estimated funding for a 15-year program. This program would, according to the Pane1, develop solar energy sufficiently to provide the market penetrations discussed below.

The more recent report on the Nation's Energy Future ${ }^{16}$ outlines a $\$ 140$ million program over the next five years that would determine, through pilot applications, the effective use of solar thermal energy for heating and cooling of buildings; examine the use of solar thermal energy for electric power generation through operation of a 10 MWe pilot plant; determine the capability to produce economically competitive photovoltaic cells by laboratory experimentation and development of mass production concepts; and construct and operate a plant 
Table A.5-1

SUMMARY OF MAJOR TECHNICAL PROBLEMS

\begin{tabular}{|c|c|}
\hline Application & Major technical problems to be solved \\
\hline Thermal energy for buildings & $\begin{array}{l}\text { Development of solar air conditioning and integration of } \\
\text { heating and cooling }\end{array}$ \\
\hline \multicolumn{2}{|l|}{ Renewable clean fuel sources } \\
\hline Combustion of organic materials & $\begin{array}{l}\text { Development of efficient growth, harvesting, chipping, drying, } \\
\text { and transportation systems }\end{array}$ \\
\hline $\begin{array}{l}\text { Bioconversion of organic materials to } \\
\text { methane }\end{array}$ & $\begin{array}{l}\text { Development of efficient conversion processes and economical } \\
\text { sources of organic materials }\end{array}$ \\
\hline $\begin{array}{l}\text { Pyrolysis of organic materials to gas, liquid, } \\
\text { and solid fuels }\end{array}$ & Optimization of fuel production for different feed materials \\
\hline $\begin{array}{l}\text { Chemical reduction of organic materials } \\
\text { to oil }\end{array}$ & $\begin{array}{l}\text { Optimization of organic feed system and oil separation } \\
\text { process }\end{array}$ \\
\hline \multicolumn{2}{|l|}{ Electric-power generation } \\
\hline Thermal conversion & $\begin{array}{l}\text { Development of collector, heat transfer, and storage } \\
\text { subsystems }\end{array}$ \\
\hline Photovoltaic & Development of low-cost long-life solar arrays \\
\hline Systems on buildings & High-temperature operation and energy storage \\
\hline Ground station & Energy storage \\
\hline Space station & $\begin{array}{l}\text { Development of light-weight, long-life, low-cost solar array; } \\
\text { transportation, construction, operation, and maintenance; } \\
\text { development and deployment of extremely large and } \\
\text { light-weight structures }\end{array}$ \\
\hline
\end{tabular}

Table A.5-2

SUMMARY OF OVERALL PROGRAM FUNDING

\begin{tabular}{lc}
\hline \multicolumn{1}{c}{ Applications } & $\begin{array}{c}\text { Long-range } \\
\text { R\&D program } \\
\text { (15 years) } \\
(\$ \mathrm{M})\end{array}$ \\
\hline $\begin{array}{l}\text { Thermal energy for buildings } \\
\text { Photosynthetic production of organic } \\
\text { materials and hydrogen }\end{array}$ & 100 \\
$\begin{array}{l}\text { Conversion of organic materials to } \\
\text { fuels or energy }\end{array}$ & 60 \\
$\begin{array}{l}\text { Electric-power generation } \\
\text { Solar thermal conversion } \\
\text { Photovoltaic conversion }\end{array}$ & 310 \\
\hline
\end{tabular}


involving the conversion of wastes into methane. Additional funding on the order of $\$ 79$ million for "indirect" applications of solar energy, e.g., wind power, ocean thermal gradients etc., are also proposed as discussed in Section A.6 of this Chapter.

\subsection{Present and Projected Application}

As noted above, solar energy currently provides some thermal energy for buildings, but is not yet used for the production of electrical power. The NSF-NASA Solar Energy Panel concluded that, with a substantial R\&D program, sufficient technical and economic progress could be made so that, by the year 2000, solar energy could supply about $10 \%$ of the thermal energy for buildings, $10 \%$ of the gaseous fuel (methane), $1 \%$ of the liquid fuel, and less than $5 \%$ of the electricity. In the Panel's view, the most significant near-term impact of solar energy will be in the heating and cooling of new buildings; their projection of probable market penetration is $10 \%$ of new buildings constructed in 1985, 50\% in 2000, and $85 \%$ in 2020 . In terms of the percentage of all buildings, these figures correspond to 1,12 , and $31 \%$, respectively.

The above estimates were made by people who are generally optimistic about the potential of solar energy. Other groups (e.g., see "United States Energy Through the Year 2000," issued by the United States Department of the Interior, December 1972) concerned with projecting energy requirements and sources estimate essentially no contribution from solar energy at least through the year 2000. Nevertheless, 
some basis appears to exist for the NSF-NASA Panel's judgment that solar energy for the heating and cooling of buildings could make some contribution before the end of the century. Little basis exists for projecting a measurable contribution of solar energy to either electricity generation or high-energy fuels since even optimistic projections of cost place solar conversion in a poor competitive position relative to coal or nuclear energy.

\subsection{Environmental Impacts}

\subsubsection{Central-Station Power Plants}

\subsubsection{Surface Effects}

Since energy from the sun is very diffuse, large land areas form one outstanding characteristic of solar-energy conversion systems. Estimated area requirements for a 1000-MWe plant are 6400 acres (10 sq miles), 19,000 acres (20 sq miles), and 320,000 acres (500 sq miles) for power produced by thermal conversion, photovoltaic conversion, and combustion of photosynthetic materials, respectively. In reality, these figures might be somewhat higher because they are based on rather optimistic assumptions concerning achievable efficiencies. Nevertheless, the proposed use of land for thermal and photovoltaic conversion is not unreasonable. Figure A.5-6 shows a comparison of total land disturbed for surface-mined coal and for solar electric plants based on thermal and photovoltaic conversions. In terms of total land disturbed, the solar plants would be more economical than coal with respect to land use over the long term. Although the comparison is not strictly 


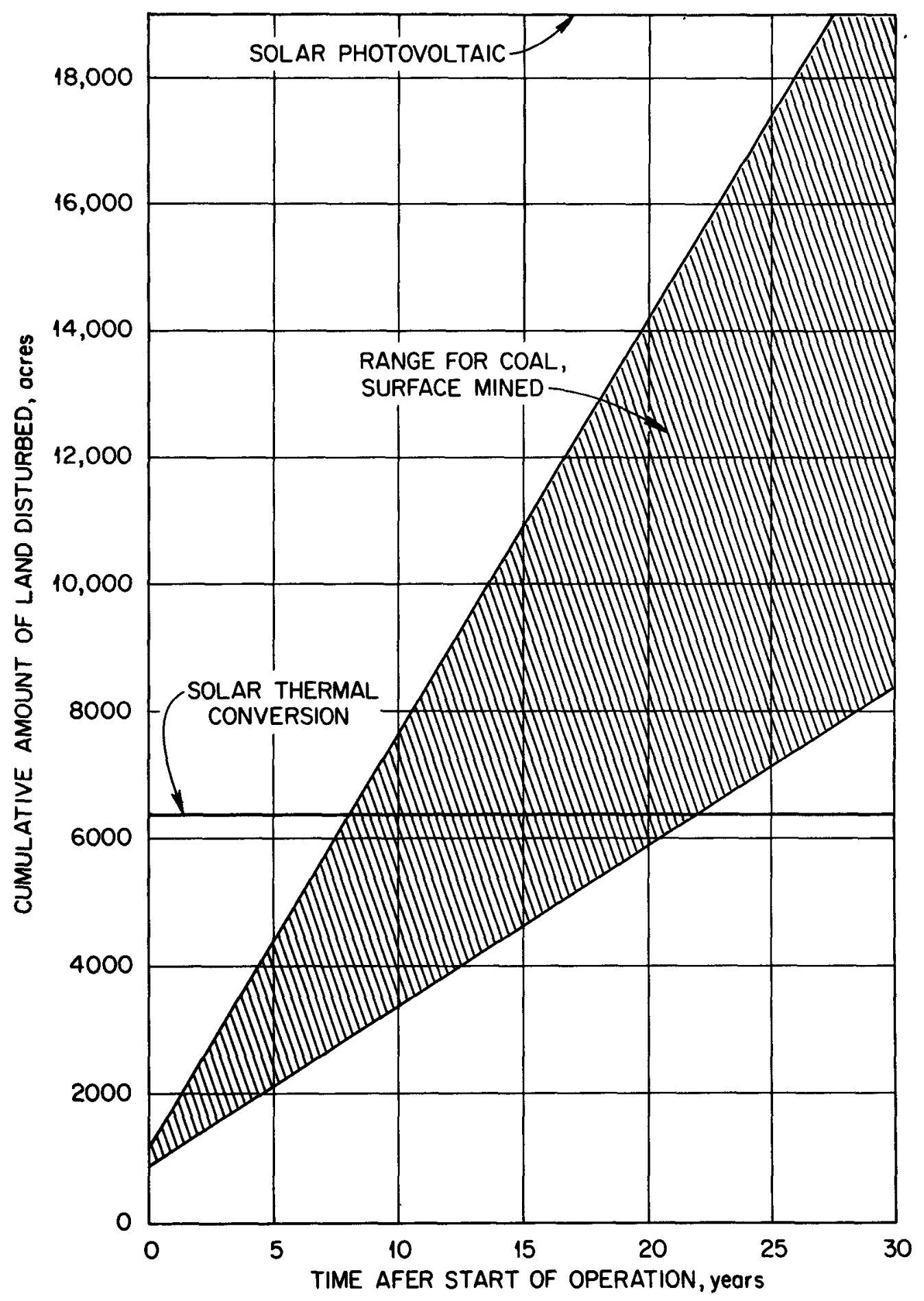

COMPARISON OF TOTAL LAND DISTURBED FROM SURFACE-MINED COAL AND SOLAR ELECTRIC PLANTS - EACH A 1000-MWe PLANT

Figure A.5-6 
valid, if proper reclamation of surface-mined land is assumed, the figure does give some perspective to the proposed use of land for solar electric plants based on thermal and photoelectric conversion. In contrast, the proposed use of land for power plants based on combustion of photosynthetic materials does seem unreasonable. They require extremely large areas of productive land. With the world facing shortages of pulpwood, lumber, and food, the sole use of land for thermal-energy production which is potentially capable of alleviating these shortages is highly questionable, especially if alternative sources of energy exist. Thus, the environmental aspects of photosynthetically produced energy will not be discussed further.

The land now most likely to be used for central-station thermal conversion or photovoltaic solar plants is in the desert and semidesert Southwest. Some open-range grazing is done on parts that receive a little rainfall. The vegetation is so sparse, chiefly creosote bush and white bur sage, with lesser amounts of saltbush, paloverde, catclaw, and cactus, that the land is not very valuable as graze land. 1 During the winter and summer rains, the desert usually has a lush cover of annual grasses and forbs and is valuable for grazing for a short period. Very little human habitation or industrial activity is on it except in the cities. If solar power plants were developed, the economic value of adjacent land would undoubtedly increase but aesthetic values might be reduced. 
To develop land for large solar power plants, it will be necessary to develop roads, to grade and fill sites for the solar collectors, and generally to develop vehicular access to large areas of desert. This process may involve destruction of much of the local ecosystems. Roads would have to be designed and maintained to minimize erosion and dust. On the other hand, some ${ }^{11}$ believe that if half the land were shaded, it could be greatly improved as graze land. This modification would require new plantings and management. Before a judgment could be made on the feasibility of this agricultural use of the land, agricultural research would be necessary.

The presence of the large solar-energy collectors that would cover half the surface in any given area would alter appreciably the surface wind conditions. Acting as an impedance to winds, the collectors would lessen the amount of erosion from unhindered winds. Also, since the water runoff from the collectors could be directed back under the shaded area, water that would fall as rain or dew could be retained longer and would increase the quantity of vegetation. Care would have to be taken that the water-runoff patterns avoided erosion.

The shade itself would have a significant effect on the vegetation. Plants indigenous to the desert require high-intensity sunlight. Some ecologists believe that these plants would die out in shaded areas. $^{17}$ 
Many species of marmals, reptiles, amphibians, birds, and invertebrates are in these desert regions. Some areas are important grazing lands for the Sonoran pronghorn antelope and the desert bighorn sheep. The Sonoran antelope is an endangered species and probably numbers less than 100 in the United States. 1 The desert bighorn, numbering several hundred, is somewhat more abundant but, nevertheless, is a threatened species. The Cabeza Prieta and Kofa Game Ranges were established primarily as permanent homes for desert bighorns, although the Cabeza Prieta also harbors much of the remnant band of Sonoran antelope.

Other hunted wildlife in the general area of proposed solar-energy plants includes large numbers of desert mule deer and javel ina (peccarya) as well as Gambel's quail and white-winged doves. Kangaroo rats, pack rats, and wood mice are all mammals that live only on water which comes from their food. The ecological equilibrium would reach a new balance as the vegetation is altered; to predict the changes that would occur in small-mammal and bird populations is difficult.

\subsubsection{Effects on Air}

No gases or particulates would be emitted from a solar plant, and no pollutant would be added to the air. In fact, by breaking up the wind, the collectors would probably decrease the dust in the air over the desert. In a thermal-conversion plant, about two-thirds of the heat collected would be discharged through the power-plant 
condenser, probably to dry cooling towers. Except for the updraft that this point source of hot air would cause, no atmospheric effects would result.

\subsubsection{Effects on Water}

At the sites most likely to be chosen for solar plants, use of dry cooling towers with thermal-conversion plants might be necessary because water would be too scarce or too expensive. However, if water were available and were used to condense the thermodynamic fluid, it will be evaporated in wet cooling towers, just as would be done in any other steam electric plant. For a photovoltaic plant, the water consumption would be negligible.

\subsubsection{Aesthetics}

The appearance of a solar plant might not arouse obvious objections, but a plant would virtually cover the visible landscape from any point near the plant. The appearance of the desert would be greatly altered; some observers might find the new appearance attractive, others might not. The opinions might depend on the number of large power stations built and their proximity to populated areas. In any case, the plant would be close to the ground and would not obstruct vision from a distance, except for possible cooling towers. Some sunlight probably would be reflected from the collector units. If electricity were transmitted over power lines, these could produce an undesirable aesthetic effect, but this impact would also be characteristic of other energy sources. 
Probably, archaeologically and historically valuable sites could be avoided in siting the solar plants. In case of unavoidable archaeological site conflict, the continuation of at least some archaeological work on the plant site itself should be possible without adverse effect.

\subsubsection{Social Effects}

Solar-energy plants would be located in areas of such low population density that they would have no significant effect on existing populations. The changes that would occur in the general vicinity of the solar plant would open up new areas to social use. People would be attracted to jobs at the plant and in secondary occupations.

To the degree that transportation can be provided for raw materials, industries that needed large quantities of electric power might move into the region.

\subsubsection{Accidents}

To imagine an accident to a solar plant which would directly affect the populace is difficult. Ruptures of heat-transfer lines could be troublesome, but not catastrophic. Engineered safeguards should reduce these to a tolerable level. Of course, a plant that would cover such a large area would be fairly vulnerable to the forces of nature. Accidents of this kind could be costly, and, depending 
on the fluid used by the designer, a spill of heat-transfer fluid might have serious local environmental effects.

\subsubsection{Systems for Residential and Commercial Buildings}

The use of solar-energy systems to supply space heating, water heating, air conditioning, and electric power for individual buildings would have very little impact on the environment. No land in addition to that required for the building itself would be needed for most buildings - at least single-story structures. The appearance of buildings would be affected somewhat, but, with proper attention to architecture, the appearance could be made pleasing. Local building codes would need to be changed, and sunlight rights would be an important factor.

\subsection{Costs and Benefits}

\subsubsection{Internal Costs}

\subsubsection{Thermal Conversion}

of the three main parts of a solar-conversion plant (collector field, storage system, and stearn-electric generating system), the collecting field is the most costly. The design of large plants is still in the conceptual stage, and a good estimate of the capital cost is extremely difficult to make. The NSF-NASA Solar Energy Panel estimated that the cost of the solar-collection and storage part of a thermal-conversion plant would be about $\$ 600$ per kilowatt of electrical capacity. Turbine-generator and other peripheral costs of the power plant would add an additional $\$ 150 / \mathrm{kW}$. This expense would result in a power cost 
of $20 \mathrm{mills} / \mathrm{kWhr}$ based on $15.5 \%$ capital charges, on a $70 \%$ plant capacity factor, and on $1 \mathrm{mill} / \mathrm{kWhr}$ for operation and maintenance. Qualifications placed on the above estimates by the Solar Energy Panel are that the costs are for mass-produced components and that the solution to several unresolved problems is presupposed. In addition, the placement of at least the first demonstration solar power plants in the desert southwest, far from population centers where the energy would be required, will significantly increase the cost of long-distance transmission of the electricity that will be produced.

A somewhat higher cost estimate was prepared by the Oak Ridge National Laboratory. ${ }^{18}$ A first-of-a-kind solar thermal-conversion plant was estimated to cost over $\$ 3300$ per kilowatt, but this cost would be reduced by a factor of 3 for advanced plants produced in quantity. Estimates of prices that coal and uranium ore would have to reach before solar energy would be competitive were $\$ 40$ per ton of coal and $\$ 250$ per pound of $U_{3} 0_{8}$, respectively. It was concluded that (1) enough uranium ore would be available at prices far below $\$ 250$ per pound to last over a century if burned in light-water reactors, and (2) sufficient coal is available in the United States at costs well below $\$ 40$ per ton to last even longer than the uranium, even if an allowance is made for the cost of measures required to overcome the effects of coal mining and processing on the environment. 
Since no design or engineering data exist for a large solar plant, all the estimates suggested above on plant costs should be considered with a certain amount of skepticism. Nevertheless, considered under even the most optimistic estimates, solar thermal-conversion plants are at a considerable competitive disadvantage relative to more conventional energy sources.

\subsubsection{Photovoltaic Conversion}

Present costs of solar-cell arrays are extremely high. For example, the Skylab solar arrays reportedly cost about $\$ 2,000,000$ per kilowatt. Cherry $^{19}$ estimates that, by improving the manufacturing process and using simple solar concentrations, silicon cell arrays could be produced for $\$ 10,000 / \mathrm{kW}$ and that this cost might be reduced to $\$ 2500 / \mathrm{kW}$ if an inexpensive process for mass producing cadmium sulfide cells were developed. Ultimately, Cherry believes, cadmium sulfide cells could be produced at $50 \$ / \mathrm{sq}$ foot $(\$ 50 / \mathrm{kW})$, and he estimates that power could be produced for about $24 \mathrm{mills} / \mathrm{kWhr}$. This figure is still not competitive with costs of energy from either coal or nuclear plants, and it would appear that several breakthroughs, even beyond those projected, in cell production and energy storage systems will be required before solar cells will become economically viable for either central station or residential applications.

\subsubsection{Burning of Photosynthetic Materials}

The cost of producing electricity from burning photosynthetic materials would be controlled by the cost of land. Since large 
areas would be required, the cost of producing energy by this means apparently would be high, especially since the land must be of reasonably good quality. One cost estimate ${ }^{l}$ for a wood-burning power plant indicates a fuel cost of more than $\$ 2$ per million Btu and a total power cost of at least $38 \mathrm{mills} / \mathrm{kWhr}$.

\subsubsection{Space Heating and Air Conditioning}

The cost of space heating, air conditioning, and water heating with solar energy is primarily related to the capital investment. Additional costs would be incurred from maintenance and fossil-fuel use during adverse weather conditions. The NSF-NASA Solar Energy Panel estimates the capital cost of water heating at $\$ 200$ to $\$ 400$. space heating at $\$ 1500$ to $\$ 2500$, and air conditioning at $\$ 3000$ to $\$ 4000$, all for a representative residence. The Panel indicated that solar energy is less expensive for heating than is electricity for a variety of U.S. locations and that it is nearly competitive with oil and gas for a few locations. Combined systems (i.e., hotwater heating, space heating, and air conditioning) were believed to be of even greater long-term promise. However, considerable engineering development of low-cost components will be required for solar energy to be a competitive alternative for residential use on a large scale.

\subsubsection{High-Energy Fuels}

A major part of the cost of high-energy fuels would be the cost of producing the raw photosynthetic materials. For example, it is 
estimated that with present technology, the cost of dry algae would be $\$ 0.05 / 1 b$. If a methane conversion efficiency of 60 to $80 \%$ is assumed, then the cost of the raw-material component of methane would be greater than $\$ 7$ per million Btu. This figure is several times that estimated for pipeline gas from coal, which may be on the order of $\$ 1.00$ per million Btu. ${ }^{20}$ The NSF-NASA Solar Energy Panel estimated that the cost of methane from algae grown on sewage wastes might be reduced to $\$ 1.50$ to $\$ 2.00$ per million Btu since a credit could be taken for sewage disposal.

\subsubsection{External Costs}

Generally speaking, environmental costs associated with the use of solar energy would be small. In some cases, the large-scale use of solar energy might alter the price structure and avallability of certain raw materials. Two materials that could be affected are gold, which has been suggested for the selective surface on thermalconversion collectors, and cadmium, which might be a basic material in low-cost solar cells. The withdrawal of large tracts of land that could be productively used for farming, pulpwood, or lumber might influence the price of these products if photosynthetically produced fuels were to be widely used.

\subsubsection{Benefits}

The benefits from solar-energy use would be electric power, thermal energy, and high-energy fuels. These products would be based on an inexhaustible energy supply and could be produced with rather minor 
environmental impacts. Utilization of solar energy would decrease the dependence on fuel sources such as coal and nuclear.

\subsection{Overall Assessment of Role in Energy Supply}

The use of solar energy as a substitute for other energy sources has very strong appeal. The resource is inexhaustible, and its use would have very minor environmental effects for most proposed applications. The major barrier to the exploitation of solar energy is cost. The use of solar energy is now uneconomical for all except very specialized applications. The outlook appears to be that solar energy has little potential as an economical, major source of electricity for several decades. In fact, the only proposed solar application that potentially could play a significant energy role in this century is as thermal energy for buildings. Although this use could be important, the impact on total electrical production is likely to be minor, at least until the year 2000. Thus, the conclusion is drawn that the use of solar energy will not materially reduce the need for alternative electrical energy sources in the foreseeable future. 


\subsection{References}

1. Assessment of Environmental Impact of Alternate Sources for Electrical Energy, Oak Ridge National Laboratory, Oak Ridge, Tenn., a report in press.

2. Argonne National Laboratory, "Solar Power Systems," Fact Sheet E-106, prepared for the USAEC.

3. M. Wolf, "Solar Energy = an Endless Supply," Consulting Engineering 40(3): 171-179 T1973).

4. NSF-NASA Solar Energy Pane1, An Assessment of Solar Energy as a National Resource, December 1972.

5. "Where Do We Stand Today on Solar Power," Electrical World 180(3): 24 (1973).

6. J. Yellot, "Energy from the Sun," Power Engineering, February 1957.

7. W. Clark, "How to Harness Sunpower and Avoid Pollution," Smithsonian 2(11): 14-21 (1971).

8. A. B. Meinel and M. P. Meinel, "Physics Looks at Solar Energy," Physics Today 25(2): 44-50 (1972).

9. D. D. Williams, Selective Radiation Properties of Particulate Semiconductor Coatings on Metal Substrates, Ph.D. thesis, Univ. of Wisconsin, Madison, 1961.

10. B. 0. Seraphim, "Solid State Solar Energy Collectors," Optical Sciences Newsletter 6(3): 103-106 (1972).

11. A. B. Meinel and M. P. Meine1, "Thermal Performance of a Linear Solar Collector," ASME Technical Paper No. 72-WA/SOC-7, November 1972.

12. A. L. Hammond, "Photovoltaic Cells: Direct Conversion of Solar Energy," Science 178: 732-733 (1973).

13. J. J. Loferski, "Some Problems Associated with Large Scale Production of Electrical Power from Solar Energy Via the Photovoltaic Effect," ASME Technical Paper 72-WA/Sol-4, November 1972.

14. P. E. Glaser, "The Feasibility of a Satellite Solar Power Station," ASME Technical Paper 72-WA/Sol-6, November 1972. 
15. P. E. Glaser, "Satellite Solar Power Station," Solar Energy 12: 353-361 (1969).

16. WASH 1281, The Nation's Energy Future, A Report to the President of the United States by The Chairman, USAEC, December.1973.

17. N. Robinson, "Solar Machines," in Proc. World Symposium on Applied Solar Energy, Phoenix, Ariz., Nov. 1-5, 1955.

18. L. G. Alexander et al., "Solar Power Prospects," paper presented at the Solar Thermal Conversion Workshop, Univ. of Maryland, Jan. 11-12, 1973.

19. W. R. Cherry, "The Generation of Pollution-Free Electrical Power from Solar Energy," Trans. ASME, J. of Eng. for Power 94(A): 78-82 (1972).

20. H. C. Hottel and J. B. Howard, New Energy Technology - Some Facts and Assessments, The MIT Press, Cambridge, Mass., 1971. 


\section{A.6 OTHER NONNUCLEAR ENERGY SYSTEMS}

\section{A.6.1 WIND POWER}

The kinetic energy of the winds can be used to produce mechanical energy or electric power. The potential amount of wind energy avallable is very large. For example, the estimate has been made ${ }^{1}$ that the energy potential of the winds over the continental United States, the Aleutian arc, and the eastern seaboard is equivalent to $10^{8}$ MWe. To convert a significant fraction of this energy potential to electricity would, of course, be impractical. The NSF-NASA Solar Energy Panel identified a number of major areas. - including the Great Lakes, the Great Plains, and offshore regions - that would be suitable for winddriven electric plants and estimated the maximal potential energy generation from these areas to be equivalent to about $19 \%$ of the annual United States electricity production estimated for the year 2000. Whether this generation could be done economically and with acceptable environmental impacts is unknown.

The question of economics is related to two factors. First, because the wind is variable, windmills have a low use factor and wind-driven power plants would require an energy-storage system. Limited experience with a large wind power plant in Vermont ${ }^{2}$ indicated an average annual use factor of 14\%. Second, a large number of small machines would have to be dispersed over a large area to make up a reasonable block of power. The storage method most often mentioned is the production of hydrogen electrolytically; the hydrogen could then be burned in a power plant or used in a fuel cell. Area 
requirements, according to Heronemus, ${ }^{3}$ would be about 1 sq mile for each 20 MWe, or $50 \mathrm{sq}$ miles for a power block of 1000 MWe in the Great Plains. Actually, the machines would physically occupy only a small portion of the area, but electrical interconnections and roads would require a significant amount of land.

Environmental problems would be related primarily to aesthetics and to potential weather modifications. A few small windmills may be quaint, but many large aeroturbines might not. Large numbers of wind-powered electric plants might alter wind patterns and, therefore, the weather. This potential effect has not been assessed.

To resolve the technical, economic, and environmental questions, the NSF-NASA Solar Energy Panel recommended a ten-year R\&D program whose cost would amount to about $\$ 610$ million. If this program were successful, the projected market penetration would be $1 \%$ of the total electrical production by the year 2000. A more recent and broaderbased study of potential energy sources ${ }^{4}$ suggested an R\&D program totalling $\$ 32$ million over the next five years. It would include the construction of a series of experimental wind generator systems of increasing size and performance capability, starting with a unit of 100 KWe size. A multiunit system making up a wind "farm" up to 10 MWe would also be constructed. In addition to testing technical performance, this program would assess economic viability and aesthetic acceptance. 
Although wind power might be able to satisfy specialized energy needs, a reasonable prediction is that electricity from the wind will not be of national significance during the remainder of this century. 


\section{A.6.2 OCEAN THERMAL GRADIENTS}

At many places in the tropical and subtropical regions of the world, the ocean surface temperatures are in the range 75 to $85^{\circ} \mathrm{F}$. The warm surface layer circulates toward the poles, where it is cooled, and flows back along the deep ocean trenches. In these lower layers of the ocean, say $2000 \mathrm{ft}$ below the surface, the temperatures are $35^{\circ}$ to $45^{\circ} \mathrm{F}$. A temperature difference between the surface and the depths of as much as $50^{\circ} \mathrm{F}$ could be used to drive a Rankine-cycle heat engine. 5,6 Although the theoretical efficiency is $9 \%^{1}$ for a $50^{\circ} \mathrm{F}$ temperature difference, the efficiency of a real power plant would be 2 to $4 \%$. A number of working fluids have been suggested for the power cycle; the most promising ones seem to be water vapor, ammonia, propane, and one of the Freons.

The first, and probably the only, ocean-thermal-gradient plant to produce electricity was a small demonstration plant built by Claude in Cuba in 1930. 5 He chose water vapor as the working fluid and produced the water vapor by boiling the tepid surface water in a vacuum chamber and condensing it in a spray condenser by use of the cold water pumped up from the ocean depths. The water vapor, which flowed in the pipe that connected the condenser with the boiler, generated electricity by driving a turbine-generator located in the pipe. Although Claude had considerable difficulty in constructing the plant and, in particular, in installing the long cold-water-inlet pipe, his plant demonstrated the technical feasibility of producing power $(22 \mathrm{~kW})$. The actual yield over the energy put into pumping the water into the vacuum condensor was small. 
Ocean-thermal-gradient power plants have been visualized either as shore-built structures or as floating structures. 5,6 The shore-built structures would have to be located in areas where the water is deep near the shore. Claude's demonstration plant was in such an area, although ocean depth at that particular location was limited. ${ }^{5}$ The floating plants are generally thought of as structures with the majority of their mass located beneath the ocean surface to minimize surface effects of waves and weather.

Two practical difficulties appear to exist with power plants operating on ocean temperature differences. First, the temperature differences are rather small, and this characteristic gives rise to low efficiencies. Thus, a large amount of thermal energy would have to be transported through the system, and this transport would require much pumping and a large heat-transfer surface. The second problem is that, for the most part, sites suitable for ocean-thermal-gradient power plants are located out to sea, far from load centers, thus making the transmission of electrical energy difficult and expensive.

The production of hydrogen by electrolys is or of energy-intensive products such as aluminum are probably the most likely uses of energy from such plants. The coupling of an ocean thermal gradient power plant with "maricultural" activities, i.e., increasing the yields of fish by bringing up nutrient-rich cold waters from lower levels, has also been proposed. A recently suggested application of ocean thermal gradient technology is the proposed construction of a 7,180 KWe (net) 
sea thermal station off the coast of a Caribbean island at a cost of about $\$ 18$ million. It was to produce electricity at a cost of 6 mills/ kwh, and would also produce 6 million gallons of fresh water datly. This project is not currently being pursued.

Because of the technical problems described above, the commercial feasibility of ocean-thermal-gradient power plants is uncertain. Consequently, the NSF-NASA Solar Energy Panel ${ }^{1}$ recommended an initial three-year program oriented toward problem definition, concept feasibility, and cost studies. The Panel recommends that, if the results of this initial program are favorable, a 15-year R\&D program, whose cost would amount to $\$ 530$ million, be initiated. The Panel projects a market penetration of $1 \%$ of the electrical power by the year 2000 If this R\&D program should be successful.

The more recent report on the Nation's Energy future 4 visualizes a $\$ 27$ million program over the next five years, emphasizing the design, production and testing of system components. The objective of this program would be to determine the technical feasibility of producing electric power from ocean thermal gradients by laboratory-scale testing of prototypes and full-scale testing of necessary components, including the heat exchanger, the deep-water pipe, and the overall plant structural design. A test facility would be constructed under this program. 
Although ocean thermal gradients appear worthy of a closer look, present information indicates that power from this source will not play a significant energy role in the foreseeable future. 


\section{A.6.3 TIDAL ENERGY}

The estimate is made that the total amount of energy in the tides of the ocean, if it were accessible, would provide about half the energy. needs of the entire world. ${ }^{7}$ Because so few sites exist where the harnessing of this energy would be practical, use of only a small fraction of the potential amount would be possible, even if all the available sites were used.

The tidal movement of the ocean is caused principally by the gravitational effect of the moon, with the sun also exerting a smaller effect. On the open ocean, the average height of the tide is only about $2 \mathrm{ft}$. The physical characteristics of the shorelines, estuaries, and bays and the topography, together with wind conditions, greatly amplify the tides. In basins where these factors combine to establish resonance, amplifications of 50 to 100 times are attained. At such locations, tides might be used to generate electricity. Tidal energy could be converted into electric power by enclosing the basins with dams to create a difference in water level between the ocean and the basin and then using the water flow to drive hydraulic turbines to turn electric generators. 8

Two sites in the United States are worthy of consideration for generating electricity by tidal action. 9 These are the Bay of Fundy area, which actually lies on the Canadian-United States frontier, and the Turnagain Bay in Cook Inlet in Alaska. The Bay of Fundy has nine sites and has a potential power production of about 29,000 MW. The 
Alaskan site could produce about $9500 \mathrm{MW}$. One site on the Bay of Fundy was subjected to detailed cost analysis ${ }^{10}$ on the basis of 1968 price levels. The estimated cost was too high relative to those of alternatives to be of interest at the time of the study.

Because of lack of resources and potentially high cost, tidal power probably will not be an important factor in energy supply for the future. 


\section{A.6.4 HYDROGEN AND OTHER SYNTHETIC FUELS}

Hydrogen and other synthetic fuels such as hydrazine, methanol and ammonia are anticipated to play an important role in future energy uses. ${ }^{11,12}$ These fuels do not provide a long-term, renewable or plentiful source of energy, such as nuclear power, solar power or coal, but are of interest because they may be derived from these abundant energy resources, and provide a convenient fuel form for transport, storage and utilization. Thus, they represent a potential al ternative for supplying the long-term needs for gaseous and liquid fuels, as well as a possible means for central station electric storage, analagous to the pumped storage concept. The latter use of hydrogen would involve the production of hydrogen by electrolysis of water during periods of low power demand, its storage, and its reconversion back to electricity, perhaps in a fuel cell, during periods of peak power demand. Hydrogen could also be used for electricity production in small dispersed stationary plants to provide power for residential and commercial uses. Other applications of hydrogen and the synthetic fuels that may be derived from it include use as general purpose fuels for heating and industrial processes, as fuels for automotive and aircraft propulsion, and as materials in various industrial processes.

The principal use of hydrogen today is as an industrial chemical for the reduction of metals from ores, and in the production of ammonia for agriculture. The main obstacles to the use of hydrogen in other applications at this time are its high cost relative to oil products 
and natural gas and, for motive applications, difficulties in storage of the fuel as a gas or liquid. These storage difficulties can be alleviated in varying degrees by use of alloys which form hydrides, and by the use of the other synthetic fuels, e.g., hydrazine, methanol or ammonia. However, for purposes of this discussion, the main interest in hydrogen is its possible future use as an energy storage mechanism in central station electricity production, or as a fuel supply to smaller electricity generating stations operating on fuel cells, gas turbines, or some other technology employing hydrogen.

The principal processes that are currently used for producing hydrogen include electrolysis of water and the partial oxidation or reforming of fossil fuels, principally natural gas. In the near future, hydrogen can be expected to be produced economically from coal and, perhaps, from oil shale. In the far term, as fossil resources decline, closed cycle thermochemical cracking of water, and re-emphasis on water electrolysis, would seem to be attractive methods of hydrogen production. The cost of hydrogen will depend on the cost of the primary source of energy and the efficiency of the process used to produce hydrogen.

The current economics of electrolytic hydrogen are determined by the capital cost and utflization of the electrolysis plant and by the cost of electrical power. The capital cost of present large-scale plants ${ }^{13}$ is about $\$ 95 / 1 \mathrm{~b} \mathrm{H}_{2} /$ day. At a fixed charge rate of $15 \%$ and a $90 \%$ plant factor, the capital charge is equivalent to $4.3 \$ / 1 \mathrm{lb} \mathrm{H}_{2}$ or $84 \mathrm{t} / 10^{6} \mathrm{Btu}$, 
assuming no credit for byproduct oxygen. At an electric power cost of $5 \mathrm{mills} / \mathrm{kWh}$, the power cost in terms of hydrogen produced is about $10 \$ / 1 \mathrm{~b} \mathrm{H}_{2}$, resulting in a total cost, excluding labor, maintenance, and overhead costs, of $14.3 \$ / 1 \mathrm{~b} \mathrm{H}$, or about $\$ 2.80 / 10^{6} \mathrm{Btu}$. This is considerably higher than the cost of other fuels (e.g., low Btu gas can be produced from coal at a cost of about $60 t$ to $85 \$ / 10^{6} \mathrm{Btu}$ ). The cost of electrical power used to produce hydrogen would depend, of course, on the type of generating plant providing the power and on the rate structure. Power may be obtained at a very low cost during off-peak demand periods and at a higher cost during periods of peak demand on the electric generating system. In any event, the high heat of combustion of hydrogen $(\sim 52,600 \mathrm{Btu} / 1 \mathrm{~b})$ and its ability to produce electricity by improved conversion methods (e.g., fuel cells) could lead to a cost for electricity produced by hydrogen that is competitive with that from other fuels.

Although water electrolysis is already a relatively efficient process it appears that further improvements may be achieved through research and development. It may be possible to reduce the energy requirements to around 13 to $15 \mathrm{kWh} / 1 \mathrm{~b} \mathrm{H}_{2}$ with an attendant decrease in the portion of the cost of hydrogen attributable to the input electric power. There is only a moderate amount of R\&D in progress on water electrolys is at the present time. Some work is being done by industry on lowering cell fabrication costs and on improving their performance and lifetime. 
Additional research and development would also be needed in techniques for the storage of hydrogen elther as a liquid or as a metal hydride, or for the storage of anmonia or methanol. The objective of such work would be to provide safe and convenient systems for both small portable storage applications and large-scale storage systems as may be required for central station electric storage.

With regard to its environmental characteristics, hydrogen represents a clean fuel in that it is made from water and its combustion results primarily in water vapor, with little or no other pollutants or emissions of the type associated with most other fuels. There would, of course, be some environmental effects from the production of hydrogen, whether this should be directly from coal, or electrolytically through the use of power generated in some other type of plant. In that case, the environmental effects from the use of hydrogen would depend indirectly on those from the type of power plant used in its production, whether this be nuclear, fossil, solar, etc. However, the production of hydrogen can be done at a site independent of the central electric generating facility, and, if this hydrogen were then used to produce electricity at a smaller generating station (e.g., powered by fuel cells), the siting advantages inherent in this flexibility might be worthwhile.

As implied previously, the development and widespread use of synthetic fuels will not lessen the need to develop primary energy sources such as advanced nuclear systems. On the contrary, the substitution of 
hydrogen and synthetic fuels for petroleum and natural gas would emphasize the need to develop new primary sources of energy.

Several studies have been made of the potential means by which hydrogen may function as the base of a future energy economy. These include consideration of hydrogen production, distribution and storage networks for the various applications mentioned above. In one study ${ }^{13}$, it has been assumed that $20 \%$ of the electrical energy delivered in the year 2000 is produced from hydrogen. In another evaluation ${ }^{12}$, it has been estimated that just to meet one-half of the projected transportationfuel needs for the year 2000 with electrolytically produced hydrogen would require an additional electrical generating capacity of nearly one million megawatts, or over twice the currently expected nuclear generating capacity at that time. However, if closed cycle thermochemical production is used rather than water electrolysis to produce hydrogen, then only about one-third the expected nuclear generating capacity would be needed for this purpose.

Whether or not hydrogen and other synthetic fuels will be used to the extent currently envisioned by some planners will depend, as in the case of the other energy sources discussed in this Statement, on a myriad of technical, economical, environmental, political, soctal and other factors, as well as the relative success of other energy sources in achieving commercial and public acceptance. In particular, the need for a separate distribution and storage system, the development of vehicles and/or electric generating stations capable of efficiently 
using hydrogen, and the need for other renewable sources of energy that could be used to produce hydrogen, pose important problems to the eventual establishment of a hydrogen energy economy. 


\section{A.6.5 References}

1. NSF-NASA Solar Energy Panel, An Assessment of Solar Energy as a National Energy Resource, December 1972.

2. Mechanical Engineer's Handbook, T. Baumeister, Ed., 6th ed., McGraw-Hil1, New York, 1958, pp. 9-8-9-13.

3. W. E. Heronemus, "Gentle Solutions for Our Energy Needs," Congressional Record 118(17): Pt. II (1972).

4. WASH-1281, The Nation's Energy Future, A Report to the President of the United States, submitted by Dr. Dixy Lee Ray, Chairman, U.S. Atomic Energy Cormission, December 1973.

5. G. Claude, "Power from Tropical Seas," Mech. Eng. 52(12): 1039-1044 (1930).

6. J. H. Anderson, Jr., "Economic Power and Water from Solar Energy," ASME Technical Paper No. 72-WA/Sol-2, November 1972.

7. Ayres and Scott, Energy Sources, the Wealth of the World, McGraw-Hill, New York, 1952.

8. Resources and Man, A Study and Recommendations by the Committee on Resources and Man, National Academy of Sciences, National Research Council, W. H. Freeman \& Co., San Francisco, 1969.

9. U.S. Department of the Interior, Final Environmental Statement for the Geothermal Leasing Program, vol. I, 1973.

10. R. H. Clark, "Fundy Tidal Power," Energy Intern. 9(11): 21-26 (1972).

11. "Hydrogen: Likely Fuel of the Future," Chem. Eng. News, pp. 14-17, June 26, 1972.

12. Hydrogen and Other Synthetic Fuels, A Summary of the Work of the Synthetic Fuels Panel, USAEC report TID-26136, September 1972.

13. AET-9, "Assessment of New Options in Energy Research and Development," Energy Advisory Panel, Office of Science and Technology, November 1973. 
B.

IMPROVED ENERGY CONYERSION

AND

STORAGE DEVICES 


\section{B. IMPROVED ENERGY CONVERSION AND STORAGE DEVICES}

\section{B.1 GENERAL INTRODUCTION}

The major portion of electric power generated in the United States today is based upon steam turbine energy systems. This process is well developed but converts only $39 \%$ of the fuel energy into electrical power with the balance being wasted in the form of low grade heat. More efficient conversion systems would not only reduce the amount of heat rejected to the environment but would conserve our limited fossil and nuclear fuel supplied.

Thermodynamic, technological and economic considerations limit upper efficiency to the present value. Temperatures are available from the combustion of fossil fuels that would allow for higher efficiencies if suitable technologies were available to use them. Systems for direct conversion from chemical or nuclear energy to electrical energy, (thus avoiding the heat engine cycle and consequent thermodynamic limitation), would be most desirable.

In addition, the inability to store electrical energy economically results in the necessity to provide intermediate load and peaking plants that are used only a fraction of the time. Generating capacity and electrical transmission and distribution systems capacity must be sized to carry the peak load. The net effect of operating at a load below the maximum capacity of the system is a relatively inefficient use of a large capital investment. 
Low-cost, high-turn-around-efficiency storage devices that can be placed at load centers are desirable to level load on transmission and distribution lines and to assure uninterrupted power in the event of power plant outages or transmission system failure.

It is evident that development of improved energy conversion and storage devices would:

- Conserve our energy resources;

- Reduce the extent of adverse environmental effects;

- More efficiently use our capital resources; and

- Provide electrical power reserve near the point of use.

The following sections will briefly describe the most commonly used energy conversion system used today, the steam turbine, and other conversion and storage concepts that have received or are receiving significant attention. Included in this discussion are:

- Internal Combustion Engines,

- Gas Turbines,

- Binary Cycles,

- Fuel Cells,

- Batteries,

- Thermoelectric Converters, 
- Thermionic Converters, and

- Magnetohydrodynamics.

For each concept a number of characteristics will be discussed. The intent is to describe the concept, examine its current and projected use, consider its costs and environmental impacts and provide an overall assessment of its role in meeting our energy requirements.

It should be noted that the systems reviewed are in varying stages of development and as discussed in the section, Perspectives on Alternative Energy Options, those systems in the early stages of development cannot be defined accurately with regard to costs of development, probability of achievement or schedules for achieving commercial utilization. 


\section{B.2 STEAM TURBINES}

\subsection{Introduction}

Approximately $78 \%$ of the electric generating capacity in the U.S. in 1970 was based on steam turbine energy systems and this percentage is expected to increase slightly by the year 2000 . The remaining $22 \%$ of capacity was supplied by hydroelectric ( $15 \%)$, and gas turbine and diesel electric ( $26 \%$ ) power systems. $1,2,3$

\subsubsection{General Description}

The steam turbine is a heat engine - as is any system that takes heat from a high temperature source, converts it into mechanical energy, and rejects waste heat at a lower temperature. The representation of the operation of a heat engine is shown in Fig. B.2-1. The Second Law of Thermodynamics states that it is impossible for all of the transferred heat to be converted into mechanical energy, i.e., a heat engine cannot be $100 \%$ efficient. The most efficient heat engine operating within the constraints of the Second Law is one that follows a theoretical concept known as the Carnot Cycle. While this cycle is impractical for operating heat engine systems it is usefur in evaluating the performance of actual heat engines.

Steam turbine energy systems are based on the Rankine cycle, a practical modification of the Carnot cycle. In the Rankine cycle, heat from the energy source (fossil fuel combustion gases or nuclear fuel) is transferred to water at high pressure in a boller and produces 


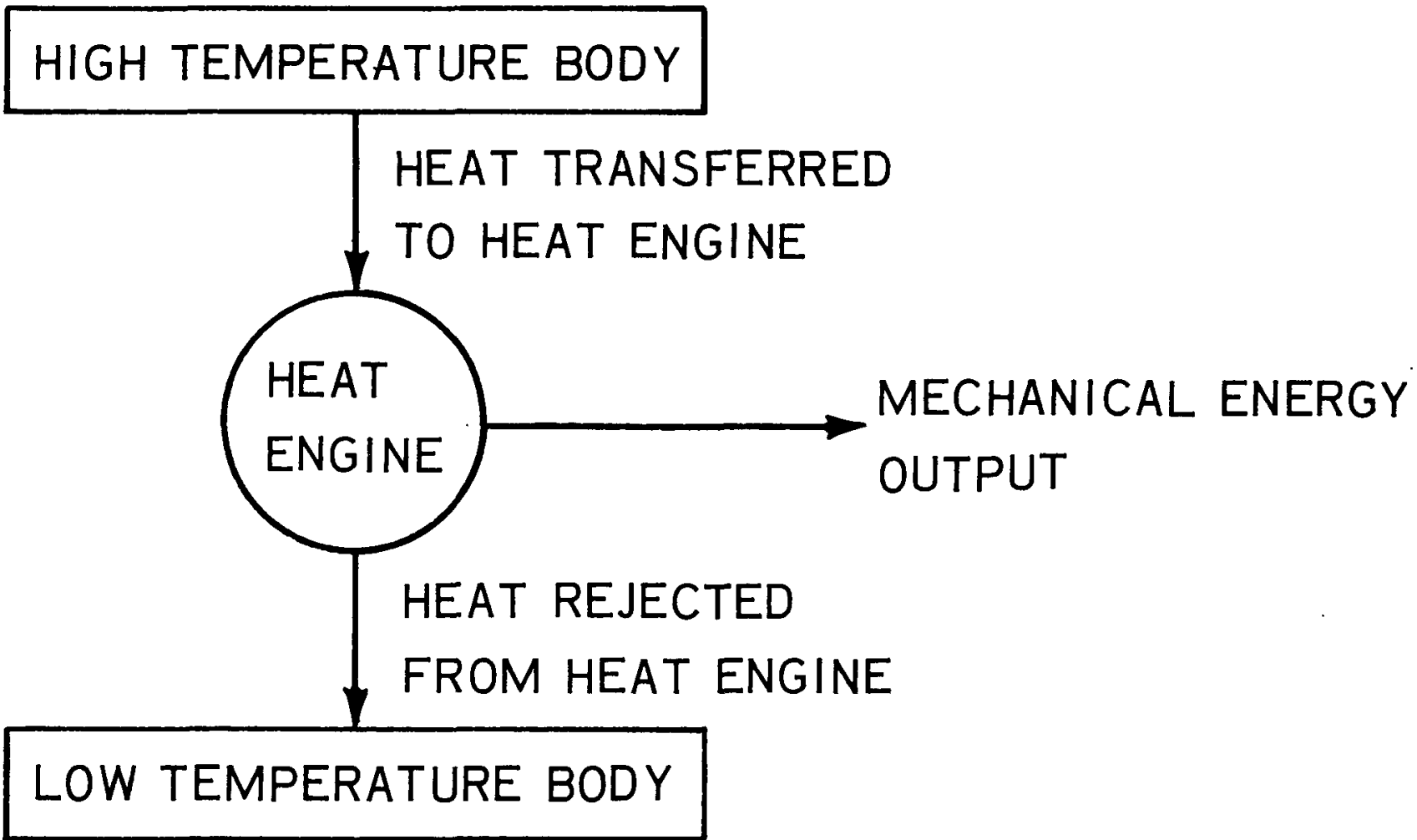

OPERATION OF A HEAT ENGINE

Figure $B .2-1$ 
high pressure, high temperature steam. The steam enters the turbine where it expands to a low pressure, low temperature steam, and in so doing does work against the turbine blades, causing a rotation of the turbine shaft which in turn drives an electrical generator. After the thermal energy in the steam has been converted to mechanical energy in the turbine, the discharged (spent) steam is reconverted into water in a condenser. The water is then pumped back into the boiler and starts the cycle over again. The heat removed in the condenser is rejected to the environment in cool bodies of water, (i.e., lakes, ponds, or rivers) or to the atmosphere by cooling towers. This cycle is shown in Fig. B.2-2.

Modifications to the Rankine cycle which improve its thermal efficiency use the concepts of regeneration and reheat. The reheat process takes a portion of the steam that has partially expanded to an intermediate pressure in the turbine, reheats it in the boiler, and then returns it to the turbine to complete the expansion process (Fig. B.2-3). The regenerative process extracts a fraction of the steam from the turbine after partial expansion, and uses it to heat the water leaving the condenser, before it enters the boiler. The device where this heat exchange occurs is called a feedwater heater. This process is shown in Fig. B.2-4.

Typical steam power plants will use both reheat and regeneration. The extent of reheat and regeneration for a particular plant 


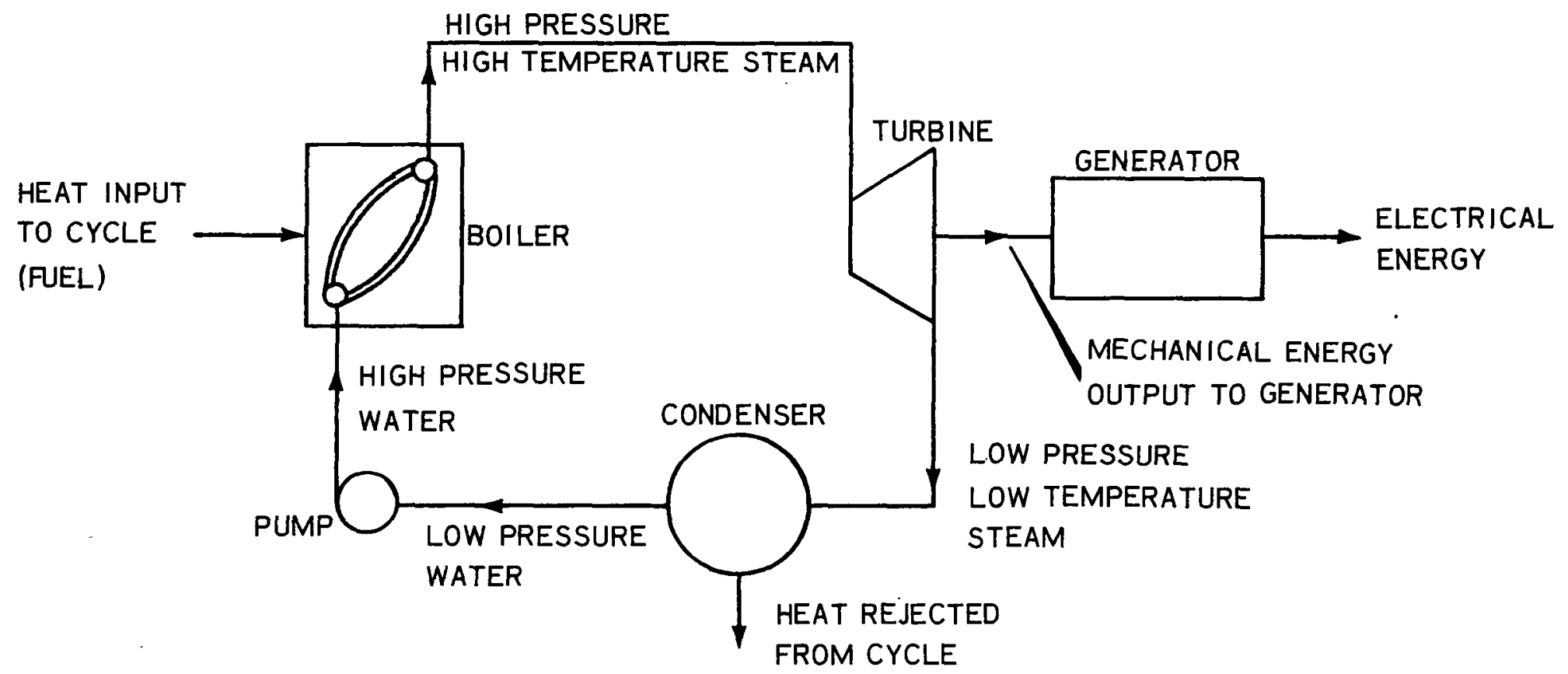

BASIC COMPONENTS OF A RANKINE CYCLE HEAT ENGINE AS USED IN STEAM TURBINE POWER PLANTS

Figure B.2-2 


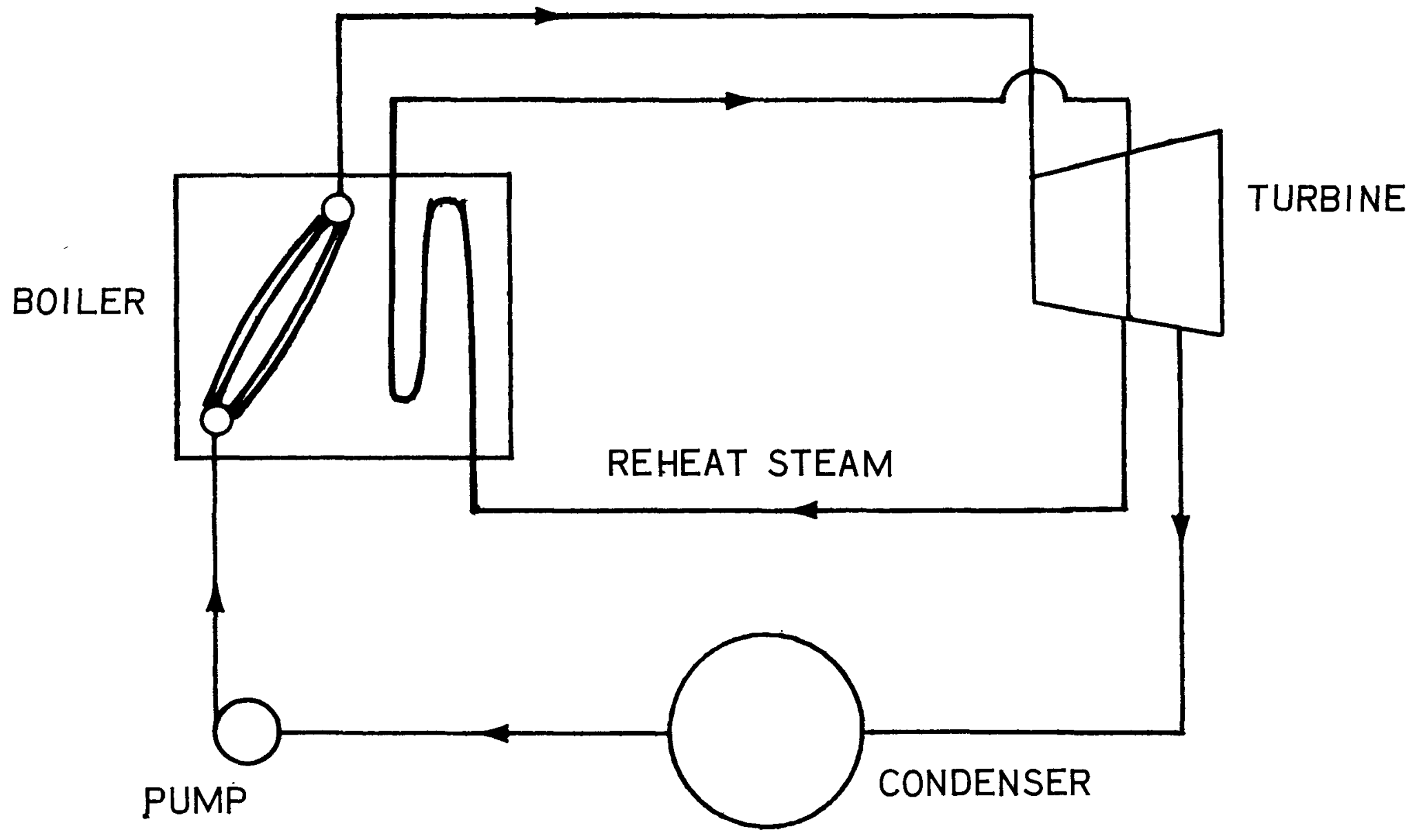

RANKINE CYCLE WITH REHEAT

Figure B.2-3 


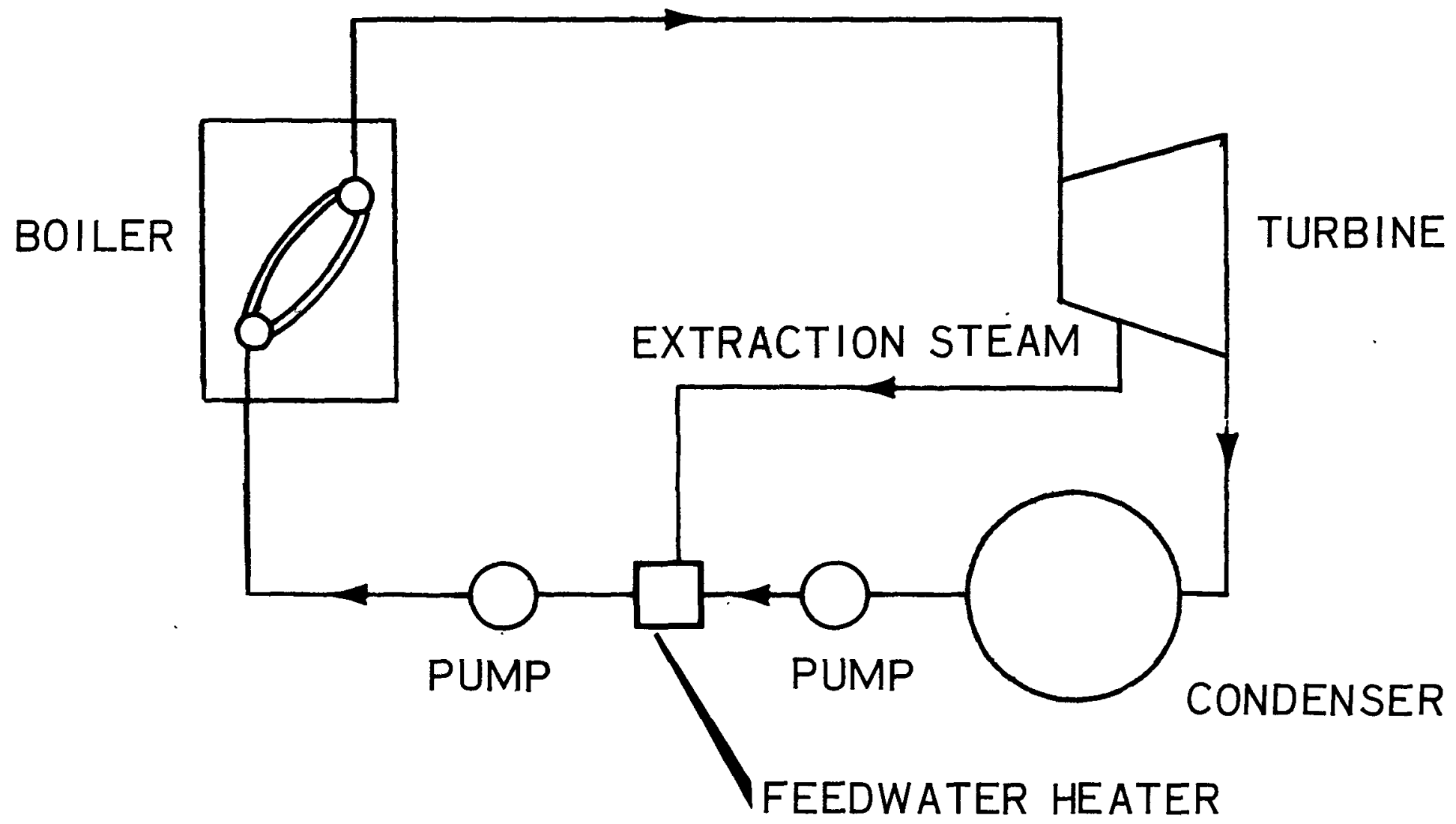

RANKINE CYCLE WITH REGENERATION

Figure B.2-4 
will be determined by economic considerations - principally the fuel cost. The Light Water Reactor (LWR) nuclear plants in operation today, for the most part, use the regenerative process only since the temperatures available in LWRs are not practical for reheat purposes.

\subsubsection{History and Status}

The steam turbine energy system became part of the electric power industry around 1900, roughly 20 years after the industry's beginning. Its importance grew and it quickly overtook reciprocating steam engines and hydroelectric power as the principal means of electric generation. By 1930 it was responsible for $70 \%$ of the total generated capacity and since then the proportion has gradually increased and currently is around $78 \% .^{4}$

Advances in technology have provided continuous improvement in the design and performance of the steam turbine system. In 1903, the approximate unit size was $5,000 \mathrm{KW}$, with initial steam conditions of $175 \mathrm{psi}$ and $375^{\circ} \mathrm{F}$, and a plant efficiency of $9.2 \% .^{5}$ Corresponding values for today's most modern plants have increased typically to $1,000,000 \mathrm{KW}, 3500 \mathrm{psig}, 1000^{\circ} \mathrm{F}$ with $1000^{\circ} \mathrm{F}$ reheat, and $39 \%$ efficiency. The trend to larger units is a result of lower capital, operating, and maintenance costs, on a per kilowatt basis, as the unit plant size increases. 
The steam conditions have, until recent years, increased in order to improve the thermal efficiency of the unit. This progress has been made possible by metallurgical advances resulting in alloys that can withstand the higher pressures and temperatures. The steam conditions declined and leveled off around 1960 because the small increase in efficiency, going from 3500 to $5000 \mathrm{psig}$, and 1050 to $1200^{\circ} \mathrm{F}$, could not justify the increase in metal costs and additional maintenance problems associated with these higher steam conditions.

Up to 1950, botlers were small and several would supply a single turbine. The continued increase in turbine size has required the design of higher output steam generators. Improvements in boller design and metallurgy have made it both economical and reliable to have a single boiler per turbine-generator.

The most significant change in the development of the steam turbine system, however, has not been improvements in system design but the use of nuclear fuel in place of the conventional fossil fuels. In these plants, the nuclear reactor, where the nuclear energy is released, takes the place of the conventional steam boiler used in fossil-fueled plants. 


\subsubsection{Present and Projected Applications}

As noted in Sect. 2.1.2 the steam turbine energy system has consistently been applied to the generation of electric power since the year 1900 . Estimated values for the remainder of the century indicate the percentage will increase somewhat over the 1970 value of $78 \%$. This includes its application to both fossil fired and nuclear steam supply systems.

The kind of service the various types of plants provide can be classified in terms of base, intermediate, or peaking load. Base-load units are large, efficient units that operate continuously at or near their full capacity. Typical annual capacity factors (percent of annual output if operated continuously at maximum capacity) are around $80 \%$. Intermediate-load units are smaller, less efficient, and typically are required to shut down and start up daily as demand varies. Capacity factors vary from 20-60\%. Peak-ioad units provide power for short periods of the day, when the demand for electricity is at its maximum, and have capacity factors of $20 \%$ and less.

Steam turbine systems are predominantly used for base and intermediate load service. Base-load service is provided by large fossil-fueled and nuclear units, whereas intermediate service is provided by either older and smaller fossil-fueled units, originally designed for base-load, or newly designed fossil-fueled units built specifically for this service. 
New peaking service is now generally provided by pumped storage, gas turbine, or diesel energy systems, rather than steam turbine systems, because of the quick start up requirements and the economics involved.

\subsection{Technical Information}

\subsubsection{Availability}

There are three U.S. suppliers for steam turbine equipment as well as several prominent foreign sources. Avallability of steam turbine units in terms of lead time - the time from project announcement to commercial operation - depends on the type of unit. Approximately five years are required until operation of fossilfueled plants. Nuclear plants, which have more sophisticated technology and more involved licensing procedures, require about eight years of lead time.

\subsubsection{Energy Source}

The fuels currently used in steam turbine power generation systems are the fossil fuels - coal, oil, and natural gas - and nuclear fuels. Figure B.2-5 shows the current and projected electric power generation by these fuels and also hydroelectric energy. These fuels are discussed in considerable detail in Section $A$ of this report. 


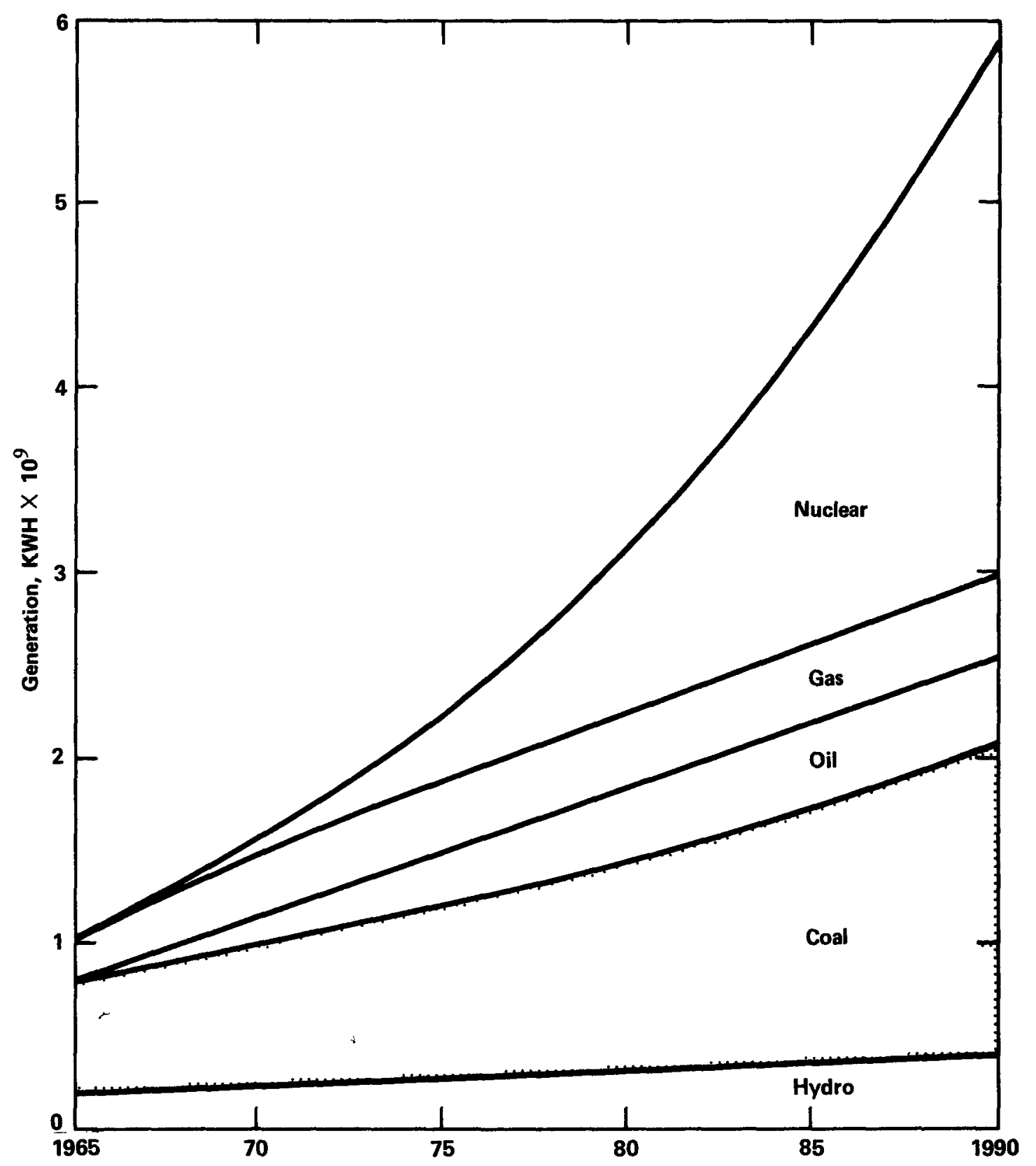

ESTIMATED ANNUAL ELECTRIC GENERATION BY ENERGY SOURCE

Figure B.2-5 


\subsubsection{Efficiency}

As discussed in section 2.1.1, the maximum efficiency for a heat engine is the Carnot cycle efficiency. This is a theoretical efficiency which cannot be achieved in practice, but serves as a measure of performance for actual cycles. The Carnot efficiency is

$$
n_{c}=\frac{T_{H}-T_{L}}{T_{H}}
$$

where

$$
\begin{aligned}
& n_{c}=\text { Carnot cycle efficiency } \\
& T_{L}=\text { Low temperature of heat rejection, }{ }^{\circ} R \\
& T_{H}=\text { High temperature of heat addition, }{ }^{\circ} R
\end{aligned}
$$

Steam turbine systems typically operate between a maximum temperature of $1000^{\circ} \mathrm{F}\left(1460^{\circ} \mathrm{R}\right)$, and a minimum temperature of $70^{\circ} \mathrm{F}\left(530^{\circ} \mathrm{R}\right)$. A Carnot cycle operating between these temperature limits of heat addition and heat rejection would have an efficiency of $64 \%$.

Actual steam turbine plant efficiencies for units in the $1000 \mathrm{MW}$ range are on the order of $38-40 \%$ for fossil-fueled and HTGR units, and 31-34\% for BWR and PWR units. Improvements to these efficiencies through the use of additional stages of reheat and regeneration are not economically practical at the present time because the increased investment costs offset the operating savings. 
Use of higher steam temperatures and pressures to improve efficiency of fossil units is limited by: (1) metals currently used are near their metallurgical limit, and (2) metals that can withstand more extreme steam conditions are too costly to be economical and have a 1 imited lifetime. Therefore, significant advances in efficiency are not expected in the immediate future.

\subsubsection{Size Limitation}

The size of steam turbine units is expected to increase, above the present maximum of about 1300 MW to reduce capital, operating, and maintenance costs on a per KW basis. Although these large units will require some improvements in turbine, generator, and boiler design, no major problems are expected.

Factors that may have an effect on plant size are cooling water and land area requirements. Since larger units require greater anounts of cooling water, and regulations are being introduced that limit the amount of heat that can be discharged into natural bodies of water, sources of cooling water for large plants has become a problem. Greater land area requirements are a result of larger coal and ash storage areas, flue gas cleaning equipment, and cooling facilities for the condenser cooling water. 


\subsection{Research and Development}

It is felt by many experts that there are not likely to be any major improvements in steam turbine technology. Advanced blade technology, seals, and moisture removal techniques as well as lower-cost, hightemperature alloys are areas receiving current attention. The use of superconductivity technology is also being explored for the construction of smaller, lighter, higher power output turboalternators (generators) since this currently represents a transportation restriction (manufacturer to power plant site).

Any major advances in efficiency will probably come from the use of topping (binary) cycles or alternative energy conversion devices.

\subsection{Environmental Impacts}

The environmental impacts associated with steam-turbine electrical generating plants are discussed extensively in Section A of this report in those portions dealing with the power production systems using the steam turbine cycle.

\subsection{Costs and Benefits}

The preponderance of the electric generating capacity of the United States today is based on the utilization of the Rankine cycle. This attests to its relative economics. The very wide range of conditions for which an individual unit may be designed; i.e., varying construction conditions, varying labor productivity, etc., lead to significant cost differences of plants installed at different 
locations within the nation. Environmental centrol costs will also add substantial amounts to the basic costs of the plant. (See Section A.2.1.7 for a detailed discussion.)

Disadvantages exist with the steam turbine energy system that are prompting investigations into alternative electric generation schemes. Principal factors are its associated adverse environmental effects and the desire for higher efficiences than can practically be obtained from a steam Rankine cycle alone. Low efficiencies result in higher rates of (1) consumption of 1 imited fuel reserves, (2) air pollution, and (3) thermal pollution. The indirect method of electric generation - energy transformations from chemical or nuclear to thermal, from thermal to mechanical, and from mechanical to electrical - along with the large and complex equipment used, are also considered system disadvantages when compared to other generation concepts.

Notwithstanding these considerations, the steam turbine system is currently the most economical and technologically developed energy system available to the electric power industry.

\subsection{Overall Assessment of Role in Energy Supply}

The steam turbine energy system is, and is expected to remain for sometime, the predominant means by which fossil and nuclear energy is converted to electrical power by central station plants. Most new plants will be in the size range of 1000 MWe and beyond. No significant improvement in the efficiency of conventional steam 
turbine systems is foreseen. However, the development of advanced energy conversion systems such as gas turbines, binary cycles and magnetohydrodynamics may provide the means of improving the efficiency of central station power plants. 


\subsection{References}

1. Federal Power Commission, "The 1970 National Power Survey," U.S. Government Printing Office, Washington, D.C., 1971.

2. Edison Electric Institute, "Historical Statistics of the Electric Utility Industry," Pub. No. 62-69, Edison Electric Institute, New York, 1962.

3. Edison Electric Institute, "Statistical Year Book of the Electric Utility Industry for 1971," Pub. No. 72-25, Edison Electric Institute, New York, 1972.

4. Federal Power Commission, "Directory of Electric Generating Plants January 1941," Pub. No. FPC S-9, Federal Power Commission, Washington, D.C., 1941.

5. Morrow, L.W.W., "Electric Power Stations," 1st ed., McGraw-Hill, New York, 1927.

6. "Compilation of Air Pollutant Emission Factors" (Revised), Pub. No. AP-42, U.S. Environnental Protection Agency, 1972. 


\section{B.3 INTERNAL COMBUSTION ENGINES}

\subsection{Introduction}

\subsubsection{General Description}

The principles of the internal combustion engine (IC) can be simply described as follows. If a mixture of fuel and air is burned in a confined space, the heat released elevates the temperature of the combustion products and remaining reactants and causes a pressure rise. If the chamber (cylinder) in which the fuel is burned is constructed with a movable wall (piston), the increase in pressure causes the piston to move. Connecting the piston to an eccentric shaft (crankshaft) through a linkage with movable joints (connecting rods) enables the pressure (power) moving the piston to be transmitted to the shaft, causing it to rotate. With suitable valves (the opening and closing of which are controlled by the rotating shaft) air, fuel, and the products of combustion can be admitted and discharged at appropriate times, supplying intermittent energy to the crankshaft. Usually a number of cylinders are mounted on a common shaft. The power output is in proportion to the number of cylinders, and if the cranks are properly phased, a more uniform flow of power to the crankshaft can be obtained. This results in a reduction in flywheel size and weight. A turbocharger is sometimes added to enhance engine performance. A flywheel can be mounted on the crankshaft to assist in providing for continuous power output. (See Fig. B.3-1). 


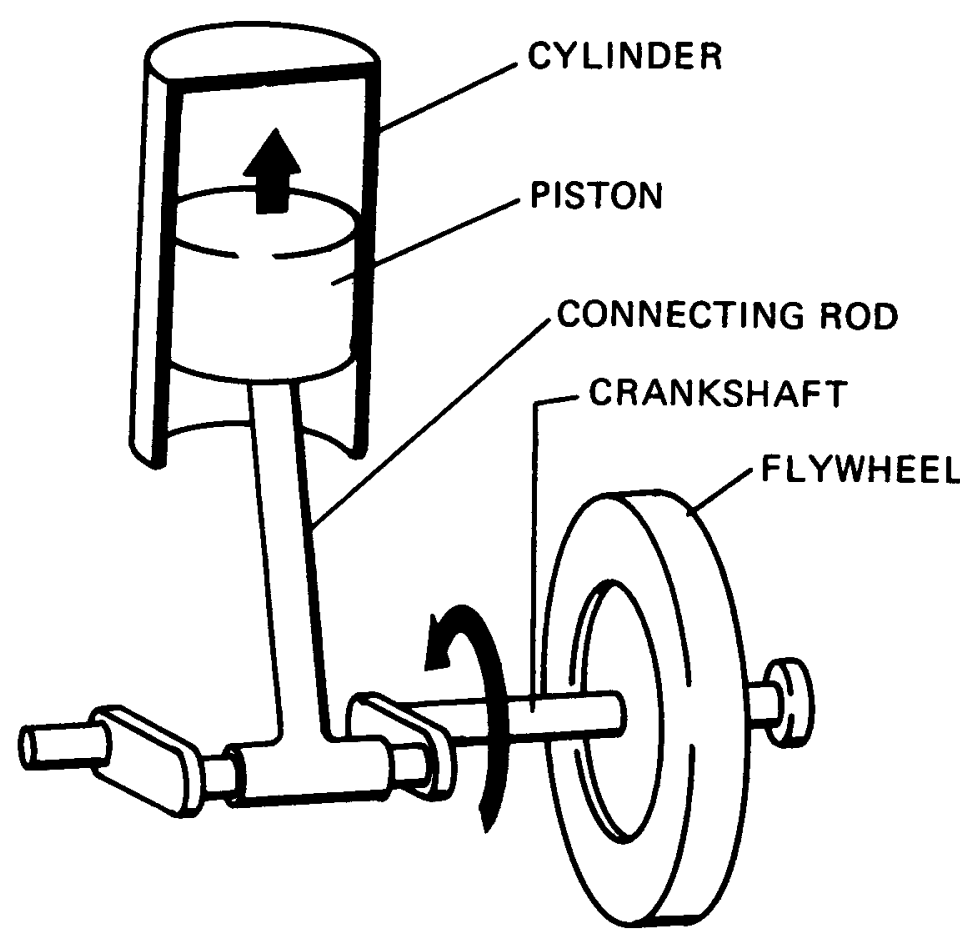

(a)

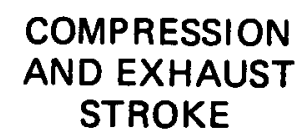

COMPRESSION STROKE

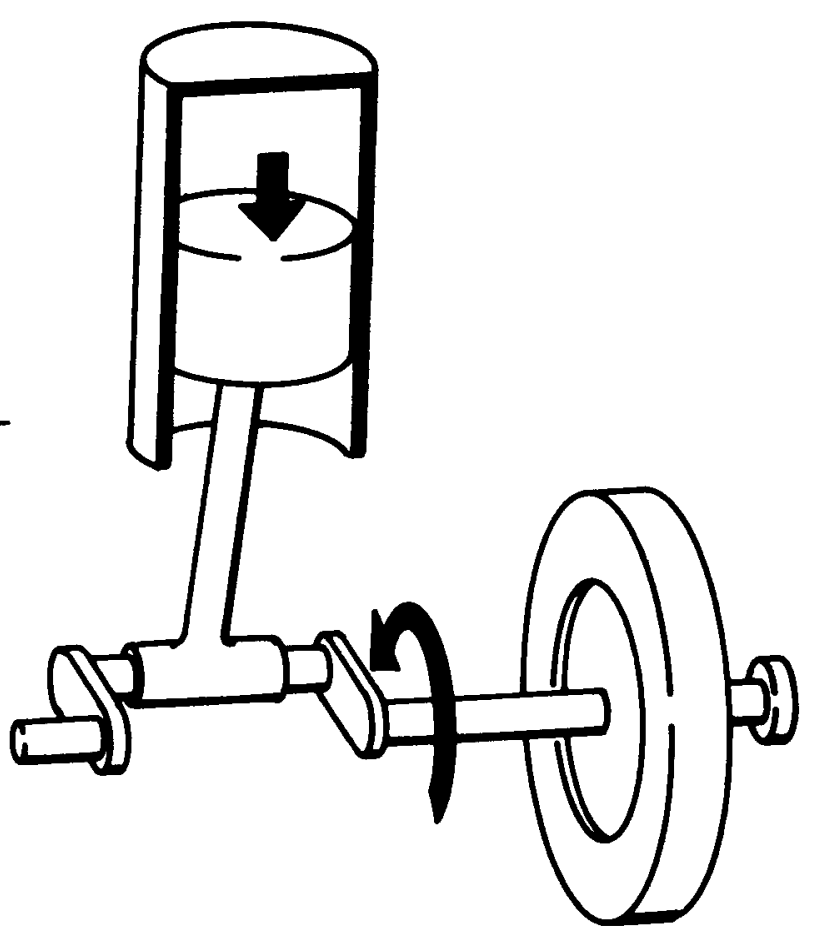

(b)

EXPANSION AND INTAKE STROKE

SCHEMATIC DRAWING OF PISTON TYPE INTERNAL COMBUSTION ENGINE

Figure B.3-1 


\subsubsection{History and Status}

The origin of the IC engine is generally credited to Christian Huygens (1629-1695), a Dutch scientist, who proposed the construction of an engine using gunpowder as a fuel. Similar schemes for the design of IC engines were proposed over the next 200 years, but were never reduced to practice.

In 1895, Rudolph Diesel built the first successful four-stroke compression-ignition engine that burned fuel ofl injected, under pressure, into the cylinder. This pioneering work laid the foundation for the development of the piston-type engines used in electrical power generation today. The first electric power generated in America by an IC engine was in 1898.

Internal-combustion (IC) engines of the piston type are familiar as the prime mover in the vehicular propulsion field. The IC engine can be fitted with an electric generator and used for small electric utility applications. The engines used in utilities are generally many times larger than those used in vehicles. They burn oil or gas, and are of the diesel type. (Such plants are referred to as diesel electrics).

Use of this type of engine for electric power generation stems from the relative simplicity of the completed plant, its ability to burn a variety of gaseous or liquid fuels, its minimal water requirements, 
and its relatively good efficiency. It is the preferred power plant with cooperative and municipal utilities where the total installed power is 10 megawatts (MW) or less.

\subsubsection{Present and Projected Application}

The diesel electric generating plant dominates the low-power end (up to $10 \mathrm{MW}$ ) of requirements in the utility field. It is used for base-load power generation in small utilities, peaking power in large utilities, starting power in some steam power plants, and emergency power for practically all nuclear plants. Diesel electric plants have the ability to start unattended on command in about 10 seconds and assume full load within 30 seconds. High starting and operating reliability is required for this application.

Diesel electric generating sets are frequently used for steamstation auxiliary power. Installed primarily for use as independent sources of starting power for station steam units, these plants may also be used for small additional power generation for the system during periods of peak demand.

\subsection{Technical Information}

\subsubsection{Availability}

of the 32 diesel engine manufacturers in the United States only six could be considered as equipment suppliers to the electric utility 
industry. The combined product line of these six companies comprises well over 100 models and sizes, making it possible for any customer to select an engine meeting his needs.'

Utilities in the U.S. have not demanded large diesel-engine generating sets. While the average size in the U.S. is about $3500 \mathrm{KW}$, the largest diesel-engine in production has 12 cylinders on a single frame and develops over 10,000 shaft horsepower (7000 $\mathrm{kW}$ electrical at $93 \%$ electrical generator efficiency. $)^{2}$

\subsubsection{Energy Source}

Virtually any liquid or gaseous fuel can be burned in a diesel engine. The principal liquid fuel in use today is a No. 2 fuel oil. Higher-density fuel oils, up to No. 6 and even crude oil - centrifuged to remove particulate matter that would clog the fuel-injection nozzles - are also used. The type of liquid fuel used is a matter of economics. The lower cost of poorer quality oils must be weighed against the effect on power output, increased emissions, and higher maintenance costs. Natural gas is typically used in dual-fuel or gas-burning enqines and is used as-delivered from the gas utility. No special fuel pre-treatment is required. 


\subsubsection{Efficiency}

The specific fuel consumption of practically all modern diesel engines used for electric power generation fall in a range near $0.40 \mathrm{lb} / \mathrm{hp}-\mathrm{hr}$. (Four-cycle engines have a slightly lower specific fuel consumption than two-cycle engines). This is the equivalent of a heat rate of $7400 \mathrm{Btu} / \mathrm{kW}-\mathrm{hr}$ ( $235 \%$ eff) at the engine output shaft which is comparable to modern steam plants whose power output may be a factor of ten higher.

\subsection{Research and Development}

After 75 years of intensive development of the diesel engine by some of the best engineering firms in the world, it is difficult to imagine any basic development that is required.

\subsection{Environmental Impacts}

Pollution from a diesel engine comes from the engine cooling system and the cylinder exhaust. All diesels used in utility generating plants are water-cooled, the engine cooling water being circulated in a closed loop. Heat is rejected through either water-to-water or water-to-air heat exchangers.

Diesel exhaust emissions classed as pollutants are the same as from any other IC engine. These are: $\mathrm{CO}, \mathrm{NO}_{x}$, unburned hydrocarbons, and particulate matter. Standards for stationary diesel engines emissions are being formulated by the U.S. Environmental Protection Agency and are expected to be available in 1974. 
The diesel engine industry has been monitoring emission products from diesel engines burning both liquid and gaseous fuel; typical findings are as follows:

\begin{tabular}{|c|c|c|c|}
\hline \multirow{2}{*}{$\begin{array}{l}\text { Engine Type: } \\
\text { Fuel Form: }\end{array}$} & $\begin{array}{l}\text { Two-Cycle } \\
\text { Spark Ignition }\end{array}$ & \multicolumn{2}{|c|}{$\begin{array}{c}\text { Four-Cycle } \\
\text { Compression } \\
\text { Ignition }\end{array}$} \\
\hline & Gas & [igurd & Gas \\
\hline Item & \multicolumn{2}{|c|}{$\begin{array}{l}\text { Exhaust Emission in } \\
\text { Grams/hp-hr }\end{array}$} & \\
\hline $\begin{array}{l}\mathrm{CO} \\
\text { NOx } \\
\text { Hydrocarbons } \\
\text { Particulates }\end{array}$ & $\begin{array}{c}2.2 \\
10.0 \\
3.5^{a} \\
N A\end{array}$ & $\begin{array}{r}0.6 \\
10.4 \\
0.3 \\
0.6\end{array}$ & $\begin{array}{l}2.3 \\
4.6 \\
5.6^{a} \\
0.5\end{array}$ \\
\hline
\end{tabular}

Diesel electric generating stations are generally noisy. This can be readily controlled and corrected by some redesign, soundproofing, and more extensive mufflers.

The clean-up of exhaust-gas emissions must await the establishment of EPA standards before the extent of the problem is known.

\subsection{Costs and Benefits}

Two types of costs are to be considered: capital and operating (power generation) - both of which can vary widely.

A 2750-kW prepackaged Electro-Motive unit in 1972 sold for about $\$ 105 / k W$. This price is also applicable to the bare, medium-speed, 
four-cycle engine. The slow-speed, two-cycle engine sold for about $\$ 30 / \mathrm{kW}$ more. In addition, installation costs for this unit on the east coast ranged from $\$ 15 / \mathrm{kW}$ for a single-unit plant to $\$ 8 / \mathrm{kW}$ for a five-unit plant. Installation costs of a medium- or slow-speed diesel plant ranged from $\$ 40$ to $\$ 50 / \mathrm{kW}$. These costs did not include fuel storage and the transformer station, cooling water, buildings, capital write-off, taxes, interest during construction, and architect's fees.

In 1970, power generation costs (includes capital amortization) for baseload, diesel-electric generating plants averaged $9.54 \mathrm{mills} /$ kWhr for a representative group of 45 plants. Capacities ranged from $51,740 \mathrm{~kW}$ in thirteen units to $2361 \mathrm{~kW}$ in four units. Costs ranged from a high of $18 \mathrm{mills} / \mathrm{kWhr}$ to a low of $4.87 \mathrm{mills} / \mathrm{kWhr}$ half of which are fuel cost. Production costs vary inversely with the size of the plant and peaking and standby plants have higher production costs than a base load plant, but are within the range noted.

While reasonably efficient and competitive with steam turbine units in the low power range diesel-electric plants do not reach the efficiency of large steam turbine units. While they are size limited in individual units, multiple unit plants can be arranged to give a desired power level. Capital costs are favorable but they can only use liquid and gaseous fossil fuels. 
3.6 Overall Assessment of Role in Energy Supply

The diesel electric plant has its own place in the electric utility industry in providing modest blocks of power for municipalities and isolated areas. Aside from power generated in the small cooperative and municipal utilities, the diesel generating plant contributes little to our total electrical requirements. Of the 367,396 MW of installed electrical generating capacity In the United States in 1971, only 4466 MW, or 1.22\% of the total, was diesel electric. The total energy ( $k W h r)$ generated was an even smaller fraction, $0.39 \%{ }^{4}$

Because of size limitations, the diesel electric plant will probably not be used to meet a system demand much in excess of $50 \mathrm{MW}$. However, it has established a position in the small municipal and cooperative electric system and has enjoyed a growth rate of over $4 \%$ per year during the past 15 years.

With the exception of any restrictions that may be imposed by the increasing price and scarcity of oil, no new developments or environmental ramifications are anticipated that, in the immediate future, will affect the use of the IC engine in the electric utility field. 


\subsection{References}

1. Diesel and Gas Turbine Catalogue, Volume 36, 1971, Published by Diesel and Gas Turbine Progress, Milwaukee, Wisconsin.

2. 1972 Plant Design Issue of Power Mag., McGraw-Hill Publishing Co.

3. Report on 011 Engine Power Costs, American Society of Mechanical Engineers.

4. Statistical Year Book of the Electric Utility Industry for 1971 Edison Electric Institute Publication No. 72-25, No. 39 


\section{B.4 GAS TURBINES}

\subsection{Introduction}

\subsubsection{General Description}

The gas turbine system has the function of converting input chemical energy of fuel into heated, compressed gas which expands while doing work on rotating blades similar to the steam turbine. The mechanical output is coupled to a generator shaft which in turn generates electrical power. Components of this sytem include a compressor, a combustion chamber, and one or more turbines together with heat exchangers, as called for by cýcle design (see Figure B.4-1). In the simplest cycle no heat exchangers are employed. An important characteristic of the gas turbine is the essential requirement for a clean (no particulates or corrosive components) gas flow through the turbine, forcing the need for a clean burning fuel, or el se a source of hightemperature thermal energy, such as a nuclear reactor, where the fuel-element coolant is the high-pressure heated gas for the turbine expansion.

\subsubsection{History and Status}

As noted in Section 2.1.2, around 1900 the steam turbine had developed to a point where it began to be used for central station power generation. Steam turbine systems use external combustion in a boller to generate steam. The advantages of using turbine machinery with internal combustion led to numerous gas-turbine engine developments which did not fully mature until after 1945 


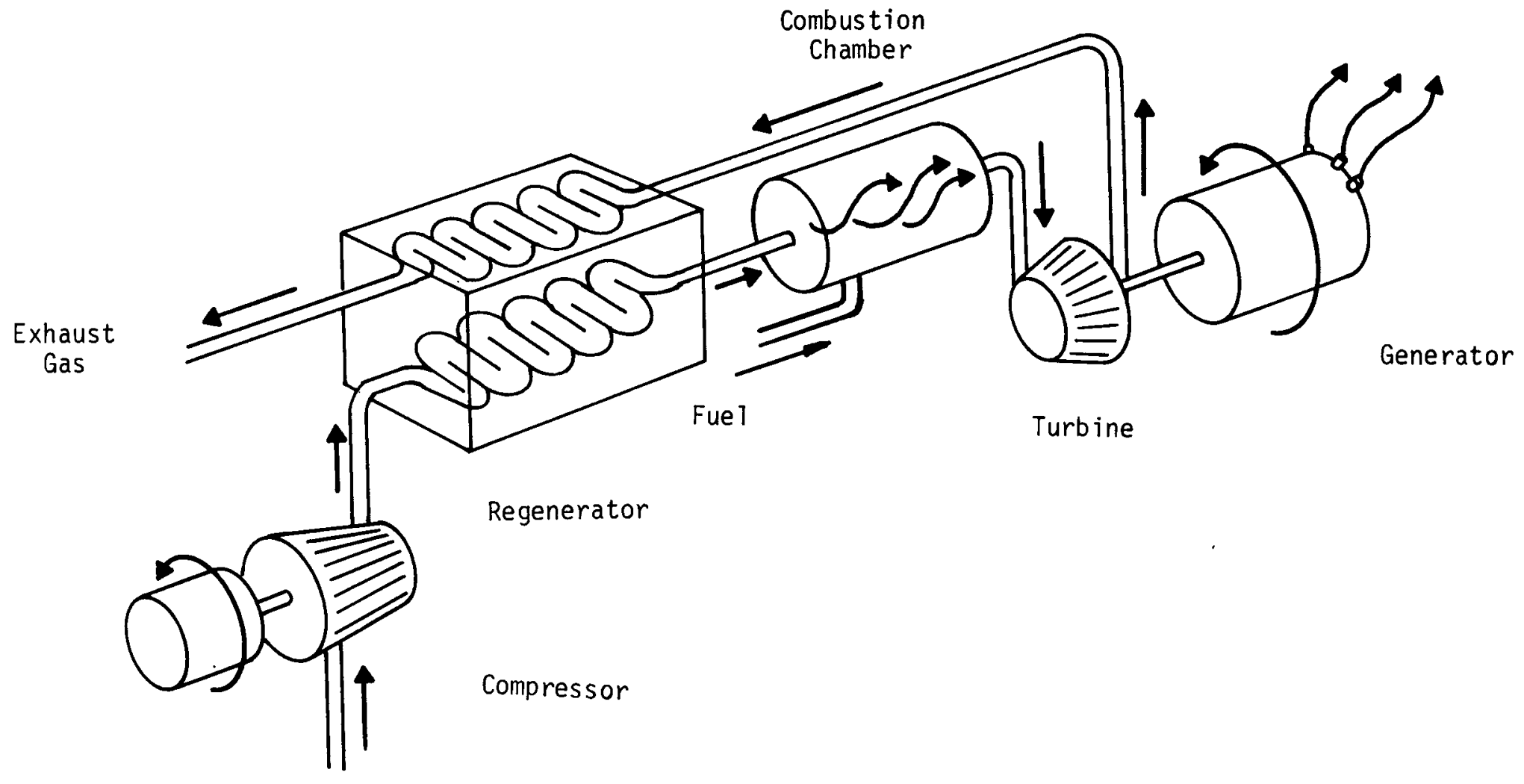

Air

REGENERATIVE CYCLE GAS TURBINE

Figure B.4-1 
as a result of the largely military - supported R\&D effort on supercharged aircraft piston engines. Much of the technology of the aircraft development is used, after a modest time lag, in the industrial gas-turbine field.

In the early 1960 period the industrial gas-turbine market blossomed with its applications to natural-gas transmission-line pumping, the petrochemical industry, locomotive propulsion, and emergency and peaking electrical energy generation.

This type of power plant was introduced into the electric utility field in 1949 and was regarded as a curiosity until early in the 1960s when utilities recognized and accepted its usefulness in meeting their peak load demands. Its acceptance in the electric utility industry for this purpose has been substantial over the past ten years so that almost $8 \%$ of the installed generating capacity is now in gas-turbine power plants.

\subsubsection{Present and Projected Applications}

Today the simple-cycle gas-turbine prime mover is favored for new equipment to accommodate the peak portion of the electrical power demand. Fast start, low initial cost and short delivery time are features desired for peak load plants and are met by gas turbine units. An important variation of the simple-cycle system is the combined gas turbine and steam plant. Here the hot exhaust from the power turbine is used to generate steam in an unfired boiler. The steam is used in 
a conventional system to generate $50 \%$ more power without additional fuel (Figure B.4-2). The combined cycle thermal efficiency is comparable to that of a modern steam plant and is being used by some utilities for serving intermediate system loads. It is forecast that by 1980 the gas turbine and the combined gas turbine and steam power plant could be providing some $25 \%$ of the power requirements of the electric utility industry in meeting peak and intermediate load demands. Gas turbine cycles are expected to be used in high temperature gas cooled reactor (HTGR) and gas cooled fast reactor (GCFR) systems.

\subsection{Technical Information}

\subsubsection{Availability}

Heavy-duty-type and aircraft-engine-derivation-type electric power gas turbines are currently available in sizes ranging from approximately 3 to 100 MWe when combined with a heat-recovery steam generator and a steam-turbine generating unit. Replication of these units is employed to produce plant capacities up to 1000-MWe. For instance, such a plant might consist of four gas-turbines, and their electrical-generator packages, plus one steam turbine with its electrical generator.

There are three major U.S. suppliers of large, heavy-duty, industrialtype gas turbines (50 MWe and greater) and three major suppliers for large, aircraft-engine-derivative systems. If, as expected, the 


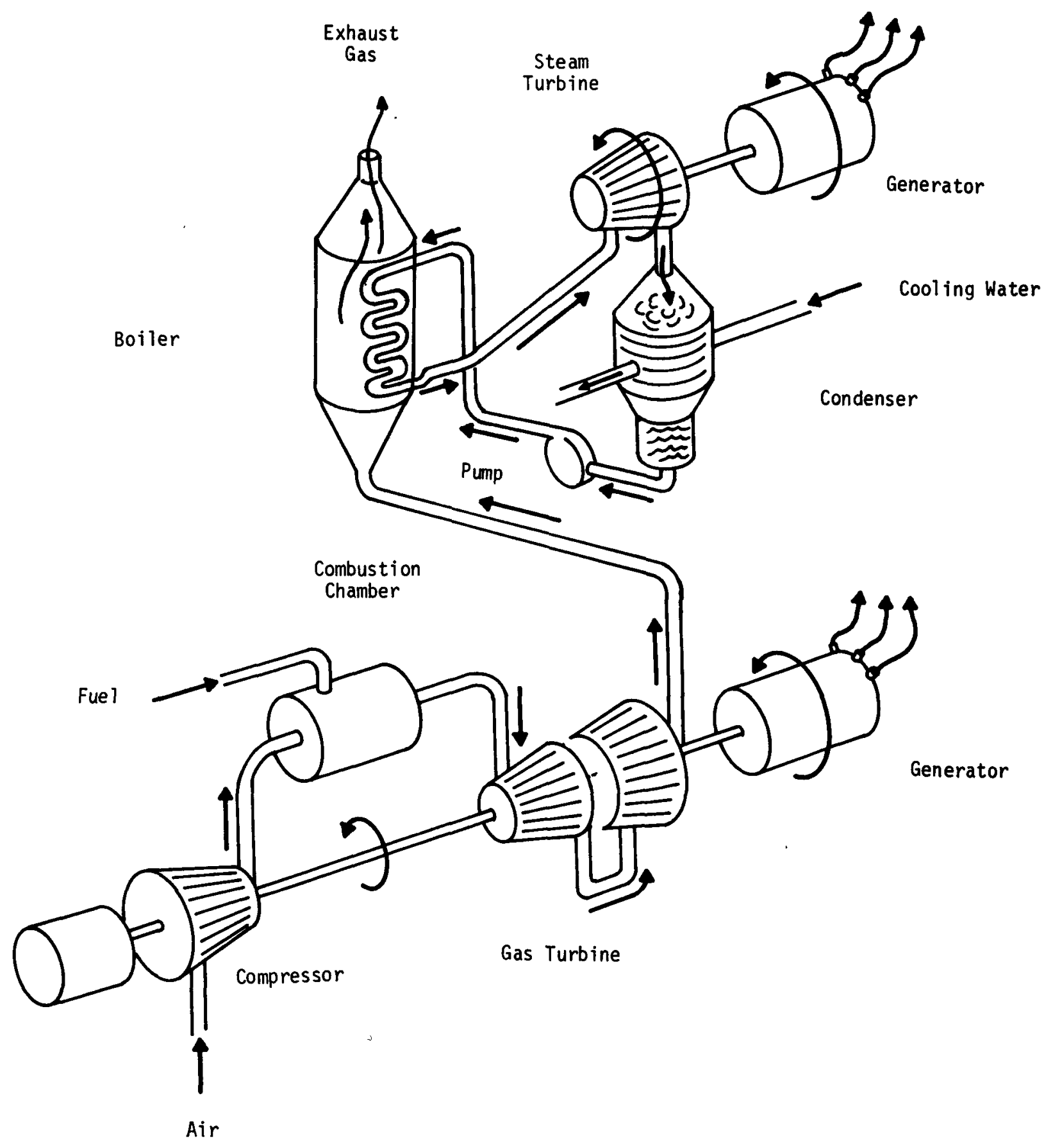

COMBINED CYCLE GAS TURBINE

Figure B.4-2 
combined cycle and its variants make substantial inroads into the midrange market, the short lead time advantage now offered by gas-turbine manufacturers (12-18 months) may well be lengthened. Alternatively, manufacturing capacity, not only for the gas turbine, but also for electrical generators, regenerators, and heat-recovery boilers will need to be expanded.

\subsubsection{Energy Source}

One of the salient characteristics of a gas turbine is its requirement for a clean fuel so that the gas flow through the turbine is neither erosive from particulates, nor corrosive from vanadium, sodium, potassium, lead, and sulfur compounds. Calcium is also troublesome, as it forms hard deposits. All of these elements are contained in residual fuel oils--the low-cost residue of the petroleum refining processes that produce the distillate fuel oils (diesel and kerosene) and gasoline. As a consequence of this, careful selection of comparatively clean residual and crude fuel oils must be made and these must then be further treated before fuel ofl products can be used for gas-turbine operations. In addition the growing need for our limited oil resources for other applications makes this energy source questionable for large scale use in the electric power industry.

Gaseous fuels present no problems of this nature. Natural gas as distributed by utilities is an ideal fuel but its scarcity also militates against use for electric power generations. Considerable attention is 
being given to the possibility of using high or low BTU gas derived from coal gasification and there does not seem to be any technical problem in doing so. Coal gasification may well become an economical technique for removing sulfur. The gas turbine and the combined cycle plant might adapt very well to this type of fuel.

High temperature helium-gas-cooled thermal nuclear reactors (coupled to steam-turbine converters) are now being studied by the utflities as a viable alternative to water-cooled reactors. It is expected, therefore, that increased emphasis may be placed on the closed-cycle helium-gas turbine as the energy conversion system, instead of the steam turbine (Figure B.4-3).

\subsubsection{Efficiency}

Gas-turbine plants now available have the following efficiencies:

- Simple cycle, $27 \%$,

- Combined cycle, 36-38\%,

- Regenerative cycle, 34\%.

With currently available materials and turbine-cooling technology, commercial designs should be avallable in the 1975-77 period, having better thermal efficiencies, by a factor of 1.1 or more, which could make the combined cycle competitive with the best available conventional steam plants. By 1980, it is expected that further evolutionary progress might yield improvements resulting in a 1.2 multiplier on present-day thermal efficiency performance. 


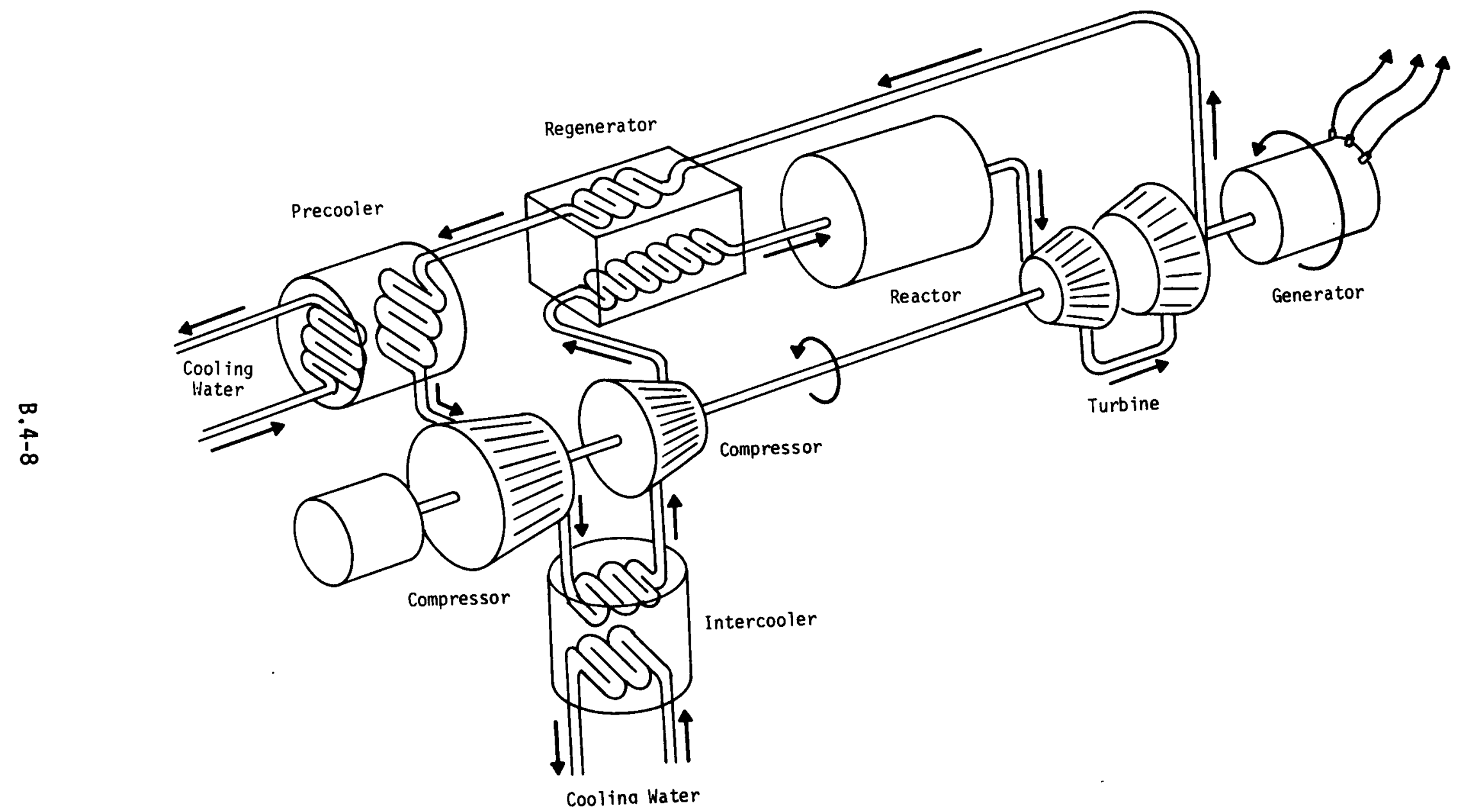

NUCLEAR CYCLE GAS TURBINE

Figure B.4-3 


\subsubsection{Size Limitations}

One great advantage of the gas-turbine cycle engine is that it lends itself to the concept of modular design and factory fabrication. The result is substantial economies in lead time and costs for field erection. Another advantage of the modular concept is that good partload fuel economy can be realized by shutting down one or more units when only part of the capacity is needed. Multiplicity of units also affords improved reliability and avallability, as maintenance can be done to a single unit with only a partial reduction in capacity. These capabilities are highly desirable for plants used for the midioad service range.

\subsubsection{State of the Art}

The power obtained from the turbine components and the power required to drive the compressor are dependent on gas flow temperatures and component efficiencies. It is important to have a high turbine inlet temperature, and to design the flow path over the compressor and turbine blades to minimize losses, in order to achieve better fuel economics.

The outstanding advantages of the gas turbine for aircraft propulsion has produced the research and development effort that led to the improved aerodynamics of flow path design, metal alloys allowing high turbine inlet temperatures, and improved methods of cooling turbine blades and nozzles. The fall-out of this technology has greatly improved the position of the gas turbine and has led to its acceptance for peak-load central station power service. 
Other important components of the industrial gas turbine and its variants are the heat exchangers for regeneration, steam generation and other functions such as intercooling and precooling, as needed by the closed cycle. Large size regenerative heat exchangers for operation above $1000^{\circ} \mathrm{F}$ have not been built and pose difficult problems since operating conditions require materials that are high cost and difficult to fabricate.

In summary, the central-station-type gas-turbine engines available today represent advanced state-of-the-art designs evolving from the well-funded aircraft-gas-turbine R\&D. The heat-exchanger components, on the other hand, could benefit from an accelerated development effort.

\subsection{Research and Development}

For central station power units, R\&D is required in the following areas:

- New-design combustion chamber--convincing service experience is needed to prove that oxides of nitrogen can be significantly reduced.

- Advanced technology--early design application is needed of available blade-cooling techniques and improved high-temperature materials.

- Exhaust heat boilers--improved designs for lower cost and lower bulk are required.

- Reliability--for intermediate-load operation more demonstrated operating experience is required to show that gas turbines can 
operate at their design temperature for tens of thousands of hours without maintenance. (Some plants have operated 30,000 hours without maintenance.)

- Regenerators--designs are needed for higher-temperature operation at a lower cost and bulk. More suppliers are needed for this component, as there is now only one manufacturer in this country of industrial-type regenerators. The top operating temperature that regenerates with conventional materials needs to be established. More long-term service is required to prove operating relfability.

In addition, the closed-cycle helium-gas turbine coupled with a thermal nuclear reactor requires the following types of developments: Resolution of the effect of fission products and fuel debris from a failed fuel element on turbine corrosion and maintenance. Turbine shaft seal development is a major developmental area. This seal functions to prevent leakage of helium where the power turbine shaft passes through the turbine casing to drive the electrical generator. Also, the heat exchangers--the helium-to-helium regenerator, the intercooler, and the precooler--require substantial R\&D effort to produce economical designs.

\subsection{Environmental Impacts}

The site requirements for gas-turbine fossil-fuel plants are modest in acreage and elevation. The noise levels are low, as the high- 
frequency noise typical of turbomachinery may be acoustically treated at low cost.

Stack gas pollutants are virtually nil insofar as carbon monoxide and hydrocarbons are concerned. As a low-sulfur, low-ash fuel is a requirement for the turbine operation, flyash and sulfur dioxide emissions are also negligible. However, a present problem area is the stack effluent of oxides of nitrogen ( $\mathrm{NO}$ and $\mathrm{NO}_{2}$ ). The technique now used to treat the problem is to inject demineralized water into the combustion chamber, at a mass flow rate comparable to the fuel rate, for loads above $40 \%$ of rating. Most gas-turbine manufacturers feel that they will be able to offer combustion chambers that will reduce oxides of nitrogen without the necessity for water injection.

A set of emission standards is needed, such as the maximum values applying to conventional steam plants to provide realistic design targets for R\&D in oxides of nitrogen reduction.

Simple-cycle and regenerative-cycle plants, relative to the combined gas-turbine and steam-cycle plants, do not have an extensive requirement for cooling water. The combined gas turbine steam cycle has cooling water requirements about $40 \%$ or less than that of a conventional steam plant. 


\subsection{Costs and Benefits}

Low initial cost is an area that has made gas turbine energy systems particularly attractive to utilities. The efficiency has been of lesser importance for peaking service but whether this will hold in the future, because of the dwindling supply of clean fuel, is largely unknown. The relative station costs and performance levels of gas turbine plants are as follows:

- Simple Cycle

$\$ / K W$

- Regeneration Cycle

- Combined Gas and Steam Turbine
Thermal

Eff. \%

27

34

37

The comparable fossil fired steam turbine plant figure (from Section A.2.1.7) is $\$ 180 / \mathrm{Kw}$ for a plant without sophisticated environmental controls; this could escalate to over $\$ 300 / \mathrm{KW}$ when environmental controls are added. The efficiency of modern steam turbine plants is about $40 \%$.

\&

The cost advantages of the gas-turbine cycles arise primarily from the el imination of a fired, high-pressure boiler with its superheater, reheater, and regenerative feed-water heaters. These steam-generating components cost about $\$ 40-50$ per KWe. Though a boiler is incorporated in the combined cycle, its cost is only about $\$ 15-20$ per KWe, as it is an unfired heat exchanger operating at a low pressure (less than 1000 psi). 
Further advantages of the gas turbine are lower construction costs, about $\$ 5$ less per KWe, and lower interest and escalation charges by about $\$ 20$ less per KWe, due in part to much shorter field erection times. Projections for the future indicate that the gas-turbine-plant percent of base-line cost figures will improve further. This conclusion results from the fact that available technological improvements, which may be incorporated into the 1975-80 designs, will increase specific power by $40 \%$ or more. The result is that a given size (and cost) of turbomachinery has a higher KWe rating. Moreover, there will be significant gains in thermal efficiency, though percentage-wise not as much as for the rating gain.

\subsection{Overall Assessment of Role in Energy Supply}

The gas turbine is a highly flexible prime-mover concept. It can be tailored to higher-efficiency application (e.g., combined, regenerative, and helium-closed cycles) at the expense of initial capital costs, or alternatively a low first-cost cycle (e.g., the simple cycle and the water-injected variant) at the expense of lower efficiency with the associated higher fuel costs.

On the basis of present technology, the role of the gas-turbine prime mover as an electric power producer through 1990 should be largely in peaking and intermediate load operation, where it will contribute possibly as high as $30 \%$ of the power capability and about $15 \%$ of the total electrical energy production. Developments in gas turbine technology that improve efficiency might make this system more attractive 
for base load service. Gasification of coal could enhance the gas turbine's position by making it a possible alternative for baseload service.

The helium closed-cycle gas turbine coupled to a high temperature gas cooled nuclear reactor appears to have attractive features for a base-load generating plant. Substantial research and development will be required to demonstrate this role. 


\subsection{References}

1. J. W. Sawyer (editor), Gas Turbine Engineering Handbook, Gas Turbine Publications, Inc.

2. Anon., "Competitive Bids and Order," Gas Turbine World, OctoberNovember, 1972. 


\section{B.5 BINARY CYCLES}

\subsection{Introduction}

As noted in Section B.2 a fossil-fueled steam turbine system cannot take full advantage of the high temperatures available because of metallurgic and economic limitations. In order to improve this situation, it is often useful to consider the combination of two or more heat engine cycles that cover different parts of the temperature range. A combination of two different cycles is commonly referred to as a binary cycle. When a second cycle is added to the high temperature end of another cycle it is called a topping cycle. The gas turbine/steam cycle shown in Section B.4 (Figure B.4-2) is one illustration of a topping cycle; two others (mercury and potassium) are discussed in this section.

On the other hand, when the second cycle is added to the low temperature end it is called a tailing (or bottoming) cycle. Various refrigerants have been considered for use in steam turbine tailing cycles, but the main efforts have been concentrated on ammonia. Steam-ammonia cycles incorporate a loop using ammonia on the lowpressure side of a steam cycle. Two basic configurations are generally considered, one where the ammonia loop contains an ammonia turbine and one where it does not.

The ammonia tailing cycle provides a conceptual method for heat rejection with dry cooling towers while retaining an acceptably high system efficiency. This permits the use of generating sites where cooling water is not available. The particular advantage of 
ammonia as a working fluid arises from its low specific volume at heat rejection temperatures which leads to material savings in heat rejection equipment, especially dry cooling towers.

Several studies have been carried out to identify the components and the characteristics of the steam-ammonia cycle although no actual experimental work directed toward the use of this technique for large-scale power production has been done. Preliminary cost estimates indicate a slight economic advantage for the binary bottoming cycles, but these estimates are based on studies and cost estimates of equipment that has not been designed or built. Although these tailing cycles may have some advantages over the single fluid cycle, they appear to be marginal.'

Further discussion is limited to liquid metal binary topping cycles.

\subsubsection{General Description}

In Section B.2 it was noted that electrical utilities generate most of their electrical energy in fossil-fuel-fired Rankine cycle steam turbine plants. Some of the low melting point metals, such as mercury (melting point $-38^{\circ} \mathrm{F}$ ), when vaporized, can be used like steam as the working fluid to drive a turbine. The principle advantage of "liquid-metals" as the working substance in a power plant is their high boiling or vaporizing temperature at a modest boiler pressure (e.g., mercury boils at $907^{\circ} \mathrm{F}$ at 100 psia in contrast to water boiling at $662^{\circ} \mathrm{F}$ at $2400 \mathrm{psia}$ ). Potassium, which boils at $1400^{\circ} \mathrm{F}$ at one 
atmosphere, can also be considered as a working fluid. The lower boiling pressure allows, in principle, an acceptable boller cost in spite of the higher boiling temperature. While the liquid-metals possess advantages relative to water in the boiler portion of the plant, water has the advantage in the condenser. This results from the liquid-metal vapor densities being so low as to make the condenser (and low pressure end of the turbine) excessively large and costly. This difference can be resolved by combining a liquidmetal Rankine cycle with the water Rankine cycle. In this concept the metal vapor condenser, now operating at acceptable vapor densities, serves as a boiler for the water cycle. Thus, while each individual cycle is not of high thermal efficiency, the binary cycle has a high efficiency because the energy rejection from the high temperature topping cycle is used again in the boiler of the lower temperature water cycle.

\subsubsection{History and Status}

Between 1922 and 1950, the General Electric Company constructed a series of six fossil-fueled mercury and water binary cycle power plants for utility and industrial use. Mercury plants demonstrated long-life capability; the original South Meadow Station of the Hartford Electric Light Company operated from 1928 until 1947 when it was dismantled. During this interval, it accumulated more than 110,000 service hours, about $70 \%$ of the total life of the plant. Kearny, 
placed into service in 1933, achieved more than 86,000 service hours by 1950 and continued in operation past the $110,000-h r$ mark. ${ }^{2-13}$

Mercury topping cycles were not built after 1950. Steam-power-plant operating conditions increased, resulting in efficiencies that exceeded those of the existing mercury plants. Moreover, steam-plant capacities grew substantially larger than those of the mercury plants, resulting in further economies. Finally, the price of mercury fluctuated enough to render construction of new mercury topping cycles with their large mercury inventory uncertain and risky. There does not appear to be much current interest in pursuing the mercury topping cycle for fossilfueled power plant application.

During the 1960's the technologies of several advanced power-conversion concepts were pursued for the space program, with the aim of providing electric power from a nuclear reactor. Among these concepts were mercury and potassium Rankine cycle plants. Mercury-conversion systems and components, including turbines, were operated at $1500^{\circ} \mathrm{F}$ and above. The results of these relatively small power rating space application efforts have demonstrated the technical feasibility of mercury and potassium Rankine power-conversion systems operating at high temperature. Their use for topping plants for more efficient and much higher power rating stationary power plants on earth is suggested as a space technology spinoff for industrial use. 
There is no previous history of use of potassium topping cycles in utility power plants but potassium topping cycles for central-station power have been studied as far back as the early 1960's. More recently, a potassium topping cycle has been proposed by ORNL for use with the molten-salt nuclear reactor. ${ }^{14} \mathrm{~A}$ three-fluid (i.e., ternary cycle) system involving a gas turbine in addition to the potassium and steam cycles has also been suggested. Alternative fossil-fuels considered for this system included coal, oil, and gas. 15,16 Others have also studied a potassium-steam binary cycle of more conventional design using coal as a fuel.

\subsubsection{Present and Projected Application}

Binary power cycles, with a potassium topping cycle on a steam cycle, possesses the potential of a higher energy conversion efficiency than the single fluid steam cycle. It would probably produce lower-cost power in plants of large capacity rather than small, and would operate more efficiently at design capacity than at part load. Consequently, binary cycle plants should find application primarily as base-load plants.

The potassium topping cycle has potential for use above about $1400^{\circ} \mathrm{F}$. At present, except for the HTGR, nuclear heat sources for the potassium cycle are nonexistent. Use of the potassium topping cycle with HTGR has not been investigated. However, the use of potassium-steam binary 
cycles with fossil-fueled heat sources for the large, base-load plants has been studied. The need to develop high-temperature furnace/boilers as part of a program to bring potassium topping cycles to fruition is recognized.

Because of the physical and thermodynamic properties of the mercury working fluid, mercury topping cycles require a heat source that will boil the mercury in the temperature range of about $900-1300^{\circ} \mathrm{F}$. The LMFBR is expected to operate with a sodium outlet temperature of $1100^{\circ} \mathrm{F}$ or higher. A mercury-steam binary plant therefore might have some potential for use with the LMFBR and may offer certain design and operational advantages to the system, particularly with regard to eliminating sodium-water interfaces and slightly improving plant efficiency. These advantages would have to be balanced against potential cost disadvantages (see Section B.5.1.2) and the requirements for additional technological development in such areas as sodium-mercury heat exchangers.

\subsection{Technical Information}

\subsubsection{Availability}

Neither mercury nor potassium Rankine topping cycles are presently being offered commercially. The mercury system was developed at one time and the potassium system is under active investigation. Manufacturing facilities and background capability for the 
equipment in this type of system would be available from a number of well established manufacturers.

There are no inherent limitations to the size of the mercury or potassium topping cycle plants since, as is currently done in steam plants, capacity can be increased by using multiple units in a parallel-flow arrangement.

\subsubsection{Efficiency}

As noted in Section 5.1.3, the mercury binary cycle is a conversion system that might have the potential for eventual use with a system such as the LMFBR since the temperature regimes of both are similar. If the substantial development and economic problems of such a combined system were solved, net plant efficiencies of up to $46 \%$ might be achieved as compared to potential LMFBR single-cycle efficiencies of about $42 \%$.

For a coal-fueled plant with a boiler efficiency of $90 \%$, the thermal efficiency of a potassium-steam binary cycle is estimated to be $50-55 \%$, or more, over the range of turbine inlet temperatures of $1400-1800^{\circ} \mathrm{F}$. 


\subsubsection{State of the Technology}

The most recent development effort on the mercury Rankine system was carried out in the NASA-funded SNAP-8 Power Conversion System program. The objective of this work was to demonstrate for space use a man-rated, reactor-heated, mercury-conversion system of 35-90 kwe capacity of high reliability and long life. Work was performed on form-stage, axialflow turbines, boilers, pumps, valves and condensers with varying degrees of forces. The program was terminated in 1970 because of cut-backs in the space program.

During the 1960's, various agencies of the government were engaged in the development of the technology for potassium (and cesium) Rankine space power systems.

Several turbines were built and operated on potassium vapor. The largest of these were 250 and 340 horsepower. The turbine efficiencies were measured and found to be about $75 \%$, confirming design predictions. The blades and discs were, for the most part, fabricated of nickel-based alloys. Potassium boilers, condensers and pumps in relatively small sizes have been successfully tested.

\subsection{Research and Development Required}

\subsubsection{Mercury Cycle}

The application of a mercury-steam binary cycle to the LMFBR may require the use of tantalum or an equivalent refractory metal for a thin liner 
in the tubes of the boiler; otherwise the use of tantalum will be prohibitively expensive. Bimetallic tubing size and length are presently limited by available fabrication equipment. To obtain the sizes and lengths of bimetallic tubing required for a commercial power plant, the existing fabrication equipment will have to be upgraded or techniques to make reliable bimetallic tube-to-tube joints will have to be developed. In addition, other joining techniques, involving the tantalum liner and the boiler shell or tube headers, will have to be developed and proven.

SNAP-8 boilers incorporated the use of long-length, small diameter mercury flow passages at the inlet. Their use was based in part on the nonwetting behavior of mercury encountered in the early phases of the program. An alternative boiler design, based on mercury acting as a wetting fluid and not involving small-diameter passages, was tested and proven equally satisfactory. Thus, two approaches to boiler design have been successfully demonstrated. Selection of one of these approaches, followed by the construction and test of a portion or module of the full-scale boiler, would be needed.

The development of the mercury condenser/steam generator will also require the testing of a large-scale module. Although water will not react with mercury, it can cause oxidation of tantalum in the boiler. Consequently, instrumentation must be included to rapidly detect leaks of oxygen (air) and water throughout the system. 
The shaft seal of the mercury turbine at the exhaust end must limit the introduction of oxygen (air), lubricating oil, and other contaminants into the mercury loop to prevent corrosion in the boiler. At the inlet end the shaft seal must be designed to prevent leakage of mercury to the surroundings. A design study of the shaft seal followed by construction and testing is indicated. As the prototype turbine will involve a scale up in the range of 3 to 10 times the rating of previous mercury turbines, some design developments may be necessary. The successful completion of the foregoing boiler, condenser/steam generator, and turbine development would set the stage for the design of a demonstration LMFBR mercury-steam binary cycle plant.

\subsubsection{Potassium Cycle}

Scale-up of the key components of the potassium cycle is required before construction of a pilot plant can be considerd. A large-scale model of both the potassium boiler and the potassium condenser/steam generator would have to be performance-tested and operated long enough to ensure confidence in design and materials of construction.

As the scale-up from current R\&D experience for the turbine rating is in the range of 300-1000 fold, turbine blade manufacturing techniques using appropriate alloys must be developed for the very large blade sizes required. Similarly the turbine seal, which must exclude oxygen (air) from the potassium loop, must also be scaled up successfully. 
The ORNL, under a grant from the National Science Foundation, has begun the construction of a module of a potassium boiler. This is a unit of several megawatts capacity designed to operate at the $1550^{\circ} \mathrm{F}$ level.

\subsection{Environmental Impacts}

The impact on the environment of a mercury binary cycle power plant would be to reduce thermal discharges, and the consumption of fuels relative to a conventional steam power plant. The extent of these benefits would depend on the improvement in efficiency brought about by the mercury binary cycle. The design of such a power plant would have to incorporate features to restrict the release of mercury to the environment to safe levels.

Potassium binary cycle power plants should have similar effects upon the environment. The reduction of fossil-fuel consumption due to higher efficiency automatically reduces the quantity of most of the air pollutants produced per unit of electrical energy generated. Likewise, the waste heat discharged by the plant will be considerably curtailed.

The accidental discharge of large quantities of potassium to the environment would be harmful to vegetation and animal life in the immediate area of the plant. Runoff of potassium wastes into ground 
water, streams, lakes, or oceans could be detrimental. At low concentrations, potassium will not be hazardous since it is a normal constituent of foods. The use of suitable scrubbing equipment would have to be developed to prevent the release of sizable quantities of potassium from a power plant.

\subsection{Costs and Benefits}

No meaningful information exists on either the costs of mercury topping cycle that uses an LMFBR heat source or potassium topping cycle for fossil fuel plants. Clearly, because of the increased complexity, the plant capital costs will be higher than a conventional steam plant but these could be offset by higher plant efficiency. Detailed plant and equipment design studies are needed to develop more reliable cost data.

\subsection{Overall Assessment of Role in Energy Supply}

The major advantage of the binary cycles using mercury or potassium with steam is that of increased conversion efficiency. The benefits that stem from an increase in efficiency (such as reductions in fuel consumption, waste-heat release, and production of pollutants) will apply to both fossil-fired and LMFBR plants. There may be operational advantages for use of mercury topping with the LMFBR, as noted in Section B.5.1.3. The disadvantages (higher capital and maintenance costs, and increased complexity of the plant and its operation) will 
also be applicable to both. The extent to which the advantages will outweigh the disadvantages is unknown and can be determined only by systematic programs involving a continuing evaluation of costs, development of scaled up key components, operation of a pilot plant and, finally the design and operation of a demonstration power plant. A technology base exists for binary cycles resulting from previous experience with mercury-topping cycles on fossil-fired steam plants and from the space power efforts on potassium-binary cycles conducted over the past decade, for units of small capacity. 


\subsection{References}

1. W. H. Steigelmann, et a1., "Binary Cycle Power Plants Using Air-Cooled Condensing Systems," Proceedings of the American Power Conference, 1972, Vol. 34.

2. Harold, N. Hackett, "Schiller. Station, First Complete Mercury Unit Powerplant," Power Generation, March 1950.

3. Harold, N. Hackett, "Mercury-Steam Powerplants - Current Operating Results and Development in 1949-1950," Mechanical Engineering, July 1951.

4. "The Mercury Powerplant from South Meadow, 1928, to Schiller, 1949 ," Power Generation, March 1950.

5. W. N. Oberly, "The Mercury Vapor Cycle," Power Generation, March 1950.

6. 0. L. Wood, "South Meadow - First Post-War Mercury Power Unit," Power Generation, March 1950.

7. Harold, N. Hackett, "Mercury-Cycle Power Generation," Presented at the Fourth World Power Conference, July 1950, London, England.

8. Harold, N. Hackett, "Mercury for the Generation of Light, Heat and Power," Presented at the A.S.M.E. Annual Meeting, Dec. 1-5, 1941, New York, N.Y.

9. A. R. Smith and E. A. Thompson, "The Mercury-Vapor Process," Presented at the A.S.M.E. Annual Meeting, Dec. 1-5, 1941, New York, N. Y.

10. A. R. Smith and E. A. Thompson, "New Mercury-Vapor Powerplant," Steel, January 12, 1942.

11. W. L. R. Emmet and L. A. Sheldon, "The Emmet Mercury-Vapor Process," Presented at the Spring Meeting of A.S.M.E., May 26-28, 1924, Cleveland, Ohio.

12. W. L. R. Enmet, "Mercury Vapor for Central Station Power," Presented at the Spring Meeting of A.S.M.E., March 31-April 3, 1941, Atlanta, Georgia.

13. A. R. Smith, "Coordinated Production of Industrial Steam and Utility Power," Presented at World Power Conference, June 26July 3, 1933, Stockholm, Sweden. 
References: (continued)

14. A. P. Fraas, "A Potassium-Steam Binary Vapor Cycle for a MoltenSalt Reactor Power Plant," Journal of Engineering for Power, October 1966.

15. A. P. Fraas, "Preliminary Assessment of a Potassium-Steam-Gas Vapor Cycle for Better Fuel Economy and Reduced Thermal Pollution," Oak Ridge National Laboratory, ORNAL-NSF-EP-6, August 1971.

16. A. P. Fraas, "Fluidized Bed Coal Combustion System Coupled to a Potassium Vapor Cycle," Presented at the A.I.Ch.E. Annual Meeting on New Coal Combustion Techniques, New York, November $29,1972$. 


\section{B.6 FUEL CELLS}

\subsection{Introduction}

\subsubsection{General Description}

The fuel cell is a device that produces useful electrical energy from the controlled electrochemical oxidation of fuel. The reactants, fuel and oxidant, are supplied to the electrochemical cell, or cell stack, from reservoirs that, in many cases, are refillable.

The basic components of a simple hydrogen-oxygen fuel cel] are the electrodes (anode and cathode) and an electrolyte. The electrolyte can be either acidic or basic. The reactants are normally consumed only when the external circuit is completed, allowing electrons to flow and the electrochemical reaction to occur. The result is good fuel efficiency even with low or intermittent loads. When the external circuit is completed, an oxidation reaction, yielding electrons, takes place at the anode and a reduction reaction, requiring electrons, occurs at the cathode. The electrodes provide electrochemical-reaction sites and also act as conductors for electron flow to the external circuit. In the example illustrated (Fig. B.6-1) charge is transferred within the cell by migration of hydroxyl ions from cathode to anode. Continuous operation necessitates the removal of heat, water, and any inert material that enters the cell with the reactants, and reaction kinetics are usually enhanced by the incorporation of a catalyst such as platinum on the high surface area electrode surfaces. Power is produced as long as fuel and oxidant are supplied to the fuel-cell and the external electrical circuit is closed allowing current to flow. 


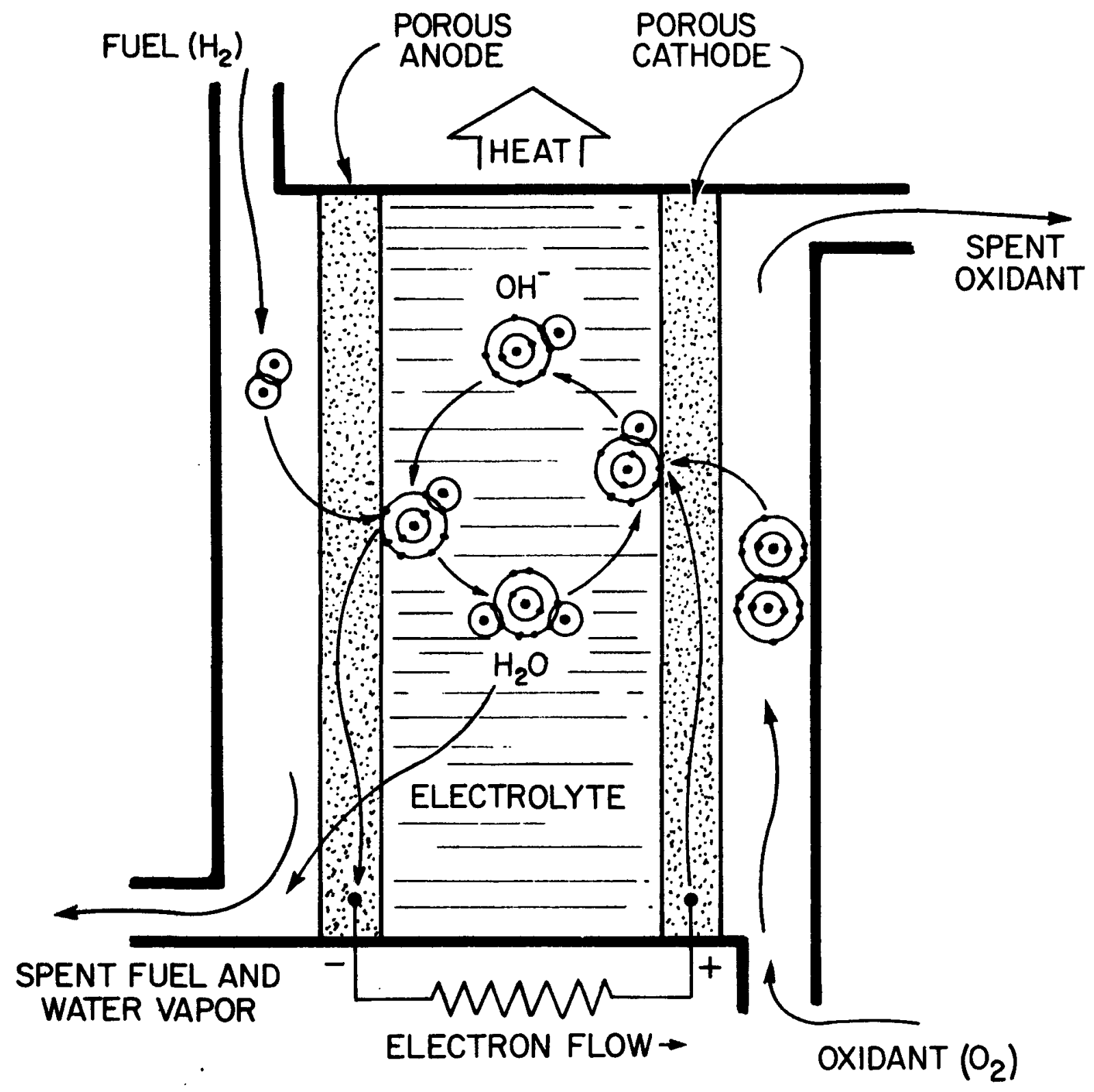

ELECTROCHEMICAL OXIDATION OF HYDROGEN IN A FUEL CELL Figure B.6-1 


\subsubsection{History and Status}

The first demonstration of what is now known as a fuel cell was reported by Sir William Grove in 1839. 1 In Grove's experiment, hydrogen and oxygen were reacted on platinum electrodes in a dilute sulfuric acid electrolyte, producing electricity, water, and heat.

Modern hydrogen-oxygen fuel cell activity dates from the work of F. Bacon in England in the late 1930's. ${ }^{2,3,4}$ In 1959, Allis-Chalmers Manufacturing Company demonstrated a 20-kWe hydrogen-oxygen fuel cell powered tractor and two years later demonstrated a forklift truck powered by a hydrogen-oxygen cell system. In late 1966, General Motors demonstrated a delivery van powered by hydrogen-oxygen fuel cells developed by Union Carbide Corporation. The reactants were stored as liquids at cryogenic temperatures and the system had a peak power output of $160 \mathrm{kWe}$.

Space power requirements resulted in the first large scale application of fuel cells. The technology of Bacon's hydrogen-oxygen cell was used by Pratt \& Whitney Division of United Aircraft (P\&W) to develop the fuel cell system for the Apollo program of the National Aeronautics and Space Administration. Gemini space missions also used hydrogen-oxygen systems for electric power. This fuel cell system, manufactured by General Electric, uses an acidic ion exchange membrane as a fixed electrolyte and operates near ambient temperature. 
In the 1960's development of low-temperature fuel cells for direct oxidation of liquid fuels was extensively pursued. These systems use fuels such as decane, methanol, formic acid and hydrazine.

Direct oxidation of carbonaceous fuels is difficult to achieve as efficiently as the oxidation of hydrogen. However, hydrocarbon fuels can be reacted with steam to produce a hydrogen rich gas for consumption in fuel cells. Such systems have been investigated in the last decade by various industrial groups in the U.S. and Europe.

For the indirect oxidation of carbonaceous fuels, steam reformer systems used with either high or low-temperature fuel cells have shown good performance and several systems are in advanced stages of development. The major effort in this area started in 1967 with the first phase of what has become a 6-year, $\$ 50$ million program. This effort, presently sponsored by 31 gas utilities that make up the TARGET group, has the goal of developing fuel cell systems using reformed natural gas (methane) as fuel. The developmental work is being done by P\&W, who in May 1971 demonstrated a 12.5-kWe system supplying all of the electrical energy to a home in Connecticut. This is the first of 60 test installations of various capacities planned. More than 4000 hours of automatic operation have been demonstrated with this system.

\subsubsection{Present and Projected Application}

Attention is now being given to fuel cell systems to generate large blocks of electrical power. Two routes are being followed: one for central power station application, and the other for dispersed

$$
\text { B. 6-4 }
$$


generation of electrical power at substations. Work on the central station application is still in the laboratory and system study phase; practical field hardware has not yet been built. However, Westinghouse Electric Corporation has been engaged in development work for the Office of Coal Research and has developed a preliminary design for a 100-kWe system based on gasification of coal and a high-temperature $\left(1870^{\circ} \mathrm{F}\right)$ zirconia electrolyte fuel cell. ${ }^{5}$ P\&W announced in December 1973, a $\$ 42$ million cooperative program with nine electric utility companies to develop a 26,000 kilowatt fuel cell.

As mentioned previously P\&W has a major program for dispersed generation using natural gas reformers and low-temperature $\left(<250^{\circ} \mathrm{F}\right)$ fuel cells of the phosphoric acid and potassium hydroxide electrolyte types. 6 The Institute of Gas Technology has been doing complementary work using low temperature phosphoric acid and higher-temperature $\left(2200^{\circ} \mathrm{F}\right)$ molten carbonate electrolyte cells. All the above fuel cells will also operate on the fuel formed from coal gasification. This work has been sponsored by segments of the gas industry, American Gas Association, Team to Advance Research for Gas Energy Transformation (TARGET) and most recently by the Edison Electric Institute (EEI).

Energy system concepts using the thermal and electric output of nuclear reactors to produce hydrogen from the dissociation of water are currently under investigation. Fuel cells for dispersed generation of electric power are an integral part of these systems. 7 
The various energy system concepts discussed above are shown in Fig. B.6-2. Parts $A$ and $E$ illustrate the more conventional central station applications based on fossil-fueled steam boilers and nuclear steam supply systems. Part B shows a fuel cell system replacement for a conventional central station steam plant while Part C shows relocation of the fuel cell system to distribution substations. This provides for higher systems reliability, and greater responsiveness to load changes through on-site gaseous fuel storage. Part $D$ illustrates the nuclear-powered equivalent of $C$. Note that no compressor is required as the electrolyzer is capable of producing high-pressure gas. Systems $C$ and D can provide gas directly to those consumers requiring reducing atmospheres or gaseous fuels for heating. The concepts shown in $B$ and $D$ can supply dc energy directly to major industrial users and the distributed generation concept of $C$ can be extended to include a local dc distribution system.

\subsection{Technical Information}

\subsubsection{Availability}

Although fuel cell systems have been manufactured on a 1 imited production basis for space application, only five organizations are presently capable of producing such systems in quantity; P\&W, GE, Westinghouse, UCC and Alsthom. None are actively marketing commercial systems of significant size. P\&H is conducting extensive field tests of its 12.5-kWe reformed natural gas system. 
لَ

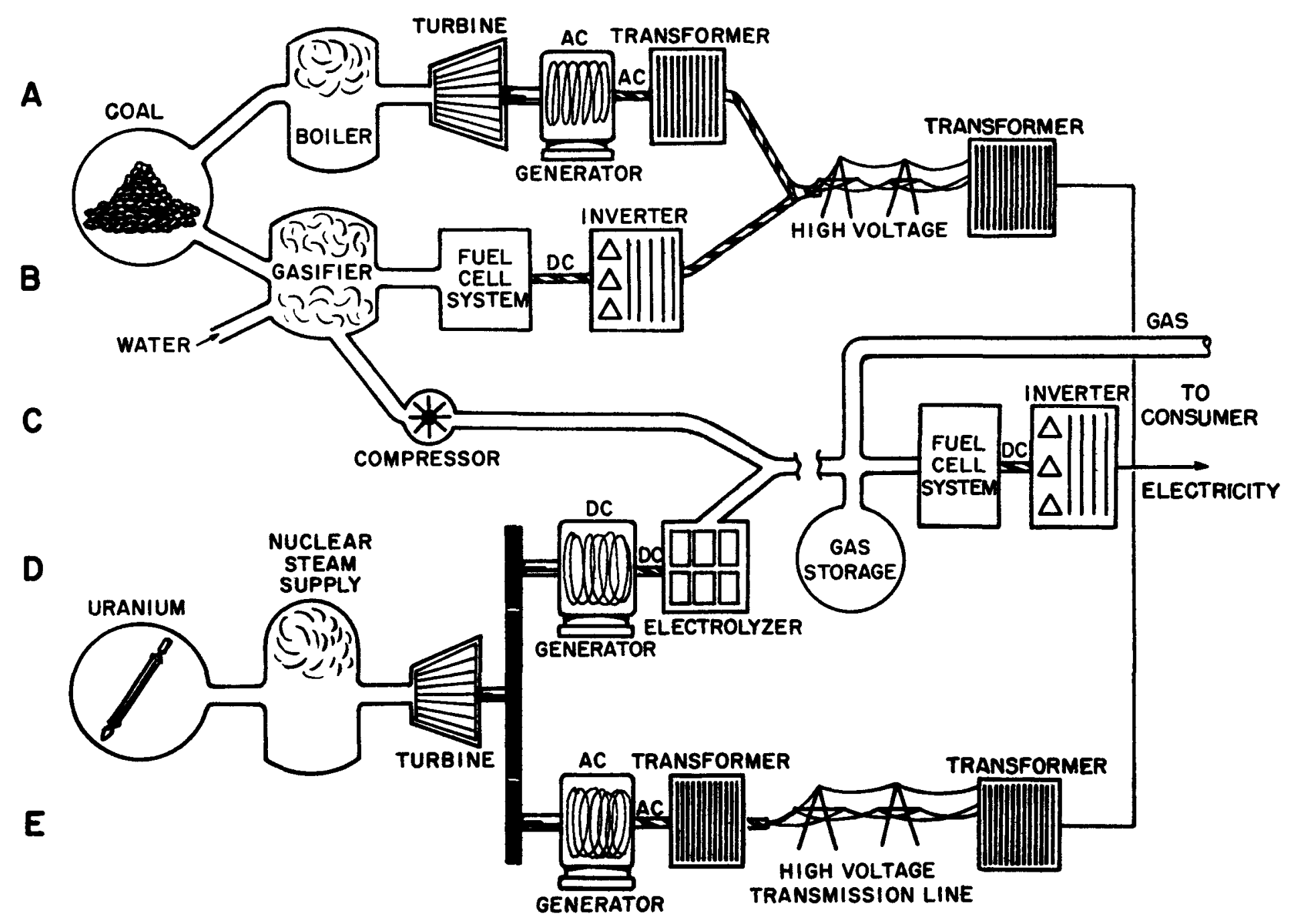

COAL AND URANIUM ENERGY SYSTEMS

Figure B.6-2 
Several fuel cell power generation systems in the 10-20 kWe range have been constructed and operated. The modular construction of fuel cells and power conditioning equipment allows a nearly direct proportional scaling into the multi-MWe range. No control stability or complexity problems are introduced in paralleling fuel cell banks to construct large systems. In fact, overall system reliability is improved through load sharing in multi-stack systems and as a result of the capability to replace modular units on a programmed basis.

\subsubsection{Energy Sources}

The fuel cells currently being developed for central station use oxidize either carbon monoxide or hydrogen. Finely powdered coal and various hydrocarbons are reformed to provide the hydrogen-rich fuel used in these fuel cells.

Three synthetic fuels have been proposed for use in nuclear-fuel cell energy systems: hydrogen, produced by electrolysis of water; methane and methanol. Both methane and methanol are produced by reacting hydrogen with carbon dioxide obtained by fractional distillation of air.

The other fuels that have been used in experimental cells, such as hydrazine, formic acid, sodium, lithium, and ammonia are too costly for use in central station energy generation.

\subsubsection{Efficiency}

The theoretical maximum efficiency of a fuel cell is a function of the fuel and oxidant used. Where systems are integrated, as with a 
reformer, the theoretical efficiency is based on the primary feed material rather than on the fuel that is electrochemically oxidized. Projected reference efficiency limits based on laboratory investigations and systems studies are as follows:

\begin{tabular}{lccc} 
Fuel & $\begin{array}{c}\text { Cell } \\
\text { Voltage }\end{array}$ & $\begin{array}{c}\text { Theoretical } \\
\text { Cell Efficiency }\end{array}$ & $\begin{array}{c}\text { Projected System } \\
\text { Efficiency, 1980 }\end{array}$ \\
\hline Hydrogen & 1.23 & 0.83 & 0.65 \\
Methane & 1.06 & 0.92 & $0.30-0.55$ \\
Coal & 1.02 & 1.00 & 0.70 \\
\hline
\end{tabular}

The areas of uncertainly result from lack of detailed engineering studies and extensive testing of large systems.

Gross efficiency is the product of the theoretical maximum efficiency and the ratio of the operating voltage to the theoretical voltage. For hydrogen-fueled cells this efficiency is $0.54-0.61$. The small amount of unreacted fuel purged from the cells to el iminate inert material is neglected.

Because of extensive heat- and mass-transfer interactions, subsystem efficiencies cannot be multiplied to determine the overall efficiency of integrated fuel cell power system. The present published efficiency of conversion of chemical energy from natural gas fuel to ac electrical energy in the $12.5-\mathrm{kWe}$ P\&W-TARGET system is $40-45 \%$. The large central station version of this system is projected to have an overall

B, 6-9 
efficiency of near 55\%. The Westinghouse high-temperature system is designed to operate at a projected efficiency of $58 \%$ for the $100-k W e$ size and near $70 \%$ for 1000 -MWe based upon dc output.

\subsubsection{Size Limitation}

Several fuel cell power generation systems in the 10-20 kWe range have been constructed and operated. The modular construction of fuel cells and power conditioning equipment allows a nearly direct proportional scaling into the multi-MWe range. Plumbing, wiring, and fault-isolation equipment requirements are also nearly proportional to the system power capability. Fuel conditioning and control equipment have a scaling factor of 0.9. Systems can be demonstrated in small sizes, and full scale systems can then be produced by conventional engineering techniques. Systems using fuel reforming or high-temperature cells are significantly more efficient in large sizes $(>100 \mathrm{kWe})$ due to the reduction in external surface area per unit volume.

No control stability or complexity problems are introduced in paralleling fuel cell banks to construct large systems. In fact, overall system reliability is improved through load sharing in multi-stack systems and as a result of the capability to replace modular units on a programmed basis.

\subsubsection{State of the Art}

Although there have been many successful programs resulting in numerous fuel cell systems for specialized applications, there remain dominant 
uncertainties with respect to commercial power applications. These uncertainities stem from a lack of:

1) Detailed engineering design of low-cost systems;

2) Detalled design of fuel cells for high volume production and long life;

3) Demonstration of the costs, lifetimes, efficiencies, and operational parameters of the projected systems.

\subsubsection{High-Temperature Fuel Cell System}

The fuel cell system being developed by the Westinghouse Electric Company for central station power production uses high temperature materials in the construction of the fuel cell. A porous nickel anode, a stabilized zirconia electrolyte, and a porous, tin-doped, indium-oxide cathode are deposited on a $0.5-i n$. dia porous, stabilized, zirconia tube with appropriate cell interconnections.

The total system consists of fuel cell battery tubes assembled into banks, a coal gasifier, and ancillary equipment. Cell banks which operate at $1850^{\circ} \mathrm{F}$ are physically located in the fluidized-bed coal gasifier, for maximum heat recovery.

\subsubsection{Low-Temperature Fuel Cell Power Systems}

The fuel cell used in a system proposed for dispersed generation of electrical power is of the plate and frame type. Simple components 
produced in high volume are assembled into series stacks and either bolted or bonded together. Flow passages, a porous catalyzed nickel anode, an electrolyte-saturated matrix, and a porous catalyzed cathode comprise the unit cell. Phosphoric acid is used as the electrolyte by P\&W with platinum-rhodium alloy as the anodic catalyst and platinum as the cathodic catalyst.

In the P\&W-TARGET system, the cells operate at about $230^{\circ} \mathrm{F}$. This system burns the effluent from the fuel cells to provide heat to reform hydrocarbons, such as natural gas, yielding a hydrogen-carbon dioxide mixture. (Heat produced in the cells is also used to preheat the water used in the reforming reaction). Pure hydrogen can be used directly in the cells as can the fuel gas from coal gasification if given proper pretreatment.

\subsection{Research and Development}

In spite of having no moving parts, fuel cells do wear out. Redistribution of catalyst, with a resulting reduction of effective reaction surface area, is the single most dominant degradation mechanism. There is also a finite solubility of catalyst in electrolyte, which further reduces the active surface area. A secondary life-limiting phenomena is corrosion of seal and currentcollection components. 
Erosion and blockage of ducts and manifolds are also seen in extended life tests. If fuel cells are to be economically applied to central station energy generation, the useful cell lifetimes must be extended beyond the $3000-20,000 \mathrm{hr}$. presently available.

The fuel cell unit design must be amenable to high-volume production techniques because thousands of cells per system will be required for electric generating systems in the multi-Me range.

Fuel cell systems will not be applied, to any significant extent, to central station power generation until economic advantages have been realistically demonstrated. This will require development of engineering experience and cost reductions in the specific areas listed below:

\section{Fuel Source Requirements}

Reliable information on fuel cell lifetime under conditions representative of large power-generating systems (100-kWe or larger).

Fuel cell materials and construction that result in minimizing cost. Large-capacity Silicon Controlled Rectifiers (SCRs) and less expensive dc-ac inverters. Complete integration of power generating systems to reduce capital and operating costs, simplify controls, and minimize heat losses. 
Reliable information on materials corrosion resistance. Process control for reduction of ash carbon content.

Natural Gas The development of less expensive catalysts and the reduction in the amount of catalyst required. Extension of fuel cell lifetime.

Hydrogen

A source of low-cost hydrogen.

\subsection{Environmental Impacts}

Central station systems using fuel cells will produce chemical pollutants similar to those obtained by conventional combustion of the same fuels. The fuel cell, however, is particularly sensitive to the same pollutants, primarily sulfur, now causing concern in conventional steam turbine-generator plants. This sensitivity will require extensive fuel pretreatment to el iminate contaminants prior to electrochemical oxidation. For an equivalent electrical power output, the higher operating efficiency of fuel cell systems will result in a reduction of the total quantity of fuel required and a reduction in the quantity of material discharged in the emission of nitrogen oxides because of the reduced temperatures to which the air streams are exposed. Waste-heat rejection is not a significant problem with fuel cell power systems since most of the waste fuel cell heat is used in the fuel gasification or reforming process. Excess heat is rejected to the atmosphere, and cooling water is not required. 
Large numbers of low-temperature fuel cells could have some impact on the catalyst material market and on the natural reserves. However, the catalyst is not consumed except for processing losses, and the total quantity available will be relatively unchanged. The total effect of this utilization of catalyst materials is unknown. (This is a problem common with certain pollution control equipment being considered for internal combustion engine powered automobiles.)

Increased utilization of dispersed generation of electrical power, made possible by the high-efficiency of relatively small fuel cell systems, should have a positive effect on the environment, particularly in urban areas. Gas transmission by buried pipeline requires less land for an equivalent amount of energy transmitted; however, the total environmental impact of buried pipelines has not been thoroughly evaluated. The remote locations envisaged for fuel-synthesis plants and the chemical removal of sulfur at these plants should result in a positive environmental effect.

\subsection{Costs and Benefits}

Since no large fuel cell power systems have been built an estimate of the costs is somewhat speculative. Costs, however, have been projected for the coal-fired high temperature system by taking into account R\&D progress to date and comparing unit costs of various elements of the cost breakdown with similar items in a coal fired steam turbine power plant. Assuming that the cost of electricity 
produced from a coal-fueled fuel cell system is equal to that from a steam turbine system, the allowable capital costs for the fuel cell system can be projected.

The result of these assumptions and calculations is to suggest that a coal-fueled fuel cell system can produce competitively priced electricity if it. can be built for a total capital cost of 294-375 $\$ / k W$. The three critical items are the fuel cell, power inverters, and spare parts. Each of these has projected cost ranges that will allow reaching the cost target.

The key item is the cost of the fuel cells themselves. The cost range allocated, 60-80 \$/kWe, corresponds to a manufactured cost of 7.00$9.30 \$ / 1 \mathrm{~b}$ based on the materials requirements. Total materials costs for these thin-film solid-electrolyte fuel cell assemblies have been estimated to be about $21 \$ / \mathrm{kWe}(2.45 \$ / 1 \mathrm{~b})$, leaving an allowable margin for manufacturing and assembly of 39-59 $\$ /$ kWe $(4.55-6.85 \$ / 1 \mathrm{~b})$. These allowable manufacturing costs show reasonably good agreement with independent direct estimates.

The major projected advantage of fossil-fueled fuel cell systems for central station power generation is that they operate at a higher conversion efficiency than is possible with any system presently in use. This higher efficiency results in a lower rate of fossil-fuel reserve depletion, reduced air pollution, and no thermal pollution of natural bodies of water. Projected economics 
of central station fuel cell power systems show equivalent capital costs and lower operating costs. For dispersed generation of electrical power using fuel cells, the capability for gaseous fuel storage at the point of usage allows a degree of freedom not found in present electric distribution systems. Coupling a hydrogen fuel cell system to a nuclear-powered hydrogen production facility offers several additional potential advantages:

- Improved load factor for the nuclear plant because it is producing a storable fuel.

- Enhanced hydrogen supply for use in the chemical and metallurgical process industries as well as for heat in homes and industrial plants, compared to that presently avallable from hydrocarbon sources.

- Pollution free generation of electricity at points of use.

\subsection{Overall Assessment of Role in Energy Supply}

The state of technology of fuel cells and reformer systems has expanded in the 1960s. It is probably sufficient for the needs of initial prototype fuel cell demonstration plants. However, when the constraints of economics and operating lifetime are imposed, the feasibility of fuel cell systems is undetermined for central station or dispersed power generation.

Fuel cells using the more elementary gaseous fuels - hydrogen, carbon monoxide and methane - will probably dominate for the 
predictable future. Continuing poor performance in the direct electrochemical oxidation of longer-chain hydrocarbons has resulted in less emphasis being placed in this area. Because of the avaflability of large coal and uranium reserves, principal emphasis will be on fuels that can be readily produced by gasification of coal or from nuclear-reaction processes.

This energy conversion system seems to be compatible with planning that centers around the near term use of coal and long term use of nuclear energy. It is also a key factor in a hydrogen energy economy as proposed by many and has a positive environmental impact. 


\subsection{References}

1. W. R. Grove, "On Voltaic Series and the Combination of Gases by Platinum," Phil Mag. 14, p. 127, 1839.

2. W. Mitche11, Jr., ed., "Fuel Cells," Academic Press, 1963.

3. G. J. Young, ed., "Fuel Cells," Reinhold Publishing Corp., 1960.

4. H. Liebhafsky and E. Cairns, "Fuel Cells and Fuel Batteries; a Guide to Their Research and Development," Wiley, 1968.

5. J. T. Brown, et al., "1970 Final Report Project Fuel Cell-Research Development," Report No. 57, For Office of Coal Research, Dept. of the Interior, August 1970.

6. D. J. Bender, "The Fuel Cel1: Commercial in the 70's?" Power, McGraw-Hi11, April 1971, pp 60-61.

7. D. P. Gregory, D. Y. C. Ng, G. M. Long, "Hydrogen Economy," in The Electrochemistry of Cleaner Environments, Plenum Press, New York, 1972. 


\section{B.7 BATTERIES}

\subsection{Introduction}

\subsubsection{General Description}

The battery is a device that produces useful electrical energy from the controlled electrochemical oxidation of fuel. The reactants, fuel and oxidant, are supplied in fixed amounts associated with individual cells (in contrast to fuel cells which can have the fuel replenished from an outside supply). The individual cells may be connected electrically, either in series or parallel to achieve desired voltage and current levels. This combination of cells is called a battery.

Cells of batteries are described as being either primary or secondary cells. Primary cells are those that are charged with chemical reactants and used once - either until the reactants are depleted or until the voltage of the cell decreases to an unacceptable level and then is discarded or recycled to the manufacturer. The standard flashlight "battery" is a type of primary cell.

Secondary cells are composed of reactants and designed in a manner such that electrical recharge (by reversal of current with some other power source) is possible when voltage has declined to an unacceptable level. The standard automobile battery is a familiar example of a series of 3 (6 Volt) or 6 (12 Volt) secondary cells. Secondary batteries (sometimes called storage batteries since they can convert electrical energy to chemical energy which can be stored and then reconverted 
to electrical energy on demand) are the most promising for utility energy storage.

The basic components of a simple secondary cell are the electrodes (anode and cathode), an electrolyte, a separator and a case. Schematically the secondary battery is similar to the fuel cell (figure B.6-1) with the electrode compartments replaced with fixed quantities of chemical reactants. A porous separator is used to hold the electrolyte in place and provide for physical separation of the anode and cathode. Power production is essentially similar to that of the fuel cell except that there is no continuous resupply of fuel and removal of reactant products.

\subsubsection{History and Status}

The first experiments of electrochemistry are attributed to Davey and Volta at the beginning of the 19th Century. Plante's studies of electrolytic polarization, beginning around 1859 , led to the real start of the development of secondary cells. After 1880 the development of secondary cells advanced at a rapid pace. The principal systems developed until the mid 20th Century were limited to the lead/lead oxide/sulfuric acid, nickel/iron/potassium hydroxide, and nickel/cadminum/potassium hydroxide cells.

Increased interest in batteries as off-peak energy storage devices for use in the electric utility system has developed since the 
mid-1960's when sodium/sulfur and lithium/chalcogen cells were first publicly announced. A number of organizations are doing research and development on these high temperature batteries for bulk energy storage. Since much of this is company-sponsored, the total level of effort is sometimes difficult to determine. Organizations doing research on batteries primarily for transportation are judged to be competent for development activities looking toward bulk storage systems as wel1. The principal work underway on 1ithium/sulfur and sodium/sulfur batteries is stated below, but it is recognized that the organizations may also be competent to work on other battery technologies.

Organization Type of Cell Goals

Argonne National Laboratory Li/S Bulk energy storage, propulsion

\begin{tabular}{|c|c|c|}
\hline Atomics International & $\mathrm{Li} / \mathrm{S}$ & Bulk energy storage \\
\hline General Motors & $19 / 5$ & Transportation \\
\hline Ford Motor Co. & $\mathrm{Na} / \mathrm{S}$ & Transportation \\
\hline TRW Systems, Inc. & $\mathrm{Na} / \mathrm{S}$ & $\begin{array}{l}\text { Bulk energy storage, } \\
\text { transportation }\end{array}$ \\
\hline General Electric & $\mathrm{Na} / \mathrm{S}$ & $\begin{array}{l}\text { Bulk energy storage, } \\
\text { transportation }\end{array}$ \\
\hline Dow Chemical Co. & $\begin{array}{l}\mathrm{Na} / \mathrm{S} \\
\text { electrolyte) }\end{array}$ & \\
\hline
\end{tabular}




\subsubsection{Present and Projected Applications}

There are no present applications of high temperature batteries - all are in the developmental stage. Storage batteries, primarily the lead/lead oxide/sulfuric acid and nickel/cadmium/potassium hydroxide types, are used in emergency, standby, and minor peaking applications in a variety of industries.

The Electric Research Council 1971 Report of R\&D Goals considered the development of bulk storage batteries to be important to the future of the electric utility industry because they could offer utilities improved generation, substation, and transmission utilization plus fast response to increased load growth, minimal siting restrictions, and reduction in licensing delays.

Three major conclusions from this preliminary study on energy storage are:

- Energy storage units should be developed for two functions: first, as a device to shave peak load, and second, as a power source during outages. In order to fulfill both purposes, a high ratio of emergency output to normal output is desired.

- Energy storage close to the load is especially attractive because it reduces the transmission capacity required to accormodate peak loads. 
- The likelihood of attaining success with both the lithium/ sulfur and the sodium/sulfur technologies is judged to be very high. Preliminary research extending over several years on each system supports this view.

The successful development of electrically rechargeable batteries capable of storing $200 \mathrm{~W}-\mathrm{hr} / \mathrm{kg}$ of battery weight, and capable of delivering up to $200 \mathrm{~W} / \mathrm{kg}$ of battery weight could have a great impact on the economy of the U.S. and the world, provided that the batteries would have a sufficient lifetime (at least 3 years and 1000 cycles) and a low cost ( $\$ 10-30 / \mathrm{kW}-\mathrm{hr}$ of energy storage capability). Batteries with these capabilities could find many applications, including power sources for high-performance electric vehicles and off-peak energy storage devices for use in the electric utility sytem. A number of approaches to such a battery have been investigated; however, only those cells operating at elevated temperatures $\left(330-600^{\circ} \mathrm{C}\right)$ have shown indications of being able to meet all of the criteria mentioned above.

\subsection{Technical Information}

\subsubsection{Availability}

No high temperature battery systems have yet been developed to the point of commercial availability.

A review of world-wide activities has indicated the existence of at least twenty high-temperature battery efforts in the world, involving 
about 150 investigators, approximately seventy of whom are in the United States. ${ }^{2}$ Only a few systems are being investigated, the main ones being sodium/beta alumina/sulfur, and lithium/molten salt/sulfur. The two main areas of potential application are electric vehicle propulsion and off-peak energy storage.

In nearly all cases, the program is in the laboratory stage, studying cells of 10- to $70-\mathrm{cm}^{2}$ active area, with lifetimes of 100 to 1000 cycles. It is likely that a few 10-20 kilowatt demonstration batteries will exist by 1977 .

\subsubsection{Energy Source}

The energy source for the storage application is electrical which can be derived from any means available.

\subsubsection{Efficiency}

The efficiency of a secondary cell, rather than being a thermodynamic efficiency, would be a turn-around efficiency. The important feature in storage is how much energy can be retrieved as compared to the amount initially invested. For the cells under consideration this turn around efficiency is about $75 \%$ excluding $A C-D C$ conversion equipment, or an overall efficiency of $60 \%$. To get the total efficiency, neglecting transmission and distribution losses, this $60 \%$ would have to be multiplied by the generating plant efficiency. Thus, for a modern steam plant with $40 \%$ efficiency, the total efficiency for battery energy storage would be $24 \%$. 


\subsubsection{Size Limitations}

From a practical point of view there is no size limitation other than that determined by the particular application. The unit cell size will probably be small $21.0 \mathrm{~A}-\mathrm{hr} / \mathrm{cm}^{3}$. The battery or battery bank will be optimized for a particular application. Energy storage factlities in the range of 10 to $100 \mathrm{MW}-\mathrm{hrs}$ are considered to be most likely.

No problems are anticipated in paralleling batteries to construct large systems. In fact, overall systems reliability is improved through load sharing and the ability to replace units of the modular systems on a programmed basis.

\subsubsection{State of the Art}

In general, high-temperature secondary cells and batteries are still in the laboratory stages of development. Argonne National Laboratory has reported on the operation of single sealed cells having capacities in the range of $60-90$ watt-hrs per kilogram of active materials and lifetimes of up to 1400 hours. Activities are under way for building batteries of up to about $35 \mathrm{Kw}$-hrs for tests starting in 1975. None of these cells or batteries have yet been optimized for long life and low cost. All of these are significant challenges. It will probably require at least two years for the development of a reliable (hundreds of cycles), 1ight-weight (100-150 W-hr/kg, 100 $\mathrm{W} / \mathrm{kg}$ ) prototype battery, if appropriate effort is devoted to the task. 
The lithium/sulfur battery is being pursued by Argonne National Laboratory (with AEC funding) and by Atomics International (with partial support from the Electric Power Research Institute for off-peak energy storage applications. The status presented is that for the program at ANL. Candidate materials and components for a prototype cell have been screened, and a reference design has been established. The positive electrode for this cell is iron sulfide; the negative electrode is a solid lithium-aluminum alloy; the electrolyte is a lithium chloride-potassium chloride molten salt mixture; the interelectrode separators are made of a boron nitride cloth. The $13-\mathrm{cm}$ diameter cell will weigh about $2 \mathrm{lb}$ and is designed to store 150 watt-hours (75 watt-hours/lb). Engineering size cells are being developed for tests.

The sodium/sulfur cell is being developed by several companies, including Ford Motor Company, General Electric and TRW. The status report is based on effort at Ford, since that organization has made the largest effort to date in the United States. Laboratory cells have been built, using a ceramic tubular electrolyte (beta alumina), and a demonstration battery has been built and tested. The battery consisted of 24 tube cells connected to give 4 parallel sets of 6 cells in series. The battery was designed for 250 watts and was tested to 300 watts. Its performance indicated a peak power of 490 watts for short 
durations. A reversible capacity of 15 ampere-hours at approximately 11 volts was measured, compared to the battery's theoretical capacity of 20 ampere-hours. Excluding insulation and packaging weight, the battery weighed 4-1/4 pounds. The energy storage capacity of about 38 watt-hours/1b was 2 or 3 times as high as that of a lead-acid battery. However, many tasks, some of them quite basic, remain to be done before a practical low-cost battery with sufficient lifetime and reliability can be built.

\subsection{Research and Development}

The most promising electrochemical systems are the sodium/sulfur cell (with solid electrolyte), and the lithium/sulfur cell (with fused salt electrolyte). It is likely that at least one of these developments will be technically successful and economically attractive.

Sodium/sulfur. The key research and development problems relate to the ceramic electrolyte (powder synthesis and characterization; extrusion of tubing; isostatic pressing; sintering, grain growth, and control of microstructure; mechanical characteristics; electrical characteristics and the sulfur electrode melt composition; dynamic properties and coupled reactions; thermodynamic studies; porous electrode design; metal corrosion, and cell performance (role of impurities). Engineering studies are needed related to the integration of batteries into power systems. 
A 12-volt sodium/sulfur battery consisting of 24 tube cells connected to give 4 parallel sets of 6 cells in series has been operated at a power level of 300 watts. This has demonstrated feasibility of the concept.

Lithium/sulfur. The key research and development problems are related to developing a low cost interelectrode separator which is resistant to the cell environment, and developing an electrical feedthrough which is resistant to the cell environment. Argonne National Laboratory has recently fabricated full-size sealed cells. These cells are being tested and a prototype cell of improved design will be built and tested. Subsequently, a $10 \mathrm{KW}$-hr battery and then a $35 \mathrm{Kw}$-hr battery module will be built. The module would then be incorporated into a large-scale battery. Program goals are directed toward increasing cell life and development of cell components which are more economical.

\subsection{Environmental Impacts}

Battery energy storage is most attractive and flexible in terms of siting considerations. There are no emissions, and resource conservation is favored by the use (as capital, not expendable) of abundant elements such as lithium, sodium, and sulfur. 
High temperature battery systems will have some heat loss to the surrounding atmosphere, but this will be minimized, inherently, by designs that are configured to optimize performance.

The use of storage batteries is applicable to all electrical power systems - fossil, nuclear, solar, etc. The impact on transmission systems is great because with the use of distributed storage they can be designed for $100 \%$ utilization. They would always operate at full capacity since the load swings would be accommodated at the user end of the transmission line.

\subsection{Costs and Benefits}

Materials costs for batteries, based on current concepts of materials to be incorporated, are easily prepared. Because of the relatively early state of current development, the estimates may be unreliable, but Argonne National Laboratory has estimated a total cost of $\$ 15 / \mathrm{Kw}-\mathrm{hr}$ for a lithium-sulfur battery of capacity $1300 \mathrm{Kw}-\mathrm{hr}$. This is about equal to the total battery cost that could be afforded for a system that is competitive with other methods of supplying peak power.

The use of secondary batteries to store electrical energy generated during daily off-peak periods of delivery during peak periods will allow greater employment of low-cost nuclear systems because of decreased variation in load on the utility generating and transmission facilities. 


\subsection{Overall Assessment of Role of Energy Supply}

In order for batteries to be economically competitive with alternative methods of providing power during peak demand periods, a capital cost in the range of $\$ 12-\$ 15 / \mathrm{kW}-\mathrm{hr}$ of energy storage capability will be required. Most existing battery systems appear to be incapable of meeting this economic goal. The most likely candidates are the elevated-temperature cells now under development. Present cost projections as seen in Section 7.5 are at the upper end of the desired range.

Battery systems used to store electrical energy probably have a place in the utflity network in the same manner as pumped storage is used. Their operational advantages, including reduction in requirements for peaking capacity, urban siting near load centers, more efficient use of transmission lines, and absence of atmospheric pollution would make them attractive, and the costs that could be borne would depend upon the specific applications. 


\subsection{References}

1. Electric Utilities Industry Research and Development Goals Through the Year 2000, ERC Publication No. 1-71, Electric Research Council, New York, June 1971.

2. M. L. Kyle, et al., "Lithium/Sulfur Batteries for Off-Peak Energy Storage: A Prel iminary Comparison of Energy Storage and Peak Power Generation Systems," ANL-7958, Argonne National Laboratory, March 1973. 


\section{B.8 THERMOELECTRIC CONVERTERS}

\subsection{Introduction}

\subsubsection{General Description}

A thermocouple is a device consisting of two dissimilar conductors joined together to form two junctions and a closed electrical circuit. As long as the temperatures of the two junctions are not equal, a current will flow in the circuit. This effect was discovered in 1822 by T. J. Seebeck. ${ }^{1}$ The Seebeck effect suggests the potential for direct conversion of heat to electricity without the use of moving parts. (See Fig. B.8-1).

Since a device that utilizes the Seebeck effect is a heat engine, it is subject to the usual laws of thermodynamics and its maximum efficiency is the Carnot efficiency. However, losses always limit a practical device to efficiencies that are some fraction of the Carnot efficiency. For a thermoelectric generator with common metal junctions, and even with a temperature difference of several hundreds of degrees (between hot and cold junctions), this fraction of Carnot efficiency is about $0.1 \%$. For the best metal junction, one formed of antimony and bismuth operating below their melting points, the efficiency is about 1\%. To be considered as a replacement for a Rankine cycle (conventional steam cycle) plant, the efficiency must be nearer to $50 \%$ of Carnot. ${ }^{2}$ It is obvious that materials other than the common metals must be used if thermoelectric power generation is to be economically 


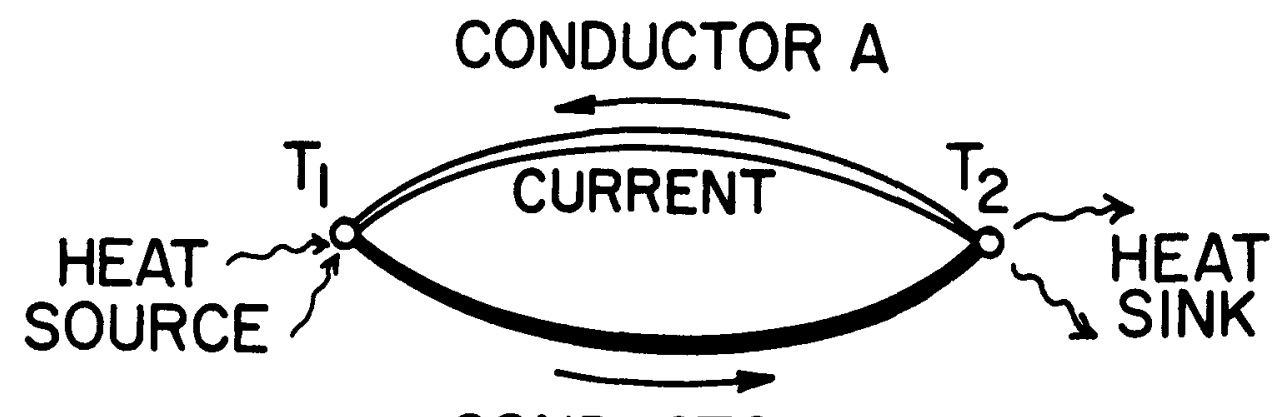

CONDUCTOR B

SIMPLE THERMOCOUPLE

Figure B.8-1 
feasible for large scale applications. A number of materials, elemental and compound, are of interest. In certain cases these materials are semiconductors. Many compounds have been studied, but only tellurides of $\mathrm{Pb}, \mathrm{Bi}, \mathrm{Ag}, \mathrm{Ge}, \mathrm{Sb}$ and $\mathrm{Sn}$ [e.g., $\mathrm{PbTe}$, $\mathrm{Bi}_{2} \mathrm{Te}_{3}, \mathrm{GeTe} \cdot \mathrm{AgSbTe}$ (TAGS), PbSnTe, BiSbTe] and SiGe have been used extensively in practical devices. These materials have potential efficiencies in the range of $11 \%-27 \%$. The efficiency of practical devices will be lower.

\subsubsection{History and Status}

A study by Rayleigh in 1885, and one by Altenkirch in 1909 made important contributions to the field of thermoelectricity. In 1929, A. F. Ioffe outlined the advantages of the thermoelectric generator (TEG) using semiconductors and calculated that their efficiency could reach 2.5-4\%. In 1940 Maslakovets described a thermoelement made of PbS that had an efficiency of about 3\%. Other important work was done in 1953 by Justi and by Goldsmid and Douglas. 3

There were a few practical applications of thermoelectricity made during the period of 1930 to 1957 . Based on Ioffe's suggestions, the Russians produced reliable sources of power for small radio transmitters during World War II. During the same period, engineers in the heating-gas industry were also experimenting with semi-conductor thermoelectric materials in an effort to find a better device to operate automatic safety controls on gas-fired heaters. 4 
Prompted by the U.S. Navy's initial interest (and later, 1958, AEC(ANPO) in thermoelectric devices and the subsequent improvements in semi-conductor technology and semiconductor devices, it is conservatively estimated that about 30 million dollars of government and industrial funds were spent on themoelectric research and development between 1957 and 1963.

Before 1958, only three U.S. corporations were involved in any degree in thermoelectric development, but between 1958 and 1963 as many as 64 companies were participating. Unfortunately, the expected breakthroughs in new materials did not develop, and by 1971 only five U.S. companies remained in the thermoelectric business.

At present, the search for materials continues. In 1957, the best thermoelectric materials were bismuth-telluride $\left(\mathrm{Bi}_{2} \mathrm{Te}_{3}\right)$ and leadtelluride (PbTe). Silicon-germanium (SiGe) alloys made their appearance as excellent high-temperature materials in the early 1960s. These three compounds are still considered as the more important thermoelectric materials with SiGe being studied and used in units for long-lived space missions. Due to materials limitations, which are related primarily to efficiency, little work has been done on the application of thermoelectric power generation to central station plants. 


\subsubsection{Present and Projected Application}

Currently, the use of thermoelectric power generation is restricted to applications for which efficiency is not the primary consideration. These applications are based on a minimum mass for a given energy output and are limited to space applications and specialized terrestrial uses (e.g., remote monitoring stations, beacons, and navigation buoys).

Several thermoelectric power systems are included in the U.S. Space Nuclear Auxiliary Power (SNAP) program. These systems are of two kinds, the difference being whether the heat is supplied by a decaying radioisotope or directly from a nuclear reactor. The largest space power supply of this type being considered required a $100 \mathrm{kWt}$ reactor to provide heat for a $5 \mathrm{kWe}$ thermoelectric generator.

Although some terrestrial applications use radioisotopes as the heat source, most use propane burner sources with either direct flame heating or catalytic bed heating.

A radioisotope thermoelectric device in the microwatt range is used as the power source for a new type heart pacemaker that is implanted in humans. 


\subsection{Technical Information}

\subsubsection{Availability}

Several companies in the U.S. are presently engaged in cormercial sales of thermoelectric devices. There seem to be no intrinsic problems with the manufacture of large numbers of devices using present-day materials. These materials have been available for a long time, and problems of joining, element design, etc., have all been fairly well worked out. However, new materials that may become avaflable, with higher figures of merit, may reintroduce these same problems. Also, in the event that nuclear reactors are used as the heat source, irradiation damage to the thermoelements may severely reduce performance over long exposure periods.

\subsubsection{Energy Source}

Thermoelectric power systems have been built and operated using several energy sources. These include fossil fuels, radioisotopes, solar energy, and nuclear reactors. 5,6

\subsubsection{Efficiency}

The product of $2 T_{m}{ }^{*}$ will determine the percent of Carnot efficiency obtainable. No known materials operating with a sink temperature of $27^{\circ} \mathrm{C}$ and a source at the maximum allowable temperature, can approach an overall efficiency of 20\%. (See Fig. B.8-2).

${ }^{*} T_{m}$ is the mean operating temperature and $Z$ is a term called the Fipure of Merit. 


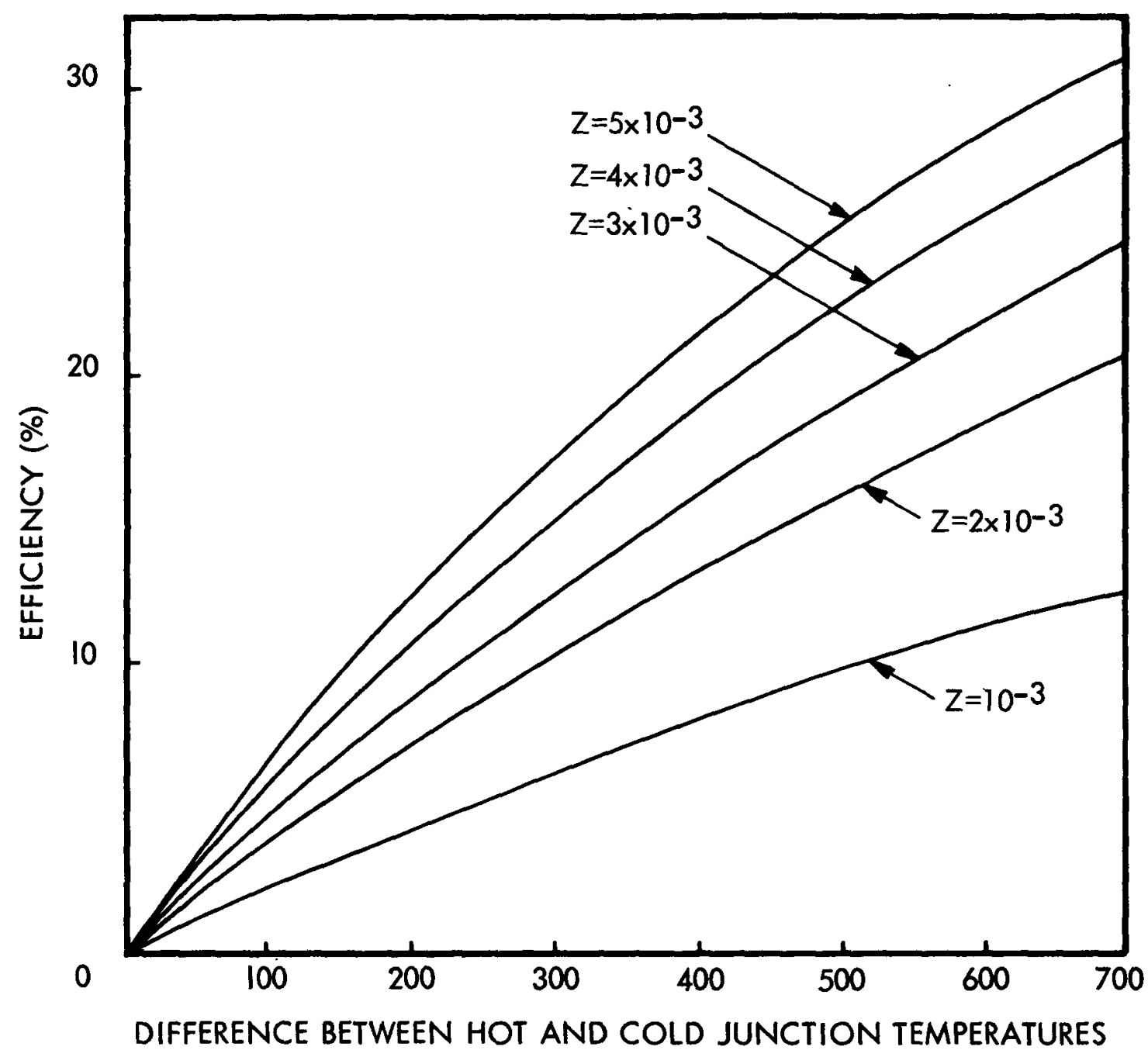

EFFICIENCY OF A THERMOELECTRIC GENERATOR

Figure B.8-2 
A number of TEGs used primarily for space applications (where efficiency is not necessarily the most important consideration) have overall efficiencies of less than $7 \%$ and most are in the 4-5\% range. TEGs for terrestrial applications are generally in the range of $4-6 \%$.

\subsubsection{Size Limitations}

A thermoelement is inherently a low power device. By appropriate series/parallel electrical arrangements, higher power outputs can be obtained. This modular system lends itself to the construction of high power systems, but still has a very low output for its size and weight.

A 150 We solar-powered TEG would use 480 couples, with a weight of $1.62 \mathrm{lb}$ for a power density of $94 \mathrm{We} / \mathrm{lb}$ for the elements alone. In the actual generator, this drops to $11.3 \mathrm{We} / 1 \mathrm{~b} .^{5}$ A radioisotope thermoelectric generator for use in a Transit Navigational spacecraft, TRIAD I, has a power density of 1.2 We/16 for the total assembly. For the thermoelectric panels, the power density is about 6 We/lb. ${ }^{7}$

\subsubsection{State of the Art}

Extensive effort has been devoted to the development of thermoelectric materials with a high figure of merit, especially those materials that operate at higher temperatures and efficiency. Silicon-germanium alloys are considered as especially promising 
for operating temperatures near $1000^{\circ} \mathrm{C}$, and these materials are under active investigation. ${ }^{?}$

The techniques of joining the couples to the metal plates to fiorm junctions and terminals are fairly well established, although these joining techniques are more art than science. Each new combination of materials introduces new problems that must be solved before the thermoelectric material can be used in a practical generator. Additional problems are often introduced by the brittle nature of most of the useful materials.

\subsection{Research and Development}

As has been pointed out, materials of higher Figure of Merit than now available must be developed. A second problem is inherent in the low unit power output. At 1 We/couple (which seems to be a practical working size), a 1000-MWe power station would require $10^{9}$ couples. Unless the output per couple can be increased significantly, the sheer number of interconnections and redundancy necessary for high reliabllity will be prohibitively expensive.

More effort is required in the basic materials area to achieve a high figure of merit. These efforts should include investigations directed at verifying or disproving Ure's estimate of 2-2.5 for an upper limit to $Z \mathrm{~T}_{\mathrm{m}}$. Without a substantial improvement in $Z$ (or $\mathrm{ZT}_{m}$ ) no amount of engineering will bring the overall system efficiency 
to a value high enough for economic consideration for central station electrical power production. An improvement in the Seebeck coefficient for a constant resistivity, $p$, would not only improve $Z$, but also would increase the voltage output per couple.

\subsection{Environmental Impacts}

Since a TEG is a thermal-conversion device with no moving parts, the only pollution results from the heat source. Naturally, being a thermal engine governed by the laws of thermodynamics, heat will be rejected to the surroundings.

The low efficiency of the TEG means more thermal energy must be rejected to the environment. Conversely, for the same useful power emitted, more fuel is consumed. With existing low efficiencies, energy sources will be depleted at a faster rate than is now the case. For central station plants this is unacceptable.

\subsection{Costs and Benefits}

Present costs for small fossil-fueled TEG systems are about $\$ 25,000$ $\$ 30,000 / \mathbf{k W e}$. This is 100 times the cost of a large conventional power plant. There is no large obvious reduction in unit cost for increasing plant size since many small elements are required and the high unit cost still prevails. Mass production would however tend to reduce this unit cost. 
An example of the cost of a thermoelectric generator was found in the catalog of an established supplier of thermoelectric devices. 8 A 20-We TEG that operates between 125 and $25^{\circ} \mathrm{C}$ requires 26 modules, each containing 31 couples. Since the cost of each module is $\$ 60$ (1971 catalog price), the cost of the TEG is \$78/watt. More recently, different suppliers offering other types of thermoelectric devices have quoted prices in the range of $\$ 40 /$ watt. There do not appear to be any benefits accruing from TEG for commercial electric power generation.

\subsection{Overall Assessment of Role in Energy Supply}

The main benefit of the thermoelectric generator is that is has no moving parts which will tend to increase. its reliability and long life. The modular construction of a TEG allows a variety of power levels to be easily obtained for a given basic couple.

The low efficiency and low power output per couple together with high unit costs will probably limit the application of TEGs to small special purpose power sources. The present economics are unacceptable for central station power application and the low efficiency would create severe drain on our energy resources. 


\subsection{References}

1. Seebeck, T. J., "Evidence of the Thermal Current of the Combination Bi-Cu by Its Action on Magnetic Needle," Abt. d. Konigl, Akak. d Wiss Berlin, 1822-23.

2. Spring, K. H., "The Thermodynamic and Economic Basis," in Direct Generation of Electricity, K. H. Spring (ed.) Academic Press, New York (1965).

3. Ioffe, A. F., Physics of Semiconductors, Infosearch Limited, London (1960).

4. Lynch, C. J., "Thermoelectricity: The Breakthrough That Never Came" in Innovation, 48 (1972).

5. Angrist, S. W., Direct Energy Conversion, Allyn and Bacon, Inc., Boston, Mass., 2nd Ed. (1971).

6. Rubinstein, M. A., "Comnercial Thermoelectric Generator Applications and Economic Considerations," Intersociety Energy Conversion Engineering Conf., Aug. (1968).

7. Proceedings of the 7th Intersociety Energy Conversion Engineering Conference, American Chemical Society, Washington, D.C. (1972).

8. The Cambion Thermoelectric Handbook, 1971 Edition, Cambridge Thermionic Corporation, Cambridge, Mass. 


\section{B.9 THERMIONIC CONVERTERS}

\subsection{Introduction}

\subsubsection{General Description}

The principle of operation of thermionic devices is based on the emission of electrons from metals at high temperatures. This phenomenon was first investigated by Thomas Edison, and was subsequently used as the basis of the conventional vacuum tube.

A thermionic converter is a device that contains an electron emitter and collector in a sealed envelope at reduced pressure. The emitter is heated, increasing the energy of the free electrons in the metal causing them to travel at higher speed. This increased kinetic energy allows the electrons to escape from the open surface of the hot emitter and to move through an intervening space to the cooler electron collector. With no external circuit connections, a potential difference (voltage) will develop between the collector and emitter. When connected to an external circuit, the potential difference will cause a current to flow. (See Fig. B.9-1). In a thermionic converter with reasonable spacing between emitter and collector, some of the emitted electrons have insufficient energy to reach the collector, so they form an "electron cloud" (or space charge) which tends to repel subsequent electrons and hence limit the available current. In order to achieve reasonable power density, a low pressure ionized vapor (usually cesium) is introduced to neutralize the space charge. 


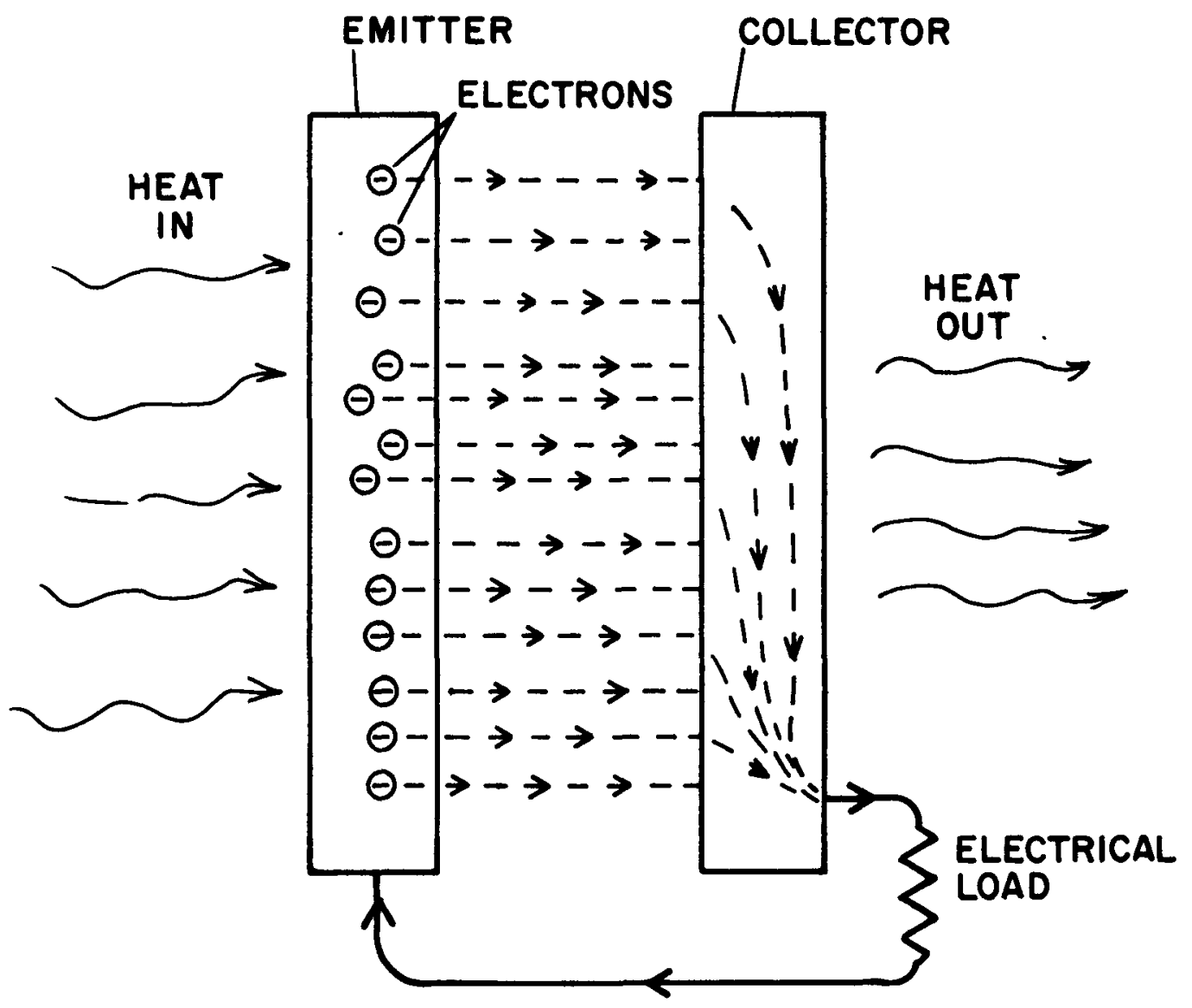

SCHEMATIC OF A THERMIONIC ENERGY CONVERTER

Figure B.9-1 


\subsubsection{History and Status}

Although it has been known for 200 years that a negatively charged metallic body loses its charge more rapidly when heated, the phenomenon of thermionic emission was not studied intensively or put to practical use until efficient sources of electrons were needed for radio communication. The modern beginnings of the study of thermionic phenomena are usually attributed to Edison who discovered the emission of electrons into a vacuum in about 1883.

The first suggestion that a thermionic converter could be used to change thermal energy to electricity appears to have been made by Schlichter, in 1915. 1 In his 1956 doctoral dissertation at MIT, Hatsopoulos described two types of thermionic converters, and his suggestions sparked serious experimental work around the world. ${ }^{2}$ Soon afterward, experimental converters that produced electricity were built in several laboratories, and, in April 1959, electrical energy was converted directly from nuclear energy by a group at the Los Alamos Scientific Laboratory.'

The bulk of the U.S. effort in thermionic energy conversion is in the area of nuclear-powered devices. ${ }^{3-5}$ Nearly all concepts utilize what has become known as the flashlight-type fuel-element design. In this concept, a number of nuclear-fueled thermionic cells are placed in a thermionic fuel element (TFE) in the same manner as a flashlight is loaded with cylindrical batteries. The 
development of this TFE, a joint AEC/NASA effort, was directed at the 100-kWe level for space nuclear electric propulsion applications. 3 This was effectively terminated in February 1973 and only a small research effort aimed at increasing the efficiency of the thermionic process remains in effect in the United States as of the beginning of 1974.

Two other countries have active themionic energy conversion programs. 3 The Soviet Union has operated at least two reactors containing thermionic devices. TOPAZ I became operational in 1970 and produced 5-10 kWe for more than $1000 \mathrm{hr} .{ }^{6}$ In 1971, experiments were begun with TOPAZ II to check the reproducibility of characteristics obtained during the test of TOPAZ I. TOPAZ III is understood to have started operating in the fall of 1972.

The Federal Republic of Germany has operated a smaller (partiallength) TFE for $1700 \mathrm{hr}$ and is considering the construction of a thermionic reactor in the 20-100 kWe range for space applications. 3 France has started fabrication of a full-length TFE for Diogene I, a 10-kWe thermionic reactor, which will become operational in 1974 and will be used for underwater applications. ${ }^{3}$ 


\subsubsection{Present and Projected Applications}

Thermionic converters have several potential applications ranging from a cardiac pacemaker that operates in the 0.1 Whe range to a modified (topping) thermodynamic cycle for a central station power plant that operates at 1000 MWe. Thermionic devices which are coupled with nuclear heat sources are especially attractive for long range and long-duration space applications because of their basic simplicity, the absence of moving parts and their relatively higher efficiency as compared to other space power generators.

Interest in the thermionic device as a topping unit for conventional central station power stations rests on its potential for increasing overall plant efficiency. Furnace temperatures which are not normally usable in conventional boilers and steam turbines, because of metallurgical limitations, can be effectively used with thermionic converters to increase the overall efficiency of the cycle. An analysis carried out for the Tennessee Valley Authority (TVA) Bull Run coal fired plant shows that thermionic topping might result in an increase of station output from 914 to 1139 MWe and a gain in plant efficiency from 41.3 to $50.6 \% .^{7}$

\subsection{Technical Information}

\subsubsection{Availability}

All work to date is of a developmental nature. Full-length TFE irradiation tests reached the $7,000 \mathrm{hr}$ endurance level by January 1973 befory the program was terminated. Reactors using 
TFEs of this design are not applicable to central power stations for economic reasons. Central power stations utilizing thermionic converter and furnace concepts have been considered. These are being examined from economic and technical standpoints.

\subsubsection{Energy Source}

Thermionic converter systems can be used with thermal inputs from any source, including solar and nuclear power. However, from the standpoint of central station power application, the major interest in thermionic conversion is as a topping unit for fossil-fueled plants. Thermionic converters are most efficient at high temperature and they match the heat-source properties of a fossil-fueled plant well. Central station nuclear power reactors are not suitable for thermionic applications since it is not practical to incorporate these conversion systems within the core of the reactor and neither the water-cooled or the sodium-cooled reactors operate at high enough coolant temperature to consider the location of the thermionic converter outside of the reactor.

\subsubsection{Efficiency}

The theoretical efficiency of a thermionic converter is limited by emitter and collector temperatures. As in any heat engine, the theoretical efficiency is seldom attained. 
The efficiency of the radionuclide-powered ISOMITE batteries is less than $1 \% .^{8}$ The efficiency of a proposed 5-kWe semi-portable power supply was estimated to be about $10 \%^{2}$ A thermionic power supply utilizing solar energy had achieved $12.5 \%$ efficiency by 1964. ${ }^{9}$ The TFE efficiencies range from $10-16 \%$ and the thermionic converters proposed for use in the fossil fueled steam plant topping cycle would operate at an efficiency up to perhaps as high as 25 to $35 \%$.

\subsubsection{Size Limitations}

Power systems that utilize thermionic converters will consist of individual units connected in series and parallel combinations to produce the voltage and current requirements for the various application. Construction will be modular and the unit size selected will depend on a number of considerations. Thermf onic module size in the Bull Run application was set at 22 MWe. Consideration is currently being given to applications in modified fossil-fueled central station boilers with plant electrical capacities in the hundreds of Mwe range.

\subsubsection{State of the Art}

Although, in concept, the thermionic converter is a relatively simple device, building long-lived efficient thermionic converters is no easy task. The electrodes must operate in close proximity to one another, and at high temperature, so that the level of power generated is sufficient for practical applications. However, the high operating temperature leads to high efficiencies. For example, 
the emitter may operate at $1880^{\circ} \mathrm{F}$ and the collector at $918^{\circ} \mathrm{F}$. Under these conditions the theoretical efficiency is $41 \%$; however, practical devices will never achieve this ideal efficiency. A high potential efficiency at high collector operating temperatures, as well as the feature of having no moving parts, makes thermionic energy conversion worthy of further consideration as a topping system with more conventional power cycles.

With the exception of the concept developed for application to the TVA Bull Run coal plant, little has been done until recently in evaluationg thermionic power systems (TPS) applied to central station power, particularly not to coal-fired plants designed to meet EPA pollution standards. Present program efforts are focusing on these applications again. The state of the art is primarily based on the AEC/NASA program. Based on this work, thermionic devices are technically feasible but need further development to extend their lifetime.

\subsection{Research and Development}

The experimental work of the 1960 s identified most of the problem areas in converter design and operation except those of the economics of central power station application. The cesium environment and high operating temperatures can cause emitter vaporization, thermal warping, insulator shorting, and seal failures. For space applications, the main problems were concerned with achieving the following: 
- Lifetime of at least $5 \mathrm{yr}$.

- Reproducible and stable thermionic converter performance.

- Demonstration that any electrical arcing that might occur is not destructive to the cell and will not result in excessive power losses.

- Qualification to expected shock and vibration environments.

- Simplification of fabrication methods and lower costs.

The use of chemical vapor deposition as a technique for cladding converter emitters with tungsten has been successful in establishing stable long-term performance. Adoption of fine-grained high-density alumina with niobium skirts brazed with a $60 \mathrm{~V} 40 \mathrm{Nb}$ alloy may eliminate the insulator problems. ${ }^{3}$ Finally, the introduction of oxygen into the converter may reduce operating temperatures and improve the overall performance. ${ }^{3}$ Both lower cost materials and fabrication methods are required. For topping cycles, research is focussed on achieving high efficiency and lower costs at lower and more practical operating temperature ranges.

\subsection{Environmental Impacts}

The operation of a thermionic generator produces no additional pollutants other than those normally present from the particular heat source used. It is important to note, however, that the use of thermionic topping in conventional central station power plants would inerease the overall plant efficiency. The topping device, in principle, utilizes all the heat supplied to it with $100 \%$ 
efficiency because its rejected heat is at a temperature above the normal steam-cycle operating temperature. Thus, the increase in overall plant efficiency results in less thermal energy rejected to the surroudings for the equivalent electrical power production.

There are no new known environmental effects introduced with a thermionic converter system. With the higher efficiency projected for a thermionic system, the pollutants normally produced by the energy source being used will be diminished for equivalent amounts of electrical energy generated.

\subsection{Costs and Benefits}

With the exception of certain terrestrial and hydrospace applications, the cost of thermionic converters for producing power has not been assessed. The value of a thermionic converter for a fossil-fueled plant can be estimated based on the incremental efficiency produced by a topping cycle operating with no degradation of the steam plant performance. Using a capital cost of $\$ 300 / \mathrm{kWe}$ and a fuel cost of $50 \$$ per million Btu for a coal fired steam plant the purchase price for each of the thermionic modules could be as high as $15 \$ /$ We and still be economically competitive. Present costs for these devices are considerably higher than this and current research is directed at achieving significant cost reductions. 
The increase in plant efficiency and the apparent ease in incorporating the thermionic modules in the botler unit of a fossil fixed plant would suggest that this is a fruitful route to follow.

\subsection{Overall Assessment of Role in Energy Supply}

A thermionic energy conversion system has the potential to improve fossil-fueled plant efficiency from the present $40 \%$ to possible $50 \%$. The system should be particularly adaptable to coal plants in which the combustion chamber temperature is well above the normal working temperature of the steam turbine. Insufficient studies are avallable to establish requirements of Thermionic Power System as applied to new coal plants that will meet EPA standards. At present, low cost, reliable converters have not been developed and thermionic topping cycles for coal fired steam turbine power plants cannot be justified on an economical basis.

The AEC/NASA programs have demonstrated the technical feasibility of in-core, nuclear heated thermionic fuel elements, but only for space power systems. These space reactor concepts are prohibitively complex and expensive for use with a commercial central station power plant. 


\subsection{References}

1. Harrowe11, R. V., "The Thermionic Converter," in Direct Generation of Electricity, Spring, K. H. Ed., Academic Press, New York, 1965.

2. Angrist, S. W., Direct Energy Conversion, Allyn and Bacon, Boston, 2nd Ed. (1971), p. 284. See also: Lazaridis, L. J. and Pantazelos, P. H., "Design of a 5-Kilowatt Flame Heated Termionic Power Supply," Thermionic Conversion Specialist Conference, 1966, Houston, Texas.

3. Conference Proceedings of the 7th Intersociety Energy Conversion Engineering Conference (IECEC), San Diego, California, September 1972, pp.1036-1078:

Beard, D. S. and Lynch, J. J., "Thermionic Reactor Program, An Overview," p. 1036.

Yang, L. and Chin, J., "Development Status of Thermionic Materials," p. 1041.

Morris J. F., "Performance of the Better Metallic Electrodes in Cesium Thermionic Converters," p. 1050.

Rufeh, "Performance Improvement of Cesium Thermionic Converters by Addition of Oxygen," p. 1054.

Holland, J. H., "Thermionic Fuel Element Development Status Summary," p. 1060.

Kroeger, E. W., et al., "An Out-of-Core Version of a Six-Cell Head-Pipe Heated Thermionic Converter Array," p. 1066.

4. Price, L. K., "Thermionic Reactor Concepts," Proceedings of the 4th Intersociety Energy Conversion Engineering Conference, September 1969, p. 122.

5. Roberts, J. J. and Croke, E. J., "Design of a 1 KWe Fast Reactor Power Supply," 2nd Intersociety Energy Conversion Engineering Conference, 1967, p. 575.

6. Gryaznov, G. M., et al., "Development and Power Tests of the Thermionic Reactor-Converter "TOPAZ", 4th U.N. International Conference on the Peaceful Uses of Atomic Energy, Geneva, September 1971.

7. Engdahl, R. E., et al., "Thermionic Topping--The Key to CoalFired Central Station Power Efficiency," 30th Annual Meeting of the American Power Conference, April 24, 1968, sponsored by Illinais Institute of Technology. 
8. "ISOMITE (BATTERIES)," Bulletin of the Donald W. Douglas Laboratories, Richland, Washington.

9. Backus, C. E., "State-of -the-Art of Thermionics - 1970," Arizona State University, Tempe, Arizona.

10. Beard, D. S., "Thermionic Fuel Element Development," 4th Intersociety Energy Conversion Engineering Conference, September 1969, p. 131. 
B.10 MAGNETOHYDRODYNAMICS

10.1 Introduction

10.1.1 General Description

The magnetohydrodynamic (MHD) generator produces electrical energy directly from thermal energy; it is a heat engine that combines the features of the turbine and the generator of the conventional steam plant into a single piece of apparatus and has the potential for conversion efficiencies in the range of 50 to $60 \%$.

In an MHD generator the rotating wire conductor of the conventional generator armature (Figure B.10-1) is replaced by an electrically conductive fluid (Figure B.10-2). As the working fluid flows through the magnetic field a voltage drop is induced across the stream causing an electrical current to flow between the electrodes. The electrodes of the MHD generator are generally two opposite walls of a rectangular duct to which electrical leads are attached (the adjacent side walls are electrical insulators). The MHD working fluid can be either a plasma (e.g., ionized gas) in an open or closed cycle system, or a homogeneous mixture of a liquid metal and an inert gas in a closed cycle system.

In the open-cycle plasma system fossil fuel is burned at a sufficiently high temperature so that the product gases are ionized. Electrical conductivity is further enhanced by "seeding" the gas with readily ionized material (i.e., salts of potassium or cesium). The conductive gas is expanded through an MHD generator producing 


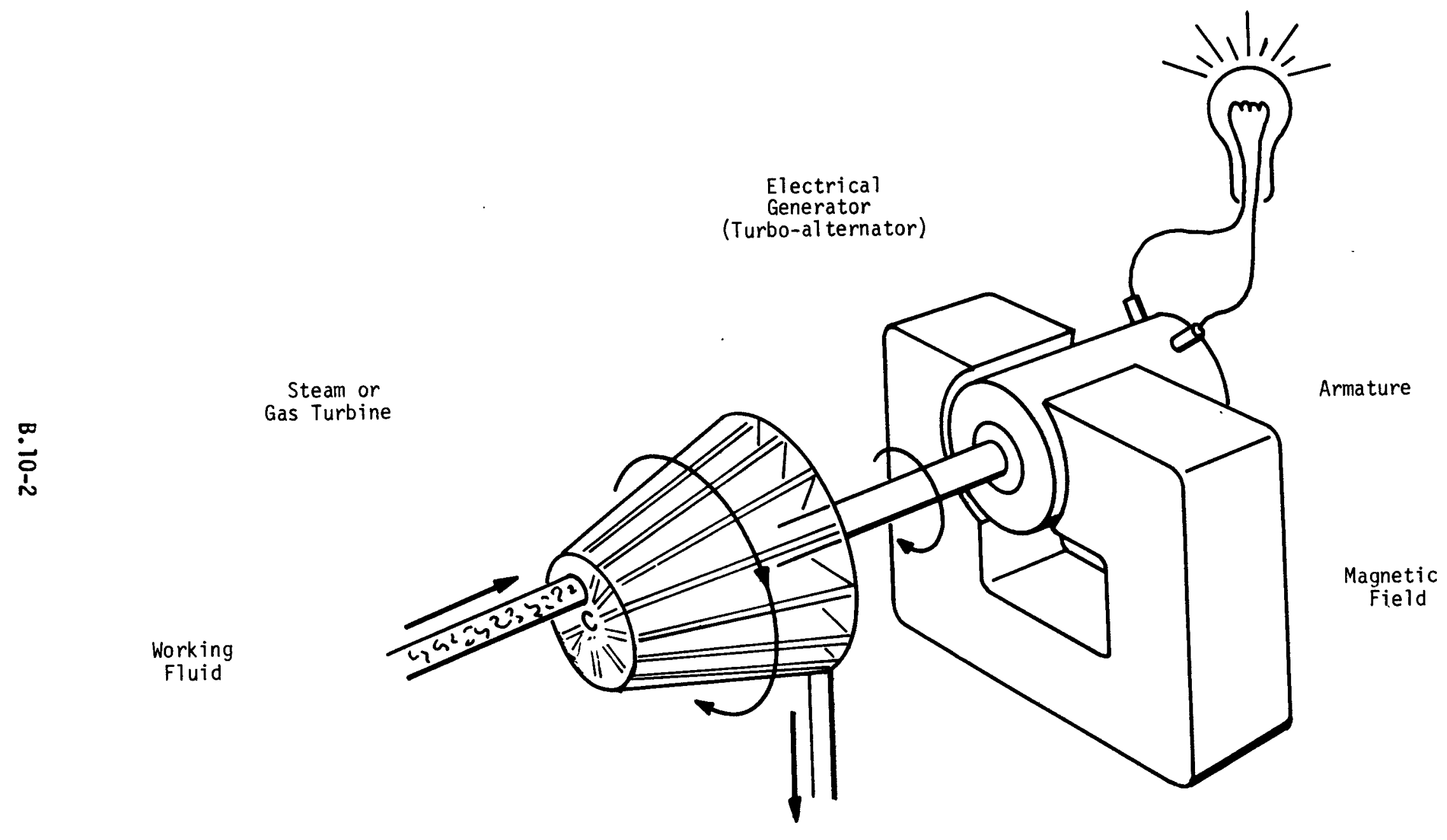

TURBINE/GENERATOR ELECTRICAL SYSTEM

Figure B. 10-1 


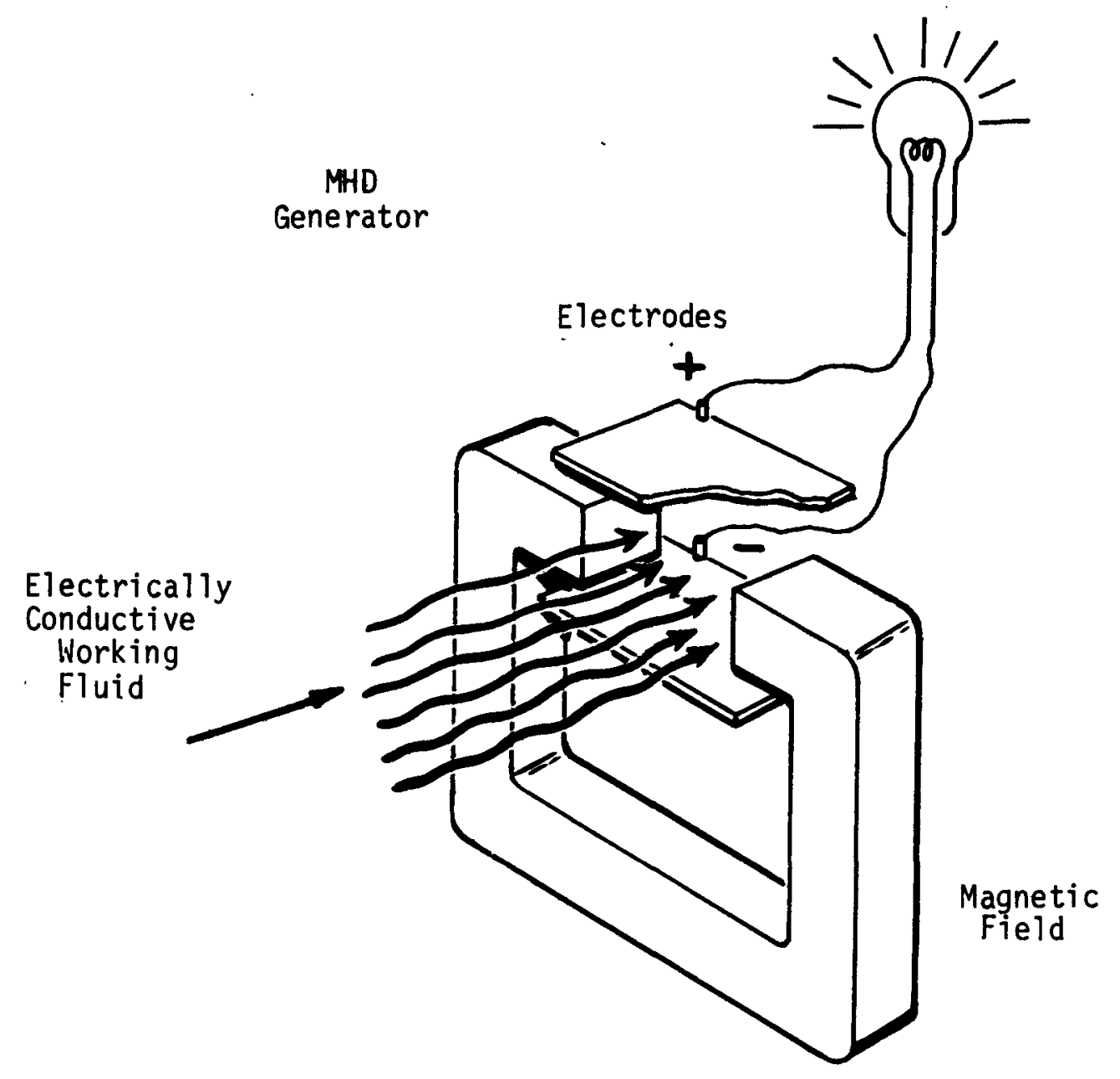

MHD GENERATOR ELECTRICAL SYSTEM

Figure B.10-2 
electricity. The exiting hot gases are further used to generate steam which is used in a conventional steam turbine energy system. Seed must be extracted from exhaust gases for reuse.

The closed cycle plasma system utilizes a seeded noble gas heated by an indirect heat source (i.e., nuclear or fossil through a heat exchanger). The hot gas expands through an MHD generator producing electricity. The cooler gas is compressed for reheating. Regenerative exchange is normally used prior to the compressor and reject heat can be jumped directly to the atmosphere.

In the liquid metal MHD concept there are two fluid circuits, the liquid metal and an inert gas. The liquid metal is heated by a fossil or nuclear heat source, and then the inert gas is dispersed into the liquid metal. As the gas expands due to being heated by the liquid metal the two fluids accelerate through the MHD generator the liquid metal providing the moving conductor capability. At the exit of the MHD generator the two fluids are separated. The liquid metal is reheated and the gas is cooled and recompressed ready for mixing. Reject heat from the gas circuit can be used to generate steam for further use or dumped to the atmosphere.

\subsubsection{History and Status}

Patents related to MHD generators began to appear in about 1910 but the first attempt to construct a large plasma generator was not 
made until the early 1940s.' This program was unsuccessful and further work was shelved until the 1950s when work on nuclear fusion led to a better understanding of plasma phenomena. This work has resulted in an increased level of interest in MHD over the past decade. ${ }^{2}$

The space programs sponsored by the U.S. and the U.S.S.R. have generated much of the materials technology that made building demonstration units possible. However, the two countries have chosen different routes in the development of open cycle plasma MHD power plants. The U.S. has developed the various system components required separately. For example, several generators have been built to deliver relatively large amounts of power (18 to $32 \mathrm{MWe}$ ) for short periods of time (several minutes). At the same time, a variety of electrode configurations have been tested for relatively long periods of time at low power levels. The U.S.S.R. has approached the problem by building a complete power plant designed to deliver 75 MWe to the Moscow grid (25 MWe from the MHD generator and 50 MWe from a steam-turbine system). Operation at the full design output of the MHD generator is expected in 1975 and, in the meantime, this system will be used to test components as they are developed.

Research on liquid metal MHD systems has been conducted on a much smaller scale than for plasma systems. Much of this work has been done with eutectic mixtures of sodium and potassium (NaK) at room temperatures. Generator efficiencies up to $75 \%$ have been 
measured for a liquid metal MHD generator with a measured output of about 1 kwe. Tests of larger generators of 5-50 kwe are currently underway or being planned. In addition, several generators have been tested or are planned to be tested at temperatures in excess of $1000^{\circ} \mathrm{F}$.

\subsubsection{Present and Projected Application}

A number of laboratory and pilot-plant scale plasma MHD generators have produced significant amounts of power (several MWe) for short time periods; however, large-scale power production remains to be demonstrated. Work is currently underway in several laboratories around the world to bring these concepts to fruition. The technology generated in this work is applicable to centralstation power generation but MHD will probably find its initial application as a topping cycle for conventional fossil-fired steam power plants. As the state of the art evolves, MHD systems could generate electrical power in central station power plants from either fossil-fired or advanced nuclear heat sources.

\subsection{Technical Information}

\subsubsection{Avallability}

All MHD power generation system concepts are in the developmental stage. The construction and startup of new experimental MHD generator facilities in the last few years illustrates significant advances in both sophistication and understanding of the operation of MHD generators. Advocates of this system believe that none of the known 
problems appear to present an impenetrable barrier to bringing MHD central station power generation to fruition and optimistically estimate that either one or all three MHD power systems could be made commercially available by the 1980s if sufficient funding were available. This, of course, will depend upon the rate at which the known, and any currently unrecognized, technical problems can be solved.

\subsubsection{Energy Source}

MHD power generators of various designs are under study which would be capable of operating over a range of heat-source temperatures from 1000 to $5000^{\circ} \mathrm{F}$ using either fossil or nuclear fuels. The normal combusion of coal produces a gaseous effluent at a temperature of $-2600^{\circ} \mathrm{F}$. With $\mathrm{O}_{2}$ enrichment, this temperature can be increased to $5000^{\circ} \mathrm{F}$. Also currently underway are programs to burn coal in fluidized beds at reduced temperatures of $1600^{\circ} \mathrm{F}$ to reduce the levels of $\mathrm{SO}_{2}$ and $\mathrm{NO}_{2}$ pollutants produced.

The open-cycle plasma system is capable of producing electrical power from high-temperature fossil-fired heat sources operating over the range of 4000 to $5000^{\circ} \mathrm{F}$. The closed-cycle plasma system could generate electricity from the advanced HTGR or a fossil-fired heat source operating over the range of $2300-3500^{\circ} \mathrm{F}$. Finally, the two-phase liquid-metal MHD system appears to be compatible with thermal energy sources operating over the range of 1000 to $2000^{\circ} \mathrm{F}$. 


\subsubsection{Efficiency}

MHD power systems have higher potential efficiencies than conventional steam and other expansion-type energy-conversion devices. First generation open-cycle MHD power plants would operate with an MHD topping-cycle on a conventional steam plant and could be expected to give overall plant efficiencies in the range of $46-50 \%$. These power plants are projected to have an ultimate efficiency in the range of $55-60 \%{ }^{3}$

The closed-cycle plasma MHD system appears capable of plant efficiencies in excess of $50 \%$ for heat-source temperatures of $2900^{\circ} \mathrm{F}$. The two-phase liquid metal MHD power systens are predicted to have overall efficiencies competitive with those of modern steam systems when operating at the same maximum cycle temperature and should have efficiencies approaching $50 \%$ at $1600^{\circ} \mathrm{F} .^{4}$

Proponents envisage that a high-performance all-MHD binary power cycle is possible utilizing the open-cycle plasma and the two-phase liquidmetal MHD concepts. In such a system an open-cycle plasma MHD generator obtains thermal energy from a fossil-fired heat source and rejects waste heat to a two-phase liquid-metal MHD generator. This dual cycle is projected to have efficiencies in excess of $60 \%$ for a maximum cycle temperature of $5000^{\circ} \mathrm{F}$. 


\subsubsection{Size Limitations}

MHD generators become more efficient as their size is increased because friction effects and heat losses become less significant as the MHD ducts become larger (i.e., as the surface to volume ratio decreases). In contrast to turbines in which forces acting on surfaces are involved in the energy-conversion process, MHD energy conversion is a consequence of a body (volumetric) force. Thus, large MHD generators should be easier to design and construct, and less expensive to operate than small ones. The size limitations for MHD central station power plants will be dependent on the limitations of supporting equipment such as pumps, heat exchangers and the like.

\subsubsection{State of the Art}

Significant advances have been made in the past ten years towards the goal of bringing the MHD concept to fruition in central-station power plants. ${ }^{2}$ In this period the open-cycle plasma system has received considerably more attention than the other two concepts. This has resulted in improved understanding of the main phenomena in the open-cycle MHD channel so that generator designs can be made and the projected performance of the MHD duct can be bracketed. The required performances of the major components for base-load applications are being approached in the case of the liquid metal MHD system. Preliminary studies using the projected generator 
enthalpy extraction and efficiencies have predicted that the future open-cycle plasma MHD power systems will be an economically viable means of base-load power generation provided the extensive R\&D required (See Section 7.3 below) can be successfully performed.

The construction and startup of experimental plants in several countries, including the 25 MWe pilot plant in the U.S.S.R., represent significant milestones in the development of open-cycle plasma MHD. The emphasis of the present work is on increasing the service life of the electrodes, walls and certain other components to ensure reliable operation of the MHD base-load power station during a predetermined service life.

The closed-cycle MHD generator has been shown to be feasible and sufficient experimental theoretical background exists to permit extrapolation to large sizes with confidence. Isentropic efficiencies up to $70 \%$ and enthalpy extraction up to $10 \%$ were recently attained. These results demonstrated that, after successful scaling up to a thermal output of $1000 \mathrm{MW}$ is achieved, a closed cycle MHD generator should achieve a performance acceptable for large electric power plants.

Since the working conditions of the closed cycle MHD non-equilibrium duct are much less severe than for the open-cycle system because 
of a cleaner gas stream and lower temperatures, fewer difficulties are anticipated in the development of long-life ducts. The prospects of the closed-cycle plasma MHD systems for base-load power generation depends upon the development of a suitable heat source.

Extensive analytical studies of two-phase liquid-metal MHD cycles have been made with detailed mathematical models of all components to show that these systems do have the potential for efficient production of electrical power. However, accurate models of the MHD components (i.e., mixer, generator, and separator) can only be developed by extensive experimental studies. The MHD generator tests at Argonne National Laboratories have shown that more than $80 \%$ of the end losses than would exist if there were an abrupt termination of the magnetic field can be eliminated. A program is currently underway to test a mixer-generator-separator system at $1000^{\circ} \mathrm{F}$. These experiments should document the performance of the two-phase liquid-metal MHD generator, and, if successful, provide sufficient information for the design and construction of a hightemperature pilot plant.

\subsection{Research and Development}

Open cycle plasma MHD power plants would have to operate with a highly erosive and corrosive working fluid at extremely high temperatures. Experimental studies thus far performed have not achieved the required performance levels of the various components. Thus, the 
major components of a plasma system require additional development to achieve the performance levels required for an efficient plant. The most important of these requirements are:

- Materials that will operate for extended periods in the high temperature, erosive environment.

- A high efficiency coal-combustor capable of handling coals having $10 \%$ or more ash.

- The plasma generator must extract 20 to $25 \%$ of the total enthalpy of the combusion products; thus far only $8 \%$ has been achieved, but scaling laws indicate that increasing the generator size should help achieve this goal. Additional study of the above-mentioned generator problems is required.

- The scrubber must remove $99.9 \%$ of the seed from the spent combustion gases - thus far $99 \%$ removal has been achieved.

- An overall isentropic generator efficiency of at least $70 \%$ is required, while only $40 \%$ has been demonstrated. This goal should also be attained by increasing the generator size.

- A diffuser efficiency of 70 to $80 \%$ is required while $35 \%$ has been reported.

- The stack gases must be cleaned to acceptable levels; recent results indicate that present-day technology should be able to meet EPA standards.

- Finally, long-term tests must be undertaken to demonstrate component longevity once the required performance levels have been demonstrated. 
The closed-cycle plasma system has basic problems of enthalpy extraction, generator and diffuser efficiency similar to open-cycle plasma systems. Recent results on the generator problems have been encouraging.

Most of the components in the liquid-metal MHD system are conventional (e.g., gas-gas and gas-liquid heat ehangers and compressors) and require little or no additional development to meet performance requirements. Additional development is required on liquid-metal pumps and the primary heat-exchanger, as well as the development of appropriate insulators and conductors for the generator walls which are compatible with the liquid-metals. Much progress has been made on the problem of keeping the variation of the relative velocities between the two phases at a small value. This is necessary to ensure high efficiencies for the generator.

\subsection{Environmental Impacts}

The effluent problems associated with MHD power plants are those associated with the energy source, i.e., fossil fuel or nuclear fuel. All of the MHD concepts have the potential to reduce thermal discharges and conserve fuel supplies when compared to the pure steam power plants, since they are projected to have improved conversion efficiencies. The total quantity of thermal emissions will be reduced in inverse proportion to the improvement in efficiency. 
It is estimated that the open-cycle MHD system will be able to meet or exceed the EPA requirements for $\mathrm{SO}_{2}$ and $\mathrm{NO}_{x}$ in effluent stack gases at costs that are predicted to be below those of conventional power plants when $2 \%$ sulfur coal is burned. Seed material must be removed and recovered from effluent gases for environmental as well as economic reasons. The seed materials being considered are alkalf metal salts and it would be undesirable to release these to the environment as finely divided particulate. Furthermore, the cost of these materials dictates that they must be recycled for economic operation. ${ }^{2}$

Fossil-fired heat sources for closed-cycle MHD systems possess the same pollution problems encountered with conventional steam plants. It is envisaged that the fluidized-bed combustor could burn high sulfur coal to supply thermal energy for the liquid-metal MHD systems without producing high $\mathrm{NO}_{2}$ and $\mathrm{SO}_{x}$ levels in the stack gases. In addition, because the two-phase liquid-metal MHD system operates on a Brayton-type (gas turbine) cycle it possesses the potential to be effectively coupled to dry cooling towers without paying a significant economic penalty.

\subsection{Costs and Benefits}

Although the technical feasibility of MHD power plants has been demonstrated, the concept is still in the developmental stage and thus very little information has been developed on the projected economic benefits to accrue from central-station MHD power plants. 
The higher efficiencies projected for the various MHD systems must provide sufficient fuel cost savings to compensate for the capital costs of the MHD systems. Most of the economic studies carried out have been for open-cycle plasma-steam systems. It has been calculated that the first generation open-cycle MHD topping systems for electrical generating plants may compete successfully with conventional steam stations in areas of high fuel costs. Future nuclear power plants would have an economic advantage over open-cycle fossil-fueled MHD power plants only in areas where fossil fuel is relatively expensive.

At the present stage of development of closed-cycle plasma MHD technology it is not possible to obtain an absolutely reliable economic evaluation for central-station power applications. Some comparisons have been made between nuclear-closed-cycle MHD and nuclear-gas-turbine plants of the future as well as existing steam-turbine power systems. The results are not conclusive as there is not enough sufficiently accurate information on the efficiency, capital costs and reliability of closed-cycle MHD.

The results of economic studies carried out in the U.S.S.R. and the Federal Republic of Germany show that a fossil-fueled steam plant produces electricity that is more expensive than the projected costs for closed-cycle MHD and gas-turbine systems of the same capacity used in conjunction with a steam bottoming cycle. These 
results are based on a theoretical generator-channel model that has been proved in small-scale experimental facilities. ${ }^{2}$

In regard to the economics of liquid-metal MHD there has been an insufficient effort in regard to in-depth conceptual plant designs and economic evaluations to make any definitive statements. The major potential benefit of MHD generators is improved conversion efficiency.

\subsection{Overall Assessment of Role in Energy Supply}

MHD generators and systems are still in a very formulative stage of research and development and much work is still required. The fundamental characteristics of the generator are still not well understood and the materials problems could be extremely significant. The prospect of high conversion efficiency and the ability to use the elevated temperatures available from the combustion of fossil fuels is particularly attractive.

While the economic aspects of MHD have not been studied in sufficient detail, preliminary analysis of open-cycle plasma MHD systems indicate that future nuclear power plants may have an economic advantage over open-cycle fossil-fueled MHD plants only in areas where fossil fuel is relatively expensive. The two-phase liquid-metal MHD system has the potential to effectively employ 
a variety of advanced heat sources currently under development in the United States. These sources include the liquid-metal cooled fast breeder reactor, the fusion reactor, and the fluidized-bed combustor. 


\subsection{References}

1. Karlovitz, et al., U.S. Patent 2,210,918, August 13, 1940.

2. MHD Electrical Power Generation - 1972 Status Report, Atomic Energy Review, Vol. 10, No. 3, IAEA, Vienna, 1972.

3. F. Hals and W. D. Jackson, "Systems Analys is of Central Station MHD Power Plants," 5 th Int' 1 Conf. on MHD Electrical Power Generation, Munich, April 1971.

4. W. E. Amend, et al., "Analysis of Liquid-Metal MHD Power Cycles for Central Station Power Generation," Proc. of 12th Symp. on Engineering Aspects of MHD, Argonne, Illinois, March 1972. 


\section{B.11 SUMMARY}

The devices discussed in this Section have been or are under current investigation for fossil or nuclear electric power generation application. Comparison of these devices is shown in Table B.11-1.

Steam turbine systems (sometimes using topping cycles) also may have application to systems using other energy sources, e.g., fusion or solar. Turbine systems using low boiling working fluids such as freon and isobutane are being strongly considered for use with geothermal energy sources. The principal environmental benefit of alternative conversion devices is derived from increased conversion efficiency which reduces the amount of rejected heat and waste products and, in addition, conserves the energy source. 
Table B.11-1

ENERGY CONVERSION DEVICE SUMMARY

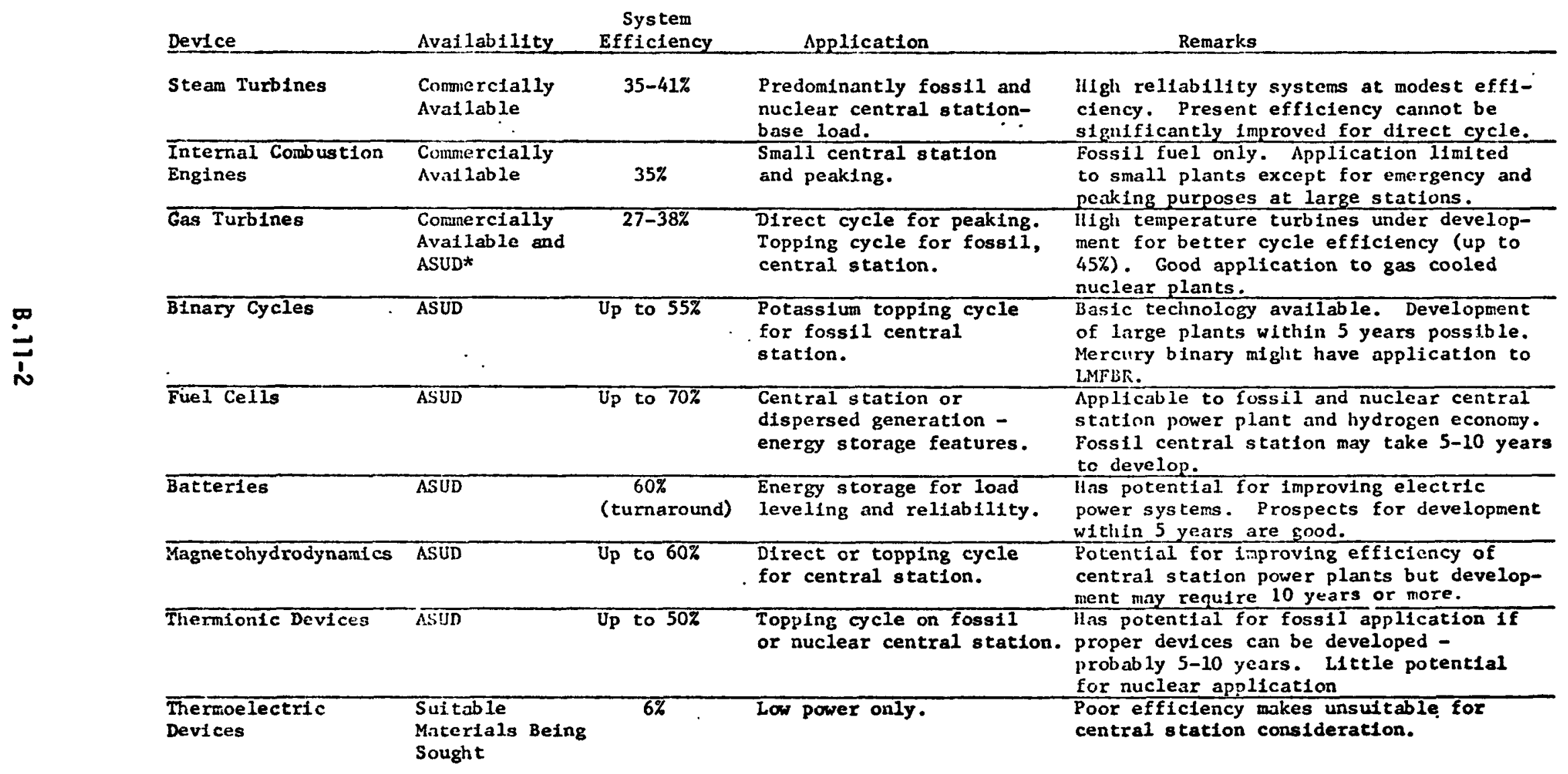

*ASUD - Advanced Systems Under Development 
C.

CONSERVATION OF ENERGY 


\section{CONSERVATION OF ENERGY \\ C.I INTRODUCTION}

In a broad sense, conservation of energy as an option for reducing the requirement for alternative energy sources is not represented solely by reduction in the production and consumption of energy. It can also be interpreted to include expansion in the utilization of readily available and environmentally-acceptable energy sources with concomitant reduction in the use of scarce or environmentallyadverse resources. In addition, actions taken to make beneficial use of energy which would otherwise be wasted (e.g., waste heat) are examples of energy conservation in that the use of this otherwise wasted energy would eliminate the need to produce this energy from other sources.

Inasmuch as the projected application of the LMFBR is for the production of electricity, the discussion in this section will be directed primarily to electric power as it relates to the several categories of energy conservation described in the preceding paragraph, i.e., it will consider the use of conserved energy as a substitute for producing power from the several types of power plants or sources discussed in this chapter.

The extent of environmental impact associated with production and consumption of electricity depends on a number of factors - the methods and efficiency of extraction of the basic energy resources needed for power generation, the methods and efficiency of power 
generation which in turn determine the quantity of energy resources needed, the quantity of power generated, and the quantity of power consumed. The following schematic drawing illustrates these categories:

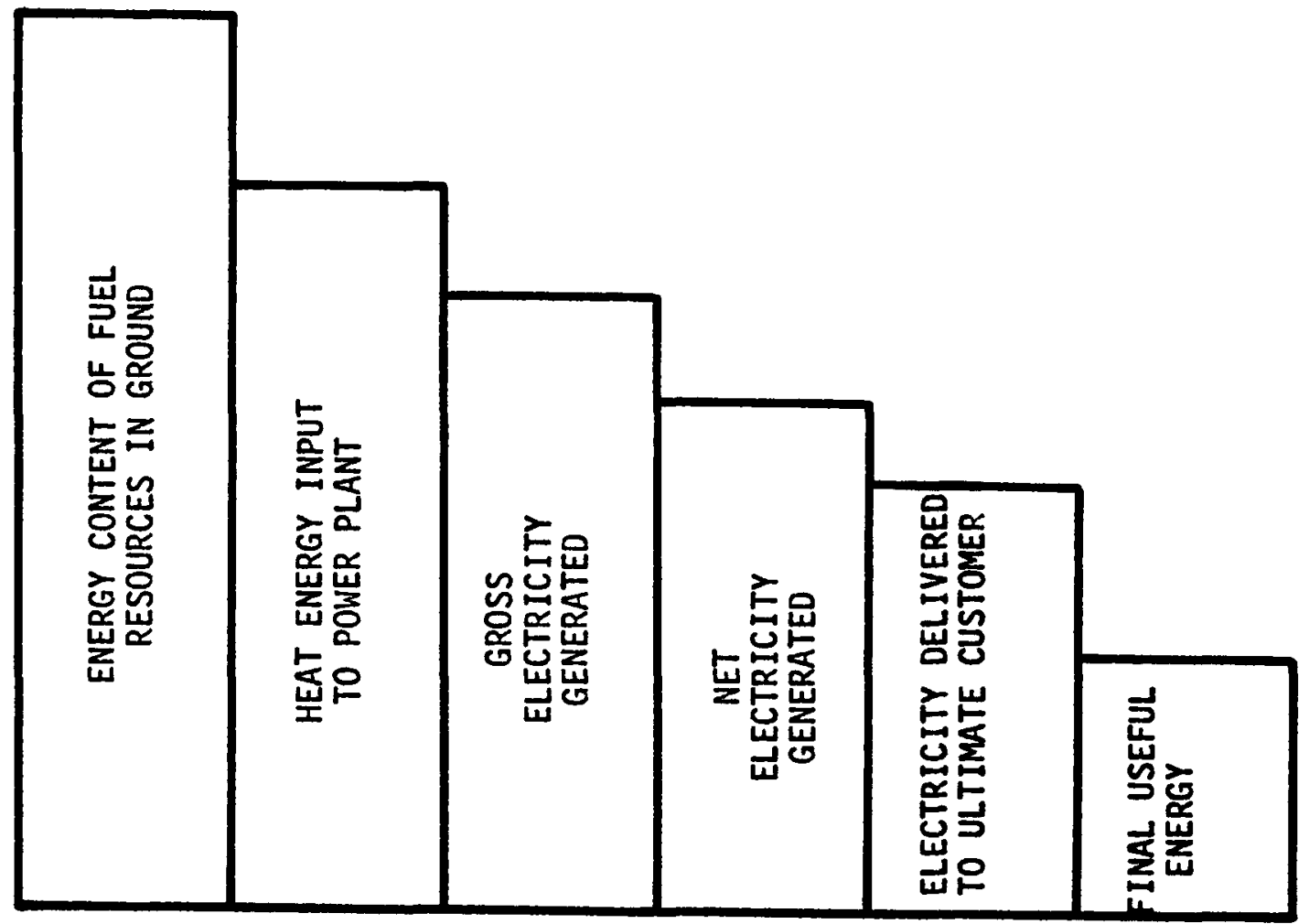

Conservation of energy would result from dropping the height of each of the bars in relation to the bar on its right, and also of lowering the last bar on the right through reduction in use of electricity.

With the exception of new energy sources (e.g., oil shale, tar sands, synthetic gas), alternative eneray systems (such as geothermal, solar, fusion power), and improved energy conversion devices (MHD, fuel cells, etc.) all of which are discussed elsewhere, this section 
examines and quantifies insofar as is feasible the principal options of conservation of energy for each of the categories illustrated above. Comments are also made on the environmental, economic, social, resources and manpower implications of the energy conservation measures considered. Finally, the amount of electricity that may be "saved" by each conservation measure is examined as an alternative to the building of additional power plants. 


\section{C.2 EXTRACTION OF ENERGY RESOURCES}

This country possesses very great resources of coal and uranium, and substantial resources of oil. Historically, extraction of these resources has been incomplete in varying degrees. Improvement in extraction efficiency would rel leve pressure on other fuels and on import requirements. Furthermore, the additional quantitity of resources would be extracted with little additional impact on the environment.

The principal potential subjects for broadening the base of extraction of fuels from present sources are stimulation of petroleum and natural gas production and increased production from underground coal mines and from uranium deposits. These are discussed below. It should be noted that an increase in the efficiency of extraction of fuels does not affect the amount of electricity that must be generated, but may reduce the need for new power plants based on other technologies, such as LMFBR.

\subsection{Stimulation of Petroleum and Natural Gas Production}

Under current technology the efficiency of extraction of oil is only about 30\%-35\%. Thus, of the approximately 425 bilition barrels of oil so far discovered in the U.S., about 290 billition barrels will remain in the ground. The development of improved extraction techniques would free a great deal of oil not only for power production but also for transportation needs, space heating, chemical feedstocks, and other applications. Importation of crude 
oil or demands on coal, gas and nuclear sources could correspondingly be reduced.

0i1 recovery efficiency has been improving at the rate of about $1 / 2$ of $1 \%$ per year. At this rate, during the next 20 years between 25 and 30 billion barrels of recoverable reserves from known discoveries would be added to domestic supplies'. If this improvement rate is to continue, it will be necessary to develop new technology as well as fully apply present technology. The National Petroleum Council has expressed the belief that a recovery rate of $50 \%$ to $60 \%$ will ultimately be achieved.

The most significant methods of stimulating recovery are fluid injection (air, gas, water, steam, miscible fluids), earth fracturing by hydraulic pressure, in situ combustion (to reduce oil viscosity and promote flow), and chemical explosives. (Nearly one million wells have been hydraulically fractured, but there is a lack of adequate knowledge of fracture characteristics and the means to make optimum use of them.) The use of nuclear explosives for oil stimulation is a possibility but has not as yet been undertaken in this country.

Although in situ combustion has not been emphasized as much as some of the other recovery methods, it appears to have considerable promise. It may find wide application in heavy-oil reservoirs. 1 
Potential adverse environmental effects of recovery stimulation include inadequate disposal of brine produced with the 0il, oil blowouts and seeps, saline water intrusion into fresh water subsurface zones, contamination of surface streams or lakes by injected water exiting to the surface, earth motion from explosives, and residual radioactivity from possible use of nuclear explosives. The refining and combustion of the additional oil produced would result in the release of sulfur and nitrogen oxides and of hydrocarbons into the atmosphere. Offsetting this would be the reduction in effluents represented by not consuming fuels replaced by the added oil and lessening of the potential for oil spills from import tankers.

A favorable environmental aspect of stimulated production from domestic oil wells is that the added production would be achieved with no significant increase in the impact caused by servicing roads, surface utilities and equipment, workers accommodations, etc.

Present projections of the use of oil in the U.S. already assume a continuing increase in extraction efficiency. Thus, if there is to be a still greater utilization of domestic oil resources, it will be necessary to intensify R\&D efforts beyond the current level of about $\$ 50$ million per year. A program outlining the expenditure of $\$ 310$ million over the next five years to increase the production of both 011 and natural gas is described in reference 3 . It includes new techniques in resource assessment, experiments in new recovery techniques, development of advanced drilling methods, etc. It also includes work on the in-situ retorting of oil shale as described in Section A.2.3. 
It is to be noted that improving oil extraction efficiency is not the same as increasing the rate of oil extraction from a well. However, the life of oil fields would be extended and more ofl could be obtained from a given field if extraction efficiency were improved. Thus, by some given year (say 2000), it may be presumed that cumulative improvement in extraction efficiency will have brought about a higher national production rate because certain fields will still be in production which otherwise would have been exhausted. How much of an impact an intensified improvement in extraction efficiency would have by 2000 is not now possible to determine with reasonable assurance. However, the increase in annual oil production would probably not exceed 5\%, or one-half million barrels per day (assuming domestic production would otherwise be 10 million barrels per day.) If all of this increase were applied to the production of electrical power, it could fuel about 20 generating plants of 1,000 WWe each. In practice, the additional ofl produced would probably be used for household, commercial, industrial, and transportation needs as well. The Interior Department projects that in the year 2000 about $7 \%$ of petroleum consumption will be for electricity production. ${ }^{3}$ At this ratio, the application of the increased oil production to power generation would yield the equivalent of one or two large generating units, about $1 / 10$ of $1 \%$ of the projected national generating capacity for that year. Another outlook on the contributions to the energy system that may be achieved if increased production R\&D is successful is provided in reference 3. 
Matural gas is obtained either from straight gas wells or in combination oil and gas wells. U.S. gross production in 1971 was 18.9 trillion cubic feet from straight wells and 5.2 trillion cubic feet from combination wells. 4

The previous discussion of stimulation of production from oil wells is applicable, also, to combination wells.

The principal method in use for stimulating straight gas wells is induced hydraulic fracturing. As with fracturing of oil reservoirs, more understanding of the characteristics of earth fractures is needed if the full potential of gas stimulation is to be achieved.

Sample field tests have been made to investigate the feasibility of using chemical explosives to stimulate low-permeability gas-bearing formations. Results range from no improvement to a 14-fold increase in flow rate. The environmental impact is expected to be minor since the detonation will not cause significant earth motion or vent to the surface. $?$

The concept of nuclear-explosive stimulation of natural gas wells is to use the rock-breaking power of the explosive to create chimneys of broken rock with diverging fractures, serving as enlarged wel1bores. Three Government-industry experiments have been conducted. The three have all demonstrated technical feasibility. Gas-recovery rates from the first two are about 7 or 8 times those of unstimulated 
wells in the same areas. ' The third is in the early stages of evaluation. Two environmental impact subjects for consideration with respect to nuclear explosives stimulation are ground motion and residual radioactivity. Careful design of the explosive, knowledge of the subsurface region, and control methods to dispose of tritiated water will be necessary. ${ }^{1}$

A Department of the Interior 1973 report, "Final Environmental Statement for the Prototype 0 il Shale Leasing Program, 15 includes a detailed discussion of nuclear stimulation of natural gas reservoirs (Page $V-87$ to $V-96$ ). Potential reserves are described as follows:

"The resource potential of the tight gas sands in the Rocky Mountain region is nearly 600 trillion cubic feet (tcf) of natural gas; the corresponding technically recoverable potential reserves have been estimated to be $300 \mathrm{tcf}$. Most of the resources amenable to nuclear stimulation are in the Green River, Piceance, and Uinta Basins. The potential reserves from these three basins correspond to about $300 \times 10^{15} \mathrm{Btu}$ or, on an energy equivalent basis, to about 50 billition barrels of oil. The rate of recovery is important when considering the reserve potential. One possible schedule being considered by AEC estimates that the annual production from full commercial development will be at just less than 100 Bcf the first year and level out at about 3.4 tcf. This would cause the basins to be drained in about 80 years." 
In view of the present and future increasingly tight supply of natural gas in relation to potential demand from the various consuming sectors, it is anticipated that the burning of gas for the generation of electrical power will steadily drop, both in actual quantities and in proportion to other uses. Gas will be looked upon as a more valuable fuel for household, commercial, and industrial uses and for chemical feedstock. The Department of the Interior projects ${ }^{3}$ the U.S. consumption of natural gas for power production and the total gas consumption to be as follows:

\section{Trillions of Cubic Feet$$
1975 \underline{1980} \underline{1985} \underline{2000}
$$$$
\begin{array}{lllll}
\text { Power } & 3.7 & 3.5 & 3.3 & 2.6
\end{array}
$$

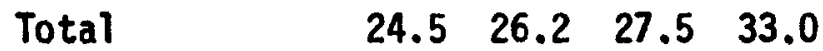

It was mentioned above that the nuclear stimulation of natural gas from tight sands could result in an eventual recovery rate of about 3.4 trillion cubic feet per year. For purposes of analysis, let us assume an additional 2.6 tcf from other methods of stimulation, or a total of 6 tcf additional natural gas available from domestic sources in the year 2000. If all of this quantity were consumed for electrical power production, it could fuel about 100 generating units of 1,000 MWe each, at an average capacity factor of $70 \%$. However, if the ratio of gas used for power production to gas used for other purposes in the year 2000 is used as shown in the table above, then the remaining gas could fuel only about eight 1000 whe 
power plants, or about $1 / 2$ of $1 \%$ of the nation's total anticipated generating capacity at that time.

All indications are that the demand for gas in future years will exceed the supply. Therefore, it is likely that increased production through stimulation of gas wells will supplement, and not replace, production from other sources, such as imported LNG, gasification of coal, etc.

\subsection{Increased Production from Coal Mines}

As of January 1, 1967 known or proved recoverable reserves of coal in the U.S. were about 390 billion tons ${ }^{6}$ (within 1000 feet of the surface and with a cutoff of 28 inches seam thickness for bituminous and anthracite and 5 feet for subbituminous and lignite.) Production and losses since that date represent only a small fraction of the total. Estimates in 1967 of total ultimately recoverable resources (including proved reserves) were about 1,605 billion tons.' This was based on an assumption of $50 \%$ recoverability from a total in the ground of 3,210 billion tons. Later estimates by the Bureau of Mines, however, are that advances in technology will increase national average recoverability to as much as $60 \%$ to $631 / 2 \%{ }^{8}$ Another source states that in the production of coal by underground methods, the generally accepted recovery rate is $50 \%{ }^{9}$ 
Coal production is presently about evenly divided between underground and surface mining. However, the trend in surface mining has been strongly upward in recent years, and down for underground mining, mainly because of the relatively high economic cost of the latter.

Different methods of surface mining include area stripping, contour stripping and auger mining.' (See Section 8.A.2 for further discussion of coal resources and mining methods.)

Area stripping is performed in flat or slightly rolling terrain (central and western U.S.) where the coal beds are continuous over large areas and often near the surface. Recovery averages about $80 \%$ but can be as high as $90 \%$. There is essentially no prospect of increasing this recovery rate.

Contour stripping is employed in the narrow valleys of the Appalachian Region. Bench cuts are made parallel to the ridges. The extent of recovery of coal from available resources varies over a wide range and is influenced by the steepness of the slopes. The depth of the bench cut is limited by the resultant height of the highwall which, in turn, is determined by the slope. Contour strip mines are usually small and short-lived. In view of the above circumstances, it is not anticipated that general improvement in recovery rates from contour strip mining will take place in the foreseeable future. 
About $3 \%$ of current coal production is from auger mining. Coal is removed from exposed coalbeds with horizontal augers (rotatina, spiral cutting tools from 18 inches to 7 feet in diameter) that penetrate to depths of about 200 feet. $^{1}$ As with contour mining, the rate of recovery from auger mining is variable, depending largely on the ground slope and size of coalbeds. Recovery ranges up to $50 \%$ but is more usually 20 to $25 \%$. There may be some improvement in this rate with industrial development of advanced equipment, but the terrain limitations in Appalachia and the anticipated continued minor role of auger mining in that region as compared to nationwide production would indicate that improved recovery would have a relatively insignificant impact.

There is, however, a possible breakthrough in technology that would maintain the efficient production of strip mining and at the same time eliminate much of the adverse environmental impact associated with strip mining. This is described in reference 1 as follows:

"...thick bedded seams of coal, for which no satisfactory underground mining method has yet been devised, might be successfully block caved by repeatedly undercutting and caving a block of coal with the augers that are now successfully and economically used in surface mining. Ninety percent or better extraction should be achieyed and coal measure rocks are sufficiently resilient so that the gradual and controlled subsidence should not 
disturb overlying rock and water tables and would scarcely be noticeable on the surface. If the concept were to be successfully demonstrated, large scale production could be achieved in a competitive range with surface mining but with minimum impact on the environment."

Underground coal mining techniques employed are room and pillar, longwall, and shortwall. In room and pillar mining, pillars of coal are left in place in the mined areas to provide support for the overlying rock and soil. Because of these pillars and of unminable coal lying under towns, lakes and highways or around gas and oil wells, the average national recovery rate has been no more than $50 \%$ to $60 \%$.

Longwall mining and shortwall mining are described in Reference 1 as follows:

"Longwall mining consists of a coal-cutter and converyor of one of several types continuously traversing a block of coal 200 to 650 feet wide and 2000 to 3000 feet long. Roof support is provided for the machine and operators by self-advancing hydraulic props but the mine roof is permitted to cave immediately after mining. Coal recovery of 80 to 95 percent and high production rates are achieved by this method but capital costs are high, 
the equipment is not versatile, and not all deposits are physically suited to longwall mining.

"The shortwall mining method is being introduced into the United States from Australia where it has had considerable acceptance. It is very similar to longwall mining with the exception that the longwall coal cutter and conveyor are replaced by conventional continuous mining machines and shuttle cars. This system is expected to find wider acceptance than longwall mining because it is somewhat more versatile and does not require as large a capital investment. Furthermore, except for self-advancing props, it utilizes equipment that most modern mines have on hand."

Longwall mining accounts for only a small portion of U.S. production today, although it is growing as shown by the following:

\begin{tabular}{cc}
$\begin{array}{l}\text { PRODUCTION FROM LONGWALL MINING } \\
\text { (Thousands of TOns) }\end{array}$ \\
\hline 1966 & 2,251 \\
1967 & 3,232 \\
1968 & 4,633 \\
1969 & 6,344 \\
1970 & 7,132
\end{tabular}


The long-term trend of methods of coal mining is uncertain. Strip mining is under fire because of adverse environmental impacts. Underground mining is becoming increasingly expensive and skilled labor more difficult to attract. For purposes of discussion the assumption is made that expanded adoption of longwall and shortwall mining and the establishment of standard procedures for the reclamation of stripped areas will be such that by the Year 2000 coal production will be equally divided between surface and underground mining.

Coal requirements for the production of electricity in 2000 are projected to be 755 million tons. ${ }^{3}$ (An additional 308 million tons is forecast as applied to the production of synthetic gas.) Under the assumptions adopted, 378 million tons each would be extracted from surface and underground sources. It has already been shown that little improvement in the efficiency of surface extraction can be expected. However, shortwall and longwall underground mining recover $80 \%$ to $95 \%$ of the coal in place as contrasted to $50 \%$ to $60 \%$ for room and pillar mining. On the assumption that shortwall and longwall mining will expand to be $50 \%$ of underground mining by the Year 2000 (189 million tons), it would be possible to extract the 189 million tons from 216 million tons of basic resource $(871 / 2 \%$ recovery) as contrasted to 344 million tons (55\% recovery) needed for the room and pillar mining, a conservation of 128 million tons. Looking at it another way, if, by the Year 2000, advantage is taken of the high recovery rate of longwall and shortwall mining by 
increasing production from the same quantity of coal in the ground as needed for room and pillar mining (344 million tons), then 301 million tons could be recovered, an increase of 122 million tons. At $92 \%$ coal processing efficiency and $99 \%$ transportation efficiency, 11 102 million tons would be available for burning under power plant boilers. At 0.9 pounds of coal per kilowatt hour this would permit the gross generation of 230 billion kilowatt hours, or about $2 \%$ of the total power generation projected for the year 2000. At an average $70 \%$ plant capacity factor, about 37 million kflowatts of generating capacity would be needed. Reference 3 projects a total generating capacity of 1,880 million kilowatts in the year 2000 .

Potentially adverse enviromental aspects of increasing coal production by short and longwall mining would include added probabilities of subsidence, increased amounts of solid wastes from coal processing, greater acid water runoffs from processing, gaseous and particulate effluents from power plant stacks, and fly ash from the furnaces.

Conversely, impact on the environment would be lessened to the extent that other fuels, replaced by the increased coal, would not be mined and consumed for the generation of electricity. 


\subsection{Increased Production from Uranium Deposits}

Since the cost of power from converter reactors varies with the cost of mining and milling uranium $(.06-.08 \mathrm{mill} / \mathrm{s} / \mathrm{kwh}$ rise for each $\$ 1 / 1 \mathrm{~b}$ rise in the cost of $\mathrm{U}_{3} \mathrm{O}_{8}$ ), whereas the cost of power from breeder reactors is insensitive to uranium costs, a major objective of the national program to bring the breeder to commercial application is to sever dependence on the limited reserves of low-cost uranium. In this respect, if the efficiency of extraction of uranium from the lowercost deposits were improved, or if incentives were established for the mining companies to mine higher-cost ores, then it would be possible to extend the time when economic power could be generated in converter reactor power plants, and defer the time when the introduction of the breeder reactor would become a matter of economic urgency.

\section{Uranium Resources and Mining Practice}

Uranium resources on January 1, 1973, were estimated by cost of production as:

\section{TONS $\mathrm{U}_{3} \mathrm{O}_{8}$}

\begin{tabular}{|c|c|c|c|}
\hline$\$ / L$ L. $U_{3} 0_{8}$ & Reserves & Potential & Total \\
\hline$\$ 8$ subtotal & 273,000 & 450,000 & 723,000 \\
\hline$\$ 8-10$ & 64,000 & 250,000 & 314,000 \\
\hline$\$ 10$ subtotal & 337,000 & 700,000 & $1,037,000$ \\
\hline$\$ 10-15$ & 183,000 & 300,000 & 483,000 \\
\hline$\$ 15$ subtotal & 520,000 & $1,000,000$ & $1,520,000$ \\
\hline$\$ 15-30$ & 180,000 & 700,000 & 880,000 \\
\hline$\$ 30$ subtotal & 700,000 & $1,700,000$ & $2,400,000$ \\
\hline
\end{tabular}


Recovery of uranium in the mining and milling processes is high, leaving relatively little room for improvement. (Milling recovers about 95\% of the resource.) However, it is common to find a wide variation in grade of the ore in a given deposit. Thus, whatever the price, substantial mineralized rock is likely to exist in the mine, too low in grade for economic extraction. Much of the higher cost uranium resources shown above is in the same deposits with $\$ 8$ per pound $\mathrm{U}_{3} \mathrm{O}_{8}$. Thus, when deposits are mined to an $\$ 8$ cutoff and then shut down, the low grade material left behind may be recoverable only at greatly increased cost, or not at all.

\section{Mining Methods}

In the U.S. uranium deposits are principally irregularly tabular ore bodies in sandstone beds, and as veins in crystalline rocks.

About 55 percent of the reserves will be mined by underground methods, while 45 percent are sufficiently shallow to be mined open pit. As drilling extends into areas where uranium is more deeply buried, greater portions will be mined by underground methods. Deposits mineable at $\$ 8$ per pound $U_{3} 0_{8}$ have been found to depths of 4,000 feet.

Open-pit mining consists of removing the overlying rock with large earth-moving equipment to expose the ore horizon and mining the ore with power shovels or backhoes. Sixty percent of 1972 production was by this method. Open-pit mining is usually done in steps with 
waste rock backfilled into mined-out areas, covering any submarginal grade mineralized material, and making it very difficult to recover later.

Underground mining is usually accomplished by vertical shafts, ore body development from drifts below the ore, and ore extraction by room and pillar methods. Rock in mine roofs is held up by roof bolts or steel jacks until ore pillars can be removed.

\section{Percentage Extraction}

Open-pit mining removes virtually all of the ore within the pit. Lower grade ore from the pit is often stacked for possible future treatment.

Underground mining practices produce a recovery of 80 to 90 percent of the uranium ore. Sometimes the ore removed may exceed estimates, as development frequently discovers uranium not included in original estimates. Recovery can be improved with new mining technology, chiefly by lowering mining cost and thereby increasing the quantity of ore available at acceptable cost.

\section{Impact of Uranium Mining on the Environment}

The area disturbed by production of uranium for a 1,000 MWe LWR with Pu recycle for 30 years using 53 percent of requirements from open pits and 47 percent from underaround mines is estimated at 210 to 290 acres. Disturbed ground includes area within confines of the pit, 
waste dumps, and bufldings; open pit operations accounts for most of the disturbed area. An additional 80 acres would be disturbed by the treatment plant.

Figure C.2-1 compares the relative acreage disturbed by uranium production under current practice with coal and oil shale produced to fuel a comparable power plant. A large proportion of the areas of disturbance can be restored after mining is completed, and put to other uses.

As the demand for uranium steadily increases with the growth of nuclear power, and with the concomitant reduction in reserves of low-cost ore, the economic forces of the marketplace will provide the incentive for mining companies to extract the more expensive ores, próbably as high as $\$ 30 / 1 \mathrm{~b}$. (Note that in an LWR $\$ 30 / 1 \mathrm{~b}$. $\mathrm{U}_{3} \mathrm{O}_{8}$ will raise the power cost over present levels by less than 2 mills/kwh.) However, in the interim and as described above, a considerable quantity of the higher-cost ore associated with lower-cost ore which has been mined will not be recoverable or will be recoverable only at greatly increased cost. Conservation of a significant portion of this otherwise wasted resource will require not only improved mining technology but also near term incentives to extract ore at higher costs than economically feasible in the conmercial market. 


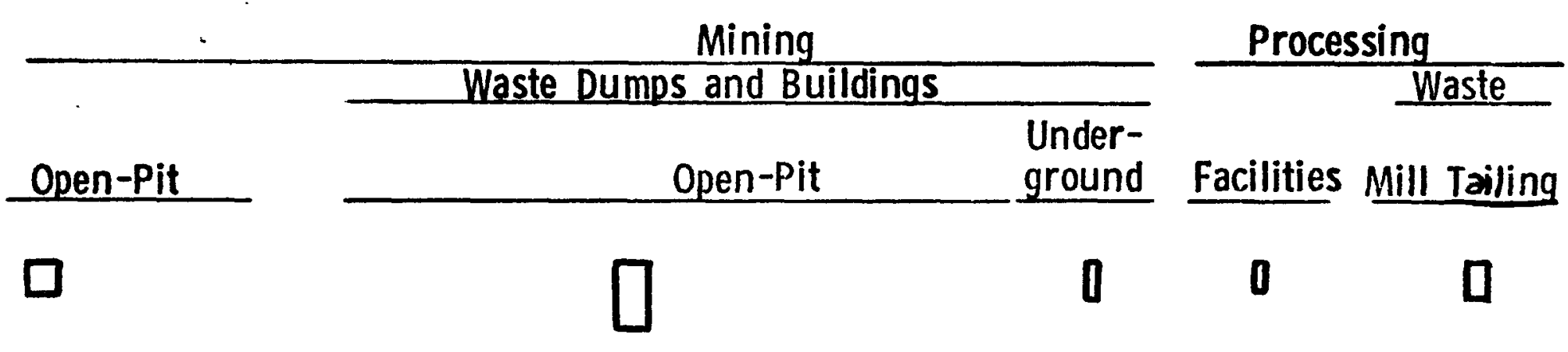

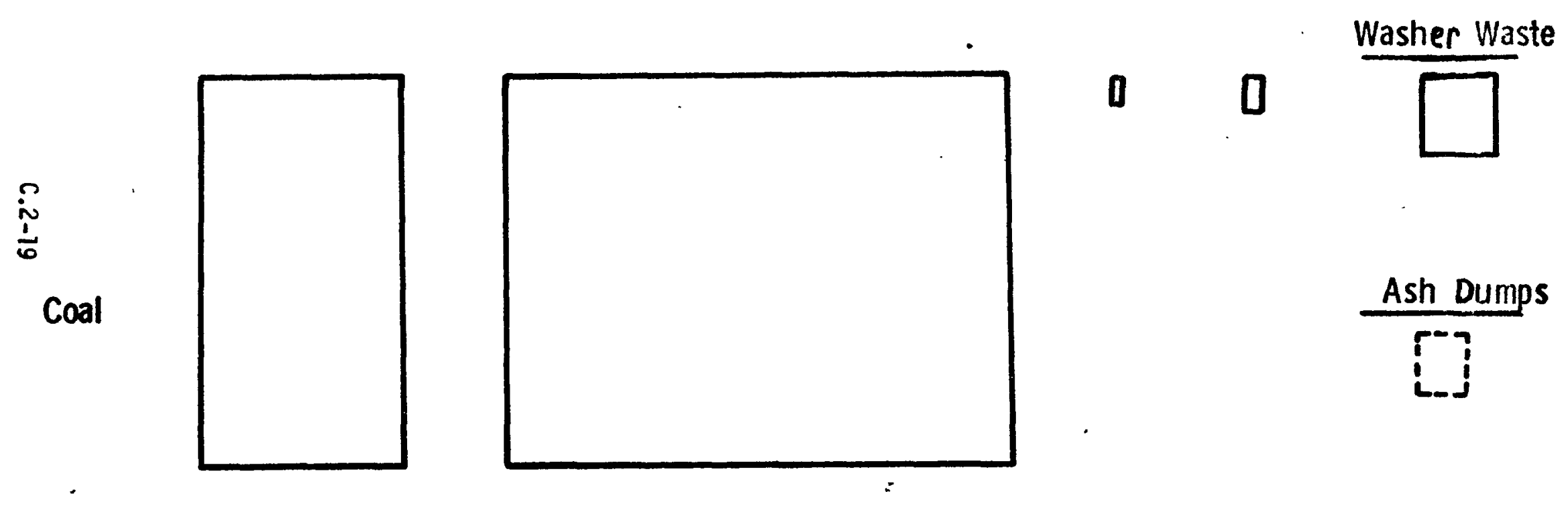

Oil Shale

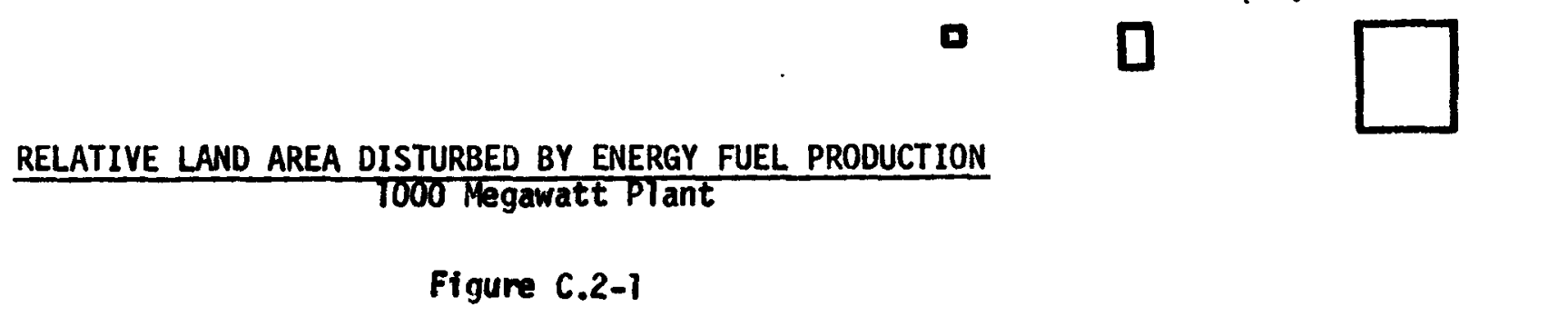


As shown in Figure C.2-2, it is projected that up to 1990 about 170,000 tons of the presently known reserves of uranium in the $\$ 8-15$ range will be lost by the mining of $\$ 8$ and under uranium.

For purposes of estimating the potential for conservation, assumptions are made that (a) losses in the $\$ 15-30$ range will be in the same proportions to $\$ 8-15$ losses as the respective reserves and (b) improved mining technology plus the establishment of incentives to extract the higher-cost ore will result in the "saving" of onethird of the uranium in the \$8-30 range that would otherwise have been lost to use. The resulting saved amount is about 100,000 tons.

In a light water reactor a ton of uranium mined will provide the fuel for the generation of about 40 million kwh. Thus, the 100,000 tons of potential resources savings could have the capability of producing nearly 4 trillion kwh in LWR's, or the output of twenty 1,000 MWe units operating at $75 \%$ capacity factor for 30 years.

\subsection{Summation of Potential For Improving Efficiency of Extraction of Energy Resources}

The preceding discussion has developed the hypothesis that if all available steps are taken in a timely fashion to improve the efficiency of extraction of eneray resources, the resulting annual increase by the year 2000 in the availability for electricity production of each of the fuels could be approximately as follows: 


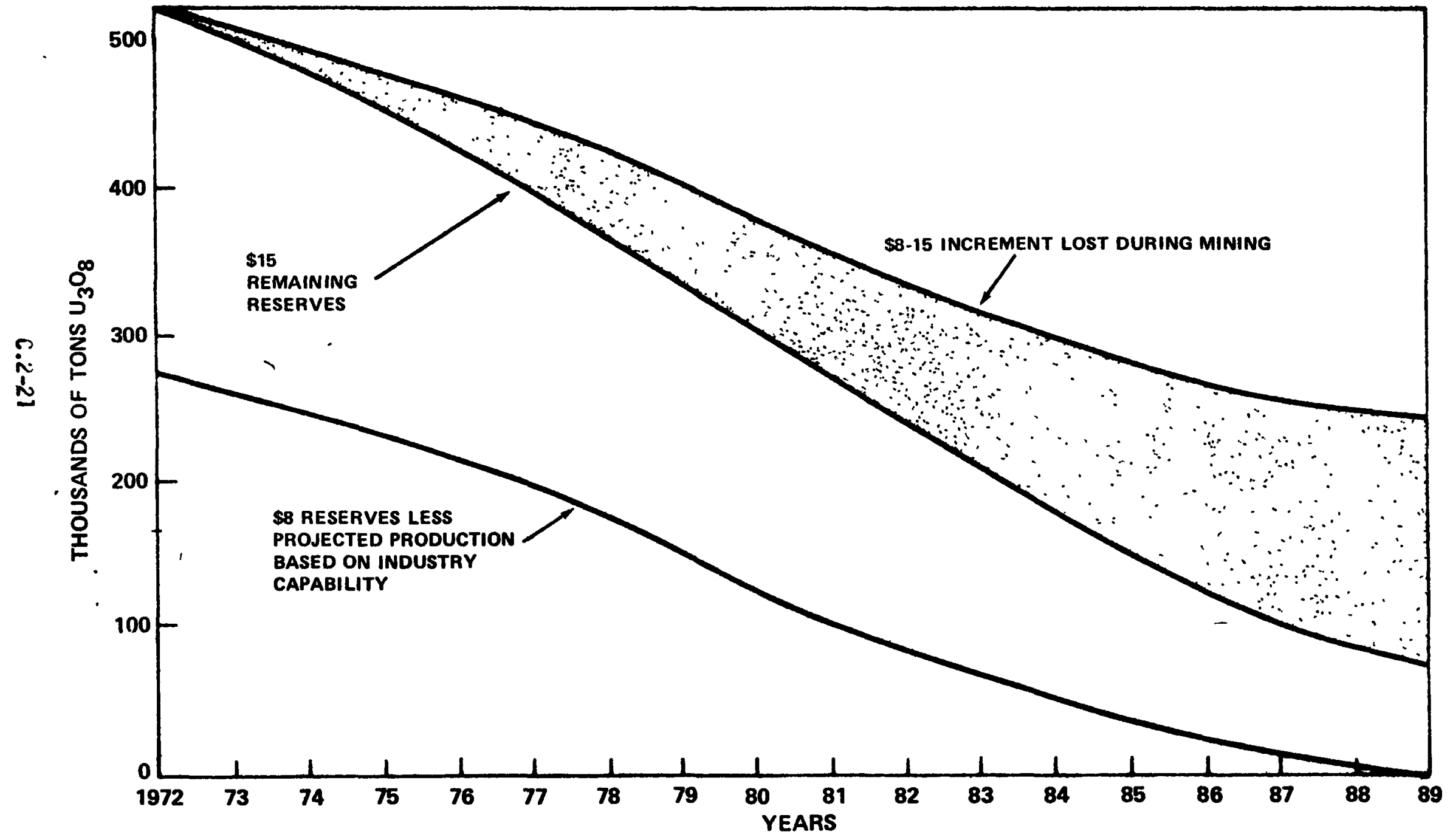

DEPLETION OF \$15 RESERVES AS \$8 RESERVES ARE MINED OUT

Figure C.2-2 
011

- 13 million barrels*

Gas

- 1/2 trillion cubic feet*

Coal

- 102 million tons

Uranium

$-3,300$ tons $^{\star \star}$

Application of each of the above quantities as fuel for power plants operating at an average of $70 \%$ capacity factor and $36 \%$ thermal efficiency would represent the following additional generating capacity:

\begin{tabular}{|c|c|}
\hline & MWe \\
\hline 011 & 1,300 \\
\hline Gas & 8,900 \\
\hline Coal & 43,800 \\
\hline Uranium & 21,500 \\
\hline Total & 75,500 \\
\hline
\end{tabular}

To put this 75,500 megawatts in perspective, comparison may be made to the following forecast ${ }^{13}$ :

Installed U.S. Generating Capacity For The Year 2000

$\begin{array}{lc} & (1000 \text { megawatts, electrical) } \\ \text { LMFBR } & 400 \\ \text { Other Nuclear } & 800 \\ \text { Non-Nuclear } & 800 \\ \text { Total Nuclear and Non- } \\ \quad \text { Nuclear }\end{array}$

\#Using the proportional application for electricity production as projected by the Interior Department in Reference 3. Total added availability would be about 14 times as much for oil and 13 times for gas.

**The 100,000 added tons extracted to the year 1990, extended over 30 years of power plant life. 


\section{C.3 PONER PLANT ENERGY CONVERSION EFFICIENCIES}

\subsection{Fossil-Fuel-Fired Steam-Electric Plants}

As noted in section 8.B.2, the efficiency of a turbine-generator generally increases with increase in the temperature of the steam supplied to the turbine. An increase in generator efficiency results in more electricity being produced for the same amount of fuel (or the need to use less fuel to produce the needed amount of electricity), and is therefore an obviously desirable characteristic. However, the necessary associated costs of temperature and corrosion resistant materials also go up as efficiency (and therefore temperature) increases. The current economic balance between efficiency and materials cost is about $1000^{\circ} \mathrm{F}$ steam at 3500 pounds per square inch (psig) pressure, and with $1000^{\circ} \mathrm{F}$ reheat. A modern ofl-burning unit using these steam characteristics can be expected to convert about $37.5 \%$ of the heating value of the fuel to electrical energy reliably and economically at present fuel costs. The corresponding efficiency for a modern coal-burning unit is about $39 \%$. The efficiencies would be raised about $1.5 \%$ if the min and reheat temperatures were increased to $1100^{\circ} \mathrm{F}$. The technology for this does exist and a few units are in service. Decisions to add more units at $1100^{\circ} \mathrm{F}$ will depend largely on future trends of fuel costs and of materials costs.

An efficiency as high as $44 \%$ could theoretically be obtained if it were practicable to use main and reheat steam at $1400^{\circ} \mathrm{F}$ temperatures. Various exotic alloys have been tested in trial installations up to 
$1200^{\circ} \mathrm{F}$, but none of these tests have been continued for a long enough period to demonstrate acceptable stability. Considerable further research and development on corrosion and erosion resistant materials, on the dissociation of steam at high temperatures (physical breakdown into hydrogen and oxygen molecules), and on the harmful effects of steam dissociation on pipe and tube materials will be necessary. Additional time would then be needed to meet learning, production and construction requirements.

Another method for improving the energy conversion efficiency of steam-electric plants is steam reheat. Today's power plants normally reheat the steam part way through the turbine. A second reheat could add about $2 \%$ to the efficiency, and a third reheat another $1 \%$. Such additional reheat would involve higher capital costs and more complicated installations with resultant risk of reduced reliability. For example, it would be necessary to increase the pressure from 3500 psig to about 5500 psig and to use heavier walled vessels, pipes, and tubes.

The Interior Department projects that 2,840 billion net kilowatt hours (KWh) of electricity will be generated in the Year 2000 by fossil fuel burning plants with a total capacity of 820,000 megawatts. ${ }^{3}$ It is, of course, purely speculative to attempt to predict what portion of this capacity will be from plants incorporating some or all of the advanced steam improvements described in this Section. However, to develop an approximate 
estimate, the assumption is made that $80 \%$ of the generation (or 2270 billion KWh) will be from large, base-loaded units, that $50 \%$ of this (or 1135 billion KWh) will be from units of recent enough installation to be able to utilize the results of R\&D and conmercial development necessary for the high steam temperatures and pressures, and that the average increase in efficiency of these units will be 5\%. Under these assumptions, for the same heat energy input, the advance design fossil plants would generate 1190 billion KWh, or an increase of 55 billion KWh. This increase is about $1 / 2$ of $1 \%$ of the total electricity projected to be generated in the Year 2000. Thus, it is seen that improvements in conversion efficiency of the type discussed above will not be of major impact in meeting our future electricity requirements. It should also be noted that the installation of higher-efficiency equipment would mean a greater demand for exotic alloying materials, higher capital costs, and the possibility of reduced reliability of operation.

Favorable environmental impact aspects from efficiency improvements would include reduced waste heat discharge because of the higher plant efficiencies, and reduction in power production from steamelectric plants not equipped with the high-efficiency turbinegenerators.

The effect on manpower requirements should be minor with some increase, however, for the production of metals for the heavierwalled vessels, pipes, and tubes, and for the shop fabrication of more complex equipment. 


\subsection{Nuclear-Fueled Steam-Electric Plants}

The probability of significant improvement in the thermal efficiency of light water reactor (LWR) nuclear power plants is low. This is primarily because the steam temperatures are necessarily 1 imited to the present low levels (about $600^{\circ} \mathrm{F}$ ) which are in turn dictated by physical 1 imits on the operating temperature of the fuel element cladding material (zircalloy). Other cladding materials (such as stainless steel) could withstand higher temperatures but would cause reduced neutron utilization.

It is possible, however, that additional reheat stages will be added to some future LWR plants, with resultant modest increase in efficiency accompanied by added investment costs and potential for reduced reliability. It is to be noted that the relative stability of fuel costs for LWR's as contrasted to the fossil fuels weakens the incentive of utilities to add reheat stages.

If, for the purpose of analysis, it is nevertheless assumed that added reheat stages will be incorporated to the extent that the average efficiency of LWR's will be increased $1 \%$ to $2 \%$ by the Year 2000, then for the same heat energy input an additional 49 billion kilowatt-hours, or about $1 / 2$ of $1 \%$ of total generation, would be generated by LWR's in that year. This figure is derived by using the current projection of 5,470 billion kilowatt hours of nuclear generation in $2000^{3}$, assuming $60 \%$ is from LWR's ${ }^{13}$, and adding $11 / 2 \%$. Nevertheless, as in the case of foss $i 1$ fueled 
plants, improvements in energy conversion efficiency are not expected to contribute significantly to meeting electricity demands.

\subsection{Utilization of Waste Heat From Power Plants}

On the average, about two-thiris of the total eneray output of thermal-electric power plants is released to the environment as waste heat. Byproduct utilization of this waste heat would not only bring about some reduction in thermal impact on the environment but would also improve the electrical conversion efficiency through a net increase in energy use.

In 1971 waste heat from thermal power plants totalled nearly 10,000 trillion Btu, the energy equivalent of 1.7 billion barrels of oil. By the Year 2000, without beneficial uses, it is projected that the total will be in the range of 45,000 to 60,000 trillion Btu, ${ }^{3,14}$ or the equivalent of 7.5 to 10 billion barrels of oil. These quantities will represent $20 \%$ to $30 \%$ of the Nation's total gross input of energy.

Possible uses of waste heat from power plants fall into the following general categories:

- Agriculture (open field cultivation, greenhouses, animal shelters)

- Aquaculture (shell and fin fish) 
- Space heating and conditioning (including snow and ice melting)

- Low temperature industrial process applications (including distillation of sewage plant effluent and materials drying)

While the underlying principles and technology exist for most of the potential applications, there has been only minor implementation for a variety of reasons, including the following:

1. Economic restraints (for example, the capital investment required for a given project may outweigh the benefit of low-cost energy).

2. Seasonal aspects (the power plant may discharge waste water at a relatively high temperature in the summer months when the user does not need it, and at a low temperature in the winter when heat is required).

3. Scheduling (the user may not be able to do without the heated water when the power plant is in a scheduled or unscheduled shutdown. To compensate, provision needs to be made for switching to an additional unit at the power station, for an auxiliary heat supply at the user site, or both).

4. Siting (because of loss of waste water heat in transit, most operations need to be conducted adjacent to or in close proximity to the energy source. In many instances 
it will not be feasible to locate the power plant near a potential user or vice versa).

5. Heat quantities involved (for the most part, the quantity of heat used or needed for an individual application is only a small fraction of the heat rejected at a typical central station power plant).

6. Quality of heat involved (the use of thermal energies for space heating, ice removal or prevention, industrial process applications, etc. is generally at higher temperatures than the $100^{\circ} \mathrm{F}$ or below normally associated with waste heat. 15 To compensate, higher investment and operating expenditures would generally be needed).

7. Utility restraints (to permit productive use of waste heat, changes may be required in the regulations that specify how a utility may function as an operating company. ${ }^{5}$ Complications as to rate schedules may arise). ${ }^{16}$

8. Coordination requirements (for a major potential use of waste heat, such as for an urban eneray center, it is necessary to achieve coordination of planning and implementation among numerous entities to a very substantial degree).

Rising fuel costs and intensified public concern with thermal pollution are apt to incite increased efforts to apply power plant condenser cooling water to useful applications in spite of the 
problems enumerated above. Just how widespread this utilization will be is impossible to predict with any confidence because of the complexity of interrelations among affected parties and the diversity of potential users. Opinions vary from pessimistic to mildly optimistic. A related indeterminate factor is the extent to which this waste heat will be used to replace energy that would otherwise be generated from some other source, as opposed to using the waste heat as a source of energy for an application or process that otherwise would not be employed. The relative amount of "replacement" versus "new" uses for waste heat is difficult to predict. Some understanding of the questions involved may be obtained from the discussion of some potential waste heat applications which follows. The coverage is necessarily brief because of limitations of space, but a number of documents have been published on the subject, some of which are included in the references 1 isted at the end of this Section.

\subsubsection{Agriculture}

\section{Open-Field Cultivation}

"Thermal effluents from power plants potentially can be used in open-field agriculture to promote rapid plant growth, improve crop quality, extend the growing season, and prevent damage due to temperature extremes. Water, used for both irrigation and heating, can be applied through nozzles (spray irrigation) or through subsurface porous pipes. With these systems the farm acts as a large, direct-contact heat exchanger for the power plant, while the 
utility provides irrigation water to the farmer". 17 This application has two significant advantages. Temporary interruptions to water flow due to power plant shutdowns can usually be tolerated, and the capital investment required is relatively modest. Potential problem areas include economic risks due to undemonstrated techniques and crop yields on large farms over extended operating times, possible side effects relative to plant disease and pest control, the limited number of power stations located in rural areas where inadequate rainfall requires irrigation or where soil warming features could be advantageously used, potential radioactive contamination from use of water from nuclear plants, unavailability of heated water for frost control during periods of power plant shutdown, equating the quantity of water that could be beneficially utilized with the quantity discharged, water consumption through evaporation and transpiration (though this would be weighed against the alternate choice of cooling towers), and legal restrictions resulting from the combination of power production and irrigation. 17

Irrigation water volume requirements vary widely depending on the time of year, the crops being grown, and the geographical location. For the U.S., the maximum would be about 10.6 inches during the month of July for such crops as cotton, peanuts, soybeans, sorghum, and beans. ${ }^{18}$ Assuming a $20 \%$ deep percolation and evaporation loss, the amount of water required from the power plant would thus peak at about 12,000 gallons per day per acre. Since the condenser cooling water circulation through a 1,000 MWe steam-electric 
generating unit is about 1 to $11 / 2$ billion gallons per day, as much as 80,000 to 120,000 acres would be needed to fully utilize the waste water from the unit. Power requirements for pumping would be about 204,000 horsepower ${ }^{18}$ or the equivalent of 152 MWe.

Where soil heating is applied it has been estimated that a 1,000 Me plant, utilizing a closed-cycle cooling system with a 500-acre evaporative cooling basin, would provide the soil heat for a 5,000 acre farm ${ }^{17}$. The Federal Power Commission projects that 160,000 MWe of steam-electric generating capacity (fossi) and nuclear) will be added in the western part of the U.S. during the period 1971-199019. If the assumption is made that $10 \%$ of the new plants will be at sites in proximity to extensive agricultural areas, and further that these areas require soil heat, then there would be a potential for the application of power plant water discharge to about 80,000 acres of farmland.

\section{Greenhouses}

The principal incentive for the use of power plant condensate in greenhouses would be to the grower through reduction in eneray costs. Benefits to the power plant operator (abatement of thermal pollution by means of a substitute heat rejection system, and a market for waste heat) would be limited by the size of the greenhouse installation. 
Estimates of the heat consumption in greenhouses range from 11,000 Btu/minute/acre ${ }^{17}$ to $80,000 \mathrm{Btu} /$ minute/acre ${ }^{20}$. If we adopt a median value of 45,000 and assume that one-fourth of the heat in the condenser cooling water will be absorbed in the greenhouse before the water is discharged to a cooling tower, cooling pond or the original source, then 250 acres of greenhouses could use the cooling water from 400 Mhe of generating capacity. (6824 Btu of waste heat in the water per kilowatt-hour generated.) The capital investment for the greenhouses would approximate $\$ 25$ million ${ }^{17}$. One percent of the projected steam-electric generating capacity of about $1,600,000 \mathrm{MW}$ by the Year 2000 could thus accommodate 10,000 acres of greenhouses. About 7,000 acres of greenhouses are in production today in the U.S.

Provisions would be needed for disposition of waste heat during summer months. Alternatives include full utilization of the power plant standard cooling system, cooling of the greenhouses by the use of evaporative pads, and open-field irrigation if siting circumstances permit the proximity of large fields and if irrigation is needed.

The following additional comments are found in Reference 17.

\footnotetext{
"There are many unanswered questions concerning the use of waste heat from power plants. Chemicals such as chromates used for water treatment in the cooling water system might affect the plants in a greenhouse. Simflarly, the pollen
} 
from the greenhouse could possibly affect the cooling system. The determination of whether such effects will occur requires experimental studies. In the case of nuclear plants the real and imagined hazards of radioactivity must be considered, and public acceptance of products produced in such greenhouse complexes would have to be analyzed. Potential sources of activity in the cooling water would have to be considered and measuring devices installed to continuously monitor the water for radioactivity.

"The most difficult questions to resolve appear to be those of institutional arrangements necessary for the financing and operating of such an enterprise in conjunction with the operating of a power plant. The organization and training of the greenhouse operating teams, agreements with the utility on shutdown schedules, provision for auxiliary heat supply, and protection of the power plant coolants from loss or fouling are several of the important problems. If risk insurance is common to greenhouse operation, the degree to which it might be affected by coupling to a power plant for heat would have to be determined.

\begin{abstract}
"All of these questions point to the necessity of conductina research or studies to resolve uncertainties which now exist. Although engineering questions can be resolved fairly easily, these and the bilogical and economic questions require demonstration projects with crops in a oreenhouse facility."
\end{abstract}

Animal Shelters

It has been well established that knowledgeable control of temperature, humidity, and ventilation in shelter can significantly increase the feed efficiency (pounds gain/pounds feed) and growth rate of the smaller farm animals. ${ }^{17}$ Waste heat from power plants can be used for animal shelter temperature control (heating in winter, evaporative pad cooling in summer) al though this has been tried out only in experimental and research projects to date. 
The waste heat from a $1000 \mathrm{MW}(\mathrm{e})$ plant is sufficient to brood almost one billion broilers annually or farrow and finish about 10 million hogs. Since a typical broiler operation currently produces about 50,000 birds a year and a large hog operation about 5,000 pigs a year, it is apparent that the potential for conservation of energy in this application is very minor. However, there are advantageous prospects of reducing user feed and fuel costs, increasing food production, and reducing or dispersing to some extent the environmental impact of power plant thermal effluents.

There are also some problems associated with the use of condenser cooling water for animal shelter temperature control, and these would have to be thoroughly investigated before a commitment could be made to large-scale waste heat applications.

\subsubsection{Aquaculture}

Webster defines aquaculture as, "The culture of sea, lake, and river foodstuffs, such as fish, oysters, seaweed, etc." Among the needs for successful aquacul ture are temperature control, nutritious but inexpensive feed, fish waste control, and adequate oxygen supply. 17

Thermal aquaculture involves the use of heated effluents to maintain optimal temperatures for growth and to produce high yields. In recent years power plant coolant water has been applied to aquaculture in a few instances. (Oyster culture on Long Island, lobsters in Maine, 
catfish in Texas and Tennessee, shrimp in Florida and a variety of species in Japan.) There is need for much more experimental and demonstration data to form a firm basis for commercial expansion. The potential depends not only on technical feasibility but also on market conditions. For example, the present U.S. per capita fish consumption of $10 \mathrm{lb} / \mathrm{yr}$ (as contrasted to Japan's $100 \mathrm{lb} / \mathrm{yr}$ ) might increase as a result of the development of a new aquacultural industry based on advanced technology. It has been projected 17 that by the Year 2000 as much as $2 \%$ of heat effluents from U.S power plants may be applied to thermal aquaculture. (Assumes 10\% of the total $10 \mathrm{lb} / \mathrm{yr}$ per capita consumptions will be supplied by thermal aquaculture.) Corresponding land requirements would be about 15,000 acres $(20,000 \mathrm{lb}$ live product/acre-year.)

The use of power plant effluent for aquaculture could present a few problems, as follows:

a. To assure reliability of heat supply, backup sources should be available in the event of power unit outages. Capability to switch rapidly from one source to the other is essential to prevent sudden temperature changes.

b. Uncorrected chlorination in the coolant water might have toxic effects. 

c. At temperature over $100^{\circ} \mathrm{F}$, copper concentrations might occur in the discharge water.

d. Water used from nuclear plants must be free of radioactivity.

e. Provision must be made for treatment of fish wastes.

f. Legal and regulatory requirements with respect to water rights and discharge of heated water must be met.

With respect to conservation of energy, the principal favorable feature of using power plant effluent for thermal aquaculture would be the elimination of the need to supply the necessary large quantities of heat from other sources. Power would be required, however, for pumping purposes and for fish farm utility services.

Thermal aquaculture will not diminish the amount of waste heat to be rejected from a power plant. The amount of heat finally returned to the water source would, however, be reduced to the extent of absorption in fish ponds, tanks or troughs and of dispersion to the air during channel flow. Also, reduction in adverse environmental impact would take place through elimination of mining, processing, transportation and use of such fuels as would have been used to generate heat for thermal aquaculture if power plant waste heat were not used. 


\subsubsection{Urban Use}

Energy in the form of heat may be applied to urban requirements in several major categories. Included are space heating, water heating, air conditioning, sewage treatment, and industrial process steam consumption.

Heat supplied by an electric power plant can be "waste heat" or lowtemperature heat. The former is the heat contained in the condenser cooling water and is normally at temperatures below $100^{\circ} \mathrm{F}$. The latter is heat in steam obtained from either an "extraction" turbine or a "back-pressure" turbine. In an extraction turbine a portion of the steam is removed at some point along the turbine after the steam has generated considerable electricity. With a back-pressure turbine, all of the steam is extracted after it has reached some desired temperature and before its full energy has been used for the production of electricity. Typical temperatures of extraction of backpressure steam put to beneficial use would be in the range of $200^{\circ} \mathrm{F}$ to $300^{\circ} \mathrm{F}$. Al though the efficiency of electricity production would be reduced by the extraction of steam, overall efficiency of energy use would be improved. Thermal and air pollution would be reduced and fuel conserved.

For urban needs it appears that the potential for beneficial uses of waste heat from power plants is quite limited in comparison to the potential for the use of low-temperature heat. Since modern power plants utilize all the energy that can be economically extracted 
from the fuel, the heat released to the environment from these plants is only a few degrees (10 to 30 degrees) above ambient temperatures. The ability to effectively use heat is a function of the temperature difference that is available, and when the difference is small it is usually expensive and difficult to take practical advantage of it.

A possible application would be district space heating and air conditioning by conveying the heated water through a piping system to residential and commercial buildinas. Since the temperature is relatively low, substantial flow volume would be required. This, in turn, would necessitate larger piping capacity and pumping power than for an equivalent system using low-temperature steam. Heavy insulation would also be needed to minimize temperature loss with increasing distance from the power plant. The practicality of going to higher temperatures is illustrated by the district heating installation in the City of Vasteras, Sweden, where the water emerges from the plant at $175-265^{\circ} \mathrm{F}$ and returns at $130-150^{\circ} \mathrm{F}^{21}$, the geothermal system at Reykjavik, Iceland; with water at $194^{\circ} \mathrm{F}$, and the Montreal Airport at $375-400^{\circ} \mathrm{F} .22$ The heating of secondary sewage treatment plants during the winter with waste heat from steam-electric plants is now being seriously considered for accelerating the process ${ }^{21}$.

There are a number of additional potential beneficial urban uses of power plant waste heat which, however, represent relatively minor or short-term energy usage and high capital costs. These include city street and sidewalk snow and ice removal, airport de-fogging, and 
airport de-icing. For example, the thermal discharge from a 1,000 Me plant could de-ice over two square miles of runway. 22

With respect to the beneficial urban use of low-temperature steam from power plants, the potential applications are all those described above for waste heat plus at least two significant additions industrial processing and the distillation of sewage. The objectives of distilling sewage would be twofold - demineralization and (if needed) enhancement of usable water supply. A model ORNL design ${ }^{23}$ indicates a heat requirement of $1.2 \mathrm{million}$ Btu/hour and a power need of $6 \mathrm{MW}(\mathrm{e})$ for a distillation plant to supplement the natural water supply for a city of one million people. If, for purposes of arriving at an approximate projection of the potential impact, it is assumed that by 2000 an urban population of $150,000,000$ will be served by such distillation plants, then the total heat energy input would be about 180 million Btu/hour, or (at 8,000 hours operation per year) the equivalent of 240,000 barrels of oil per year. More significant than the relatively modest conservation of fuel would be the contribution to the preservation of the quality of surface waters by the removal or reduction from sewage effluent of mineral contaminants such as ammonia, nitrates and phosphates. The concentrated solid waste resulting from distillation can be incinerated for heat recovery, or possibly used as fertilizer ${ }^{23}$. Considerably more research is needed, however, to overcome potential difficulties such as fouling of waste demineralization processes by organics or the control of ammonia and other volatiles. 
Energy applied to industrial processes can be in the form of direct heat, process steam, or electricity. The production of process steam accounts for about $41 \%$ of industrial fuel consumption or $17 \%$ of total national fuel consumption ${ }^{24}$. To obtain a significant portion of this steam from the turbines of electric power plants rather than by direct combustion of fossil fuels under bollers at the industrial facilities would result in a considerable overall net saving of energy. For example, consider the hypothetical case of a turbine fully utilized for electricity production with a thermal efficiency of $40 \%$. If an equivalent extraction turbine is now considered with the point of extraction being selected so that the removed steam would have energy equal to $35 \%$ of the heat input to the turbine, the thermal efficiency of electrical production would drop from $40 \%$ to $35 \%$, but the overall efficiency of energy use would be about $70 \%$ (35\% plus $35 \%)$ rather than $40 \%$. Similarly, with a back pressure turbine designed for $250^{\circ} \mathrm{F}$ exit steam, the electrical efficiency would drop to $30 \%$ but the overall efficiency of energy use could be as high as 100\% depending on how effectively the exit steam is used.

The Interior Department projects a total energy input to the industrial sector in the Year 2000 to be 58,000 trillion Btu, or 42,000 trillion Btu if electricity is excluded. ${ }^{11}$ Assuming that the current $47 \%$ share for process steam will also pertain in 2000 , there would be a theoretical maximum potential for the application of low-temperature steam from central station power plants to as much as 24,000 trillion Btu of industrial processing, or the 
equivalent of about 4 billion barrels of oil. The feasible level of application will be considerably less due to a number of factors, including the following:

a. The steam source needs to be near the user. Losses in transit require higher initial steam pressures and temperatures, as well as increased capital investment in piping, with greater distances. As the cost of fossil fuels increases, the incentive for capital investiment in low-temperature steam Tines will increase.

b. Most individual industrial plant process steam requirements are in quantities that are minor compared to the steam production capability of a modern power plant. One of the few exceptions is the Midland Nuclear Plant, currently under construction, which is planned to deliver 4 million pounds of process steam per hour to the adjoining Dow Chemical Company and, in addition, to produce 1,300 MWe of power from two units. These units, without extraction of steam, would have the capability of producing 1,600 Mhe of power. Thus, the supply of process steam to meet the needs of one of the Nation's largest chemical complexes is equivalent to only 300 MWe of electric power supply. 
c. Most industrial process steam use is concentrated in a few industries. Estimates of the percentage breakdown of industrial process steam usaqe in 1980 are: $:^{23}$

Chemicals and allied products

Petroleum refinery and related industries

Paper and allied products

Food and kindred products

other industries

d. The petroleum refinery and related industries for the most part utilize internally produced fuel for processing requirements. One outstandina exception is the linkage for the past fifteen years of the Linden Generating Station of Public Service Electric and Gas Company with the Baywater Refinery of Exxon. Desianed to achieve improved economy of operation by providina extraction steam for refinery purposes, it offers the equally valuable gain of raising the reported heat efficiency of the generation cycle from $39 \%$ to $54 \%$. This is equivalent to reducing the waste heat burden on the environment by $25 \% .^{16}$ A similar situation of internal fuel generation occurs to a lesser degree in the paper and allied products industry. 
With increasing incentive to use extraction steam in view of rising fuel costs, it is possible that industry, by the Year 2000, might be obtaining as much as $10 \%$ of its process steam from power plants, in spite of restrictions 1 isted above. The actual degree of utilization is, of course, impossible to project with confidence. However, only $10 \%$ would still have the eneray equivalent of more than one million barrels of oil per day. Partially offsetting this would be the need for more power plant capacity and the consumption of more power plant fuel to compensate for reduction in efficiency.

Advantages accruing to a utility as a result of furnishing process steam would be additional income (Consolidated Edison Company of New York reported $\$ 83$ million total steam sales in 1972) and disposal of waste heat. A principal advantage to the user would be lowercost energy. The public would benefit through conservation of fuel resources and less thermal impact on the environment. It is not anticipated that there would be a significant reduction in the use of electricity since there are few examples in industry of process steam being substitutional for electric heat. 


\section{C.4 GROSS VS. NET GENERATION OF ELECTRICITY}

\subsection{Steam-Driven Auxil iary Equipment}

An electric power plant generates more electricity (gross production) than it sends out over the transmission line (net production). The difference is the power required to run plant auxiliary equipment or for other in-house needs. If it should prove feasible in the 1990's and later to reduce auxiliary electric power consumption, an added amount of useful electricity could be sent out over the lines without increasing gross production, and the need for gross generation of power from LMFBR's (or other types of power plants) could be reduced by a like amount.

The efficiency of large turbine units can be improved by using steam instead of electricity to drive large power plant auxiliaries, such as pumps, fans, and air compressors. Power plant designers for some time have been using steam turbines to drive boiler feed pumps on large units. As an example of the possible further use of steam auxiliary drives, the efficiency of a $1000 \mathrm{MW}$ unit utilizing 3500 psig/1000F/1000F steam can be improved about $1 / 3$ of $1 \%$ by using steam rather than electric motors to drive the forced-draft fans." By employing steam drive to the extent technically feasible for other items of equipment as well, the overall plant efficiency could be improved by approximately $1 / 2$ of $1 \%$. Net generation from steam plants (fossil and nuclear) in the Year 2000 is projected $^{10}$ to be about 8 trillion kilowatt hours (KWh) of which about $80 \%$, or 6.4 trillion $\mathrm{KWh}$, would be from base load plants. A $1 / 2$ of $1 \%$ improve- 
ment in efficiency would thus save about 32 billion KWh, equivalent to the output of about five 1000 MWe units.

The extensive use of steam drive for large auxiliaries has not yet taken place because of the economic cost of the necessary long runs of steam piping. Continued rise in fuel costs may bring about a reconsideration.

Adverse environmental aspects associated with expanded steam drive include those resulting from the mining, processing, fabrication, transportation, and installation of the steam piping required. These would have to be balanced against the beneficial environmental results associated with the need to burn less fuel (either fossil or nuclear) to produce a net amount of electricity, if auxiliary electric consumption in power plants were reduced.

\subsection{Energy Demands for Pollution Abatement and Environmental Control}

Actions taken to preserve or improve the quality of the environment and to hold in check potential pollution of the land, water, and atmosphere will, in some instances, require added eneray (mostly electrical) and therefore increased consumption of fuel resources. It is the intent of this subsection first to develop an estimate of the quantity of additional energy that will be required and, secondly, to explore the extent to which this eneray might be conserved through alternative approaches, less stringent standards, or tradeoffs by such measures as recycling of materials. 
One obvious method of conserving a substantial portion of the eneray required for environmental control would be limitation, voluntary or otherwise, in the total amount of energy consumed for this purpose. A recent survey ${ }^{25}$ showed that in 1971 a group of large industrial and commercial users of electricity used 8.8 billion kilowatt hours for pollution control. This represented $7.3 \%$ of their total annual electrical requirements in that year. By 1977, this figure is expected to rise to about $10 \%$ of annual needs.

The 1970 Federal Power Commission (FPC) National Power Survey ${ }^{19}$ forecast of growth in electrical generatina capacity reflected to some extent consideration of power needs for environmental protection, but it is now realized that the acceleration of concern with the environment that has occurred since the survey was made will result in the need for more capacity than was projected. Amona the factors that will contribute to the increase are the following:

(1) Electric generating plants air pollution and water pollution control.

a. Power to operate control equipment

b. Reduced plant efficiency.

(2) Electrical enerny demands for widespread sewane disposal improvement. 
(3) Electrical eneray demands for meeting water pollution control standards in industrial processes.

(4) Where apartment buildings, commercial establishments, factories, etc., are now using direct combustion of fossil fuels for space heating and process heating, a significant number may convert to electricity because of restrictions on the emission of particulates and the oxides of sulfur and nitrogen.

In the transportation sector additional sianificant use of electrical energy may occur in place of the direct combustion of fossil fuels, with the dual objectives of conserving scarce resources and of attaining better control over environmental pollution by concentrating power generation in relatively few central station plants rather than burning fuel in a multitude of small units. Such applications could inc?ude the successful development and utilization of battery-powered automobiles and trucks, electrification of railroads, and the installation of additional metropolitan area rail rapid transit systems.

The amounts of electricity that will be required for the likely and possible applications listed above and the potential for reducing these energy needs for pollution control purposes are discussed below. 


\subsubsection{Electric Generating Plants}

To satisfy the environmental standards for a new 1,000-meaawatt electric generating plant it has been estimated ${ }^{9}$ that on the average an increase of about $7.1 \%$ in the gross total energy input will be required over the energy input for the same plant without particulate cleanup, sulfur oxide removal, and with once-through cooling. This is based on a heat rate (without environmental controls) of 9,500 Btu per kilowatt-hour, an estimated additional energy input of $600 \mathrm{Btu}$ per kilowatt-hour for environmental controls (mechanical draft tower, 2-stage scrubber for $85 \% \mathrm{SO}_{2}$ removal, and a $99 \%$ efficient electrostatic precipitator), and the equivalent of about $60 \mathrm{Btu}$ per kilowatt-hour to represent the energy required to manufacture the equipment used to control pollution. No increase in energy has been assigned to nitrogen oxide removal or disposal of any solid wastes that might be created.

Reference 3 projects an energy input of 25,200 trillion Btu for fuel burning power plants in the year 2000. On the basis of the values given in the preceding pararraph, about 1,800 trillion Btu of this total would be applied to on-site environmental control. With a heat rate in the range of 8,900 to $10,200 \mathrm{Btu}$ per kilowatt-hour (depending on progress made in improving $\mathrm{plant}$ thermal efficiency) the equivalent electric power production in the year 2000 for environmental control would thus be about 180 to 200 billion kilowatt-hours, or the output of 27 to 30 generating units of 1,000 WWe each, operating at $75 \%$ plant factor. 
The projected energy input for nuclear plants in the year 2000 is 49,230 trillion Btu from a mix of LWR's, HTGR's, and fast breeder reactors. ${ }^{3}$ since the combustion process is not involved, no energy for particulates or oxides removal would be needed. Assuming an average thermal efficiency (without environmental controls) of $36 \%$, or 9,500 Btu per kilowatt-hour heat rate, the additional eneray input requirements with a mechanical draft cooling tower and equipment to limit release of radioactive effluents would be about 350 Btu per kilowatt-hour, or $4 \%$. Thus, the added electric power production in the year 2000 for nuclear plants environmental control would be about 200 billion kilowatt-hours, or the equivalent of the output of thirty 1,000 MWe units operating at a $75 \%$ plant factor.

From the above discussion, it is seen that conservation of energy by reducing eneray needs for power plant environmental control could be achieved in two principal ways. One would be to increase the proportion of power generated by nuclear plants and decrease that generated by fossil-fueled plants. For each 1,000 MWle capacity switch there would be an annual saving of about 210 million kilowatt-hours. The second conservation measure would obviously result from a relaxation of standards established for atmospheric and water effluent limits. The reduction absurdium would be the elimination of all controls, thus saving up to 400 billion kilowatthours in the year 2000. Whatever relaxation, if any, that is actually placed into effect would be the result of social, political, technical and economic considerations stemming from such factors as scarcity of certain fuel resources and escalating fuel costs. 


\subsubsection{Sewage Disposal Improvement}

It has been estimated that during the next decade anywhere. from $\$ 10$ billion to $\$ 80$ billion will be spent on the construction of improved sewage disposal facilities. The requirements for electrical power for these facilities will depend on the methods of waste treatment adopted. Current sewage treatment methods use about $50 \%$ of their electricity requirements for pollution control purposes. A survey by the Edison Electric Institute (EEI) indicated that sewage disposal used about 1 billion kilowatt-hours in 1971, 1.3 billion in 1972 and projects about 3.6 billion annually by 1977. Subsequently, greatly increased facilities installation could bring the annual requirements by 1990 to as much as 40 billion $\mathrm{kwhr}$ and by the Year 2000 to 50 billion kwhr. The potential for reducing these requirements is difficult to assess, but would, as in the case of electrical power plants, be dependent upon technical and economic factors in the development of more efficient equipment, and on social and political attitudes toward modification of pollution standards.

\subsubsection{Industrial Water Pollution Control}

As noted above, the EEI surveys in 1971 and 1972 indicated that about $7 \%$ of current industry electric power use is strictly for pollution control, but this does not reflect future increases that may result from recently-enacted water-quality leqislation. Reference 3 projects industrial use of electrical power in 2000 will be 4.6 trillion kilowatt-hours. The anticipated 10\% application 
to pollution control, if continued, would require at that time 0.46 trillion kilowatt-hours. However, conformance to the new water pollution control standards may increase this by as much as $50 \%$ to a total of up to 0.7 trillion $\mathrm{kwh}$. This would represent the output of over 1001,000 Mwe units operating at $75 \% \mathrm{plant}$ factor. Again, the benefits of conservation could be substantial, but the likelihood of their achievement and possible magnitude are at this time difficult to predict.

\subsubsection{Conversion of Direct Fuel Burning to Purchased Electricity}

There is no readily-apparent method of determining what might be a reasonable additional capacity figure to represent the future requirements in this category, either from building usage of electricity rather than direct combustion of fossil fuels for space heating, or in the transportation sector, where a similar shift of fuels may be contemplated for vehicular transportation. The pressures towards use of centrally generated electricity as a less polluting source of energy will be countered to some extent by the fact that it is a much less efficient means of energy utilization. For example, for every Btu of gas burned in a home for space heating, about two Btu of gas (or coal, oil, nuclear, etc.) would have to be burned to produce electricity for transmission to a home and use in an electrical resistance heater to produce the same heating value as the gas. With fuel costs increasing

$$
\text { C.4-8 }
$$


significantly, the relative environmental and economic characteristics of different fuel utilization mechanisms takes on a different meaning. This, coupled with potential future changes in the technical feasibility of powering vehicles by electricity on a large scale, makes future use patterns difficult to assess. For the immediately forseeable future, it would appear that fuel utilization and economics would take on added importance relative to environmental characteristics, thereby apparently lessening any shift toward conversion to centrally generated electric heat rather than direct combustion of fossil fuels. 


\section{C.5 TRANSMISSION AND DISTRIBUTION}

In discussing the conservation of resources as affected by the planning and operation of electric utility transmission and distribution systems, it should be noted that the opportunities for savings in this sector are not large relative to those in other parts of the overall electric utility system. A total of 1,465 billion net kilowatt hours (kwhr) of electric energy was generated and received by the privately owned class $A$ and $B$ electric utilities in the U.S. in 1971. 26 of this, 103.3 billion kwhr was lost in transmission and distribution (not counting distribution losses for 209 billion kwhr sold at wholesale). Assuming 4\% distribution losses for the wholesale energy, the total of transmission and distribution losses on the systems of these class $A$ and $B$ utilities is about $7.6 \%$ of total net energy generated and received or $8.3 \%$ of the total energy utflized. These losses are about evenly split between the transmission and distribution systems.

The $8 \%$ or so of transmission/distribution losses is small relative to the $60 \%$ or greater losses experienced in the energy conversion (generation plant) stage of electric utility system operation. However, when it is considered that about 27,000 megawatts (MW) of utility power were generated solely to cover the transmission and distribution losses associated with meeting the 337,000 1973 U.S. summer peak load, efforts to reduce these losses merit attention. 
Losses in transmission and distribution systems consist of load losses and no-load losses. The load losses occur as heat produced by current flow through the electrical resistance of the line conductors and are proportional to the resistance and to the square of the current $\left(I^{2} R\right)$. In cables load losses can also occur due to currents induced in cable shields and metallic conduits. No load losses occur whenever there is voltage on the transmission/distribution systems and consist of magnetizing losses in transformers, shunt reactors and other iron core equipment, dielectric losses in capacitors and cables, and corona losses due to high potential ionization of the insulating medium. $I^{2} R$ losses constitute the principal losses in transmission systems.

\subsection{Transmisstion Systems}

The primary function of the transmission system is to transport bulk electric energy from generation stations to the main substations serving load areas. The transmission system consists of (a) overhead $(\mathrm{OH})$ transmission lines and underground (UG) cables operated at 69,000 volts (69 kV) or higher; (b) terminal equipment consisting of high voltage transformers, converters, switchgear, lightning arrestors, inductive reactors and capacitors and (c) control and metering systems, including meters, relays, communications equipment and computers. In addition to providing transmission within individual utility service areas, transmission systems also generally interconnect adjacent electric utility systems in order to achieve better operating economics and reliability of service. 
At present $\mathrm{OH}$ transmission predominates in the U.S. Less than $1 \%$ of the Nation's electric power transmission lines are installed underground. 27 Largely responsible for this situation is the fact that the installed costs of UG cable are 5 to 20 times greater than those of $\mathrm{OH}$ lines, ${ }^{28}$ depending on circuit voltage and area conditions. This situation is likely to continue through the rest of this decade, with some small percentage gain in cable installations, principally for extending high power capacity transmission into metropolitan load centers. ${ }^{29}$ The greatest increase in transmission circuit capability during the 1970's is expected to occur in Extra High Voltage (EHV) $\mathrm{OH}$ lines ( $345 \mathrm{KV}$ to $765 \mathrm{KV}$ ), as shown in Figure $C .5-1^{27}$.

New technological approaches to transmitting electric energy, namely high voltage direct current ( $H V D C$ ) $\mathrm{OH}$ lines and compressed gas cable, have been introduced in the last few years but are not expected to make any significant impact in this decade. These innovative technologies are discussed later.

There are a number of methods for reducing transmission losses, principal among which are the raising of transmission voltages, the reduction of line currents, and the reduction of line resistances. Involved in developing these options are: EHV and ultra hiah voltage (UHV) alternating current $(A C)$ transmission systems; high voltage direct current (HVDC) systems; various innovative cable systems, including cryogenic systems; and power system control. The status and prospects of these are discussed in turn. 


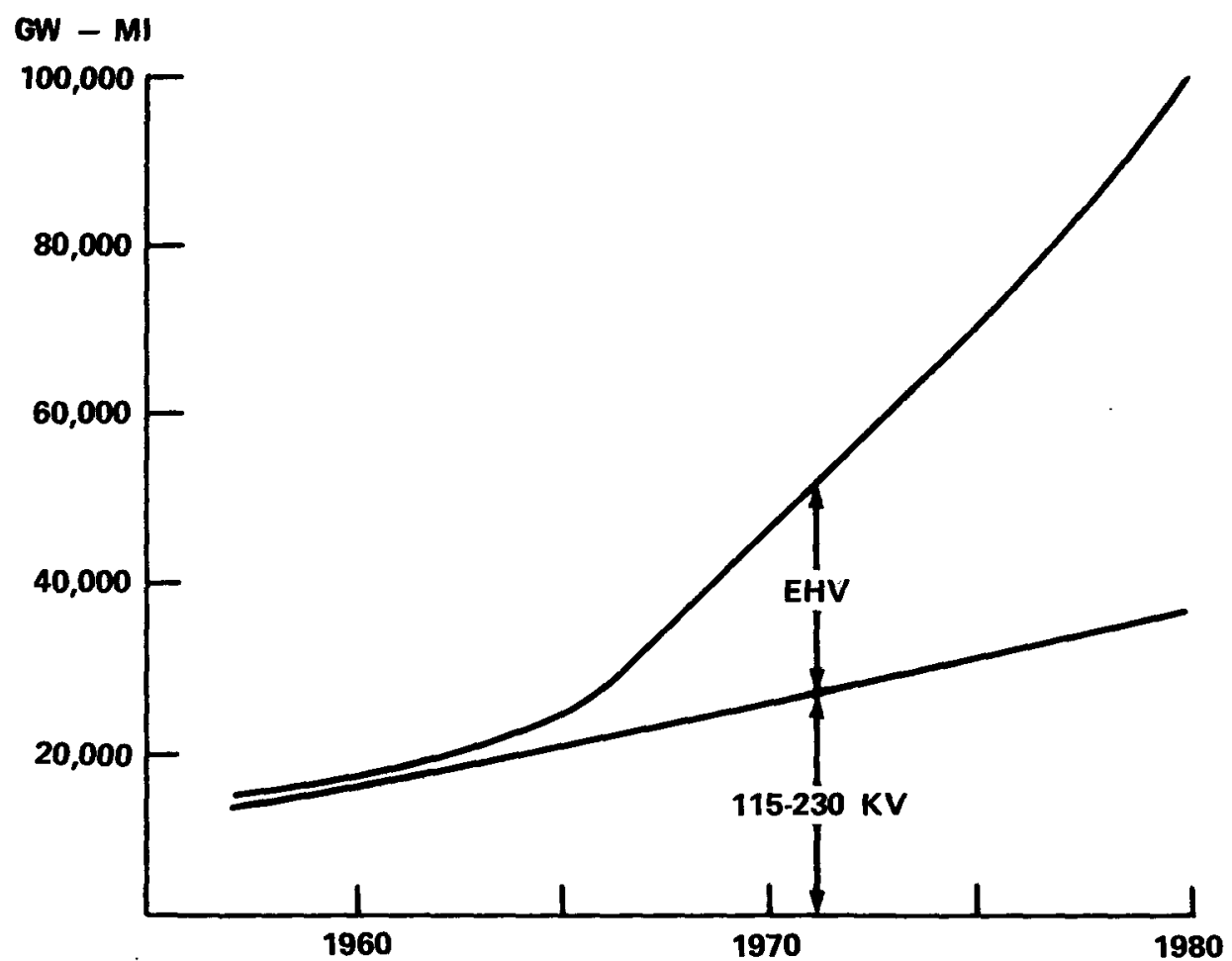

TRANSMISSION CAPABILITY

Figure C.5-1 


\subsubsection{High Voltage AC Systems}

The relationship between $\mathrm{OH}$ transmission line voltage and line losses is shown in Figure $C .5-2^{30}$. It is evident that the trend to $\mathrm{EHV} \mathrm{OH}$ transmission ( 345 to $765 \mathrm{KV}$ ) will assist appreciably in reducing transmission losses. The magnitude of this trend per transmission voltage and circuit capability in gigawatt*-miles (GW-MI) is shown in Table C.5-1. If the circuit capability in gigawatt-miles for each voltage in the Table is multiplied by the corresponding relative loss from Figure 2 and the products summed up for a particular year, the result is a measure of the transmission losses that could be expected for that year for full loading of that year's in-service circuit capability. Dividing the result by the total in-service circuit capability for that year of the voltages considered yields the specific loss of that year's transmission. Comparison of the specific loss for one year with that of the preceding year gives a measure of the reduction in overhead transmission losses to be expected from the trend to higher voltages shown in Table C.5-1. The results of such a comparison are shown in Table C.5-2.

It is apparent from Table C.5-2 that the gains in more efficient transmission as voltages are raised are not great; the saving in losses totals less than 11 billion kilowatt-hours over the seven year period 1974-80. This amount of electrical energy could be

*gigawatt - 1000 megawatts 


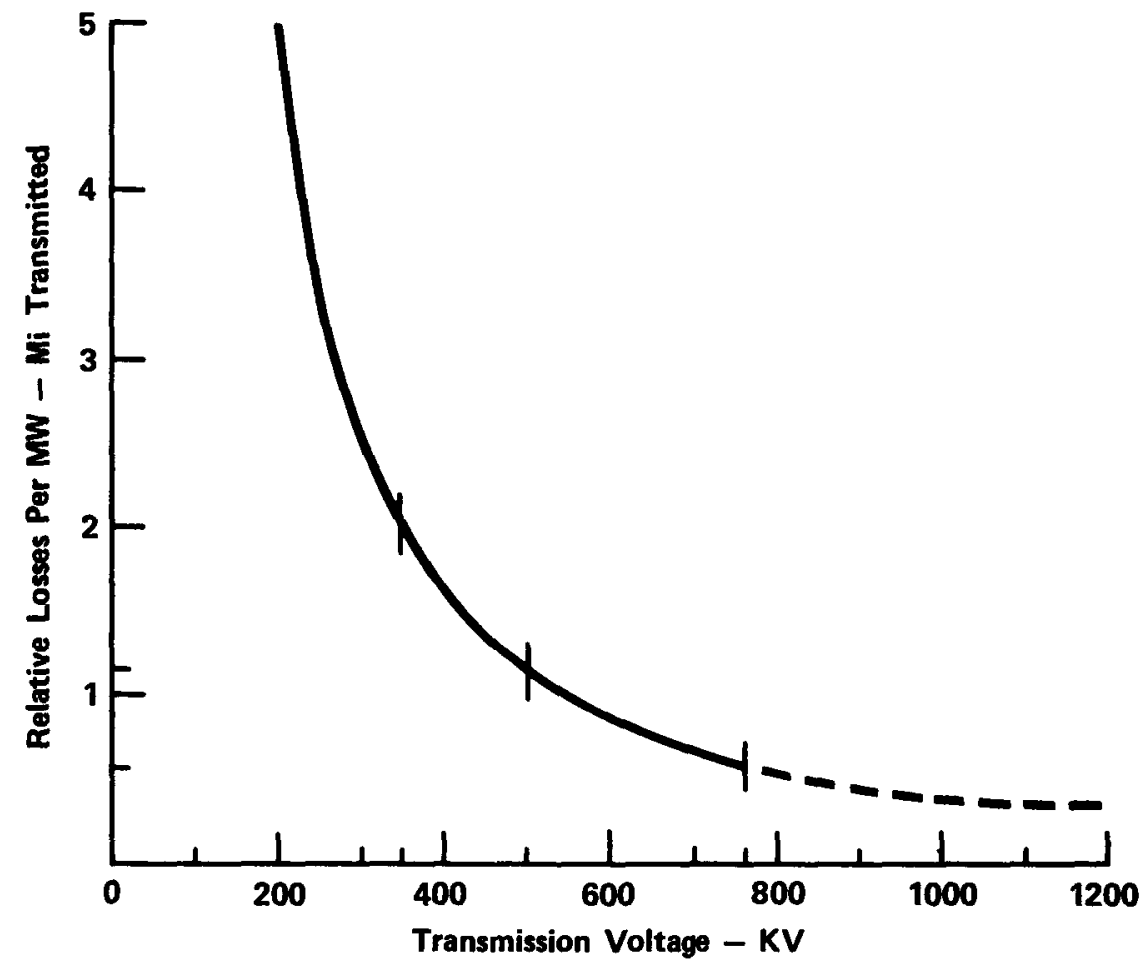

TYPICAL TRANSMISSION LOSSES

Figure C.5-2 
Table C.5-1

OVERHEAD TRANSMISSION

CIRCUIT CAPABILITY IN-SERVICE, IN GIGAWATT-MILES

SURVEY SAMPLE ADJUSTED TO NATIONAL TOTALS

\begin{tabular}{rrrrrrrrrr} 
& $115-161 \mathrm{kV}$ & $230 \mathrm{kV}$ & $345 \mathrm{kV}$ & $500 \mathrm{kV}$ & $765 \mathrm{kV}$ & $800 \mathrm{DC}$ & Total & $\Delta$ GW-MI \\
\hline 1957 & 9,791 & 3,969 & 968 & 0 & 0 & 0 & 14,728 & 702 \\
1958 & 10,226 & 4,303 & 1,240 & 0 & 0 & 0 & 15,769 & 1,041 \\
1959 & 10,487 & 4,579 & 1,289 & 0 & 0 & 0 & 16,805 & 586 \\
1960 & 10,842 & 4,931 & 1,534 & 0 & 0 & 0 & 17,807 & 1,002 \\
1961 & 11,310 & 5,658 & 1,694 & 0 & 0 & 0 & 18,862 & 1,355 \\
1962 & 11,650 & 6,166 & 2,159 & 0 & 0 & 0 & 19,975 & 1,313 \\
1963 & 12,121 & 6,657 & 2,772 & 0 & 0 & 0 & 21,530 & 1,575 \\
1964 & 12,398 & 7,472 & 2,977 & 0 & 0 & 0 & 22,847 & 1,297 \\
1965 & 12,753 & 7,845 & 3,023 & 766 & 0 & 0 & 24,984 & 2,437 \\
1966 & 13,089 & 8,812 & 4,471 & 2,086 & 0 & 0 & 28,458 & 3,474 \\
1967 & 13,482 & 9,511 & 5,471 & 4,699 & 0 & 0 & 33,463 & 4,705 \\
1968 & 13,847 & 10,162 & 6,533 & 7,291 & 0 & 440 & 38,273 & 5,110 \\
1969 & 14,221 & 10,744 & 8,344 & 8,020 & 165 & 879 & 42,484 & 4,211 \\
1970 & 14,533 & 11,183 & 9,816 & 9,506 & 978 & 1,343 & 47,419 & 4,985 \\
1971 & 14,895 & 11,823 & 11,192 & 11,018 & 1,743 & 1,343 & 52,014 & 4,595 \\
1972 & 15,347 & 12,576 & 12,779 & 12,751 & 2,573 & 1,343 & 57,369 & 5,355 \\
1973 & 15,741 & 13,290 & 14,023 & 14,186 & 2,905 & 1,343 & 61,488 & 4,119 \\
1974 & 16,157 & 14,170 & 15,499 & 16,027 & 3,443 & 1,343 & 66,639 & 5,151 \\
1975 & 16,500 & 14,978 & 17,227 & 17,410 & 3,593 & 1,343 & 71,051 & 4,412 \\
1976 & 16,776 & 15,883 & 18,802 & 18,797 & 4,000 & 1,343 & 75,691 & 4,550 \\
1977 & 17,085 & 16,540 & 20,456 & 20,640 & 5,963 & 1,343 & 82,029 & 6,428 \\
1978 & 17,401 & 17,379 & 21,808 & 22,054 & 6,996 & 1,343 & 86,983 & 4,954 \\
1979 & 17,685 & 17,934 & 22,476 & 26,218 & 8,538 & 1,343 & 94,244 & 7,261 \\
1980 & 17,997 & 18,561 & 23,838 & 28,967 & 9,520 & 1,343 & 100,226 & 5,982
\end{tabular}


Table C.5-2

PROJECTED ENERGY CONSERVATION THROUGH HIGHER OVERHEAD TRANSMISSION VOLTAGES FOR THE PERIOD 1974-1980

\begin{tabular}{|c|c|c|c|c|}
\hline \multirow[t]{2}{*}{ Year } & $\begin{array}{l}\text { Loss } \\
\text { Reduction }\end{array}$ & $\begin{array}{l}\text { Utility } \\
\text { Generation }\end{array}$ & $\begin{array}{l}\text { Savings } \\
\text { in Losses } \\
\end{array}$ & \multirow{2}{*}{$\begin{array}{c}\text { Equivalent } \\
\text { LMFBR Capacity } \\
\text { (Megawatts) } \underline{3}\end{array}$} \\
\hline & $(x)^{2}$ & $\left(10^{9} \mathrm{KWH}\right)^{2 / 2}$ & $\left(10^{9} \mathrm{KWH}\right)$ & \\
\hline 1974 & 1.39 & 2000 & 1.11 & 169 \\
\hline 1975 & 0.47 & 2140 & 0.40 & 61 \\
\hline 1976 & 0.47 & 2290 & 0.43 & 66 \\
\hline 1977 & 2.84 & 2450 & 2.78 & 424 \\
\hline 1978 & 0.98 & 2620 & 1.03 & 156 \\
\hline 1979 & 2.96 & 2800 & 3.32 & 505 \\
\hline 1980 & 1.52 & 3000 & 1.82 & 278 \\
\hline TOT & & & 10.89 & \\
\hline
\end{tabular}

1/ Loss reduction per gigawatt-mile compared to previous year.

2/ Projected at $7.0 \%$ annual rate of increase over 1,747 billion KWH generated by U.S. electric utilities in 1972 (Federal Power Commission).

3/ At $75 \%$ plant capacity factor. 
generated over that time by a base loaded generating unit rated at approximately 240 megawatts. As the incremental gains in loss reduction are expected to be less with voltage rises into the UHV range (Figure $\mathrm{C} .5-2$ ), the gains in overhead $A C$ transmission efficiency are not expected to have significant impact on conservation of energy. As mentioned previously, higher voltage lines will be installed primarily to transmit greater blocks of power economically within land usage constraints.

$I^{2} R$ losses for a given length of line can be reduced by increasing the size of the conductor, thereby reducing its resistance. Reduction in conductor resistance reduces $I^{2} R$ losses proportionately for transmission of a given amount of power. However, increasing conductor size is practiced primarily to increase circuit power capability, as in the reconductoring of existing lines, rather than to reduce losses and is not expected to result in smaller losses per unit of power transmitted.

$I^{2} R$ losses in $A C$ transmission lines can be reduced by increasing the power factor of the line. In this case synchronous condensers or banks of static capacitors are installed in the system primarily to supply the non-power currents required by the transmission line and the electrical loads connected to it, thereby decreasing the nonpower currents that otherwise would have to be supplied by the generators and reducing line currents and losses in the process. Power factor correction is already employed extensively for other 
more urgent purposes, such as increased power loading of generators and lines, system vol tage regulation, and reduced investment in system facilities. It is expected to keep pace with increases in transmission facilities and is not expected to be an option for conserving energy.

Another way to reduce transmission losses is to shorten transmission lines. Shortening the lines physically is dependent on system planning, particularly the selection of suitable generation sites. In such planning, concern about system losses is usually secondary to economic, environmental, reliability and public acceptance condsiderations.

Generation in most U.S. electric utility systems is fairly well dispersed to match load center locations, so that the opportunity is small for shortening lines and reducing losses in future bulk power system expansion relative to the present situation. An appreciation of the effect on transmission system losses of the opposite situation - long lines from large mine-mouth generating stations to distant load centers - is afforded by the data in Table C.5-3. This table, taken from the North Central Power Study, shows how system losses increase from $3.3 \%$ for $3000 \mathrm{MW}$ to $6.66 \%$ for $43,000 \mathrm{MW}$ transmitted from a single generation site to load centers varying from 200 to 815 miles distant. 
Table C.5-3

ENERGY INPUT AND SYSTEM LOSSES

\begin{tabular}{|c|c|c|c|c|}
\hline $\begin{array}{c}\text { Generation } \\
\text { capacity } \\
\end{array}$ & \multirow[t]{2}{*}{$\begin{array}{l}\text { Gen-energy } \\
\text { MW-yrs/yr } \\
\end{array}$} & \multicolumn{2}{|c|}{$\begin{array}{l}\text { System loss } \\
\text { MW percent }\end{array}$} & $\begin{array}{c}\text { System losses } \\
\text { MW-yrs/yr }\end{array}$ \\
\hline EAST & & & & \\
\hline $\begin{array}{r}3,000 \\
10,000 \\
20,000 \\
40,000 \\
\times 43,000\end{array}$ & $\begin{array}{r}2,550 \\
9,100 \\
18,400 \\
36,800 \\
36,500\end{array}$ & $\begin{array}{r}100 \\
511 \\
1,266 \\
2,704 \\
2,864\end{array}$ & $\begin{array}{l}3.30 \\
5.11 \\
6.33 \\
6.76 \\
6.66\end{array}$ & $\begin{array}{r}76 \\
435 \\
1,100 \\
2,360 \\
2,500\end{array}$ \\
\hline \multicolumn{5}{|l|}{ WEST } \\
\hline $\begin{array}{r}1,000 \\
3,000 \\
10,000\end{array}$ & $\begin{array}{r}850 \\
2,745 \\
9,200\end{array}$ & $\begin{array}{r}9 \\
36 \\
183\end{array}$ & $\begin{array}{l}0.90 \\
1.20 \\
1.83\end{array}$ & $\begin{array}{r}7 \\
31 \\
159\end{array}$ \\
\hline
\end{tabular}

FEnergy for pumping was obtained from the generating complex during offpeak periods and would be about 1,000 $\mathrm{kH}$ - yrs/year. 
Electrical losses of lines can be reduced by the introduction of series capacitors in the lines to counteract their inductance. This tends to shift power away from low-capacity, high-loss lines in the network into the more efficient, higher voltage lines having the series capacitor compensation, with consequent reduction in total network losses. 30 Utilities are planning to double present series capacitor installations over the 1973-1980 period. ${ }^{27}$ It is not feasible to estimate how much this may reduce losses without computer studies of the systems involved. However, the effect is not expected to be significant.

The no-load losses of transmission lines, principally corona losses, are small compared to $I^{2} R$ losses. Corona losses become worse on $A C$ overhead lines during rainy conditions, but on the average are still only on the order of a few percent of line load losses. Corona losses are generally higher for UHV lines than for lower voltage transmission, and this factor is significant in the economics for selecting optimum transmission voltage.

Economic dispatch of electric energy in bulk power systems is being implemented widely in U.S. electric utilities. It schedules the output of the generators on the system in such a way as to minimize the overall cost of delivering electric energy to the consumer. As cost is directly related to fuel consumption, including energy generated to supply transmission losses, the effect is to minimize fuel consumption in generation-transmission systems.

Although undergrounding of transmission lines is not expected to be extensive in the near future because of economic reasons, cable systems 
do represent a means of saving on transmission energy losses. Conventional high pressure, oil-filled (HPOF) pipe type high voltage cables are very efficient conductors of electric energy. Over a distance of 10 kilometers, for instance, the total losses $\left(I^{2} R\right.$ losses and dielectric losses) at full-load current amount to as 1ittle as 0.2 to $0.3 \%$ of the power transmitted. 31 As very few cables carry full load continuously and as the conductor loss is proportional to the square of the transmitted power, cable losses are generally even less than the percentages mentioned. This low loss is enforced on the conventional self-cooled cable systems by the difficulties encountered in dissipating the heat (losses) generated in the cable to the surrounding soil and eventually to the atmosphere.

As mentioned previously, the main opportunity for new application of transmission cables should be their extension through high density suburban and urban areas to feed new loads. For this service, conventional self cooled high pressure oil filled (HPOF) cables at $345 \mathrm{KV}$ (paper insulation) and $500 \mathrm{KV}$ (synthetic insulation) would have permissible total losses about two-thirds those of $\mathrm{OH}$ lines of the same voltage rating and equivalent conductor sizes.

If it is assumed that $75 \%$ of the new load between 1973 and 1980 has to be supplied from urban main substations and $50 \%$ of this is supplied equally over new $345 \mathrm{KV}$ and $500 \mathrm{KV}$ HPOF cables averaging 10 miles in length, the saving in transmission losses in 1980 would 
be only about 30 W compared to serving the new urban load only by $\mathrm{OH}$ lines. In the following decades the requirements for such undergrounding probably will be met with the advanced cable systems discussed later.

\subsubsection{High Voltage, Direct Current (HVDC) Systems}

HVDC is receiving increased attention for both $O H$ and UG transmission because of its ability to transport more electric energy per unit width of right-of-way (greater energy density) than with an equivalent $A C$ line. ${ }^{32}$ Because of the absence of $A C$ reactive (non-power) currents and the resistance-increasing skin-effect experienced with AC transmission, the $I^{2} R$ load losses of HVDC are less than that of EHV AC for transmission of a given amount of power, as are the no-load losses due to the practical el imination of $A C$ induced dielectric losses. If it is assumed that HVDC and EHV overhead lines are built with the same insulation level and conductor size and operated at voltages that produce equivalent electrical stressing of the insulating medium ( $500 \mathrm{KV} \mathrm{AC}$ vs. $800 \mathrm{KV} \mathrm{DC}$, for instance) the HVDC line losses would be about $65 \%$ of the $A C$ line losses for transmission of a given amount of power. ${ }^{30}$ This HVDC advantage in line losses will be partially offset, however, by losses in the HVDC conversion terminals, which are on the order of 4 I/2 times those resulting from AC transformation. At the comparison voltage levels mentioned ( $500 \mathrm{KV} \mathrm{AC}$ vs. $800 \mathrm{KV} \mathrm{DC}$ ), the HVDC overhead line would have to exceed 300 to 400 miles in lenath before its losses, including those of the conversion equipment at 
its terminals, would be less than those of an EHV AC line with voltage transformation at its terminals.

The economics of HVDC systems favor its use instead of EHV AC systems for large amounts of power transmitted over long distances - in excess of 300 to 400 miles for $\mathrm{OH}$ lines and 30 to 50 miles for UG cables. 32 These distances correspond to distant generation sites (hydro stations, mine-mouth thermal plants and nuclear power parks), where HVDC overhead lines might be used, and long runs through populated or natural beauty areas, where UG DC transmission might be appropriate. The future proliferation of such distant generation is problematic and the magnitude of $D C$ UG transmission into heavy load areas may be small compared to $A C$. The choice of $A C$ vs $D C$ will be made on a case by case basis. It is difficult to know at present how extensively HVDC will be introduced into U.S. systems and what the effect might be on transmission losses.

\subsubsection{Innovative Underground Transmission}

Research and development is being conducted on new means of transmitting bulk electric energy under ground so as to increase circuit capabilities and operate at voltages compatible with overhead systems while achieving better economics. Principal among these approaches are forced cooling of conventional HPOF cables, compressed gas cable systems, cryogenic cable systems (both cryoresistive and superconducting) and microwave (waveguide) systems. 
During the 1980's there is likely to be increasing demand for higher capability circuits (up to $5000 \mathrm{MW}$ by 1990) to carry electric power into suburban and urban load centers. Forced cooling of conventional HPOF cable, compressed gas and cryoresistive cable systems will probably share this application. Beyond 1990 the need will grow for even greater circuit capabilities, perhaps 10,000 $\mathrm{MW}$ and greater, 28 with the ability to transmit electric energy with very low loss for considerable distances, perhaps hundreds of miles. Superconducting cable would be expected to fill this role.

The choice of cable system for each underground application would most likely be determined more by consideration of economics, space and routing requirements and reliability than by losses. Operating parameters of the various types of innovative systems are shown in Table C.5-4. It is to be noted that in the cases of forced coolina of both HPOF and compressed gas cables, cryoresistive cable systems and microwave wavenuide systems the specific losses are greater than with conventional HPOF self-cooled cable. Therefore, the only saving in electric eneray losses to be expected would be from substitution of superconducting cable sytems for others after 1990 or so.

A projection of energy conservation using superconducting cables for the period 1990-2000 is shown in Table C.5-5.33 Based on the relative energy dissipations indicated in Table C.5-4, it is calculated that about 700,000 megawatt-hours (MWH) would be saved if 
Table C.5-4

POWER LOSSES IN UNDERGROUND POWER SYSTEMS

System

HPOF - $345 \mathrm{KV}$ Naturally cooled Forced cooled

Compressed Gas Cable - $500 \mathrm{KV}$ Naturally cooled Forced cooled

Cryoresistive Cable

Nitrogen cooled - $500 \mathrm{kV}$

Hydrogen $\sim-500 \mathrm{KV}$ $\frac{\text { Max. Power }}{\text { (MVA) }} \frac{\text { Power Loss }}{(\text { m/mite })}$

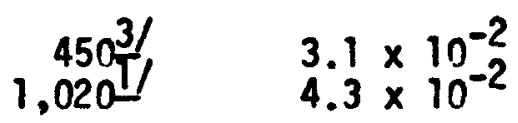

$2,200 \frac{11}{1 /}$
6,500

$1.3 \times 10^{-2}$
$4.5 \times 10^{-2}$

$3,500 \frac{21}{21}$
$3,500=$

$5.6 \times 10^{-2}$
$4.3 \times 10^{-2}$

Superconducting Cable

$A C$

DC

Microwave (waveguide)
$3,0003 /$
$10,01 /$

$5 \times 10^{-3}$

$4.5 \times 10^{-4}$

$10,000^{1 /}$

$6 \times 10^{-2}$

1/ Reference 28, Table 4.1, page 4.5

2/ From Ref. 34, Table 4, page 30, Phase B

3/ Reference 33, Table 1, page 12 
Table C.5-5

PROJECTED ENERGY CONSERVATION USING SUPERCONDUCTING CARLEC FOR THE PERIND $1990-2000$

\begin{tabular}{|c|c|c|c|c|c|c|}
\hline Year & $\begin{array}{l}\text { U.S. } \\
\text { Generation } \\
\text { Capacity } \\
M W\end{array}$ & $\begin{array}{l}\text { Power Plant } \\
\text { Construction } \\
\text { MW/Year }\end{array}$ & $\begin{array}{l}\text { Circuit-Miles of } \\
\text { U/G Transmission } \\
\text { Added per Year }\end{array}$ & $\begin{array}{l}\text { Total Circuit miles } \\
\text { of } U / G \text { Transmission }\end{array}$ & $\begin{array}{l}\text { Total Circuit } \\
\text { Miles of Super- } \\
\text { conductinn U/F } \\
\text { Transmissinn }\end{array}$ & $\begin{array}{l}\text { Total Eneray } \\
\text { ronserved by Year } \\
2 n^{\prime} n \text { in Super- } \\
\text { conductina Circuits } \\
\text { Mu:h* }\end{array}$ \\
\hline 1990 & $1.0 \times 10^{6}$ & $7 \times 10^{4}$ & $80 n$ & $10,0 n n$ & 0 & \\
\hline 1995 & $1.4 \times 10^{6}$ & $1.0 \times 10^{5}$ & 1000 & $14,0 \mathrm{nn}$ & $1 n n$ & \\
\hline 2000 & $1.7 \times 10^{6}$ & $1.3 \times 10^{5}$ & $120 n$ & $2 n, n \cap n$ & $30 n$ & $7 \times 10^{5}$ \\
\hline
\end{tabular}

*Based on 2000 MVA capacity, and 65\% load factor. 
the UG circuit additions over the period 1990-2000 were in superconducting $A C$ cable rather than conventional HPOF self-cooled cable. This is equivalent to the 10 year output of a generator rated approximately 10 megawatts. The saving would be even less if the superconducting cable were selected over compressed gas cable.

\subsection{Distribution Systems}

The distribution system takes the electric eneray from the transmission system (at the low voltage side of the latter's bulk power receiving substations) and transports it to points of utilization. The typical U.S. distribution system consists of subtransmission lines (usually ranging from 69 to $138 \mathrm{KV}$ ), primary distribution substations, primary distribution 1 ines $(2.4$ to $34.5 \mathrm{KV})$, distribution transformers, secondary distribution lines (120/240 volts) and service lines to residential and commercial customers. Large commercial and industrial customers customarily are supplied at primary distribution or even subtransmission voltages.

Distribution systems may be constructed as overhead systems, underground systems, or, as is usually the case today, a combination of both. The trend is toward more undergrounding, particularly for the primary and secondary distribution systems feeding suburban loads. ${ }^{35}$ For many years, these systems have been designed to operate with minimum losses consistent with the economic use of material and within environmental and mechanical 1 imitations. 
Losses in disbribution systems consist of load losses and no-load losses, as explained previously. The proportion of these losses within the overall system are approximately as follows:

1. Subtransmission System $0.48 \%$

2. Distribution Substations $0.47 \%$

3. Primary Distribution System $0.82 \%$

4. Distribution Transformers 2.04\%

5. Secondary Distribution System $0.15 \%$

6. Service lines to customers $0.03 \%$ Total Distribution $\quad 3.99 \%$

(Approximately 4.0\%)

It is evident that the greatest losses occur in the distribution transformers, followed by the primary distribution lines feeding these transformers.

The potential exists for reducing losses in distribution transformers by optimizing their loading. The relationship of transformer losses to transformer loading is shown in Figure C.5-3 for transformers af present designs. ${ }^{36}$ The losses are higher for lightly loaded transformers because in that range their approximately constant no-load losses are higher per unit of load. The optimum range for loading transformers from the point of view of losses would be from about $160 \%$ to $200 \%$ for distribution transformers and $140 \%$ to $230 \%$ for primary distribution station transformers. Transformers are usually 


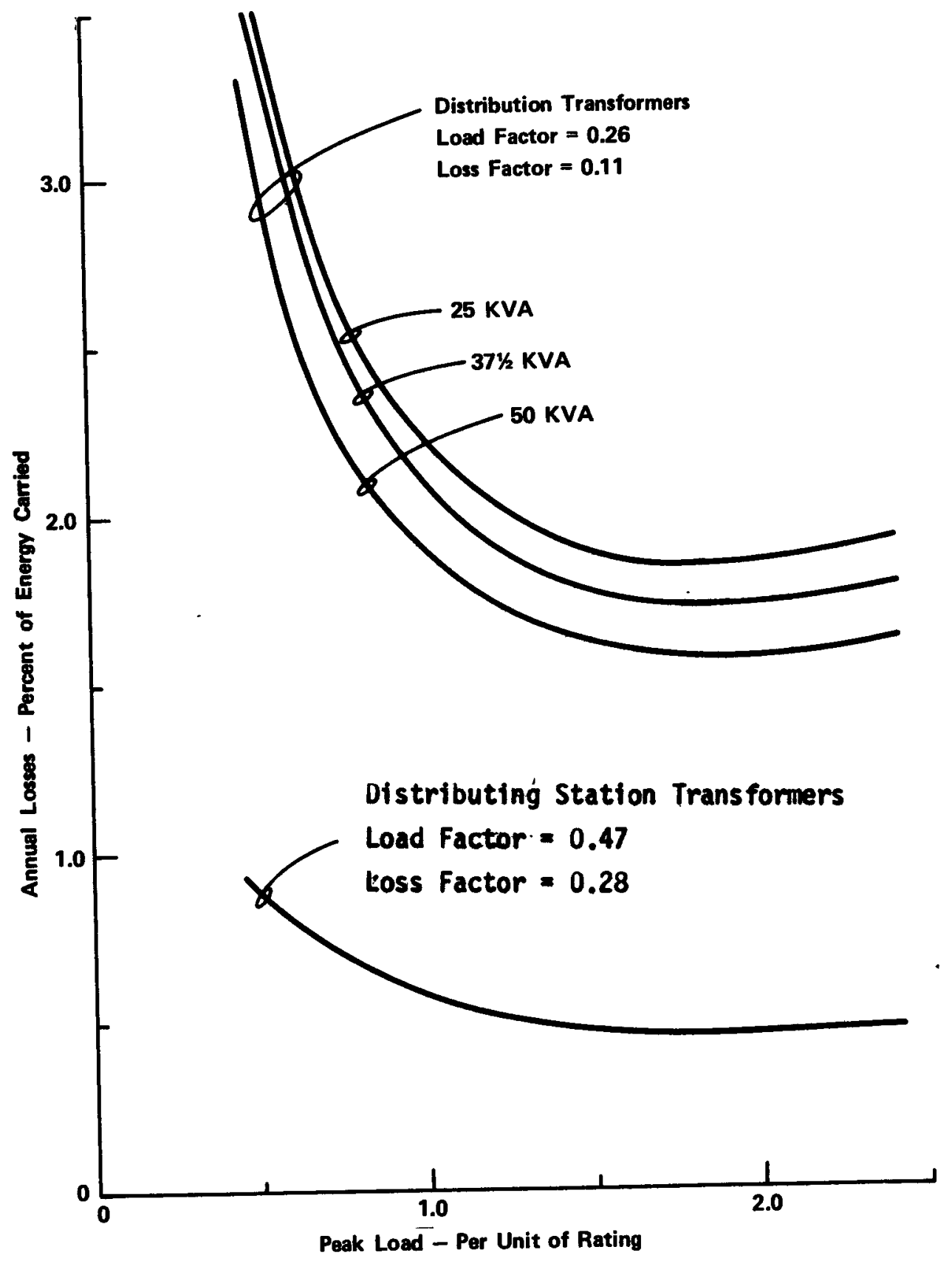

TRANSFORMER ENERGY LOSSES

Figure C.5-3 
loaded up to the lower end of these ranges in order not to have excessive system voltage drops and shortening of transformer service life. However, in order to give energy conservation more emphasis, consideration could be given to increasing transformer loading when it is below the optimum for losses. 36

A measure of the conservation of energy that could be achieved by optimizing the loading of distribution transformers is estimated as follows. It can be assumed that in 1985 peak loading of distribution transformers averages $120 \%$ of unit rating. ${ }^{36}$ In Figure C.5-3 this corresponds to annual losses for a 50KVA transformer of $1.75 \%$ of energy carried. It is further assumed that the loading of the distribution transformers on the system is progressively increased after 1975 at $5.79 \%$ per annum until $160 \%$ average peak loading is achieved by 1991, after which the loading is held at this point to achieve near minimum transformer energy losses. At $160 \%$ peak loading the annual losses for the 50 KVA transformer of Figure C.5-3 are $1.59 \%, 0.16 \%$ lower than for $120 \%$ peak loading. If the annual reductions in 50KVA distribution transformer losses are taken as the average for U.S. systems that can be achieved by the increased loading assumed and these reductions are multiplied by the corresponding annual electric energy projected to be carried by all distribution transformers in the U.S., the loss savings shown in Table C.5-6 are the result. The total savinas in distribution transformer losses for the Years 1986 through 2000 would be almost 65 billion kilowatt hours (KWH). By the year 2000 the annual saving 


\section{Table C.5-6}

SAVINGS IN DISTRIBUTION TRANSFORMER ENERGY LOSSES

\begin{tabular}{|c|c|c|c|c|c|}
\hline Year & $\begin{array}{l}\text { Trans former } \\
\text { Peak Load } \\
(\%)\end{array}$ & $\begin{array}{l}\text { Loss } \\
\text { Saving } \\
\frac{(\%)}{(\%)}\end{array}$ & $\begin{array}{l}\text { Distributed [neray 1/ } \\
\text { (Residential \& Comm.) } \\
\text { (Billion KWH) }\end{array}$ & $\begin{array}{l}\text { Saving } \\
\text { in losses } \\
\text { (Billion KWH) }\end{array}$ & $\begin{array}{l}\text { Saving } 2 / \\
\text { in Capacity } \\
\text { (MW) }\end{array}$ \\
\hline 1985 & 120.0 & - & 1820 & - & - \\
\hline 1986 & 126.9 & 0.04 & 1925 & 0.77 & 127 \\
\hline 1987 & 134.2 & 0.07 & 2036 & 1.43 & 237 \\
\hline 1988 & 142.0 & 0.11 & 2154 & 2.37 & 392 \\
\hline 1989 & 150.2 & 0.13 & 2279 & 2.96 & 490 \\
\hline 1990 & 158.9 & 0.16 & 2411 & 3.86 & 639 \\
\hline 1991 & 160.0 & 0.16 & 2551 & 4.08 & 675 \\
\hline 1992 & 160.0 & 0.16 & 2699 & 4.32 & 715 \\
\hline 1993 & 160.0 & 0.16 & 2855 & 4.57 & 756 \\
\hline 1994 & 160.0 & 0.16 & 3020 & 4.83 & 799 \\
\hline 1995 & 160.0 & 0.16 & 3195 & 5.11 & 845 \\
\hline 1996 & 160.0 & 0.16 & 3380 & 5.41 & 895 \\
\hline 1997 & 160.0 & 0.16 & 3576 & 5.72 & 946 \\
\hline 1998 & 160.0 & 0.16 & 3783 & 6.05 & 1001 \\
\hline 1999 & 160.0 & 0.16 & 4002 & 6.40 & 1059 \\
\hline 2000 & 160.0 & 0.16 & 4235 & 6.78 & 1122 \\
\hline \multicolumn{4}{|c|}{ Total } & 64.66 & \\
\hline 1/ As & $\begin{array}{l}\text { sumed } 50 \% \text { of } \\
\text { e assumed to }\end{array}$ & $\begin{array}{l}\text { total U. } \\
\text { increase }\end{array}$ & $\begin{array}{l}\text { S. utility electric ene } \\
\text { at a yearly comonunded }\end{array}$ & $\begin{array}{l}\text { ray sales. The } \\
\text { rate of } 5.79 \% \text {. }\end{array}$ & se sales \\
\hline
\end{tabular}


in losses would be approximately equivalent to the generating capacity of an 1100 megawatt (MW) turbine-generator.

The only significant losses in overhead primary distribution power lines are the load $\left(I^{2} R\right)$ losses. They may be reduced by decreasing the current (I) or the resistance (R).

As indicated in the discussion of transmission systems, current in a power line can be reduced by increasing the line voltage or by raising the system power factor. For distribution of a given amount of power, the saving in line losses will be proportional to the square of the reduction in 1 ine current. However, primarily to maximize the power capability of distribution lines and improve system economics, utilities have been converting to higher distribution voltages ${ }^{35}$ and have installed many power factor correction capacitors to raise distribution system power factors. The secondary benefit has been a reduction in distribution line losses. In order to achieve the primary benefits stated, utilities will continue to raise the voltage of individual distribution lines and install more capacitors, with consequent reduction in line losses; such action will not constitute an independent option for conservation of energy.

Reduction in conductor resistance reduces load $\left(I^{2} R\right)$ losses proportionately. For distribution circuits this can be achieved by changing the conductor material or increasing the conductor size. 
In recent years, aluminum has been the matertal most used for conductors in distribution systems, based on physical characteristics and economics. Other materials are available but are not expected to challenge aluminum's position. For distribution purposes, the practical way to reduce the resistance is to increase the conductor size. Conductor size normally is based on system economics considering projected load increases, provision for load transfer during line outages, maximum-allowable voltage drop, and installation and loss costs and is limited by current-carrying capacity and ecological and mechanical considerations. This has resulted in a conductor size generally larger than that necessary to carry the normal load, with the result that resistance losses in existing distribution systems tend to be relatively low and installing still larger conductors will further reduce energy losses only to a limited degree. 36 


\section{C.6 UTILIZATION OF ENERGY}

Conservation of energy at the point of end-use has received little attention in comparison to that given to conservation in energy supply and conversion processes. Whereas research and development on more efficient ways to generate electricity or burn fossil fuels has been extensive, programs to conserve energy in the manufacture of goods and the provision of services for residences and commercial butldings have been relatively insignificant until recently, despite the magnitude of the potential for energy savings.

Energy economics in the U.S. have been largely responsible for this inattention to conservation of energy in its end uses. Until very recently the Gross National Product of the U.S. has been wedded to cheap, abundant energy. Electricity, for instance, over the last several decades became an increasingly better bargain for the production of goods and services and it is only in the last several years that its price has trended upwards, largely due to fuel and equipment costs related to minimizing environmental impacts. This avallability of energy that was inexpensive relative to other components of production cost discouraged investment in more energy-efficient buildings, equipment and processes. Where energy was in essentially unlimited supply at low prices the trade-offs in economic justification favored low initial investment rather than more efficient, less costly operation. Now, with rising energy costs and sometimes limited supplies of fuels, purchasers will have to become increasingly aware of the lifetime operating costs and 
energy consumption of the products purchased, as well as their initial costs. Technological and managerial steps to foster more efficient utilization of energy at the points of end-use will reduce operating costs and extend fuel availability.

Energy consumption by end-use in the U.S. as determined in an authoritative study ${ }^{37}$ is shown in Table C.6-1. During the interval 1960-1968 the Nation's annual consumption of total energy increased from 43.1 to 60.5 quadrillion Btu at a growth rate (compounded) of 4.3\% per year. The industrial sector accounted for the greatest use of energy, $41.2 \%$ of the National total in 1968, while the cormercial sector, the smallest, used only $14.4 \%$. However, the latter was the fastest growing, at $5.4 \%$ annually, while the former was the slowest growing, at $3.9 \%$.

A relatively small number of energy applications constitute the greatest market for energy in the U.S., as indicated for 1968 in Table C.6-2. The twelve applications shown account for all but approximately $3 \%$ of total U.S. energy consumption. Their relative shares of the energy market are not changina rapidly despite the somewhat slower growth rates of the larger applications. Industrial uses, transportation and space heating constitute for the foreseeable future the largest targets for conservation in the utilization of energy. 
Iable $C .6-1$

ENERGY COASUMPTION IIN THE IMIITED STATES RY END USE $1960-1968$

(Trillions of Btu and Percent per Year)

\begin{tabular}{|c|c|c|c|c|c|}
\hline Sector and End Use & $\begin{array}{l}\text { Consum } \\
1960\end{array}$ & $\frac{m+10 n}{1968}$ & $\begin{array}{l}\text { Anniual Rate } \\
\text { of Growth } \\
\end{array}$ & $\begin{array}{r}\text { Percer } \\
\text { Nationa } \\
1960\end{array}$ & $\begin{array}{l}t \text { of } \\
\text { Total } \\
\text { T968 } \\
\end{array}$ \\
\hline $\begin{array}{l}\text { Residential } \\
\text { Space heating } \\
\text { Water heating } \\
\text { Cooling } \\
\text { Clothes drying } \\
\text { Refrigeration } \\
\text { Air conditioning } \\
\text { Other }\end{array}$ & $\begin{array}{r}4,848 \\
1,159 \\
556 \\
33 \\
569 \\
134 \\
309 \\
\end{array}$ & $\begin{array}{r}6,675 \\
1,736 \\
637 \\
208 \\
692 \\
427 \\
1,241 \\
\end{array}$ & $\begin{array}{l}4.1 \% \\
5.2 \\
1.7 \\
10.6 \\
8.2 \\
15.6 \\
5.5\end{array}$ & $\begin{array}{l}11.38 \\
2.7 \\
1.3 \\
0.2 \\
0.9 \\
0.3 \\
1.9\end{array}$ & $\begin{array}{l}11.0 \% \\
2.9 \\
1.1 \\
0.3 \\
1.1 \\
0.7 \\
2.1\end{array}$ \\
\hline Total & 7,968 & 11,616 & 4.8 & 18.6 & 19.2 \\
\hline $\begin{array}{l}\text { Commercial } \\
\text { Space heating } \\
\text { Water heating } \\
\text { Cooking } \\
\text { Refrigeration } \\
\text { Air conditioning } \\
\text { Feedstock } \\
\text { Other }\end{array}$ & $\begin{array}{r}3,111 \\
544 \\
98 \\
534 \\
576 \\
734 \\
145 \\
\end{array}$ & $\begin{array}{r}4,182 \\
653 \\
139 \\
671 \\
1,113 \\
984 \\
1,025 \\
\end{array}$ & $\begin{array}{r}3.8 \\
2.3 \\
4.5 \\
2.9 \\
8.6 \\
3.7 \\
28.0\end{array}$ & $\begin{array}{l}7.2 \\
1.3 \\
0.2 \\
1.2 \\
1.3 \\
1.7 \\
0.3\end{array}$ & $\begin{array}{l}6.9 \\
1.1 \\
0.2 \\
1.1 \\
1.8 \\
1.6 \\
1.7\end{array}$ \\
\hline Total & 5.742 & 8,756 & 5.4 & 13.2 & 14.4 \\
\hline $\begin{array}{l}\text { Industrial } \\
\text { Process steam } \\
\text { Electric drive } \\
\text { Electrolytic processes } \\
\text { Direct heat } \\
\text { Feed stock } \\
\text { Other }\end{array}$ & $\begin{array}{r}7,646 \\
3,170 \\
486 \\
5,550 \\
1,370 \\
-118 \\
\end{array}$ & $\begin{array}{r}10,132 \\
4,794 \\
705 \\
6,929 \\
2,202 \\
198 \\
\end{array}$ & $\begin{array}{l}3.6 \\
5.3 \\
4.8 \\
2.8 \\
6.1 \\
6.7\end{array}$ & $\begin{array}{r}17.8 \\
7.4 \\
1.1 \\
12.9 \\
3.2 \\
0.3\end{array}$ & $\begin{array}{r}16.7 \\
7.9 \\
1.2 \\
11.5 \\
3.6 \\
0.3\end{array}$ \\
\hline Total & 18,340 & 24,960 & 3.9 & 42.7 & 41.2 \\
\hline $\begin{array}{l}\text { Transportation } \\
\text { Fuel } \\
\text { Raw materials }\end{array}$ & $\begin{array}{r}10,873 \\
141 \\
\end{array}$ & $\begin{array}{r}15,038 \\
146 \\
\end{array}$ & $\begin{array}{l}4.1 \\
0.4\end{array}$ & $\begin{array}{r}25.2 \\
0.3\end{array}$ & $\begin{array}{r}24.9 \\
0.3\end{array}$ \\
\hline Total & 11,014 & 15,184 & 4.1 & 25.5 & 25.2 \\
\hline National total & 43,064 & 60,526 & 4.3 & $100.0 \%$ & $100.0 \%$ \\
\hline
\end{tabular}

Note: ETectric utility consumption has been allocated to each end use. Source: Stanford Research Institute, usinn Bureau of Mines and ntiner sources. 


\section{Table C.6-2}

SIGNIFICANT END-USES OF ENERGY IN THE U.S. (1968)

Transportation (fuel; excludes lubes and greases)

Percent

of

Total

Space heating (residual, commercial)

$24.9 \%$

Process steam* (industrial)

17.9

Direct heat* (industrial)

16.7

Electric drive (industrial)

11.5

Feedstocks, raw materials (comercial, industrial, transportation)

5.5

Water heating (residential, commercial)

$4 . n$

Air conditioning (residential, commercial)

2.5

Refrigeration (residential, commercial)

2.2

Lighting (residential, commercial)

$-1.5$

Cooking (residential, commercial)

1.3

Electrolytic processes (industrial)

1.2

Total

$97.1 \%$ 
A number of recent studies have been dedicated to examining ways in which the consumption of energy can be reduced, principal amona these is one published in October $1972^{38}$ by the former Office of Emeraency Preparedness (OEP). The objective of this study was the suggestion of programs which would either improve the efficiency with which eneray is consumed or minimize its consumption, while providing the same or similar services to the consumer. The conservation measures suggested deal primarily with the utilization of energy in the major consuming sectors: Industrial, Transportation, Residential and Commercial.

The study concludes that full implementation of the measures suggested could reduce projected U.S. energy demand in 1980 (96 quadrillion Btu) by 15 to $17 \%$ and 1990 demand (140 quadrillion Btu) by 23 to $25 \%$. Graphical representation of idealized projections of U.S. energy consumption based on putting the sugoested eneroy conservation measures into practice is shown in Fiqure C.6-1.

The most significant energy conservation measures suggested to achieve these reductions are the installation of improved insulation in new and old homes, the use of more efficient space heatinn and cooling equipment, the introduction of more efficient industrial processes and equipment, and the shift to more efficient modes of transportation. The possible eneray savinas corresponding to implementation of these measures are listed by sector and end-use in Table C.6-3, which is a compilation of the potential savings 


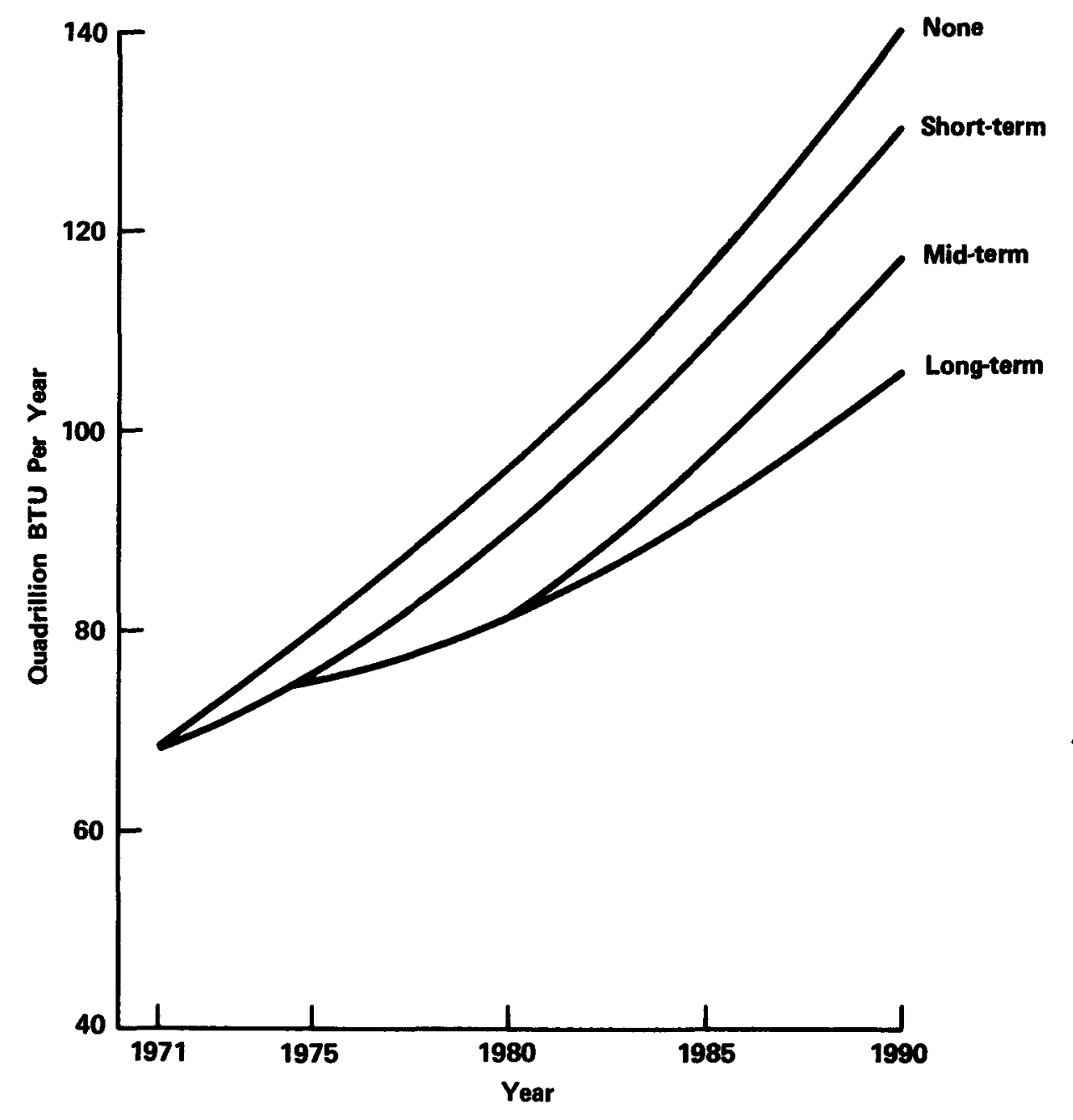

IDEALIZED PROJECTIONS OF ENERGY CONSUMPTION BASED ON SUGGESTED CONSERVATION MEASURES

Figure C.6-1 
Table C.6-3

POSSIBLE ANNUAL ENERGY SAVINGS

BY SECTOR AND END USE

Sector and

End Use

Industrial

Process steam

Direct heat

Electric drive

Electrolytic processes

Other

Residential

Space heating

Water heating

Air conditioning

Refrigeration

Cooling

Other, includina lighting

Commercial

Transportation

Totals (in $10^{15} \mathrm{Btu}$ )

Equivalent Generation $2 /\left(10^{9} \mathrm{kwh}\right) \quad 1440-1630$

Equivalent Base Load

Generating Capacity $3 /$ (GW)
Savings in Gross Eneray Input

(1015 Btu)

$\underline{1980} \underline{1990}$
4.5-6.4
included above
included above
included above
included above
included above

9.0-12.0

3.6

2.2

0.25

0.50

0.10

0.05

0.50

1.5

4.8

8.0

$14.4-16.3(15-17 \%) 4$

$32.0-35.0(23-25 \%)$

$356 n-3890$

$220-250$

540-590

1/ Commercial end uses.

2/ At the electric utility generation bus, assuming average plant heat rates of $10,000 \mathrm{Btu} / \mathrm{kwh}$ in $1980,9000 \mathrm{Btu} / \mathrm{kwh}$ in 1990 and 8000 Btu/kwh in 2000.

3/ At $75 \%$ generating plant capacity factor.

4/ Percentage savings refer to the total projections of U.S. eneray consumption in 1980 of $96 \times 10^{15} \mathrm{Btu}$, in 1990 of $140 \times 10^{15} \mathrm{Btu}$ and in 2000 of $190 \times 10^{15} \mathrm{Btu}$ considered in reference 2 . 
reported in the OEP Study. It should be noted that the savings indicated in Table 8 are expressed in terms of primary source energy inputs before conversion to the eneray forms ultimately utilized. Thus, when divided by the average electric generatina plant conversion rate of 9000 Btu per Kwh projected for 1990, the 32 to 35 quadrillion Btu savings estimated possible for that year are equivalent to an electric generation of 3560 to 3890 billion Kwh, which in turn is equivalent to 540 to 590 ginawatts of baseload generating capacity.

Some of the savings shown in Table C.6-3 are projected to result in direct reductions in electric eneray requirements; others miaht actually result in greater electric eneray consumption due to greater use of electric mass transit, for instance. Other applications would reduce the direct consumption of fossil-fuels at points of end-use. In all cases of net eneray reduction, however, fuel in some form would be saved and miaht be suitable as a substitute for another primary eneray source. Implementation of energy conservation as an alternative to the use of a primary eneray source, however, should not result (1) in the use of high quality fuels in relatively limited supply for inappropriate purposes - natural aas for boiler fuel, for instance; (2) in jeopardizing domestic raw material supplies - petroleum for industrial feedstocks or suitable coal for the metallurgical industry, for example; (3) in maintainina the need to import scarce fuels, petroleum, and natural aas, for instance, and (4) in maintaining the necessity of employing eneray sources 
having excessive environmental impacts. In other words, it would be of dubious advantage to conserve on energy use in order to consume less of the plentiful domestic resources, while continuing to burn increasing amounts of relatively scarce domestic fossil fuels.

It is evident from the data in Table C.6-1 that the greatest opportunities for conservation in the utilization of energy should lie in the fields of industrial thermal processes, thermal performance of structures, and transportation. This expectation is broadly reflected in the energy savings shown in Table C.6-3. These savings are estimated possible without deliberate curtallment of the Nation's output of goods and services. Another view of the savings that may be achieved by reducing end-use consumption of energy and improving the management of our energy resources and policies is provided in reference 3. This reference also outlines a five year, $\$ 210$ million program aimed at achieving these goals.

The following discussion deals with some of the means of achieving the savings discussed above, including some quantitative estimates of their magnitude.

\subsection{Industrial Thermal Processes}

The industrial processes listed in Table C.6-1--process steam, direct heat, electric drive and electrolytic processes--accounted for $37.3 \%$ of the Nation's energy consumption in 1968. Of this, the industrial thermal processes alone, process steam and direct heat, total $28.2 \%$ of U.S. energy requirements, about the same as that required to support all residential and conmercial building services. 
The average heat transfer efficiency of individual equipment used in direct heat or process steam operations is not hiah, approximately $30 \%$. The heat transfer efficiency of heat treating furnances is also about $30 \%$, due to the loss of approximately $50 \%$ of combustion heat in the stack gases. ${ }^{39}$ The overall efficiency of thermal processing plants (e.g., heat treating facilities, paper mills, glass factories) is even lower than the nominal efficiencies of the individual devices, sometimes as low as $5 \%, 40$ because plants are not commonly operated as systems making optimal use of energy. For example, it has been demonstrated that computer control of fuel management in hot strip steel mill operations to govern such things as the startup and shutdown of furnaces and their idling temperatures can reduce furnace fuel requirements by $25 \%$.

Substantial conservation of eneray should be possible through design of equipment that consumes less energy for a given productive output and the application of control for more efficient management of systems and processes.

Recommendation of specific measures for more effective energy utilization in industry is more difficult than in the case of residential/commercial heating, for example, because of the many and varied processes employed in industry. Also, industrial process research is almost always proprietary. However, certain examples can be mentioned where application of new technology would conserve significant amounts of energy. Gas fired vacuum furnaces 
have recently been developed for industry and, together with well designed vacuum insulation, heat pipe technology, and modern heat transfer and combustion techniques, these furnaces operate with $25 \%$ of the total fuel consumption of previous vacuum furnaces. ${ }^{41}$

The application of fluidized bed processing* to cement kilns and similar apparatus offers the prospect of considerable savings in industrial fuel utilization (cement production accounts for about $2 \%$ of U.S. fuel consumption). Recent advances in design of fluidized bed equipment may increase the heat transfer efficiency to approximately $50 \%$, instead of the present $30 \%$. In addition, the time for completion of the reaction time in the kiln may be reduced substantially, with consequent improvement in the productivity of cement making. 39

The heat pipe, a device which permits rapid and highly controllable heat transfer over long distances with minimal drop in temperature, can be applied to reduce fuel requirements. Heat pipes can be used as heat sources for vacuum furnaces and prospects appear aood for their application to glass furnaces. Heat pipes could also be used to extract heat from stack gases, thereby usino heat that would otherwise be wasted. ${ }^{39}$

\footnotetext{
\#In a fluidized bed, a stream of fluid (usually gas) is forced up through a bed of small particles. The fluid drag on the particles overcomes the gravity force, and the entire bed of particles can be made to flow, and exhibits other mechanical properties similar to those of a true fluid. In thermal reactors the hot gaseous products of combustion may be used to fluidize a bed. With the hot fluid surrounding individual particles, heat transfer to the solid takes place efficiently and rapidly.
} 
It is estimated ${ }^{41}$ that approximately $30 \%$ of the energy used in industrial processes could be saved through the application of existing techniques and that the use of these techniques would be economically justifiable at present fuel prices. As fossil fuel prices increase, the employment of these techniques become increasingly attractive. The development of more efficient devices and processes and the application of better waste heat management may be expected to yield savings exceeding the $30 \%$ mentioned.

\subsection{Thermal Performance of Structures}

Energy is consumed in buildings principally for space heating and cooling and water heating. As shown in Table 7, these services for residences and commercial buildings required $24.4 \%$ of U.S. energy consumption in 1968.

Heat losses or gains in buildings are due to inadequate insulation, excessive ventilation, high air infiltration rates and excessive fenestration. ${ }^{41}$ A measure of the improvement considered possible through improved thermal insulation and control of air infiltration are the newly implemented FHA minimum property standards (1972) that require heat losses to be less than 1000 Btu per thousand cubic feet-degree day in comparison to the FHA standards of 1965 that permitted heat losses of $2000 \mathrm{Btu}$ per thousand cubic feet-degree day. Few buildings are desianed to exceed the performance levels of the FHA 1972 standards, and therefore it is reasonable to 
assume that most of the residential buildings in use today may consume approximately $40 \%$ more energy for heating and air conditioning than they would had they been insulated and sealed in accordance with present day minimum property standards. Sample fuel observations indicate that the situation is not significantly different for existina commercial buildings. ${ }^{41}$

Future standards for insulation, ventilation and infiltration may offer even greater potential for saving energy. It is considered technically and economically feasible to reduce heating losses from buildings to approximately $700 \mathrm{Btu}$ per thousand cubic feet-degree day through better insulation. If implementation of this standard were achieved it would be feasible to reduce total eneray requirements of buildings by more than $50 \%$ through well-designed insulation and careful control of ventilation.

The choice of heating system can also affect energy conservation. The end-use efficiency of fuel use for electric resistance heating in the home is essentially $100 \%$, but when the eneroy conversion efficiency at the electric generating plant, averaging about 33\%, and the electric system transmission/distribution efficiency of about $91 \%$ are considered, the overall efficiency of electric heating is approximately $30 \%{ }^{42}$ The end-use efficiency of qas- or oil-burning home heating systems is on the order of $60 \%$. The latter figure might be lowered somewhat due to greater losses delivering the fuel to residences and commercial buildinas rather than in bulk to central 
generating stations, but the overall efficiency of gas or oil heating still would be much higher.

The use of electrical heat pumps could just about equalize the overall efficiencies of electric, gas and oil heating systems, due to the fact that the heat pump delivers about 2 units of heat energy for each unit of electric energy it consumes. ${ }^{42}$ Heat pumps are not initially expensive when installed in conjunction with central air conditioning, but they have occasioned high maintenance costs due to equipment failure. Extensive programs by manufacturers to improve component reliability could result in their greater market acceptance and a saving in energy consumption over electric resistance heating.

Air conditioning ranks third in the residential/commercial end uses listed in Table C.6-2 representing 2.5\% of total U.S. energy consumption, but is important beyond its ranking because it is a large contributor to summer peak loads on electric utility systems, which in turn determine system generating capacity.

Room air conditioners were installed in over 29 million American homes in 1972, which represents a market saturation of about $44 \%$. ${ }^{42}$ Strong growth in sales is expected to continue. As there is considerable range in the efficiency of room air conditioners, from about 4.7 to $12.2 \mathrm{Btu}$ per watt-hour, the future sale of the more efficient units could contribute significantly to energy conservation. 
An estimate of the impact of more efficient room air conditioners on energy consumption is available from Table C.6-4, which is taken from a recent study. ${ }^{43}$ By examination of Figure C.6-2 and consideration of the fact that low-efficiency machines generally have lower selling prices and, as a result, appear to be better bargains to the casual shopper, a present-day average efficiency of $6 \mathrm{Btu} / \mathrm{watt}$-hr can be assumed. An improved average efficiency of $10 \mathrm{Btu} / \mathrm{watt}$-hr appears to be attainable without any technological breakthrough this level is well below the maximum efficiency available today. Such an improvement would result in a cumulative saving of electricity consumption over the 8-year period of 212 billion kilowatt-hours. This is equivalent to 2.4 times the 1970 total electricity sales of the Tennessee Valley Authority or 6.5 times the 1970 sales of the Consolidated Edison Company. The 1980 connected load of the room air conditioners sold during the 8-year period would be 145,000 MW with an efficiency of $6 \mathrm{Btu} /$ watt-hr, or 87,000 MW with an efficiency of $10 \mathrm{Btu} /$ watt-hr. Although not all of the air conditioners would ever be operating at the same time, this 58,000 M!! reduction in connected load due to the efficiency improvement would surely result in an appreciable reduction in installed generating capacity requirements for the Nation's utilities.

Hot water heating required $4 \%$ of total U.S. energy consumption in 1968. Once the water was used its remaining heat went down the drain. If some of this enerny were recovered through heat 


\section{Table $0.6-4$}

ESTIMATED SHIPMENTS, COOLING CAPACITY, AND AMOUNT

$$
\text { OF COOLING - 1973-1980 }
$$

\begin{tabular}{lcccc}
\hline Year & $\begin{array}{c}\text { Shipments } \\
\text { Millions }\end{array}$ & $\begin{array}{c}\text { Capacity Shipped } \\
109 \\
\text { Btu }\end{array}$ & $\begin{array}{c}\text { Annual Cooling } \\
1012 \text { Btu }\end{array}$ & $\begin{array}{c}\text { Cumulative Cooling } \\
\text { 10 }\end{array}$ \\
\hline 1973 & 7.25 & 84.1 & 74.5 & 74.5 \\
1974 & 7.77 & 90.1 & 79.8 & 154.3 \\
1975 & 8.33 & 96.6 & 85.6 & 239.9 \\
1976 & 8.93 & 103.6 & 91.8 & 331.7 \\
1977 & 9.57 & 111.0 & 98.4 & 430.1 \\
1978 & 10.25 & 118.9 & 105.3 & 535.4 \\
1979 & 10.99 & 127.5 & 113.0 & 648.4 \\
1980 & 11.78 & 136.6 & 121.0 & 769.4 \\
& \multicolumn{2}{l}{ Total cooling for 8-year period } & 3183.7
\end{tabular}

Total Power Consumed:

At efficiency of 6 Btu/watt-hr

At efficiency of 8 Btu/watt-hr

At efficiency of $10 \mathrm{Btu} /$ watt-hr

At efficiency of 12 Btu/watt-hr
$530.6 \times 10^{9} \mathrm{~kW}-\mathrm{hr}$ $398.0 \times 10^{9} \mathrm{kH}-\mathrm{hr}$ $318.4 \times 10^{9} \mathrm{~kW}-\mathrm{hr}$ $265.3 \times 10^{9} \mathrm{~kW}-\mathrm{hr}$ 


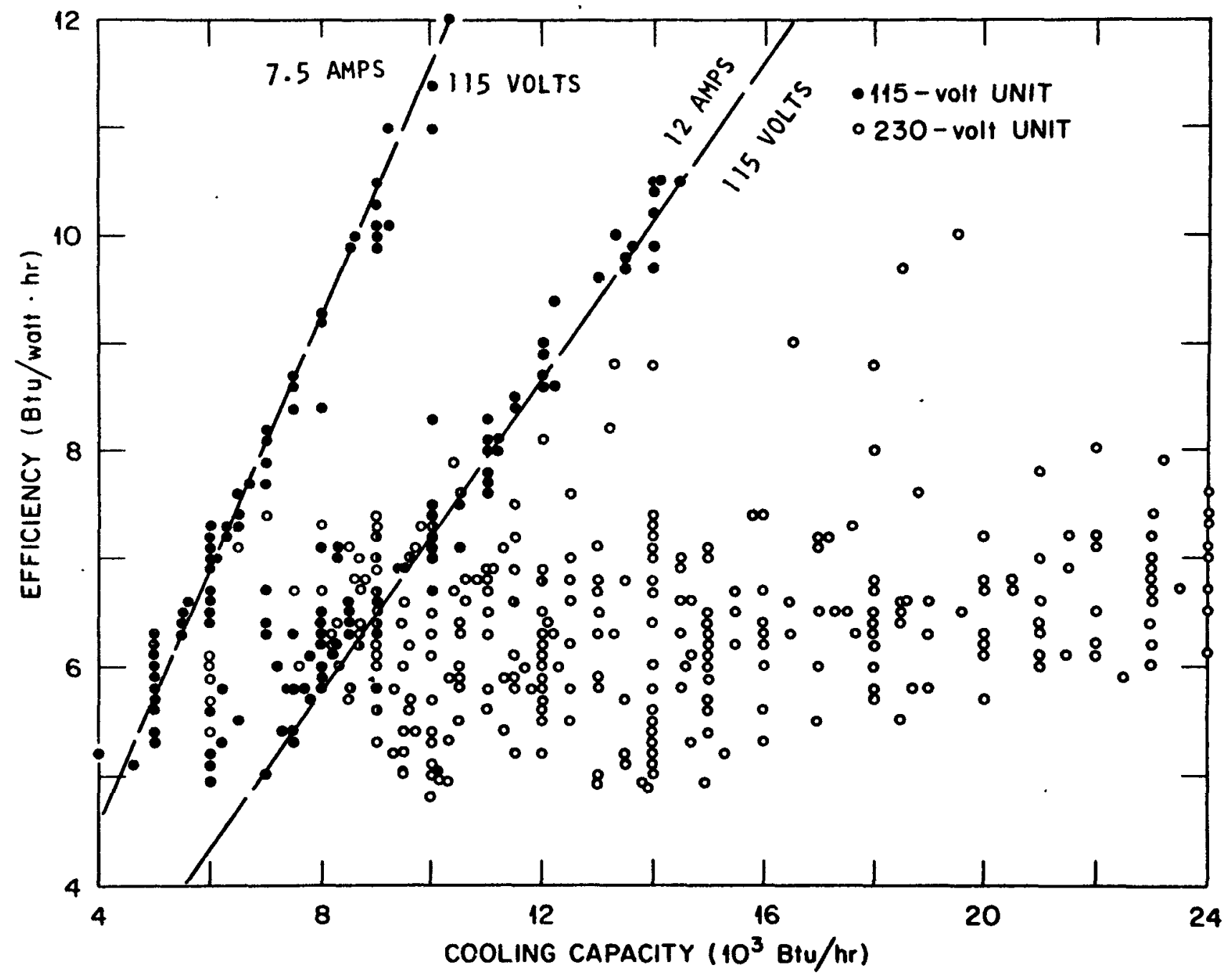

EFFICIENCY OF ROOM AIR CONDITIONERS

Figure $\mathrm{C.6-2}$ 
exchangers, to supplement space heatinn requirements for instance, it would represent a substantial saving in fuel. Solar water heaters could be employed, as they are in a number of countries. One source 41 estimates they could provide a relief of $2 \%$ or more of total National energy requirements.

\subsection{Transportation}

In 1970 transportation consumed 16.4 quadrillion Btu of energy, approximately $1 / 4$ of the total National eneroy requirement. Petroleum supplied $96 \%$ of the 1970 transportation requirement. Automobiles were the leading consumer at $55 \%$ of the enercy for the transportation sector (14\% of total U.S. enerny consumption), with trucks second at $21 \%$ and aircraft third at $7.5 \%$. The remaining $16 \%$ covers railroads, buses, waterways, nipelines and other cateaories. ${ }^{44}$

Table $c .6-5^{42}$ shows approximate values for eneray consumption and average revenue in 1970 for passenger and freight transport. The range in energy efficiency amono modes is large. Over the last decade or so the trend in transportion on the whole has been in the direction of use of less energy-efficient means and declines in the energy efficiency of individual modes. Trucks have been taking away intercity freiont business from the more eneroyefficient railroads; buses and railroads have been losina passenner traffic to more eneray intensive aircraft and automobiles (recent petroleum product shortages have shown signs of arresting these 
Table C.6-5

ENERGY AND PRICE DATA FOR TRANSPORT

Intercity Freight Transport

Mode

Energy

(Btu/ton-mile)

Pipeline

Railroad

Waterway

Truck

Airplane

450

670

680

2,800

42,000

Price

(cents/ton-mile)

0.27

1.4

0.30

7.5

21.9

\section{Passenger Transport}

Mode

Bus

Raflroad

Automobile

Airplane

Mass transit

Automobile
Energy (Btu/passenger-mile)

\section{Intercity*}

1,600

2,900

3,400

8,400

Urbant

3,800

8,100
Price

(cents/passenger-mile)

3.6

4.0

4.0

6.0

8.3

\# Load factors (\% of transport capacity utilized) for intercity travel are about: bus, $45 \%$; railroad, $35 \%$; automobile, $48 \%$; and airplane, $50 \%$. thoad factors for urban travel are about: mass transit, 20\%; automobile, $28 \%$. 
trends). Lower eneray efficiency of specific transportation modes has been the result of such things as the air-conditioning of automobiles, heavier automobiles - partly in response to recently required safety provisions, larger engines, and engine emission controls (emission controls currently being installed and projected are estimated to result in an additional gasoline consumption by 1980 of the order of 2 million barrels per day. $)^{44}$

A number of actions have been suggested to increase eneray efficiency, improve the balance between transportation modes and reduce the overa1l demand for transportation. These include incentives for the use of smaller automobiles (savinas approaching 3 million barrels per day by 1985 are possible here), subsidized mass transit systems, and improved traffic flow through priority lanes for buses and car pools and traffic metering systems. Longer ranae recommendations encompass new transportation technoloay and urban design. The latter includes the development of urban clusters that would reduce drastically the need for low enercy efficiency transportation. ${ }^{44}$

A measure of the order of energy savinas possible by a shift of transportation to the more efficient modes already avaflable is given in Table C.6-6. The traffic shown in this table is that for 1970 in the U.S. The actual dispersion of traffic for 1970 amona the various modes is indicated as well as a hypothetical rearrancement of the traffic to effectuate energ̣y savings. In the hypothetical scenario, half the freight traffic actually carried by truck and 
Table C.6-6

ACTUAL AND HYPOTHETICAL ENERGY CONSUMPTION PATTERNS FOR TRANSPORTATION IN 1970

\begin{tabular}{|c|c|c|c|c|c|c|c|c|}
\hline \multirow[b]{2}{*}{$\begin{array}{l}\text { Total } \\
\text { traffic }\end{array}$} & \multicolumn{6}{|c|}{ Percentage of total traffic } & \multirow[b]{2}{*}{$\begin{array}{l}\text { Total } \\
\text { energy } \\
\left(10^{1}{ }^{\text {Btu }}\right)\end{array}$} & \multirow[b]{2}{*}{$\begin{array}{l}\text { Total } \\
\text { cost } \\
\left(10^{9} \$\right)\end{array}$} \\
\hline & Air & Truck & Rail & $\begin{array}{l}\text { Waterway } \\
\text { and } \\
\text { pipeline }\end{array}$ & Auto & Bus* & & \\
\hline
\end{tabular}

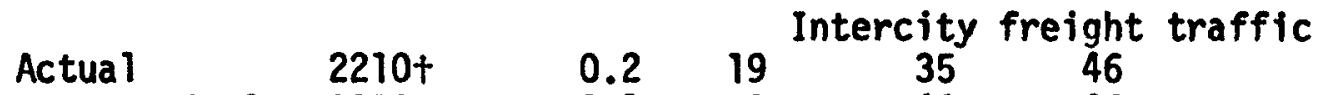

Hypothetical 2210

$0.2 \quad 19 \quad 35 \quad 46$

46

2400

45

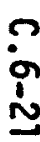

$\begin{array}{ll}\begin{array}{ll}\text { Actual } \\ \text { Hypothetical }\end{array} & 1120 \dagger \\ & 1120 \\ & \\ \begin{array}{ll}\text { Actual } \\ \text { Hypothetical }\end{array} & 710 \dagger \\ 710\end{array}$

10
5

Intercity passenger traffic

$\begin{array}{rrrr}1 & 87 & 2 & 4300 \\ 12 & 58 & 25 & 3500\end{array}$

47
45

Urban passenger traffic

Hypothetical 710 .

$97 \quad 35 \quad 5700$

Totals

Actual

Hypothetical

12,400

9600

160

141

*Intercity bus or urban mass transit.

tBillion ton-miles

fBillion passenger-miles 
airplane is assumed to have been carried by rail; half the intercity passenger traffic carried by airplane and one-third the traffic carried by car are assumed to have been carried by bus and train; and half the urban automobile traffic is assumed to have been carried by bus. The load factors (\% of transport capacity utilized) and prices are assumed to be the same for both calculations. The hypothetical scenario requires only $77 \%$ as much energy to move the same traffic as for the actual case. The saving of 2.8 quadrillion Btu is equal to approximately $4 \%$ of the U.S. energy requirement for 1970 . 


\section{C.7 CONCLUSIONS}

From the preceeding discussions, it is seen that a wide variety of energy conservation measures exists, but that their potential for significantly alleviating current fuel shortages or becoming, individually or as a group, a viable alternative to the LMFBR is mixed. A number of potential conservation measures, while attractive in theory, appear to offer only little relief to fuel scarcities, and in themselves may lead to significant economic or environmental penalties. Other conservation methods are worth pursuing, and should be implemented where practical. The relative advantages and disadvantages of the conservation measures discussed in this section are summarized below.

Improvements in methods of resource extraction for coal, oil, gas and uranium could, if implemented, result in the availability of additional fuel to such extent that if it were all allocated to the production of electricity (which is unlikely), it could support an additional generating capacity of 75,000 We annualiy by the Year 2000 (see section 8.C.2.4). This is less than $4 \%$ of the installed U.S. generating capacity projected for that time period. This increased fuel availability would require substantial investment in improving extraction efficiencies, and would result in various environmental impacts above or beyond those associated with current resource extraction methods, such as possible contamination of surface streams by water injected into oil wells, radiological and other effects of nuclear explosives that may be used in the 
stimulation of natural gas wells, increased ground subsidence over coal mines, etc. Any decisions on implementing increased resource extraction methods would have to balance the potential payoff in fuel availability against the economic and environmental costs associated with each method.

Potential improvements in power plant conversion efficiencies using current technology for fossil and nuclear fueled plants appear to be limited, and are not expected to significantly change the amount of usable energy that may be extracted from power plant fuels. (This discussion does not apply to basic changes in technology, such as MHD power generation, as discussed in Section 8.B.) Within current technology, it is possible that some improvements in conversion efficiency may come about due to the development of high temperature alloys, for example, but due to economic considerations and the small potential payoff (see p. C.3-3), it is expected that conversion efficiency improvements will follow, rather than provide the impetus or incentive for, any future changes in technology such as alloy development.

Utilization of waste heat from power plants is generally considered a fertile untapped area for energy conservation, but as noted in Section 3.3 its full potential may never be realized due to a variety of technical and economic reasons. Further, the extent to which waste heat utilization may actually replace some other energy source is difficult to quantify. Nevertheless, both economic and environmental 
advantages would appear to exist in the utilization of waste heat in certain specific applications, and this would appear to be a viable conservation measure in such instances.

Minor improvements in the ratio of net vs. gross generation of electricity could be obtained through the use of steam rather than electricity to drive plant auxiliary equipment. A more significant improvement in this ratio might be obtained through a reduction in the energy devoted to pollution control in the production of electricity as well as other goods and services. The anticipated use by 1977 of 10\% of electricity by industrial and commercial users for the operation of pollution control equipment represents a substantial resource. Any changes in this approach as a means of alleviating fuel shortages or as an alternative to development of the LMFBR would have sinnificant sncial as well as environmental and economic consequences, and would merit wide discussion on a national basis by all concerned elements of government, industry and the public.

With regard to possible conservation of energy through reducing losses in the transmission of bulk electric energy from generating plants to the distribution system, the amount of energy that might be saved by increased attention to this area is not large. The principal methods that could be employed, such as raising of transmission voltages or reduction of resistance, result in only minor efficiency gains; the countrywide savings that could accrue from 
raising of voltages in the $240 \mathrm{KV}$ and above range over the period 1974-80 has been estimated to be equivalent to the output of one 240 MWe base loaded generating plant. The use of innovative underground transmission methods is not expected to lead to significant energy conservation. Only the installation of superconducting cable systems, not likely before the late $1980^{\prime}$ 's, would result in an appreciable reduction in transmission losses underground. This reduction is estimated to be only on the order of the output of one base-loaded 10 MWe generator over the period 1990-2000. Thus, the transmission of electricity does not appear to be a fertile area for large savings from conservation measures.

The situation with regard to distribution systems is not different. The major potential in this area is in optimizing the loading of distribution transformers; this is shown in section 5.2 to result in a total annual savings by the year 2000 of the equivalent of the generation of one base-loaded 1100 MWe power plant. While not insignificant on an absolute basis, this generating capacity is only a minute fraction of the installed generating capacity that will exist by the Year 2000 .

Conservation of energy at the point of end-use has only recently begun to receive wide attention and to result in measurable savings of energy. The measures that could lead to the most significant savings are the installation of improved insulation in homes, the use of more efficient space heating and cooling equipment, the 
introduction of more efficient industrial processes and equipment, and the shift to more efficient modes of transportation. One study ${ }^{38}$ concluded that the full implementation of energy conservation measures in all areas, industrial, residential, commercial and transportation, could reduce projected U.S. energy demand in 1980 by 15 to $17 \%$, and in 1990 by 23 to $25 \%$. These savings would be equivalent to an annual base-loaded generating capacity totalling 220,000 to 250,000 MWe in 1980 and 540,000 to 590,000 MWe in 1990 (provided all these end-uses of energy were served in the form of electricity, which will not be the case).

The greatest opportunities for conservation in the utilization of energy lie in the fields of transportation, space heating and cooling, and industrial thermal processes. Conservation of energy in transportation is a recognizable and fertile area for significant savings. The major actions that can be taken, and which already have to some extent, include increases in engine efficiency, improvement in the balance between transportation modes and reduction in the overall demand for (and use of) transportation. One study of a hypothetical shift of 1970 traffic between transportation modes such that each type of cargo is carried by the most efficient means of transportation showed that only $77 \%$ as much eneray was needed to move the same traffic as in the actual case. This savings amounted to about $4 \%$ of the U.S. energy requirement for the year considered, and represents only one of the possible eneray economies in 
transportation. Thus, it is evident that a substantial potential exists for applying and achieving important savings in this field.

Industrial thermal processes alone accounted for $28 \%$ of total U.S. energy requirements in 1968. The average heat transfer efficiency of individual equipment used in direct heat or process steam operations is not high, approximately $30 \%$. The overall efficiency of complete thermal processing plants is even lower. By the use of new equipment such as fluidized bed combustors, vacuum furnaces and heat pipes, and the application of control for more efficient management of processes, it is estimated that more than $30 \%$ of the energy in thermal industrial operations could be saved.

Energy is consumed in buildings principally for space heating and cooling and water heating. These services for residences and commercial buildings required a little over $24 \%$ of U.S. energy consumption in 1968. Through higher standards for building insulation, ventilation and infiltration it is considered feasible to reduce the total space conditioning eneray requirements by at least $50 \%$.

In conclusion, it is clear that some energy conservation measures are worth pursuing, and should be implemented where practical. Other measures, which may appear equally attractive on brief examination, would actually offer only minor or insignificant savings. The economic and environmental effects of individual 
conservation measures must also be considered before any decisions on implementation are made. Those measures that meet all necessary criteria should be made a part of our energy use patterns as soon as practicable. 


\section{C.8 REFERENCES}

1. "Extraction of Energy Fuels," PB-220 328, prepared for the Bureau of Mines by the Federal Council for Science and Technology, September 1972. Distributed by the National Technical Information Service, Department of Commerce.

2. WASH-1281, The Nation's Energy Future, A Report to the President of the United States by The Chairman, U.S. Atomic Energy Commission, December 1973.

3. "United States Energy Through the Year 2000," U.S. Department of the Interior, December 1972.

4. "Gas Facts 1971," American Gas Association.

5. Final Environmental Statement for the Prototype 0il Shale Leasing Program, Vol. II, U.S. Department of the Interior, 1973.

6. U.S. Geological Survey Circular 650.

7. U. S. Geological Survey Bulletin 1275.

8. "Bituminous Coal Facts, 1972," National Coal Association.

9. "Conservation of Energy," Cormittee Print, Serial No. 92-18, prepared at the request of the Chairman, Senate Cormittee on Interior and Insular Affairs, 1972.

10. "Bituminous Coal Data 1971," National Coal Association.

11. "Energy and the Environment - Electric Power," Council on Environmental Quality, August 1973.

12. "Fossil-Fueled Steam Turbine Generation Systems," F. W. Schneider position paper for the Task Force on Technical Aspects of the Technical Advisory Committee on Conservation of Energy, National Power Survey.

13. "Nuclear Power, 1973-2000," WASH-1139(72), USAEC, December 1, 1972.

14. "0ils and Gas Imports Issues," Hearings before the Senate Interior and Insular Affairs Cormittee, January 10, 1973, P. 629 .

15. "Waste Heat Utilization." Included in Technical Evaluation Report of the Task Force on Energy Conversion Research to the Technical Advisory Committee, FPC, 1974 National Power Survey. 
16. National Conference on Waste Heat Utilization, Gatlinburg, Tennessee, October 27-29, 1971.

17. "Agricultural and Aquacultural Uses of Waste Heat," ORNL-4797, July 1972.

18. "Nuclear Energy Centers, Industrial and Agro-Industrial Complexes," ORNL-4290, November. 1968.

19. The 1970 National Power Survey, Federal Power Commission.

20. "Waste Heat Use in Greenhouses," Van der Horst, Journal of The Water Pollution Control Federation, March 1972.

21. "Hidden Waste - Potentials for Energy Conservation," The Conservation Foundation, Washington, D.C., D. B. Large Editor, 1973. (Page 66)

22. Proceedings of the Conference on the Beneficial Uses of Thermal Discharges, Albany, New York, September 17-18, 1970.

23. "Use of Steam-Electric Power Plants to Provide Thermal Energy to Urban Areas," ORNL-HUD-14, January 1971.

24. "Patterns of Energy Consumption in the U.S.," Office of Science and Technology, January 1972.

25. "Power Needs for Pollution Control," Electrical World, April 1, 1973.

26. "Statistics of Privately Owned Electric Utilities in the United States, 1971," Federal Power Commission.

27. "Third Biennial Survey of Power Equipment Requirements," Parts III and V, National Electrical Manufacturers Association (NEMA), 1973.

28. "Underground Power Transmission," October 1971, page 2-4, Arthur D. Little, Inc. for the Electric Research Council.

29. "24th Annual Electrical Industry Forecast," Electrical World, September 15, 1973.

30. Position Paper on Transmission Systems (C. C. Diemond) of the Task Force on Technical Aspects of the Technical Advisory Cormittee on Conservation of Energy for the Federal Power Commission's updating of the 1970 National Power Survey.

31. "Economics of Underground Transmission with Cryogenic Cables," P. Graneau, IEEE Transactions on Power Apparatus and Systems, January, 1970. 
32. FCST Energy R\&D Goals Study, Report of Technical Group on Electrical Transmission and Systems - July 14, 1972.

33. Position Paper on Cryogenic Transmission (E. B. Forsyth) of the Task Force on Technical Aspects of the Technical Advisory Committee on Conservation of Energy for the updating of the FPC's National Power Survey.

34. "Resistive Cryogenic Cable," Phase B Report, May, 1970 by General Electric Co. for EEI Project RP 78-6.

35. "The Distribution of Electric Power," a Report to the Federal Power Commission by the Distribution Technical Advisory Committee for the National Power Survey, June 1969.

36. Position Paper T-4 on Distribution Systems (L. J. McLaughlin) of the Task Force on Technical Aspects of the Technical Advisory Committee on Conservation of Energy for the Federal Power Commission's updating of the 1970 National Power Survey.

37. "Patterns of Energy Consumption in the United States," January 1972, by the Stanford Research Institute for the Presidents' Office of Science and Technology.

38. "The Potential for Energy Conservation, A Staff Study," October 1972, Executive Office of the President, Office of Emergency Preparedness.

39. "A Brief Report on Technology for Energy Consumption in Industrial Thermal Processes, "draft dated 6/13/73 for the Technical Advisory Committee on Research and Development of the National Power Survey, by Charles A. Berg, National Bureau of Standards.

40. "Commercial and Industrial Energy Conservation," section 3.6, chapter III, of the December $1973 \mathrm{draft}$ for the report of the Technical Advisory Committee in Research and Development, National Power Survey.

41. "Energy Conservation through Effective Utilization," Charles A. Berg, National Bureau of Standards, February 2, 1973.

42. "Efficiency of Energy Use in the United States," Eric Herst and John C. Moyers, Science Magazine, March 30, 1973.

43. "The Room Air Conditioner as an Energy Consumer," John C. Moyers, Oak Ridge National Laboratory, October 1973. 
44. "Energy Conservation," G. A. Lincoln, Science Magazine, Apri1 13, 1973. 